\title{
Archaeological Testing to Determine the National Register Eligibility Status of 18 Prehistoric Sites on Camp Bowie, Brown County, Texas Volume 1
}

Raymond P. Mauldin

Center for Archeological Research, University of Texas at San Antonio

David L. Nickels

Cory J. Broehm

Follow this and additional works at: https://scholarworks.sfasu.edu/ita

Part of the American Material Culture Commons, Archaeological Anthropology Commons, Environmental Studies Commons, Other American Studies Commons, Other Arts and Humanities Commons, Other History of Art, Architecture, and Archaeology Commons, and the United States History Commons

Tell us how this article helped you.

This Article is brought to you for free and open access by the Center for Regional Heritage Research at SFA ScholarWorks. It has been accepted for inclusion in Index of Texas Archaeology: Open Access Gray Literature from the Lone Star State by an authorized editor of SFA ScholarWorks. For more information, please contact cdsscholarworks@sfasu.edu. 
Archaeological Testing to Determine the National Register Eligibility Status of 18 Prehistoric Sites on Camp Bowie, Brown County, Texas Volume 1

\section{Creative Commons License}

(c) (1) (8)

This work is licensed under a Creative Commons Attribution-NonCommercial 4.0 International License 


\section{Archaeological Testing to Determine the National Register Eligibility Status of 18 Prehistoric Sites on Camp Bowie, Brown County, Texas}

Volume 1
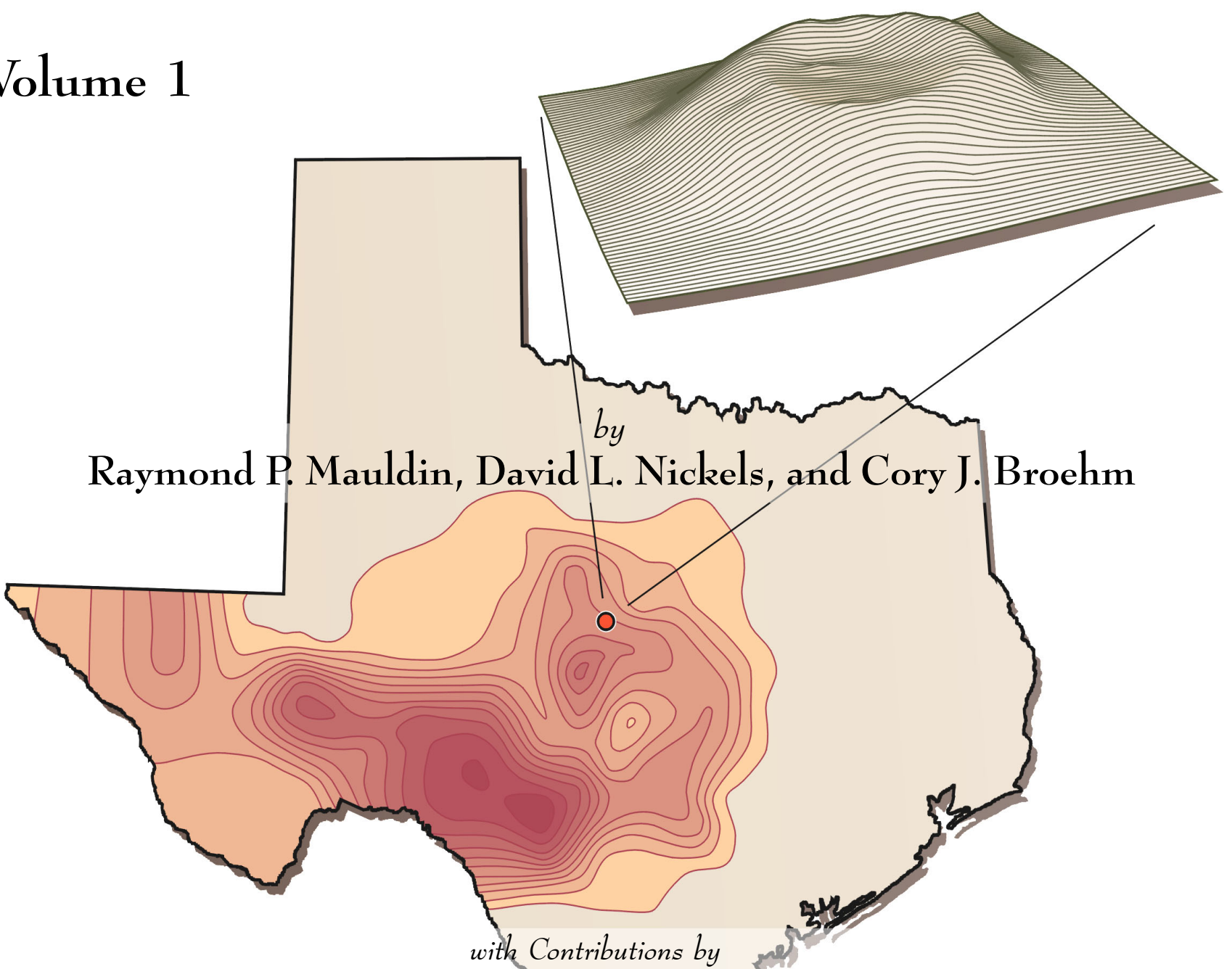

C. Britt Bousman, J. Philip Dering, Glenn A. Goodfriend, Linda Hodges, Jeffrey R. Francis, and Barbara A. Meissner

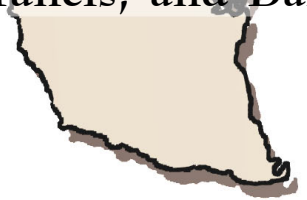

Adjutant General's Department of Texas Directorate of Facilities and Engineering Environmental Branch, Austin, Texas
Center for Archaeological Research The University of Texas at San Antonio Archaeological Survey Report, No. 334 

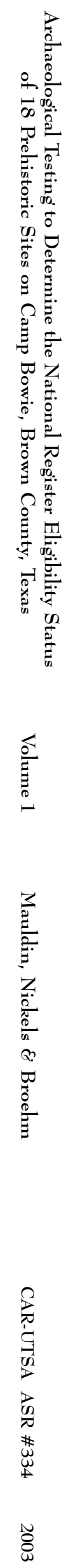


\section{Archaeological Testing to Determine the National Register Eligibility Status of 18 Prehistoric Sites on Camp Bowie, Brown County, Texas}

\section{Volume 1}

Raymond P. Mauldin, David L. Nickels, and Cory J. Broehm

with Contributions by

C. Britt Bousman, J. Philip Dering, Glenn A. Goodfriend, Linda Hodges, Jeffrey R. Francis, and Barbara A. Meissner

Texas Antiquities Committee Permit No. 2310

Raymond P. Mauldin

Principal Investigator

Robert J. Hard, former Principal Investigator

Prepared for:

Adjutant General's Department of Texas Directorate of Facilities and Engineering Environmental Branch, Austin, Texas

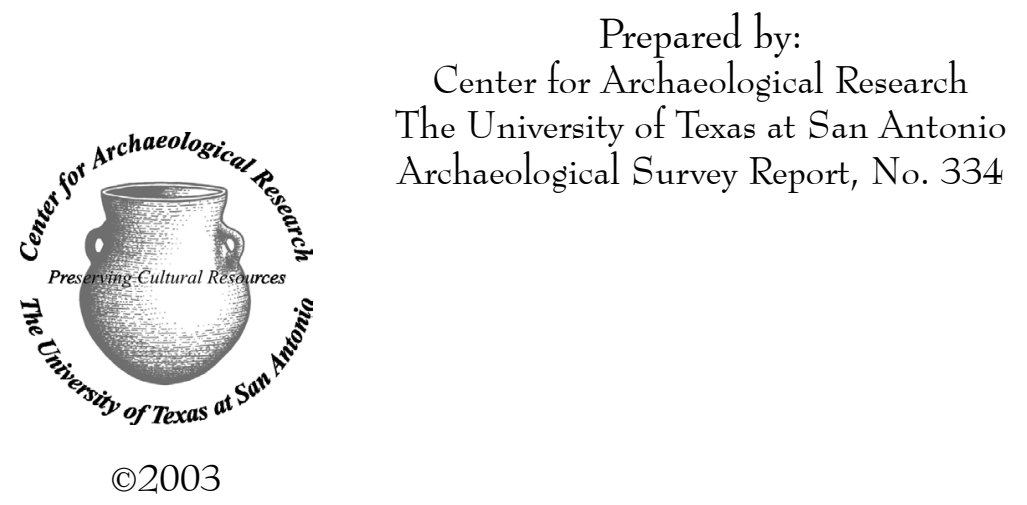


The following information is provided in accordance with the General Rules of Practice and Procedure, Chapter 26.24 (Investigative Reports), Texas Antiquities Committee:

1. Type of investigation: Testing

2. Project name: Camp Bowie Testing of 18 Sites

3. County: Brown

4. Principal investigators: Raymond P. Mauldin

5. Name and location of sponsoring agency: Adjutant General's Department of Texas

6. Texas Antiquities Permit No.: 2310

7. Published by the Center for Archaeological Research, The University of Texas at San Antonio, 6900 N. Loop 1604 W., San Antonio, Texas 78249-0658, 2003

A list of publications offered by the Center for Archaeological Research is available. Call (210) 458-4378; write to the Center for Archaeological Research, The University of Texas at San Antonio, 6900 N. Loop 1604 W., San Antonio, Texas 78249-0658; e-mail to car@lonestar.utsa.edu; or visit CAR's web site at http://car.utsa.edu.

Cover Figure: density map of the percentage of burned rock middens across Texas, with a surface plot of the burned rock midden on site 41BR492.

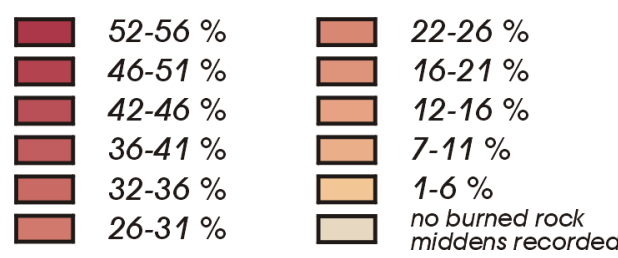




\section{Abstract}

Between the fall of 1999 and the summer of 2001, archaeologists from the Center for Archaeological Research (CAR) at The University of Texas at San Antonio conducted National Register Eligibility testing on 18 prehistoric sites within Camp Bowie in Brown County, Texas. The work was conducted for the Texas Army National Guard. The sites were recommended for testing during an inventory survey of Camp Bowie conducted between 1993 and 1998 (Wormser and Sullo-Prewitt 2001). Sixteen of the 18 sites tested contained burned rock middens. It was on the basis of that feature type that these sites were recommended for testing. Two sites (41BR261 and 41BR276) lacked burned rock middens, but Wormser and Sullo-Prewitt (2001) recommended these sites for testing based on the presence of diagnostic projectile points and the potential for buried features. As burned rock middens were a major element of the recommendations, much of this report focused on understanding those feature types. In all, 19 middens were tested.

On the basis of these testing efforts, CAR recommends that 12 sites (41BR65, 41BR87, 41BR228, 41BR246, 41BR250, 41BR253, 41BR420, 41BR433, 41BR473, 41BR478, 41BR492, and 41BR493) should be considered eligible for inclusion to the National Register of Historic Places and warrant designations as State Archeological Landmarks. Either avoidance of these locations, or some form of mitigation on portions of these sites, will be necessary. Our testing suggests that the remaining sites either lack clear evidence of significant data (41BR261 and 41BR276) or have data of questionable integrity (41BR415, 41BR441, 41BR474, and 41BR480). In these cases, CAR recommends that these sites are not eligible for inclusion to the National Register of Historic Places and they do not warrant designation as State Archeological Landmarks. 
NRHP Testing of 18 Prehistoric Sites on Camp Bowie, Brown County, Texas Volume Contents

Volume 1

Chapter 1: Project Overview

Chapter 2: The Environmental Setting of Camp Bowie

Chapter 3: Archaeological Background

Chapter 4: Background and Research Issues

Chapter 5: Testing Methods and Levels of Effort

Chapter 6: Individual Site Testing Summaries

Chapter 7: Chronological Placement of Camp Bowie Burned Rock Middens

Chapter 8: Development of Burned Rock Middens at Camp Bowie

Chapter 9: Subsistence Issues in Camp Bowie Middens

Chapter 10: Investigating Midden Sites at Camp Bowie

Chapter 1 1: Burned Rock Middens in Texas

Chapter 12: Recommendations

Volume 2

Appendix A: Radiocarbon Results

Appendix B: Vertebrate Faunal Remains

Appendix C: Ethnobotanical Remains

Appendix D: Mussel Shell Analyses

Appendix E: Recovered Projectile Points

Appendix F: Selected Other Tools

Appendix G: Geomorphology

Appendix H: Magnetic Sediment Susceptibility Testing

Appendix I: Description of Human Remains

Appendix J: Diagnostic Artifacts from Burned Rock Middens 


\section{Table of Contents: $\quad$ Volume I}

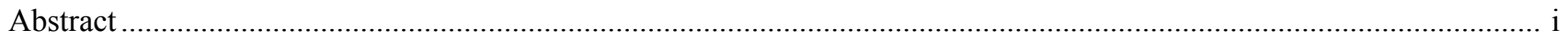

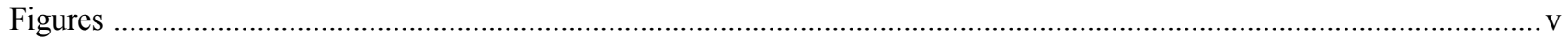

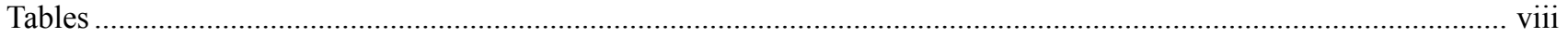

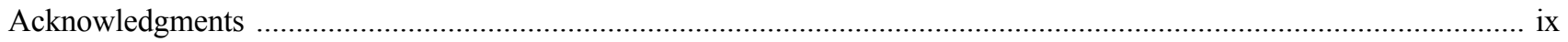

Chapter 1: Project Overview by Raymond P. Mauldin

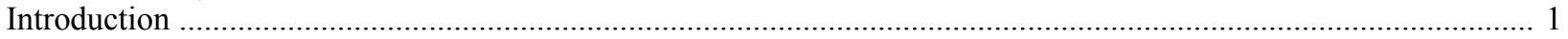

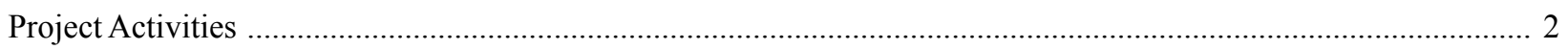

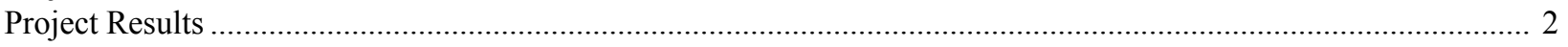

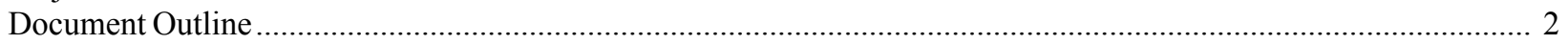

Chapter 2: The Environmental Setting of Camp Bowie by Raymond P. Mauldin and David L. Nickels

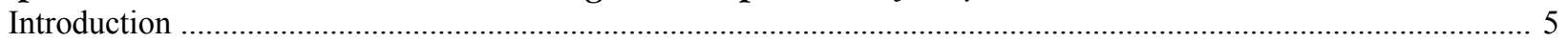

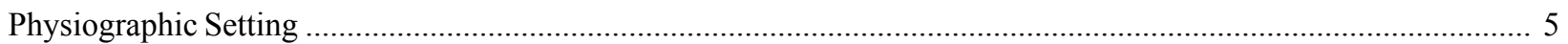

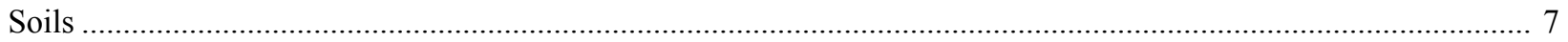

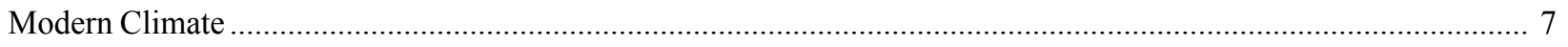

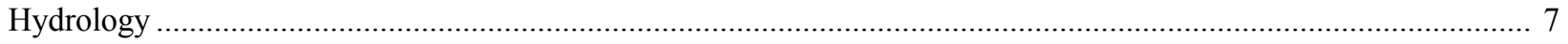

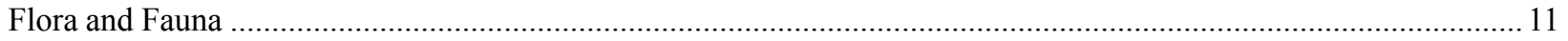

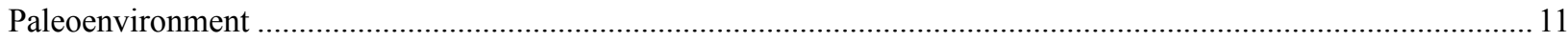

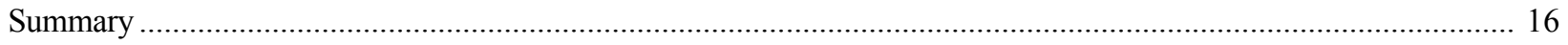

Chapter 3: Archaeological Background by Raymond P. Mauldin, David L. Nickels, and Cory J. Broehm

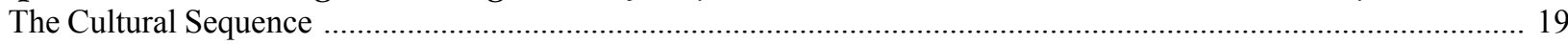

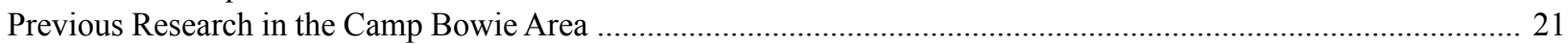

Chapter 4: Background and Research Issues by Raymond P. Mauldin

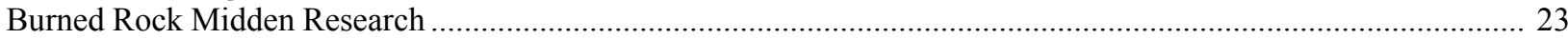

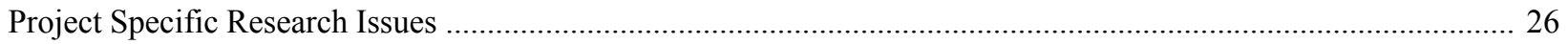

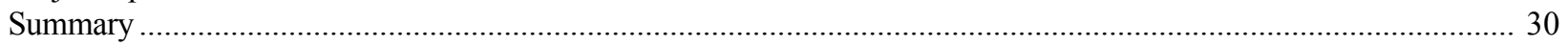

Chapter 5: Testing Methods and Levels of Effort by David L. Nickels and Raymond P. Mauldin

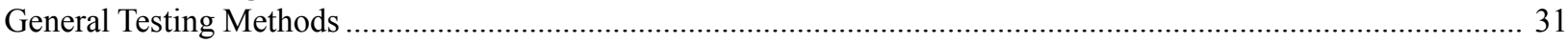

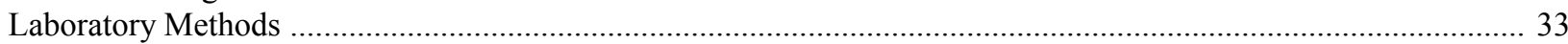

Chapter 6: Individual Site Testing Summaries by Raymond P. Mauldin, David L. Nickels, and Cory J. Broehm

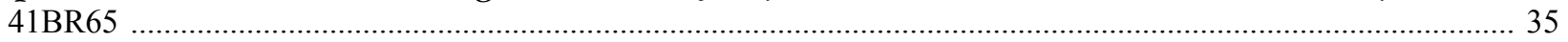

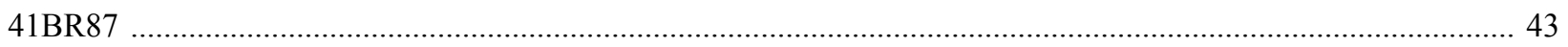

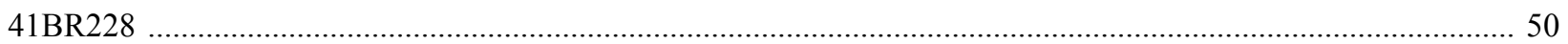

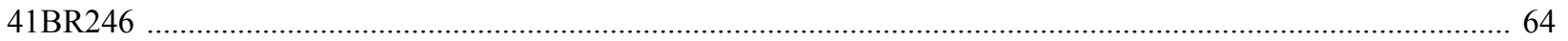

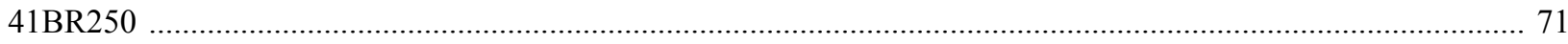

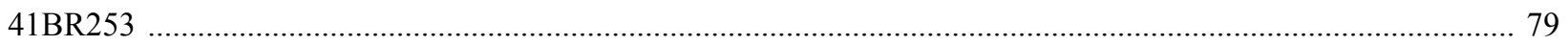

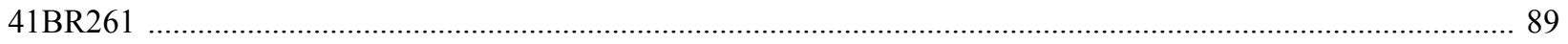

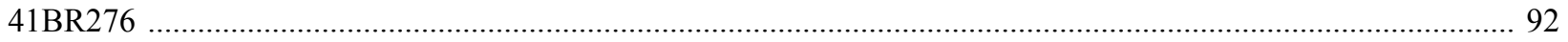

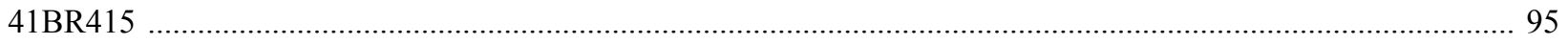

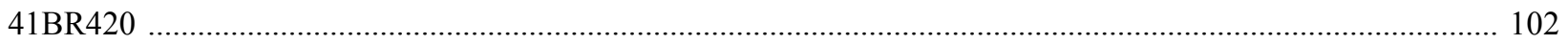

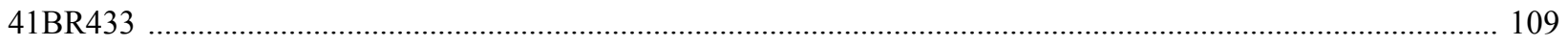

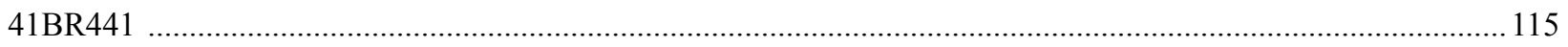

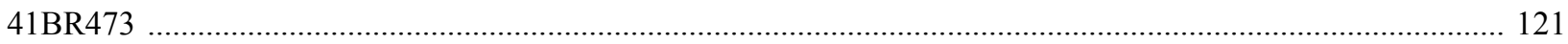

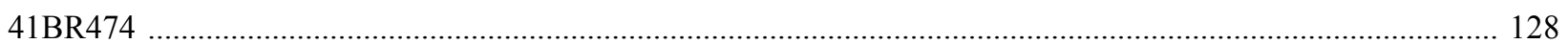

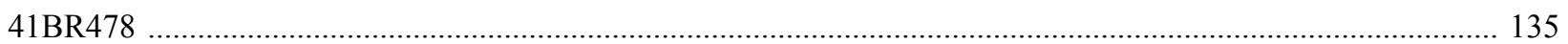

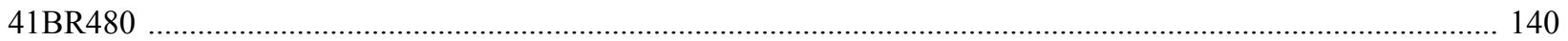

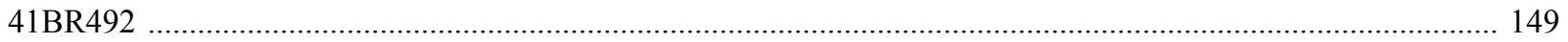

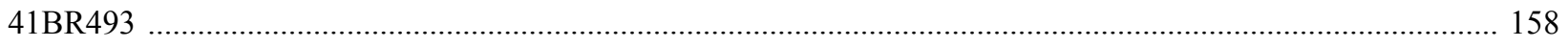

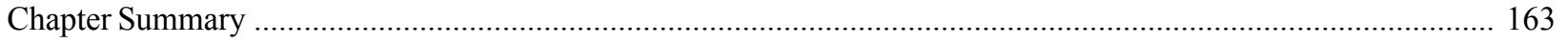


Chapter 7: Chronological Placement of Camp Bowie Burned Rock Middens by Raymond P. Mauldin and David L. Nickels

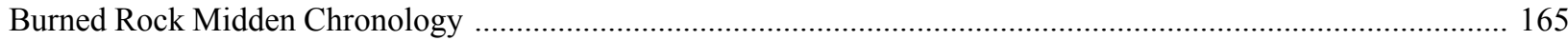

Summary

Chapter 8: Development of Burned Rock Middens at Camp Bowie by Raymond P. Mauldin

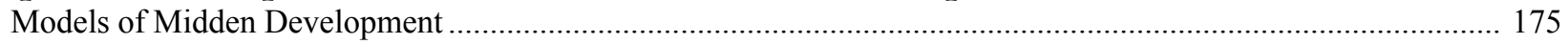

Exploring Patterns in Artifacts and Mussel Shell in Midden and Non-midden Contexts ....................................... 176

Patterns in Burned Rock ................................................................................................................... 183

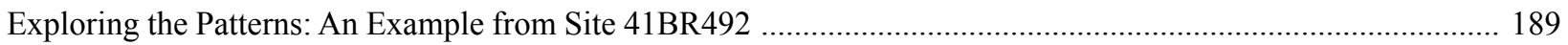

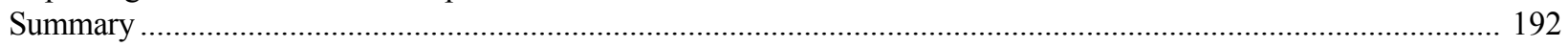

Chapter 9: Subsistence Issues in Camp Bowie Middens by Raymond P. Mauldin

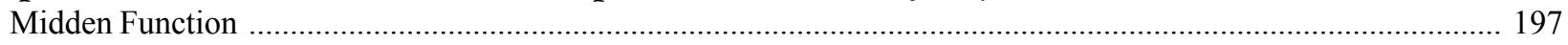

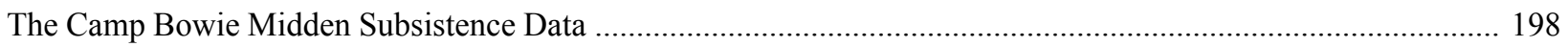

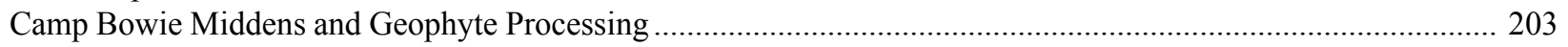

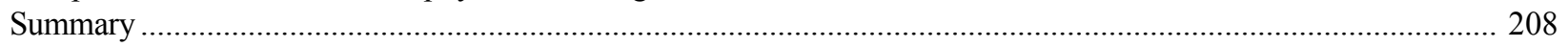

Chapter 10: Investigating Midden Sites at Camp Bowie by Raymond P. Mauldin

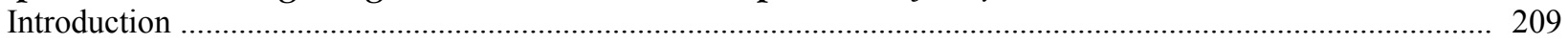

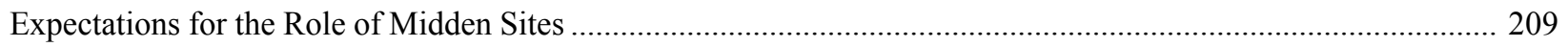

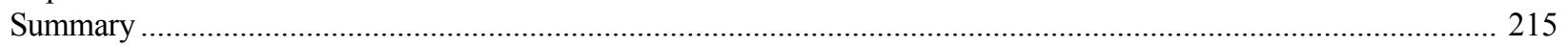

Chapter 11: Burned Rock Middens in Texas by Raymond P. Mauldin and David L. Nickels

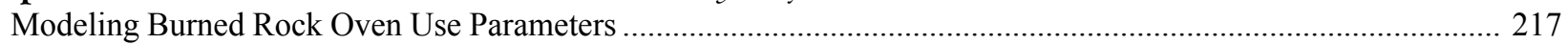

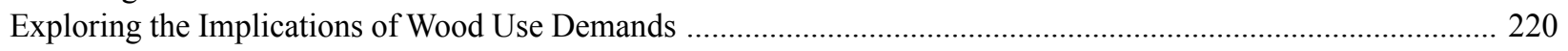

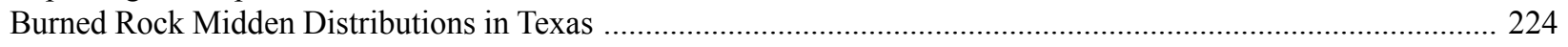

Summary of Burned Rock Midden Research ……….................................................................................... 229

Chapter 12: Recommendations by Raymond P. Mauldin

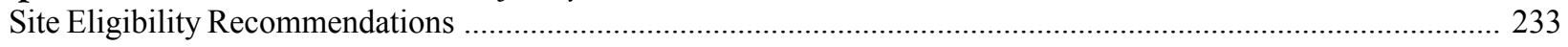

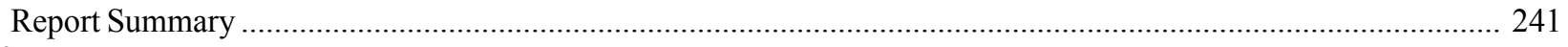

References

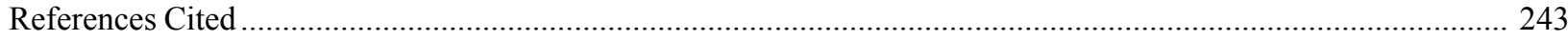




\section{Figures:}

\section{Volume I}

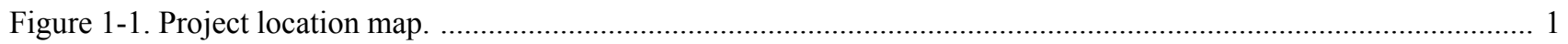

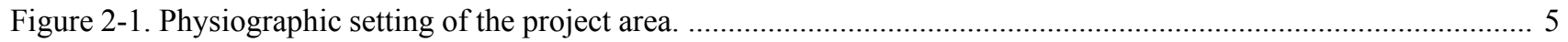

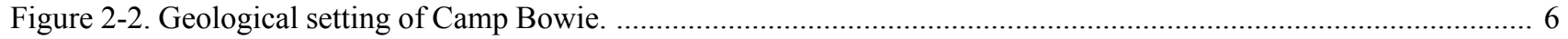

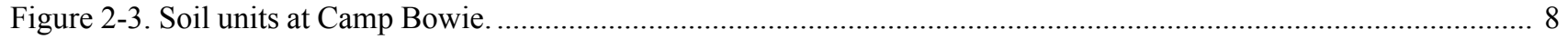

Figure 2-4. Average maximum and minimum temperatures by month for Brownwood. ............................................... 9

Figure 2-5. Average rainfall by month for Brownwood. ......................................................................................... 9

Figure 2-6. Yearly rainfall data from 1948 through 1976 gathered by the National Climatic Data Center. ..................... 10

Figure 2-7. Photo of Devils River taken after several days of substantial rain in February of 2001 ............................... 10

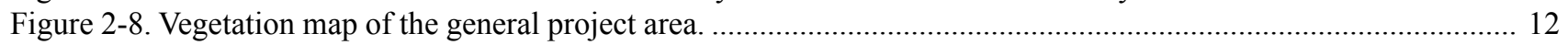

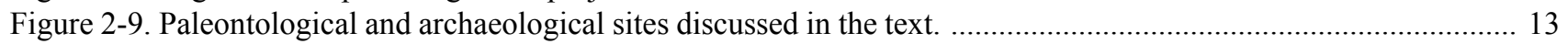

Figure 2-10. Poaceae pollen percentages for Patschke and Boriack Bogs. ................................................................... 14

Figure 2-11. Regional climatic indicators for Central Texas. ................................................................................ 17

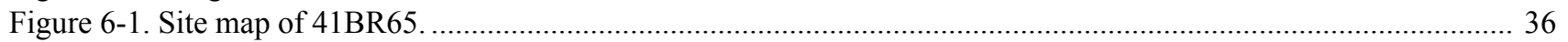

Figure 6-2. Shovel test density by depth for Zones 2 (top) and 3 (bottom), 41BR65 ................................................ 38

Figure 6-3. Detailed map of 41BR65 showing location of excavation units. .............................................................. 39

Figure 6-4. Profile of north walls of Units 1, 6, and 7 on site 41BR65 .................................................................. 41

Figure 6-5. Profile of south wall of Unit 5 with Feature 2 identified, 41BR65 .......................................................... 42

Figure 6-6. Plan view of Unit 5 at $26 \mathrm{cmbd}$, with Feature 5 identified, 41BR65..................................................... 42

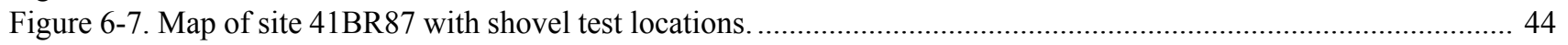

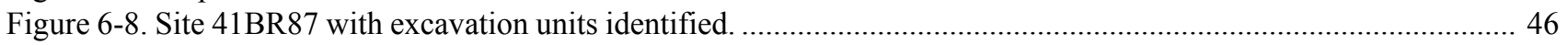

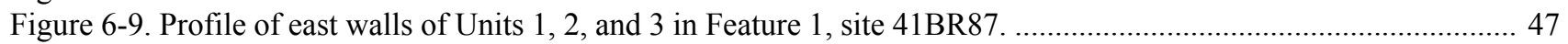

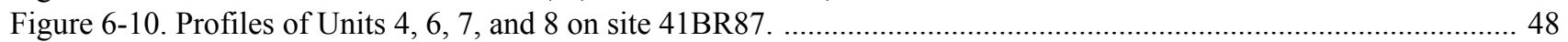

Figure 6-11. Profile of Feature 4, located in western wall of Unit 5, 41BR87....................................................... 49

Figure 6-12. Plan view of Feature 5, Unit 6 (at $30 \mathrm{cmbd}$ ), 41BR87. .................................................................. 49

Figure 6-13. Site 41BR228 with burned rock middens, mortar holes, and surface collection areas identified. ................. 52

Figure 6-14. Map of site 41BR228 with shovel tests and excavation units identified................................................... 53

Figure 6-15. Densities of fire-cracked rock and debitage by level for non-midden shovel tests at 41BR228. ................. 55

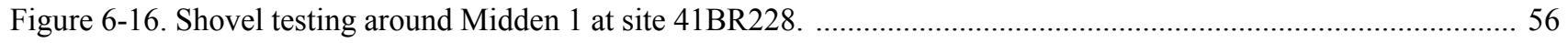

Figure 6-17. Profile of east walls of Units 1, 2, and 3 through Midden 1 on 41BR228. ............................................ 58

Figure 6-18. Blow-up of Feature 4, 41BR228, with shovel tests and excavation units identified................................... 59

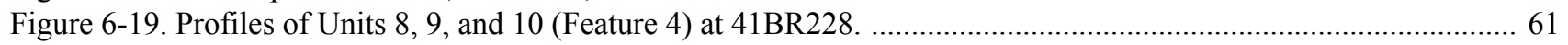

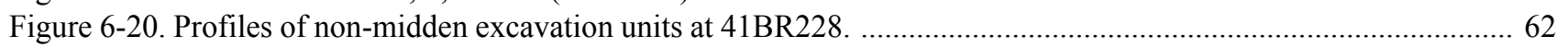

Figure 6-21. Site 41BR246 with burned rock midden and shovel tests identified. ..................................................... 65

Figure 6-22. Burned rock midden area on site 41BR246 with shovel tests and excavation units identified. .................... 66

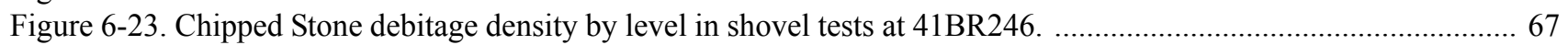

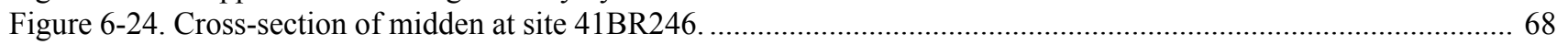

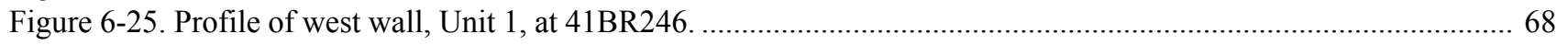

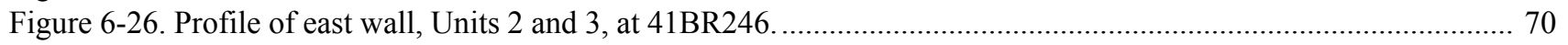

Figure 6-27. Feature 2 (at $40 \mathrm{cmbd}$ ), Unit 5, on 41BR246............................................................................. 71

Figure 6-28. Site 41BR250 with burned rock midden, shovel tests, collection areas, and excavation units identified. .... 72

Figure 6-29. Blow-up of burned rock midden area on site 41BR250 ....................................................................... 75

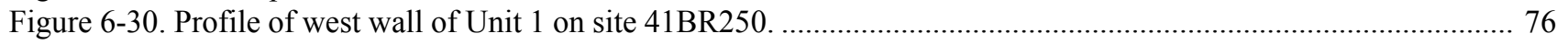

Figure 6-31. Profile of west wall of Units 2 and 3 on site 41BR250 ................................................................... 77

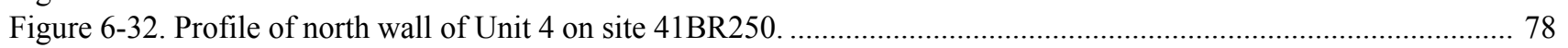

Figure 6-33. Site 41BR253 with burned rock middens, shovel tests, and surface collection areas identified. .................. 80

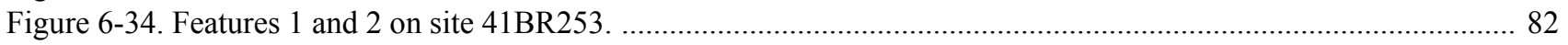

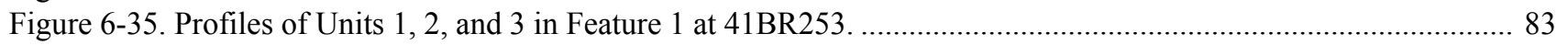

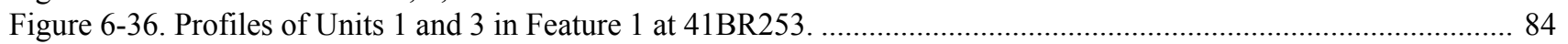


Figure 6-37. Cross-section of Feature 2 at 41BR253 (view to the west). .................................................................... 85

Figure 6-38. Profile and plan view of Units 4, 5, and 6 in Feature 2 at 41BR253................................................... 86

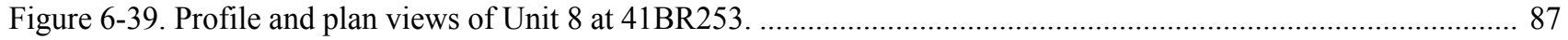

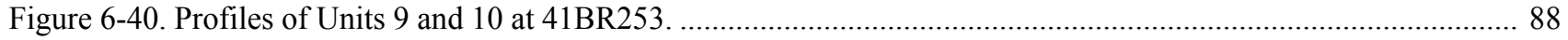

Figure 6-41. Site 41BR261 with shovel tests, excavation units, and surface collection area identified.......................... 91

Figure 6-42. Site 41BR276 with shovel tests, excavation units, and surface collection area identified.......................... 93

Figure 6-43. The surface of Feature 1 and the location of Unit 1 on site 41BR276 .................................................. 94

Figure 6-44. Site 41BR415 with shovel tests and excavation units identified. ........................................................... 96

Figure 6-45. Bar graph of fire-cracked rock and chipped stone debitage for shovel tests on 41BR415 ........................ 97

Figure 6-46. Profile of east walls of Units 1, 2, and 3 in Feature 1, site 41BR415 .................................................. 99

Figure 6-47. Plan view of Feature 3, Unit 2 at 30-40 cmbd, site 41BR415. ....................................................... 100

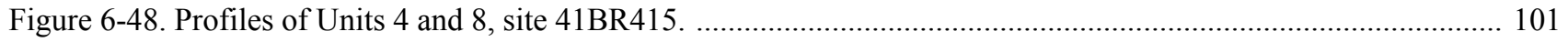

Figure 6-49. Map of site 41BR420 with the burned rock midden, shovel tests, and surface collection area identified... 103

Figure 6-50. Midden area of site 41BR420 with positive shovel tests and excavation units identified. ........................ 104

Figure 6-51. East (top) and west (bottom) profiles of Units 1 and 2 in Feature 1, site 41BR420.............................. 106

Figure 6-52. Plan view of Feature 2 at 10-25 cmbd, Units 1 and 2, site 41BR420 .................................................... 107

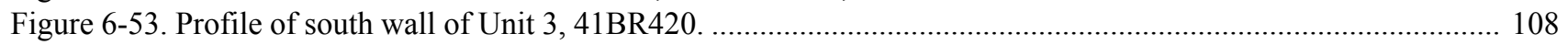

Figure 6-54. Profile of west wall of Unit 5 showing Feature 3, 41BR420........................................................... 108

Figure 6-55. Map of site 41BR433, with midden and shovel tests identified. .......................................................... 110

Figure 6-56. Midden area of 41BR433 with positive shovel tests and excavation units identified............................... 111

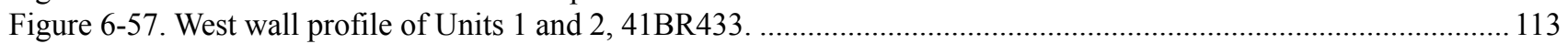

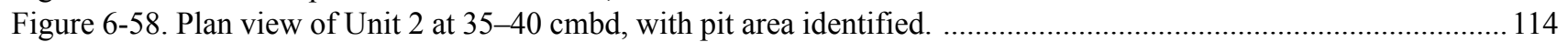

Figure 6-59. Profile of east wall of Units 3 and 4 in Feature 1 at 41BR433..................................................... 115

Figure 6-60. Plan view of Unit 4 at $20 \mathrm{cmbd}$, with Feature 1 boundary identified. ..................................................... 116

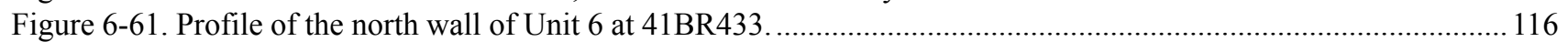

Figure 6-62. Map of site 41BR441 with midden, shovel tests, and collection areas identified..................................... 117

Figure 6-63. Blow-up of burned rock midden area on site 41BR441 with excavation units and backhoe trench. ............ 119

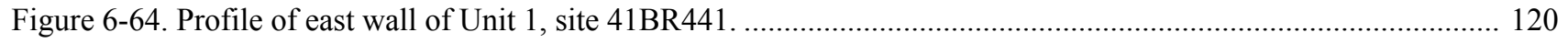

Figure 6-65. Profile of west wall of Backhoe Trench 1, 41BR441. .......................................................................... 121

Figure 6-66. Site 41BR473 with burned rock midden and shovel tests identified. ................................................... 123

Figure 6-67. Site 41BR473 with burned rock midden and excavation units identified. ............................................ 124

Figure 6-68. Profile of east walls of Units 2 and 3 on site 41BR473. ............................................................... 126

Figure 6-69. Contour map and cross-section of Feature 1, 41BR473. .............................................................. 127

Figure 6-70. Site 41BR474 with burned rock middens and shovel tests locations identified. .................................... 129

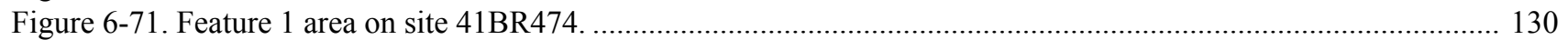

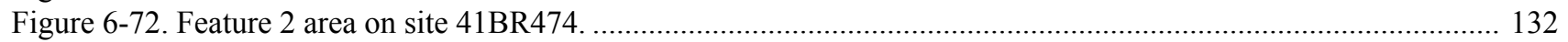

Figure 6-73. Plan view of Unit 6 at $10 \mathrm{cmbd}$ with possible edge of Feature 2 identified, 41BR474 ........................... 134

Figure 6-74. Site 41BR478 with burned rock midden and shovel tests identified. ................................................... 136

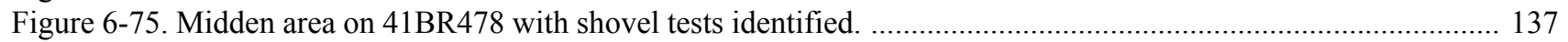

Figure 6-76. Profile of north walls of Units 1, 2, and 3 in Feature 1 at site 41BR478.............................................. 139

Figure 6-77. Site 41BR480 with burned rock midden, sheet midden, and shovel tests identified. ................................ 142

Figure 6-78. Blow-up of sheet midden area on 41BR480 ................................................................................. 143

Figure 6-79. Blow-up of burned rock midden (Feature 1) area on 41BR480 ......................................................... 145

Figure 6-80. Profile of sheet midden exposed in drainage (looking east), 41BR480 .............................................. 146

Figure 6-81. Profile of north walls of Units 1, 2, and 3 in Feature 1, site 41BR480 .................................................. 148

Figure 6-82. Plan view of Unit 2 showing Feature 4 at $35 \mathrm{cmbd}$, 41BR480 .............................................................. 149

Figure 6-83. Profile of Feature 2, located in north wall of Unit 5, 41BR480 ..................................................... 150

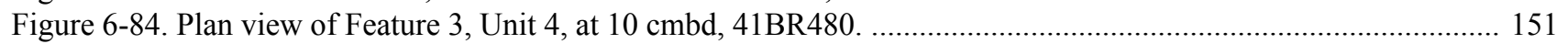


Figure 6-85. Site 41BR492 with burned rock midden, shovel tests, and excavation units identified. ........................... 152

Figure 6-86. Plan view and cross-section of Feature 1 area, site 41BR492. ........................................................... 153

Figure 6-87. Profile of east walls of Units 1 and 2, Feature 1, site 41BR492. .......................................................... 155

Figure 6-88. Profile of west wall of Unit 3, Feature 1, site 41BR492 ..................................................................... 156

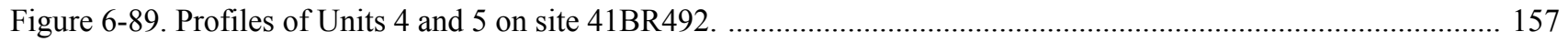

Figure 6-90. Site 41BR493 with burned rock midden, shovel tests, and excavation units identified. ........................... 159

Figure 6-91. Density of chipped stone per level in shovel tests, Levels 1 through 5, at site 41BR493 ......................... 161

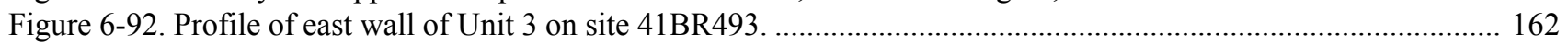

Figure 7-1. West wall of ring Unit 3 at 41BR492, with radiocarbon dates. ................................................................ 166

Figure 7-2. Probability distribution for 31 midden dates, with primary time period of use identified in blue. ............... 167

Figure 7-3. Radiocarbon dates on 87 midden use episodes from 40 sites in Central Texas. ......................................... 168

Figure 7-4. Two examples of deep Late Prehistoric dates from Camp Bowie middens. ............................................... 170

Figure 7-5. Counties reviewed for midden sites with diagnostic artifacts. ............................................................. 172

Figure 7-6. Components per 100 years by temporal period for burned rock middens in counties in Figure 7-5 ............ 174

Figure 8-1. Schematic cross-section of a repeatedly used central-based roasting feature. …....................................... 176

Figure 8-2. Plot of internal and external chipped stone densities from shovel tests. ................................................... 177

Figure 8-3. Box plots of midden and non-midden chipped stone densities. .............................................................. 180

Figure 8-4. Asp/Glu ratios and A/I values for mussel shell with heated, non-heated, and modern shell identified.......... 181

Figure 8-5. Estimated age of non-heated mussel shell using A/I ratios. .................................................................. 182

Figure 8-6. Box plots of midden and non-midden shell weights per cubic meter of sediment. .................................... 183

Figure 8-7. A model of midden accumulation as a function of rock breakage and replacement. ................................... 184

Figure 8-8. Box plots of percentages of rock in the 6-inch or greater size range for ring and central excavation units. . 186

Figure 8-9. Box plots of percentages of rock in the 2-6-inch size range for ring and central excavation units. .............. 187

Figure 8-10. Box plots of percentages of rock in the 1-2-inch size range for ring and central excavation units. ............ 187

Figure 8-11. Plot of the percentages of rock in the $>6$-inch group against the 2-6-inch group for central and ring units. 188

Figure 8-12. Standardized weights for the less than 1-inch size fraction by site for central and ring units..................... 188

Figure 8-13. Cross-sections of Units 1, 2, and 3 in the burned rock midden on 41BR492. ........................................ 190

Figure 8-14. Rock size data for the 41BR492 midden. .......................................................................................... 193

Figure 8-15. Large rocks in Unit 2 and 1-2 inch sized rocks in Unit 3 by level, 41BR492. Data are standardized. ....... 194

Figure 8-16. Comparison of standardized values of rock weights, Unit 1, 41BR492 . ............................................... 194

Figure 8-17. The standardized number of rocks within the 1-3-inch size range for ring Unit 3, 41BR492. ................. 195

Figure 8-18. Comparison of rock in the 1-3-inch size range and MS readings for Unit 3, 41BR492. ......................... 196

Figure 9-1. Fragment of white-tailed deer metatarsal exhibiting chemical weathering and fungus. ............................. 200

Figure 9-2. Collected bulbs and bulb fragments from sites at Camp Bowie. .............................................................. 201

Figure 9-3. Examples of "slag" collected from middens, and "slag" created at CAR .................................................. 202

Figure 9-4. Examples of raw and baked bulbs of common camas (C. quamash). ........................................................ 204

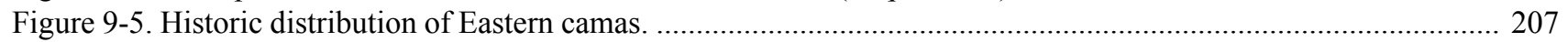

Figure 10-1. Plot of indexed site artifact density and indexed non-cortical debitage. ................................................... 213

Figure 10-2. Plot of indexed coefficient of variability for flake length and indexed non-cortical debitage. ................... 214

Figure 10-3. Plot of indexed site artifact density and indexed coefficient of variability for flake length. ..................... 214

Figure 10-4. Box plots of distance to drainages for burned rock midden sites and other prehistoric sites. .................... 216

Figure 11-1. Wood collection rates for multiple events in the Chihuahuan Desert. ..................................................... 221

Figure 11-2. Possible collection cost curves for rock and wood in three different wood densities.............................. 221

Figure 11-3. Vegetation map monitoring wood availability for central and west Texas. .............................................. 222

Figure 11-4. Box plots comparing midden heights for middens in Brown County and Culberson County. ..................... 223

Figure 11-5. Box plots comparing midden diameters in Brown County with middens in Culberson County. ................ 224

Figure 11-6. Counties used in distributional study, with percentages of burned rock middens identified....................... 227

Figure 11-7. Density map of the percentage of burned rock middens across Texas. ..................................................... 228 


\section{Tables: $\quad$ Volume I}

Table 1-1. Selected Characteristics of 18 Tested Sites on Camp Bowie ..................................................................... 3

Table 4-1. Research Issues Related to Site Integrity and Eligibility Determinations ................................................... 30

Table 7-1. Diagnostic Artifacts and Radiocarbon Dates by Periods for Camp Bowie Middens ................................... 171

Table 8-1. Chipped Stone Data from Midden and Non-Midden Contexts ............................................................... 178

Table 8-2. Rock Counts by Size Class for Burned Rock Midden Units ................................................................... 185

Table 8-3. Rock Weights (small fraction) and Number of Rocks by Size Class, Site 41BR492 ….............................. 191

Table 10-1. Midden Sites with Raw and Scaled Data on Lithic Assemblages ........................................................ 212

Table 10-2. Summary Characteristics of Individual Sites in Figures 10-1 through 10-3 ............................................. 215

Table 10-3. Comparison of Midden Radiocarbon Dates and Site Level Diagnostic Dates .......................................... 216

Table 11-1. Chi-Square Cross-tab with Adjusted Residual Values for Sites by Geological Formation .......................... 219

Table 11-2. County Level Burned Rock Midden Data ............................................................................................ 225 


\section{Acknowledgments}

In the early fall of 1999, Dr. Robert J. Hard, then director of the Center for Archaeological Research, called me into his office and asked me to direct a project evaluating a series of sites with burned rock middens in some place called Camp Bowie for some organization called the Texas Army National Guard. I spent about an hour trying to talk him out of the idea. I had no real interest in the issues surrounding burned rock middens, no background in the area, and had other things to do. What little I knew about these features, and the issues surrounding them, suggested to me that everybody had a strong opinion on what was going on. I did not need to be cast into this particular quagmire. Wasn't there someone else on the staff that could spend multiple months in Brownwood, wherever that was, breaking trowels on burned stone? Robert can be stubborn. He argued that someone without any baggage on this issue might be a useful addition to the problem. I have known Robert for over 20 years, and sometimes it is just easier to give in then argue with him. So, armed with advice from a bunch of folks at CAR, including Associate Director, Dr. C. Britt Bousman, and Project Archaeologist, Dr. Steve Tomka, I headed north to meet Dr. Alan Wormser and Ms. Shellie Sullo-Prewitt of the Texas Army National Guard. Fortunately, Dave Nickels and an experienced crew went with me. That seems like a long time ago. Lots of things have happened since then. Dave and Britt are now at Southwest Texas State University. Steve is now the director of CAR. Robert has gone back to teaching full-time. Alan Wormser has left Texas. Shellie Sullo-Prewitt is once again Shellie Sullo. And, at last, I seem to have finished this report. I do not know if Robert was wise in pushing this project on me. I do know, however, that the work could not have happened without the help of a bunch of people.

First and foremost in that "bunch" was the field crew. On the two major undertakings that comprised the field portion of this project, the crews consisted of Richard Jones, Leonard Kemp, Jennifer Logan, Ruth Mathews, Kaylee McCray, Clemente Murguia, Sylvia Reyna, Rick Robinson, Bryant Saner, Lisa Shaddox, Carol Villalobos, and Jason Weston. David Nickels and Cory Broehm directed various aspects of the field work under my supervision. These are all good people. They worked hard, often under difficult conditions, and did an excellent job. A special thanks is due to Dave Nickels. It is not often you get a chance to work with somebody who is persistent, hard working, pleasant, smart, and honest. Dave is all those things. If Dave tells you something, you can pretty much count on it being the truth. If I ever grow up, I want to be like Dave.

Dr. Steve Tomka, the current director of the Center for Archaeological Research, has always been supportive of this project. More than a few times he has listened to me ramble on about some idea, looked over sections, and guided me in more profitable directions. Well, at least he tried. Thanks Steve.

Ms. Shellie Sullo has listened to lots of excuses over the last year. Shellie is too nice for her own good. I hope that she finds this report of some use, and that all the trouble was worth it. Thanks Shellie.

Several people at Camp Bowie deserve mention. Sgt. Maj. Marcus Pilkington, his staff, and all the security folks at the camp were a pleasure to work with. They pulled us out of the mud, both literally and figuratively, a couple of times. Everett "Bo" Nelson conducted the backhoe work and the backfilling. Man, do I appreciate the backfilling. Roger and the staff at Executive Inn in Early made our visit to the area enjoyable. I sort of miss the place at times.

Several people have provided discussion or comments on various aspects of this research. These include Dr. Steve Black, Dr. C. Britt Bousman, Cory Broehm, Diane Cargill, Dr. Phil Dering, Dr. Steve Tomka, Shellie Sullo, Dr. Harry Shafer, Dr. Russell Greaves, Dr. Robert Hard, Dr. Angela Linse, David Nickels, Dr. G. Lain Ellis, Richard Mahoney, Mike Quigg, Dr. Tom Hester, and Michael Jordan. Thanks for the advice, references, and request for clarifications. You all have made this a much better report. 
A special thanks to Margaret Howard who spent a lot of time and energy going through the draft of this document and provided many useful comments. She then took most of a Saturday morning to sit down and go over the report with me. Thanks Margaret. My guess is that we still disagree on several aspects of burned rock middens, but I do appreciate your perspective.

A variety of current and former CAR staff and administrative people were instrumental in pulling all this off. Ms. Marybeth Tomka and the CAR laboratory staff have been incredibly helpful in the processing and cataloging of the project material. They managed to keep everything organized. A special thanks is due to Jennifer Neel-Hartman who spent an amazing amount of time on the catalog and records for this project. Jennifer, I think it is close to over. Carol Villalobos and Preston McWhorter processed the flotation samples. Lithic analysis was conducted by Rick Robinson, Scott Speil, and Jason Weston. Pam Popejoy, Jason Weston, and Dave Nickels conducted the magnetic soil susceptibility analysis. Barbara Meissner conducted the work on the vertebrate faunal material and Jeff Francis conducted the infield analysis of the human remains. Thanks to all. Bruce Moses and Rick Young produced the maps in this report. Look at the graphics - these guys are good. Johanna Hunziker edited the document, and is responsible for the overall layout. Thanks Jo. I have had lots of editors, and you are one of two that I ever really liked. Also, thanks to Sherri Suñaz, Tammy Hosek, and Mike Wright. Without you three, we might as well just lock the doors, turn off the lights, and head to the house.

David Olmos, Coordinator of Electron Microscopy Labs at the University of Texas at San Antonio, conducted work on the "slag." Ms. Linda Hodges and Dr. Britt Bousman of Southwest Texas State University conducted the Geomorphic work. Dr. Philip Dering, Texas A\&M University, conducted the flotation analysis. Dr. Glenn Goodfriend, George Washington University, conducted the analysis on mussel shell. All these folks did a great job. Thanks. Unfortunately, Dr. Goodfriend died earlier this year. I never met him. In this age of e-mail, I never even talked to him on the phone. I know that he worked too many Sundays, and that he was kind enough to take time away from his Sunday afternoons to try and help me understand something about shell. Thanks for your help Glenn.

Raymond P. Mauldin

Assistant Director

Center for Archaeological Research

May 2003 


\section{Chapter 1:}

\section{Project Overview}

\section{Raymond P. Mauldin}

\section{Introduction}

The purpose of this project was to conduct archaeological testing to determine the National Register eligibility status of 18 archaeological sites at Camp Bowie in Brown County, Texas (Figure 1-1). The sites were recorded during an inventory survey of Camp Bowie conducted, at various times, between 1993 and 1998 (Wormser and Sullo-Prewitt 2001). Of the 186 sites recorded during that survey, Wormser and Sullo-Prewitt (2001) recommended that six historic sites and 18 prehistoric sites be considered potentially eligible. They further recommended that testing and archival research was necessary to clarify the eligibility status of those sites.
The current report reflects the testing of those 18 prehistoric sites. The fieldwork was conducted between the fall of 1999 and the summer of 2001 by archaeologists from the Center for Archaeological Research (CAR) at The University of Texas at San Antonio.

Table 1-1 lists the 18 prehistoric sites investigated during this project, along with selected characteristics. Note that 16 of the sites contain at least one burned rock midden, and three sites contain multiple middens. It was on the basis of these feature types that these 16 sites were recommend for testing by Wormser and Sullo-Prewitt (2001). Only two sites, 41BR261 and 41BR276, lacked burned rock middens.

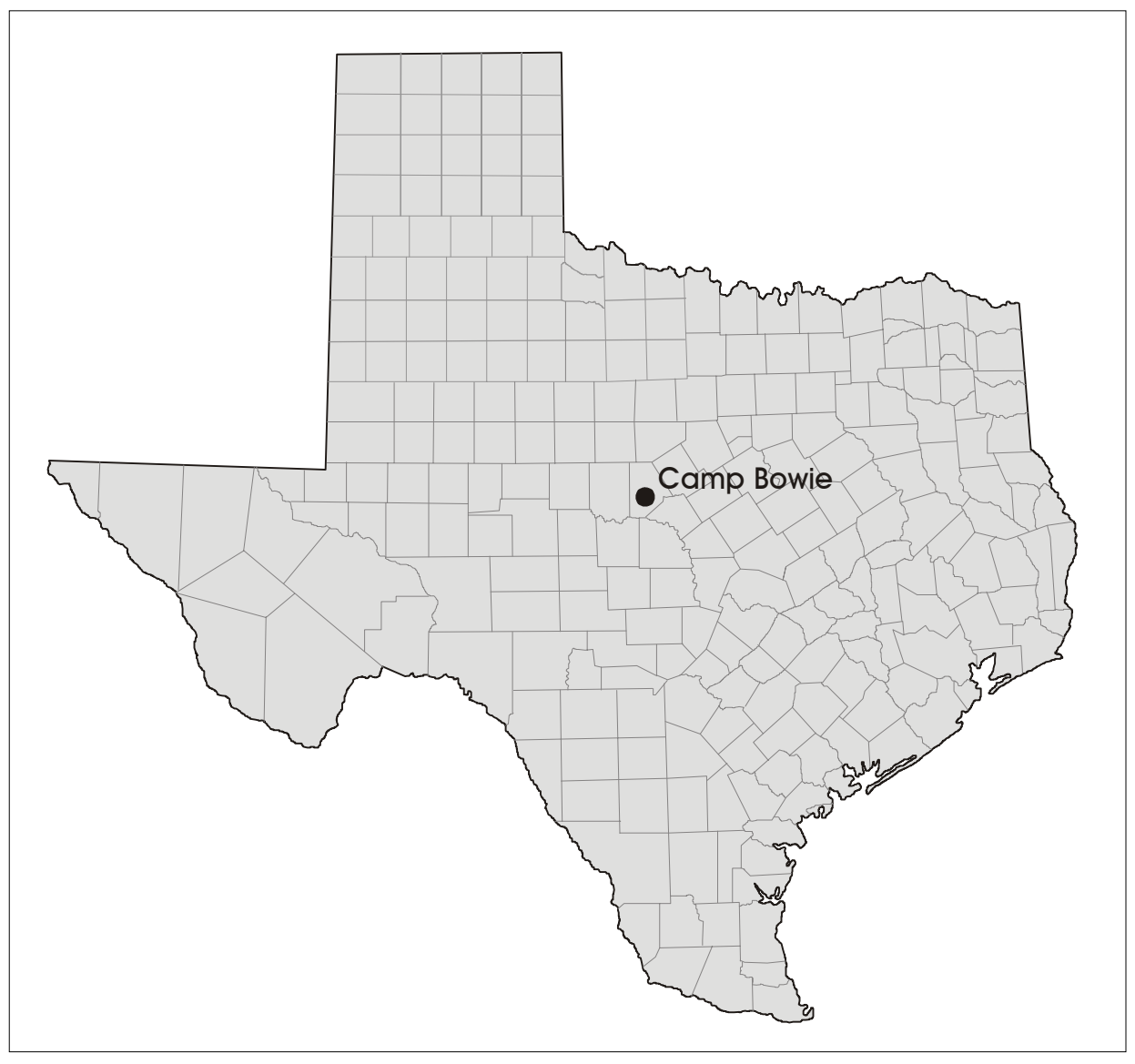

Figure 1-1. Project location map. 
However, Wormser and Sullo-Prewitt (2001) recommended these sites for testing based on the presence of diagnostic projectile points, moderate densities of surface flakes, cores, other tools, and the potential for buried features.

The primary objective of the testing efforts at the sites was determination of site eligibility to the National Register of Historic Places (NRHP) and for designation as State Archeological Landmarks (SAL). Each archaeological site was to be categorized as either 1) eligible or 2) not eligible for inclusion to the NRHP; and/or 1) warranted, or 2) not warranted for SAL designation. Our primary criteria for site eligibility were site and/or feature integrity (i.e., physical and cultural). The main goals of the testing efforts were focused on determining the degree of integrity of the archaeological deposits and features present at each site. Assuming that some degree of site and/or feature integrity could be demonstrated, a secondary goal of site testing was to investigate the degree to which the archaeological deposits could yield information relevant to understanding the nature of burned rock midden sites and/or various aspects of regional prehistory (i.e., subsistence practices, technological organization, chronological frameworks).

\section{Project Activities}

Field work at the 18 sites consisted of extensive shovel testing to define potential activity areas and features away from middens, selected surface collection of material using two or three meter (radius) circles, and excavation of 1-x$1-\mathrm{m}$ units. The excavation units were placed both within burned rock middens and in areas away from features. In all, 913 shovel tests were placed on the 18 sites. CAR sampled the surface distributions by collecting material from 21 areas, and excavated 98 1-x-1-m units. Fifty-four of these units were in burned rock middens. In all, 19 burned rock middens were tested.

\section{Project Results}

The excavation and analytical work summarized in this report suggests that in twelve cases significant data are present in good context. These sites are 41BR65, 41BR87, 41BR228, 41BR246, 41BR250, 41BR253, 41BR420, 41BR433, 41BR473, 41BR478, 41BR492, and 41BR493. CAR recommends that these 12 sites be considered eligible for inclusion to the National Register of Historic Places, and warrant designations as State Archeological Landmarks. Either avoidance of these locations by training activities, or some form of mitigation at these sites, will be necessary. In the case of the remaining sites, our testing suggests that they either lack clear evidence of significant data (41BR261 and 41BR276) or have data of questionable integrity (41BR415, 41BR441, 41BR474, and 41BR480). In these cases, CAR recommends that these sites are not eligible for inclusion to the National Register of Historic Places, and they do not warrant designation as State Archeological Landmarks.

While the focus of this report is necessarily on the question of eligibility at a site level, the work at Camp Bowie has resulted in a number of contributions to understanding aspects of Central Texas archaeology. Most of these contributions center around documenting the nature of burned rock middens. In short, the results presented here suggest that burned rock middens at Camp Bowie generally 1) represent ovens, 2) were used to bake high-starch foods, primarily consisting of bulbs of eastern camas, as well as wild onion and dog's-tooth violet, 3 ) date primarily to the Late Prehistoric period, and 4) represent the accumulation of multiple use events over varying lengths of time. While other researchers have certainly suggested several of these conclusions (e.g., Black and Creel 1997; Treece 1993), the results of the Camp Bowie testing provide added support for these conclusions, as well as raise a number of additional questions regarding the use of this feature type in Texas.

\section{Document Outline}

This document is designed to provide eligibility information on 18 sites located on Camp Bowie, Brown County, Texas. However, as 16 of the 18 sites contain burned rock middens, and as these middens are the primary feature type used to argue that these 16 sites are potentially eligible for nomination both to the National Register of Historic Places and as State Archeological Landmarks (see Wormser and Sullo-Prewitt 2001), much of the current report focuses on documenting and understanding these feature types.

The report is divided into two volumes. Volume 1 contains 12 chapters while volume 2 provides supporting documentation. In the current volume, Chapter 2 provides an overview of the natural setting of the project area. Chapter 3 provides archaeological background for the project, including a short review of previous work on burned rock middens in Texas. Chapter 4 outlines the research perspective that governed the testing, and includes several research issues that are considered in subsequent chapters. The fifth chapter outlines the field and laboratory methodology, while Chapter 6 
Table 1-1. Selected Characteristics of 18 Tested Sites on Camp Bowie

\begin{tabular}{|c|c|c|c|c|c|}
\hline $\begin{aligned} \text { Site \# } \\
\text { 41BR }\end{aligned}$ & Site Type & $\begin{array}{c}\text { Elevation } \\
\text { (feet) }\end{array}$ & Age & $\begin{array}{c}\text { \# of Burned } \\
\text { Rock Middens } \\
\end{array}$ & Additional Comments \\
\hline 65 & $\begin{array}{l}\text { Burned Rock } \\
\text { Midden }\end{array}$ & 1380 & $\begin{array}{l}\text { Unknown, } \\
\text { Historic }\end{array}$ & 1 & Ring midden. \\
\hline 87 & $\begin{array}{l}\text { Burned Rock } \\
\text { Midden }\end{array}$ & 1350 & Unknown & 1 & Large, flat midden. No surface artifacts. \\
\hline 228 & $\begin{array}{l}\text { Burned Rock } \\
\text { Midden }\end{array}$ & 1480 & Late Archaic & 2 & $\begin{array}{l}\text { Dense surface artifacts. Mortar holes. } \\
\text { Located in saddle. }\end{array}$ \\
\hline 246 & $\begin{array}{l}\text { Burned Rock } \\
\text { Midden }\end{array}$ & 1340 & Unknown & 1 & $\begin{array}{l}\text { Possible crescent-shaped midden. Artifacts } \\
\text { on ridge above midden. }\end{array}$ \\
\hline 250 & $\begin{array}{l}\text { Burned Rock } \\
\text { Midden }\end{array}$ & 1330 & $\begin{array}{l}\text { Late Archaic, } \\
\text { Late Prehistoric }\end{array}$ & 1 & $\begin{array}{l}\text { Ring midden. Cluster of surface artifacts on } \\
\text { ridges to south. }\end{array}$ \\
\hline 253 & $\begin{array}{l}\text { Burned Rock } \\
\text { Midden }\end{array}$ & 1330 & Unknown & 2 & $\begin{array}{l}\text { One midden flat, one is ring. Surface } \\
\text { artifacts present. }\end{array}$ \\
\hline 261 & Open Campsite & 1330 & Early Archaic & 0 & $\begin{array}{l}\text { Lithics on surface. Pandale points } \\
\text { associated with surface scatter. }\end{array}$ \\
\hline 276 & Open Campsite & 1470 & Late Archaic & 0 & $\begin{array}{l}\text { Lithics on surface. Pedernales and possible } \\
\text { Bulverde points on surface. }\end{array}$ \\
\hline 415 & $\begin{array}{l}\text { Burned Rock } \\
\text { Midden }\end{array}$ & 1360 & $\begin{array}{l}\text { Middle Archaic, } \\
\text { Late Archaic }\end{array}$ & 1 & Possible dome midden. Lithics on surface. \\
\hline 420 & $\begin{array}{l}\text { Burned Rock } \\
\text { Midden }\end{array}$ & 1415 & Unknown & 1 & $\begin{array}{l}\text { Originally thought to have multiple } \\
\text { middens. Surface artifacts present. }\end{array}$ \\
\hline 433 & $\begin{array}{l}\text { Burned Rock } \\
\text { Midden }\end{array}$ & 1460 & Late Archaic & 1 & $\begin{array}{l}\text { Small ring midden. Flakes observed on } \\
\text { surface. Limestone rock. }\end{array}$ \\
\hline 441 & $\begin{array}{l}\text { Burned Rock } \\
\text { Midden }\end{array}$ & 1410 & Late Prehistoric & 1 & $\begin{array}{l}\text { Midden probably bulldozed. Possible Cuney } \\
\text { point base. Surface lithics. }\end{array}$ \\
\hline 473 & $\begin{array}{l}\text { Burned Rock } \\
\text { Midden }\end{array}$ & 1375 & Unknown & 1 & Ring midden. Light lithic scatter upslope. \\
\hline 474 & $\begin{array}{l}\text { Burned Rock } \\
\text { Midden }\end{array}$ & 1385 & Unknown & 2 & $\begin{array}{l}\text { Originally thought to have } 4 \text { middens. } \\
\text { Middens have been bulldozed. }\end{array}$ \\
\hline 478 & $\begin{array}{l}\text { Burned Rock } \\
\text { Midden }\end{array}$ & 1410 & Early Archaic & 1 & $\begin{array}{l}\text { Possible dome midden. No surface artifacts } \\
\text { present near midden. }\end{array}$ \\
\hline 480 & $\begin{array}{l}\text { Burned Rock } \\
\text { Midden }\end{array}$ & 1365 & Unknown & 1 & $\begin{array}{l}\text { Midden partially buried. Sheet midden also } \\
\text { present. High surface density. }\end{array}$ \\
\hline 492 & $\begin{array}{l}\text { Burned Rock } \\
\text { Midden }\end{array}$ & 1390 & Unknown & 1 & $\begin{array}{l}\text { Possible dome midden. No surface artifacts } \\
\text { present. }\end{array}$ \\
\hline 493 & $\begin{array}{l}\text { Burned Rock } \\
\text { Midden }\end{array}$ & 1300 & Unknown & 1 & $\begin{array}{l}\text { Possible dome midden. Some possible } \\
\text { historic material present. }\end{array}$ \\
\hline
\end{tabular}


presents a site by site discussion of the levels of effort as well as a general summary of the results. Chapters 7 through 11 use aspects of that summary to focus on specific research issues dealing with burned rock middens. Chapter 7 discusses the chronology of burned rock middens, while Chapter 8 considers their formation. Chapter 9 investigates subsistence. The tenth chapter focuses on issues of site use, while Chapter 11 considers a number of general issues concerning burned rock middens in Texas, and provides a summary of burned rock midden research undertaken on this project. The twelfth and final chapter provides eligibility recommendations for the 18 sites investigated.

Volume 2 contains ten appendices that provide supporting data. Appendix A provides data on radiocarbon results from the project. Appendix B provides a discussion of faunal material. Appendix C summarizes flotation and macrobotanical results. Appendix D provides information on mussel shell. Appendix E provides scans of projectile points recovered on the project. Appendix F provides scans of selected bifaces and other tools collected from sites. Appendix G provides a geoarchaeological overview of selected sites. Appendix $\mathrm{H}$ provides a discussion of the magnetic soil susceptibility results. Appendix I provides a brief description of human remains encountered at site 41BR253. Finally, Appendix J presents data on burned rock middens in selected counties in Texas. 


\title{
Chapter 2: The Environmental Setting of Camp Bowie
}

\author{
Raymond P. Mauldin and David L. Nickels
}

\section{Introduction}

This chapter summarizes the modern and historic climate, hydrology, soils, lithic resource distribution, and floral and faunal resources of the project area. Several aspects of the modern physical environment, such as broad-scale patterns in soils and lithic resources, can be applied to much of the prehistoric sequence. While modern climate and hydrological data are not directly applicable to most of the prehistoric sequence in the project area, this discussion provides a baseline for considering paleoenvironmental changes that are discussed at the end of this chapter. livestock, have resulted in the extensive alteration of the natural vegetation (Horizon Environmental Services 1992; Wormser and Sullo-Prewitt 2001).

\section{Physiographic Setting}

Physiographically, the area is within the Rolling Plains subdivision (Figure 2-1), with the Edwards Plateau located just to the east, and the Llano Uplift located to the south (see Gould 1975; Nance and Wermund 1993). The terrain of the Rolling Plains is characterized as gently sloping to

The project area is located in north-central Texas, in Brown County, just south of the town of Brownwood (see Figure 1-1). Brown County covers an area of about 615,000 acres (Clower 1980). The major hydrological feature is Pecan Bayou, a river that enters the county from the northwest and cuts across the county, exiting in the southeast into the Colorado River. The Colorado forms the southern boundary of the county.

Located on the Brownwood and Indian Creek USGS 7.5' quadrangles, Camp Bowie serves as a training area for the Texas Army National Guard. The facility is home to a variety of training activities, including tank maneuvers, small arms training, and airdrops (Nature Conservancy of Texas 1996). Roughly 58 percent of the 9,297 -acre $\left(37.62-\mathrm{km}^{2}\right)$ training area is state-owned, with the remaining 3,887 acres (15.73 square kilometers) being owned by the federal government (Wormser and Sullo-Prewitt 2001). The 18 sites tested on this project are located throughout the Camp, with 12 sites on state land and six on federal land. In addition to military training, a variety of other activities, including cattle and sheep grazing, the construction of stock ponds and earthen dams, and support facilities for

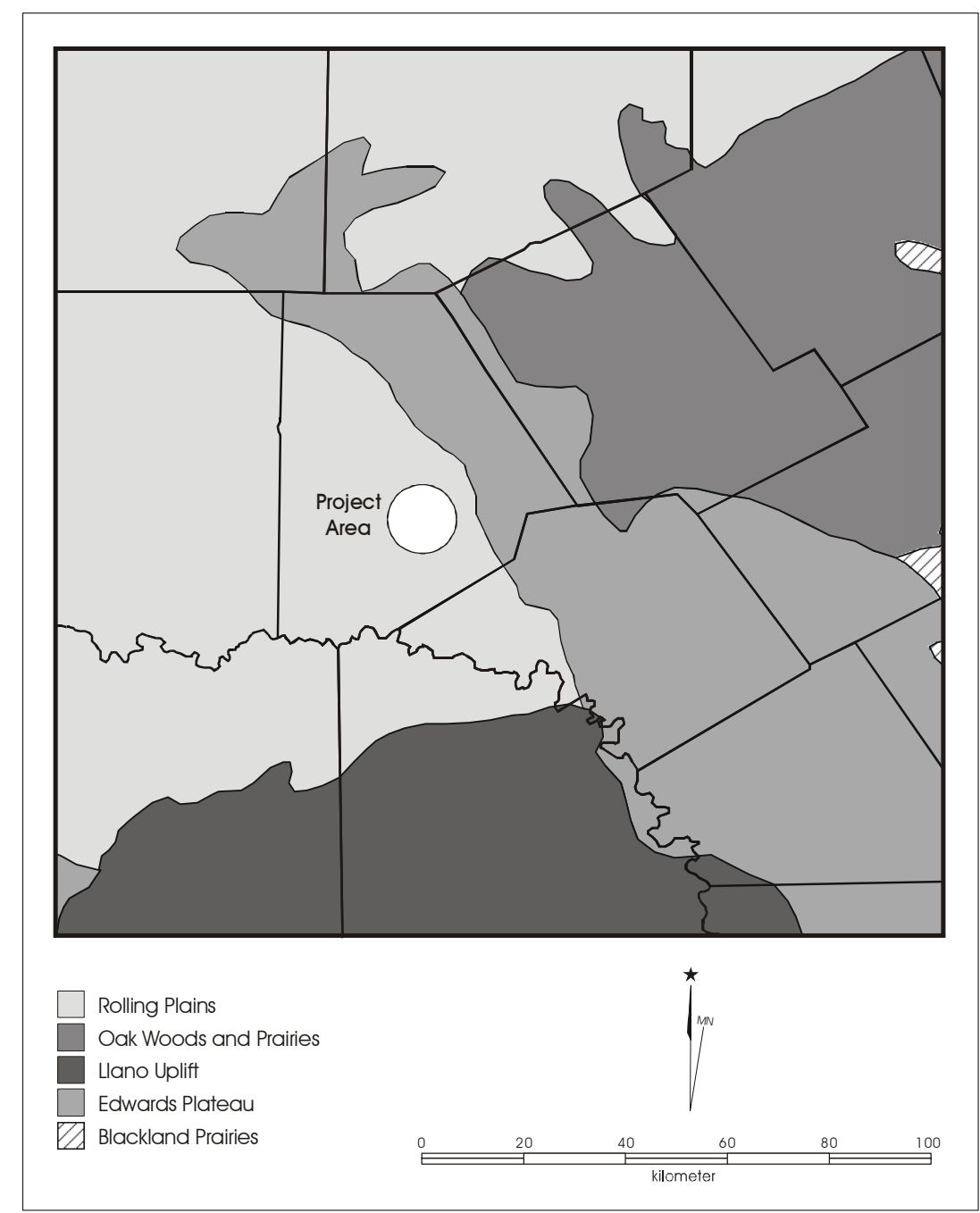

Figure 2-1. Physiographic setting of the project area. 
hilly (Fenneman 1931:54) as a result of varying erosion of primarily Paleozoic rock formations. The Edwards Plateau topography is a more rugged, stream-eroded topography, underlain by Cretaceous limestone. The Llano Uplift is essentially an eroded basin composed of Precambrian granitic and metamorphic rock (Swanson 1995).
Geographically, Camp Bowie is within the Lampasas Cut Plain district. The region is characterized as gently sloping to hilly. Elevations on the camp boundary range from 1,290 feet $(393 \mathrm{~m})$ to just over 1,590 feet $(485 \mathrm{~m}$ ) above mean sea level (AMSL). Figure 2-2 presents the major geological formations within the camp. Holocene age (Qal) floodplain

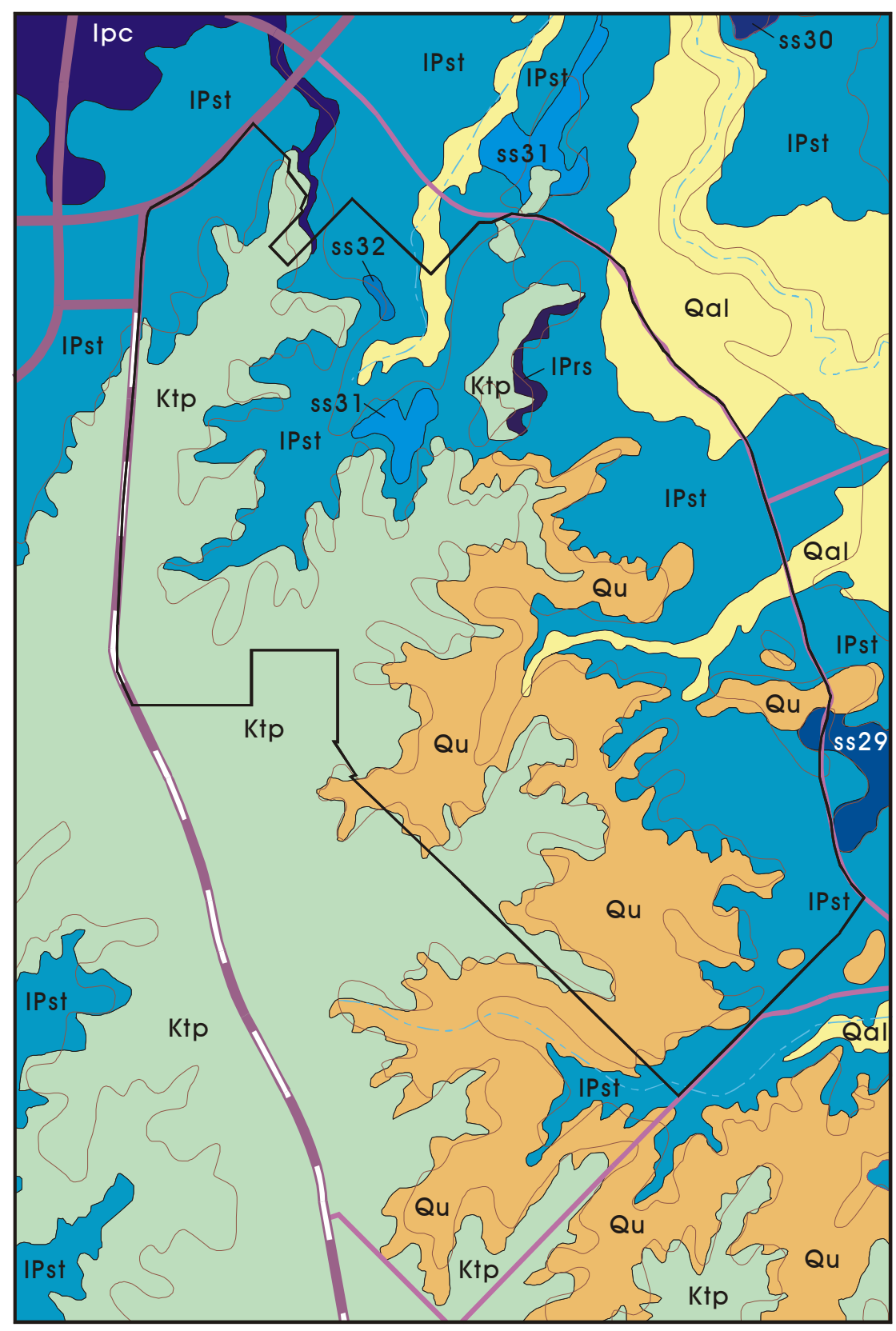

Figure 2-2. Geological setting of Camp Bowie. 
deposits, containing a variety of gravels, are associated with the secondary streams within the camp, as well as the Pecan Bayou floodplain just to the northeast of the project area. The Qu designation denotes Holocene or Pleistocene surficial deposits, which can exceed 50 feet in thickness in some areas. These are primarily limestone, with cherts and some quartz present. The Travis Peak Formation (Ktp), is Cretaceous in age, and contains a variety of materials including conglomerate, sandstone, and limestone. Cherts and quartz are present in the lower part of the formation. Finally, the Strawn Group (IPst) is a Pennsylvanian-age deposit containing sandstone, shale, mudstone, conglomerate, siltstone, and limestone. Several cases of sandstone deposits (e.g., ss32) are present as well (Barnes 1976; see also Drake and Thompson 1893).

\section{Soils}

Very shallow to deep, loamy and clayey soils cover the uplands of Brown County, while deep loamy and clayey soils cover the floodplains (Clower 1980). Figure 2-3 presents the soils within the Camp Bowie boundary. The soils are calcareous sandy loams, silty loams, and clay loams. Upland soils are thin and sandier, with low water holding capacity. Lowland soils tend to be dominated by clay, with low permeability and high water holding capacity (Nance and Wermund 1993; Wormser and Sullo-Prewitt 2001).

Wormser and Sullo-Prewitt (2001) classified the USDA soil units at Camp Bowie into three general groups designed to monitor the potential of the soils to contain buried, potentially intact cultural deposits. The tripartite distinction was based on their evaluation of the soil age and formation history. They suggest that sites on or in the Deleon, Frio, Winters, and Nukrum soils have a moderate-to-high potential for buried archaeological material. Soils with low-tomoderate potential for buried, potentially intact sites include Pedernales fine sandy loam and Sagerton clay loam. The remaining soils have a low probability of containing buried cultural deposits with integrity.

\section{Modern Climate}

Characterized as subtropical subhumid, the climate of the area is one of hot summers and mild winters. Figure 2-4 presents the average maximum and minimum temperatures by month for Brownwood (Bomar 1995:218-221). The average yearly temperature is $65^{\circ} \mathrm{F}$. The growing season averages about 239 days a year, with the average first freeze occurring on November 16 and the last freeze happening on March 21. The coldest temperature ever recorded was $-6^{\circ} \mathrm{F}$ on December 23, 1989, while the warmest temperature was $111^{\circ} \mathrm{F}$ on August 7, 1964 (Bomar 1995). Data from the National Climatic Data Center (NCDC) for Brownwood between January of 1948 and December of 1977 (NCDC 2001) provides additional information on the year-to-year variability in temperature. On average, maximum temperatures during this roughly 30 -year period exceeded $99^{\circ} \mathrm{F} 24$ times a year, and on 50.2 days a year the temperature fell below freezing.

Annual precipitation is approximately 26.1 inches $(66 \mathrm{~cm})$. Figure 2-5 demonstrates that within a year, rainfall tends to be bimodal, with peaks in May and September. December and January are, on average, the driest months of the year (Bomar 1995:229; Nance and Wermund 1993). The highest annual rainfall was recorded in 1959 when 42.3 inches $(107.4 \mathrm{~cm})$ of precipitation, while the driest year was 1954 with only 12.8 inches $(32.5 \mathrm{~cm}$; Nance and Wermund 1993). Figure 2-6, which presents yearly rainfall data from 1948 through 1976 gathered by the NCDC (2001), demonstrates considerable yearly fluctuations. During this period measurable precipitation fell, on average, 58.2 days a year, with 7.3 days a year having rainfall in excess of .99 inches.

\section{Hydrology}

Streams in the Camp Bowie area make up a portion of the Colorado River drainage basin. Pecan Bayou, located to the northeast of Camp Bowie, is the primary river drainage in Brown County. Within the camp boundaries, streams are small and seasonally active. Drainage to the west of the northwest-southeast trending ridge that crosscuts the camp flows into Lewis Creek, a seasonally active stream, and eventually into Pecan Bayou. On the east side of the dividing ridge, drainage is generally into Devils River, another seasonally active stream that eventually empties into Pecan Bayou. Figure 2-7 is a photo of Devils River taken in February of 2001 after several days of substantial rain. While the drainage continued to flow for several days after this photo was taken, Devils River was generally dry during 2000 and 2001. Finally, more than 30 cattle tanks are clearly visible on recent (1995) aerial photos, and water control features are present on all of the primary drainages in the camp. Though no springs were noted on either USGS quadrangle map within the immediate area of Camp Bowie, seasonally active seeps are present within the camp boundaries. 


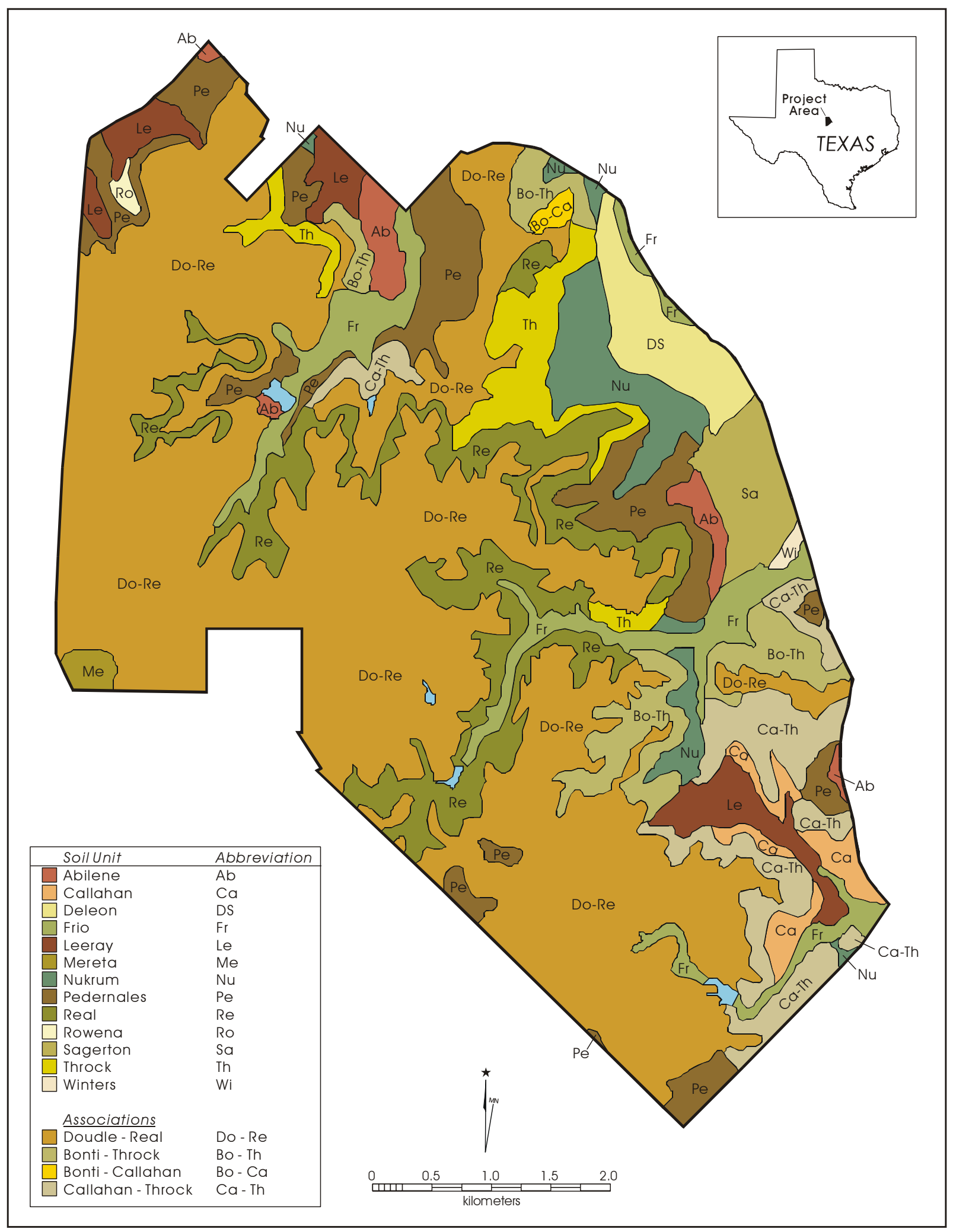

Figure 2-3. Soil units at Camp Bowie. 


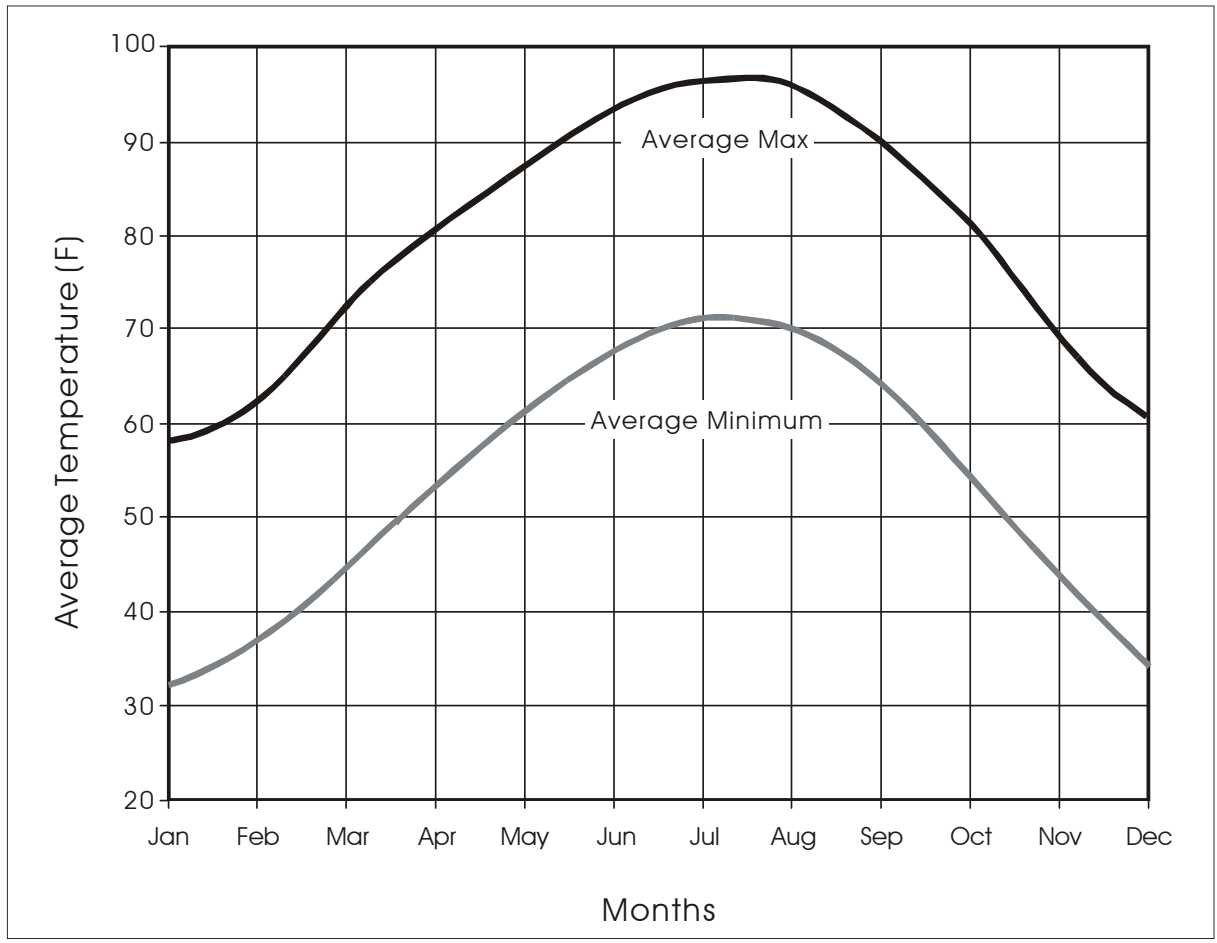

Figure 2-4. Average maximum and minimum temperatures by month for Brownwood.

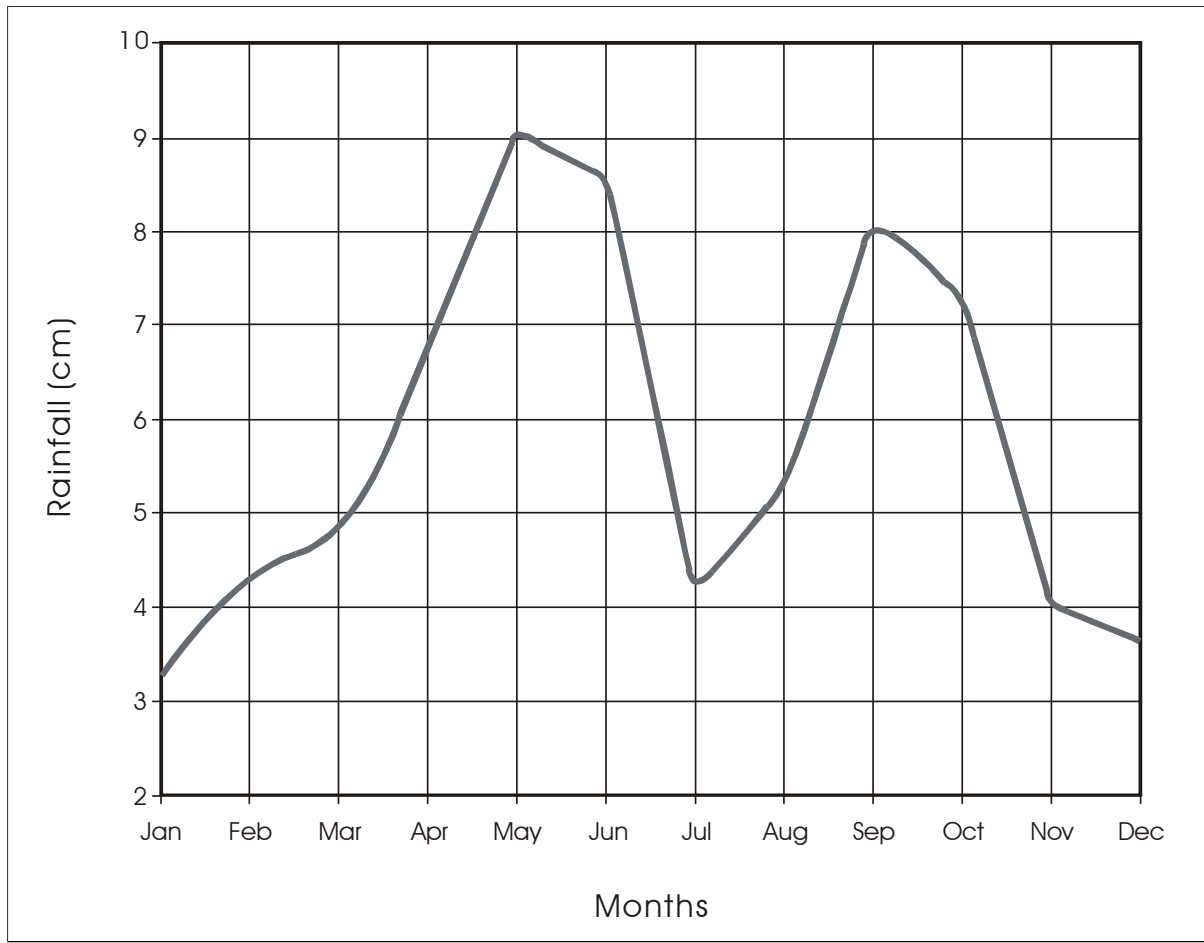

Figure 2-5. Average rainfall by month for Brownwood. 


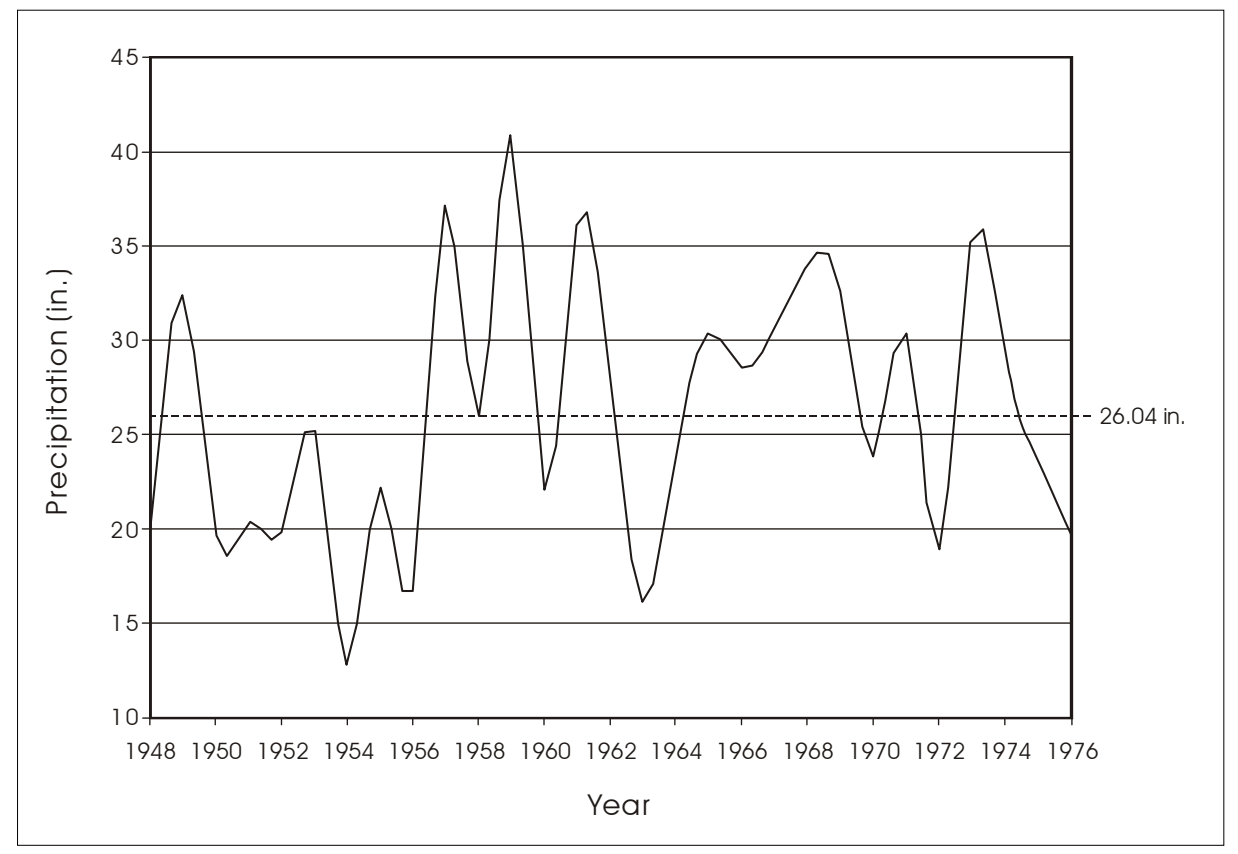

Figure 2-6. Yearly rainfall data from 1948 through 1976 gathered by the National Climatic Data Center.

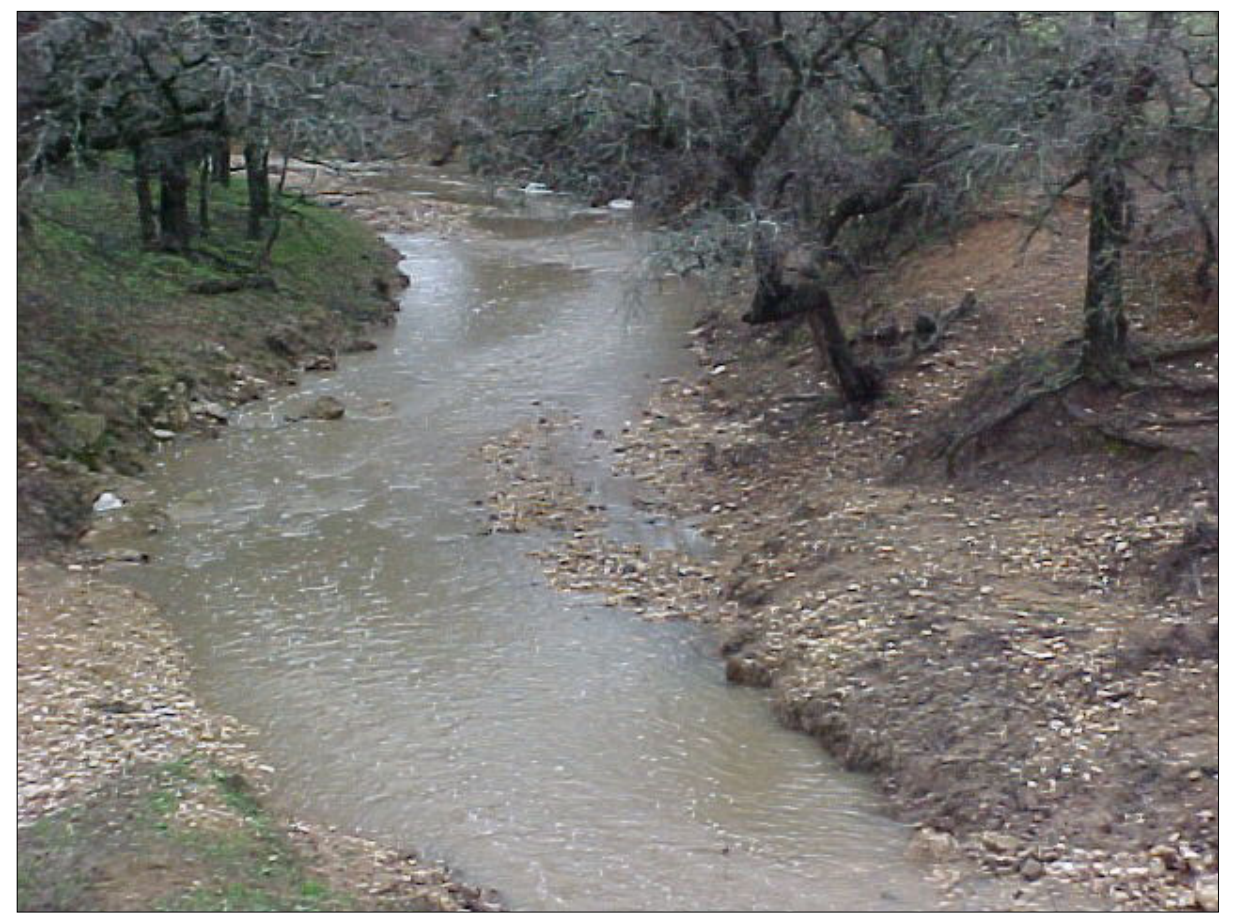

Figure 2-7. Photo of Devils River taken after several days of substantial rain in February of 2001 . 


\section{Flora and Fauna}

Figure 2-8 presents the regional, modern vegetation of the general area. A Live Oak, Mesquite, Ashe Juniper Parkway dominates the southwestern portion of the county, with an Oak, Mesquite, Juniper Parkway bracketing the Pecan Bayou drainage area. Silver Bluestem and Texas Wintergrass are present along the eastern edge of the county.

A biological inventory of Camp Bowie, prepared by Texas Parks and Wildlife (TPW 1994), provides an extended discussion of both plants and animals observed, or expected to be present, at Camp Bowie. The extant plant communities appear to have been altered by a variety of land uses, including attempts to increase grass cover for livestock. Much of the area can be characterized as a Live OakMesquite-Ashe Juniper community. Major tree and shrub species present include a variety of oaks, ashe juniper, mesquite, pecan, cedar elm, American elm, lotebush, and whitebush. Grasses, including Texas grama and buffalo grass, with a variety of cacti are also present. Major mammalian fauna include white-tailed deer, jackrabbit, and cottontail (Adjutant General's Department 1992; TPW 1994; The Nature Conservancy of Texas 1996).

\section{Paleoenvironment}

Recent research, particularly during the past decade, has contributed immensely toward understanding the paleoenvironment of the state (e.g., Bousman 1998; Brown 1998; Caran 1998; Frederick 1998; Fredlund et al. 1998; Kibler 1998; Ricklis and Cox 1998). These studies continue to refine and complicate the larger context of Late Quaternary climatic change. Unfortunately, the paleoclimate of Texas contains significant gaps primarily due to the scarcity of deep, finely stratified, and well-dated deposits (Stahle and Cleaveland 1995:51), as well as uneven history of work across the state. Nowhere are these gaps more apparent than in the immediate study area. Consequently, this section relies on information taken from a variety of studies located primarily to the east and south of the current project, along with data from the Southern Plains.

For this study, we use a number of different data sets, including pollen, phytolith, geomorphic, oxygen isotope, and faunal data, in an attempt to document aspects of the paleoenvironment from the close of the Pleistocene until the modern era (Figure 2-9). Each of these data sets monitors climate and vegetation changes at varying spatial and temporal scales. In addition, each data set has specific problems associated with preservation, sampling, chronological control, and interpretation. A detailed review of the problems and prospects associated with each specific data set is beyond the scope of this chapter, and several excellent discussions are available (e.g., Bousman 1998; Collins 1995; Hall and Valastro 1995; Johnson and Goode 1994).

\section{Late Pleistocene (ca. 18,000-10,000 BP)}

In Central Texas, pollen spectra from Boriack Bog (Figure 2-9) suggest a shift from grasslands before 16,500 BP (BP; years before 1950) to woodlands before $12,500 \mathrm{BP}$ in a moist and cool climate (Bousman 1994:79). The same spectra reveal a decline in spruce (probably cold-adapted) pollen by $15,000 \mathrm{BP}$, indicating a trend toward a warmer climate. Bousman's (1992) oxygen isotope evidence from South Texas complements the bog pollen data and suggests early warming by $15,000 \mathrm{BP}$.

Toomey et al. (1993) argue that evidence from Hall's Cave in the Edwards Plateau in Central Texas (Figure 2-9) indicates summer temperatures in the Late Pleistocene were $6^{\circ} \mathrm{C}$ cooler than present averages, and that by $13,000 \mathrm{BP}$ (or 12,500 BP [Toomey and Stafford 1994]) the wetter interval became warm and more arid. Between 12,500 and $11,800 \mathrm{BP}$, the Boriack Bog data indicate that a drier episode stimulated a brief shift to grasslands, corroborated by oxygen isotope ratios showing a cooler setting in South Texas (Bousman 1992, 1994:80). The Hall's Cave record indicates a wetter interval around 11,000 BP (Toomey and Stafford 1994).

Recently, Camper (1991) has reanalyzed Patschke Bog, a Central Texas bog near Boriack Bog (Bousman 1994, 1998) that was originally investigated by Potzger and Tharp (1943, 1947). The samples presented by Camper appear to represent a continuous, and relatively well-dated sequence stretching back to 17,000 BP. However, as Bousman (1998:207-208) notes, the Patschke data have significant frequencies of local marsh taxa, such as alder (Alnus) and Cyperaceae, which make the identification of regional changes difficult. In an attempt to clarify the pattern of regional change indicated at Patschke Bog, we reviewed the raw pollen grain counts from Patschke Bog (Camper 1991). While Bousman (1998) is correct in noting the high level of marsh taxa throughout the deposits, it appears that Camper's grain counts, unavailable to Bousman in 1998, are extremely high. Average counts are just over 370 grains per level, and none of the 51 separate levels has a count lower than 270. It is therefore possible to eliminate the marsh taxa pollen for 


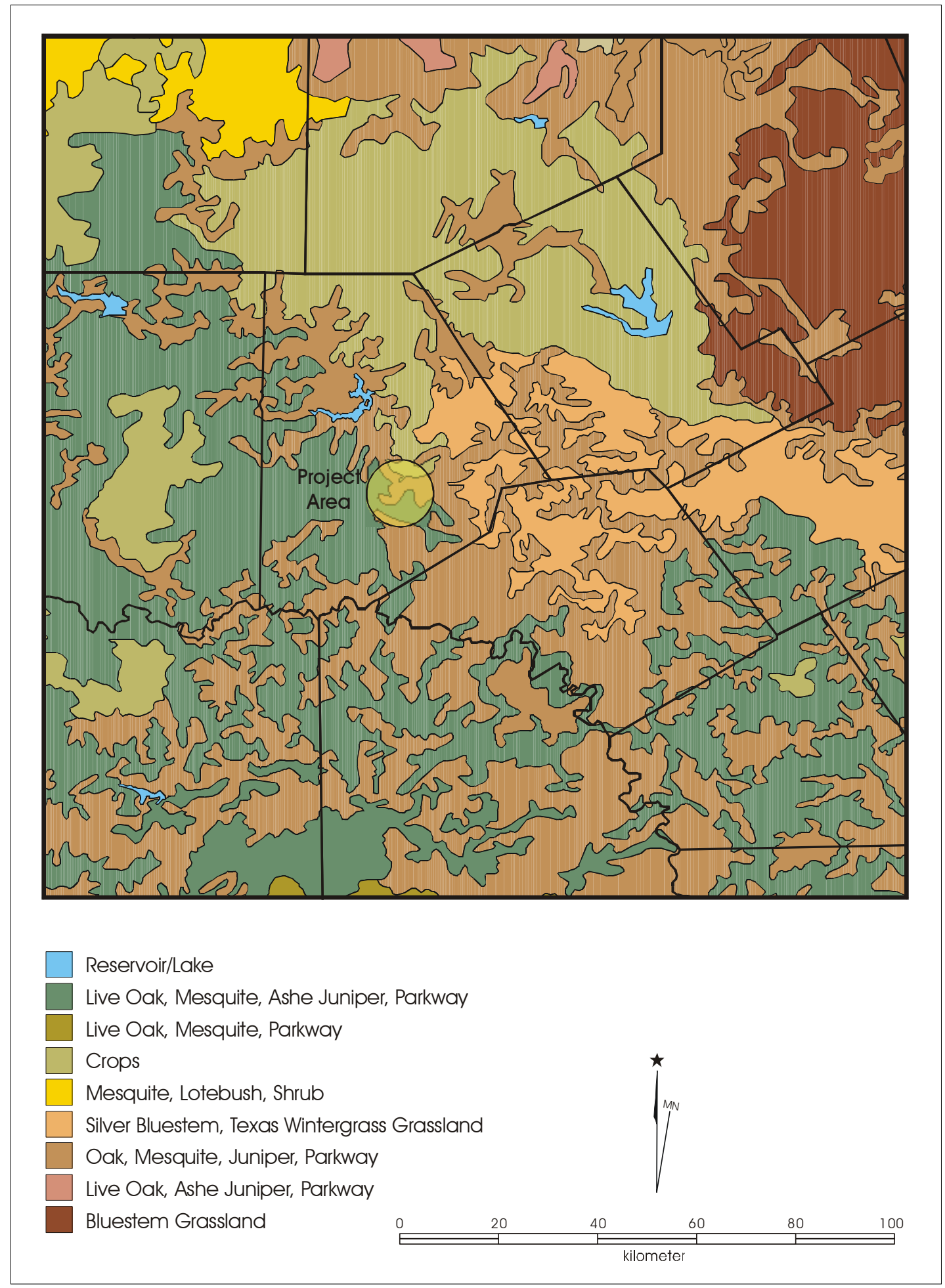

Figure 2-8. Vegetation map of the general project area. 
Patschke Bog, an exercise that results in an average sample size of just over 215 grains per level with more than 50 percent of the levels having sample sizes above 200. Only in three cases do the revised counts drop below a sample of 100 grains, and in each of these low sample cases, adjacent levels with higher pollen frequencies support the overall pattern revealed by the low sample levels.

While a complete examination of the potential of these data are beyond the scope of the present chapter, Figure 2-10 lists the revised percentages for grass (Poaceae) taxa for Patschke Bog, as well as the grass percentages for Boriack Bog with major contaminants removed (Bousman 1998). An examination of the figure shows good correlation with
Bousman's (1998) summary, especially in light of the fact that the dating of the sediment core analyzed from Boriack Bog (Core 1) is based on four radiocarbon dates from an adjacent core (Bousman, personal communication 1999). The Patschke Core 4 samples are supported by four radiocarbon dates from that core, and by additional dates from Core 2 located less than two meters away from Core 4 (Camper 1991:31).

The Patschke pollen sequence (Figure 2-10) suggests that between roughly $17,000 \mathrm{BP}$ and $15,500 \mathrm{BP}$, a cool grassland environment may have been present. After 15,500 BP, a rapid decline is indicated which reaches a low at roughly 14,000 $\mathrm{BP}$. While there is a brief spike in grass percentages around

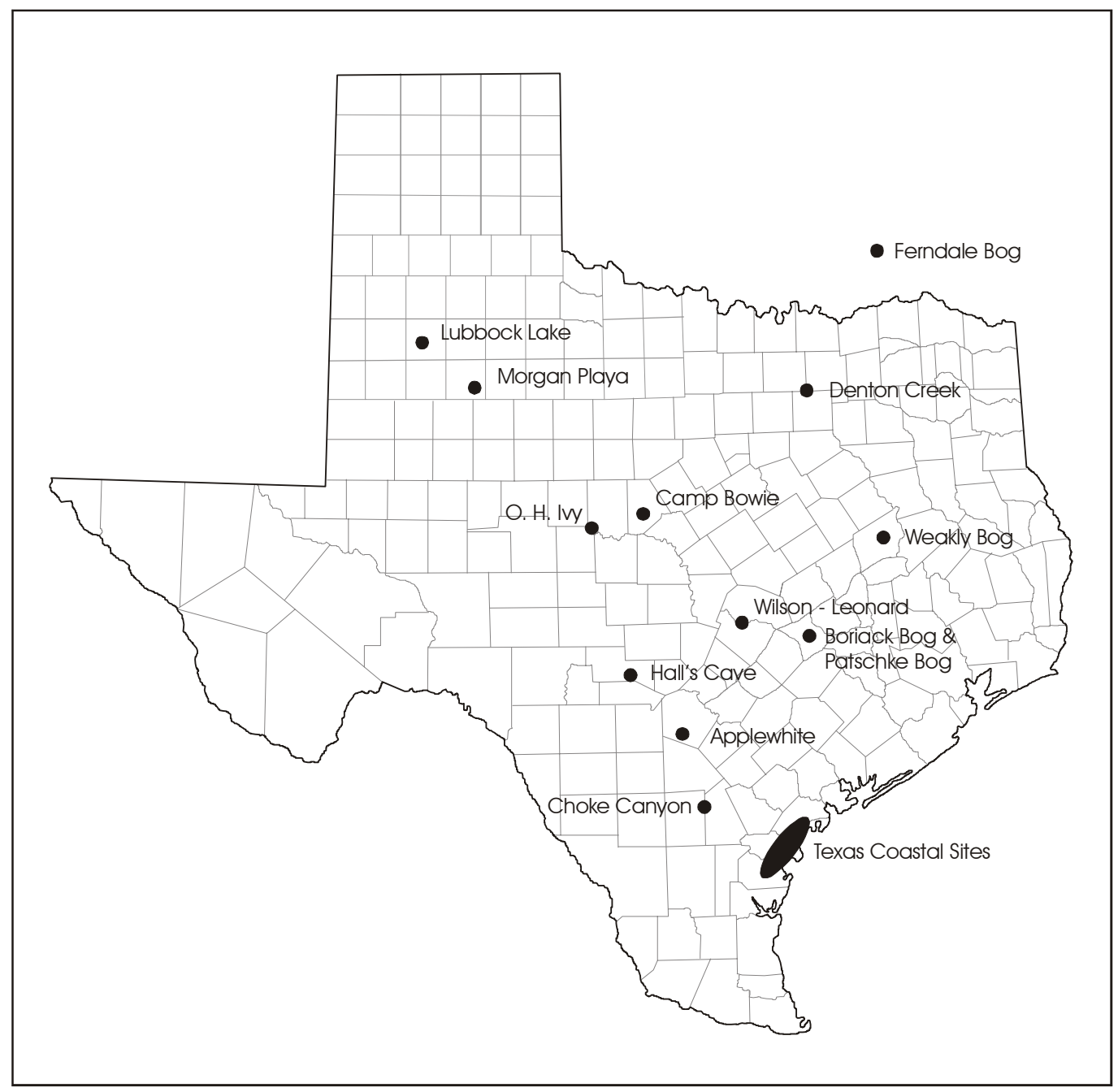

Figure 2-9. Paleontological and archaeological sites discussed in the text. 


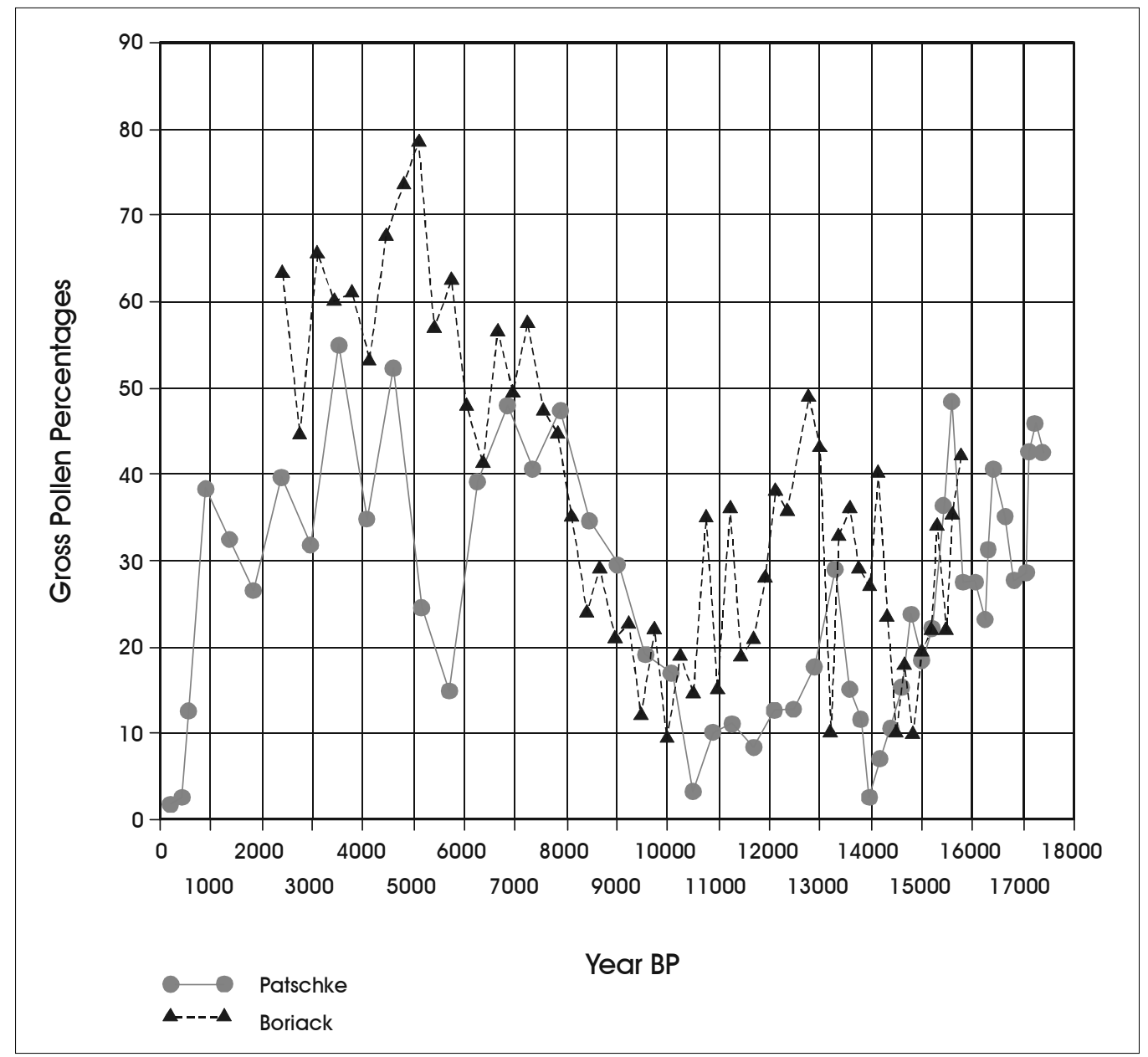

Figure 2-10. Poaceae pollen percentages for Patschke and Boriack Bogs.

13,200 BP, low grass frequencies are present until roughly $10,500 \mathrm{BP}$. Though not shown in the figure, pollen from cold-adapted arboreal species such as spruce (Picea) are not present in the Patschke sequence after about 8000 BP, and are not frequent after the Late Pleistocene.

\section{Early Holocene (ca. 10,000-8000 BP)}

Pollen samples from the Llano Estacado and the dry caves of the trans-Pecos region prompted Bryant and Shafer (1977:15-19) to suggest a gradual warming and drying trend throughout the Holocene (after about 10,000 BP). Others, including Aten (1979) and Gunn and Mahula (1977), use data from Oklahoma and eastern Texas to propose a more variable change from the colder, wetter Pleistocene to the modern climate.
Innovative research in opal phytolith analysis from archaeological sites on the Coastal Plain of South Texas (Figure 2-9; Robinson 1979) also show that, at least since the Early Holocene, climatic change has been highly variable. Climatic fluctuations in the Holocene are also suggested by Bousman (1998), based on the Boriack and Weakly Bog data from Central Texas (Figure 2-9). Toward the Pleistocene-Holocene boundary at about 10,000 BP, arboreal species in the Boriack Bog spectra show a return of woodlands by $9500 \mathrm{BP}$, followed by their decline and a reestablished predominance of open vegetation communities. Woodlands, reestablished by $8750 \mathrm{BP}$, were replaced by grasslands by 7500 BP (Bousman 1994:80). The gradual warming trend is supported by the consistent increase in grass pollen at Patschke (Figure 2-10). Robinson (1979:109) associated his oldest phytolith sample, although 
poorly dated, with a late Paleoindian or Pre-Archaic period and suggested an age of about $8000 \mathrm{BP}$. The predominance of tall grass species, white oak phytoliths, a generally high frequency of other tree species (unidentifiable), and the generally small size of the grass phytoliths indicated a wet environment. Fossil pollen counts from Ferndale Bog in southeastern Oklahoma (Figure 2-9) indicate grasslands were predominant in that area and in East Texas around 11,000-8000 BP (Bryant and Holloway 1985). Analysis of opaline phytoliths recovered from Zone A in Morgan Playa (Figure 2-9) on the Rolling Plains of northwest Texas (Garza County) indicate a higher than expected percentage of $\mathrm{C} 3$ grasses, with $\mathrm{C} 4$ tall grasses present, suggesting a wetter (ca. $10 \mathrm{~cm}$ of annual rainfall) environment than today. Zone A represents an approximated period between the Early Holocene and 7900 BP (Fredlund et al. 1998).

\section{Middle Holocene (ca. 8000-4000 BP)}

The continuous decline of the woodlands in the Early Holocene was briefly checked around $6000 \mathrm{BP}$, but resumed its slide until $5000 \mathrm{BP}$ when arboreal pollen slowly increased with the appearance of a wetter climate (Bousman 1994:80). This mid-Holocene arid period indicated at Boriack Bog agrees with data presented by Nordt et al. (1994) from the Applewhite project near San Antonio (Figure 2-9), where a dry period for roughly the same time frame $(6000-4800$ BP) is indicated. Humphrey and Ferring (1994) discovered the same arid episode in north-central Texas, but with greater duration (6500-4000 BP), agreeing with the revised interpretation from Hall's Cave for an arid episode between 7000 and 2500 BP (Toomey and Stafford 1994). Johnson and Goode (1994) report a later occurrence between 5000 and $2500 \mathrm{BP}$ (calibrated). The opal phytolith records from the Wilson-Leonard site (Figure 2-9) in Central Texas (Fredlund 1994), and two sites on Coleto Creek in South Texas (Robinson 1979:111), agree with increasing aridity in the Middle Holocene, indicated by spreading grasslands around $4400 \mathrm{BP}$ and ca. $4500 \mathrm{BP}$, respectively. However, a sample from slightly higher in the Coleto Creek strata with roughly the same age argues for a quickly appearing, yet brief, wet episode (Robinson's [1979:111] Sample 4), followed by a return to an arid climate up to ca. $2750 \mathrm{BP}$. Grass pollen data from Patschke suggest a grassland setting for the Middle Holocene, but with a marked, brief decline between 6000 and $5000 \mathrm{BP}$, hinting at a wetter interval.

Phytolith analysis of sediments from the Choke Canyon project (Figure 2-9) adds to the claim of considerable climatic variability (Robinson 1982:597-610). Between
5300 and 4300 BP, Robinson (1982:598) infers a cool, mesic climatic regime that shifts to a more arid period and then returns to conditions both cooler and wetter than today's by 3250 BP. Fredlund et al. (1998) see significantly more moisture present during the period 5600-7900 BP than today in the form of $\mathrm{C} 4$ tall grasses from opaline phytoliths at Morgan Playa, northwest Texas. However, between ca. 5600 and 600 BP, Fredlund et al. (1998) have identified an increase in the presence of $\mathrm{C} 4$ short grasses that are characteristic of a more xeric (ca. $5 \mathrm{~cm}$ of annual rainfall) and slightly warmer environment than exists in modern times. Fossil pollen counts from Ferndale Bog are again used to infer the Middle Holocene environment of East Texas. Although not supported by fossil pollen, Bryant and Holloway (1985:55) believe that percentages of taxa such as oak, sweetgum, and pine, which adapt to drier conditions, may have increased. As the grasses and weeds decreased, oak, which was present at the end of the late-glacial period, has steadily increased. Percentages of sedge pollen, which thrives in moist environments, also began to increase with the decline of grasses and weeds, peaking at around $6500 \mathrm{BP}$, dropping off slightly, and then peaking again a few hundred years ago (Bryant and Holloway 1985:55).

\section{Late Holocene (4000-0 BP)}

There are indicators that climate continued to fluctuate in the Late Holocene. Nordt et al. (1994) suggest a warm and dry episode between 3000 and 1500 BP based on stable carbon ratios from deposits at Applewhite Reservoir. Toomey and Stafford (1994) see a wet period appearing about $2500 \mathrm{BP}$ at Hall's Cave. Their observations agree with those of Robinson (1979:112), suggesting a very wet episode. Ricklis and Cox's (1998) study of oyster growth patterns on the Texas Gulf coast (Figure 2-9) tentatively implies a shift to a cooler climate at ca. $3000 \mathrm{BP}$, emerging out of a much warmer Middle Holocene. The Gulf Coast data tend to agree with the Choke Canyon analysis that points to mesic conditions (similar to today's) by $2450 \mathrm{BP}$ (Robinson 1982:598-599). Afterward, a shift to more xeric conditions occurred by $1000 \mathrm{BP}$, but Robinson suggests that they may have been more mesic than modern conditions. The predominance of short grass species agrees with large quantities of bison remains documented in archaeological context at Choke Canyon (Robinson 1982:599). Grass pollen frequencies in the Boriack and Weakly bog pollen spectra indicate drying episodes at 1600-1500 BP and 500-400 BP (Bousman 1994:80). Data from Patschke suggest a fluctuating but generally dry period early in the Late Holocene, with accelerated mesic conditions after about 
1000 BP. Studies of eolian dune sediments west of Big Spring in northwest Texas (Frederick 1998) and near Lubbock in the Panhandle (Holliday 1985), along with eolian deposits in Boren Rockshelter (Figure 2-9) southeast of Lubbock (Kibler 1998), suggest a dry period occurred in the region between 1300 and $800 \mathrm{BP}$.

Brown (1998) demonstrated that the mean oxygen isotope values $\left({ }^{18} \mathrm{O}\right)$ for freshwater mussel shells from Denton Creek (41DL270) in north-central Texas (Figure 2-9) can be used to make general inferences about past air and water temperatures, rainfall, and evaporation. Isotope values occurring in mussel shells from dated contexts suggests a cool and wet climate around $3500 \mathrm{BP}$, a warm, dry climate around $2850 \mathrm{BP}$, then cooling off and becoming wetter between 2500 and $1500 \mathrm{BP}$, and finally, a warming trend occurring after 1500 BP (Brown 1998:164). The conclusions reached from Brown's study of freshwater mussels are generally comparable to those of Humphrey and Ferring's (1994) study of soil carbonate stable isotopes. The carbon isotope data from north-central Texas indicates that between 4500 and 2000 BP the climate was moist, but began drying by $2000 \mathrm{BP}$, and for the next 500 years the area was much drier. However, around $1500 \mathrm{BP}$ another shift occurred, and after $1500 \mathrm{BP}$ the climate again returned to wetter conditions. Data from Ferndale Bog suggests oaks and pines, which adapt to drier conditions, peaked around 700 years ago, dropping in quantity slightly through the present, while sedges have increased significantly in the past few hundred years (Bryant and Holloway 1985).

\section{Summary}

A consideration of the previous discussion suggests that the paleoenvironment of Texas is quite varied. While, in part, this variability may reflect problems with comparing different proxy data sets that measure different aspects of climate at varying spatial and temporal scales, as well as problems with the temporal assignment of particular samples or sequences, the variability may be real, especially during certain periods. This point can be seen in Figure 2-11, a summary of climate patterns suggested by four different data sets. The figure includes two faunal data sets as relative indicators of xeric and mesic conditions. The first data set uses Dillehay's (1974) presence/absence data for bison in the Central Texas and Southern Plains area (see also Collins 1995; Creel et al. 1990; Hurt 1980) as well as faunal material from Hall's Cave reported by Collins (1995). In addition, two pollen data sets, the frequency of grass pollen taken from the revised counts at Patschke Bog, and the arboreal pollen frequencies taken from the second counts at Boriack Bog with potentially local marsh taxa removed are represented (Bousman 1998). While a variety of other data sets are available, these four were selected because they span much of the 12,000 years of interest and are only reflective of two different data types, pollen and fauna.

At a general level, there is good agreement between these four different data sets, especially for the period before 4000 BP. There are also periods throughout the sequence where differences are present. The waning of the Pleistocene clearly marked a transition from a cooler, wetter environment to one that steadily grew warmer and drier. All four data sets indicate that much of the Early Holocene was relatively mesic. The Middle Holocene is generally warm and/or dry, with a brief mesic period suggested sometime between 6000 and $5000 \mathrm{BP}$. Between about 1500 and 750 years ago, all three available data sets hint at a dryer period, while a more mesic interval is suggested by two of the three applicable data sets for the last 750 to 800 years (see Figure 2-11).

In terms of the Camp Bowie area, the impact of these climatic changes on the floral and faunal communities over the last few thousand years is unknown. The impacts of climate change on floral and faunal resources are difficult to separate from changes to the landscape that have been induced by recent and historic human intervention. These changes include the clearing of wooded areas, the pumping of water for irrigation that has lowered water tables, grazing by livestock, and the impacts of military training. 


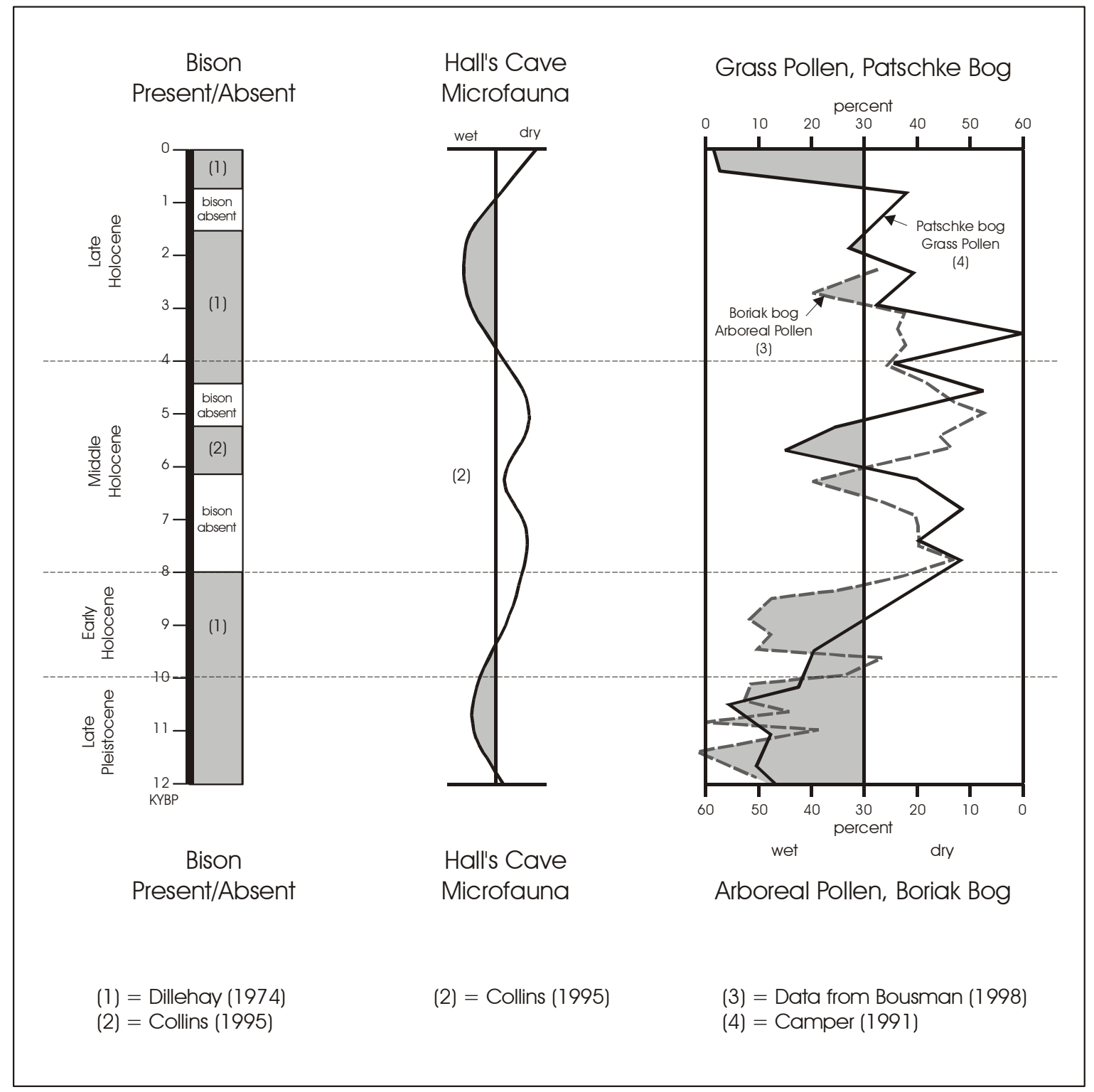

Figure 2-11. Regional climatic indicators for Central Texas. 



\title{
Chapter 3: $\quad$ Archaeological Background
}

\author{
Raymond P. Mauldin, David L. Nickels, and Cory J. Broehm
}

\section{The Cultural Sequence}

The Brown County/Camp Bowie area falls in the northwest corner of the Central Texas archaeological region (Collins 1995; Turner and Hester 1993). The major prehistoric cultural periods defined for this region are briefly described in this chapter. Additional information can be found in Collins (1995) and Johnson and Goode (1994). Wormser and Sullo-Prewitt (2001) and Leffler (2002) provide an overview of the historic period centered on Brown County.

\section{Paleoindian}

The Paleoindian period marks the first appearance of humans in the New World, although the exact date for their arrival is unclear. Traditionally, the Paleoindian period is first marked by the appearance of Clovis points in North America, which in turn are replaced by Folsom points. The later portion of the Paleoindian period $(10,000-8000$ BP) is characterized by a variety of dart points, including Plainview, Dalton, Angostura, Scottsbluff, and Golondrina (Black 1989a, 1989b). Despite changes in these various projectile point types through time, their geographic range is widespread.

Artifacts, particularly projectile points, are often only isolated finds, though camp, lithic procurement, kill, cache, ritual and burial sites are known (Collins 1995). Early Paleoindian peoples have generally been conceptualized as hunter-gatherers ranging over wide areas in pursuit of now extinct megafauna, such as mammoth and Bison antiquus. This view of Paleoindian peoples, much like the dating of this period, is now being reassessed. While they certainly exploited Late Pleistocene megafauna, these peoples are perhaps better characterized as more generalized huntergatherers. Certainly by the later Paleoindian time frame, after the extinction of these megafauna, the hunting aspect of subsistence shifted to exploitation of large herbivores such as deer and Bison bison.

\section{Archaic}

The Archaic period can be broadly defined by changes in projectile point types, an increase in numbers and types of sites (including burned rock hearths and middens), and by an increase in the variety of artifact styles, with many artifacts evidenced by more limited geographical distribution. While a number of finer subdivisions exist for the Archaic (e.g., Prewitt 1981; Weir 1976), this period can be broadly divided into the Early, Middle, and Late Archaic.

\section{Early Archaic}

Collins (1995:383) dates the Early Archaic from 8800 to 6000 BP in Central Texas, with three divisions based on projectile point types, while Hester (1995:436-438) identifies the Early Archaic with Early Corner Notched and Early Basal Notched dart points roughly dating between 7950 to $4450 \mathrm{BP}$. The extinction of large herds of megafauna and the changing climate at the beginning of the Holocene appears to have stimulated a behavioral change by the prehistoric inhabitants of Texas. While the basic huntergatherer adaptation probably remained intact, an economic shift away from big game hunting was necessary. In general, more intensive exploitation of local resources in Central Texas, such as deer, fish, and plant bulbs, is indicated by greater densities of ground-stone artifacts, fire-cracked rock cooking features, and more specialized tools such as Clear Fork gouges and Guadalupe bifaces (Turner and Hester 1993:246, 256). Weir (1976) speculates that Early Archaic groups were small and highly mobile, an inference based on the fact that Early Archaic sites are thinly distributed and that diagnostic projectile point types are seen across a wide area, including most of Texas and northern Mexico. Hurt (1980) suggests that the decline in the number of bison on the plains forced the inhabitants to broaden their diets to pursue plants and animals which would produce the same amount of calories and protein with the same or slightly more effort expended.

\section{Middle Archaic}

Collins (1995:383) defines this intermediate interval of the Archaic as lasting from about 6000-4000 BP in Central Texas. The Middle Archaic appears to have been a time of increased population, based on the large number of sites from this period in South and Central Texas (Story 1985:40; Weir 1976:125, 128). The reasons for this increase are not known, but the amelioration of a very dry period (Altithermal) during the Early Archaic is often seen as the prime mover (Story 1985:40). A wide variation in projectile 
point styles at the Jonas Terrace site suggests "a time of ethnic and cultural variety, as well as group movement and immigration" (Johnson 1995:285). Hurt (1980) posits that the quantity of diversified game animals on the Southern Great Plains decreased, and thus led to an intensified, less broad diet. On the South Texas Plains, exploitation of widely scattered, year-round resources such as prickly pear continued (Campbell and Campbell 1981:13-15), as did hunting deer and rabbit. However, a shift to concentrated, seasonal nut harvests in the riverine environments of the Balcones Escarpment seems to have occurred (Black 1989a, 1989b). Weir (1976) believes that an expansion of oak on the Edwards Plateau and Balcones Escarpment led to intensive plant gathering and acorn processing. He also believes that the widely scattered bands prevalent in the Early Archaic began to coalesce, at least during the acorn-gathering season, into larger groups who shared the intensive work of gathering and processing the acorn harvest (Weir 1976:126).

Bison bone is encountered in archaeological sites in Central and South Texas, at least occasionally, during all but the earliest part of the Middle Archaic (Dillehay 1974). There has been a tendency to equate presence of burned rock middens with absence of bison (Prewitt 1981); however, examinations of several recent faunal reports show that after about 4500 BP bison and burned rock middens are contemporaneous, though not at the same sites, at least in the southern Edwards Plateau and northern South Texas Plain (Meissner 1993).

\section{Late Archaic}

Collins (1995:384) dates the final interval of the Archaic in Central Texas to approximately 4000-800 BP. Hester believes the Late Archaic in South Texas may better be defined as between 2350-1250 BP, while Hofman's (1989:45) synthesis of these data places the Late Archaic on the Southern Plains at 3000-2000 BP, and possibly later. Johnson and Holliday (1986:46) specify 4500-2000 BP as the Late Archaic period on the Llano Estacado. Some researchers believe populations increased throughout the Late Archaic (Prewitt 1985), while others feel populations remained the same or fell during this period (Black 1989a). Prewitt (1981:80-81) asserts that the accumulation of burned rock middens nearly ceased during the course of this period; however, excavations at a number of sites (e.g., Houk and Lohse 1993:193-248; Johnson 1995) provide evidence that large cooking features up to $15 \mathrm{~m}$ in diameter were still very much in use. Subsistence is assumed to have become less specialized during the Late Archaic (Black 1989a:30). Hurt (1980) asserts that bison began returning to the Southern Great Plains area, and we see an increase in intensive processing of bison, as well as mussel shells during the Late Archaic. However, by about 1450 BP, bison had again disappeared (Dillehay 1974).

The proliferation of human cemeteries has been attributed to this period, with the earliest occurrences dating to the South Texas Middle Archaic (Hester 1995:439-440). Cemeteries at Loma Sandia date between ca. 2550 and 2750 BP (Taylor and Highley 1995). Story (1985:44-45) believes the presence of cemeteries at sites such as Ernest Witte (Hall 1981), Hitzfelder Cave (Givens 1968), and Olmos Dam (Lukowski 1988) indicates that Late Archaic populations in Central and South Texas were increasing and becoming more territorial.

A late subperiod or interval of the Late Archaic is frequently referred to as the Terminal Archaic or Transitional Archaic. Weir (1976) defines the Terminal Archaic as 1650-1150 BP, while Turner and Hester (1993) cite data placing the Transitional Archaic as 2250-1250 BP. This Terminal Archaic period is represented by diagnostics such as Ensor, Frio, and Matamoras points which appear to overlap the Late Archaic and Late Prehistoric periods (Hester 1995:442). Weir (1976) believes this marked a transition period characterized by a disappearance of burned rock middens and bison and a reappearance of highly mobile hunters and gatherers. Others (Black and McGraw 1985; Skelton 1977) argue that in some locations burned rock middens did not disappear and sites were more intensely occupied during the Transitional Archaic period. During the Early Neo-Indian period on the Southern Great Plains (ca. 1450-950 BP), Hurt (1980) presents evidence for a decrease in bison processing. This decrease is consistent with Dillehay's (1974) contention that there were fewer bison available in the area due to climatic changes.

\section{Late Prehistoric}

The term Late Prehistoric is commonly used to designate the period following the Late Archaic in Central and South Texas. Collins (1995:385) recognizes that the commonly used date of $1200 \mathrm{BP}$ for the end of the Archaic and beginning of the Late Prehistoric in Central Texas is arbitrary, and Hester (1995:442) acknowledges the problematic issue of selected tools appearing at both Late Archaic and Late Prehistoric sites. A series of distinctive traits marks the shift 
from the Archaic to the Late Prehistoric period, including the technological shift to the bow and arrow and the introduction of pottery to Central Texas and the northern South Texas Plain (Black 1989a:32; Story 1985:45-47). Two complexes following the Late Archaic in the Southern Great Plains region are the Plains Woodland from about 2000-1150 BP, and the Plains Village from 1150-450 BP (Hofman 1989:61-90). Most researchers agree the early Late Prehistoric period was a time of population decrease (Black 1989a:32). Though small burned rock middens associated with Scallorn and Edwards points have been found (Goode 1991:71; Houk and Lohse 1993:193-248), most researchers argue that they are rare. Settlement is increasingly focused on rockshelters such as Scorpion Cave in Medina County (Highley et al. 1978) and Classen Rockshelter in northern Bexar County (Fox and Fox 1967). Cemeteries from this period often reveal evidence of conflict (Black 1989a:32).

Beginning rather abruptly at about $650 \mathrm{BP}$, a shift in technology occurred. This shift is characterized by the appearance of the first ceramics in Central Texas (bonetempered plainwares), Perdiz arrow points, the introduction of blade technology, and alternately beveled bifaces (Black 1989a:32; Huebner 1991:346). Prewitt (1985) suggests this technology encroached from north-central Texas. Patterson (1988), however, notes the Perdiz point was first seen in southeast Texas by about $1350 \mathrm{BP}$, and was introduced to the west some 600-700 years later. Hester (1995:444) recognizes this phase as the "best documented Late Prehistoric pattern" throughout South Texas, with dates ranging between ca. $650 / 700$ to $300 / 350 \mathrm{BP}$.

Steele and Assad Hunter (1986) argue for the occurrence of a distinct change in diet between the Late Archaic and the Late Prehistoric components in two sites in the Choke Canyon Reservoir area in South Texas. Analysis of the number of identified specimens (NISP) shows a marked increase in artiodactyl elements during the late Late Prehistoric, an increase largely due to the addition of bison to the "menu" (Steele and Assad Hunter 1986:468). Huebner (1991) suggests that the sudden return of bison to South and Central Texas resulted from a more xeric climate in the plains north of Texas, and increased grass in the CrossTimbers and Post Oak Savannah in north-central Texas, forming a "bison corridor" into the South Texas Plain along the eastern edge of the Edwards Plateau (Huebner 1991:354355). Sites from this period frequently have associated bison (Black 1986; Black and McGraw 1985; Prewitt 1974).

\section{Previous Research in the Camp Bowie Area}

A review of archaeological literature for the Camp Bowie area produced limited results. Only a handful of excavation projects have been conducted, and with the exception of the recent survey of Camp Bowie (Wormser and SulloPrewitt 2001), few small surveys have been carried out. Archaeological research in the Brown County area dates to the early portion of the twentieth century with the excavations by J. E. Pearce at the Pitman burned rock midden site (41BR3) conducted in 1919 (Campbell 1952; Kirby and Moir 1976). Pearce trenched two middens, both of which appeared to have been ring or crescent-shaped. While both contained large quantities of charcoal and fire-cracked limestone and a few fragments of bone and shell, it appears that neither midden contained any tools (Campbell 1952).

Between the early work of Pearce in 1919 and the 1970s, no substantial archaeological investigations seem to have occurred in Brown County. Beginning in the early 1970s, a series of survey projects were conducted, including two surveys by Texas A\&M University (Shafer et al. 1975a, 1975b), a survey of Cordell and Camp Bowie City Park Sites in Brownwood completed by Kegley and Black (1978), a survey by Southern Methodist University along Pecan Bayou north of Brownwood (Kirby and Moir 1976), and a survey by Prewitt and Associates for the City of Brownwood sanitary landfill site (Prikryl 1983). All of these surveys consistently recorded lithic scatters and burned rock features, including the presence of large ring and domeshaped middens.

In 1975, as part of an archaeological assessment, Shafer et al. (1976) report on the excavation of a burned rock midden at 41BR72. Eight units were excavated during the 1975 work. While lithic artifacts were recovered, no bone or identifiable charcoal was noted. The midden was described as mounded in form, and no central pit or depression was noted.

In 1979, the Texas Archeological Society Field School was located near Cross Cut in the far northwest corner of Brown County. A short summary of that work, edited by Hoffrichter and Davis (1981), suggests that some level of testing was conducted on thirteen different sites, five of which had burned rock middens. Three ring middens, at sites 41BR9, 41BR104, and 41BR109, and two "mound" middens, at 41BR105 and 41BR110, were tested. A review of the excavation summaries at these sites suggest that the 
overall recovery of artifacts was low, and several summaries suggest the presence of scattered charcoal and mussel shell in the middens.

In 1986, Espey, Huston \& Associates conducted testing at 41BR313 and 41BR314 (Gearhart and Voellinger 1986), two sites originally documented by Prikryl (1983) as a result of the sanitary landfill survey mentioned previously. A total of four $1-x-1-m$ units was excavated at these two sites. Testing did not reveal stratified deposits, and no additional work was conducted.

Prior to the 1993-1998 inventory survey of Camp Bowie (Wormser and Sullo-Prewitt 2001), little systematic work had been conducted on the installation. A portion of the area surveyed on the Brownwood Laterals Watershed Survey, conducted by Texas A\&M in 1975 (Shafer et al. 1975b), was acquired by the Texas Army National Guard (TXARNG). Three sites (41BR65, 41BR66, and 41BR68) were incorporated into Camp Bowie as a result of that acquisition. In addition, Wormser and Sullo-Prewitt (2001) reference small-scale survey work on the Camp conducted by Briggs (1992) as well as two TXARNG staff reports (Wormser et al. 1994, 1997).

TXARNG archaeologists conducted an inventory survey of Camp Bowie between 1993-1998 (Wormser and SulloPrewitt 2001). A total of 186 prehistoric and historic sites was recorded. A variety of prehistoric site types were identified, including open campsites, lithic workshops, lithic procurement sites, and burned rock midden sites. Based on diagnostic artifacts, the prehistoric sites spanned much of the prehistoric sequence, from the late Paleoindian period through the Late Prehistoric. As noted in Chapter 1, 24 sites were recommended for additional investigation. Eighteen of these sites, 16 of which had burned rock middens present, were investigated during the current project. 


\title{
Chapter 4: $\quad$ Background and Research Issues
}

\author{
Raymond P. Mauldin
}

As shown in Table 1-1, 16 of the 18 sites tested during this project have burned rock middens present, and a total of 19 middens was present on these 16 sites. Given the near ubiquity of burned rock middens on the sites tested during this project, a discussion of selected attributes of burned rock midden research is provided. This is followed by a discussion of project specific research issues.

\section{Burned Rock Midden Research}

Burned rock middens have been investigated in Central Texas for close to 100 years. Much of this research has centered on questions of how middens were created, when they were used, and what they represent. A number of excellent reviews of the history of research on these features are available (see Black et al. 1997; Creel 1986; Gearhart 1987; Hester 1994; Howard 1983; Treece 1993). The reader is referred to these sources for additional information on this feature type.

\section{Midden Construction}

J. E. Pearce (1919) provided the first systematic investigation of this feature type. Based on limited excavation, he concluded that these represent "kitchen" middens resulting from a series of fires. "Limestone slabs were probably placed about the fires to keep the fire together and for cooking and boiling water" (Pearce 1919:230). These slabs would eventually fracture. The fractured rock was then "thrown back in a heap and new slabs placed in and about the fire" (Pearce 1919:230). Pearce (1938) subsequently suggested that a single fire was placed on the highest point of the midden, and the resulting mound represented the discard associated with that fire.

Based on work at the Heffington Site, as well as other excavations, Kelley and Campbell (1942) question the model of midden formation proposed by Pearce. Kelley and Campbell (1942:320-322) argued that middens were builtup by the "use and reuse of favored areas for the building of stone-lined hearths." They go on to suggest "hearths seem to have been made by scooping out a shallow pit in the debris of previous hearth linings." This practice resulted in a "complex assemblage of superimposed and intersecting hearths" with no stratigraphy (Kelley and Campbell 1942: 320). Consequently, while both Kelley and Campbell (1942) and Pearce $(1919,1932)$ suggest that burned rock middens were the result of hearth activities conducted on the mounds as such, Kelley and Campbell argue for multiple hearths that intersect in complex ways while Pearce argues for a single hearth that was the central focus of the repeated fires.

The assumption that the middens were the center of generalized activities related to cooking appears to have been commonplace until the late 1960s. Based on excavations at the John Ischy Site, Sorrow (1969) proposed that middens represented "communal dumps" for discarded fragments of hearthstones and other cultural debris. "The burned rock midden was, in fact, part of the site utilized primarily for discarding fragmented hearthstones. The primary living area was not on the midden itself" (Sorrow 1969:51). Hester (1970, 1971), working at the La Jita Site, found areas outside of the midden that contained high artifact density. Like Sorrow, Hester $(1970,1971)$ proposed that these higher artifact density areas were the center of activity, in contrast to the earlier models that assumed that activities were centered on the midden.

This "communal dump" model differed from the earlier "hearth models" of Kelley and Campbell (1942) and the "central cooking model" of Pearce (1919, 1932, 1938) primarily in the location of hearth construction. The communal dump model suggests that hearth construction was elsewhere, with the rock and other cultural debris being discarded in the midden, while the earlier models suggest that both activities were occurring at the same location.

Much of the discussion of burned rock midden construction, especially within the last 30 years, has focused on identifying different types of middens that are thought to have different modes of construction. While earlier researchers were certainly aware of these differences (e.g., Kelley and Campbell 1942; Pearce 1938), the primary work on midden typology was produced by Weir (1976). Weir proposed that middens could be classified into four major types. Type 1 middens are "oval and mounded in shape with no surface indication of any subsurface features" (Weir 1976:34). According to Weir, this type is primarily limited to Central Texas, often has high artifact densities, and can frequently exceed 25 meters in diameter. Type 2 middens are a "circular aggregation of burned rock around a central pit" (Weir 1976:35). These middens range in size from roughly 7.5 
meters to just over 15 meters in diameter. The central pit feature may be represented by a slight depression. The middens have a lower density of artifacts, frequently have charcoal present, and occur primarily in the western and northwestern portions of Central Texas. Type 3 middens occur primarily on the western edge of Central Texas and into the Southwest. This type is similar to Type 2, in that a central pit is present dug into the ground, and a smaller ring of rock is present. Finally, Weir's Type 4 middens are simply thin layers of burned rock. These are often referred to as burned rock scatters (Weir 1976:40).

Since Weir's publication, most researchers in Central Texas have made a distinction between Type 1 middens, also referred to as domed middens, and Type 2 middens, referred to as annular or ring middens. That is, a simplified version of Weir's typology was generally accepted as reflecting midden variety. Two different types of middens, possibly with two different construction methods, became the focus of investigation.

For example, Howard (1983) considered the distribution of projectile points within Type 1, or mound middens, in Travis County. Focusing on a burned rock midden at the Booker Site (41TV627), she conducted a series of analyses designed to investigate the "mode of construction." Howard identified four different modes of construction that would implicate the validity of the intersecting hearth model and the central dump. These models were seen as most likely responsible for the formation of Type 1 middens (Howard 1983:8083). After conducting a series of tests, she suggested that "with respect to time, the distribution of projectile points is statistically random" within the midden (Howard 1983:110). Howard (1983) interprets this as support for the "intersecting hearth" model, though acknowledges that other factors, such as turbation or recorder bias, could account for the lack of patterning.

Similarly, several of the authors in a compilation of papers on Texas burned rock middens (Hester 1994) maintain a distinction between Type 1 and Type 2 middens. For example, Collins (1994a:2) notes "it seems clear that there are two functionally different forms of these features. One is domed... and the other is annular...." Prewitt (1994:25), in the same volume, states that burned rock middens "can generally be divided into two categories: domed and annular." The typology of two distinct types of middens, each of which resulted from different uses, appears to be well established in the literature (e.g., Abbott and Frederick 1990; Creel 1986; Gearhart 1987; Quigg and Ellis 1994).
In a review of burned rock midden research, Black (1997) argues that the typology formalized by Weir may not be useful. He suggests that both Types 1 and 2 middens probably represent central focused cooking activities as was originally suggested by Pearce. Specifically, Black (1997; see also L. Ellis 1997) suggests that the primary activities involved the repeated use of these features as ovens. However, Black also expanded a notion, first hinted at by Pearce (1938), that later occupants could use middens, once established, as an occupation surface. These sets of activities would introduce additional material into the midden.

Leach and Bousman (2001 [1998]), following earlier researchers (e.g., Black 1997; Pearce 1938), argue that the most probable scenario for the accumulation of burned rock middens involves their functioning as earth ovens. Repeated use of such facilities, including the cleaning out and discard of broken rock and the addition of new rock, would form a mounded ring. In addition, they suggest that borrowing of sediment from around a midden to form an earthen cap for the oven, coupled with the repeated use of the feature, would result in the incorporation of a variety of artifacts into the midden that are not necessarily associated with the primary use of the feature. While similar to Black's scenario, where some portion of the cultural material recovered from the midden is not related to midden use, Leach and Bousman suggest that earlier material, rather than later material, will be incorporated into the midden as a result of building the earthen cap (see also Black and Creel 1997:280). In the scenario suggested by Leach and Bousman (2001 [1998]), then, the degree to which middens are constructed on top of extant camps is a factor in midden content, as artifacts unrelated to the midden, either temporally or behaviorally, may be incorporated into the midden fill. This scenario has implications for the dating of middens with diagnostics.

\section{Midden Chronology}

In 1919, Pearce began a systematic investigation of middens that involved increased excavation. In 1932 he published a brief description of the cultural chronology based in part on that midden excavation. He noted a segregation of point styles from different levels, with the lower areas of mounds having a "pure hunter type," the middle levels having a "higher hunter type with a great multiplicity of flint implements but without the bow," and the upper levels "representing a much finer culture with the bow and arrow" (Pearce 1932:49). 
Additional support for Pearce's stratification within middens came from Huskey's (1935) work on mound sites in the upper Nueces River. Huskey identified two types of burned rock mounds, with type "A" having three strata that primarily spanned the Archaic period, and type "B" lacking strata, being characterized by "very small arrow and bird points" (Huskey 1935:109). Huskey's observations regarding the dominance of "small arrow and bird points" in some middens has, until recently (e.g., Black and Creel 1997; Goode 1991; Treece 1993), been ignored by most researchers concerned with chronology.

Weir (1976:34-40), relying primarily on associated diagnostic artifacts, suggests that his Type 1 middens probably date between $5000 \mathrm{BP}$ and $2800 \mathrm{BP}$, while Type 2 middens date from about $4200 \mathrm{BP}$ into the Late Prehistoric period. Weir suggests that peak use of Type 2 middens was probably between 2800 and $1800 \mathrm{BP}$. More recently, Prewitt, using diagnostic artifacts supported by radiocarbon dates, argues that most burned rock middens date principally to the period between $5000 \mathrm{BP}$ and $1750 \mathrm{BP}$, with peak use at 4600 and 4000 BP (Prewitt 1981:73-76, 1985). In a subsequent summary, Prewitt (1994:26) concluded "the general age range of central Texas burned rock middens is fairly well established to be middle Archaic, or roughly 5000 to 2250 B.P." He goes on to note "few will question that they [burned rock middens] primarily are middle Archaic in age."

Based on a number of excavations and associated artifacts within burned rock middens, most researchers had argued that these features were predominately built during the Archaic period (see Prewitt 1991; Johnson 1995; Houk and Lohse 1993:193-248), an opinion that was consistent with the notions of Pearce (1932). While there were certainly reports of Late Prehistoric middens (e.g., Goode 1991; Huskey 1935; Lukowski 1987; Treece 1993), these were often considered anomalous rather than characteristic of midden use. Collins (1994b:161-167), for example, notes that Late Prehistoric bone dates from a midden at 41HY209$M$ were "younger than expected" and were unrepresentative of the true period of midden use, judged to be Late Archaic based primarily on diagnostic projectile points. Late Prehistoric material, when encountered in burned rock middens, is often argued to represent a "veneer" over the midden surface. This later occupation is not seen as contributing to the formation of the midden itself (e.g., Ricklis and Collins 1994).
Recently, Black and Creel (1997) have summarized 141 radiocarbon dates from 35 middens on 29 sites located in central Texas. These dates suggest that while middens have radiocarbon dates that cover over 8,000 years, the majority of dates fall within the last 2,000 years, and most appear to date to the Late Prehistoric period. This distribution is substantially different than that suggested by earlier researchers, summarized previously, which was based primarily on the presence of diagnostic artifacts within middens. Black and Creel (1997:273-280) acknowledge the possibility that the overall distribution may be impacted by differential preservation of organic material, thus skewing the distribution towards more recent periods. Nevertheless, in several cases middens containing Late Archaic dart points have radiocarbon dates in the Late Prehistoric period. It is certainly possible that these diagnostic points have been incorporated into the midden deposits, either as a result of recycling of earlier point forms (Black and Creel 1997:280) or, following the suggestions by Leach and Bousman (2001 [1998]) noted previously (see also Black and Creel 1997:280), as part of the earthen cap covering the burned rock oven. In either case, the radiocarbon database is compelling evidence that a significant component of burned rock middens may, in fact, date to the Late Prehistoric time period, though it does not, in itself, rule out earlier use.

\section{Midden Function}

With the increasing use of flotation techniques and more rigorous field methods over the last 30 years, concerns related more directly to what middens were used for have gained prominence in investigations. In this section, arguments related to midden function are reviewed.

Many of the early investigations assumed that the midden deposits represented the remains of generalized cooking activities rather than a focus on any particular food resource. For example, Pearce (1919:230) suggested that the hearth atop a burned rock midden was used for "cooking and boiling water" while Kelley and Campbell (1942:320) suggested that the multiple hearths were used primarily for "baking and roasting." A notable exception to this trend is the work of Wilson (1930:59-61) who suggested that middens were the result of specialized processing of sotol. This suggestion was based on ethnographic accounts of similar features (e.g., Opler 1941) as well as the co-occurrence of sotol and burned rock middens in Wilson's study area. 
Subsequently, other researchers began to focus on individual plant foods as candidates for processing in burned rock middens. Foremost among these has been acorns. The idea that acorns were a primary food processed in burned rock middens was probably first suggested by Hester (1973). Hester noted that many of the major burned rock midden sites were associated with oak groves. Following Hester, Weir (1976) noted that Type 1 middens "may have developed as a result of specialized nut processing," though he also suggests that "animal (deer) processing" was another possibility (Weir 1976:125).

While a number of other researchers have suggested that acorns could have been a primary resource processed in burned rock middens (e.g., Black and McGraw 1985; Gunn and Mahula 1977:279; Turner 1989), Creel, in a series of articles $(1978,1994)$ as well as in his dissertation (1986), presents the most comprehensive study of this possibility. Following earlier suggestions that middens may have played a role in acorn processing, Creel investigated the distribution of Weir's Types 1 and 2 burned rock middens relative to the distribution of oak savanna environments. Creel (1986, 1997) demonstrates a significant relationship between the modern distributions of oak and burned rock middens. In addition, he has considered aspects of past distributions of oak savanna that seem to further support his argument (Creel 1994). Specifically, Creel suggests that Type 1 middens formed from discarded rock used in the stone boiling of acorns. Citing the experimental work of Witkind (1977) and Jones (1980), Creel (1986:127-128) suggests that extensive stone boiling of acorns with limestone would result both in the effective neutralization of tannic acid in acorns (see also Turner 1989:186) and the production of fractured rock. If acorns were extensively used and if stone boiling was used to process acorns, then substantial amounts of broken, altered limestone would be produced. These altered limestone fragments were then deposited in dumps, creating Type 1 middens. Such a scenario fits well with the notion of Type 1 middens as secondary dumps suggested by Hester (1971) and Sorrow (1969). Creel (1986:128) argues that Type 2 middens "may very well have been much used earth ovens for baking bread (and perhaps other foods as well)."

A variety of other suggestions have been made regarding what subsistence items were processed in burned rock middens, including sotol (Wilson 1930), geophytes (Dering 1997), and meat and clams (e.g., Black and Creel 1997). Compilations of ethnobotanical data from burned rock middens by Howard (1991) and Dering (1997) demonstrate that a variety of carbonized seeds and fruit fragments have been recovered from midden contexts. Specifically, remains representing sotol/yucca, prickly pear pads and seeds, geophytes, and acorns have been recovered, with acorns appearing to be the most common item. In addition, a variety of animal remains have been identified in middens, including deer, bison, cottontail, turtle, and mussel shell (see Decker 1997; Neck 1997). Citing this diversity of resources, Black and Creel (1997) suggest that a variety of different food stuffs may have been processed, and that the search for a single group of plants or animals that are consistently processed with burned rock middens may not be productive.

\section{Project Specific Research Issues}

The summary of burned rock midden research suggests a variety of research topics for investigation. During this project, three issues specifically related to eligibility determination were given priority. These three issues concern site integrity, site chronology, and subsistence strategies. In addition to these specific eligibility considerations, we considered two other broad issues, the distributional characteristics of thermal features at a large spatial scale and a variety of issues related to site structure. Each of these topics is briefly considered here.

\section{Site Integrity and Eligibility}

Eligibility determinations are usually phrased in terms of the overall research potential of a site. The integrity of the cultural deposits are a critical variable in that determination, for if the deposits are significantly mixed by either cultural or physical processes, the potential of the assemblage to answer commonly asked questions is frequently seen as degraded. While in part this vision of the archaeological record reflects on our ability to ask questions as well as on our level of methodological sophistication, it is also an outgrowth of a position that views integrity as a dichotomy; sites either have it or they do not. Integrity, and by extension the research potential of a location, is more productively viewed as a continuum. There is no such thing as a "pristine" site. With sufficient temporal resolution, it is probably the case that all sites or assemblages are, to some degree, mixed by cultural and physical processes. The integrity, and by extension the research potential of a location, can only be considered with regards to a particular suite of questions. For some questions, sites at the high end of the integrity continuum are critical, but for other questions, sites that traditionally are viewed as having low integrity, are critical. For example, if our research goals are centered on reconstructing the subsistence patterns during a particular temporal period, sites which have been repeatedly occupied 
by a variety of different groups over thousands of years have low research potential if these occupations cannot be clearly separated. Conversely, single component sites, those traditionally viewed as having high integrity and high research potential, are of less use if our research questions center on understanding processes of reoccupation or processes of long-term change in the use characteristics of a given location.

With this perspective in mind, we consider 1) questions related to the integrity of deposits within the burned rock middens, 2) questions related to the integrity of deposits on the remaining portions of midden sites, as well as in situations of sites without burned rock middens (e.g., 41BR276), and 3) integrity questions related to larger scale issues such as why middens are located where they are, and the overall use history of middens.

For investigating questions such as what items were processed in burned rock features and for determining when that processing occurred, both of which are issues of subsistence and chronology, situations with high integrity are desirable. With regard to burned rock midden features, the "incorporation scenario" discussed previously, in which off-midden deposits are incorporated into middens, must be assessed. Specifically, we must determine the relationship between midden and off-midden deposits. If material within a midden is, in part, a function of capping the rock oven, then testing in the immediate vicinity of these features should reveal artifacts and features such as borrow pits in the area surrounding the midden. Conversely, if the deposits within a midden are related primarily to midden use, then no such deposits should be encountered.

For assessing questions related to off-midden features and deposits on the remaining portions of the sites, it was necessary to conduct off-midden testing. Previous research at these sites (Wormser and Sullo-Prewitt 2001) and observations during CAR's work suggest that the overall density of material is low. We therefore enjoined a strategy of off-midden shovel testing, coupled with limited surface collection, selected 1-x-1-m excavation units, and small backhoe trenches in selected locations. We believe this strategy was sufficient to determine the nature and integrity of off-midden deposits, as well as potentially provide data relevant to chronology, subsistence, and site structure considerations.

Finally, integrity questions related to larger scale issues were considered. For some of our larger scale questions, such as why middens are located where they are, integrity of a particular midden was not a major consideration. That is, even if the midden had low physical and cultural integrity, simply by its presence it could contribute data to exploring these types of questions. However, for questions related to site structure that attempt to link off-midden and midden deposits, integrity issues are again critical. These issues were addressed using the same methodology and data sets outlined above for considering off-midden deposits.

\section{Chronological Issues}

The review of chronology presented at the beginning of this chapter clearly suggests that, at least in some cases, diagnostic artifacts recovered from middens reflect different ages than do the radiocarbon dates. As Black and Creel (1997) note, radiocarbon assays from 35 middens clearly suggest that the primary period of midden use may be at the end of the Late Archaic and into the Late Prehistoric period. This period of use is substantially later than previous researchers have suggested, based on diagnostics (e.g., Prewitt 1981, 1985; Weir 1976). It is certainly possible that these diagnostic points have been incorporated into the midden deposits (see Black and Creel 1997:280; Leach and Bousman 2001 [1998]) as part of the earthen cap covering the burned rock oven. However, dart points would have to be extremely common on such sites to adequately account for the patterns of diagnostics.

It is also possible that earlier uses of the middens are not reflected by charcoal as a result of differential preservation. We investigate this chronological problem by submitting a variety of dates from several different contexts within middens, as well as focusing, where dated material is available, on charcoal deposits in the spoil of the middens rather than the midden core. These deposits are less likely to be disturbed by subsequent use of the central feature. Comparisons of the entire range of radiocarbon dates with diagnostics, both within the midden as well as outside the midden, are also conducted. Finally, where available, we have submitted radiocarbon samples from off-midden contexts. The use of a combination of dating methods, along with careful consideration of the integrity of the selected radiocarbon samples, helps to clarify the chronological placement of middens on Camp Bowie.

\section{Subsistence Strategies}

As with the chronological consideration above, assessing the integrity of both midden and non-midden deposits was a critical first step in linking the deposits both to specific 
feature types and specific temporal periods. Within all burned rock middens, all external features, and a sample of excavation units, we collected matrix samples which, coupled with the results of our screening of all deposits through $1 / 4$-inch mesh, helped form the basis of a comprehensive subsistence study. Specifically, we focused on determining the potential of these various contexts for the recovery of floral and faunal material. If deposits with a known level of integrity and chronometric potential could be identified, and if these deposits also have some level of subsistence remains present, then the site has the potential for investigating both questions related directly to the nature of materials processed in burned rock middens, as well as smaller thermal features, and the nature of subsistence related activities at a larger scale. In addition, the lithic tools associated with these same deposits should provide additional data for the investigation of subsistence activities. It was unlikely, given the scale of testing, that sufficiently large samples of floral, faunal, or lithic tools would be acquired to directly address any of these research concerns. However, our goal was simply to identify and explore the potential of the deposits.

\section{Other Research Considerations}

\section{Site Organization}

A critical component of the research issues considered here involve aspects that can be grouped under the general topic of site organization. By site organization, we specifically refer to investigating the manner in which various components of a site (e.g., burned rock middens, off-midden features, artifact clusters) may be related. A variety of possibilities exist, ranging from a scenario in which burned rock middens are special purpose occupations to a scenario in which burned rock midden sites are residential in nature, with the midden being only one component of a variety of general activities. It is also possible that artifacts and other features on a particular burned rock midden site represent earlier, or later occupations, of the same area. Unraveling which of these various scenarios is operating in any particular case is a daunting task, requiring detailed data from within a site on artifact assemblages represented by surface concentrations and subsurface levels, feature characteristics, chronometric data, and patterning in the location of the site components.

It is possible that ring midden sites represent special activity occupations generated during the short-term procurement and processing of specific resources. Beginning with such an assumption implies that burned rock midden sites should contain a narrow range of artifact and feature types, as well as a small number of artifacts and features, perhaps centered around the immediate area of the burned rock midden. Conversely, it may be the case that burned rock middens are only one component of a more general, residential occupation. Under this position, we would expect midden sites to have a rich and abundant artifact and feature assemblage. Cross-cultural analysis of the organization of activity areas on hunter-gatherer sites indicates that the more intrusive an activity and the greater amount of debris it generates, the more likely that the activity will be located away from the site core. If burned rock midden sites are residential in nature, then it should be the case that middens, which represent intrusive activities that require large quantities of fuel and rock, and generate a great deal of debris, should be on the margins of sites rather than at their center. Finally, it may be the case that these sites are a product of site reuse under changing site functions (e.g., specialized burned rock midden activity sites reoccupied as residential camps). Under this scenario, artifacts and features found away from the midden have no systemic behavioral relationship to the midden itself, but high assemblage richness may be anticipated at the site level.

The likelihood that some combination of these scenarios might exist at any one of the Camp Bowie sites, and the need to identify whether midden sites represent specialized limited activity sites, residential camps with specialized features, or palimpsests derived from reoccupied sites, raised the need to explore both the burned rock midden and offmidden areas of the site. Work at the Culebra Creek Site (41BX126) in Bexar County (Nickels et al. 2001 [1998]), as well as our previous discussion regarding burned rock midden integrity, suggests that the construction of a burned rock midden on a previously occupied living surface can result in the incorporation of artifacts into the midden itself during capping episodes, making off-midden and midden areas appear contemporaneous. However, the lack of artifacts in the midden, but their presence off-midden, does not guarantee their behavioral relatedness. The recovery of datable remains from numerous off-midden features and the comparison of their time spans with dates derived from the midden itself would allow us to tease apart the behavioral relationship between midden and off-midden portions of such sites. Finally, the presence of midden sites with only small quantities of artifacts and very limited assemblage richness may be interpreted as strong evidence for specialized limited activity sites.

With regard to feature characteristics, it is the case that early approaches to understanding the use and formation of burned rock middens focused on the burned rock midden feature 
and its morphological characteristics in relative isolation from other types of heating facilities or thermal features present on the site. More recent approaches (L. Ellis 1997; Wandsnider 1997) to the interpretation of hearths and other burned rock features have shifted to an emphasis on the heat retention characteristics of thermal features. Such approaches allow the consideration of the entire range of burned rock facilities from ring middens to isolated hearths as variants along a continuum. Each feature type is seen as possessing unique heat retention characteristics ideally suited for the preparation of specific classes of food items requiring distinct cooking temperatures and cooking times.

Using this interpretive perspective, we can theoretically link ring middens and other burned rock facilities that may be found on a site into a systemic whole that implicates site structure. That is, it is likely that thermal facilities with different heat retention characteristics exist on the same site, as many different food items may be processed during an occupation. Specific feature types can be identified by reference to general morphological characteristics (e.g., feature size, quantity and characteristics of rock) and then further investigated through paleomagnetic studies of rock designed to reveal firing temperatures (e.g., Nickels et al. 2001[1998]). These different thermal features types, once identified, can then be used to consider associational relationships between ring middens and off-midden facilities and activity areas. The task is complicated by the potential that some of the sites may have been repeatedly occupied, with each reoccupation episode representing different site functions and contributing different features and artifact assemblages to the site.

We assume that if these reoccupation episodes occur in quick succession and by the same group of people, the archaeological record would simply be a summary representation of average land use of the spot. Relative homogeneity in temporal diagnostics, low richness in raw material types, and perhaps technological continuity in reduction strategies and manufacture techniques may be indicative of this type of repeated landscape and site reuse. On the other hand, reuse of the site by distinct cultural groups may yield a broader range of temporal diagnostics, raw material types, and technological variability between artifact clusters. Datable materials and artifact samples from both midden and off-midden locations are critical to investigating which of these various scenarios may be applicable in any given case.

\section{Landscape Considerations}

The previous discussion refers to the interpretation of the variability in thermal facilities and artifact scatters encountered on a site. An additional aspect of each site involves the overall land use system. More precisely, what are the factors that condition the placement of burned rock features across the landscape? This form of inquiry, perhaps best exemplified by the work of Creel (e.g., 1997), requires comparisons at larger spatial scales.

Thermal features such as ring and domed middens represent the use of large quantities of rock, fuel, and packing material, and imply the processing of specific types of food resources (e.g., sotol, acorns, etc.; see Creel 1997; Wandsnider 1997). Of these, rock is the most widely distributed, and probably the heaviest and most labor-intensive resource to procure. Wood for fuel is common, but without the use of axes, it is probable that the primary source of fuel would be dry, dead wood. If these features are large oven facilities representing some level of reuse, a significant amount of both rock and wood may be required for each processing event, though rock can certainly be reused to some degree.

Given the strong tendency for the distribution of fuel wood, rock, and packing material, all essential for feature construction and use to overlap in stream settings, it is not surprising that most concentrations of burned rock midden sites occur in riverine contexts (e.g., Block House Creek area, Williamson County). Interestingly, these settings also contain water, a critical resource that may condition overall levels of reuse and the degree to which middens have a tendency to be located on previously used locations. The latter, of course, has a variety of implications both for the incorporation scenario outlined previously, as well as site structure considerations. Furthermore, the actual edible resource being processed in these oven features would probably be the lightest and, though the distribution of the resource may have been patchy, the least energy expensive to procure. It is possible, then, that the resources that most directly condition the location of middens are the cooccurrence of fuel and rock rather than the distribution of the potentially edible resource. That is, to the degree that rock, fuel wood, packing material, and resources do not occur in the same setting, it is probable that the location of these features is primarily conditioned by the distribution of rock and fuel wood. This perspective raises the possibility that the correlation between acorns and burned rock middens noted by Creel (1986) in west-central Texas is more directly 
related to the distribution of fuel wood in the Oak Savanna vegetation communities, and the presence of rock in these same settings, rather than tied to the distribution of acorns as a food item. We surmised that regional comparisons of burned rock midden densities in areas such as Camp Bowie with regions characterized by different types and densities of fuel and rock sources may illustrate the primary factors that are responsible for burned rock midden site locations and regional variability in densities. The Camp Bowie midden sites could provide a strong comparative basis for this type of regional analysis. Beyond simply the spatial location of a particular burned rock midden site, however, the Camp Bowie sites could contribute information of rock type and the type of wood used in feature firing.

\section{Summary}

Burned rock middens have been the focus of research in Central Texas since the beginning of the last century. The primary concerns center on questions of midden construction, midden use, and the temporal placement of these features. The testing of 18 sites at Camp Bowie, 16 of which contained burned rock middens, allows us to systematically consider a variety of research issues. The research issues discussed in this chapter, coupled with the methodology we enjoined to investigate those issues (see Chapter 5), form a coherent whole in which site integrity, at various scales, condition the utility of any given research focus. While difficult to separate into distinctive questions, Table 4-1 provides a summary of these general issues. However, note that these questions, and the data collection methods outlined in the following chapter, are simply general guidelines that will allow us to assess the potential of each site to provide relevant data. The overall level of our testing effort, then, was not designed to answer these research questions, but rather to assess the data potential of the sites with regard to these research questions. Nevertheless, we feel that the results of the project make a significant contribution to ongoing research on burned rock middens.

Table 4-1. Research Issues Related to Site Integrity and Eligibility Determinations

\begin{tabular}{|c|}
\hline Midden Formation Issues \\
\hline $\begin{array}{l}\text { 1. Incorporation Model: mixing, borrowing, and redistribution of sediments, rock, ecofacts, and artifacts. Some } \\
\text { component of material in midden not associated with midden use. } \\
\text { 2. Activity Association Model: artifacts, ecofacts, rocks, and sediment associated directly with midden use. }\end{array}$ \\
\hline Chronological Issues \\
\hline $\begin{array}{l}\text { 1. Late Prehistoric/Late Archaic use of burned rock middens as reflected by radiocarbon dates. } \\
\text { 2. Middle Archaic/early Late Archaic use of burned rock middens as reflected by incorporated projectile points. } \\
\text { 3. Dating of off-midden features and artifact clusters. }\end{array}$ \\
\hline Subsistence Issues \\
\hline $\begin{array}{l}\text { 1. Faunal, floral, and artifactual remains in midden reflect the actual use of midden. } \\
\text { 2. Faunal, floral, and artifactual remains in a midden are a function of the transport of sediment into the burned rock } \\
\text { midden as a result of reuse and capping of these oven features. } \\
\text { 3. Collect artifacts, floral, and faunal material from both surface, subsurface, and features from off-midden contexts. }\end{array}$ \\
\hline Site Organization Issues \\
\hline $\begin{array}{l}\text { 1. Are burned rock midden sites special purpose locations as indicated by patterns in artifact and feature variety, } \\
\text { feature design, and within site spatial patterning? } \\
\text { 2. Are burned rock midden sites residential in nature as indicated by patterns in artifact and feature variety, feature } \\
\text { design, and within site spatial patterning? } \\
\text { 3. Are burned rock middens on a site related to artifact clusters and other features away from the midden as } \\
\text { reflected by chronometric dates, spatial information, and artifact assemblage data? }\end{array}$ \\
\hline Spatial Considerations \\
\hline $\begin{array}{l}\text { 1. Are middens positioned on the landscape in a pattern that would suggest the criteria are related to food resources, } \\
\text { fuel wood availability and/or rock availability? } \\
\text { 2. What are the patterns in rock type and specific types of wood used in features? }\end{array}$ \\
\hline
\end{tabular}




\title{
Chapter 5: Testing Methods and Levels of Effort
}

\author{
David L. Nickels and Raymond P. Mauldin
}

Prior to the initiation of any fieldwork, CAR met with representatives from the TXARNG and the State Historic Preservation Office (SHPO) to establish acceptable and required fieldwork and reporting standards for the project. Access to specific sites was limited as a function of ongoing training requirements. We incorporated flexibility in our logistical plans to accommodate any scheduling conflicts without significant delays in the work effort. The fieldwork consisted of limited surface collecting, shovel testing, excavating, and backhoe trenching. Ninety-eight hand dug units, and 913 shovel tests were excavated. In addition, 21 areas within selected sites were surface collected. Several small backhoe trenches were cut on selected sites, and numerous cutbanks and natural exposures were examined.

\section{General Testing Methods}

The primary objective of the testing efforts at the 18 sites was determination of site eligibility for the National Register of Historic Places (NRHP) and for designation as State Archeological Landmarks (SAL). Each archaeological site was categorized as either 1) eligible, or 2) not eligible for inclusion to the NRHP; and/or 1) warranted, or 2) not warranted for SAL designation. Since one of the primary criteria for site eligibility was site and/or feature integrity (i.e., physical and cultural), the main goal of the testing efforts was to determine the degree of integrity in the archaeological deposits and features (i.e., the burned rock middens) present at each site with respect to the aforementioned research issues. Assuming that sufficient site and/or feature integrity could be demonstrated, a secondary goal of site testing was to demonstrate that the archaeological deposits could yield, or were likely to yield, information relevant to understanding the nature of burned rock midden sites and/or various aspects of regional prehistory (e.g., subsistence practices, chronological frameworks, land use).

To address these two complementary aspects of site eligibility, our testing efforts focused on two aspects of each site: 1) definition of the nature of the features found on-site and the determination of their physical and/or cultural integrity, and 2) identification and recovery of archaeological data types (i.e., faunal remains, ethnobotanical remains, datable charcoal samples, lithic assemblages, etc.) that could yield information regarding broader research issues.
The project geomorphologist visited and examined the geomorphological setting of many of the sites in order to identify the processes operating and impacting archaeological materials. These investigations had two main goals: 1) the definition of the geomorphological integrity of the site, and 2) the identification of depositional settings that may yield buried and undisturbed materials.

Site testing efforts aimed at addressing the issue of physical integrity focused on features (e.g., burned rock middens, buried hearths, lithic concentrations). These efforts in general, incorporated the excavation of multiple (2-3) adjoined $1-x-1-m$ test units within the midden, excavations of 1-x-1-m units centered on isolated hearth features, and the excavation of a limited number of non-feature-centered $1-\mathrm{x}-1-\mathrm{m}$ units to determine the nature and integrity of the site's cultural stratigraphy.

Testing efforts dealing with the second aspect of site eligibility combined data derived from midden-centered work, with off-midden explorations to define the potential relationship between features, activity areas, and archaeological remains. These efforts included, but were not limited to, obtaining artifact samples from off-midden areas of the sites through shovel testing, surface collections made in artifact clusters, and the artifacts obtained from non-feature centered 1-x-1-m excavation units. In addition, if preservation conditions were favorable, radiocarbon samples and matrix samples intended for ethnobotanical, geomorphological, and micro-debitage analysis were obtained at each site. Where possible, samples were collected from each unit cross-cutting the central feature and talus of each midden, and from off-midden contexts and/or isolated thermal features or hearths. These samples provided a glimpse at variability in the organization of activities across the site, as well as allowing us to discuss the temporal relationship between activities performed in association with the burned rock midden, and those identified away from the midden.

\section{Field Methods}

At most sites with a midden, a 5-x-5-m grid system was placed over and around the burned rock feature using compasses and 50-m tape measures. Where possible, the grid was extended away from the midden in the four cardinal 
directions to a distance that would cover areas of artifact concentrations or areas that appeared to have the potential for buried cultural deposits or features. Sites 41BR261 and 41BR276 did not contain middens and thus a systematic shovel test grid was not established around middens on these two sites. Two lengths of rebar were driven into the ground to serve as Datums 1 and 2 at each site, and were left in the ground at the end of the project.

The 913 shovel tests were placed on the 18 sites to evaluate artifact density relative to distance away from the middens, and to locate buried features. With the exception of 41BR261, all shovel tests were on grid lines. At site 41BR261, shovel tests were placed in areas that appeared to have the deepest soils and the potential for buried cultural features. All tests were approximately $30 \mathrm{~cm}$ in diameter, and excavated in 10-cm arbitrary levels to either bedrock or sterile sediments or soils. All sediments were screened through $1 / 4$-inch wire mesh. Shovel test data were recorded on CAR forms and included sediment texture, consistency, structure, and color, as well as gravel size and frequency, and artifact content. Artifacts removed from subsurface contexts were bagged and recorded. Soil samples were also collected from selected shovel tests. All shovel test locations were recorded using a hand-held Trimble GeoExplorer II Global Positioning System (GPS) unit.

During the shovel testing activities by CAR, notes were made on surface areas of the site containing artifact and firecracked rock concentrations and point-plotted diagnostics. Those notes were compared to the results obtained from the shovel test results to assist in the placement of excavation units in areas offering the greatest potential for encountering buried deposits. Ninety-eight 1-x-1-m units were excavated. Fifty-four units were placed in middens, and 44 units were dug outside of middens. All units were located on the established site grid and assigned numerical designations. They were $1-\mathrm{x}-1-\mathrm{m}$ in size, and were dug in 10-cm arbitrary levels using trowels, picks, and shovels. All sediments were screened through $1 / 4$-inch wire mesh.

Except in areas of obvious disturbance, a sediment sample of at least one liter was collected from the center of every $10-\mathrm{cm}$ level for flotation analysis. This allowed for the recovery of a sample of materials that would have passed through the larger $1 / 4$-inch screen size. Additional samples were collected in and around features or from soils that appeared to be organically enriched by human occupation.

\section{Collection Recording Procedures}

In general, a single lot number was assigned to all material recovered from within a $10-\mathrm{cm}$ level. Therefore, lithic debitage, charcoal, fauna, and flotation samples from within a single level would be given the same lot number. Lot numbers were recorded on a Master Data Recovery Form along with provenience information, and types and quantities of material collected. In the CAR lab, this form was checked against the recovered material to account for all artifacts collected in the field. Unique Item numbers were also utilized in the field and assigned to diagnostic artifacts and tools recovered from the surface and trench profiles. Artifacts and charcoal recovered from trench profiles and given Unique Item (UI) numbers were shot in with the GPS prior to their collection. Feature numbers were assigned when identified, with Feature 1 designating an entire burned rock midden. Features were drawn in profile or plan view and then photographed.

Both the shovel testing and the excavation of 1-x-1-m units produced extensive amounts of fire-cracked rock. For shovel tests, counts of burned rock and heat spalls by $10-\mathrm{cm}$ level were made. For each level within an excavation unit, all burned and fractured rock one inch or greater than in size was size sorted and counted by size class. Observations were made on different material types, though in the vast majority of cases sandstone was the dominant material. For those items less than one inch, weights were recorded. Fire-cracked and burned rock were discarded in the field.

\section{Soil Susceptibility Samples}

Soil susceptibility samples were collected from many of the sites on this project. Samples were removed in a miniature column fashion from the walls of selected excavation units. First, the area of the wall to be sampled was scraped to insure a recent exposure to the atmosphere. An approximate 4-x-4-cm soil sample was taken vertically from top to bottom in 3-cm increments. The samples were collected in labeled bags and their proveniences then recorded on a field form before being transported to the CAR laboratory. Selected samples were processed at the CAR lab. The soils were removed from bags and placed in plastic $2-\mathrm{cm}$ cubes. The cubes were labeled alphabetically in order to provide a cross reference with their provenience at the site. Each sample was then placed in a Bartington MS2 magnetic susceptibility meter to measure its magnetic susceptibility. 


\section{Surface Collection Areas}

A 100 percent inventory and collection of observed surface artifacts was taken from selected circular "dog-leash" areas of surface artifact concentrations on 11 sites. Twenty-one different areas were sampled, with the size of the radius of the circle established as either 2 or $3 \mathrm{~m}$. Each artifact was recorded on a standard form specifying flake types, cores, tested cobbles, bifaces, utilized and retouched pieces, and diagnostic artifacts.

\section{Site Mapping and Photography}

Site maps, showing site boundaries, datum locations, shovel tests, sampled areas, collected items, features, areas of high artifact density, directions to visible landmarks, and physical features on the landscape, were recorded. Mapping was done by GPS, and by pace and compass. Landforms, roads, or streams that would be helpful in relocating the site were shown.

Archival quality $35-\mathrm{mm}$ black-and-white prints, and $35-\mathrm{mm}$ color slides were made of all sites and artifacts where appropriate. CAR staff took photographs using color print and slide film in a Pentax camera with zoom lenses. Photographs were recorded on standard CAR photo forms in the field. In addition to photographing general excavation activities, particular attention was given to features such as hearths and midden internal cooking features.

\section{Backhoe Trenches}

The project geomorphologist conducted investigations using a backhoe on selected sites and profiles were recorded with standard soil survey staff procedures. Backhoe trenches were dug between one and three meters deep, and were strategically placed within or around middens at some sites. Descriptive information on specific backhoe trenches is presented in Appendix G.

\section{Laboratory Methods}

Cultural materials recovered from the testing procedures outlined above were inventoried at the CAR laboratory. All artifacts recovered were identified and analyzed. Proveniences for the materials entering the CAR laboratory were double checked through the use of bag and lot numbers which were recorded on a Bag Log form during the field investigations. Numbers were assigned to all artifact bags in the field. Artifacts and samples were separated by artifact type and recovery context to facilitate analysis. Processing of recovered artifacts began with washing and sorting into appropriate categories (e.g., debitage, projectile points, bifaces, unifaces, cores). Individual categories were then analyzed by specific attributes designed for each group. All data were then entered into an Excel ${ }^{\circledR}$ spreadsheet.

\section{Curation of Records and Artifacts}

All cultural material collected during the Camp Bowie testing was prepared and stored in accordance with federal regulation 36 CFR part 79, and in accordance with current guidelines of the Texas Archeological Research Laboratory. Artifacts processed in the CAR laboratory were washed, air-dried, and stored in archival-quality bags. Acid-free labels were placed in all artifact bags. Each bag was labeled with a provenience or corresponding lot number. Tools were labeled with permanent ink and covered by a clear coat of acrylic. In addition, a small sample of unmodified debitage from each lot was labeled with the appropriate provenience data. Other artifacts were separated by class and stored in acid-free boxes. Boxes were labeled with standard labels. Field notes, forms, photographs, and drawings were placed in labeled notebooks. Photographs, slides, and negatives were placed in archival-quality sleeves. All notebooks were stored in acid-free boxes. Documents and forms were printed on acid-free paper. A copy of the survey report and all computer disks pertaining to the investigations were stored in an archival box and curated with the field notes and documents. Upon completion of the project all cultural materials and records were sent to the Texas Archeological Research Laboratory for permanent storage. 



\title{
Chapter 6: Individual Site Testing Summaries
}

\author{
Raymond P. Mauldin, David L. Nickels, and Cory J. Broehm
}

This chapter provides detailed descriptions of the testing results for each of the 18 sites investigated on the current project. A general site description is provided, followed by the results of shovel testing, surface collections, and 1-x-1$\mathrm{m}$ excavation units. While we present summary data on artifacts, radiocarbon dates (Appendix A), vertebrate fauna (Appendix B), flotation and macrobotanical identifications (Appendix C), and shell (Appendix D), details of these data sets are discussed in subsequent chapters where necessary. In addition to these samples, CAR collected magnetic soil susceptibility samples from many of the sites discussed below, however, only selected samples were processed. These are discussed, where appropriate, in subsequent chapters (see also Appendix H). Finally, note that in conjunction with geoarchaeological work conducted on this project, backhoe trenches were placed on selected sites, and on 14 sites excavation profiles were described by the project geoarchaeologists. Details of this work are presented in Appendix G, although selected aspects of the trenches and profiles are discussed in the current chapter.

\section{BR65}

\section{Site Description}

Site 41BR65 was described by Wormser and Sullo-Prewitt (2001:45-46) as a multicomponent site containing a ring burned rock midden and a historic concrete slab and stone trough. The site was initially recorded by Texas A\&M Anthropology Laboratory in February 1975. TXARNG cultural resources staff revisited the site during the summer of 1995. CAR personnel visited the site in the fall of 1999 , and work was conducted during the winter of 1999 and the spring of 2000.

Site 41BR65 is on an upper terrace of Devils River, which is located about $200 \mathrm{~m}$ to the south. At an elevation of 1,350 feet $(411.5 \mathrm{~m})$ AMSL, the site is on a silty and rocky clay loam that supports oak, mesquite and tall grasses. At the time of CAR's work, ground surface visibility was approximately 25 percent, with grass covering most of the surface. The site is roughly $7,850 \mathrm{~m}^{2}$ in area. The main prehistoric feature is a circular burned rock midden measuring approximately $14 \mathrm{~m}$ in diameter, with a small, slight central depression about $4 \mathrm{~m}$ across. The west side of the midden has a gradual slope to the outside. On the east side, the outer edge is steeper. The midden is roughly $1 \mathrm{~m}$ high on the east side and $50-60 \mathrm{~cm}$ high on the west side. The midden was covered with prickly-pear cactus.

\section{Shovel Test Results}

Forty-nine shovel tests were excavated at this site. The majority of these tests were focused on the immediate area around the midden (Figure 6-1). As outlined in the previous chapter, shovel tests were excavated in 10-cm levels, with all sediments screened. Shovel tests were terminated when Pleistocene sediments, bedrock, or multiple sterile levels were encountered. On the current site, shovel tests were usually terminated when dense, red clay was encountered, though in several cases successive sterile levels were used as justification for termination. At 41BR65 the red clay ranged in depth from as high as $25 \mathrm{~cm}$ below surface (bs) to over $60 \mathrm{cmbs}$. The 49 shovel tests encompassed 206 levels, with no shovel test going below $62 \mathrm{cmbs}$.

No ground stone, mussel shells, or snails were found in any of these tests. However, just over 140 chipped stone items were recovered, including six bifaces, a uniface, and a core (see Appendix F). In addition, over 2,750 fire-cracked rocks were counted in shovel tests. Chipped stone was present in 63 percent of the 49 shovel tests and fire-cracked rock was found in 51 percent. Thirty-six of the 49 shovel tests $(73.5 \%)$ were positive.

Figure 6-1 shows that those shovel tests located close to the midden were frequently positive. In order to investigate this pattern, three spatial zones were created. Four of the shovel tests $(10,14,19$, and 20) fall within the midden, an area referred to as Zone 1. An additional 21 shovel tests were located within an arbitrary $15-\mathrm{m}$ radius centered on the midden. This area was designated Zone 2. Finally, the area beyond the $15-\mathrm{m}$ radius was referred to as Zone 3 . Twentyfour shovel tests were located in this zone.

All four of the midden shovel tests were, not surprisingly, positive, being dominated by fire-cracked rock. Nineteen of the 21 shovel tests $(90.5 \%)$ in Zone 2 were positive. The percentage of positive shovel tests drops to 54.2 percent (13 of 24) for the Zone 3 shovel tests. Positive shovel tests, then, are centered on the midden. 


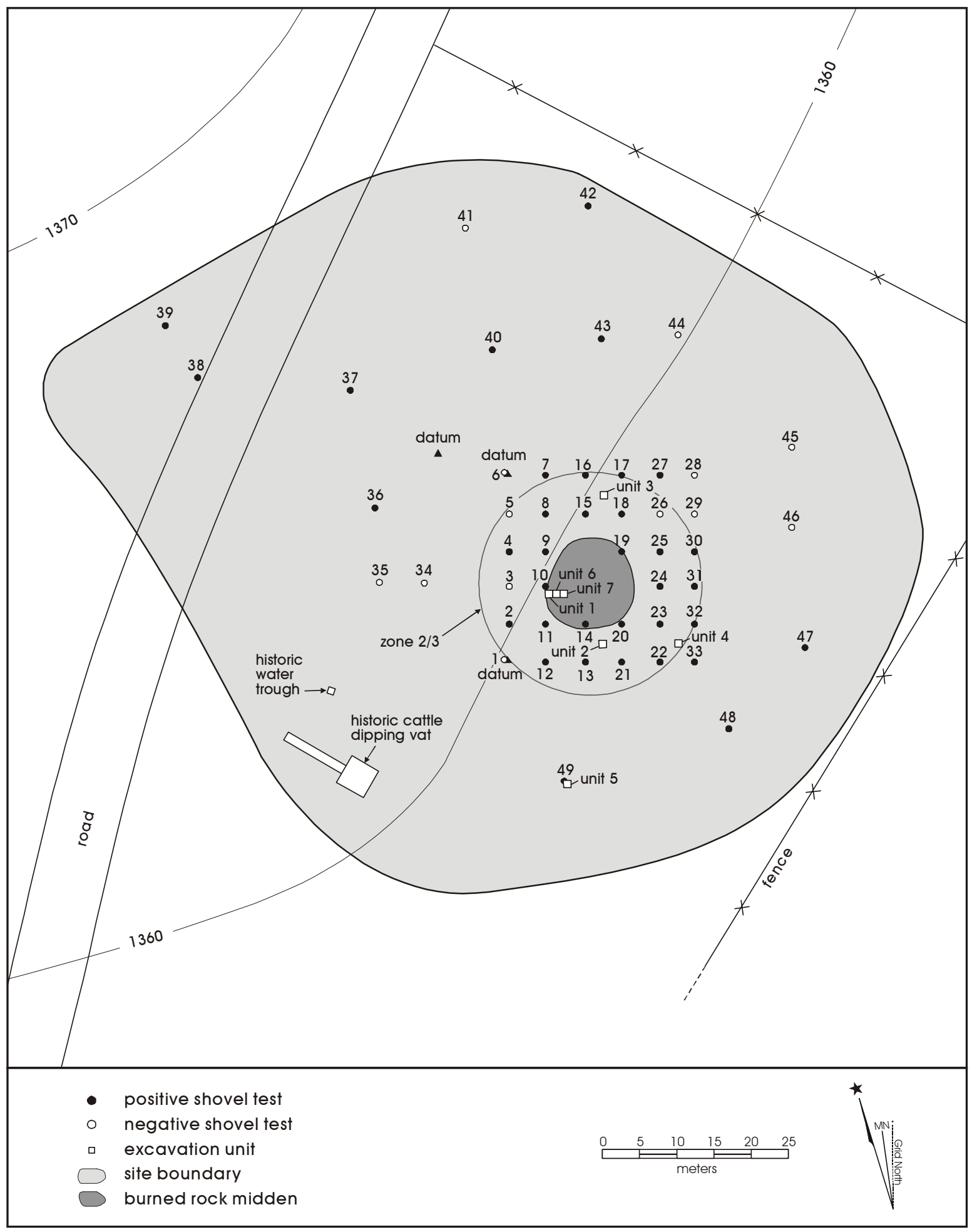

Figure 6-1. Site map of 41BR65. 
The density of fire-cracked rock and chipped stone also varies by zone. The four midden shovel tests represented 21 excavation levels. Over 2,500 fire-cracked rocks were present in these levels, with a density of 120.8 fire-cracked rocks per level. In contrast, for the 91 levels in the 21 shovel tests within Zone 2, fire-cracked rock density was only 1.81 per level, and in Zone 3 the density fell to .62 fire-cracked rocks per level. Chipped stone density was highest in Zone 2 , with 0.96 items per level. Zone 3 had an average density of 0.55 items. Within the midden, only .19 chipped stone items per shovel test level was present.

Figure 6-2 presents the density of chipped stone and firecracked rock (FCR) by level for Zones 2 (top) and 3 (bottom). At a general level, Figure 6-2 shows that the highest density of material occurred within the upper $30 \mathrm{~cm}$ of the site. In fact, the upper $30 \mathrm{~cm}$ (Levels 1-3) contained 92 percent of all chipped stone and 87 percent of all fire-cracked rock outside of Zone 1. The distributions do, however, differ slightly between the zones. In Zone 2, chipped stone density is highest in Level 2, with all chipped stone confined to the upper five levels. Fire-cracked rock density has a similar pattern. In Zone 3, the highest densities are within the first $10 \mathrm{~cm}$ (Level 1). It may be the case that areas away from the midden (i.e., Zone 3) have some combination of higher levels of erosion or lower levels of deposition relative to the immediate midden area.

The shovel test data suggest that most material is confined to the upper $30 \mathrm{~cm}$ of the site. In addition, the distribution of material suggests higher densities of material associated with the midden. Finally, while the midden is dominated by fire-cracked rock, almost no chipped stone was recovered in the midden.

\section{Surface Collections}

No surface collection areas were placed at this site. Surface density was extremely low, with few artifacts observed. However, a single item was collected from the surface of the site. This was a possible Edgewood point fragment (see Appendix E), suggesting occupation at the site during the end of the Late Archaic.

\section{Excavation Results}

Seven 1-x-1-m units containing an estimated total of 4.09 $\mathrm{m}^{3}$ of sediment and rock were excavated at this site (Figure 6-3). Based on the preliminary shovel test results, four offmidden units were excavated. The single ring-midden present on site was explored using three contiguous 1-x-1-m units. These units were positioned to work into the midden from the area of Shovel Test 10. This excavation block cut through the midden talus.

\section{Midden Units}

The midden area was designated Feature 1. The three contiguous units excavated in the midden (Units 1, 6, and 7) cut primary through the talus; the central pit, if present, was not clearly identified (Figure 6-4). Unit 1 was located on the outside apron of the midden, with Unit 7 cutting primarily into the ring. Excavation notes, as well as the profile (Figure 6-4), suggests that all three units were excavated through the bottom of the feature. As summarized by Bousman and Hodges (Appendix G), worm casts were common in the upper few levels of the excavation, and this portion of the midden, representing the ring, accumulated on the surface rather than being placed in any previous excavation.

We estimate that $1.76 \mathrm{~m}^{3}$ of rock and sediment were removed from the feature with an additional $.70 \mathrm{~m}^{3}$ removed below the feature. Forty-six artifacts were collected from the midden deposits, a density of just over 26 items per cubic meter of sediment. However, the majority of these artifacts came from Unit 1, located on the midden edge. The two units within the central portion of the talus had an artifact density of just over 13 items per cubic meter. Below Feature 1 , the artifact density in the trench increased to 62.9 artifacts per cubic meter.

The three units placed in the midden produced 14,269 firecracked rocks over one inch in size. An additional $129 \mathrm{~kg}$ of fire-cracked rock less than one inch in size was present. While chert, conglomerate, and limestone were present in the midden, sandstone accounted for over 95 percent of the material.

Two features were noted within the burned rock midden. Feature 6 was defined as a possible internal feature within the midden in Unit 7 at $20 \mathrm{~cm}$ below datum (bd). The feature appeared as a moderate concentration of tabular sandstone, laying generally flat. The feature was located in the western portion of the unit, and a similar concentration was present in Unit 6. The feature may represent a concentrated dumping of rock or the surface of a smaller thermal feature. No associated pits or other indication of the feature could be identified. Feature 7 was defined below Feature 1 in Unit 1 at $50 \mathrm{cmbd}$. It is probable that the feature is the result of rodent activity. 


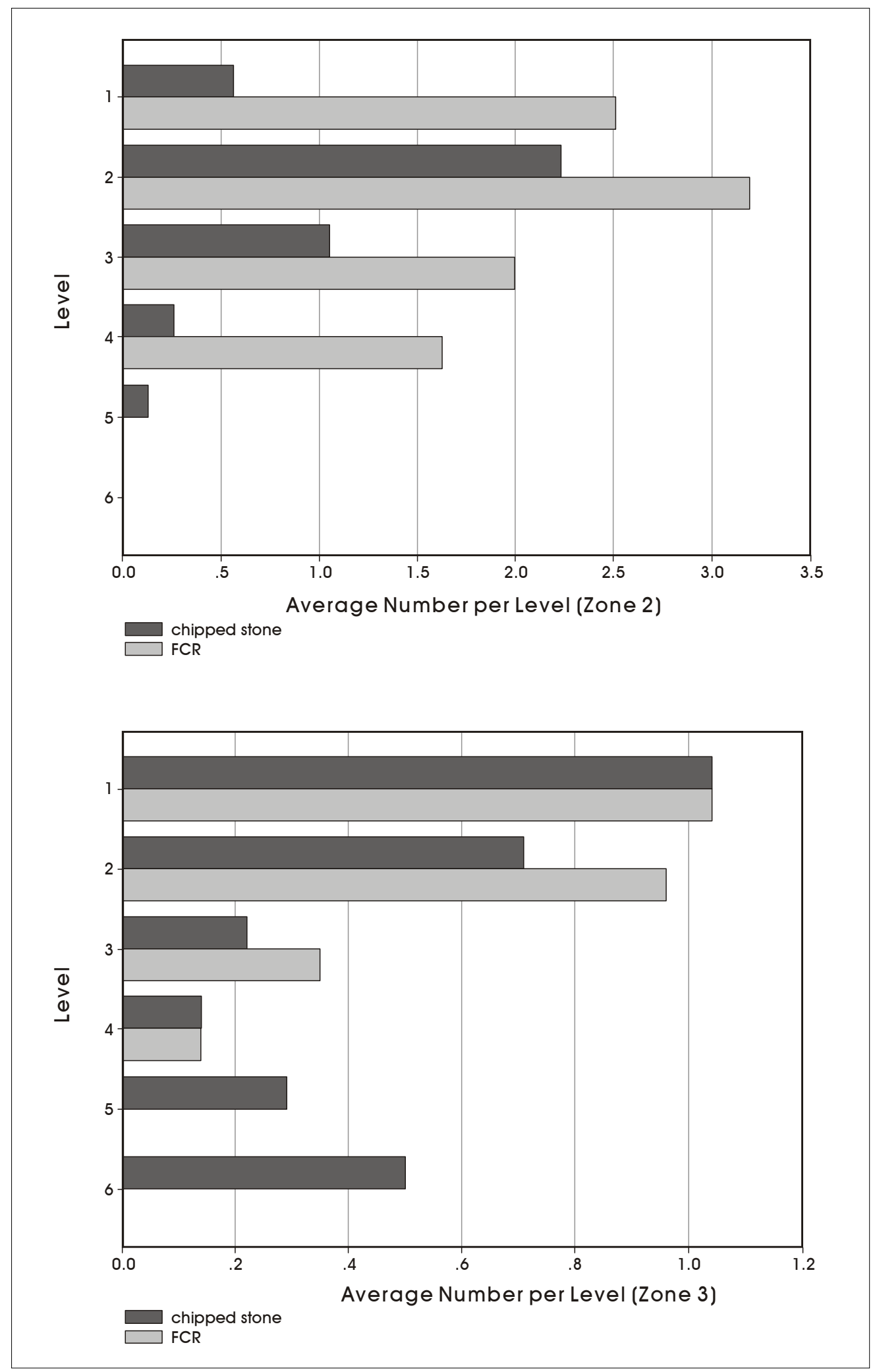

Figure 6-2. Shovel test density by depth for Zones 2 (top) and 3 (bottom), 41 BR65. 


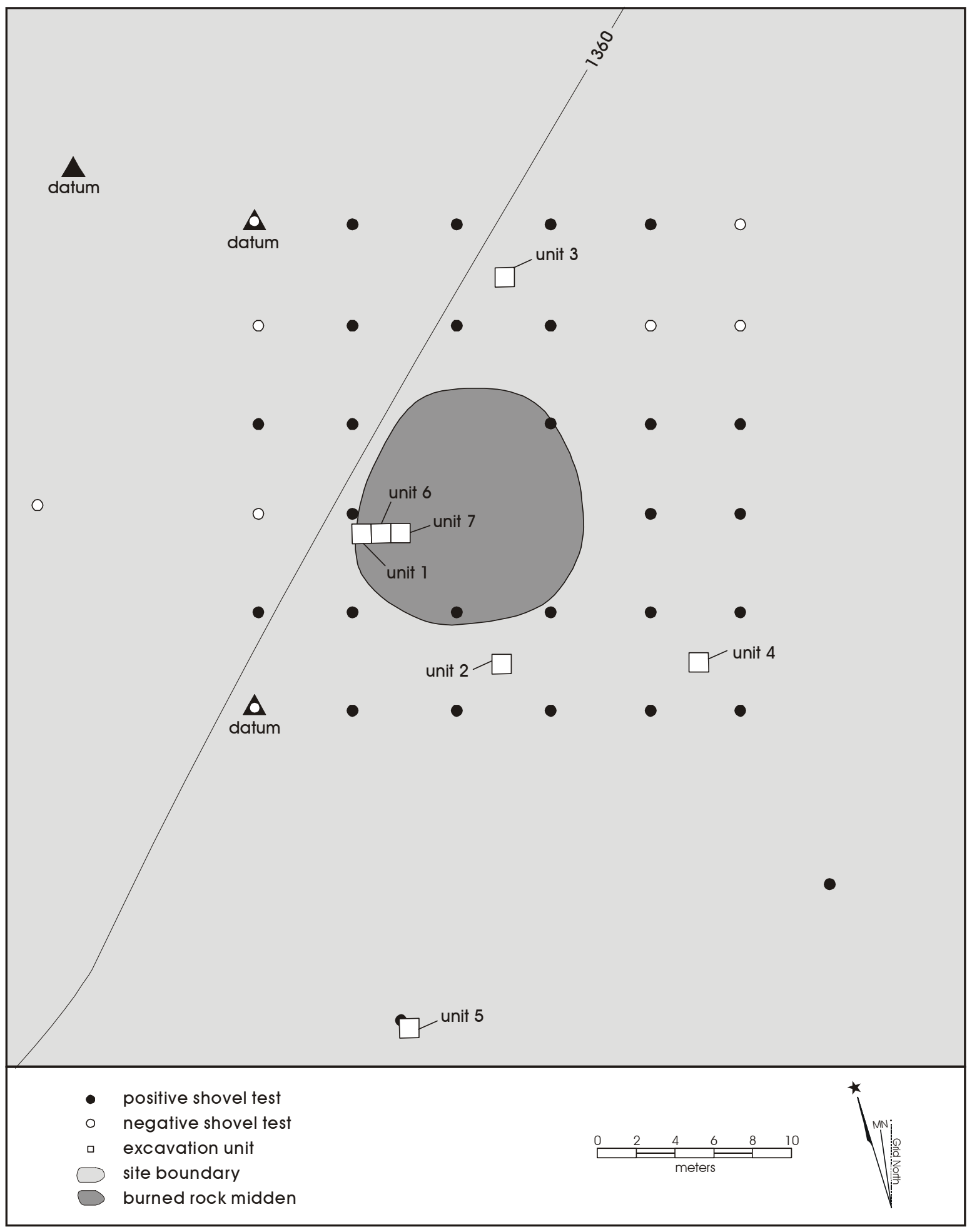

Figure 6-3. Detailed map of 41 BR65 showing location of excavation units. 


\section{Off-Midden Units}

Four 1-x-1-m units, containing an estimated $1.53 \mathrm{~m}^{3}$ of sediment, were excavated outside of the midden (see Figure 6-3). As with the shovel test data discussed previously, the highest artifact density occurred closest to the midden, with Unit 2 having a density of 206.7 artifacts per cubic meter. Conversely, Unit 5, located farthest from the midden, had the lowest artifact density among the units (46.4 per cubic meter). The artifact density for the external units was just over 135 artifacts per cubic meter.

Roughly 84 percent of the 207 artifacts recovered from outside the midden were found from 10 to $30 \mathrm{cmbd}$, with only a single peak of artifacts present in any single unit. For example, in Unit 2, 70 percent of the 93 artifacts recovered were within Level 3 (20-30 cmbd). In Unit 3, just over 61 percent of the artifacts were in Level $2(10-20 \mathrm{cmbd})$. Similarly, Unit 4 had a single peak of artifacts at 20-30 $\mathrm{cmbd}$. Unit 5 was only excavated to $27 \mathrm{cmbd}$, but 11 of the 13 artifacts occurred within 10 to $27 \mathrm{cmbd}$.

Fire-cracked rock was present in all external units, and followed essentially the same distributional pattern noted above for chipped stone. The greatest number of rock was present in Unit 2 where 316 fire-cracked rocks greater than one inch in size were recorded. Unit 5, located farthest from the midden, had the fewest number of rocks with only 34 items greater than one inch in size.

Four features were noted outside of the midden. Features 3 and 4 were identified at the base of Level 2 within Unit 3 . These features were identified as two areas of soft sediment within a hard, silty clay matrix. Neither feature had any charcoal present. It is probable that they represent animal burrows.

Two additional features (Features 2 and 5) were identified in Unit 5. Feature 2 was defined at $16 \mathrm{cmbd}$ as a slightly darker, softer area confined initially to the southeast section of the unit. The feature was excavated down to $27 \mathrm{cmbd}$. The fill was a loose, sandy silt, reddish-brown in color, and appeared to cut into the underlying hard reddish-brown clay. Figure 6-5 presents a profile of the south wall of Unit 5 with the feature identified.

Feature 5 was identified at $26 \mathrm{cmbd}$ in Unit 5. It appeared as a small, dark, circular stain roughly $15 \mathrm{~cm}$ in diameter. As can be seen in Figure 6-6, the feature was surrounded by larger rock. The fill was removed from the feature. Small flecks of charcoal were present and the feature was conical in cross-section. The feature was approximately $12 \mathrm{~cm}$ deep. It is possible that the feature was a post hole, as the unit is located near the historic material at this site. However, the feature may be prehistoric in age.

\section{Artifact Summary}

Site 41BR65 yielded 443 chipped stone and ground stone artifacts. This includes 420 flakes, 12 bifaces, a single core, a core rejuvenation flake, a uniface, a graver, two sandstone metate fragments, four utilized flakes, and a single projectile point fragment. Appendix F presents scans of selected tools from this site, and the point is presented in Appendix E. Within the chipped stone, chert dominates the raw materials, accounting for over 96 percent of the assemblage. Roughly 79 percent of the 420 flakes lacked cortex, with only four flakes $(0.95 \%)$ having 100 percent dorsal cortex cover.

\section{Other Samples}

Ten vertebrate faunal specimens weighing 5.57 grams were recovered from this site. These were highly fragmented and, in several cases, badly worn. As summarized in Appendix $\mathrm{B}$, the majority of the specimens $(\mathrm{n}=6)$ were artiodactyl, with other mammal taxa and birds also represented. Though several of the specimens are badly worn, the low recovery of faunal material does not appear to be simply a function of preservation, as carbonized material within the midden was well preserved.

A variety of samples were collected for both ethnobotanical as well as radiocarbon analysis. As summarized by Dering (Appendix C), the macrobotanical samples consisted of 73 charred items weighing 9.5 grams. The samples were either point collected, or collected from the screen. Dering identified these specimens as wood (Quercus sp.) and bulbs. Fifty-eight samples of bulbs and bulb fragments were noted from the midden at this site. Where identification was possible, these bulbs were identified as Eastern camas (Camassia scilloides). In addition, Dering (Appendix C) found oak and juniper wood, as well as an unidentified bulb fragment from two flotation samples selected from the midden excavations.

Small quantities of mussel shell were present in all midden excavation units, as well as in Level 2 of excavation Unit 3. Shell was collected from 13 different excavation levels at 41BR65. Goodfriend's identification of 100 of the more complete specimens of mussel from the project (see Appendix D) included six specimens from this site. These 


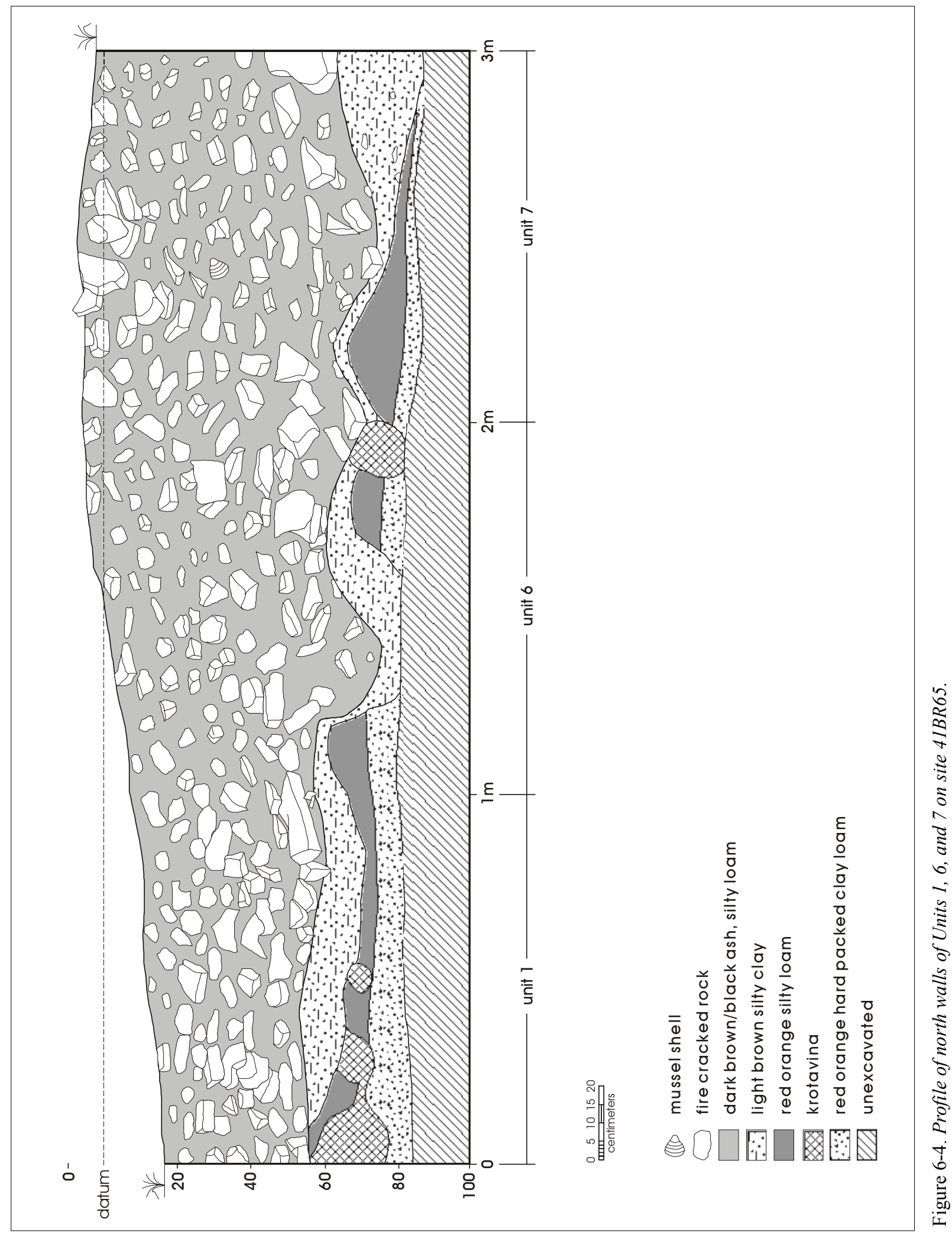




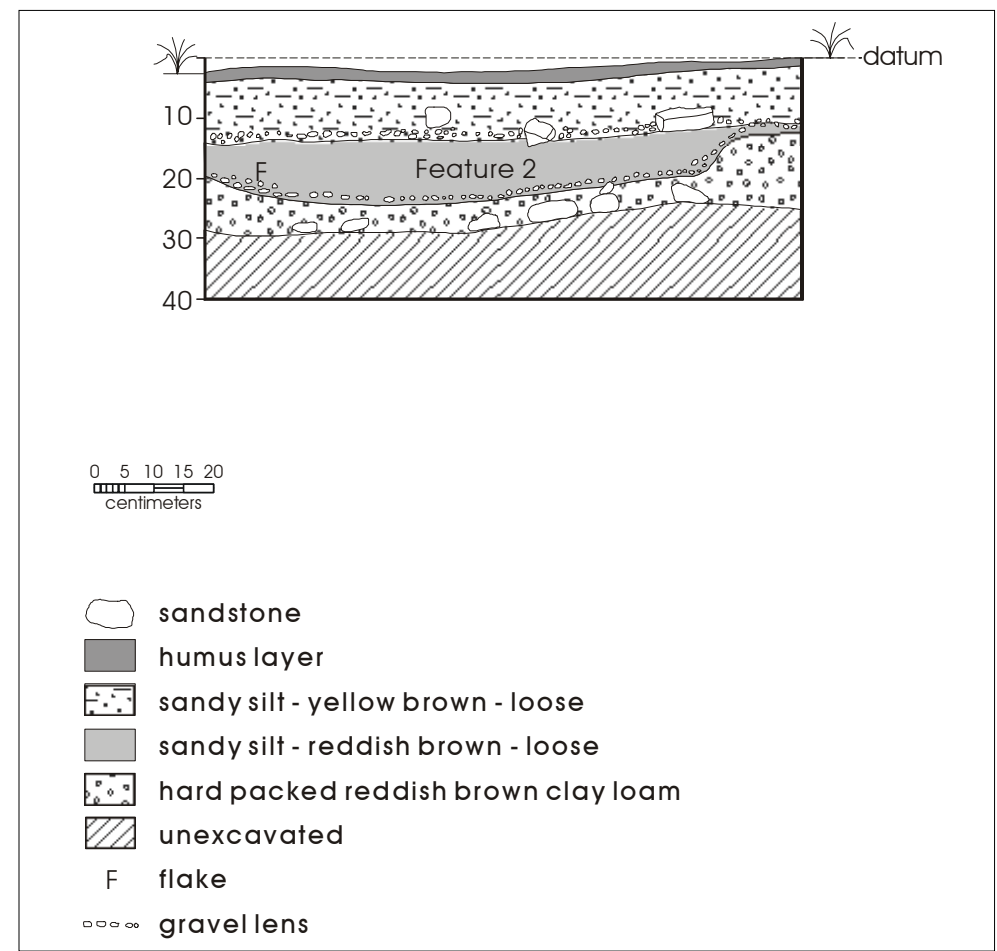

Figure 6-5. Profile of south wall of Unit 5 with Feature 2 identified, 41 BR65.

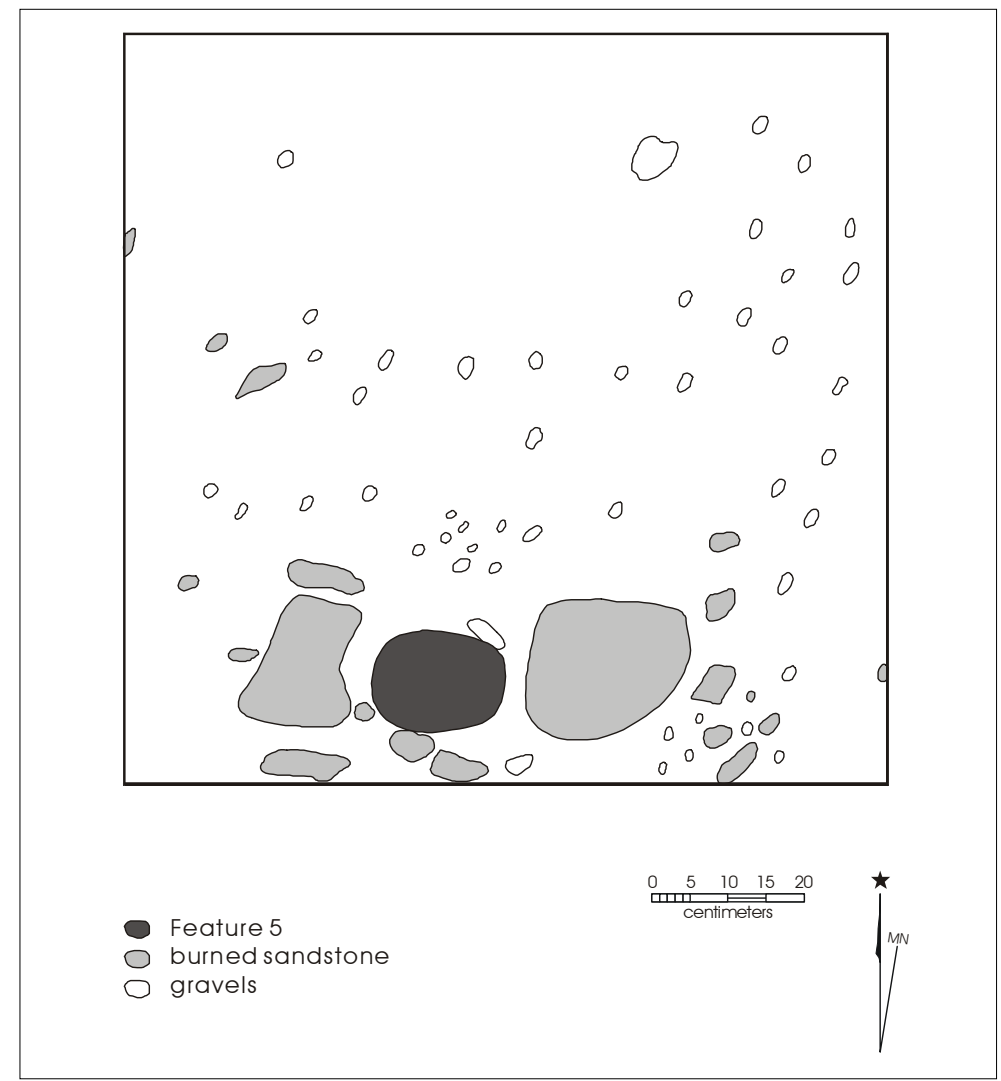

Figure 6-6. Plan view of Unit 5 at $26 \mathrm{cmbd}$, with Feature 5 identified, 41 BR65. six specimens represented three species, including Amblema picata $(\mathrm{n}=3)$, Quadrula houstonensis $(\mathrm{n}=1)$, and Quadrula apiculata $(\mathrm{n}=2)$.

\section{Radiocarbon Dates}

Three radiocarbon samples were submitted from the site. All three were collected from Unit 7 within the midden. They represent Levels 3 (20$30 \mathrm{cmbd}), 5(40-50 \mathrm{cmbd})$, and the base of the midden, Level 6 (50-60 cmbd). The calibrated, corrected date for Level 3 is $970 \pm 40$ years BP. Calibrated, corrected dates on Levels 5 and 6 are $1140 \pm 40$ and $1160 \pm 40 \mathrm{BP}$, respectively. Appendix A lists all details of these dates. To the degree that these dates reflect the onset and termination of midden use, it appears that the beginning use associated with Levels 5 and 6 of the midden was sometime between A.D. 780 and 960 , with use dates from Level 3 occurring between A.D. 1010 to 1160 . Using the interval estimate in the OxCal radiocarbon calibration program (Ramsey 2000), there is a 95 percent probability that the interval between the bottom two dates and the upper date in Unit 7 represents at least 50 years and no more than 340 years. Using the midpoint of the distribution as an estimate, it appears that the midden may have formed in about 195 years at the beginning of the Late Prehistoric period.

\section{Summary}

Our work at site 41BR65, then, suggests that the burned rock midden dates primarily to the beginning of the Late Prehistoric period. We have little data on the chronometric placement of the remaining prehistoric portions of the site as only a single fragment of a projectile point, collected from the surface, was recovered. This point may represent a Late Archaic manufacturing period.

Shovel testing and excavation results from outside the midden revealed buried deposits, with moderate density and variety of chipped stone. Shovel test data suggest that the midden was the focus of activities. In excavations outside the midden, an artifact density of roughly 135 artifacts per cubic meter was present. Inside the midden, density was only 13 items per cubic meter. Both 
faunal material and mussel shell were recovered from the excavations. Macrobotanical samples, as well as flotation samples, produced a high frequency of bulbs. No other economic plants were identified. Wood identified included oak and juniper. Radiocarbon dates suggest that the midden dates to the Late Prehistoric period, with a beginning use sometime between A.D. 780 and A.D. 960. Analysis suggests that much of the midden may have formed in between 50 and 340 years.

Clearly, preservation for ethnobotanical material within the midden is excellent. In addition, we have no data to suggest that the context of the material recovered from the site has been extensively disturbed. As outlined in Appendix G, worms have impacted the midden sediment with casts commonly observed. While rodent activity was certainly noted in the midden during excavation, the disturbance appears to be minimal. Outside of the midden, features are present.

\section{BR87}

\section{Site Description}

Site 41BR87 was described by Wormser and Sullo-Prewitt (2001:47-48) as a prehistoric campsite with a burned rock midden. The site was originally recorded in 1976 by Texas A\&M and TXARNG cultural resources staff relocated the site in 1996. A single shovel test was placed at the site in 1996. Cultural material was recovered to a depth of $30 \mathrm{~cm}$ below the surface. CAR personnel visited the site in the fall of 1999, and work was conducted during the winter of 1999 and the spring of 2000.

41BR87 is on a gentle rolling slope trending to the north and west. Devils River is located approximately $200 \mathrm{~m}$ to the southeast of the site. The site is located at an elevation of 1,350 feet (411.5 m) AMSL, and covers an area of roughly $5,675 \mathrm{~m}^{2}$. Vegetation includes oak, elm, mesquite, prickly pear, tasajillo, and agarita. At the time of CAR's work, ground surface visibility was extremely limited by dense grass. No artifacts were observed on the surface.

The midden is circular in shape and measures approximately $15 \mathrm{~m}$ in diameter. The surface is essentially flat, though Wormser and Sullo-Prewitt (2001:47) note that a central depression was observed in 1996. The midden's relief above the surrounding landscape varies from about 30 to $70 \mathrm{~cm}$, with the rock accumulation being thicker on the northern, downslope side. No surface artifacts were observed in 1999.

\section{Shovel Test Results}

CAR excavated 41 shovel tests at this site. As with 41BR65, the majority of the shovel tests were focused around the burned rock midden (Figure 6-7). On the current site, shovel tests were terminated when compact, brownish-red clay was encountered. This clay stratum was consistently present across the site, and ranged in depth from 24 to $35 \mathrm{~cm}$. The 41 shovel tests encompassed 136 levels, with all shovel tests being dug into Level 3 (20-30 cmbs) and no shovel test excavated below $45 \mathrm{cmbs}$.

No ground stone artifacts or mussel shells were encountered in any of the shovel tests. However, 215 flakes were recovered, as well as three bifaces, four utilized/retouched flakes, and two cores (see Appendix $\mathrm{F}$ for examples). In addition, roughly 1,045 burned and fire-cracked rock were recorded in the shovel tests. Chipped stone was present in 95 percent of the shovel tests and burned or fire-cracked rock was recorded in 73 percent. All of the shovel tests were positive at this site.

Only a single shovel test, number 12, was excavated in the midden. Using the same analytical scheme developed for 41BR65, Zone 1 (the midden) has only this single shovel test. Zone 2, the area outside the midden but within a $15-\mathrm{m}$ radius, contained 22 shovel tests. Zone 3 , the area beyond 15 $\mathrm{m}$, contained 18 shovel tests. Shovel Test 12 in Zone 1 had a large quantity of fire-cracked rock but only two flakes, from Level 4, were recovered. In Zone 2, 95 percent of the shovel tests had fire-cracked rock, and 91 percent had chipped stone. In Zone 3, only 83.3 percent had fire-cracked rock, but all shovel tests in Zone 3 had chipped stone present. Consequently, while positive shovel tests with fire-cracked rock were located close to the midden, positive shovel tests with chipped stone were more frequent away from the midden.

Densities of chipped stone and fire-cracked rock follow the same general pattern as the percentage of positive shovel tests. For the Zone 2 area, the 22 shovel tests contained 73 different levels and 116 chipped stone artifacts were recovered. There was, then, an average of 1.59 items per excavated level. In Zone 3, chipped stone density was 1.83 items per level. The midden shovel test had only two chipped stone artifacts for a density of .4 items per level. Chipped stone density, then, is highest away from the midden. In contrast, Zone 1 had an average of 130.2 fire-cracked rocks per shovel test level, Zone 2 an average of 3.47, and Zone 3 an average of 2.43 per excavated level. Fire-cracked rock density, then, decreases away from the midden. 


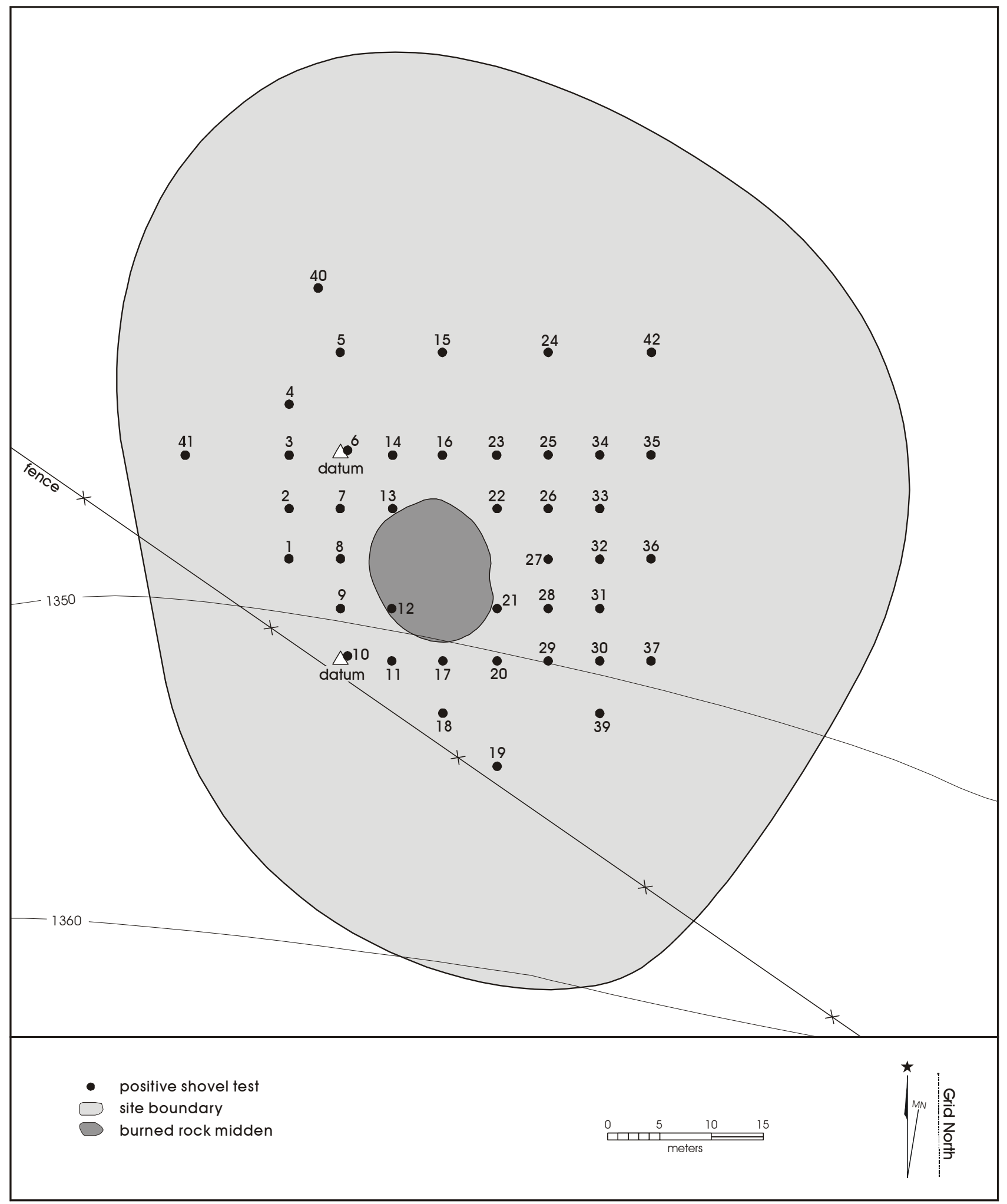

Figure 6-7. Map of site $41 B R 87$ with shovel test locations. 
Outside of the single midden shovel test, most of the chipped stone artifacts were concentrated in Level $2(10-20 \mathrm{cmbs})$. In fact, 66 percent of the non-midden shovel test artifacts were present in this level, with Level $1(0-10 \mathrm{cmbs})$ containing 21 percent and Level 3 having 13 percent. No artifacts were recovered below Level 3. In addition, both Zone 2 and Zone 3 had roughly similar distributions, with 67 percent of the Zone 2 artifacts and 65 percent of the Zone 3 artifacts present in Level 2. For fire-cracked rock a similar vertical pattern is present outside of the midden, with 54 percent of the rock present in Level 2, and no real difference between the zones.

\section{Surface Collections}

Ground visibility on the site at the time of our work was extremely low. No surface material was observed. As a consequence, no surface collection areas or unique items were collected at 41BR87.

\section{Excavation Results}

Eight 1-x-1-m units containing an estimated $3.66 \mathrm{~m}^{3}$ of material were excavated at this site (Figure 6-8). Three contiguous $1-\mathrm{x}-1-\mathrm{m}$ units were excavated in an effort to crosscut the talus and cut into any central depression. Five off-midden units, all 1-x-1-m in size, were positioned around the midden in hopes of discovering features and clarifying off-midden use.

\section{Midden Units}

The midden was designated Feature 1. The three contiguous 1-x-1-m units excavated in the midden (Units 1,2, and 3) cut primarily through the talus. A central pit, if present, was not discovered in this limited testing, though examination of the profile (Figure 6-9) suggests lower rock density in Unit 1, towards the center of the feature. Excavation notes, as well as Figure 6-9, suggest that all three units cut through the midden deposit. As noted by Bousman and Hodges (Appendix G), variations in the sediment observed in the midden deposits are consistent with multiple events.

We estimate that $1.8 \mathrm{~m}^{3}$ of sediment and rock were removed from the feature, with an additional $.32 \mathrm{~m}^{3}$ excavated below the feature. The midden deposits yielded 215 artifacts, with nine artifacts found below the midden. Artifact density within the midden was just over 119 items per cubic meter. Below the midden, density dropped to roughly 28 items per cubic meter.
The three units produced 10,973 fire-cracked rocks greater than one inch in size. An additional $178.4 \mathrm{~kg}$ of rock less than one inch in size were recorded. While chert, conglomerate, and limestone were noted in the midden, sandstone accounted for over 95 percent of the fire-cracked rock counted. Two additional features were noted within Feature 1. These were designated Feature 6 and Feature 7. Both were defined near the base of the midden, and both are probably the result of rodent activity.

\section{Off-Midden Units}

Five 1-x-1-m units, containing an estimated $1.54 \mathrm{~m}^{3}$ of deposit, were excavated outside of the midden (see Figure 6-8). Artifact density was high in these units, with a density of just over 268 chipped stone artifacts per cubic meter. Density was variable, with the lowest density in Unit 5 (83 artifacts per cubic meter), located just over $22 \mathrm{~m}$ away from the center of the midden. The four units within $15 \mathrm{~m}$ of the midden all had chipped stone densities in excess of 150 items per cubic meter, with Unit 8 having the highest density on the site, 477 items per cubic meter.

The off-midden units reflect the same shallow depth to the underlying red clay as seen in the shovel tests. The average depth of the five units was just over $30 \mathrm{cmbd}$. Figure 6-10 presents profiles of four of these external units that document the shallow nature of the deposits.

As with the shovel test data, almost 75 percent of the chipped stone artifacts were present in Level $2(10-20 \mathrm{cmbd})$, with Level 3 containing roughly 23 percent. As the red clay was consistently encountered within the upper $30 \mathrm{~cm}$ of the deposit, only Unit 7 was excavated below $30 \mathrm{~cm}$, into the red clay. No artifacts were recovered from that limited excavation.

Fire-cracked rock was noted in all external excavation units, though no counts of rock were made for Unit 4 . The highest rock recovery in the four external units where rock was counted was in Unit 6, where 230 items were counted, and the lowest recovery was in Unit 7 with 26 rocks. Just over 55 percent of the 389 fire-cracked rocks recorded in external units were in Level 2 (10-20 cmbd), with Level 3 containing roughly 40 percent.

Four features, designated 2 through 5 , were identified in these outside units. Feature 2, defined in Unit 5 at 10 to 20 cmbd, was a $30 \mathrm{~cm}$ by $22 \mathrm{~cm}$ cluster of fire-cracked rock located in the southwest corner of the unit. It was probably associated with Feature 4, a gray-brown silty loam intrusion 


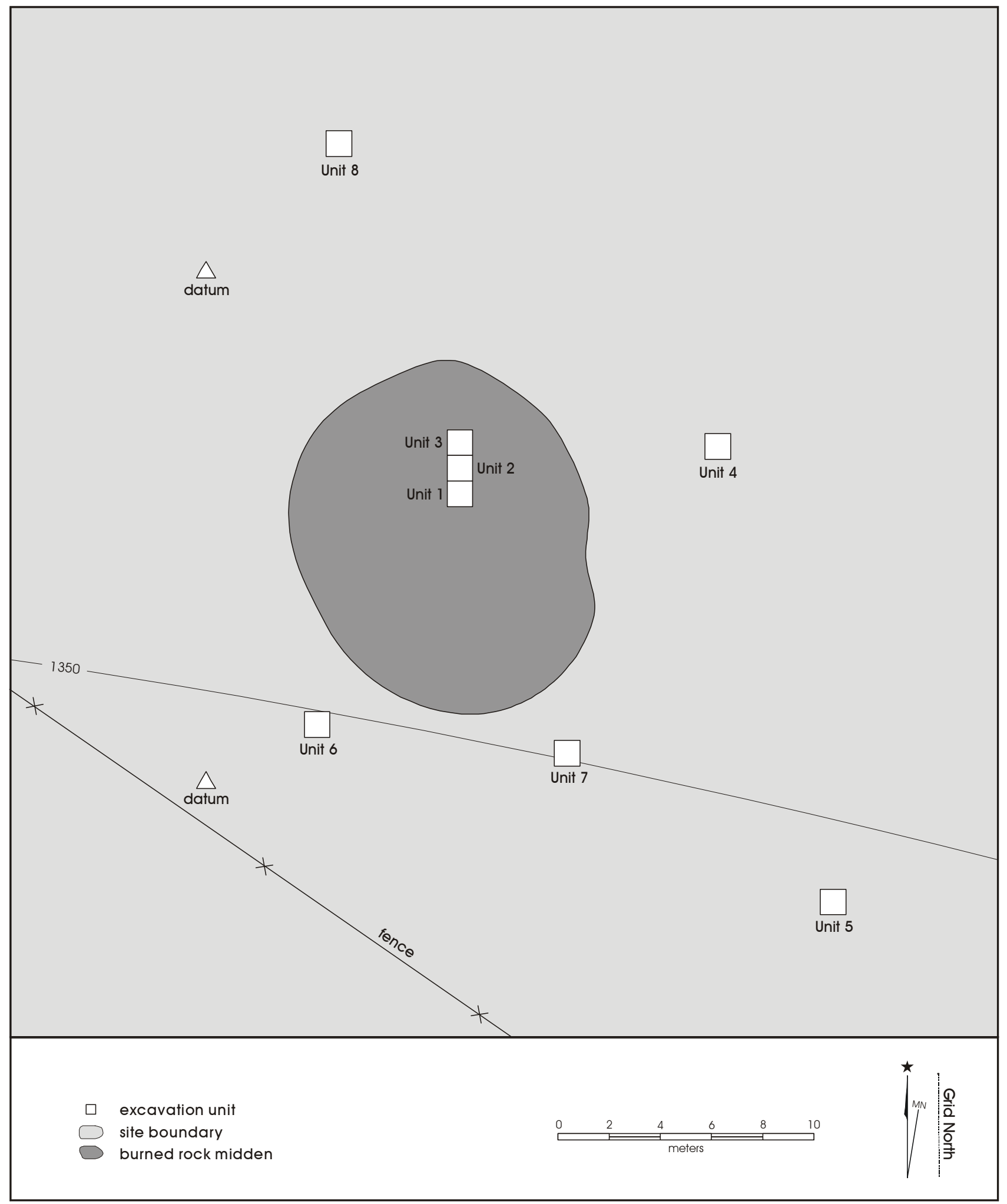

Figure 6-8. Site 41BR87 with excavation units identified. 


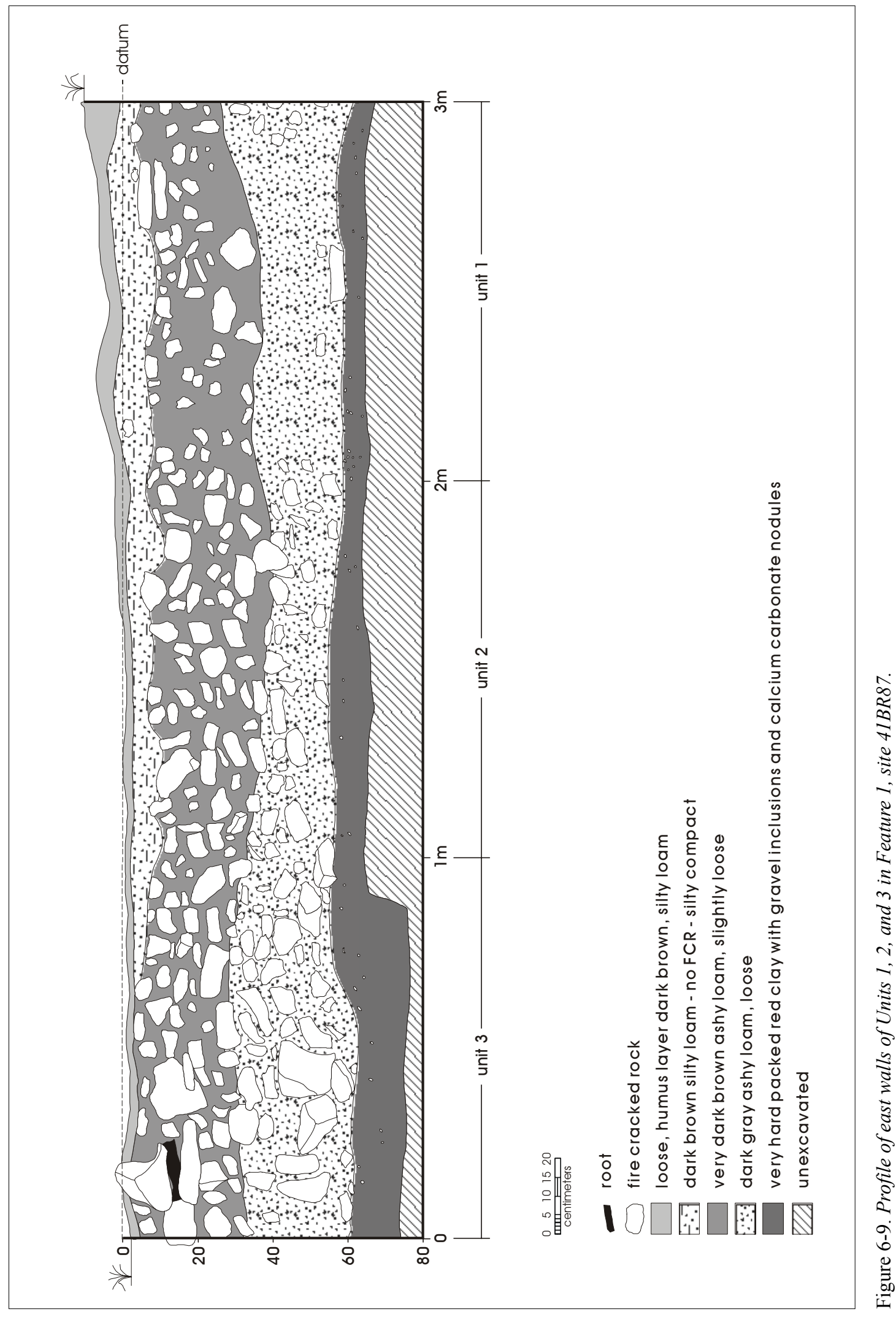




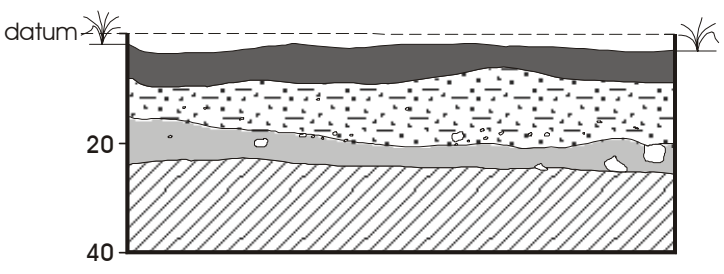

41BR87, Unit 4, West Wall Profile

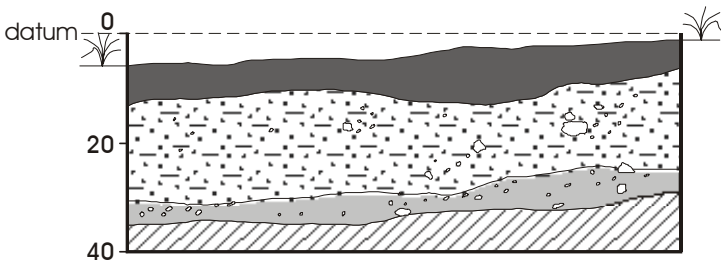

41BR87, Unit 7, East Wall Profile

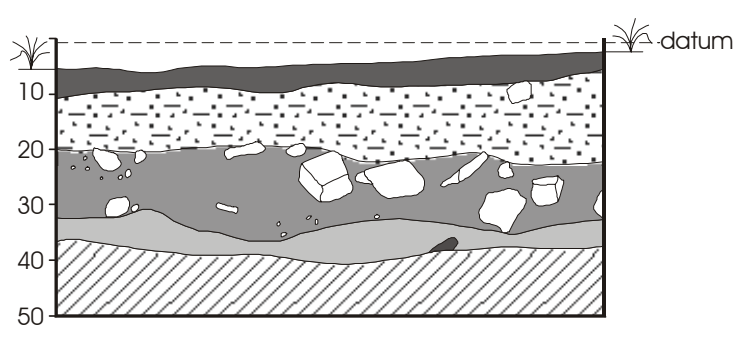

41 BR8 7, Unit 6, North Wall Profile

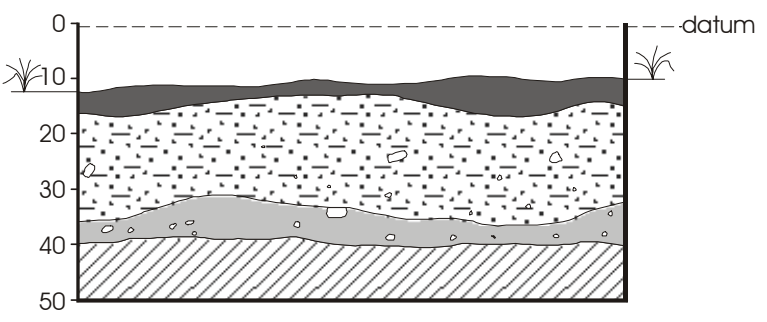

41BR87, Unit 8, South Wall Profile

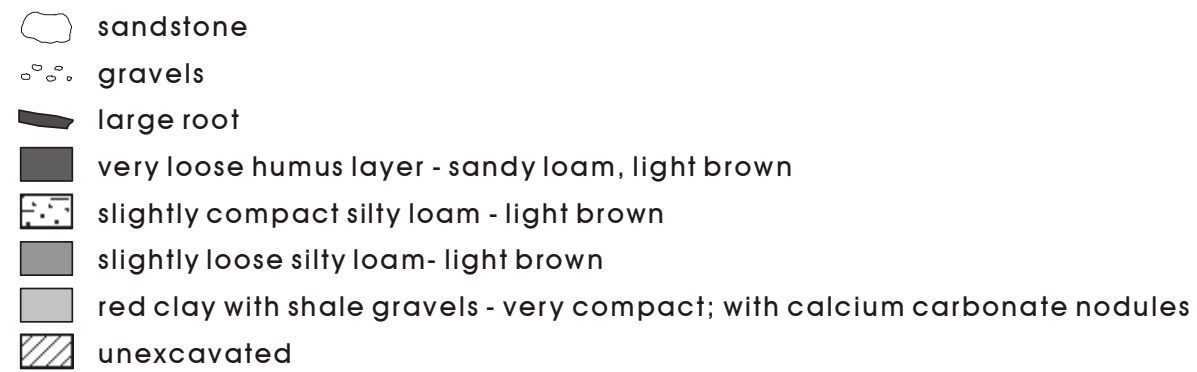

Figure 6-10. Profiles of Units 4, 6, 7, and 8 on site $41 B R 87$.

observed in the center of the western profile wall. Figure 6-11 presents the profile for Feature 4. The feature was defined at roughly $11 \mathrm{cmbd}$ and terminated at the red clay. Note that Feature 2 was observed at the same level, and fire-cracked rock was concentrated in the southwestern corner. While no charcoal was observed in the fill, the presence of both the concentration of rock and the pit feature suggests an external hearth that was excavated from a surface roughly $11 \mathrm{~cm}$ below the current ground surface.

Feature 3 was defined in Unit 7. The feature was identified at $15 \mathrm{cmbd}$ as a slightly darker area of sediment and several small burned sandstone rocks in the southern section of the unit. The feature, bisected by the southern wall of the unit, was roughly $22 \mathrm{~cm}$ in diameter along the east to west axis, and extended into the unit approximately $12 \mathrm{~cm}$. The feature was circular. Excavation of the feature suggested a shallow basin, with a terminal depth of $24 \mathrm{cmbd}$. While no charcoal was present in the fill, a single sample was collected at a depth of $20.5 \mathrm{cmbd}$, roughly $15 \mathrm{~cm}$ away from the lip of the feature. As with Feature 4, this feature probably represents a small hearth.

Feature 5 was defined in Unit 6 at roughly 20 to $30 \mathrm{cmbd}$. The feature initially appeared as a differential concentration of fire-cracked sandstone, located in the northern $40 \mathrm{~cm}$ of the unit. Upon removal of the rock, gray-brown sediment with extremely small charcoal flecks was visible at $30 \mathrm{cmbd}$. The stained area formed a large arch covering the northern section of the unit. The remaining portion of the unit was the red clay substrate. Excavation of the stained area produced a basin-shaped feature, dug into the red clay 
substrate, which terminated at roughly $40 \mathrm{cmbd}$. Figure 6-12 presents a composite plan view of the rock and associated staining. This feature may be the outside edge of Feature 1, the burned rock midden. While time constraints prevented any further exploration of this possibility, the feature clearly represents thermal activity, and may define the outside edge of Feature 1.

\section{Artifact Summary}

41BR87 yielded 887 chipped stone and ground stone artifacts. This total includes 859 flakes, nine bifaces, four cores, nine utilized or retouched items, five fragments of ground stone, and one piece of ochre. Appendix F presents scans of selected tools from this site. Within the flake assemblage, chert dominates the raw material types, accounting for over 99 percent of the material. Roughly 69 percent of the flakes lacked cortex, with 19 flakes (2.2\%) having 100 percent dorsal cortex cover.

Four diagnostic projectile points were recovered from the site (see Appendix E). A probable Godley point was recovered from Level 1 of Shovel Test 29. This point dates from the Late Archaic to the Late Prehistoric. A broken Ensor point, dating to the transitional Archaic or later, was recovered from Level 2 of Unit 6. A Scallorn point, dating to the Late Prehistoric, was recovered from Level 2 of Unit 3. Finally, a Late Prehistoric Fresno point was collected from Level 2 of Unit 8. The points, then, suggest occupation from the end of the Late Archaic into the Late Prehistoric.

\section{Other Samples}

No vertebrate faunal material was recovered in the excavations at this site. This lack of faunal material does not appear to be a function of preservation, however, as preservation of carbonized material within the midden was excellent.

A variety of ethnobotanical samples were collected from the site. As summarized by Dering (Appendix C), two flotation samples and three macrobotanical samples were submitted for analysis. The macrobotanical samples were identified as six bulb

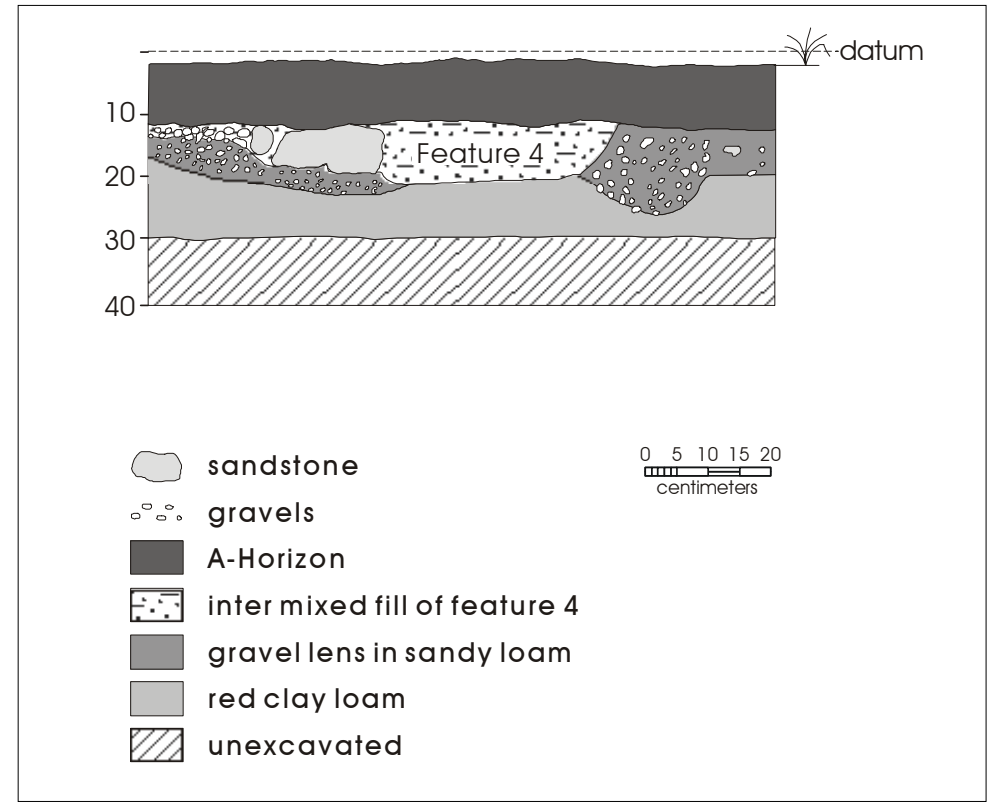

Figure 6-11. Profile of Feature 4, located in western wall of Unit 5, 41 BR87.

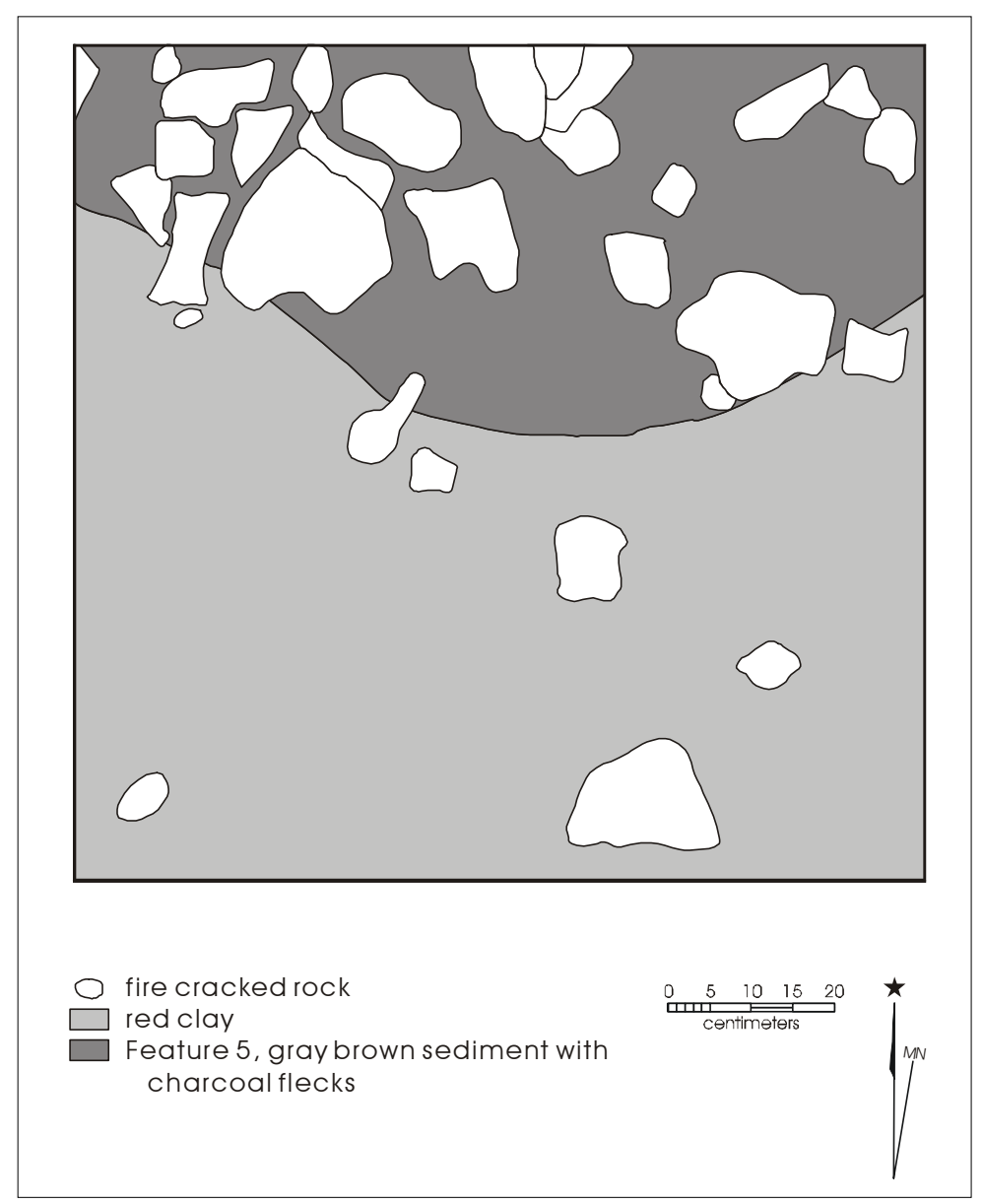

Figure 6-12. Plan view of Feature 5, Unit 6 (at $30 \mathrm{cmbd}$ ), $41 \mathrm{BR} 87$. 
fragments, though all were of an undetermined plant type. The two 1.5 liter flotation samples produced 4 grams of material that was identified as bulb fragments and oak wood.

Mussel shell was recovered from four different excavation units, three of which were within the midden. Just over 344 grams of shell was recovered from the site. Four samples from this site were in the samples identified by Goodfriend (Appendix D). These were identified as Quadrula apiculata $(\mathrm{n}=2)$, Quadrula houstonensis $(\mathrm{n}=1)$, and Cyrtonaias tampicoensis $(\mathrm{n}=1)$.

\section{Radiocarbon Dates}

Three radiocarbon samples from this site were submitted. Two of these samples came from Unit 2 within the midden (Feature 1). They represent Level $4(30-40 \mathrm{cmbd})$ and below the base of the midden at Level $7(60-70 \mathrm{cmbd})$. The calibrated, corrected date for the Level 4 sample is $860 \pm$ 40 years BP. A calibrated, corrected date on Level 7 is 1180 \pm 40 BP. Appendix A lists all details of these dates. If these dates are in context, it appears that the beginning of midden use, associated with Level 6, was sometime after A.D. 770 and 900, with use dates for Level 4 in the range of A.D. 1060 to 1250 . Using the interval estimate in the $\mathrm{OxCal}$ radiocarbon calibration program (Ramsey 2000), there is a 95 percent probability that the interval between the bottom date and the upper date in Unit 2 represents at least 110 years and no more than 490 years. Using the midpoint of the distribution as an estimate, the midden may have formed in around 300 years at the beginning of the Late Prehistoric period. Recall, however, that the bottom date is below the feature, while the top date is at an average of $35 \mathrm{~cm}$ below the top of the midden. The actual age of development and use, then, is probably later than the maximum A.D. 770 to 1250 range of the two dates.

An additional radiocarbon sample was submitted from Unit 7. The sample, taken from a depth of $20-21 \mathrm{cmbd}$, was located within $15 \mathrm{~cm}$ of Feature 3, and was just slightly into the surface from which the feature was excavated. The corrected, calibrated date from this off-midden sample was $1290 \pm 40$ years BP. Using the 1-sigma range, the sample probably dates to between A.D. 680 and 775 . This date range overlaps with the date from below the midden. To the degree that these radiocarbon dates reflect site use, it appears that the site was initially occupied sometime after the A.D. 680 to 775 range, and site use terminated sometime after A.D. 1060 to 1250 .

\section{Summary}

CAR's work at site 41BR87 suggests that the burned rock midden dates to the Late Prehistoric period. Analysis suggests that much of the midden may have formed in between 110 and 490 years. An additional radiocarbon date from Feature 3, external to the burned rock midden, dated from A.D. 680 and 775. Four diagnostic projectile points were recovered from the site. These suggest an occupation span covering the end of the Late Archaic period into the Late Prehistoric period.

Shovel testing and excavation results from outside the midden revealed buried deposits consistently present above $30 \mathrm{~cm}$, with a moderate to high density of chipped stone. The vertical distribution of material in both shovel tests and excavation units is consistent with a single period of use. In excavation units outside the midden, an artifact density of roughly 268 artifacts per cubic meter was present. Within the midden deposits, density was somewhat lower at 119 items per cubic meter. No vertebrate faunal material was recovered from the excavation, though mussel shell was present. Macrobotanical samples, as well as flotation samples, produced several bulbs and bulb fragments. No other economic plants were identified. Wood identified included oak.

Conditions for preservation of ethnobotanical material within the midden are excellent. In addition, we have no data to suggest that the context of the material recovered from the site has been extensively disturbed. Rodent activity was noted in the midden, though the disturbance appears to have been minimal. Outside of the midden, several features are present and artifact densities are high.

\section{BR228}

\section{Site Description}

Wormser and Sullo-Prewitt (2001:49-51) describe site 41BR228 as an open campsite with a burned rock midden, bedrock mortar holes, and dense scatters of lithic debris. TXARNG cultural resources staff originally recorded the site in 1994. Although no shovel tests were excavated, TXARNG archaeologists made observations on surface artifacts, and a small number of items were collected from the site. The collected items included a Late Archaic Bulverde point and the base of a Late Archaic Pedernales 
point. CAR archaeologists visited the site in the fall of 1999, and work was conducted during the winter of 1999 and the spring of 2000.

Site 41BR228 occupies a saddleback ridge at an elevation of about 1,480 feet $(451 \mathrm{~m})$ AMSL. The site is extensive, covering an area of roughly $24,200 \mathrm{~m}^{2}$, with material being distributed around a sandstone and limestone ridge that bisects the site (Figure 6-13). Bedrock is exposed in several places. When CAR visited the site in 1999, vegetation consisted of short grasses, prickly pear, yucca, sotol, mesquite, juniper and oak. The nearest source of water is an intermittent tributary of the Devils River, located about 500 $\mathrm{m}$ to the north of the site. Devils River is located roughly $1,250 \mathrm{~m}$ to the south of the site and Lewis Creek is roughly $1 \mathrm{~km}$ to the west.

The original recording of the site by TXARNG archaeologists noted a single burned rock midden on the northeastern end of the site (Figure 6-13). The midden, designated Feature 1, was described as consisting of sandstone and limestone, with a height of approximately 1 $\mathrm{m}$ and a diameter of $15 \mathrm{~m}$ (Wormser and Sullo-Prewitt 2001:49). A central depression was present. When CAR visited the site in 1999, a track vehicle had been driven over this midden.

During the course of CAR's work at the site in the spring of 2000, a second midden (designated Feature 4) was discovered near the southwestern end of the site. This second midden is on a slope, and is mostly buried. It was found during shovel testing, and the surface manifestations of the midden have been disturbed both by colluvial deposition and by vehicular impact.

Twelve bedrock mortar holes occurring in two clusters are located in the limestone bedrock (Figure 6-13). The first cluster is on the north side of the ridge and consists of nine mortar holes. The second cluster consists of three mortar holes. The mortar holes are all circular in shape, with most being approximately $8-10 \mathrm{~cm}$ in diameter, and 6-10 $\mathrm{cm}$ deep. However, in several instances the diameters are between 20 and $25 \mathrm{~cm}$, with depths of up to $20 \mathrm{~cm}$. The mortar holes in the second cluster are all in the smaller size range.

During our visit in 1999 and subsequent work in 2000, a variety of lithic artifacts, including bifaces, unifaces, and large quantities of debitage, were observed on the surface of 41BR228. The highest densities were along an old two-track road that is located to the north, and parallel with, the east-west trending ridge.

\section{Shovel Test Results}

Ninety-three shovel tests representing 221 separate levels were excavated at the site. As with the previously described sites, the majority of shovel tests were focused around the burned rock midden described by Wormser and SulloPrewitt (2001:49-50), with additional shovel tests placed to define the site boundaries and depth of deposits. Additional shovel tests were concentrated to define the second midden once it was discovered during general shovel testing (Figure 6-14).

Fifty-one shovel tests were excavated around the easternmost midden. Nineteen shovel tests were excavated to try and define the westernmost midden. An additional 23 tests were dug to define the depth and character of the remaining portions of the site (Figure 6-14). The shovel tests were shallow, with bedrock usually encountered within $30 \mathrm{~cm}$ of the surface. Shovel tests excavated in the area around the eastern midden averaged only 2.02 levels, or roughly 20 $\mathrm{cmbs}$, before bedrock was encountered. Around the western midden, shovel tests averaged 3.26 levels (ca. $33 \mathrm{cmbs}$ ). The 23 shovel tests that were not near middens averaged 2.42 levels per test. Outside of the midden deposits, only Shovel Tests 71, 72, and 73, on the northern edge of the site, had sediments present at depths below $40 \mathrm{~cm}$.

A variety of material was recovered from the shovel tests, including 308 flakes, one ground stone fragment, six bifaces, two utilized/retouched items, six cores, and one projectile point. Mussel shell was noted in 18 shovel tests. In addition, approximately 1,805 pieces of burned and fire-cracked rock, primarily sandstone, were counted from the shovel testing at 41BR228. Sixty-one of the 93 shovel tests $(65.6 \%)$ were positive (Figure 6-14), with 55.9 percent containing chipped stone debitage and 45.2 percent containing fire-cracked rock. The projectile point, recovered from Level 3 in Shovel Test 72, was identified as a Langtry, a Late Archaic point form.

Seven shovel tests (numbers $16,18,79,84,85,88$, and 89) were excavated in the two middens. Figure 6-15 shows the density of fire-cracked rock (top) and chipped stone debitage (bottom) by level with these six midden shovel tests excluded. The density of fire-cracked rock is clearly highest in the initial level $(0-10 \mathrm{cmbs})$, with a fairly consistent decrease in density with increasing depth. However, the 


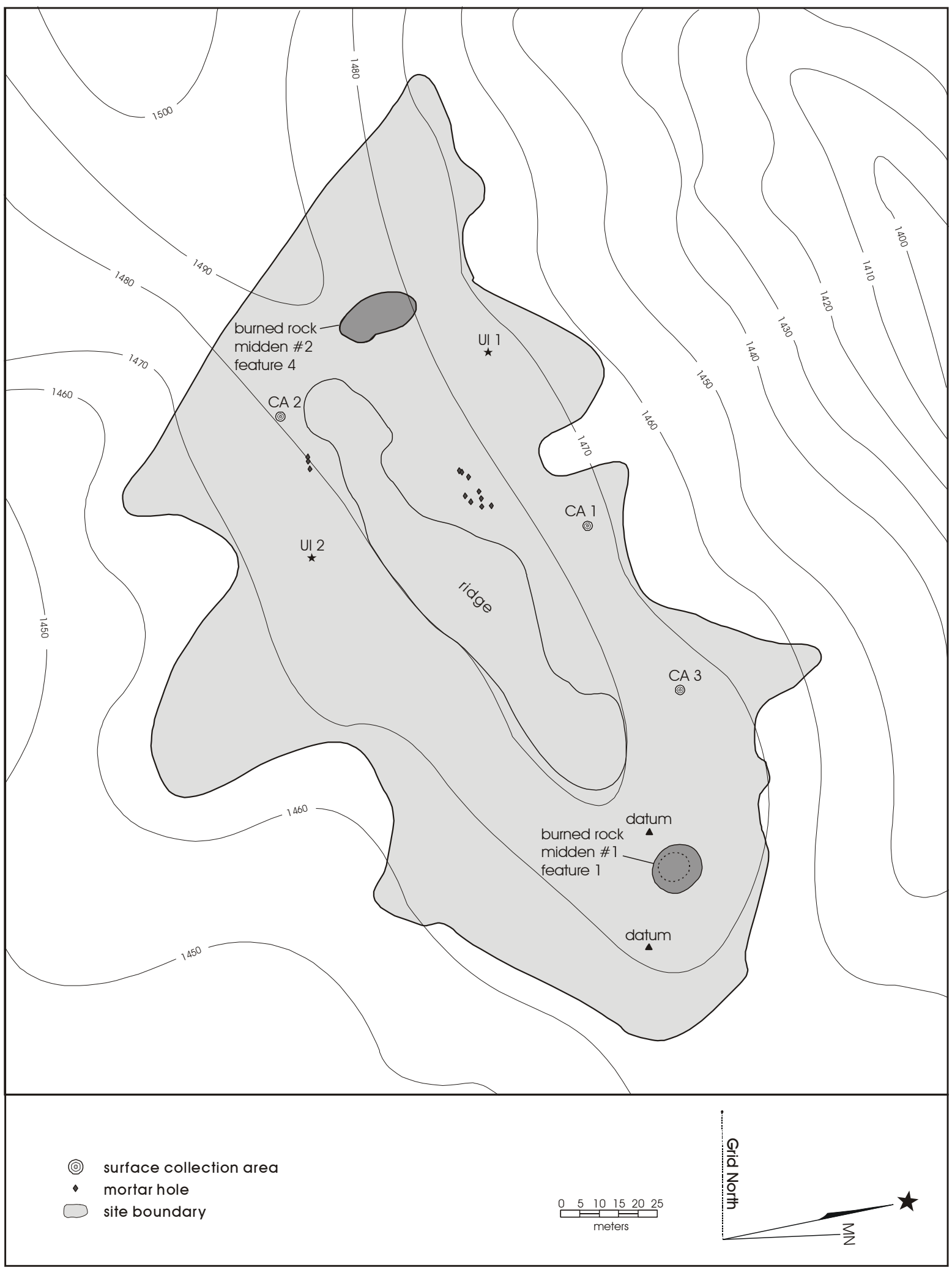

Figure 6-13. Site 41BR228 with burned rock middens, mortar holes, unique items, and surface collection areas identified. 


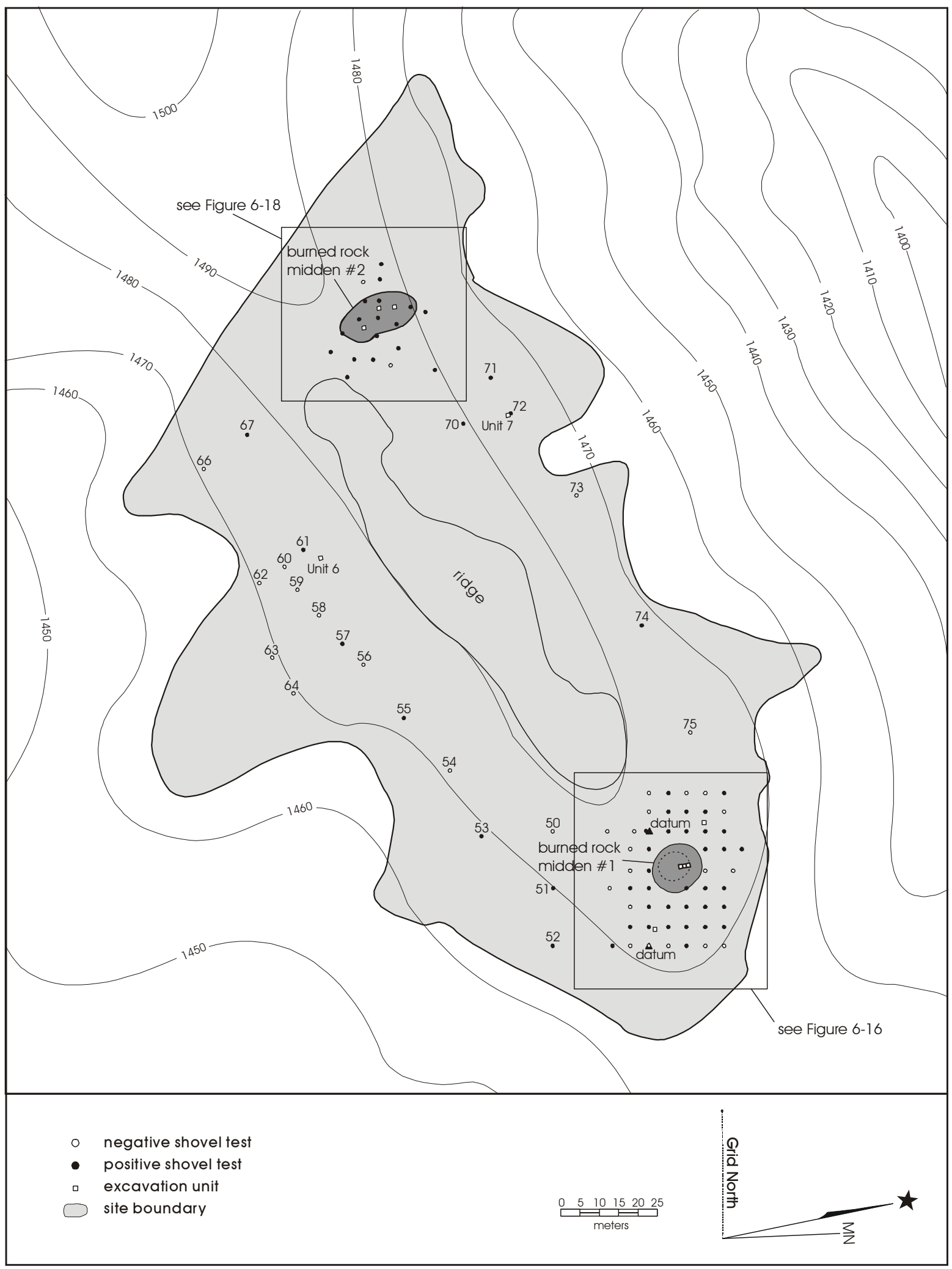

Figure 6-14. Map of site 41BR228 with shovel tests and excavation units identified. 
chipped stone density graph has three distinct modes, with high densities in Levels $1(0-10 \mathrm{cmbs})$ and $3(20-30 \mathrm{cmbs})$, and the highest density below Level $4(+40 \mathrm{cmbs})$. While it was not possible to excavate most non-midden shovel tests below Level 4, the chipped stone density graph suggests that, at least in some areas of this site, deeper deposits with relatively high densities of chipped stone may be present.

As noted above, we concentrated shovel tests around the midden on the eastern end of the site. The second midden, discovered in shovel tests, was not systematically explored. Consequently, we focus on Midden 1 to consider spatial and vertical relationships in the shovel test data relative to the burned rock midden features at this site. Figure 6-16 provides a blowup of this midden, along with the systematic grid of shovel tests in this area that will form the basis for this comparison. Only a single shovel test, number 16, was excavated within the confines of the midden (Zone 1). Within a $15-\mathrm{m}$ radius off the midden center (Zone 2), 23 shovel tests were excavated. Finally, there are an additional 26 shovel tests excavated outside of the 15-m radius, but within close proximity to the midden (Zone 3 ).

The single midden shovel test (ST 16) in Feature 1 contained moderate densities of fire-cracked rock in the upper three levels. However, no debitage, tools, cores, or shell were recovered from this shovel test. Within Zone 2, 18 of the 23 shovel tests ( $78.3 \%$ ) were positive. Fifteen of the 23 shovel tests $(65.2 \%)$ had debitage and 14 of the $23(60.9 \%)$ had fire-cracked rock. In Zone 3, only 53.8 percent $(\mathrm{n}=14)$ of the 26 shovel tests were positive, with only $11(42.3 \%)$ containing debitage and only eight $(30.8 \%)$ containing firecracked rock. The densities of chipped stone and firecracked rock in and around the midden also patterns by zone. Not surprisingly, fire-cracked rock density is highest in the midden, with an average of 65.20 items recovered per excavated level. In Zone 2, fire-cracked rock density drops to 4.63 items per excavated level, and within Zone 3 the density is only .87 items per level. While no debitage was recovered from the single midden shovel test, 63 items were present in the 46 excavated levels within Zone 2, a density of 1.37 items per level. This density drops slightly to only 1.06 items per level in Zone 3.

Consequently, the area immediately around the midden tends to have both a higher frequency of positive shovel tests, a higher frequency of such tests with fire-cracked rock, and a higher frequency of shovel tests with debitage. Outside of the midden, both chipped stone and burned rock density decrease. These data suggest that the feature may have been a primary focus of activity in this portion of the site.

The results of shovel testing at 41BR228 demonstrate that the deposits are primarily shallow. Outside of the middens, only a single area was present with sediments below $40 \mathrm{~cm}$. About 66 percent of the shovel tests were positive. Recovery of fire-cracked rock was primarily in the upper level, with recovery of chipped stone having three levels of higher density. Shovel testing revealed a second midden at the site (Feature 4), and a series of tests help refine the location of that feature. Systematic testing around Midden 1 (Feature 1) suggests that the feature was probably a focus of activity in this portion of the site.

\section{Surface Collection}

The shallow nature of the deposits revealed by the shovel testing at this site is consistent with the high surface artifact density observed. Given the densities, three surface collection areas, each from different areas of the site, were selected for investigation. In addition to these three systematic collection areas, two projectile points, a Late Archaic Bulverde (UI 1) and a Late Prehistoric Scallorn (UI 2), were collected from the surface (see Figure 6-13).

In all three surface collection areas, a point was selected as the center for a circle with a radius of $3 \mathrm{~m}$. All material within the roughly $28.3 \mathrm{~m}^{2}$ area defined by the circle was collected. These three areas produced 415 pieces of debitage, a variety of retouched/utilized tools, bifaces, cores, and a single projectile point. Examples of the formal tools can be found in Appendix F, and the point is illustrated in Appendix E. In all cases, the material was dominated by chert, with other raw materials comprising less than three percent of the assemblage.

There was considerable variability represented between these three areas. Area 1 contained 155 items, a density of about 5.5 items per square meter. Recovered from this area were 145 pieces of debitage, one core, five bifaces, and four retouched/utilized items. Within the debitage, 78 percent lacked any cortex, with only 8.3 percent having more than 50 percent cortex present. Area 2 contained 184 pieces of debitage, six bifaces, eight utilized/retouched pieces, and two cores - a density of just over seven items per square meter. Approximately 70 percent of the debitage from this area lacked cortex, with 8.2 percent having more than 50 percent cortex present. A single point fragment, probably a 


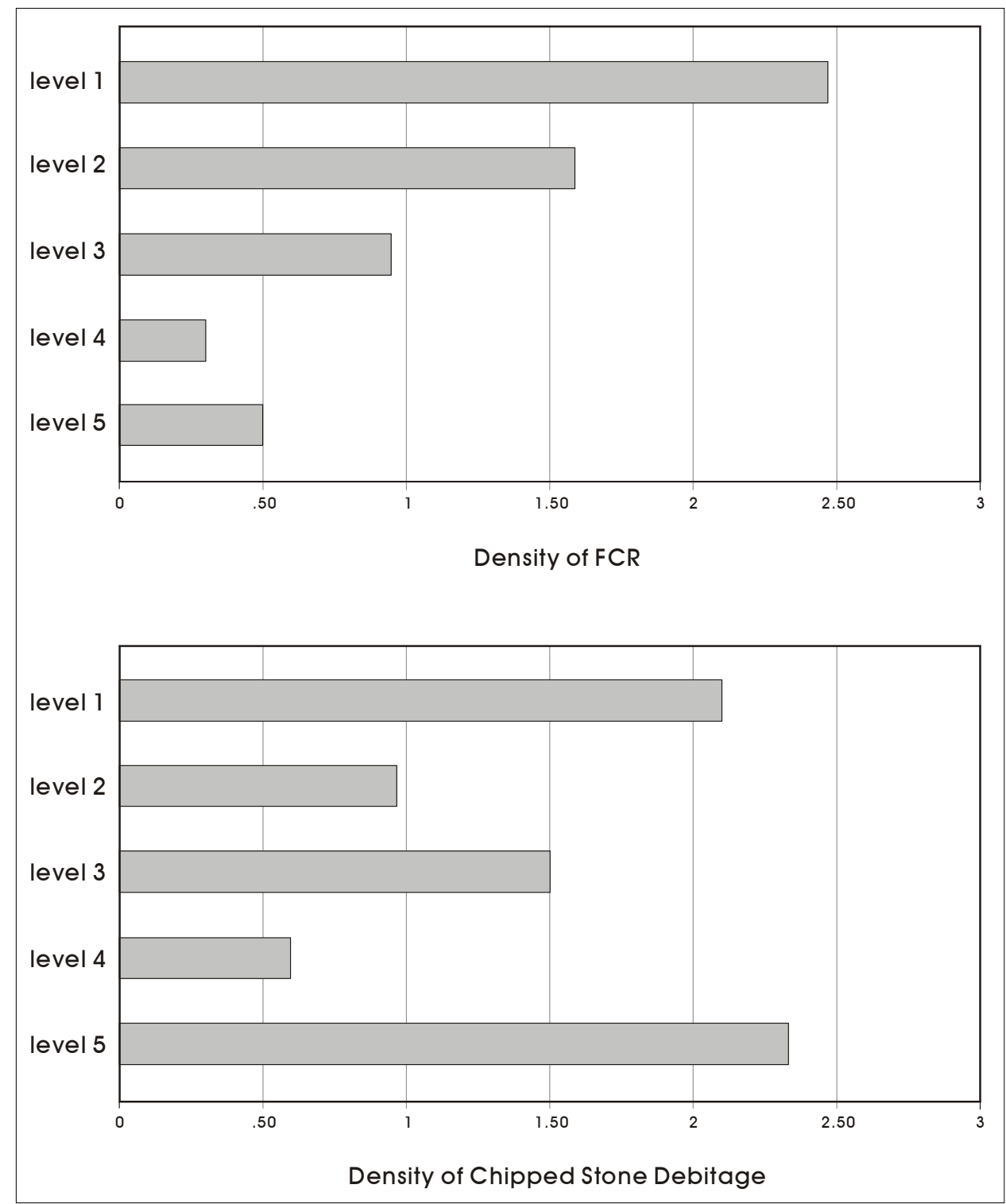

Figure 6-15. Densities of fire-cracked rock and debitage by level for non-midden shovel tests at $41 B R 228$.

Bulverde point suggesting occupation in the early part of the Late Archaic, was recovered from this area. Area 3 contained 86 pieces of debitage, two cores, one biface, and a single utilized/retouched item-a density of 3.2 items per square meter. In addition, fire-cracked rock was recovered from Area 3. Roughly 59 percent of the 86 pieces of debitage lacked cortex, and items with more than 50 percent cortex made up 12.8 percent. Finally, note that both Area 1 and Area 3 had mussel shell present.

\section{Excavation Results}

A volume of roughly $4.86 \mathrm{~m}^{3}$ of sediment, taken from ten $1-\mathrm{x}-1-\mathrm{m}$ units, was removed from this site (see Figure 6-14). Three contiguous 1-x-1-m units (Units 1, 2, and 3), representing $1.83 \mathrm{~m}^{3}$, were excavated in Midden 1 . Two 1-x-1-m units (Units 4 and 5), having a total volume of $.43 \mathrm{~m}^{3}$, were excavated in the immediate vicinity of this midden. Three units (Units 8, 9, and 10), representing 


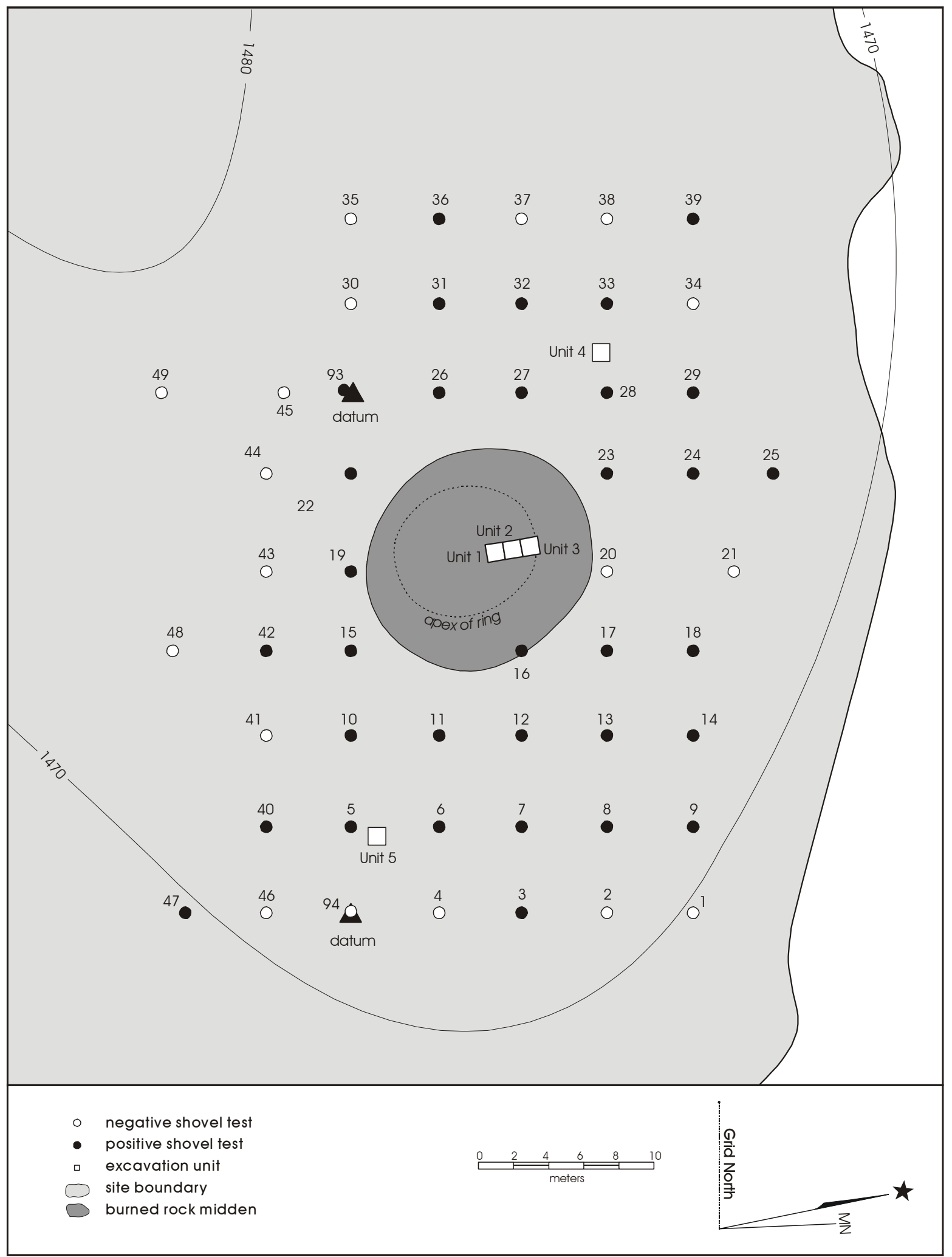

Figure 6-16. Shovel testing around Midden 1 at site 41BR228. 
$2.11 \mathrm{~m}^{3}$ of sediment, were excavated to help define the second midden. Finally, two units (Units 6 and 7), one on each side of the ridge, were excavated. These two units contained a volume of $.49 \mathrm{~m}^{3}$.

\section{Midden Units}

Three contiguous units, designated 1, 2, and 3, were excavated in Feature 1. These were positioned in an attempt to cut through the talus of the feature, as well as provide information on any central pit features. Figure 6-17 provides a profile of these units, which shows that while no central pit was discovered in this area, Unit 3 clearly cuts into the talus. Examination of the profile, as well as excavation notes, suggests that no clear features were present in either Units 1 or 2 that would indicate a pit, and it is likely that any central feature is farther to the south. All three units were dug to the underlying bedrock. As summarized by Bousman and Hodges (Appendix G), no visible calcium carbonate accumulations were noted in this midden, though some minor turbation was present.

We removed $1.83 \mathrm{~m}^{3}$ of sediment from these units. Artifacts recovered included 400 pieces of chipped stone debitage, three projectile points, two utilized/retouched items, four bifaces, and four ground stone fragments. Artifact density in the midden was just over 225 artifacts per cubic meter. Two of the three projectile points were recovered from Unit 3. These were classified as a Tortugas point (Level 1) and a Bulverde point (Level 6), suggestive of Middle Archaic and Late Archaic occupations. The third point, an untypable arrow point, was recovered from Unit 1, Level 2.

We recovered 13,385 fire-cracked rocks greater than one inch in size from these three units. As additional $199.0 \mathrm{~kg}$ of rock less than one inch in size was also recorded. While chert, limestone, and conglomerate were noted from the midden, sandstone accounted for over 99 percent of the material in the midden.

An additional feature, Feature 3, was noted at the base of the midden in Units 1 and 2. It is likely, however, that this feature is the result of rodent activity.

The second midden at this site, designated Feature 4, was visible, at least to some degree, on the surface as a slight rise of burned rock, possibly forming half of a ring. However, track vehicles had impacted this area, and the ground surface slopes dramatically to the north with some material probably being redeposited downslope. Consequently, no well-defined central feature area or talus was visible on the surface. Figure 6-18 presents a blowup of the Feature 4 area showing the probable outline of the midden based on the surface material and shovel tests in this area, as well as the location of three 1$\mathrm{x}-1$-m excavation units. These units, designated 8,9 , and 10 , were placed to clarify the location and depth of this feature.

We removed $2.11 \mathrm{~m}^{3}$ of sediment from these three units. Figure 6-19 presents profile drawings of the units, with probable depths of the feature identified. Note that in all three cases, excavation was conducted below the bottom of the feature. Feature deposits accounted for $1.65 \mathrm{~m}^{3}$ of material removed, with an additional $.46 \mathrm{~m}^{3}$ being below the feature. As summarized by Bousman and Hodges (Appendix G), distinctive differences in calcium carbonate accumulations in Units 8 and 9 relative to Unit 10 suggest that deposits in Unit 10 are of a more recent age.

Within the midden deposits, 166 pieces of debitage, two projectile points, six bifaces, two utilized/retouched items, and three ground stone fragments were recovered for an artifact density of just under 105 artifacts per cubic meter. From deposits that were estimated to be below the midden, a single biface and 28 chipped stone artifacts were recovered, yielding a density of 63 artifacts per cubic meter.

The two diagnostic projectile points recovered from these units were a Transitional/Late Archaic Frio point from Unit 8, Level 5 and an early Late Archaic Pedernales point from Unit 9, Level 7 (see Appendix E).

Over 13,500 fire-cracked rocks greater than one inch in size were removed from these three units. While chert, limestone, and conglomerate were noted from the midden, sandstone accounted for over 97 percent of this material. An additional $200.6 \mathrm{~kg}$ of rock less than one inch in size was also recorded.

Examination of the profiles in Figure 6-19, excavation notes, and the surface distribution of material suggest that Feature 4 has probably been impacted by a variety of processes. The original central location of the feature may have been near Unit 10. However, a significant amount of material appears to have been redeposited downslope. This deposition, coupled with rodent disturbance and disturbances caused by track vehicles, renders any clear interpretation of this feature, beyond the designation as a burned rock midden, difficult. 


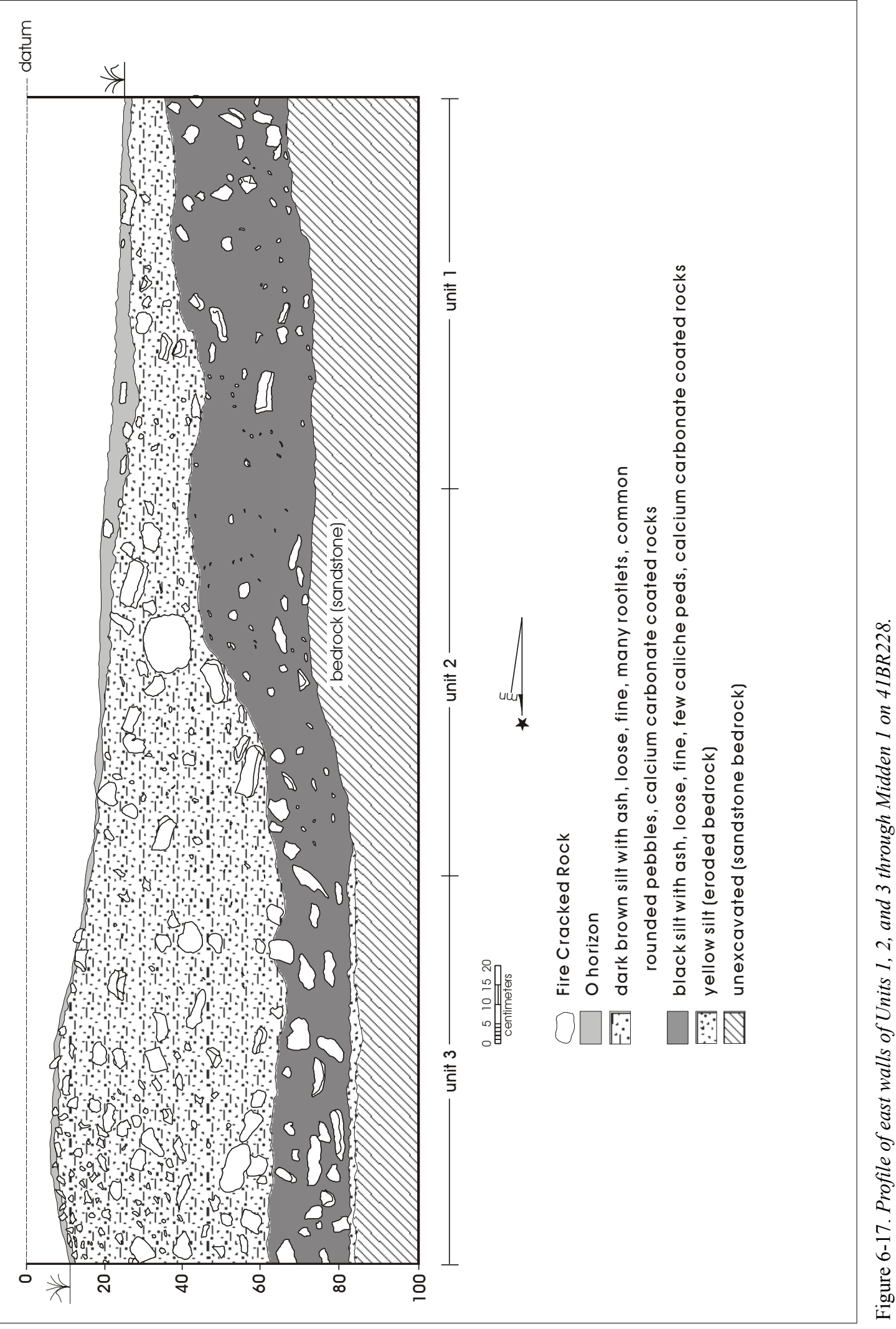




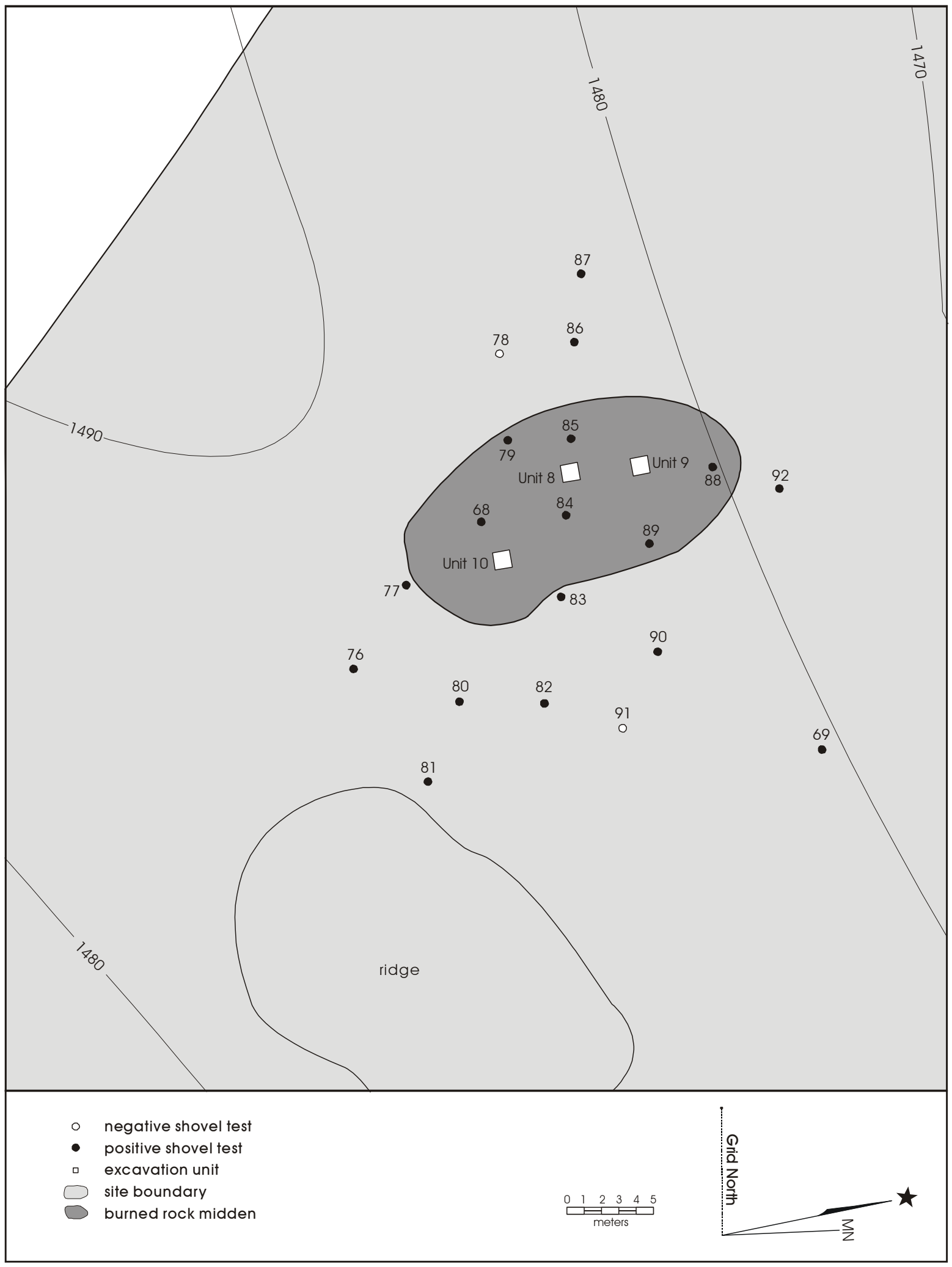

Figure 6-18. Blow-up of Feature 4, a burned rock midden on 41BR228, with shovel tests and excavation units identified. 


\section{Off-Midden Units}

Four units were excavated outside of midden deposits. Units 4 and 5 were excavated near the easternmost midden, Feature 1 (see Figure 6-16). Unit 6 was excavated on the south side of the east/west trending ridge, near Shovel Tests 59,60 , and 61 . Unit 7 was excavated on the north side of the ridge, in the vicinity of Shovel Tests 71, 72, and 73 (see Figure 6-14). Recall that this latter area had consistently deeper deposits represented in the shovel testing. Figure 6-20 provides profiles of all four of these non-midden excavation units.

From Unit 4, we removed a volume of $.29 \mathrm{~m}^{3}$ of sediment. This unit proved to be shallow, reaching a depth of roughly 35 cmbd. Unit 4 contained 317 flakes, five bifaces, two cores, three utilized/retouched pieces, one projectile point, and two projectile point preforms. The majority of material came from Level 2 (11-20 cmbd). This level included the projectile point, a Late Prehistoric Fresno type, as well as the two Fresno preforms. Two hundred and seventy-seven items were recovered from this $9 \mathrm{~cm}$ level, a density of over 3,000 artifacts per cubic meter. In addition, Feature 3, a small cluster of fire-cracked sandstone, was identified in this unit at $11 \mathrm{cmbd}$. The feature was not associated with any pit, but appeared to simply be a higher density of firecracked rock. The unit had 146 pieces of fire-cracked rock greater than one inch in size. The vast majority of this material was sandstone.

Unit 5, located on the eastern side of Feature 1 (see Figure 6-16), was only excavated to a maximum depth of $19 \mathrm{cmbd}$ before bedrock was encountered (Figure 6-20). Nevertheless, 262 pieces of debitage, one biface, one core, and two utilized/retouched items were recovered from the $.14 \mathrm{~m}^{3}$ of sediment. Roughly 67 percent of the artifacts were present in the initial level, a level that contained only $.05 \mathrm{~m}^{3}$ of deposits. Artifact density in this level was in excess of 3,500 items per cubic meter. No fire-cracked rock was noted in this unit.

Unit 6 was located in the area of surface Collection Area 2 which contained a Late Prehistoric Scallorn point (see Figure 6-13). As with most other non-midden excavations at this site, Unit 6 was shallow. Only two levels, representing a volume of $.15 \mathrm{~m}^{3}$, were removed before bedrock was encountered. Nevertheless, 59 pieces of chipped stone debitage, a single utilized/retouched flake, and a brownware sherd were recovered from the excavation. All material came from Level 2 yielding an artifact density of 610 items per cubic meter. The brownware sherd, one of only two recovered from the project, is probably Leon Plain (see Appendix F).

Finally, Unit 7 was placed to explore the deeper deposits to the north of the central ridge (Figure 6-14). As expected, this excavation was deeper than most of the non-midden units, removing $.34 \mathrm{~m}^{3}$ of sediment (Figure 6-20). Seven hundred and five flakes, three cores, two utilized/retouched items, and five projectile points and point preforms were collected from the excavation. A possible Andice point, reflective of an early Middle Archaic occupation, was recovered from Level 1. In addition, an untypable Late Archaic dart point was present in this level. Level 3 contained an Early Archaic Gower point, an arrow point preform, and an untypable dart point. The upper four levels had high artifact density, with the highest density of over 9,500 items per cubic meter in Level 1. Sixty-one pieces of fire-cracked rock greater than one inch in size were collected from this unit. An examination of the profile (Figure 6-20) shows that Level 4 is capped by a deposit with a high frequency of calcium carbonate coated pebbles, a deposit that, in shovel tests at this site, is usually below the primary archaeological deposits. Note also that the distribution of projectile points outlined above suggests that the material above $30 \mathrm{~cm}$ in this unit may be redeposited.

\section{Artifact Summary}

CAR collected 2,660 pieces of debitage, 35 bifaces, 17 cores, 27 utilized or retouched items, and eight fragments of ground stone from 41BR228. In addition, a single brownware sherd was collected. Appendix F presents scans of selected tools from this site. Chert dominated the raw materials, accounting for over 99 percent, with quartzite, limestone, and a variety of other materials present. Roughly 80 percent of the flakes lacked cortex, with only 19 flakes $(0.7 \%)$ having 100 percent dorsal cortex cover.

During CAR's work, 17 projectile points or projectile point preforms were recovered from the site (Appendix E). In addition, TXARNG cultural resources staff recovered two points, a Bulverde and a Pedernales (Wormser and SulloPrewitt 2001). We recovered six Late Prehistoric arrow points and preforms, including one Scallorn point and three Fresno points and preforms. Six Late Archaic forms were recovered, including a Frio, a Pedernales, a Langtry, and three Bulverde forms. A Tortugas and an Andice point reflect Middle Archaic occupation. Finally, a Gower point, reflecting Early Archaic use, was recovered. Additionally, two probable dart point fragments were recovered. The point 


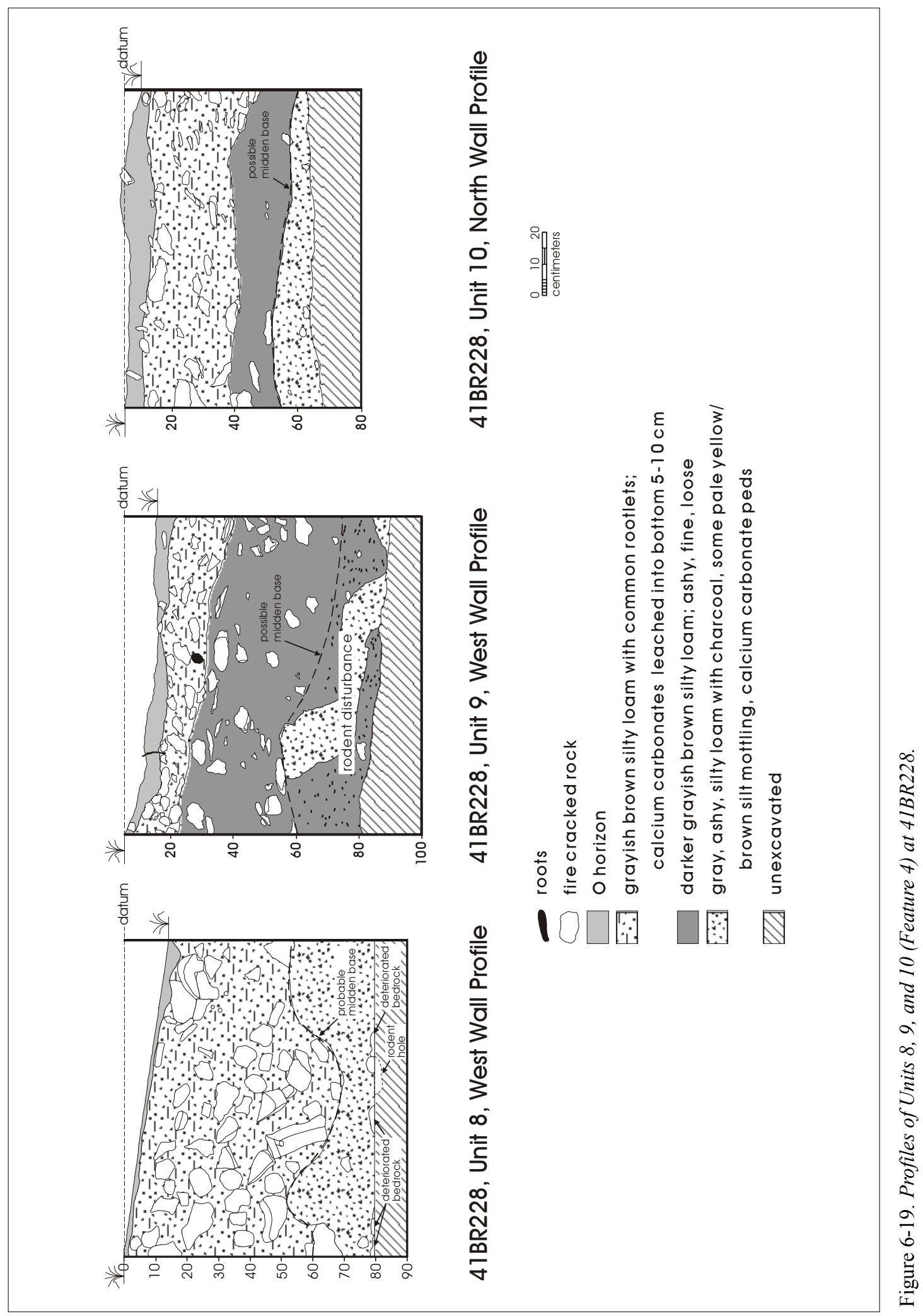




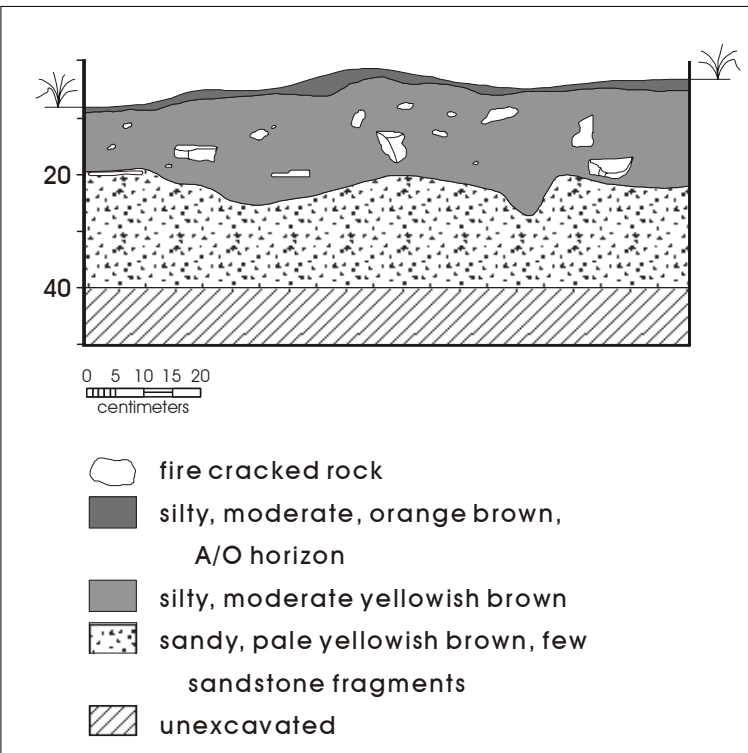

\section{BR228, Unit 4, South Wall Profile}
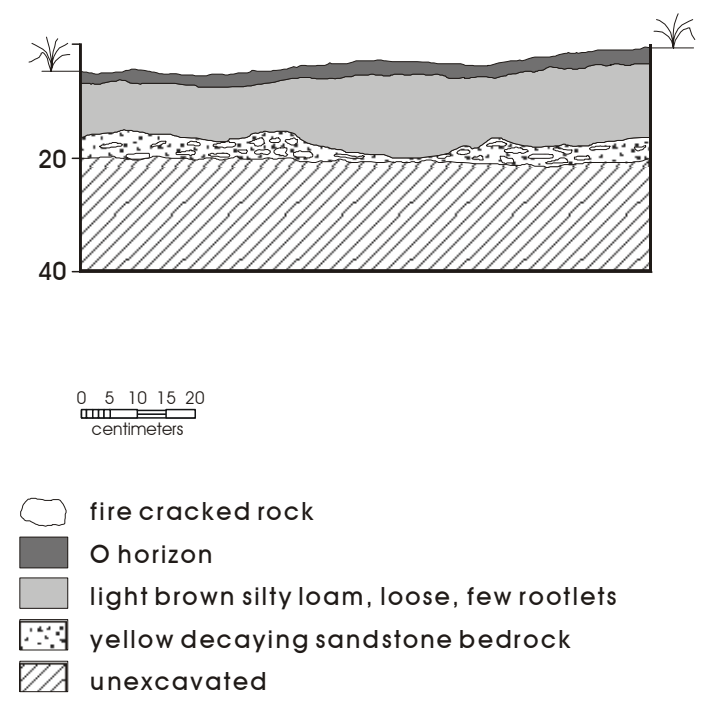

41BR228, Unit 6, North Wall Profile

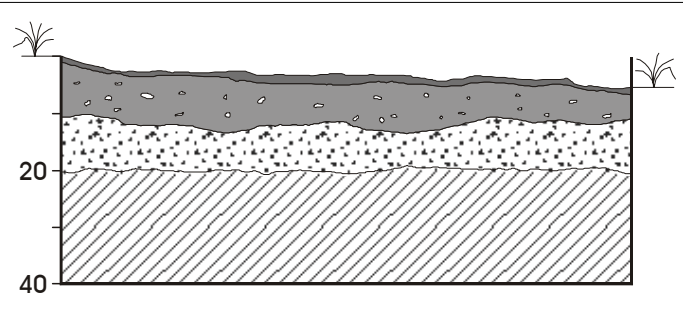

$0 \quad 5101520$
$\frac{\text { muा }}{\text { centimeters }}$

$\square$ fire cracked rock

thin O horizon

light brown silty loam with few rounded, calcium carbonate-coated pebbles

$\because \because$ yellow eroded bedrock, silty, platy, caliche-like with few limestone fragments

unexcavated

\section{BR228, Unit 5, West Wall Profile}

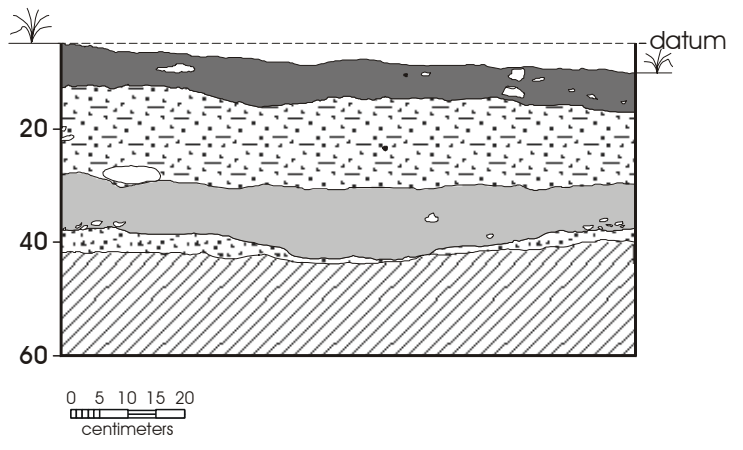

- roots

$\bigcirc$ fire cracked rock

light brown O/A horizon

brown silty loam with common rounded calcium carbonate-coated pebbles, few $1 / 4$ " roots

grayish to yellowish brown silty loam with common limestone and sandstone fragments, few rounded pebbles

$\because \because$ yellow, decaying, platy sandstone bedrock

DZ unexcavated

Figure 6-20. Profiles of non-midden excavation units at 41BR228.

\section{BR228, Unit 7, West Wall Profile}


forms, then, suggest some level of occupation from the Early Archaic through the Late Prehistoric.

\section{Other Samples}

No vertebrate faunal material was recovered in the excavations at this site. This lack of faunal material does not appear to be solely a function of preservation, however, as preservation of carbonized material within the midden was good. A variety of samples were collected for both ethnobotanical as well as radiocarbon analysis.

As summarized by Dering (Appendix C), the ethnobotanical samples analyzed from 41BR228 included macrobotanical material from 10 different excavation levels, as well as four flotation samples. Twenty-seven bulbs and bulb fragments, all of which were identified as Eastern camas (Camassia scilloides), were present in the macrobotanical samples. While most of this material was from Feature 1, a single bulb was recovered from the second burned rock midden (Feature 4). Oak (Quercus sp.) was recovered from three of the flotation samples. In addition, 12 bulbs were recovered from flotation sample 17, taken from Feature 1.

As noted above, mussel shell was commonly identified in the shovel testing at 41BR228, and shell was collected from two of the surface collection areas. Shell was also common in the excavations. Only excavation Unit 6 lacked any shell. In all, over $1.35 \mathrm{~kg}$ of mussel shell was recovered from our work at the site. Goodfriend identified 10 samples (Appendix D). These included Quadrula apiculata $(\mathrm{n}=1)$, Quadrula houstonensis $(\mathrm{n}=5)$, Amblema plicata $(\mathrm{n}=3)$, and Cyrtonaias tampicoensis $(\mathrm{n}=1)$.

\section{Radiocarbon Dates}

Four radiocarbon samples were submitted from this site. Two of these samples came from Unit 3 within Feature 1, the eastern burned rock midden. They represent Level 3 (30-40 cmbd) and the base of the midden at Level 7 $(70-80 \mathrm{cmbd})$. The corrected date for the Level 3 sample is $850 \pm 40$ years BP. The corrected date from the sample in Level 7 is $1040 \pm 40$ BP. Appendix A lists all details of these dates. If these dates are in context, the beginning of midden use, associated with Level 7, was sometime after A.D. 900 to 1030, with use dates for Level 3 falling between A.D. 1160 and 1255. Using the interval estimate in the OxCal radiocarbon calibration program (Ramsey 2000), there is a 95 percent probability that the interval between the bottom date and the upper date in Unit 3 represents at least 30 years and no more than 320 years. Using the midpoint of the distribution as an estimate, the midden may have formed in around 175 years during the Late Prehistoric period.

The remaining two radiocarbon samples were submitted from Unit 8 and Unit 10 in the area of Feature 4, the second burned rock midden at the site. The Unit 10 sample was taken from a depth of 50-60 cmbd, at the base of the feature. The corrected date from this sample was $1210 \pm 50$ years BP. Using the 1-sigma range, the sample probably dates to between A.D. 720 and 890 . The sample from Unit 8, taken from a depth of 50-60 cmbd, had a corrected date of 2980 \pm 40 years BP. Using the 1-sigma range, the calibrated date is between 1300 and 1120 B.C. To the degree that these dates reflect midden use, Feature 4 may have originally been used in the Late Archaic, with additional uses during the Late Prehistoric. The geomorphic description of Units 8 and 10, presented in Appendix G, are entirely consistent with the dates presented here.

\section{Summary}

CAR's work at site 41BR228 suggests that the burned rock midden designated as Feature 1 dates to the Late Prehistoric period. Analysis suggests that much of the midden may have formed in between 30 and 320 years. Two dates from the second midden area, designated Feature 4, suggests a more complicated use history with both Late Prehistoric and Late Archaic use. Seventeen projectile points were recovered from the site. These suggest an occupation span covering much of the prehistoric period from the Early Archaic through the Late Prehistoric.

Shovel testing, surface collection, and excavation results from outside the middens reveal high surface artifact density and shallowly buried deposits with extremely high chipped stone density. The distribution of chipped stone in shovel tests suggests the possibility of multiple occupations at the site. Outside the midden, excavation artifact density averaged 1,491 artifacts recovered per cubic meter. Within the Feature 1 midden deposits, density was lower at roughly 225 items per cubic meter. Feature 4 midden deposits had about 105 items per cubic meter. No faunal material was recovered from the excavation. Mussel shell was common at this site. Macrobotanical samples produced bulbs and bulb fragments, with most material coming from Feature 1. 
Flotation samples produced oak charcoal, as well as bulbs. Other than the bulbs, no economic plants were identified in samples from 41BR228.

Conditions for preservation of ethnobotanical material within the first midden (Feature 1) were excellent, with the second midden (Feature 4) having lower recovery. While the site has been impacted both by erosion and vehicular traffic, and while rodent disturbance was noted in both middens, the context of the material recovered from excavations at the site appears to be adequate. The midden material from Feature 1 has minimal disturbance. Finally, note that outside of the midden, a feature was recorded in the excavations.

\section{BR246}

\section{Site Description}

Wormser and Sullo-Prewitt (2001:58-59) describe 41BR246 as a burned rock midden site with associated lithic debris. TXARNG cultural resources staff originally recorded the site in 1994. Three shovel tests were excavated, one of which was positive with material down to $45 \mathrm{cmbs}$. TXARNG archaeologists made observations on surface artifacts, and collected three bifaces, one hammer stone, and a modified flake. CAR archaeologists visited 41BR246 in the fall of 1999, and work was conducted during the early summer of 2001. Site 41BR246 extends across a north facing ridge, with a burned rock midden located at the toe of the ridge. The elevation is roughly 1,340 feet (408.5 m) AMSL. The site covers an area of approximately $19,800 \mathrm{~m}^{2}$. When CAR visited the site in 1999, vegetation consisted of short grasses, prickly pear, juniper, oak, and agarita. 41BR246 is located about $150 \mathrm{~m}$ from a seasonal drainage into Devils River, with Pecan Bayou roughly $1.5 \mathrm{~km}$ to the northwest and Lewis Creek about $1 \mathrm{~km}$ to the west.

The original recording of the site by TXARNG archaeologists noted a single burned rock midden. The midden was described as $15 \mathrm{~m}$ in diameter and crescent-shaped (Wormser and Sullo-Prewitt 2001:58). CAR's observations on the midden suggest that it is roughly $50 \mathrm{~cm}$ high on the north side and roughly $10 \mathrm{~cm}$ above ground on the southern, upslope side. The feature is approximately $13 \mathrm{~m}$ in diameter, and is dominated by sandstone. At the time of CAR's visit to the site, no artifacts were observed around the midden, but a cluster of material was present on the ridge on the southern end of the site (Figure 6-21).

\section{Shovel Test Results}

Forty-eight shovel tests representing 249 separate levels were excavated at the site. The majority of the shovel tests were focused around the burned rock midden with additional shovel tests placed to define the site boundaries and depth of deposits (Figure 6-22). These shovel tests were deep, averaging almost $52 \mathrm{cmbs}$. Outside of the midden itself, sediments in the shovel tests were primarily sandy clay. Small amounts of gravel occurred below $20 \mathrm{~cm}$ in most shovel tests. Sediment was generally loose to compact. Shovel tests were terminated at $50 \mathrm{~cm}$ if no artifacts had been recovered in the $40-50 \mathrm{~cm}$ level.

Figure 6-22 shows that the number of positive shovel tests at 41BR246 was low, with the vast majority of positive tests present near the midden in a cluster along its western and northwestern sides. Chipped stone was recovered from only eight of the 48 tests $(16.7 \%)$ and fire-cracked rock was noted in only nine shovel tests (18.8\%). Only 11 of the $48(22.9 \%)$ shovel tests were positive. As two of these shovel tests, numbers 19 and 17, were within the midden and were positive for burned rock, the percentage of positive shovel tests outside of the midden was only 19.6 percent.

Material recovered from the shovel tests included 27 flakes, one biface, two edge modified tools, one piece of ochre, and one projectile point. Mussel shell was noted in two shovel tests. Burned rock from shovel tests was not counted for this site, but it was noted as being present in 28 levels from nine shovel tests. The projectile point, recovered from Level 2 in Shovel Test 38, was identified as a Nolan, a Middle Archaic point form.

As noted above, only two shovel tests (17 and 19) were excavated in the midden. While both had fire-cracked rock noted in all levels, only Shovel Test 19 had artifacts present. A flake was found in Level 3, an additional flake was recovered from Level 4 , and a utilized/retouched flake was found in Level 8 (70-80 cmbs).

Figure 6-23 presents the chipped stone debitage density by level for the non-midden shovel tests. Note that while the number of items is low $(\mathrm{n}=25)$, a single, distinct mode is clearly present at Level $6(50-60 \mathrm{cmbs})$. Note, however, that there is also a clear break between Level 3 (20-30 cmbs), with .196 items per level, and Level 4 (30-40 cmbs), with no items recovered. The upper three levels all have artifacts, though the density is quite low. Examination of 


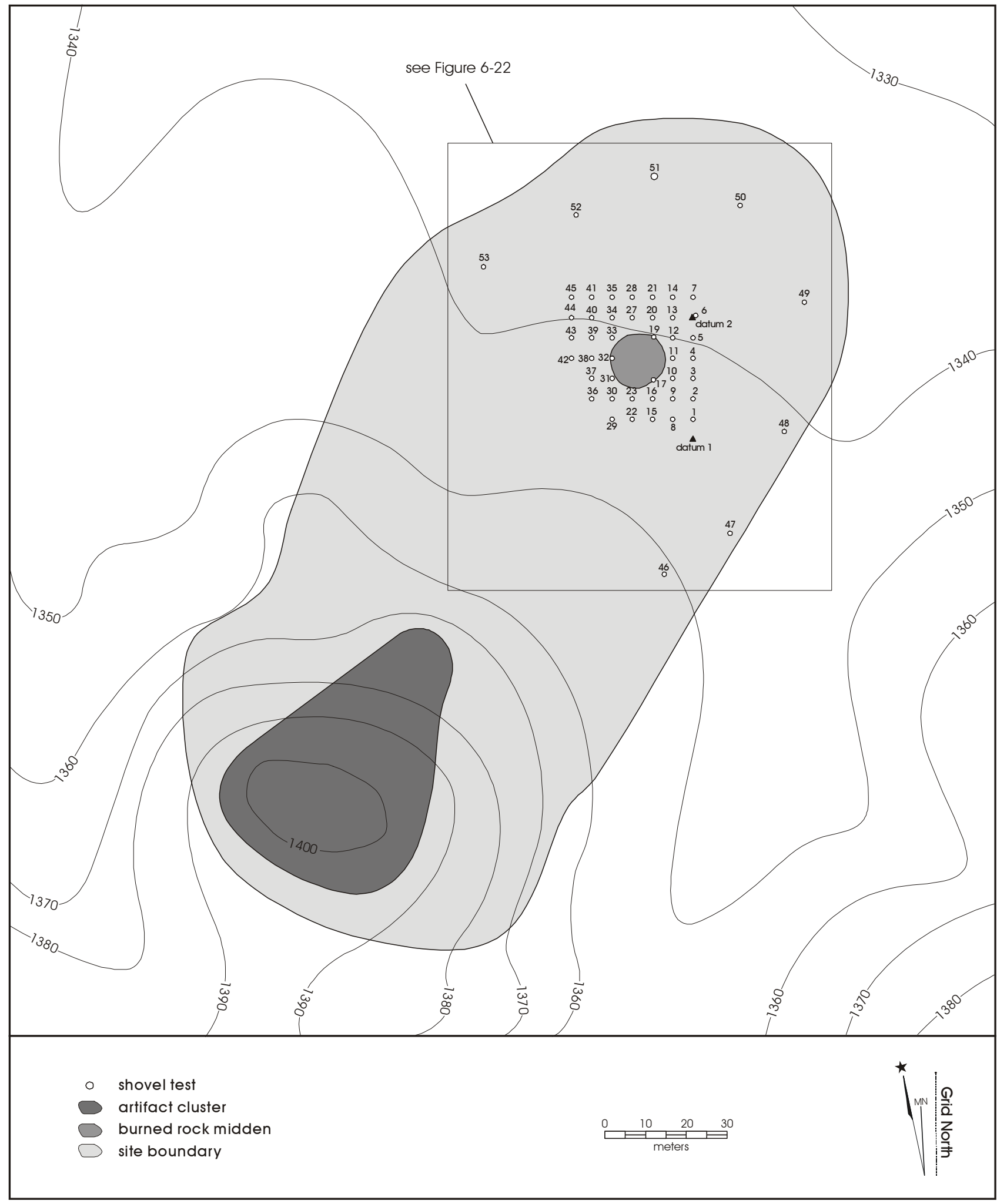

Figure 6-21. Site 41BR246 with burned rock midden and shovel tests identified. 


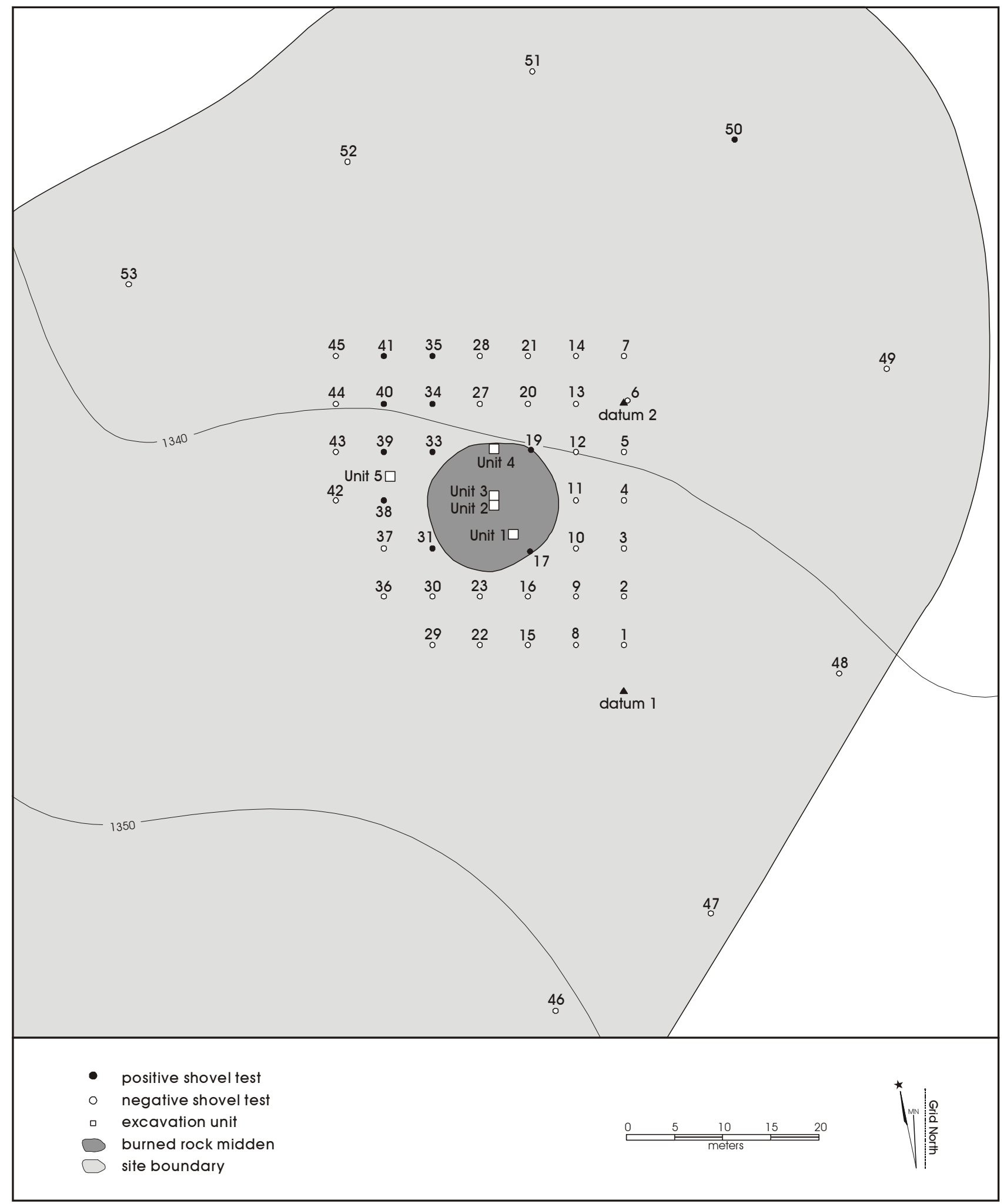

Figure 6-22. Burned rock midden area on site $41 B R 246$ with shovel tests and excavation units identified. 


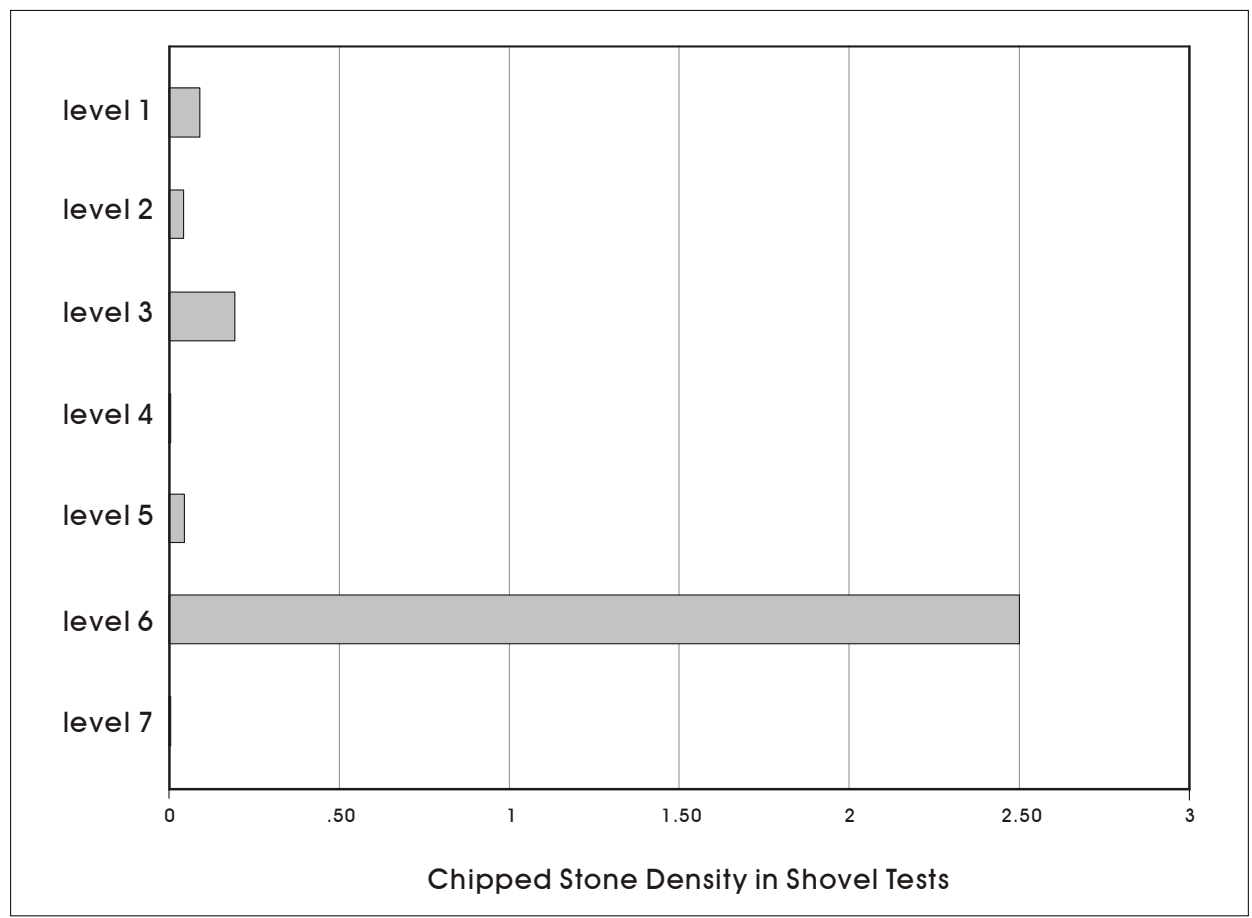

Figure 6-23. Chipped Stone debitage density by level in shovel tests at 41BR246.

individual shovel tests shows that debitage from Shovel Test 39 accounts for the lower mode in the figure as this single shovel test had nine of the 12 items $(75 \%)$ recovered from below $30 \mathrm{cmbs}$ at the site. While the sample size is small, the graph suggests the possibility that two distinct occupations may be present at this site.

\section{Surface Collections}

No surface collection areas were placed on 41BR246. While, as noted above, a low-density cluster of chipped stone was present on the ridge to the south of the midden, there was a lack of surface material associated with the feature. In addition, no unique items were observed on the surface.

\section{Excavation Results}

Five 1-x-1-m units were excavated at site 41BR246 (see Figure 6-22). Four were excavated to more clearly define the midden, as well as determine preservation potential, artifact content, and depth of deposits. An additional 1-x-1$\mathrm{m}$ unit was excavated in the area of Shovel Tests 38 and 39 to explore the potential that this area had evidence of multiple occupations. A total volume of roughly $5.58 \mathrm{~m}^{3}$ of sediment was removed in these five units. The four midden units contained a total volume of $5.03 \mathrm{~m}^{3}$, with the external unit containing $.55 \mathrm{~m}^{3}$.

\section{Midden Units}

While the shovel tests more clearly defined the spatial extent of the midden, no central area was visible prior to excavation. That is, it was not clear to us prior to excavation exactly where the center of this particular feature was. Consequently, four units were placed in the midden in an attempt to more clearly define the feature. Unit 1 was excavated in the southern portion of the midden. Two contiguous units, designated Units 2 and 3, were excavated in the approximate center of the midden. A fourth unit, designated Unit 4, was excavated on the northern edge of the midden (see Figure 6-22). As can be seen in Figure 6-24, Units 2 and 3 fell on the highest point of the midden. They probably represent the midden edge. Unit 1 is probably close to the center of the feature, while Unit 4 is on the northern edge.

Figure 6-25 is a profile of the west wall of Unit 1. The upper $20 \mathrm{~cm}$ of the profile is yellow silt that is unrelated to the midden deposits. The midden matrix dominates the 60 to $70 \mathrm{~cm}$ below that silt deposit. Underlying the midden is 


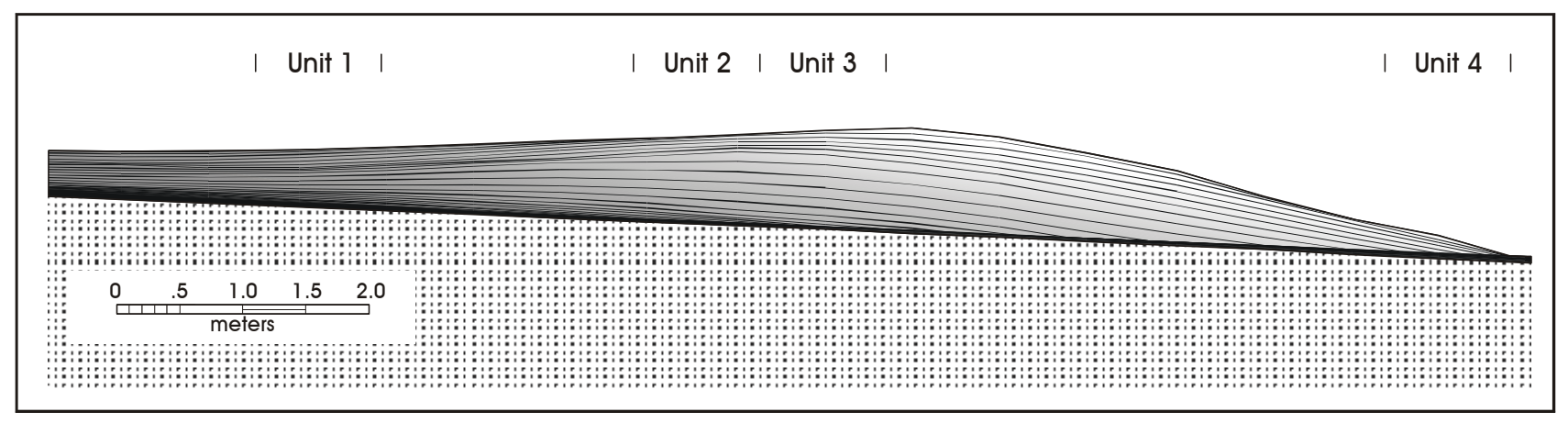

Figure 6-24. Cross-section of midden at site 41BR246.

brown sandy clay sediment. Note that the bottom of the midden is sloping up to the south, suggesting that this unit is within some sort of pit. Figure 6-26 presents a profile of Units 2 and 3, excavated on the apex of the midden. Comparisons with Figure 6-25 shows that these two units had both significantly greater depth and a much higher frequency of burned rock. Finally, Unit 4, located on the northern edge of the midden, also had a high density of rock present. While not profiled, both the excavation notes and rock counts suggest that high densities of fire-cracked rock characterized this unit. Unit 4 was excavated to a depth of $96 \mathrm{~cm}$ below surface, with the upper $76 \mathrm{~cm}$ being in the midden.

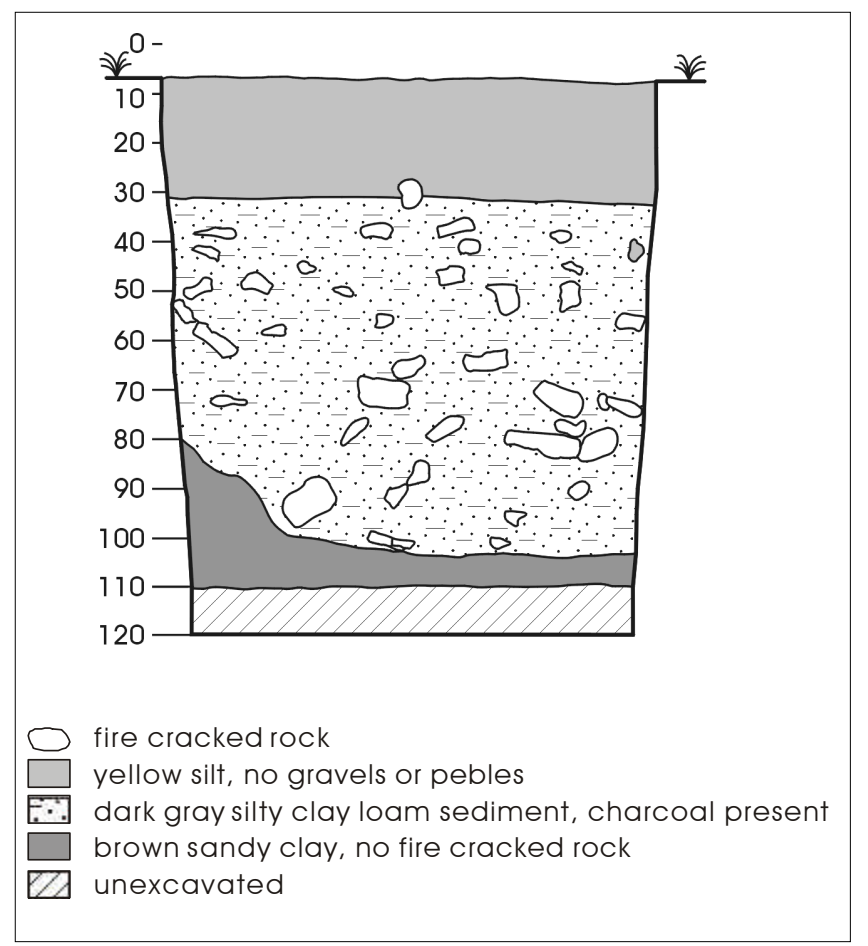

Figure 6-25. Profile of west wall, Unit 1, at 41BR246.
CAR removed $5.03 \mathrm{~m}^{3}$ of sediment from these midden units, with roughly $4.52 \mathrm{~m}^{3}$ being in midden deposits. Artifacts recovered from the excavations included 76 pieces of chipped stone debitage, two utilized/retouched items, two bifaces, and two pieces of ochre. Only 65 artifacts were found in deposits clearly associated with the midden. Artifact density in the $4.52 \mathrm{~m}^{3}$ of midden deposits, then, was just over 14 artifacts per cubic meter. Mussel shell was also common in the midden units, being noted in almost every level. We collected 689 grams of mussel shell from the midden units.

We removed 28,865 fire-cracked rocks greater than one inch in size from these four units. An additional $406.5 \mathrm{~kg}$ of rock less than one inch in size was also recorded. While chert, limestone, and conglomerate were noted from the midden, sandstone accounted for over 98 percent of the material in the midden.

\section{Off-Midden Units}

The single external 1-x-1-m unit was placed in the vicinity of Shovel Test 39, which had yielded evidence potentially indicative of multiple occupations, and Shovel Test 38, which had a Middle Archaic Nolan point in Level 2 (see Figure 6-22). The unit was excavated to a depth of $55 \mathrm{cmbd}$. While no profile is available for this unit, the excavation notes suggest that the sediment is extremely hard and gravelly, especially in the upper two levels, and probably represents colluvial deposits from the nearby slope. Artifacts were present on the upper ridge, above this unit, and it is likely that many of the artifacts recovered here were related to that upper distribution. In contrast to the midden units, artifact recovery in Unit 5 was high, with 178 pieces of chipped stone debitage, two projectile points, one core, four bifaces, and three utilized/retouched flakes. Artifact density was 340 items per cubic meter. Also in contrast to the midden units, mussel shell was not recorded for Unit 5. 
Artifact distribution was primarily concentrated in Levels 2 through 5. These four levels had 179 of the 188 recovered lithics. Level 4 had the highest recovery, with 66 items. The two projectile points, a Late Prehistoric Scallorn stem and an untypable arrow point, were recovered from Level 3 (20$30 \mathrm{cmbd})$. Recall that a Nolan point was recovered from Shovel Test 38, just to the south of Unit 5, at 10-20 cmbs. The presence of this Middle Archaic form above the Late Prehistoric forms may be related to the colluvial deposition suggested by the Unit 5 excavation. A low density of lithic material is present upslope from the midden. It is possible that this material is Middle Archaic in age and that it is being deposited on top of the Late Prehistoric material. Of course, it is also possible that the stratigraphy in this section of the site may be significantly mixed by other factors.

In addition to the artifacts, Feature 2 was recorded in Unit 5. The feature, a cluster of tabular sandstone, some of which appeared to have been burned, appeared at between 28 and $32 \mathrm{cmbd}$, at the bottom of Level 3. The cluster was confined to the southwestern corner of the unit (Figure 6-27), and while a slight darkening of the soil was noted, no associated pit could be identified. The function of this feature is unknown.

\section{Artifact Summary}

Two hundred and eighty one pieces of debitage, seven bifaces, seven utilized/retouched items, three projectile points, and one core were collected from 41BR246. Appendix F presents scans of selected tools from this site, while Appendix E presents the projectile points. Chert dominated the raw materials, accounting for over 99 percent of the stone recovered, with quartzite $(n=1)$ and an unidentified material $(\mathrm{n}=1)$ also present. Roughly 77 percent of the flakes lacked cortex, with only three flakes (1\%) having 100 percent dorsal cortex cover.

Three projectile points were recovered from the site (see Appendix E), all from the same general area. The recovery of a Nolan point suggests a Middle Archaic use. A stem from a Scallorn projectile point and an untypable arrow point suggest Late Prehistoric use of the site.

\section{Other Samples}

Six vertebrate faunal pieces were recovered from the excavation, all from excavation units within the midden. Unit 1 (see Figure 6-22) has a fragment of an astragalus from a white-tailed deer (Odocoileus virginianus) recovered from Level 5, and a single deer-sized fragment recovered from Level 6. From Unit 2, four deer-sized fragments were recovered from Level 14. Only three of the six fragments from the midden were burned (Appendix B). The low frequency of faunal material does not appear to be simply a function of preservation. Like many of the middens on this project, Feature 1 at 41BR246 had good preservation of carbonized material.

As summarized by Dering (Appendix C), bulbs, bulb fragments, and tubers were common in the 16 macrobotanical lots submitted from this site. In all, 40 such items were recorded. While most were indeterminate, Eastern camas (Camassia scilloides) was identified from one lot. In addition, Dering suggests that the tubers resemble Pediomelum (e.g., prairie turnip, prairie peanut, scurfpea), though positive identification could not be made. One of the two flotation samples from the midden produced bulbs, and oak charcoal was recovered from both samples.

As noted above, mussel shell was commonly recorded in the midden excavation units. While the amount of shell was less than $.7 \mathrm{~kg}$, only seven of the 48 levels excavated within the midden did not contain shell. In contrast, shell was not recorded in the single external unit, Unit 5. Goodfriend identified 11 samples of mussels (Appendix D). These included Quadrula apiculata $(\mathrm{n}=3)$, Amblema plicata $(\mathrm{n}=3)$, Potamilus purpuratus $(\mathrm{n}=3)$, and Tritogonia verrucosa $(\mathrm{n}=2)$.

\section{Radiocarbon Dates}

Two radiocarbon samples were submitted from the site. Both were from Unit 3 . The first sample came from $31-40 \mathrm{cmbd}$, while the second came from $128-140 \mathrm{cmbd}$. The corrected date for the Level 4 sample was $650 \pm 40$ years BP, while the sample from Level 14 yielded a date of $860 \pm 40 \mathrm{BP}$. Appendix A lists all details of these dates. Assuming that these dates are in context, it appears that the beginning of midden use, associated with Level 17, was sometime before the 1-sigma range of the date from Level 14 (i.e., A.D. 1060 to 1250), with termination of midden use occurring sometime after the Level 4 date of A.D. 1295 to 1390 . Using the interval estimate in the $\mathrm{OxCal}$ radiocarbon calibration program (Ramsey 2000), there is a 95 percent probability that the interval between the Level 14 date and the upper date from Level 4 represents at least 50 years and no more than 330 years. Using the midpoint of the distribution as an estimate, the approximately $1 \mathrm{~m}$ of deposits separating the two dates may have formed in around 190 years sometime in the Late Prehistoric period. 


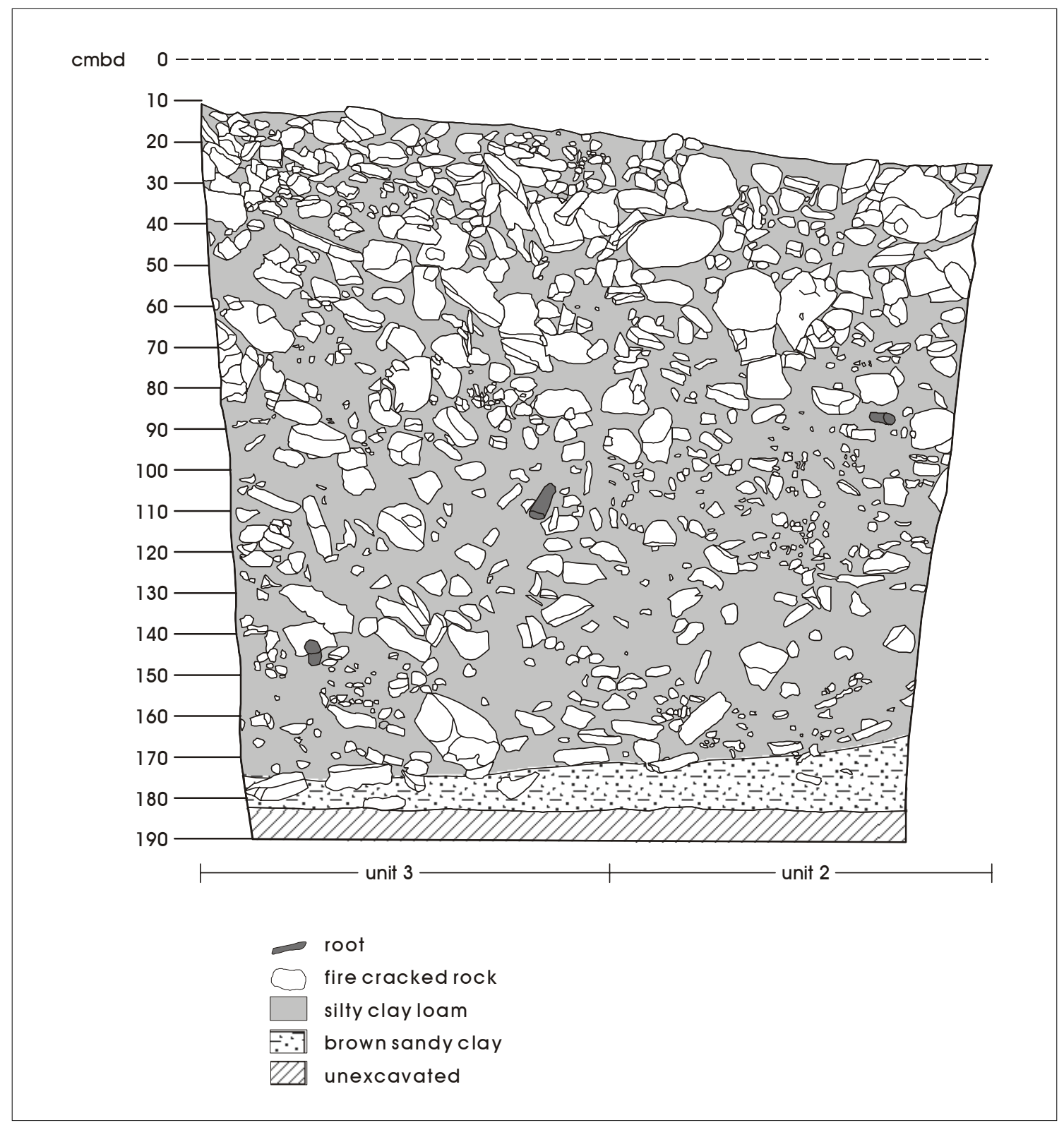

Figure 6-26. Profile of east wall, Units 2 and 3, at 41BR246.

\section{Summary}

Our work at site 41BR246 suggests that the burned rock midden dates to the Late Prehistoric period. Analysis suggests that much of the midden may have formed in between 50 and 330 years. Three projectile points were recovered, suggesting occupation in both the Middle Archaic and the Late Prehistoric.
The distribution of chipped stone in shovel tests from outside of the midden suggests the possibility of multiple occupations. Excavation results from outside the midden reveal high subsurface artifact density, with roughly 340 items recovered per cubic meter. Excavation within the midden deposits produced much lower densities, with a recovery rate of about 14 items per cubic meter. A low frequency of vertebrate faunal material, probably 
representing deer, was recovered from the midden. Mussel shell was common within the midden, though absent from the single external excavation unit. Macrobotanical samples produced bulbs and bulb fragments, including several fragments of tubers. Flotation samples produced bulbs and oak charcoal. Other than the bulbs and tubers, no economic plants were identified at 41BR246.

Conditions for preservation of ethnobotanical material within the midden were excellent. While the site has been impacted both by erosion and rodent disturbance, the context of the material recovered from excavations within the midden appears to be good. Finally, note that outside of the midden, a feature was recorded in the excavations.

\section{BR250}

\section{Site Description}

Wormser and Sullo-Prewitt (2001:60-61) describe site 41BR250 as a burned rock midden site with associated lithic debris. TXARNG cultural resources staff originally recorded the site in 1995. While no shovel tests were excavated, TXARNG archaeologists made observations on surface artifacts, and collected a biface, a Pedernales point base, and an

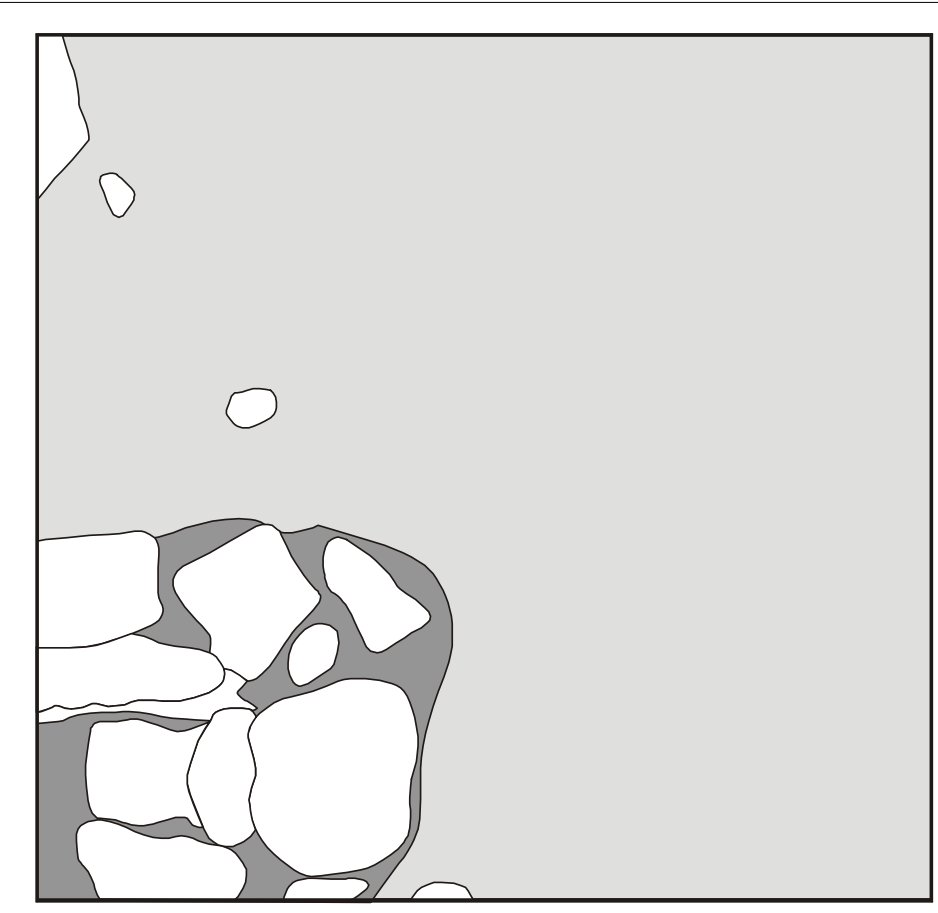
expanding-stem, side-notched arrow point. These artifacts suggest a Late Archaic and a Late Prehistoric occupation of the site.

CAR archaeologists visited the site in the fall of 1999 , and work was conducted during the early fall, and spring of 2000. 41BR250 extends along a southeast facing landform extending from a north-south ridge. A single burned rock midden, measuring roughly $10 \mathrm{~m}$ in diameter, is located near a small drainage on the northern end of 41BR250, and a series of lithic scatters are present on the southeast facing landform (Figure 6-28). The elevation of 41BR250 is roughly 1,330 feet (405.4 m) AMSL, and the site covers an area of roughly $10,200 \mathrm{~m}^{2}$. When CAR visited 41BR250 in 1999, vegetation consisted of short grasses, prickly pear, mesquite, and agarita. The site is located roughly $1.1 \mathrm{~km}$ from Lewis Creek, with Pecan Bayou being $1.45 \mathrm{~km}$ to the northeast. An intermittent tributary of Devils River is located roughly $450 \mathrm{~m}$ to the southeast.

A small drainage is located on the edge of the site, near the midden (Figure 6-28).

The midden is roughly $10 \mathrm{~m}$ east-west by $15 \mathrm{~m}$ north-south A central depression is present, surrounded by a low rock ring. The feature rises approximately 40 to $75 \mathrm{~cm}$ above the surrounding ground surface on all sides, with material spilling into the drainage on the north. The feature is dominated by sandstone. What appears to be a recent intrusion into the midden is present near the center. The intrusion appears as a roughly $1 \mathrm{~m}$ circular area, roughly 20 $\mathrm{cm}$ in depth, and basin-shaped. The midden is located on a slightly lower shelf relative to the ridge. At the time of CAR's visit to the site, no artifacts were observed around the midden, but a series of dense lithic scatters, matching those described by Wormser and Sullo-Prewitt (2001:60), were present along the ridge. 


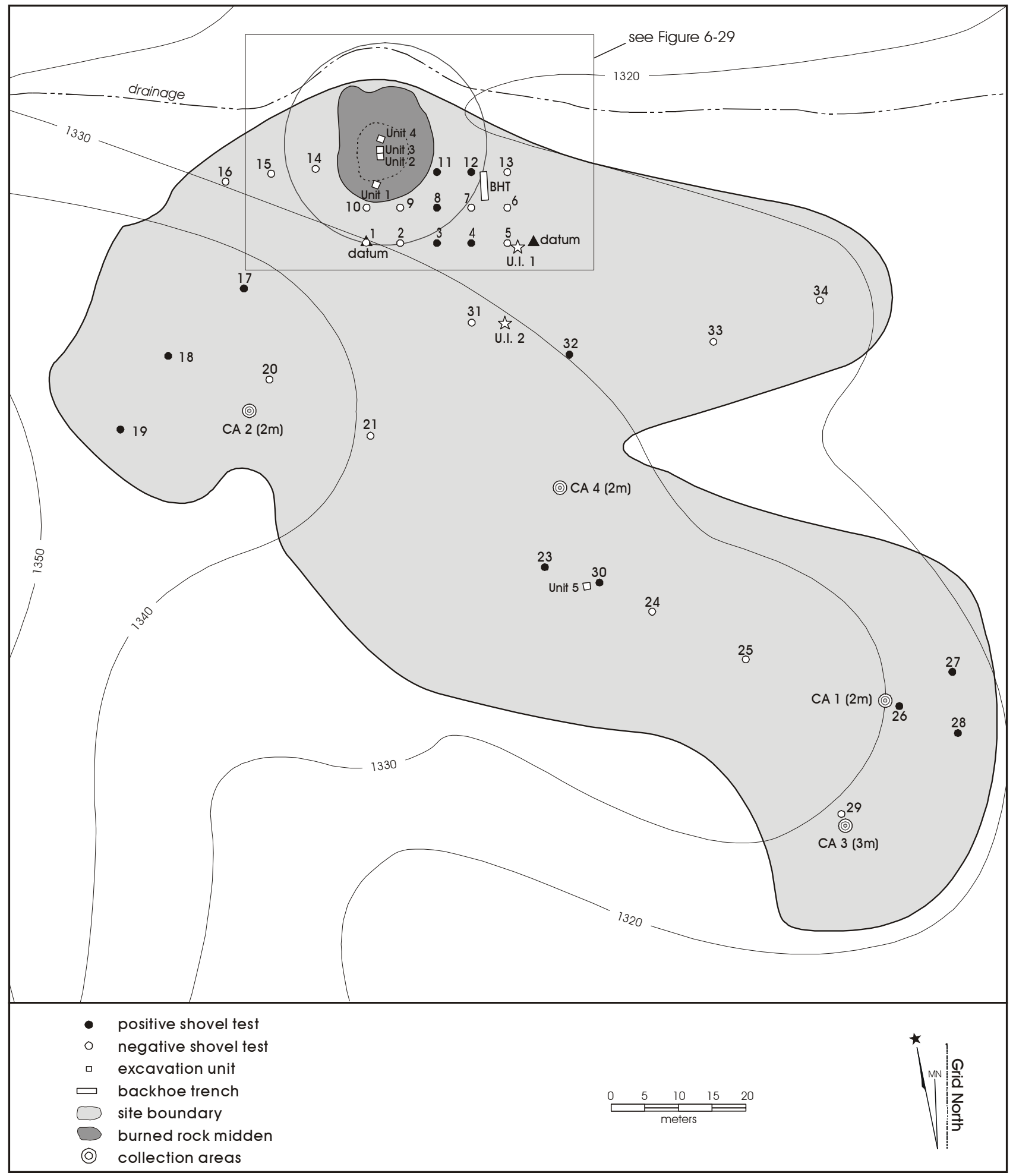

Figure 6-28. Site 41BR250 with burned rock midden, shovel tests, collection areas, and excavation units identified. 


\section{Shovel Test Results}

Thirty-three shovel tests representing 124 separate levels were excavated at the site. Because the midden was located on the northern periphery of the site against a drainage, the usual pattern of surrounding the midden with shovel tests at 5 -m intervals was not followed. Rather, 16 shovel tests were excavated near the midden on the lower shelf, and an additional 17 shovel tests were excavated along the ridge. No shovel tests were excavated in the midden. The 33 shovel tests averaged $37 \mathrm{cmbs}$, and termination of shovel tests was usually due to encountering the underlying bedrock, a decaying, yellow sandstone. Shovel tests near the midden were deeper, with an average depth of $44 \mathrm{cmbs}$, while the ridge-line shovel tests averaged only $32 \mathrm{cmbs}$. Sediments were generally loose to compact, and were frequently described as a sandy silt, yellow to pale brown in color. In places along the ridge-line, sediments were a dark red, with higher clay content, suggesting an extremely old surface.

The number of positive shovel tests at 41BR250 was low (see Figure 6-28). About 42 percent of the 33 shovel tests were positive. Only 10 of the 33 tests had chipped stone present, and fire-cracked rock was recovered from six of the shovel tests. Five of the 16 shovel tests near the midden, on the lower shelf, were positive (31.3\%), while nine of the 17 shovel tests along the ridge (53\%) were positive.

Material recovered from the shovel tests included 43 flakes and 19 pieces of fire-cracked rock. No other artifacts were recovered. Mussel shell was noted in three shovel tests. Thirty-four of the 43 flakes were recovered from Level 1, with the remaining nine flakes present in Levels 2 through 4. No artifacts were recovered from below Level 4. Clearly, these data suggest a low frequency of subsurface material, with most material confined to Level $1(0-10 \mathrm{cmbs})$. Deposits along the ridge probably represent either an eroded surface, or an older, stable surface with little deposition.

\section{Surface Collections}

Given the low frequency of subsurface recovery, and the high frequency of surface material along the ridge, a series of systematic surface collections were conducted at 41BR250. Four collection areas were placed along the ridge. In addition, two unique items were collected. Unique Item 1 was a mano. Unique Item 2 was a Pandale projectile point, suggestive of Early or Middle Archaic use of the area (see Appendix E). Figure 6-28 presents the locations of these unique items, as well as the locations of the four collection areas, each of which is discussed below.

Collection Area 1 consisted of a circle with a radius of $2 \mathrm{~m}$, located on the eastern edge of the ridge (see Figure 6-28). We collected 454 pieces of chipped stone debitage, 16 bifaces, four cores, two utilized/retouched items, and five pieces of fire-cracked rock from this area. Artifact density was about 38 artifacts per square meter in this collection area. Roughly 72 percent of the debitage from this area lacked cortex, and 1.8 percent of the debitage had 100 percent cortex cover on the dorsal surface. Chert was the dominant material type, accounting for 99 percent of all the debitage.

Collection Area 2 was located along the ridge on the southwestern portion of the site (Figure 6-28). The collection area consisted of a circle with a radius of $2 \mathrm{~m}$. One hundred and ninety-four pieces of chipped stone debitage, six bifaces, one core, four ground stone fragments, and six pieces of fire-cracked rock were collected from this area. In addition, a Pedernales-like point and an Ensor point were recovered from this collection area (see Appendix E). Artifact density was 16.5 artifacts per square meter in this collection area. Roughly 62 percent of the debitage from this area lacked cortex, and three percent of the debitage had 100 percent cortex cover on the dorsal surface. Chert was the dominant material type, accounting for over 99 percent of all the debitage. All four ground stone items were sandstone.

Collection Area 3 was located on the southeastern point of the ridge, in the vicinity of Collection Area 1 (Figure 6-28). This collection area consisted of a circle with a radius of 3 $\mathrm{m}$. Only 25 pieces of chipped stone debitage, one biface, and one core were collected from this area. Artifact density was only .95 items per square meter. Roughly 84 percent of the debitage from this area lacked cortex, and no item had more than 50 percent cortex cover. Chert was the dominant material type, accounting for 96 percent of all the debitage.

Collection Area 4 was located along the ridge in the central portion of the site (Figure 6-28). This collection area consisted of a circle with a radius of $2 \mathrm{~m}$. One hundred and forty-nine pieces of chipped stone debitage, three bifaces, four cores, three utilized/retouched items, and eight pieces of fire-cracked rock were collected from this area. In addition, an untypable projectile point was recovered from this area. Artifact density was just over 13 artifacts per square meter. Only 56 percent of the debitage from this area lacked 
cortex, but only 1.3 percent of the debitage had 100 percent cortex cover. Chert accounted for 100 percent of all the debitage. In addition, mussel shell was recovered from the surface collection.

Results from the surface collections at 41BR250 show that, to the degree that these areas reflect the general surface, artifact density is highly variable, even over a short distance such as between Collection Area 1, with a density of over 38 artifacts per square meter, and Area 3, with a density of under one per square meter. There is also variability in artifact content, as well at reduction strategies, with noncortical flakes comprising between 56 percent and 84 percent of the debitage within given collection areas. In addition, the surface collection areas, as well as the isolated collections, suggest that this portion of the site may have been occupied from the Early or Middle Archaic into the terminal Late Archaic.

\section{Excavation Results}

Five 1-x-1-m units were excavated at site 41BR250 (see Figure 6-28). Four units (numbers 1 through 4) were excavated to more clearly define the midden, as well as determine preservation potential, artifact content, and depth of deposits. An additional 1-x-1-m unit (Unit 5) was excavated along the ridge, near Shovel Test 30, to clearly document the lack of deposition in this section of the site. A volume of roughly $4.32 \mathrm{~m}^{3}$ of sediment was removed in these five units. In addition, a single backhoe trench (BHT) was placed to the east of the midden (see Figures 6-28 and 6-29).

\section{Midden Units}

Four units were placed in the midden in an attempt to more clearly define the feature (Figure 6-29). Unit 1 was excavated in the southern portion of the midden, on the midden ring. Two contiguous units, designated numbers 2 and 3, were excavated in the center of the midden. Unit 4 was excavated to the north of this 1-x-2-m excavation, and was positioned to crosscut the possible pit dug into the midden.

Figure 6-30 is a profile of the west wall of Unit 1 with three distinct zones identified. Only the upper two zones are probably related to the feature, with the underlying hardpacked, yellowish silty clay being below the feature.

Figure 6-31 presents a profile of the west wall of Units 2 and 3 , excavated in the center of the midden. Comparison with Figure 6-30 shows that these two units had a significantly greater frequency of larger fire-cracked rock, as well as a slightly greater depth. While no internal pit is visible in the profile, excavation notes from both units suggest that several different layers of larger rock, possibly forming separate internal pits, were stacked in these units. As summarized by Bousman and Hodges (Appendix G), sediments within the central portion of the midden at this site suggest, based on variations in calcium carbonate accumulation and differences in the level of disturbance by worms, at least two major periods of midden use.

Finally, Figure 6-32 is a north wall profile of Unit 4. The small pit feature is visible at the top of the profile, and a review of excavation notes suggests that the upper $37 \mathrm{~cm}$ of this unit have been disturbed by this intrusion. It is probable that this is a recent feature.

A volume of $4.17 \mathrm{~m}^{3}$ of sediment was removed from these four midden units, with roughly $4.03 \mathrm{~m}^{3}$ being in midden deposits. Few artifacts were recovered from these midden excavations. Only 12 pieces of chipped stone debitage, one core, and two projectile points were collected from the excavations - an artifact density of 3.6 artifacts per cubic meter of sediment. Mussel shell was also present in the midden, with just over 300 grams being collected from three of the four units. While shell was recorded in the excavation notes for Unit 2, no shell was recorded in the laboratory for this unit. The two projectile points consisted of an untypable specimen from Unit 1, Level 2, and a Late Prehistoric Scallorn point from Unit 4, Level 9. In addition, a single brownware ceramic sherd, probably Leon Plain, was present in the heavy fraction of a flotation sample taken from Unit 1 at between 90 and $100 \mathrm{cmbs}$.

We removed 28,369 fire-cracked rocks greater than one inch in size from these four units. An additional $340.3 \mathrm{~kg}$ of rock less than one inch in size was also recorded. Sandstone accounted for 100 percent of the recorded raw material in the midden.

\section{Off-Midden Unit}

The single external 1-x-1-m unit (Unit 5) was placed near Shovel Test 30 along the central portion of the ridge (see Figure 6-28). This unit was only excavated to a depth of 20 cmbd. While no profile is available for this unit, the excavation notes suggest that the sediment was extremely gravelly, with decayed sandstone bedrock encountered at $15 \mathrm{cmbd}$. Twelve chipped stone debitage were recovered from this excavation, all from the initial level. A single mussel shell fragment was also present. 


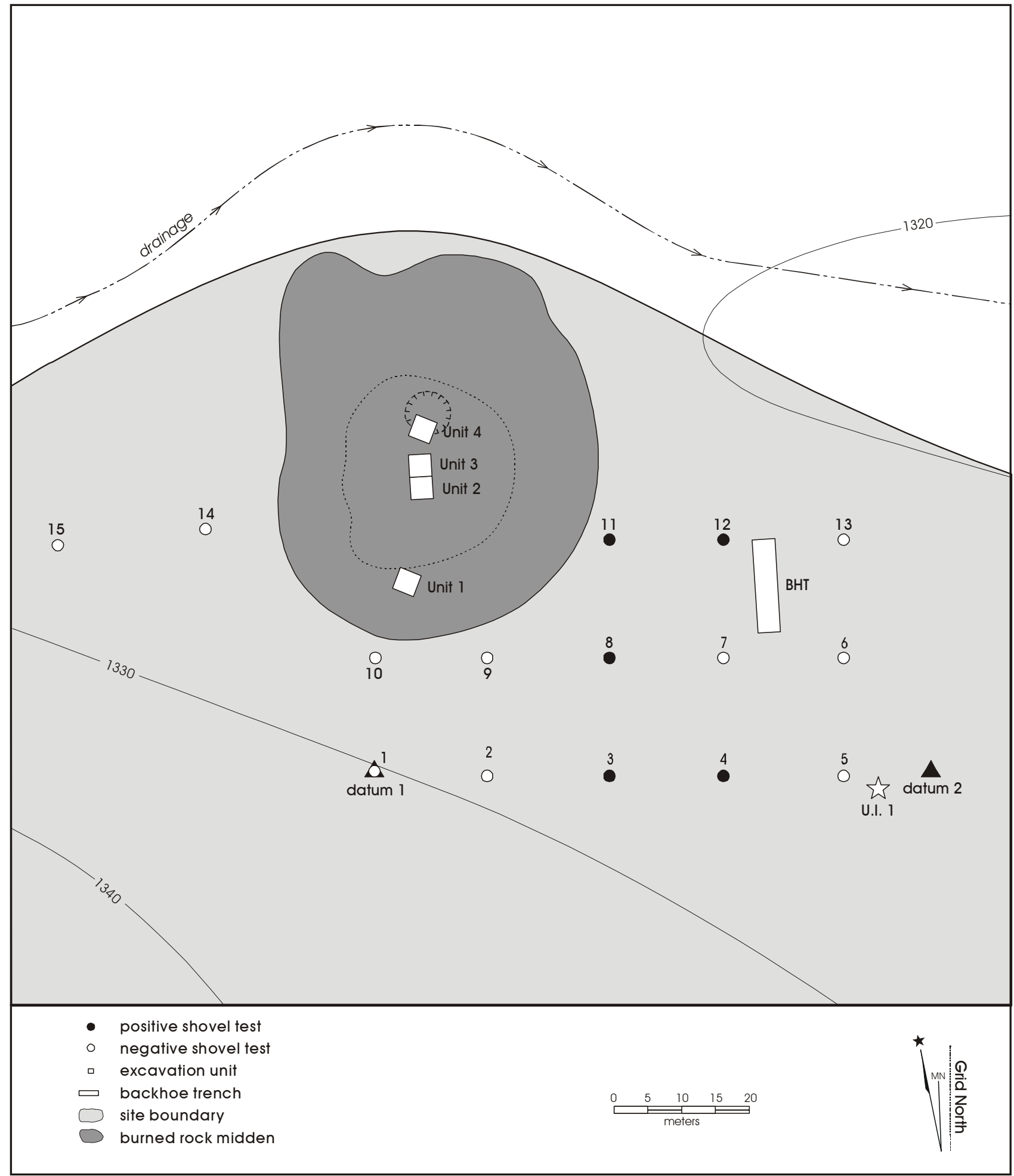

Figure 6-29. Blow-up of burned rock midden area on site 41BR250. 


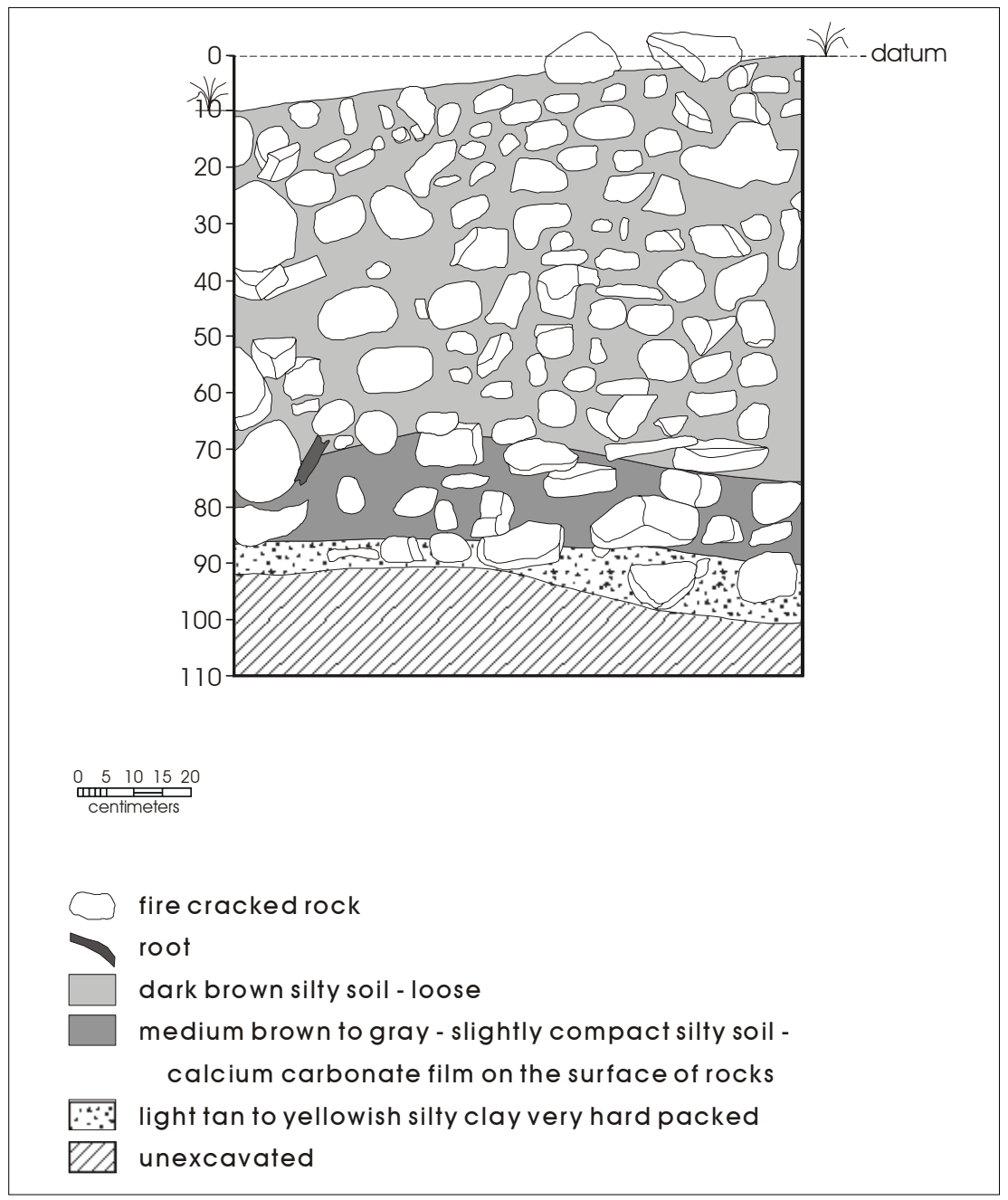

Figure 6-30. Profile of west wall of Unit 1 on site 41 BR250.

Reference to Figure 6-28 shows the location of a single backhoe trench placed on this site during geoarchaeological work. While a detailed description of that profile is provided in Appendix G, the trench revealed a thin buried A horizon on this lower shelf that may correlate to the period of midden construction.

\section{Artifact Summary}

A total of 889 pieces of debitage, 26 bifaces, 12 cores, five utilized/retouched items, two manos, six projectile points, and seven ground stone fragments were collected from 41BR250. The vast majority of this material was recovered from surface collections along the ridge, with both excavation units and shovel tests having low recovery. Appendix E presents scans of the projectile points, while
Appendix F presents scans of selected tools from this site. Chert dominated the raw materials, accounting for over 99 percent of all chipped stone. Roughly 68 percent of the flakes lacked cortex, with only 16 flakes (1.8\%) having 100 percent dorsal cortex cover.

Two of the six projectile points were untypable (see Appendix E). The recovery of a Pandale point suggests a Middle Archaic use. The recovery of a probable Pedernales and an Ensor type suggests a Late Archaic use. Finally, a Scallorn point, suggesting Late Prehistoric use of the site, was recovered. In addition, a single ceramic sherd of what is probably Leon Plain, again suggesting Late Prehistoric use of the site, was recovered from the heavy fraction of a flotation sample in the midden. The only diagnostics recovered from the midden were Late Prehistoric in age. 


\section{Other Samples}

Site 41BR250 had some of the higher rates of vertebrate faunal recovery on the project. Forty-three specimens with a weight of 69.45 grams were recovered (Appendix B). All faunal material was recovered from excavation within the central portion of the midden, in Units 2, 3, and 4. With the exception of a single large mammal fragment from Level 2 , all faunal material was below $30 \mathrm{~cm}$ in depth, though only five of the 43 specimens were burned. The material was fragmentary and, in several cases, had extensive chemical weathering, making species level identification impossible.
Nevertheless, reference to Appendix B shows that a variety of mammals were represented at the site, probably including deer, bison, and several smaller species. Ten specimens representing birds were recovered from Unit 4, Level 8 and Unit 2, Level 6.

As summarized by Dering (Appendix C), samples from six different excavation areas were submitted for macrobotanical identification. These contained 91 bulbs and bulb fragments. Two of these lots were examined in greater detail, with both Eastern camas (Camassia scilloides) and wild onion (Allium sp.) identified. The two flotation samples

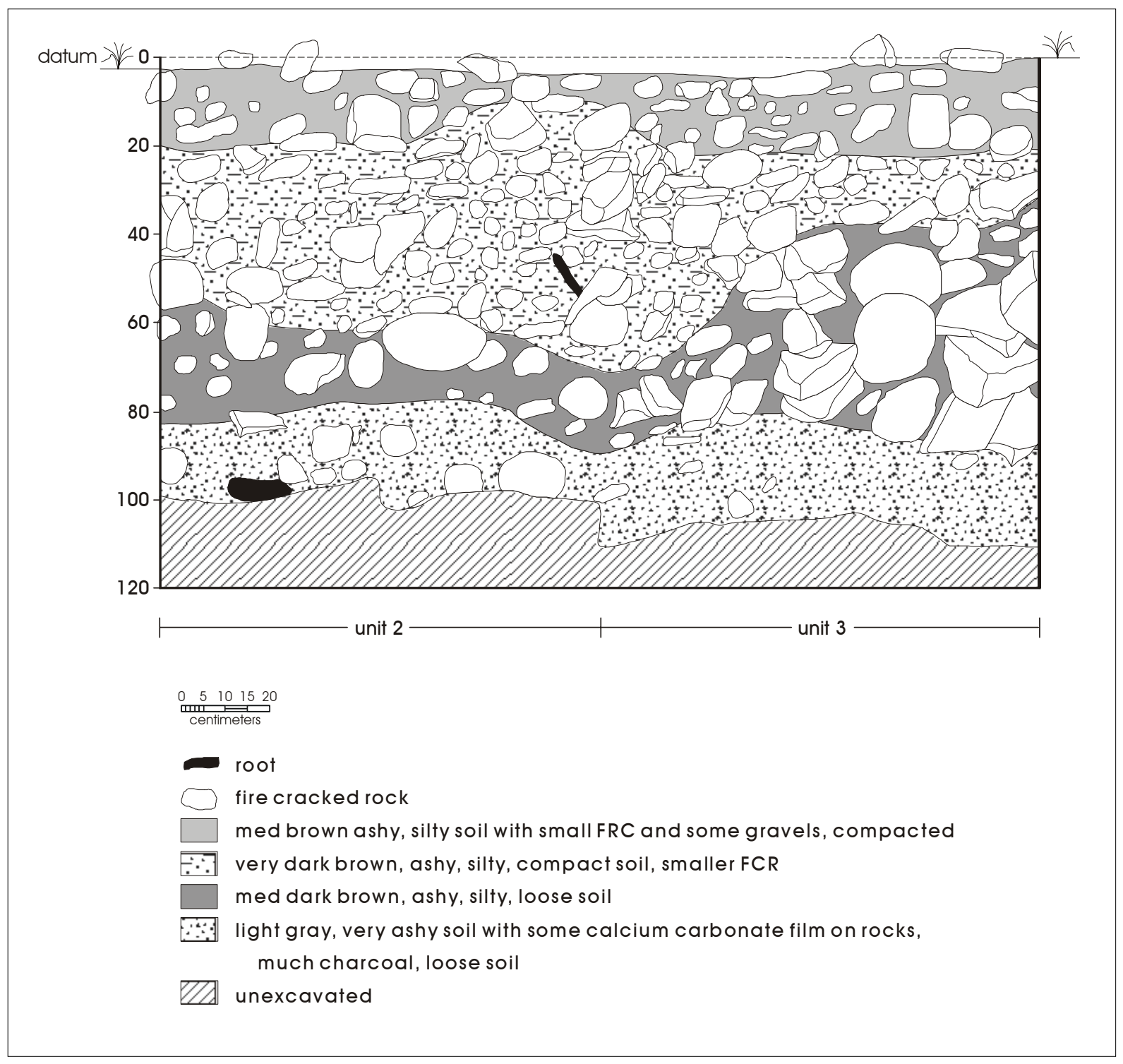

Figure 6-31. Profile of west wall of Units 2 and 3 on site $41 B R 250$. 


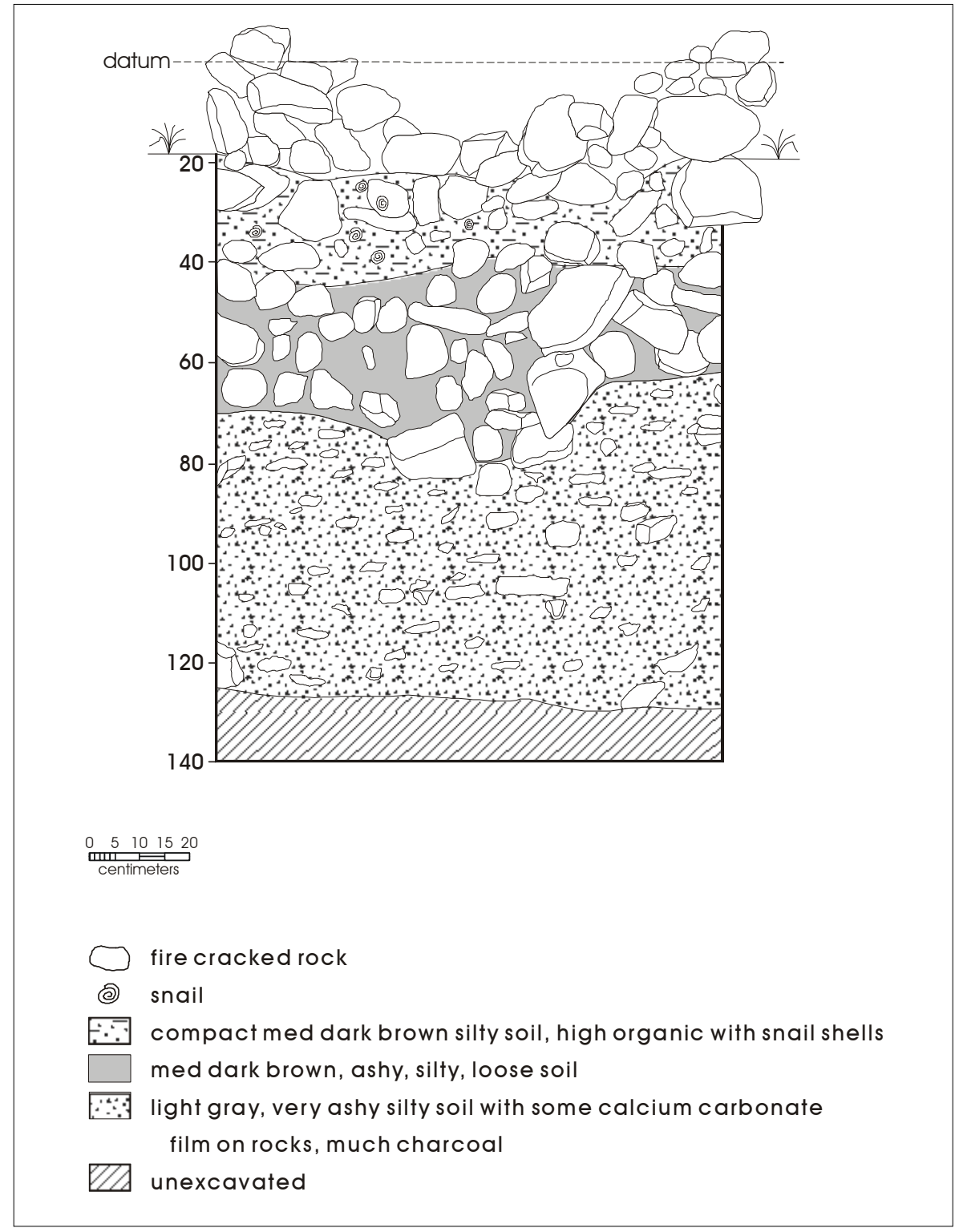

Figure 6-32. Profile of north wall of Unit 4 on site $41 B R 250$.

analyzed from this site only produced wood charcoal, with both oak and mesquite being identified.

Mussel shell was collected from both the surface as well as excavations. In all, almost 329 grams of mussel shell was recovered from our work at the site. Five of the six samples submitted to Goodfriend for identification could be classified, with two species identified (Appendix D). These two species were Amblema plicata $(\mathrm{n}=4)$ and Tritogonia verrucosa $(\mathrm{n}=1)$.

\section{Radiocarbon Dates}

Only one radiocarbon sample was submitted from this site. The sample came from the base of the midden, in Unit 4, at $110-120 \mathrm{cmbd}$. The corrected date for the sample is $790 \pm$ 40 years BP (Appendix A). If the sample is in context, and using the corrected, calibrated range at 1-sigma, it appears that the beginning of the midden use was sometime between A.D. 1220 and 1280. This date is consistent with the diagnostics recovered from above this sample. The date is 
associated with the lower zone discussed by Bousman and Hodges (Appendix G), suggesting that midden termination may be well after this A.D. 1220 to 1280 time range.

\section{Summary}

Based on a single date from the bottom of the midden, as well as the recovery of Late Prehistoric material from within the midden, the burned rock feature at 41BR250 dates to the Late Prehistoric period, with an initial use occurring around A.D. 1220 to 1280 . Diagnostic artifacts recovered from the midden fill, including a single brownware ceramic, are consistent with that use range. Diagnostic projectile points collected from outside the midden, along the ridge, suggest occupations in this area occurred in both the Middle and Late Archaic periods.

The low number of positive shovel tests, the observation that the vast majority of recovered material was within Level 1 of the tests, the high surface artifact concentrations along the ridge, and the nature of both the surface and subsurface sediment suggest that much of this site has been eroded. The single excavation unit from outside the midden revealed moderate subsurface artifact density, with a recovery rate of roughly 60 items recovered per cubic meter. Excavation within the midden deposits produced low densities, with a recovery rate of less than four artifacts per cubic meter. A moderate frequency of faunal material, probably representing deer, bison, small mammals, and birds, was present within the midden. Mussel shell was common within the midden, and was also present on the surface of the site. Economic plants noted in the macrobotanical samples were restricted to bulbs and bulb fragments, with both Eastern camus and wild onion being identified. Flotation samples produced wood charcoal representing oak and mesquite.

Conditions for preservation of ethnobotanical material within the midden were excellent. While the ridge portion of the site probably has been significantly impacted by erosion, no disturbance, other than minor bioturbation related to rodents and impacts associated with worms (see Appendix G), was noted in sections of the midden deposits.

\section{BR253}

\section{Site Description}

Wormser and Sullo-Prewitt (2001:62-63) describe site 41BR253 as a burned rock midden site, containing two burned rock middens, and associated lithic debris. TXARNG cultural resources staff originally recorded the site in 1995. While no shovel tests were excavated, TXARNG archaeologists made observations on surface artifacts, and collected a single biface.

CAR archaeologists visited the site in the fall of 1999, and work was conducted during the spring of 2000. Site 41BR253, covering an area of roughly $16,450 \mathrm{~m}^{2}$, spans two prominent landforms (Figure 6-33). The elevation of 41BR253 is about 1,325 feet ( $404 \mathrm{~m})$ AMSL. When CAR visited the site in 1999, vegetation consisted of short grasses, prickly pear, mesquite, oak, juniper, and agarita. The site is located about $1 \mathrm{~km}$ from Lewis Creek, with Pecan Bayou being $1.7 \mathrm{~km}$ to the northeast. An intermittent tributary of Devils River is located about $300 \mathrm{~m}$ to the south of 41BR253.

The eastern burned rock midden, Feature 1, is rectangular in outline, and measures roughly 10 by $8 \mathrm{~m}$. The midden has a flat top and rises approximately $50 \mathrm{~cm}$ above the surrounding area. The outline of the midden suggests the possibility that the feature may represent the coalescence of at least two smaller features. No artifacts were observed in the immediate area of this midden, although artifacts are present a short distance to the south of the feature. The second midden, Feature 2, is much larger, being roughly 16 $\mathrm{m}$ in diameter, and rising almost $2 \mathrm{~m}$ above the surrounding surface. The midden is circular, with a central depression and a pronounced rock ring. Scattered chipped stone is present to the north of this midden. Both features are dominated by sandstone, which outcrops in the area. In addition, a lithic scatter is present on the northern landform (see Figure 6-33).

\section{Shovel Test Results}

Eighty-two shovel tests representing 394 separate levels were excavated at the site. As with several previous sites, the middens were surrounded, to the degree possible, with shovel tests placed on a 5-m grid. Forty-seven shovel tests were excavated around the eastern midden, designated Feature 1, and 32 shovel tests were excavated around the western midden, designated Feature 2. In addition, three shovel tests were excavated on the southeastern edge of the site (see Figure 6-33). No shovel tests were excavated on the northern edge of the site, as this ridge top lacked any significant sediment accumulation.

The 82 shovel tests averaged $48 \mathrm{cmbs}$. Shovel tests near Feature 1 were deeper, with an average depth of $52.3 \mathrm{cmbs}$, 


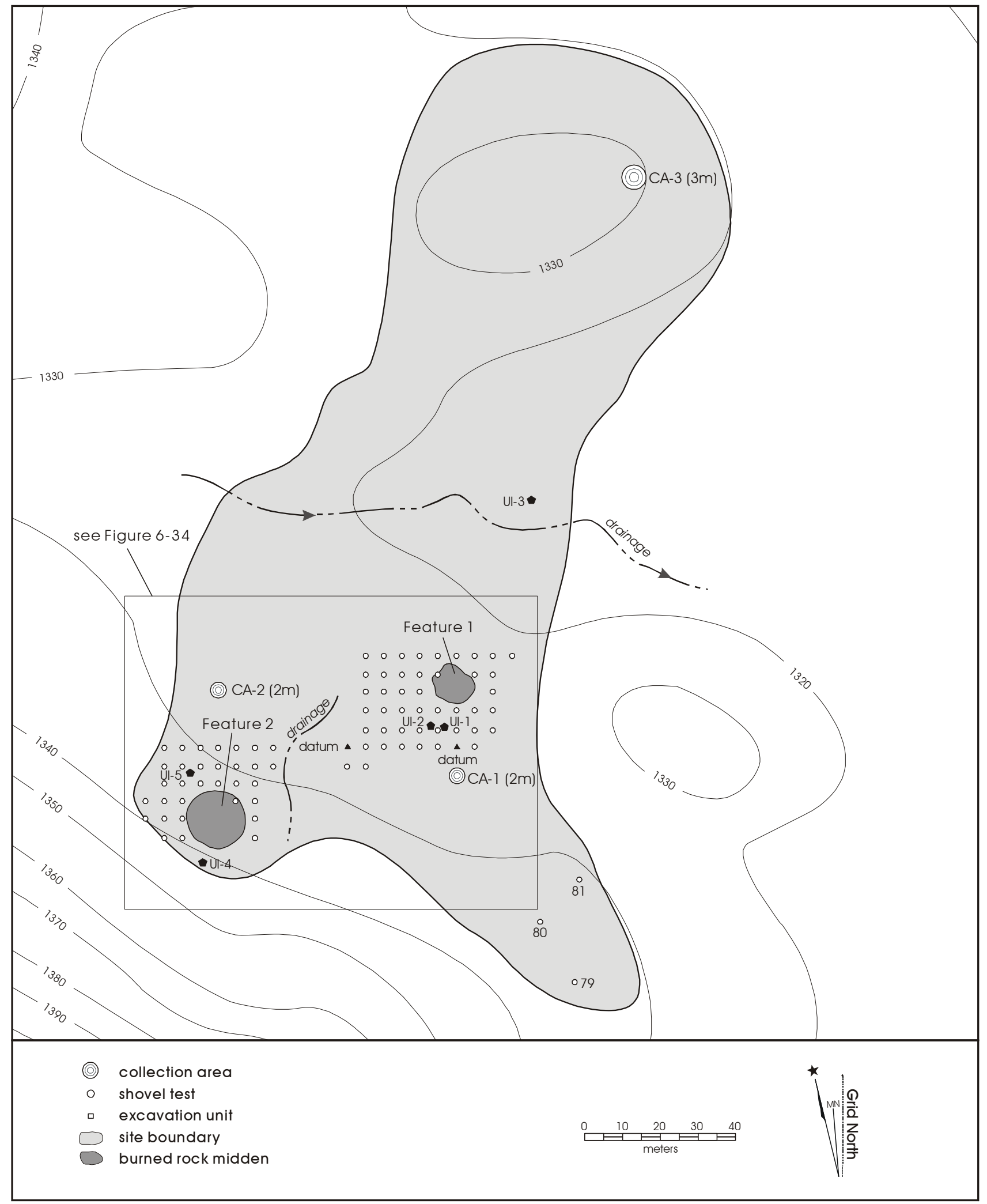

Figure 6-33. Site 41BR253 with burned rock middens, shovel tests, and surface collection areas identified. 
and were generally terminated due to lack of artifacts. Those shovel tests surrounding the western midden averaged 42.5 cmbs, and shovel tests were often discontinued as a result of encountering the underlying bedrock. Finally, the three shovel tests placed on the southeastern section of the site averaged $40 \mathrm{cmbs}$. Here, termination was a result of a lack of artifacts as well as encountering decomposed sandstone bedrock. Sediments in the three areas were distinct. In the eastern area, sediments were primarily loose to compact yellow or pale brown sand, with a small amount of clay. Calcium carbonate coated gravels were frequently encountered at depths below $40 \mathrm{cmbs}$. Sediments around the western midden were compact to hard, with higher levels of clay. Higher frequencies of gravel, as well as calcium carbonate coated gravels and pebbles, were noted in these shovel tests. Finally, shovel tests on the southeastern section contained compact sediments, dominated by a pale brown to yellow silt.

As can be seen in Figure 6-34, the number of positive shovel tests at 41BR253 was relatively low. Only 36.6 percent of the 82 shovel tests had chipped stone or fire-cracked rock. Chipped stone was present in 24 of the 82 tests $(29 \%)$, and fire-cracked rock was recovered from $16(19.5 \%)$. Around Feature 1, roughly 32 percent of the shovel tests were positive. Around Feature 2, 47 percent of the shovel tests were positive. None of the three isolated shovel tests were positive.

Material recovered from the shovel tests included 162 flakes, 103 pieces of fire-cracked rock, three bifaces, two utilized/ retouched items, and three projectile points. Mussel shell was noted in three shovel tests. The points included two untypable arrow points or preforms and a Cuney point. The latter came from Level 2 in Shovel Test 58. Artifact density was much higher around Feature 2, with a recovery of just over one artifact per excavated shovel test level. In addition, Level $1(0-10 \mathrm{cmbs})$ contained an average of 3.3 artifacts per level, with lower density ( .35 artifacts per level) below $20 \mathrm{~cm}$. Only 29 artifacts were recovered from the 246 levels excavated around Feature 1, a recovery rate of less than .12 items per level. In addition, no clustering of density occurred around the western midden, with relatively even densities in all levels.

\section{Surface Collections}

Three surface collection areas were placed on 41BR253 (see Figure 6-33). All collection areas were circular, with Collection Areas 1 and 2 having a radius of $2 \mathrm{~m}$, and
Collection Area 3 having a radius of $3 \mathrm{~m}$. In addition to the surface collection material, six unique items were collected from the surface. Unique Item (UI) numbers 1 and 2 were metate fragments collected near Feature 1 (Figure 6-33). Unique Item 4, near Feature 2, was a metate fragment. Unique Item 3 was a biface fragment, and UI 5 was an untyped arrow point fragment (Figure 6-33). Provenience information on UI 6, a utilized/retouched flake, was lost.

Collection Area 1, located just to the south of Feature 1 (Figure 6-33), contained 32 pieces of chipped stone debitage, three bifaces, three arrow point blanks (see Appendices E and F), one core, and two utilized/retouched items. Artifact density was roughly 3.26 items per square meter in this collection area. Debitage lacking cortex dominated the chipped stone debris, accounting for 87.5 percent. No debitage with 100 percent cortex was recovered from this collection area. Chert was the dominant material type, accounting for 97 percent of all the debitage.

Collection Area 2 was located to the north of Feature 2 (Figure 6-33). The collection area contained 38 pieces of chipped stone debitage, five bifaces, five cores, two utilized/ retouched flakes, and one stem of a Late Prehistoric Perdiz point (Appendices E and F). Fire-cracked rock was also noted in this collection area. Artifact density was just over four artifacts per square meter. Sixty-six percent of the debitage lacked cortex, and there were no cases of debitage with 100 percent cortex cover. Chert was the dominant material type, accounting for 97 percent of all the debitage.

Collection Area 3 was located in the northern portion of the site (Figure 6-33) and was placed to sample an isolated lithic scatter confined to the ridge top. We recovered 231 pieces of debitage, one biface (Appendix F), two cores, and two utilized/retouched items for an artifact density of 8.3 items per square meter. Seventy-three percent of the debitage from this area lacked cortex, and only two of the 231 flakes had 100 percent cortex cover. Chert was the dominant material type, accounting for over 99 percent of all the debitage.

\section{Excavation Results}

Ten 1-x-1-m units were excavated at site 41BR253 (see Figure 6-34). Three units (1,2, and 3) were excavated in the eastern midden (Feature 1) and three units $(4,5$, and 6$)$ were excavated in the western midden (Feature 2). Units 7 and 8 were excavated just to the north of Feature 2. Unit 9 was excavated near Shovel Test 39, roughly half way between the two middens, while Unit 10 was excavated to 


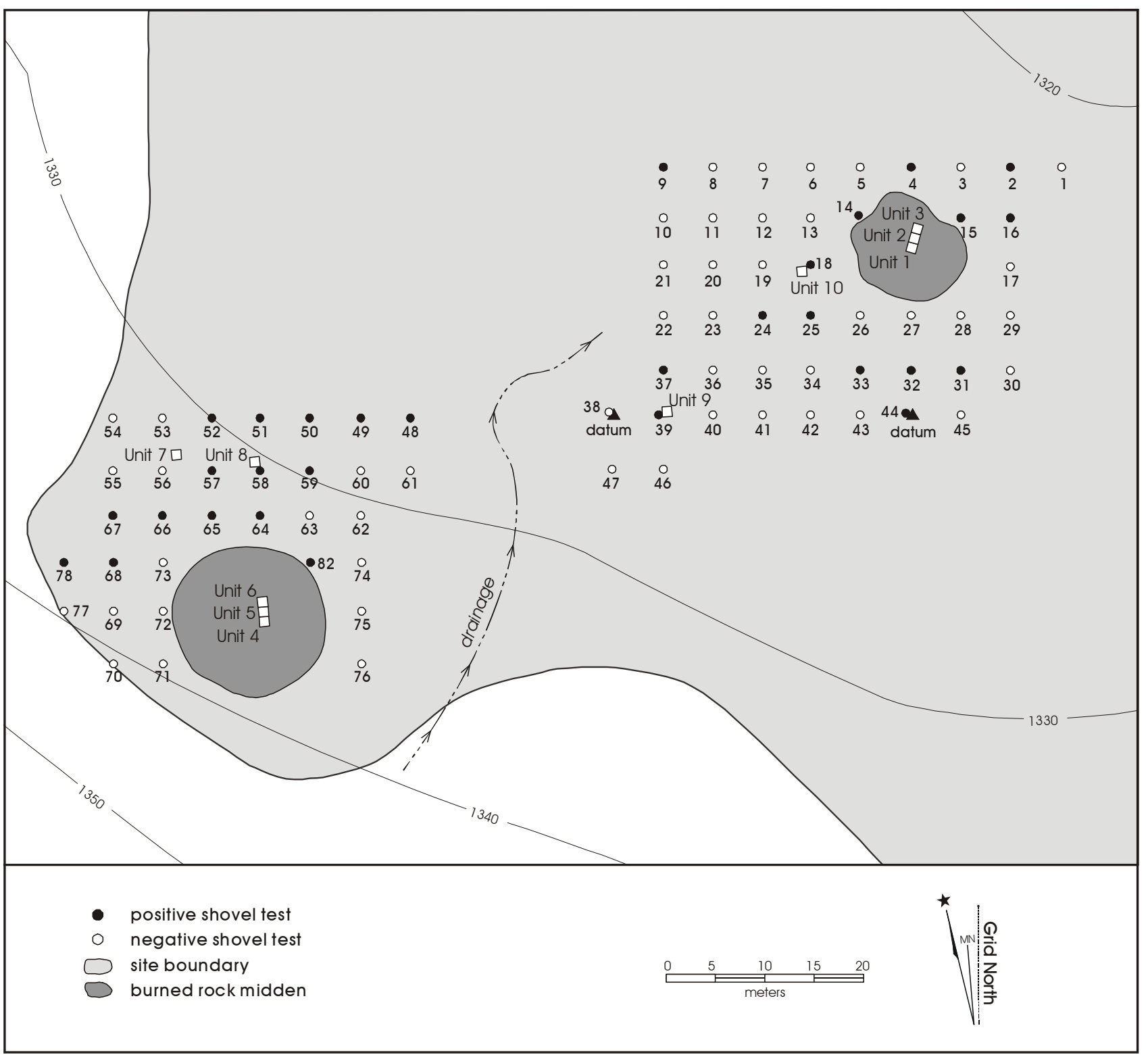

Figure 6-34. Features 1 and 2 on site 41BR253.

the west of Feature 1. A total volume of roughly $4.9 \mathrm{~m}^{3}$ of sediment was removed in these ten units.

\section{Midden Units}

Feature 1 was sampled with three contiguous 1-x-1-m units. Figure 6-35 presents profiles for the east and west walls of the trench, while Figure 6-36 presents profiles on the north and south ends of the trench. The profiles show that the stratigraphy within this feature is complex, with a minimum of two smaller pit features present, along with several isolated clusters of fire-cracked rock. During excavation, two features, designated Features 4 and $4 a$, were identified. Both features were clusters of tabular fire-cracked rock. The two possible pit features in the east profile of Unit 1 (Figure 6-35) and in the north profile of Unit 3 (Figure 6-36) were not assigned feature numbers.

Based on these limited excavations, it is not possible to clearly identify what Feature 1 represents. The presence of multiple pits, as well as isolated clusters of fire-cracked rock, suggests the possibility that this area may represent a different pattern of accumulation of debris than has been observed elsewhere 
on the project. However, comparisons of profiles for Units 1 and 3 clearly suggest higher rock density in Unit 3 , and examination of the Unit 1 profiles in Figure 6-35 suggests the possibility that the upper few centimeters of this unit, dominated by a hard-packed, light brown silty sand, has filled in a basin that formed the original feature surface (see Appendix G). Without this deposition, it is probable that the feature would have had a basin appearance, similar to many of the other middens on the project.
We removed $1.32 \mathrm{~m}^{3}$ of sediment from the midden. Seventyone pieces of chipped stone debitage were collected from these units, an artifact density of 53.8 artifacts per cubic meter. No tools, cores, or other artifacts were recovered from these units.

These three units contained 4,378 fire-cracked rocks greater than one inch in size. An additional $73.9 \mathrm{~kg}$ of rock less than one inch in size was also recorded. Sandstone accounted

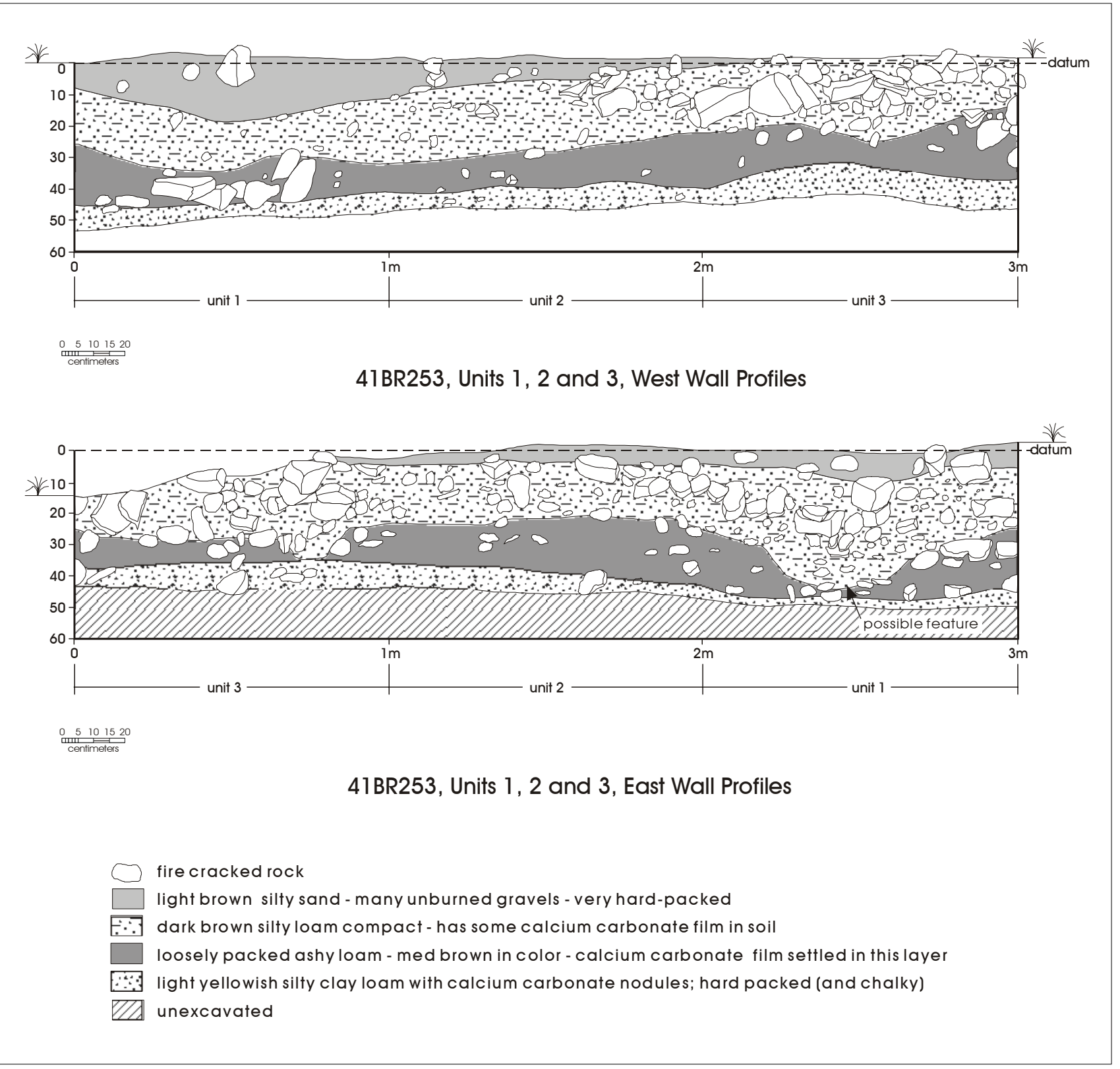

Figure 6-35. Profiles of Units 1, 2, and 3 in Feature 1 at 41BR253. 


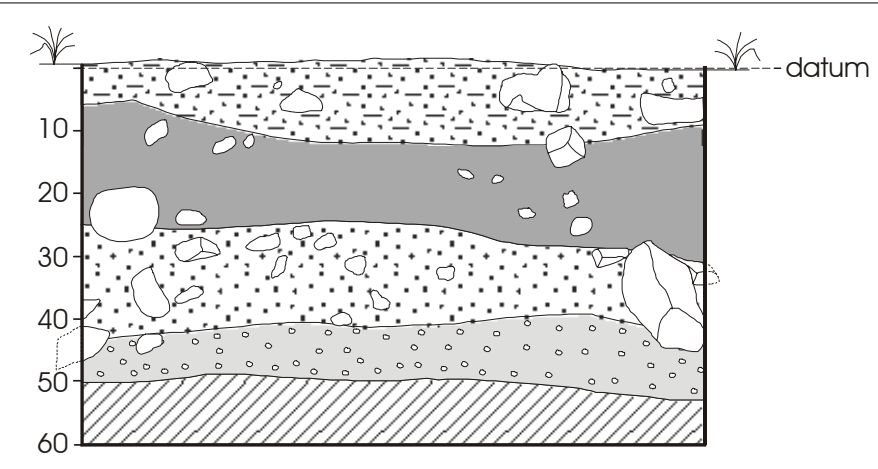

41 BR253 Unit 1, South Wall Profile

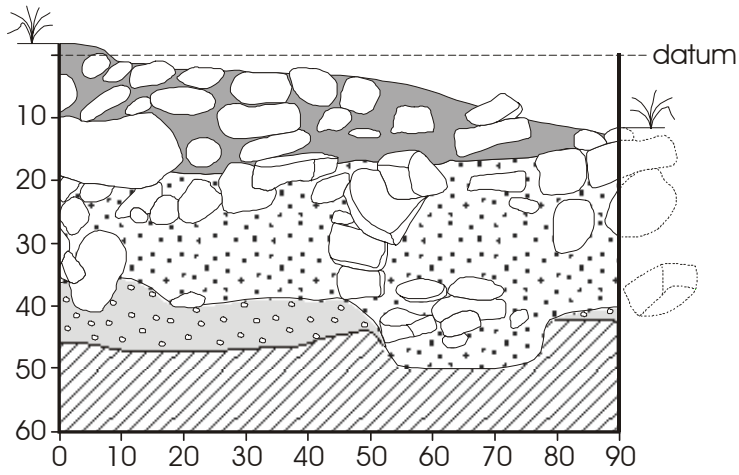

41 BR253 Unit 3, North Wall Profile

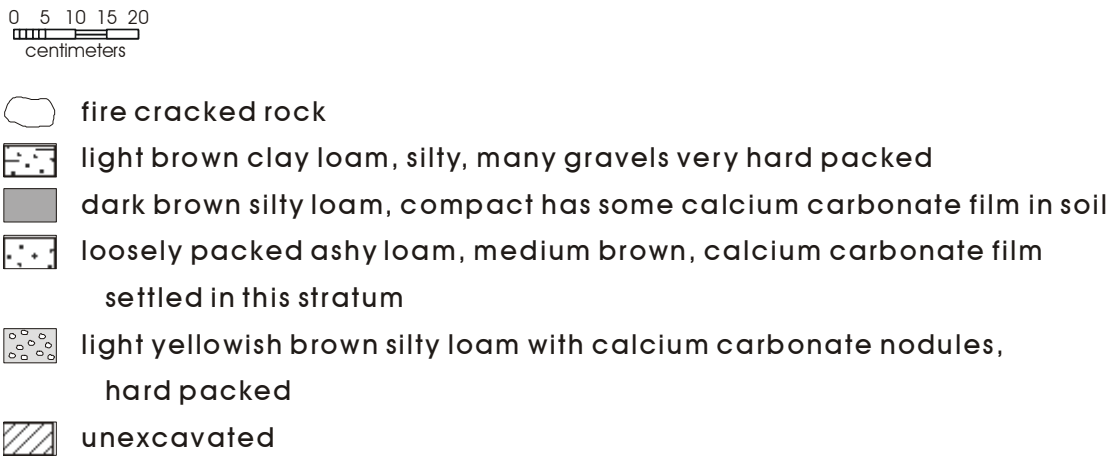

Figure 6-36. Profiles of Units 1 and 3 in Feature 1 at 41 BR253.

for roughly 98 percent of the recorded raw material, with limestone and conglomerate also being present.

The western midden, Feature 2, is a large feature with a clear central depression and rock ring. As can be seen in Figure 6-37, a cross-section of the feature, the midden is roughly $2 \mathrm{~m}$ above the ground surface on the northern edge, and is set against the slope of the ridge on the southern edge. This feature was sampled with three contiguous $1-x-1-m$ units, designated Units 4, 5, and 6, that were placed in the central portion of the feature (see Figure 6-34).

Figure 6-38 presents a profile of the west wall of this feature, along with a plan view of the three units at $40-50 \mathrm{~cm}$ below surface. Examination of the profile and plan view documents the major feature encountered in this area, a series of human skeletal remains. The remains, designated Feature 7, initially consisted of a human mandible encountered at $45 \mathrm{~cm}$ below surface in the western portion of Unit 4. When encountered, all excavation was stopped in these units, and CAR contacted the Texas Army National Guard, the Texas Historical Commission, and the Sheriff's Department for Brown County. After appropriate consultation with these agencies, excavation proceeded. Mr. Jeff Francis, staff osteologist at CAR, was brought to the site to oversee this subsequent work and provide a field description of all material recovered.

All subsequent remains were confined to the western profile of Unit 5 (see Figure 6-38). All subsequent material was left in situ, and the mandible, along with all fill surrounding the remains, were left in Units 4 and 5. Examination of the profile will demonstrate that the area immediately above and to the left of the remains was characterized by large, sandstone rocks, many of which were not fire-cracked. While no clearly defined pit could be identified in the sediment, it is likely that these rocks were associated with this interment. Bousman and Hodges (Appendix G) describe the deposits in Unit 4 . They note that this unit was highly turbated by earthworms, with virtually all of the fine-grained sediment representing earthworm excrement. 
Francis identified a series of bones in the west wall, including a mandible with three intact teeth, the right elbow joint, the left and right innominates, the sacrum, the left and right proximal femora, a rib fragment, and the left and right distal tibiae (Appendix I). Based on this examination, Francis suggests that the remains represent those of an adult (ca. 25-49) female, possibly buried in a flexed position. However, given the distribution of remains, and the amount of wear on the teeth, two burials may be present, one representing an older ( $>30 \mathrm{yrs}$ ) individual, and one representing a younger individual ( $<25$ years).

In addition to Feature 7, Feature 3, a possible rock-lined pit, was identified in Units 5 and 6 at $20 \mathrm{cmbd}$. The feature may represent a use-episode of the midden. However, the feature has been disturbed both by Feature 7, as well as by extensive tree roots.

We removed $2.14 \mathrm{~m}^{3}$ of sediment from Feature 2. Of this, we estimate that $1.90 \mathrm{~m}^{3}$ represented midden deposits, though some portion of this total had been disturbed by Feature 7. Only 15 pieces of chipped stone debitage and a single biface were recovered from this excavation, an artifact density of 7.5 artifacts per cubic meter.

These three units contained 9,896 fire-cracked rocks greater than one inch in size. An additional $214.5 \mathrm{~kg}$ of rock less than one inch in size was also recorded. Sandstone accounted for over 99 percent of the recorded raw material, with limestone, conglomerate, and chert noted as present.

\section{Off-Midden Units}

Four non-midden units were excavated at this site (see Figure 6-34). Units 7 and 8 were placed to the north of Feature 2. Unit 7 was placed over what was thought to be a surface feature, designated Feature 5, while Unit 8 was placed near Shovel Test 58 . Both units were extremely shallow, and both were terminated at Level 2. Feature 5 was determined to have no depth, no associated pit, and consisted only of a few fire-cracked sandstone. Figure 6-39 presents profile and plan views of Unit 8, with another feature, designated Feature 6, identified at $10 \mathrm{cmbd}$. Like Feature 5, this firecracked rock feature had no associated pit, consisting only of a layer of fire-cracked sandstone. We removed $.20 \mathrm{~m}^{3}$ of sediment from Unit 7, and $.16 \mathrm{~m}^{3}$ from Unit 8. Both units had high artifact recovery, with 229 chipped stone debitage, two cores, five bifaces, two utilized/retouched flakes, and two projectile points coming from these two shallow units. Artifact density was 270 items per cubic meter for Unit 7 and over 1,140 items per cubic meter for Unit 8 . The two projectile points, both recovered from Unit 8, were a possible Perdiz and an untyped arrow point (see Appendix E).

Unit 9 was placed roughly half way between the two middens at the site, while Unit 10 was placed just to the west of Feature 1 (see Figure 6-34). Figure 6-40 provides profiles of these two units. Unit 9 consisted of a series of alternating layers of gravel-dominated deposits and a compact silty loam. These layers appear to represent colluvial deposition. Artifact recovery within the $.47 \mathrm{~m}^{3}$ of sediment was low, with four pieces of chipped stone debitage and a single

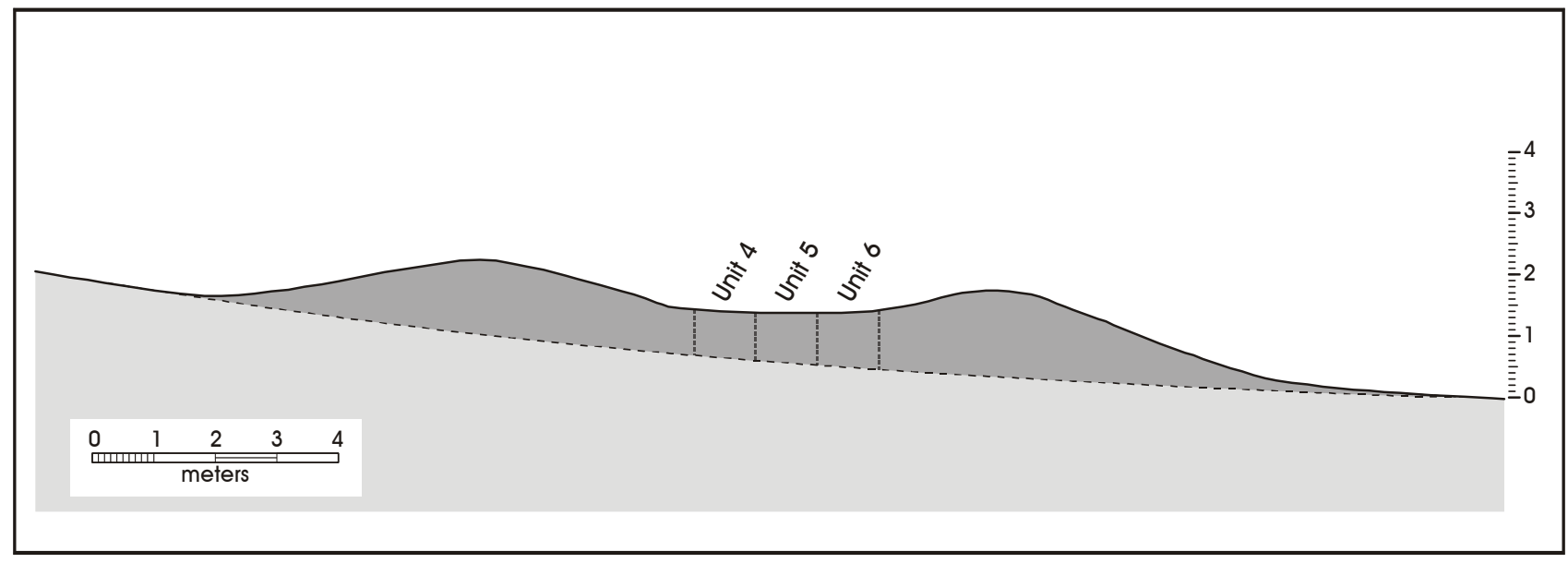

Figure 6-37. Cross-section of Feature 2 at $41 B R 253$ (view to the west). 


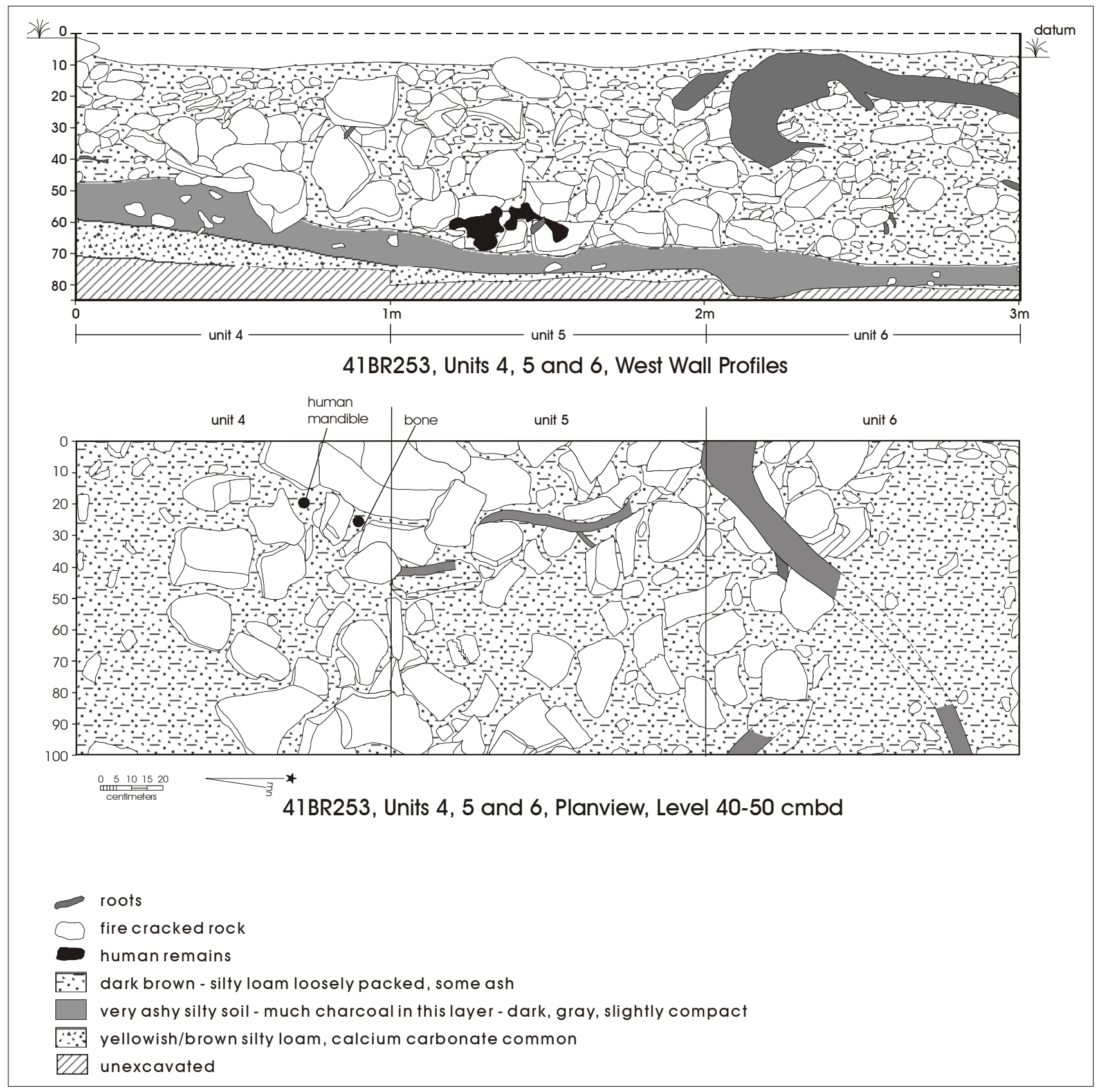

Figure 6-38. Profile and plan view of Units 4, 5, and 6 in Feature 2 at 41BR253.

projectile point, a Late Prehistoric Alba (see Appendix E), being the only artifacts recovered.

The profile for Unit 10 (Figure 6-40) identified six different strata. Note that the upper $10 \mathrm{~cm}$ of this unit was a yellowish brown silty loam that was similar to the deposit identified above Feature 1, just to the east of this unit (see Figure 6-35). As with Unit 9, only four chipped stone debitage were collected from this $.61 \mathrm{~m}^{3}$, an artifact density of only 6.6 artifacts per cubic meter. 


\section{Artifact Summary}

Seven hundred and eighty-six pieces of debitage, 19 bifaces, 10 cores, nine retouched/utilized items, and three ground stone fragments were collected from 41BR253. Appendix F presents scans of selected tools from this site. Chert dominated the raw materials, accounting for over 99 percent of all chipped stone. Roughly 75 percent of the flakes lacked cortex, with only 12 flakes (1.5\%) having 100 percent dorsal cortex cover. The majority of the artifacts were collected from the surface. Midden recovery of artifacts was generally low, especially in Feature 2. Recovery of artifacts in nonmidden units was variable, with high densities present near Feature 2, and low densities in the remaining areas.

Eleven projectile points were recovered from 41BR253 (see Appendix E). These included three arrow point blanks, four untypable arrow points, one possible Perdiz, one Perdiz stem, an Alba point, and a Cuney point. All of these points are reflective of Late Prehistoric use of the site.

\section{Other Samples}

Seven pieces of vertebrate faunal material were recovered from the excavations at the site. As summarized by Meissner (Appendix B), two fragments of a large mammal, probably representing deer, were recovered from Feature 1. One of these fragments was burned. From Feature 2, two fragments of a mammal of undetermined size, along with a mandible and a tooth of a Blacktailed jackrabbit, were recovered. In addition, a fragment of a mammal of undetermined size was recovered from Level 4 of Unit 10.

As summarized by Dering (Appendix C), samples from 15 different areas were submitted for macrobotanical identification from this site. Bulbs were common, with 110 bulbs and bulb fragments represented in these samples. Eastern camas was present from Feature 1. Wild onion (Allium sp.) was also recovered from this feature. The four flotation samples analyzed from this site contained only wood charcoal, with both oak and willow represented.

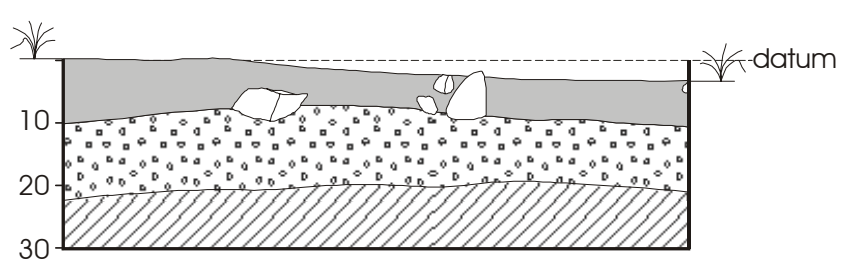

41BR253, Unit 8, North Wall Profile

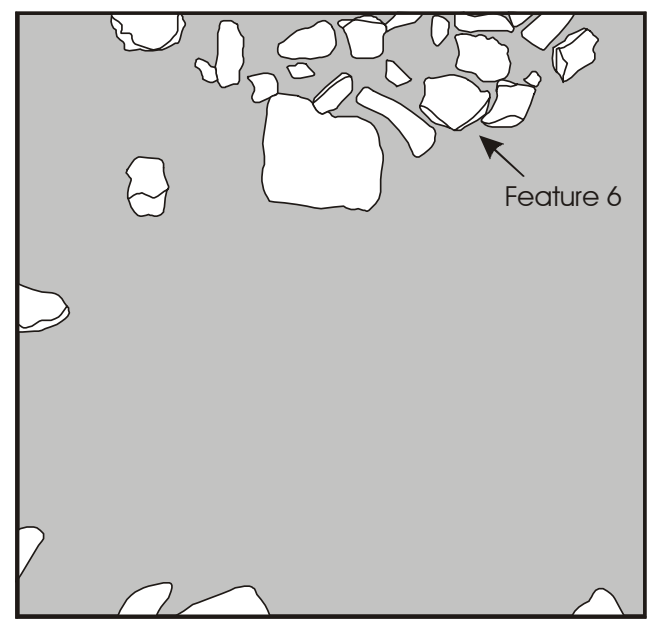

41BR253, Unit 8, Plan View @ 10 cmbd
FCR

very hard packed light brown silty loam FCR in this level only compactyellowish brown clay loam, calcium carbonate nodules unexcavated

Figure 6-39. Profile and plan views of Unit 8 at $41 B R 253$. 


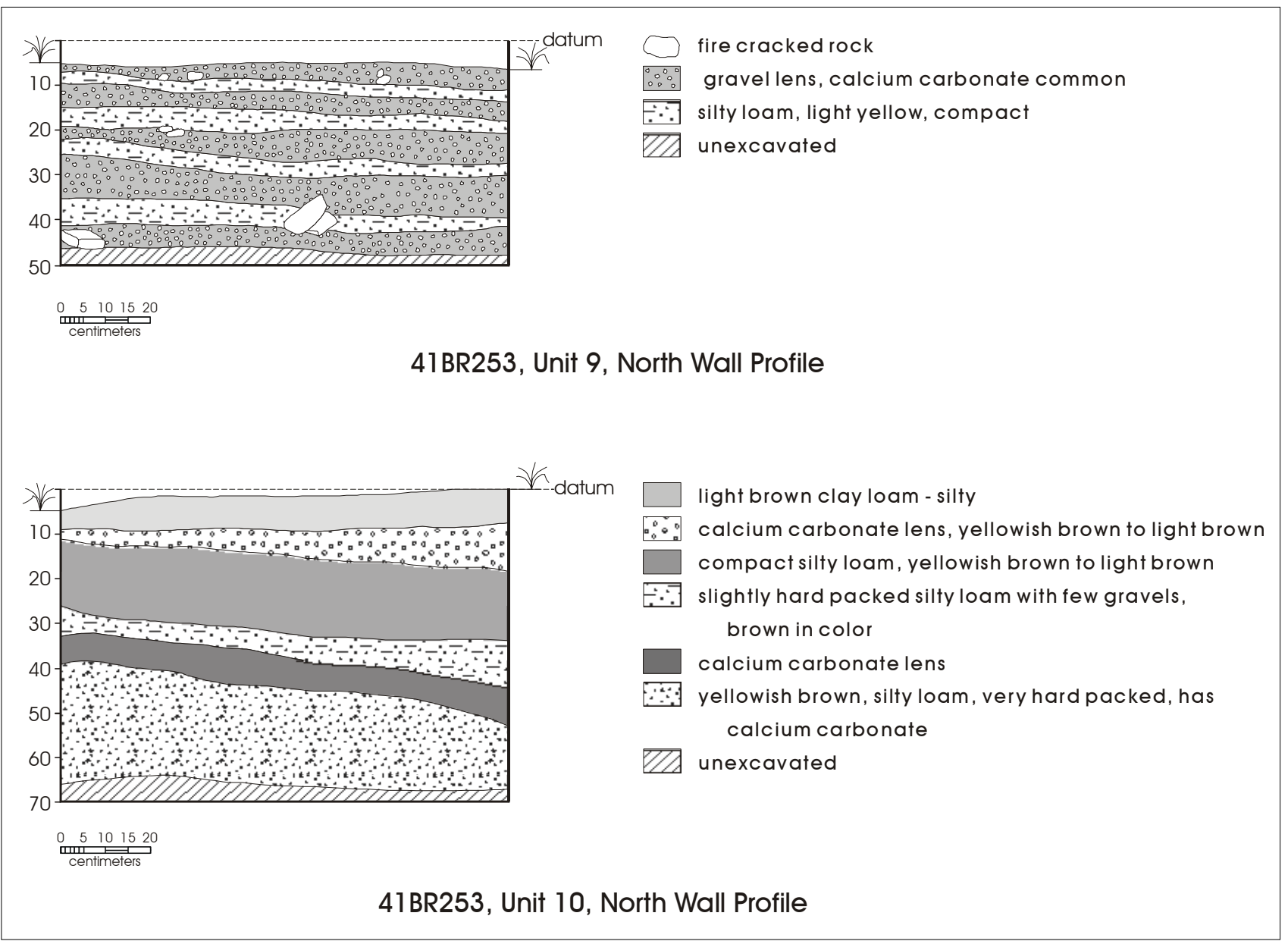

Figure 6-40. Profiles of Units 9 and 10 at 41BR253.

Mussel shell was identified both in shovel tests as well as excavation units, and though not collected, fragments of mussel shell were present on the surface. Though not present in large quantities, shell was recovered from all excavation units with the exception of Units 9 and 10. In all, roughly 286 grams of shell was recovered from the site. Goodfriend identified six samples from this site (Appendix D). These included Quadrula apiculata $(\mathrm{n}=1)$, Quadrula houstonensis $(\mathrm{n}=3)$, Amblema plicata $(\mathrm{n}=1)$, and Cyrtonaias tampicoensis $(\mathrm{n}=1)$.

\section{Radiocarbon Dates}

Four radiocarbon samples were submitted from the site. Two of these samples came from Unit 2 in Feature 1. They represent Levels $3(19-30 \mathrm{cmbd})$ and $5(40-50 \mathrm{cmbd})$. The corrected date for the Level 3 sample is $730 \pm 40 \mathrm{BP}$. The corrected date on the sample from Level 5 is $750 \pm 40 \mathrm{BP}$. In addition, two dates from Feature 2 were obtained. These came from Levels $5(40-50 \mathrm{cmbd})$ and $8(70-80 \mathrm{cmbd})$ in Unit 6 . The corrected dates for these samples are $850 \pm 40$ $\mathrm{BP}$ and $1120 \pm 40 \mathrm{BP}$, respectively. Appendix A lists all details of these dates.

If these dates are in context, it appears that for Feature 1, the beginning of midden use, associated with Level 5, was sometime between A.D. 1244 and 1292, with use dates for Level 3 being between A.D. 1250 and 1300. Using the interval estimate in the OxCal radiocarbon calibration program (Ramsey 2000), there is a 95 percent probability that the interval between the bottom date and the upper date in Unit 2 represents as little as zero years and no more than 130 years. Feature 1, then, may have formed quite rapidly late in the Late Prehistoric period. 
Feature 2 is somewhat earlier, with calibrated date ranges for the base of the midden (Level 8) of A.D. 890 to 980, and Level 5, in the midden itself, ranging between A.D. 1160 and 1255 . This midden, then, was most probably used sometime after A.D. 890, and use probably terminated sometime after A.D. 1255. Using the interval estimate in the OxCal radiocarbon calibration program (Ramsey 2000), there is a 95 percent probability that the interval between the base of the midden and Level 5 in Unit 6 represents at least 80 years, and no more than 430 years. Feature 2, then, seems to have formed relatively slowly during the Late Prehistoric period.

\section{Summary}

CAR's work at site 41BR253 suggests that both of the burned rock middens date to the Late Prehistoric period. All of the diagnostic projectile points recovered from the site are consistent with that Late Prehistoric period assignment.

Shovel testing and surface collection results from outside the middens revealed moderate surface density and shallowly buried deposits. While the percentage of positive shovel tests at a site level was relatively low, almost 50 percent of the shovel tests excavated outside of Feature 2 were positive, with high densities in the initial level. Surface collection areas placed near both the middens produced moderate recovery. Surface Collection Area 3, located roughly $130 \mathrm{~m}$ away from the midden areas, produced high recovery.

In excavation units outside of the middens, an average artifact density of roughly 34 artifacts per cubic meter was present. However, units associated with Feature 2 had densities of over 100 items per cubic meter, with external units in the remaining portions of the site having only 5.6 artifacts per cubic meter. Within Feature 1, artifact density was higher than the surrounding units, with roughly 54 items recovered per cubic meter. In Feature 2, artifact density was much lower than the surrounding units, with only 7.5 items recovered per cubic meter of sediment. Both vertebrate faunal material and mussel shell was present in the excavation units. Macrobotanical samples submitted for identification consisted primarily of bulbs and bulb fragments, with both Eastern camus and wild onion being identified. Flotation samples produced only wood charcoal of oak and willow. Other than bulbs, no other economic plants were identified. Finally, remains of at least one individual were uncovered in Feature 2.
Conditions for preservation of ethnobotanical material within the middens are good. In addition, we have no data to suggest that the context of the material recovered from the middens on the site has been extensively disturbed. While worm casts are common in the midden deposits suggesting some disturbance, especially in a section of Feature 2 (see Appendix G), and while rodent burrowing was noted in both middens, the level of disturbance is not extensive. Outside of the midden, several features are present and artifact densities on the surface are moderate.

\section{BR261}

\section{Site Description}

Wormser and Sullo-Prewitt (2001:66-67) describe site 41BR261 as an open campsite and possible lithic procurement area at the base of an eroded ridge slope. TXARNG cultural resources staff noted a dense concentration of artifacts, and collected three Early Archaic Pandale points, two biface fragments, and a scraper from the site. In addition, two shovel tests were excavated. Shovel Test 1 , excavated to a depth of $30 \mathrm{cmbs}$, contained two flakes at $10-20 \mathrm{cmbs}$. The other shovel test, excavated to $25 \mathrm{~cm}$, contained no artifacts. Given the potential that the site contained evidence of an Early Archaic campsite, and had buried material present in one of the shovel tests, Wormser and Sullo-Prewitt (2001:67) recommended further evaluation of the site.

CAR archaeologists visited the site in the fall of 1999, and work was conducted during the spring of 2000. Site 41BR261, at an elevation of roughly 1,380 feet (ca. 420.6 $\mathrm{m})$ AMSL, is located at the base of a steep hill. Several deep gullies cut through the site and sheetwash erosion has impacted the surface. Gravel is common on the surface, probably as a result of colluvial deposition from the adjacent hill. The site covers an area of about $13,800 \mathrm{~m}^{2}$. When CAR visited the site in 1999, vegetation consisted of Mormon tea, yucca, prickly pear, sage, various grasses, and oak. Site 41BR261 was one of only two sites on the current project that lacked a burned rock midden. However, a possible eroding hearth was observed on the site, near where Wormser and Sullo-Prewitt (2001:66) noted the Pandale points and the concentration of artifacts. 


\section{Shovel Test Results}

Eighteen shovel tests were excavated at this site (Figure 6-41). Many of the shovel tests were described as containing compact to hard deposits, and gravels and pebbles dominated most levels. While sediments varied across the site, the upper levels of the shovel tests consisted of sandy clay sediment with gravel. Dense clay was present at varying depths below $20 \mathrm{~cm}$. Shovel tests were terminated when either the underlying clay layer was encountered or when repeated sterile levels were recorded. The shovel tests encompassed 67 levels for an average depth of $37 \mathrm{cmbs}$. No shovel test was excavated below $50 \mathrm{cmbs}$.

Only two of the 18 shovel tests (11\%) were positive for chipped stone (Figure 6-41). Three chipped stone items, all recovered in Level 1, were collected from Shovel Tests 8 and 13. Fire-cracked rock was present in 10 shovel tests, though on this colluvial slope, angular rock, easily mistaken as fire-cracked, was common. No other artifacts were identified through shovel testing at the site. Ten of the 18 shovel tests were positive.

\section{Surface Collections}

Figure 6-41 shows the location of the single surface collection area on 41BR261. The collection area, consisting of a circle with a radius of $3 \mathrm{~m}$, was placed in the approximate location identified by Wormser and Sullo-Prewitt (2001:67) as containing a dense concentration of artifacts. Only eight artifacts were collected. These consisted of four chipped stone, two cores, one biface, and one utilized/retouched flake. Artifact density was .28 artifacts per square meter.

In addition to the artifacts from the collection area, a single projectile point fragment was collected from the surface and identified as UI 1 (see Figure 6-41). This item probably represents a Late Archaic point form, possibly a Tortugas.

\section{Excavation Results}

Two 1-x-1-m units were excavated at this site (see Figure 6-41). Unit 1 was placed over the possible surface feature. The feature was manifested as a ca. $75 \mathrm{~cm}$ by $75 \mathrm{~cm}$, roughly circular concentration of about 25 small to moderate $(<8 \mathrm{~cm}$ in diameter) fire-cracked sandstone. The unit was positioned to bisect the feature. Upon excavation, the fire-cracked rocks were resting on a gravel and clay matrix. No staining or other indications of an associated pit were uncovered. No charcoal was observed. Five chipped stone flakes, two of which were collected from the surface, were present in the unit. A total of $.19 \mathrm{~m}^{3}$ of sediment was removed during this excavation.

Unit 2 was placed near one of the two shovel tests that was positive for chipped stone. Three levels were excavated in this unit, with Level 3 being dominated by silty clay and high gravel content. Only three chipped stone flakes were recovered in the $.23 \mathrm{~m}^{3}$ of sediment removed from this unit.

\section{Artifact Summary}

Nineteen artifacts were recovered from the site. These included 15 pieces of chipped stone debitage, two cores, one biface, and the probable Tortugas point fragment (see Appendices $E$ and F). Chert accounted for 14 of the 15 pieces of debitage. Cortex was lacking on 60 percent of the debitage, with only one of the 15 flakes having 100 percent dorsal cortex present.

\section{Other Samples}

No faunal or ethnobotanical material was collected from this site. No shell was recovered from the excavations. No charcoal was observed at the site.

\section{Summary}

Site 41BR261 was one of two sites tested on this project that lacked a burned rock midden. While a surface feature was tested, excavation results documented that the feature was eroded and no ethnobotanical remains or datable material was recovered. While previous work at the site had recovered three Pandale points, our work produced a single point, probably Late Archaic in age.

Shovel testing and surface collection results from the site revealed a low density of both surface and subsurface material. As noted by Bousman and Hodges (Appendix G), the site is located on a series of colluvial fans of unknown age. The fans have deposited rock and gravel that made identification of burned rock difficult. Excluding those shovel tests that were positive for burned rock, only 11 percent of the shovel tests at this site were positive. These 


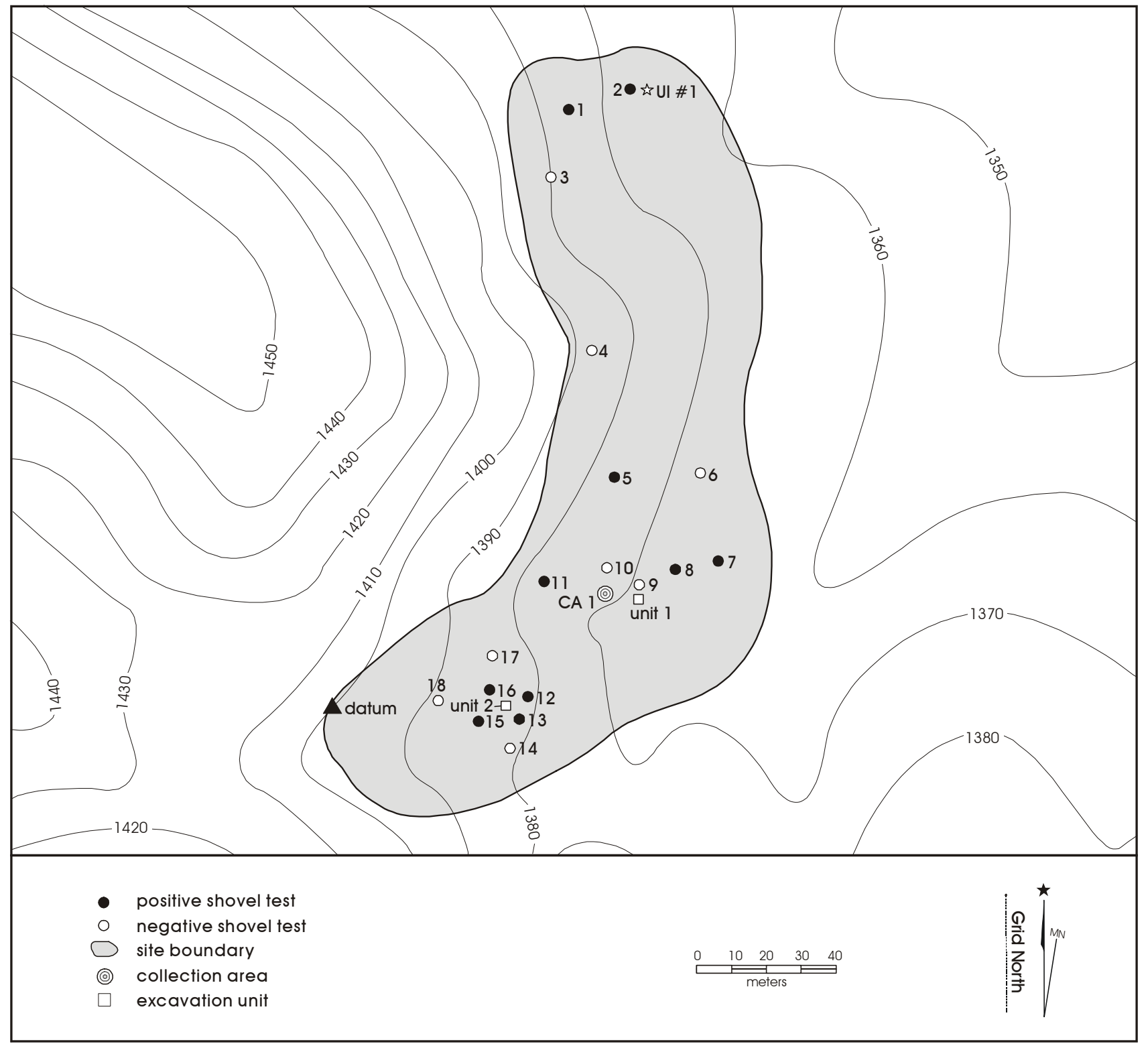

Figure 6-41. Site 41BR261 with shovel tests, excavation units, and surface collection area identified.

tests recovered only three chipped stone items, all from Level 1. The two excavation units produced an artifact density of 19 items per cubic meter of sediment. No vertebrate faunal material or mussel shell was present in either the shovel tests or the excavation units. Conditions for preservation at the site are poor. Surface densities are low, and subsurface deposits appear to be minimal. Testing of the single feature identified at this site suggested that the feature was eroded. 


\section{$41 \mathrm{BR} 276$}

\section{Site Description}

Wormser and Sullo-Prewitt (2001:74-75) describe site 41BR276 as an open campsite, located on a gentle slope just to the east of a small, unnamed drainage. TXARNG cultural resources staff recorded the site in 1995. Two projectile points diagnostic of the Late Archaic, a Pedernales and a Bulverde, were collected from the surface. In addition, 71 artifacts were observed or collected from the site, including a biface fragment, a medial point fragment, and over 60 flakes. A single shovel test, excavated to $50 \mathrm{cmbs}$, produced no cultural material. Given the potential that the site contained evidence of a single component, Late Archaic campsite, Wormser and Sullo-Prewitt (2001:75) recommended further evaluation of the site.

CAR archaeologists visited the site in the fall of 1999, and work was conducted during the spring of 2000. Site 41BR276 is at an elevation of roughly 1,475 feet (ca. 449.6 m) AMSL, and covers an area of about $2,760 \mathrm{~m}^{2}$. Few artifacts were observed on the surface. Since the original description of the location, 41BR276 has been impacted by maintenance activity associated with a road through the area. This road, described as a "jeep trail" by Wormser and Sullo-Prewitt (2001:75), has been widened and deepened by grading. When CAR visited the site in 1999, vegetation consisted of Mormon tea, yucca, prickly pear, sage, various grasses, and oak. 41BR276 is the second site on the current project that lacked a burned rock midden, however, a possible hearth was observed in the road during CAR's visit.

\section{Shovel Test Results}

Thirty-three shovel tests were excavated at this site (Figure 6-42). Many of the shovel tests were described as containing a loose, brown to yellow sandy silt. In the vast majority of cases, shovel tests were terminated when the underlying bedrock was encountered. The 33 shovel tests at 41BR276 encompassed 65 levels for an average depth of just under $20 \mathrm{cmbs}$. Only a single shovel test was excavated below $40 \mathrm{cmbs}$, with most encountering bedrock between 20 and 30 cmbs.

Ten of the 33 shovel tests (30\%) contained chipped stone artifacts, though only 11 artifacts were recovered from these positive tests. Nine pieces of chipped stone debitage, one biface (Appendix F) and one utilized/retouched flake were recovered, with over 81 percent of these items collected from Level $1(0-10 \mathrm{cmbs})$. Fire-cracked rock was noted in three of the 33 shovel tests. Eleven of the 33 tests (33\%) were positive (Figure 6-42).

\section{Surface Collections}

Figure 6-42 shows the location of the surface collection area on 41BR276. The collection area, consisting of a circle with a radius of $2 \mathrm{~m}$, was placed in the road where several artifacts were visible. Six pieces of debitage, one biface (Appendix F), and one core were collected, reflecting a density of about .64 artifacts per square meter.

\section{Excavation Results}

Two 1-x-1-m units were excavated at this site (see Figure 6-42). Unit 1 was placed over the surface feature exposed in the road. As shown in Figure 6-43, the feature consisted of roughly 75 fire-cracked sandstone and limestone rocks spread over an area of approximately $1.40 \mathrm{~m}$ by $1.20 \mathrm{~m}$. A very slight darkening of the sediments around the rock was observed, though no charcoal was visible. Upon excavation, no pit was observed, and the slight staining quickly vanished. While a small number of fire-cracked rocks were still visible at the end of Level 1 (ca. $8 \mathrm{cmbd}$ ), bedrock was beginning to be exposed. Given the lack of staining, the disturbed position of the feature, and the presence of bedrock, the unit was terminated. Eight artifacts, all of which are chipped stone debitage, were recovered from the $.07 \mathrm{~m}^{3}$ removed from this unit.

Unit 2 was placed near positive Shovel Test 17, the only shovel test on the site that had a depth below $40 \mathrm{~cm}$ (see Figure 6-42). Three levels were excavated in this unit, removing a total volume of $.27 \mathrm{~m}^{3}$, before bedrock was encountered. Eight chipped stone items, including one core, were recovered from this unit.

\section{Artifact Summary}

Only 36 artifacts were recovered from the site. These included 31 pieces of chipped stone debitage, two cores, two bifaces (see Appendix F), and a single utilized/retouched flake. Chert accounted for 100 percent of the debitage. Cortex was lacking on 87 percent of the debitage, with no flake having 100 percent cortex present. 


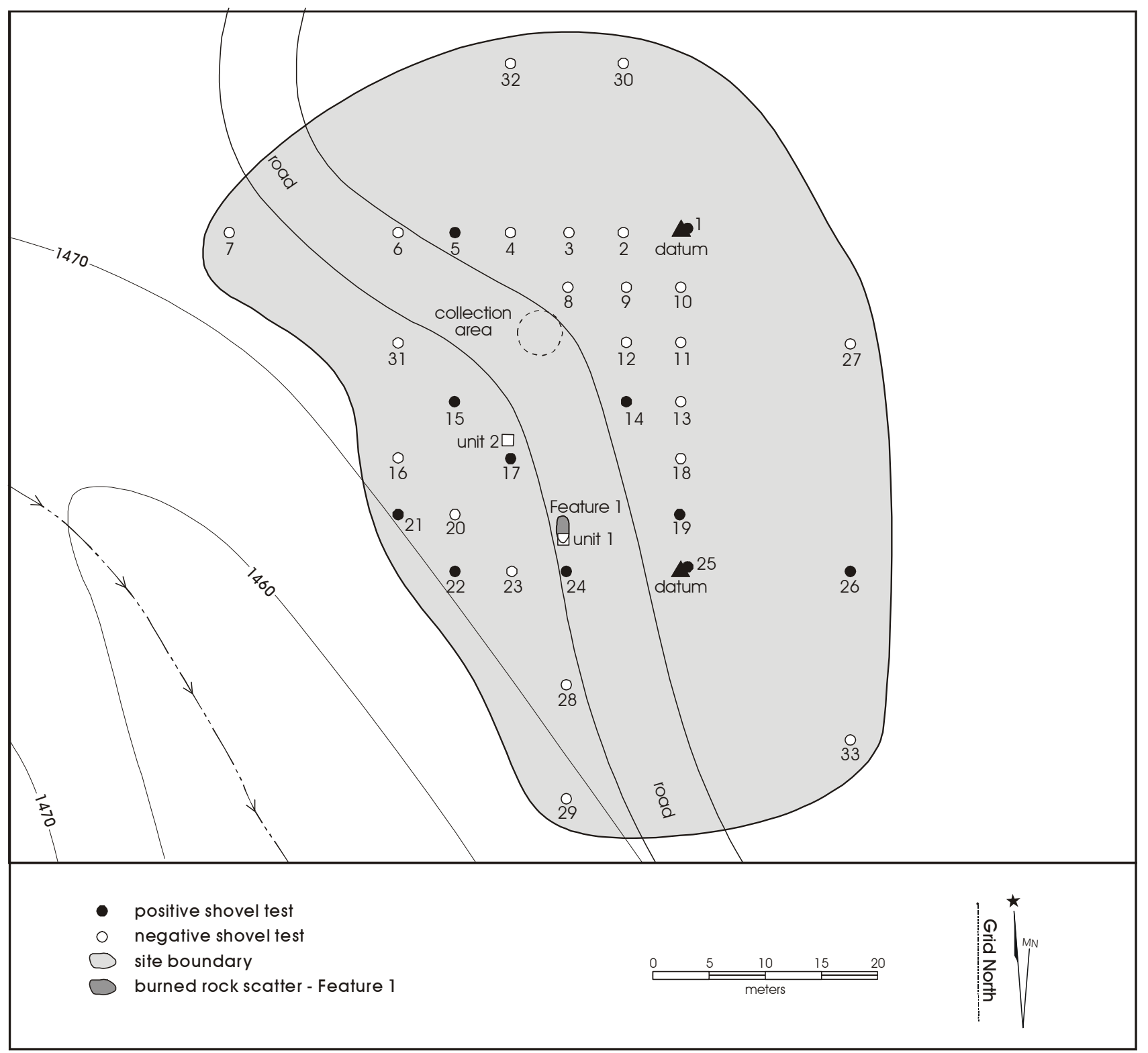

Figure 6-42. Site 41BR276 with shovel tests, excavation units, and surface collection area identified.

\section{Other Samples}

No faunal or ethnobotanical material was collected from this site. No shell was recovered from the excavations. No charcoal samples were recovered from the site.

\section{Summary}

Like 41BR261, site 41BR276 lacked burned rock middens. While a single surface feature was tested, the feature was discovered in a well-maintained road surface. Excavation results documented that the feature was eroded and disturbed. No datable material was recovered. While previous work at the site had recovered Late Archaic diagnostics, no additional diagnostics were discovered during our work.

Shovel testing and surface collection results from site 41BR276 revealed a low density of both surface and subsurface material. As noted by Bousman and Hodges (Appendix G), the site is located on a colluvial fan of 
unknown age. Bedrock commonly occurs within 10 or 20 $\mathrm{cm}$ of the current surface. While 33 percent of the shovel tests at this site were positive, only 11 chipped stone artifacts were recovered. Eighty-one percent of the artifacts recovered were from Level $1(0-10 \mathrm{cmbs})$. While the two excavation units produced an artifact density of 50 items per cubic meter of sediment, both excavation units encountered bedrock within a few levels of the surface. No faunal material or mussel shell was present in either the shovel tests or the excavation units.

Conditions for preservation at the site are poor. Surface densities are low, and subsurface deposits appear to be minimal. Testing of the single feature identified at this site suggested that the feature was eroded and damaged by road maintenance.

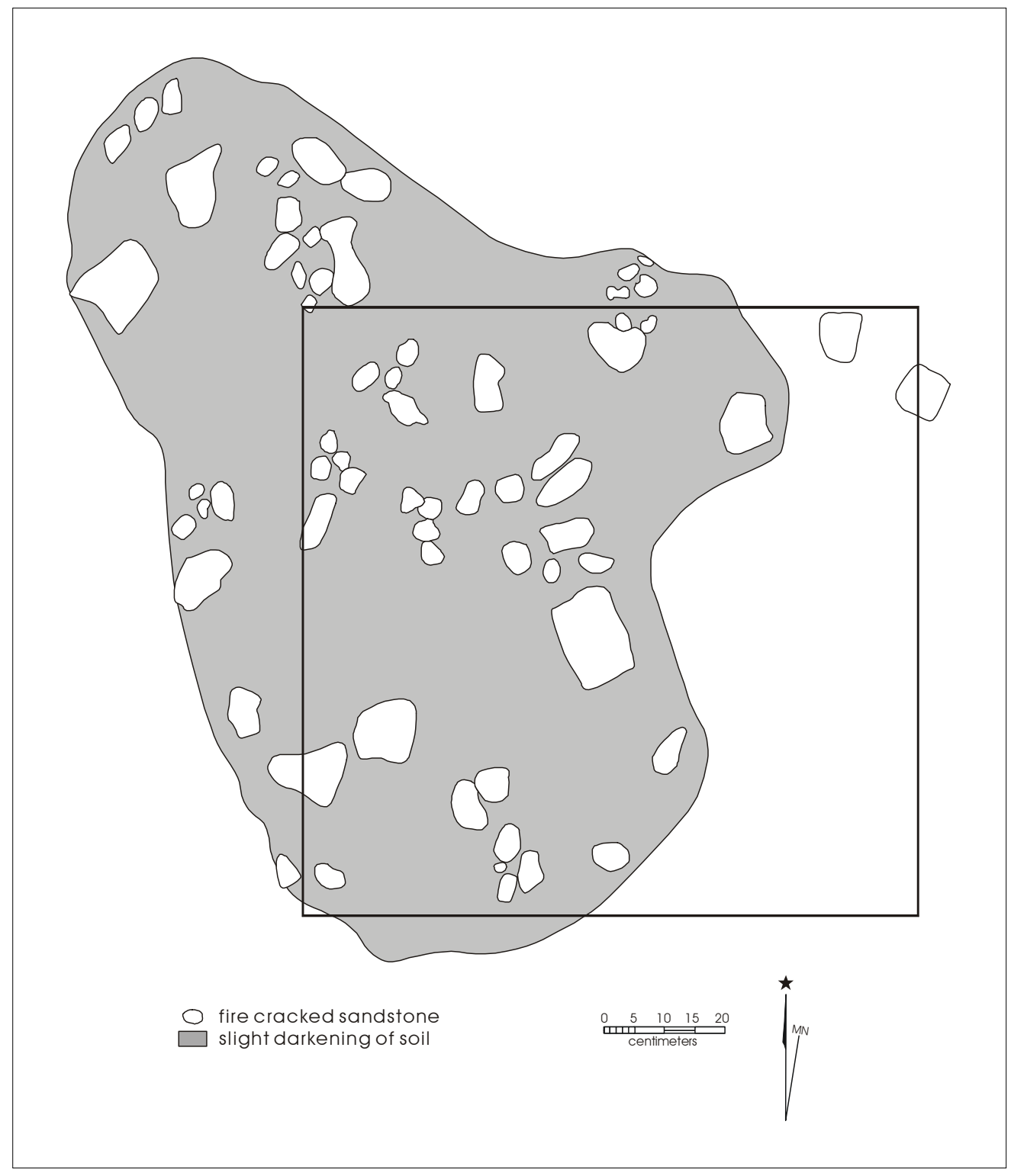

Figure 6-43. The surface of Feature 1 and the location of Unit 1 on site 41BR276. 


\section{$41 \mathrm{BR} 415$}

\section{Site Description}

Wormser and Sullo-Prewitt (2001:93-96) describe 41BR415 as a burned rock midden site containing a light to moderate density of lithics. The site is in an upland setting. A small, unnamed drainage is located to the northwest. TXARNG cultural resources staff recorded the site in 1995. They describe the single midden as roughly $12 \mathrm{~m}$ in diameter and $75 \mathrm{~cm}$ in height. Wormser and Sullo-Prewitt noted that a tank trail cut through the center of the site.

Wormser and Sullo-Prewitt (2001:93-96) report that a variety of artifacts were observed or collected at this site, including two Late Archaic Pedernales points, a Middle Archaic Nolan point, and a projectile tip from an arrow point suggesting Late Prehistoric use. Nine shovel tests were excavated at this site. It appears that three of these shovel tests were positive, with a low density of artifacts present down to $30 \mathrm{cmbs}$. In addition, a variety of other artifacts were observed on the surface, including biface and uniface fragments, ground stone fragments, and several cores and tested cobbles (Wormser and Sullo-Prewitt 2001:94-96).

CAR archaeologists visited the site in the fall of 1999, and work was conducted during the spring of 2000 . Few artifacts were observed on the surface of the site. Since the original description of the location, site 41BR415 has been impacted by maintenance activity associated with the road that bisects the site. Wormser and Sullo-Prewitt (2001:95) describe the road as a "tank trail." By the fall of 1999, the road was roughly $8 \mathrm{~m}$ in width, and excavated to a depth of roughly 30 to $40 \mathrm{cmbs}$. In addition, a portion of the site, roughly 60 $\mathrm{m}$ by $30 \mathrm{~m}$, had been graded (Figure 6-44). The burned rock feature consisted of a low mound with fire-cracked sandstone visible on the surface. A second feature, consisting of firecracked rocks, was exposed to the west of the midden in the road. The elevation is roughly 1,365 feet $(416 \mathrm{~m})$ AMSL, and the site covers an area of about $12,950 \mathrm{~m}^{2}$. When CAR visited the site in 1999, vegetation consisted of grasses, mesquite, juniper, agarita, oak, yucca, and prickly pear.

Figure 6-44 shows the location of a single backhoe trench excavated by Bousman and Hodges during their geoarchaeological work at this site. In addition to describing the trench, Bousman and Hodges also described a profile in the drainage to the west of the site (see Figure 6-44). As discussed in Appendix G, they suggest that the site sits on an alluvial fan, deposited in at least two stages, with lower deposits dating to the Late Pleistocene.

\section{Shovel Test Results}

Seventy shovel tests were excavated at this site. No shovel tests were excavated in the midden, though several were placed immediately around the feature. Most shovel tests were concentrated to the northwest of the midden (Figure 6-44), where some surface artifacts were present. Sediments observed in shovel tests varied across the site, but shovel tests were generally terminated either when a compact to hard calcium carbonate dominated strata was encountered or when multiple, consecutive negative levels were present. The 70 shovel tests encompassed 307 levels. All shovel tests were dug into Level 2 (ca. $20 \mathrm{cmbs}$ ) and several shovel tests excavated to Level 7 (ca. $70 \mathrm{cmbs}$ ). The average depth of the shovel tests was approximately $43.9 \mathrm{cmbs}$.

No ground stone was encountered in any of the shovel tests, however, 97 items of chipped stone debitage, three cores, two bifaces, and three utilized/retouched items were recovered. Shell was noted in seven shovel tests. In addition, roughly 346 pieces of fire-cracked rock were recorded in the shovel tests. Chipped stone was present in 40 of the 70 tests $(57 \%)$ and fire-cracked rock was recorded in 57 shovel tests (81\%). Fifty-eight of the 70 shovel tests excavated at this site were positive (Figure 6-44).

Figure 6-45 presents the density of fire-cracked rock (top) and chipped stone debitage (bottom) by level for the shovel tests excavated at the site. Clearly, both data sets have similar distributions, with highest densities in Levels 1 and 2, and a consistent drop-off in densities with increasing depth. The shallow nature of the deposits at this site is also suggested by the observation that 82 percent of the fire-cracked rock and 73 percent of the chipped stone debitage was recovered from within $0-20 \mathrm{~cm}$ of the surface.

The feature, identified in the road and designated Feature 4, was tested with a single shovel test (ST 42). The feature consisted of a light gray stain and roughly 20 small, crushed, fire-cracked rocks, spread over an area of about $1.75 \mathrm{~m}$ by $.75 \mathrm{~m}$. No charcoal was visible. The feature appeared to be the bottom of a fire-cracked rock feature that had been mostly removed by road maintenance activities. The single shovel test, placed roughly $25 \mathrm{~cm}$ outside of the disturbed feature boundary, produced a single flake from Level 1 . No charcoal or other material was present. The shovel test was terminated 


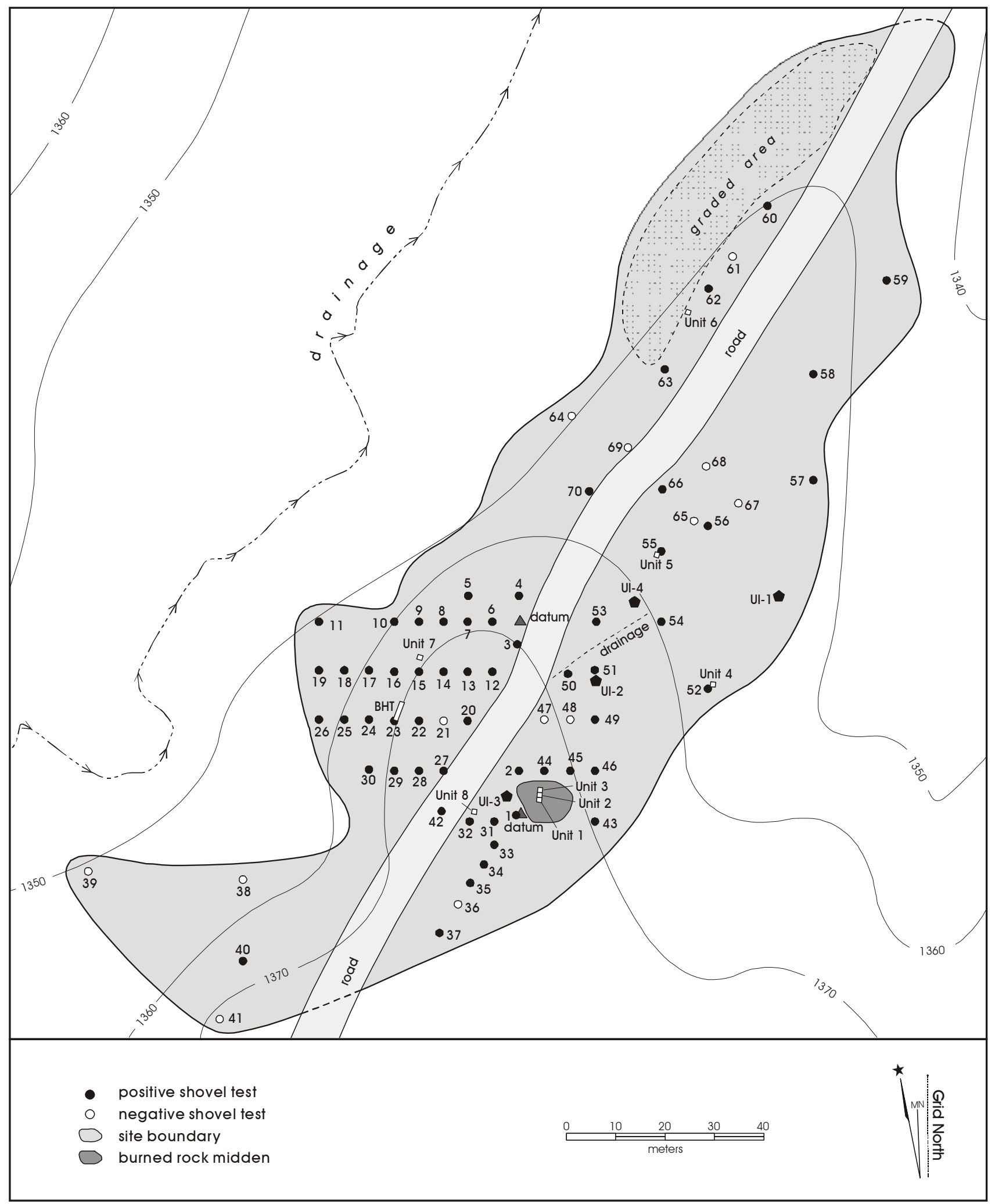

Figure 6-44. Site 41BR415 with shovel tests and excavation units identified. 
at $20 \mathrm{~cm}$ below the road surface, which itself was roughly 30 to $40 \mathrm{~cm}$ below the primary surface at this site.

\section{Surface Collections}

While in several areas of the site surface artifacts were observed, there was no single area with a dense concentration of material. Consequently, no systematic surface collection area was placed on this site. However, three bifaces and a single utilized/retouched flake was collected from the surface (Figure 6-44).

\section{Excavation Results}

Eight $1-\mathrm{x}-1-\mathrm{m}$ units containing an estimated $3.41 \mathrm{~m}^{3}$ of material were excavated at this site (Figure 6-44). Three

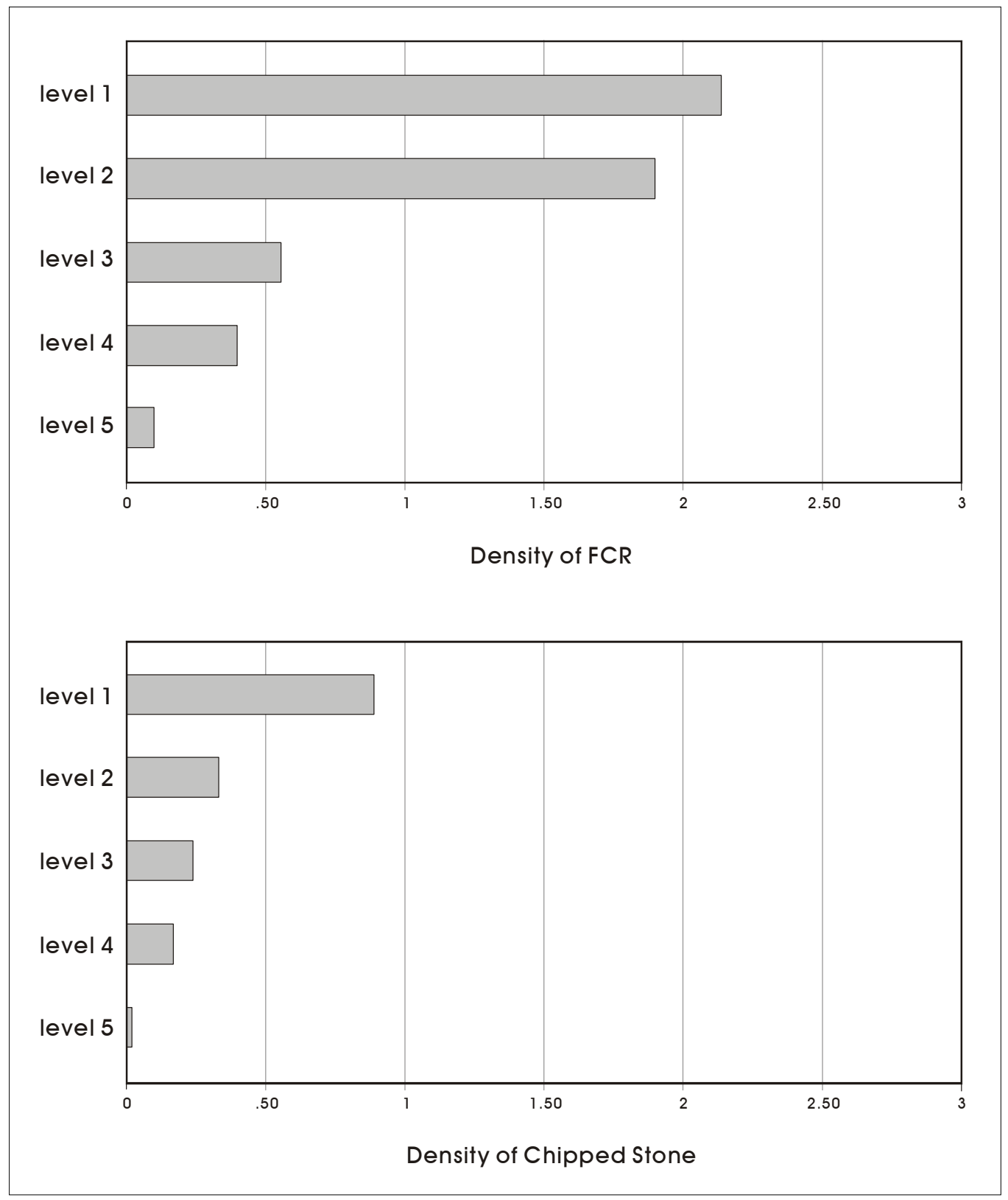

Figure 6-45. Bar graph of fire-cracked rock (top) and chipped stone debitage (bottom) for shovel tests on $41 B R 415$. 
contiguous 1-x-1-m units were excavated in an effort to crosscut the feature. Five off-midden units, all 1-x-1-m in size, were positioned at various other places on the site to define and clarify the character of deposits on the site.

\section{Midden Units}

The midden, designated Feature 1, was sampled with Units 1,2 , and 3. Figure $6-46$ provides a profile of these three units. The upper 20 to $40 \mathrm{~cm}$ of the feature consisted of a high density of fire-cracked rock within a dark brown, silty loam matrix. Underlying this is a zone of ashy silt sediment, gray to black in color. This zone, generally $20 \mathrm{~cm}$ in thickness, contained fewer rocks. Finally, yellow silty clay with a high frequency of gravel, representing the natural surface, was uncovered. Units 2 and 3 were excavated below the bottom of the feature, well into the natural surface. Extensive rodent disturbance was present throughout the feature, with several such areas identified in Figure 6-46.

While disturbed by rodents, a possible central pit at the bottom of Unit 1 is visible in the feature profile, defined both by many of the tabular rocks sloping toward the unit, as well as the deeper area along the southern edge of the profile. In addition, a second feature, designated Feature 3, was identified in Unit 2 at between 30 to $40 \mathrm{cmbd}$. Figure 6-47 presents a plan view of this feature, clearly showing a ring of rock with lower rock density to the south. Comparison of Figure 6-47 with Figure 6-46 shows that, as with the pit in Unit 1, a series of sloped, tabular fire-cracked rocks are visible along the Unit $2 / 3$ boundary. A small (ca. $25 \mathrm{~cm}$ ) pit may be present near the bottom of the larger feature. This pit may be associated with Feature 3.

Roughly $1.63 \mathrm{~m}^{3}$ of sediment and rock were removed from Feature 1, with an additional $.25 \mathrm{~m}^{3}$ excavated below the feature. Fifty-seven chipped stone artifacts were removed from the midden deposits, with four artifacts found below the midden. Artifact density within the midden was just below 35 items per cubic meter. Below the midden, density dropped to 16 items per cubic meter. In addition, two pieces of red ochre were recovered from midden deposits.

We removed 9,890 fire-cracked rocks greater than one inch in size from the three units. An additional $183.5 \mathrm{~kg}$ of rock less than one inch in size were recorded. While chert, conglomerate, and limestone were noted in the midden, sandstone accounted for over 98 percent of the fire-cracked rock counted.

\section{Off-Midden Units}

Five 1-x-1-m units, containing an estimated $1.53 \mathrm{~m}^{3}$ of deposit, were excavated outside of the midden (see Figure 6-44). Unit 4 was placed to explore a possible feature noted in Shovel Test 52. Unit 5 was placed in an area that was thought to potentially be another burned rock midden, though excavation did not confirm this suggestion. Unit 6 was placed to explore the potential of deposits on the northern end of the site while Unit 7 was excavated in the center of a series of positive shovel tests. Finally, Unit 8 was excavated near the burned rock midden.

The off-midden units were highly variable in terms of sediment. Unit 4, excavated off the slope on the midden area, and Unit 8, excavated near the midden (see Figure 6-44), had different depositional sequences relative to the other units. Figure 6-48 presents profiles of these two units, demonstrating both their greater depth and their depositional sequences. Conversely, Units 5, 6, and 7, all excavated along the ridge, were shallow, being terminated within $30 \mathrm{~cm}$ of the surface when an underlying calcrete layer was encountered. The upper sediments were a yellow to brown sandy loam, with high frequencies of gravel.

Chipped stone densities in these external units were variable ranging from a low of roughly 48 chipped stone artifacts per cubic meter in Unit 5 to a high of just under 142 artifacts per cubic meter in Unit 8. Units 5, 6, and 7, all located along the center of the site (Figure 6-44), had high chipped stone artifact densities in Level 1 and falling artifact densities with depth. For these three units, Level 1 had an average of roughly 189 chipped stone items per cubic meter, Level 2 an average of 50 artifacts per cubic meter, and Level 3 a density of only 19.4 artifacts per cubic meter. This pattern of high artifact densities in the upper levels is consistent with the general shovel test results discussed previously.

Unit 4 had a different pattern of recovery, with only three chipped stone items recovered from Levels 1 and 2. Level 3 had 35 items, Level 4 had 11, and Level 5 had only four items. It may be that this unit, located near the bottom of a slope, had significant deposition over the prehistoric surface. Unit 8, located next to the midden, had high recovery in the upper two levels with 54 items, consistent with the pattern in Units 5, 6, and 7. However, while there was a low of only two items in Level 3, 12 items were recovered from Level 4. The Level 4 materials are the only evidence for deeper deposits at this site. Fire-cracked rock was noted only in 


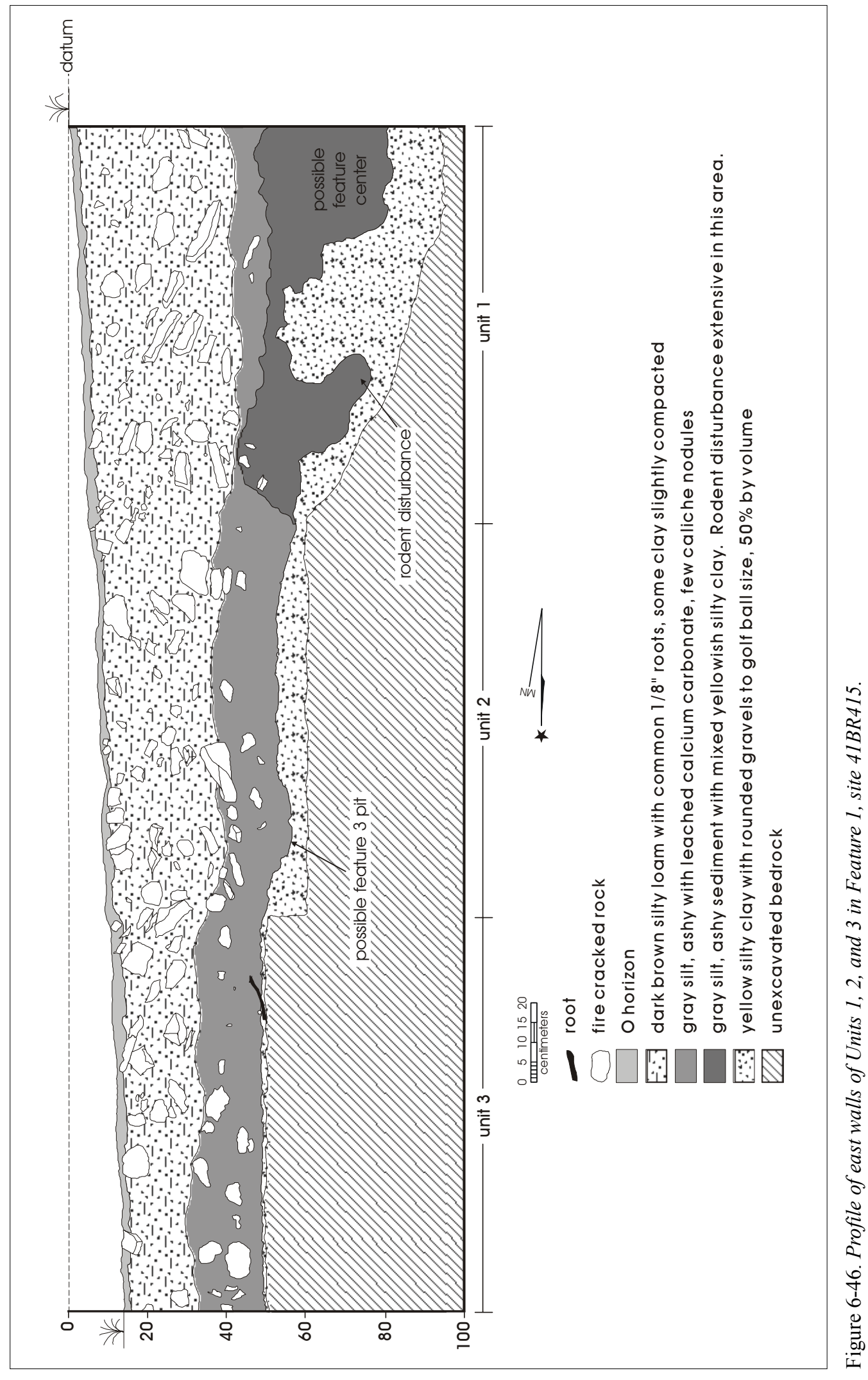




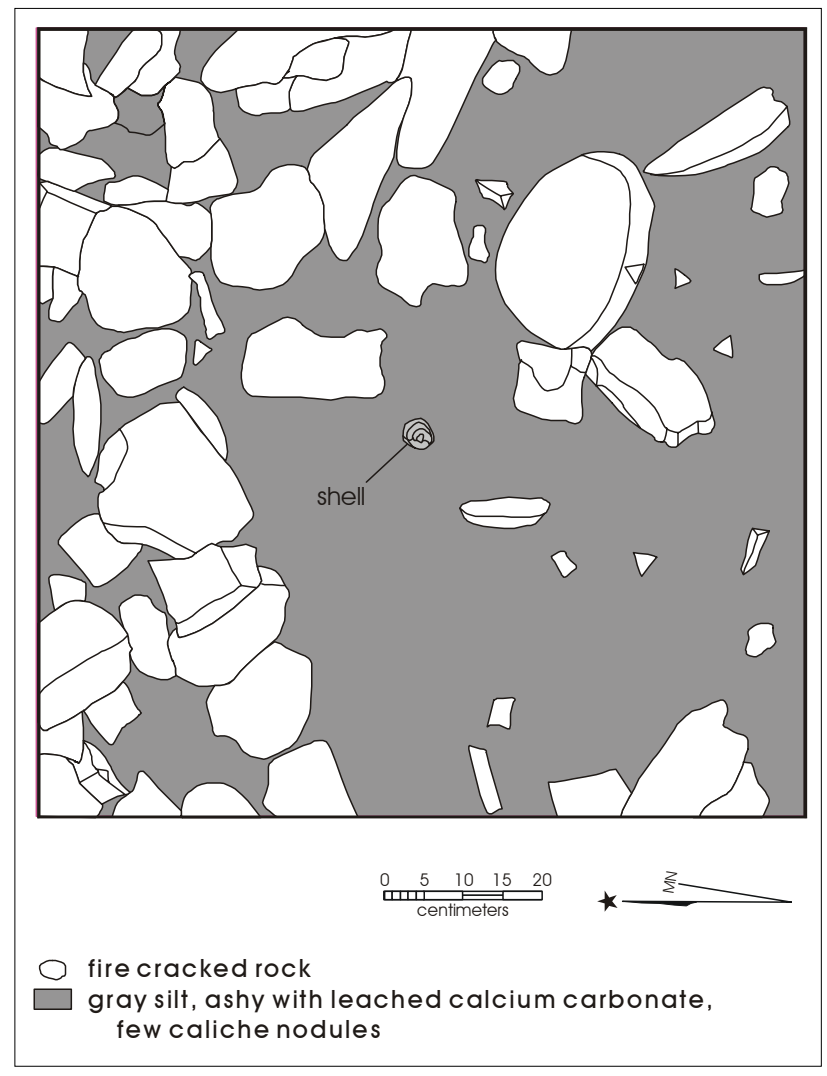

Figure 6-47. Plan view of Feature 3, Unit 2 at 30-40 cmbd, site $41 B R 415$.

Unit 5, an area originally suspected as reflecting a burned rock midden. However, it is unclear if a significant number of these rocks were, in fact, burned.

\section{Artifact Summary}

Three hundred and fifty-two chipped stone artifacts were collected from 41BR415. This total includes 332 flakes, 11 bifaces, four cores, and five utilized/retouched items. In addition, two pieces of ochre were recovered. Appendix F presents scans of selected tools from this site. Within the flake assemblage, chert dominates the raw materials, accounting for over 99 percent of the material. Roughly 84 percent of the flakes lacked cortex, with only six flakes $(1.8 \%)$ having 100 percent dorsal cortex cover.

No diagnostic projectile points were recovered from CAR's work at the site. As noted previously, Wormser and SulloPrewitt (2001) collected two Late Archaic Pedernales points, a Middle Archaic Nolan point, and a tip from an arrow point, the latter suggesting Late Prehistoric use.

\section{Other Samples}

No vertebrate faunal material was recovered in the excavations at this site. This lack of faunal material may be related to preservation, as carbonized material within the midden was not common.

As summarized by Dering (Appendix C), ethnobotanical recovery from this site was limited. No macrobotanical samples were observed during the excavations. The two flotation samples from the burned rock midden produced low recovery, with only a fragment of oak and a fragment of juniper charcoal represented.

Mussel shell was recovered from seven of the eight excavation units, as well as several shovel tests. Just over 536 grams of shell were recorded. Nine samples from this site were in the samples identified by Goodfriend (Appendix D). These samples were identified as Quadrula apiculata $(\mathrm{n}=2)$, Quadrula houstonensis $(\mathrm{n}=4)$, Cyrtonaias tampicoensis $(\mathrm{n}=1)$, and Amblema plicata $(\mathrm{n}=2)$.

\section{Radiocarbon Dates}

No radiocarbon samples were submitted from this site. As noted previously, recovery of carbonized material from the Feature 1 excavation was generally low. In addition, charcoal sample sizes were small, increasing the probability that significant movement of these samples could have occurred. The high level of rodent disturbance within the burned rock midden, coupled with the small size of the charcoal, significantly increases the probability of sample movement.

\section{Summary}

CAR's work at site 41BR415 failed to produce any new chronometric information on the temporal placement of either the site or the midden. No new diagnostics were recovered and, given the disturbed context of the midden, no radiocarbon dates were submitted. Diagnostic points recovered by Wormser and Sullo-Prewitt (2001:93-96) suggest use of the site during the Middle Archaic, Late Archaic, and Late Prehistoric time frames.

No surface collection areas were placed at this site. Shovel testing results from outside the midden revealed a moderate density of shallowly buried deposits. While the percentage of positive shovel tests at a site level was relatively high, 


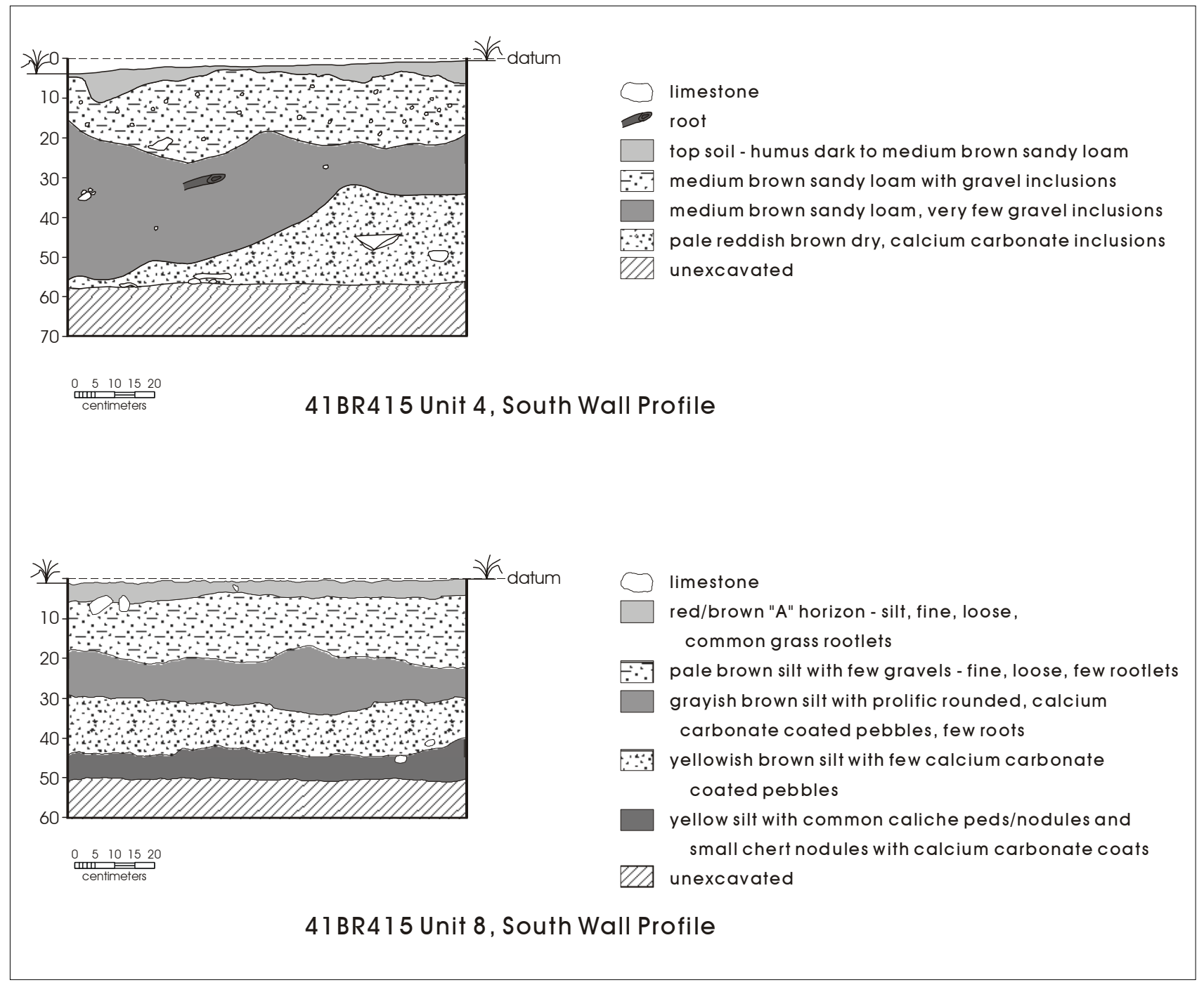

Figure 6-48. Profiles of Units 4 and 8, site 41BR415.

roughly 82 percent of the fire-cracked rock and 73 percent of the chipped stone recovered was from the upper $20 \mathrm{~cm}$, suggesting that the deposits are shallow. In excavation units outside of the midden, artifact density was moderate. As with the shovel test data, the highest recovery was in the upper levels, with consistent drop-offs below Level 1. Within Feature 1, artifact density was slightly lower than in outside units, with less than 35 items recovered per cubic meter of sediment. While mussel shell was present in the excavation units, faunal and macrobotanical samples were not recovered. Flotation samples from the midden produced only small fragments of oak and juniper charcoal.

Conditions for preservation of ethnobotanical material within the midden are poor. Though worm and insect casts are common in the midden deposits, rodent burrowing was extensive (see Appendix G). Outside of the midden, several features are present, but they too had poor preservation. 


\section{$41 \mathrm{BR} 420$}

\section{Site Description}

Wormser and Sullo-Prewitt (2001:98-99) describe site 41BR420 as a burned rock midden site containing chipped stone. They defined two, and possibly three, burned rock middens. The site is at the base of an east-facing toeslope dominated by sandstone. TXARNG cultural resources staff recorded the site in 1995. They describe one of the middens as roughly $7 \mathrm{~m}$ in diameter, and $40 \mathrm{~cm}$ high. A second midden is described as $12 \mathrm{~m}$ in diameter, and roughly $70 \mathrm{~cm}$ high. Wormser and Sullo-Prewitt (2001:98) note a concentration of roughly 20 flakes located $60 \mathrm{~m}$ north of the two middens. In addition to the two middens, they recorded a possible third midden, and observed a number of 2 to 3-m clusters of sandstone across the site. They suggest that these may represent additional features. A variety of artifacts were observed at this site, including bifaces, cores, and flakes (Wormser and Sullo-Prewitt 2001:98). Only a single biface was collected. One shovel test was excavated at the site to a depth of $22 \mathrm{cmbs}$. No artifacts were recovered (Wormser and Sullo-Prewitt 2001:98).

CAR archaeologists visited the site in the fall of 1999 , and work was conducted during the spring of 2000. The elevation of the site is about 1,415 feet (ca. $431 \mathrm{~m}$ ) AMSL, and the site covers an area of roughly $9,900 \mathrm{~m}^{2}$. Though Wormser and Sullo-Prewitt noted a lithic concentration, CAR observed few artifacts on the surface. We defined a single midden consisting of fire-cracked sandstone (Figure 6-49). The feature was circular, roughly $10 \mathrm{~m}$ by $9 \mathrm{~m}$, and about $70 \mathrm{~cm}$ in height. A slight depression was visible on the surface of the feature. A number of other concentrations of sandstone were observed on the surface of the site, though many of these did not appear burned. These unburned concentrations appeared to correspond to the second feature defined by Wormser and Sullo-Prewitt (2001). When CAR visited the site in 1999, vegetation observed included grasses, oak, mesquite, juniper, and prickly pear. Ground visibility around the midden, and on the southern end of the site, was limited by leaf and tree clutter. Ground visibility on the northern end of the site was excellent, with the surface being a gravely sand matrix. The northern end of the site had a series of erosional features present (see Figure 6-49).

\section{Shovel Test Results}

Fifty-two shovel tests were excavated at this site. The majority of the shovel tests were focused around the single burned rock midden identified by CAR. Additional shovel tests were placed to the west of the midden to explore areas where TXARNG archaeologists had identified a second midden. Finally, shovel tests were scattered to the northwest of the midden to both search for any additional features, as well as identify the characteristics of the subsurface deposits. No shovel tests were excavated in the midden (see Figure 6-49). Shovel tests were terminated when compact brownishred clay was encountered. To the west of the midden, towards the slope, this was consistently present at 10 to $20 \mathrm{cmbs}$. As the distance from the slope increased, the depth of the red clay increased, often to depths below $50 \mathrm{~cm}$. In these cases, shovel tests were terminated when consecutive negative levels were encountered below $30 \mathrm{~cm}$. The shovel tests encompassed 179 levels, with all shovel tests being dug into Level $2(10-20 \mathrm{cmbs})$ and no shovel test excavated below $60 \mathrm{cmbs}$. Average shovel test depth was $34 \mathrm{cmbs}$.

No ground stone or mussel shells were encountered in any of the shovel tests. However, 83 flakes were recovered, as well as one biface and one utilized/retouched flake. In addition, roughly 221 burned and fire-cracked rocks were recorded in the shovel tests. Chipped stone was present in 48 percent of the shovel tests and burned or fire-cracked rock was recorded in 34.6 percent. Roughly 52 percent of the shovel tests were positive.

The vertical distribution of this material suggests that the occupation is confined to the upper $30 \mathrm{~cm}$ of deposits. Ninety-five percent of both the chipped stone and firecracked rock was recovered from the upper $30 \mathrm{~cm}$. Artifact density for the upper three levels was 0.54 chipped stone debitage and 1.43 fire-cracked rock per level. Densities below $30 \mathrm{~cm}$ dropped to 0.12 items per level for chipped stone and 0.33 for fire-cracked rock.

Figure 6-50, a blow up of the midden area, shows that most of the positive shovel tests were concentrated to the northeast, east, and southeast of the midden, with tests on the western side having a much lower frequency of recovery. In addition, a series of cut, sandstone blocks forming a possible structure are present near Shovel Test 50. Examination of this area, as well as several similar structures near 41BR420 that were constructed by the military, suggests that this structure is probably military in origin.

\section{Surface Collections}

While excellent ground surface visibility was present on the northern end of the site, the lithic scatter noted by 


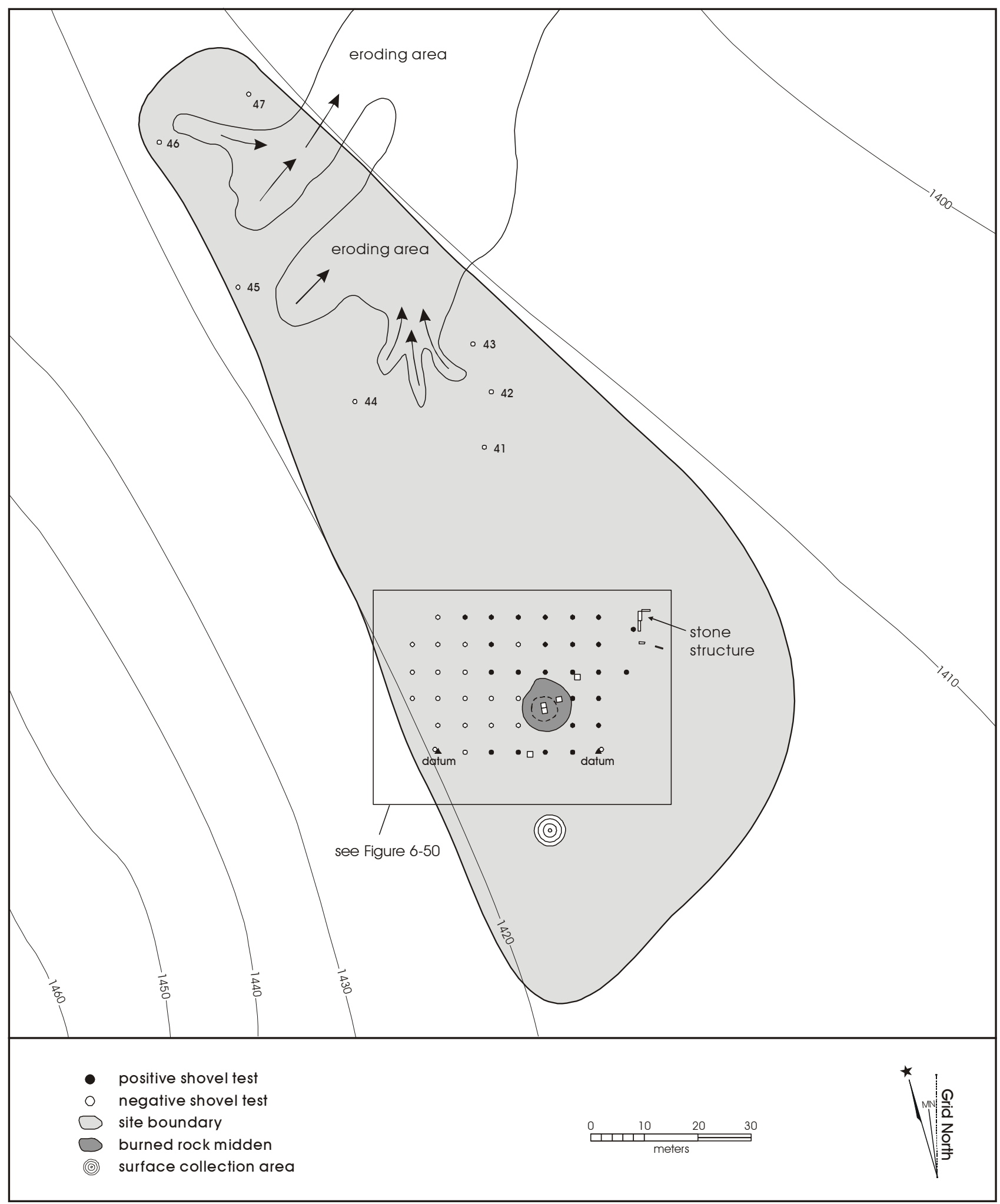

Figure 6-49. Map of site 41BR420 with the burned rock midden, shovel tests, and surface collection area identified. 


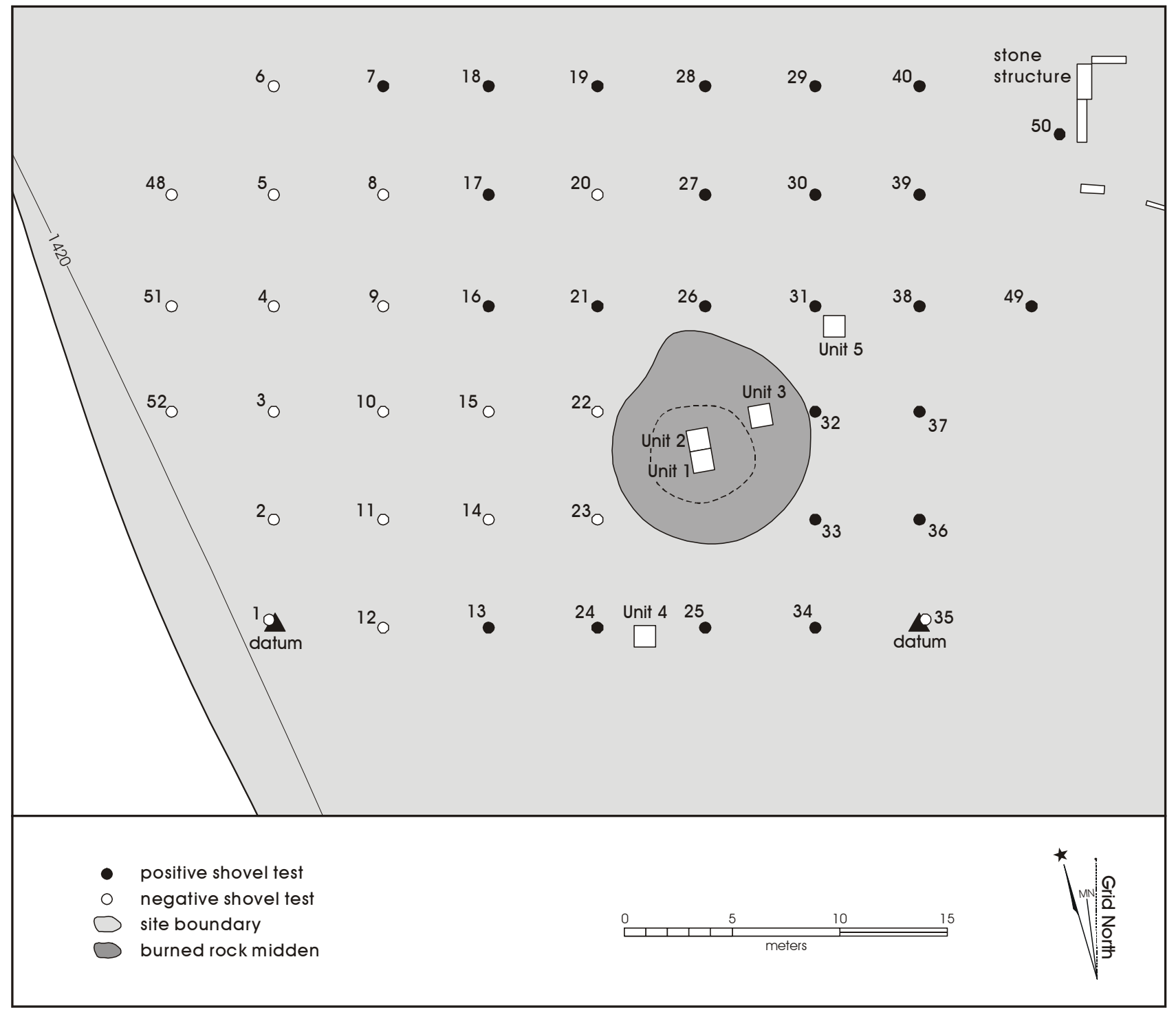

Figure 6-50. Midden area of site 41BR420 with positive shovel tests and excavation units identified.

Wormser and Sullo-Prewitt (2001:98) was not relocated. The location of the scatter was in an area that has been extensively eroded. Consequently, only a single collection area, located to the south of the midden, was placed on this site. A circle, $3 \mathrm{~m}$ in diameter, was placed in this area (see Figure 6-49). Leaf and tree duff was cleared from the area, and 100 percent of the surface material was collected. Nineteen chipped stone items, all debitage, were present in this area for a surface density of .67 items per square meter. Twelve of the 19 items lacked cortex, and there were no flakes with 100 percent dorsal cortex cover.

\section{Excavation Results}

As shown in Figure 6-50, five 1-x-1-m units, with a total volume of $2.5 \mathrm{~m}^{3}$, were placed on this site. Two contiguous $1-x-1-m$ units were excavated in the midden, placed to cut into the central depression. A third unit (Unit 3) was placed on the talus of the midden. Two 1-x-1-m units were excavated outside of the burned rock feature. Unit 4 was placed to the south of the midden while Unit 5 was placed near Shovel Test 31, a test that had produced both chipped stone and a concentration of fire-cracked rock. 


\section{Midden Units}

The midden was designated Feature 1. Figure 6-51 presents profiles for the east and west walls of Units 1 and 2, placed in the central area of the midden. A total volume of $1.18 \mathrm{~m}^{3}$ was removed in these two units. The midden deposits were turbated by insects and earthworms, though rodent disturbance was minimal (see Appendix G).

Examinations of the profiles, especially the east wall profile, shows that at least two pits may be present, evidenced by bowl-shaped depressions with differential fill. During excavation, a single internal feature, designated Feature 2, was defined as a circular concentration of fire-cracked rock along the border of Units 1 and 2. Figure 6-52 presents a plan view of this feature. The plan view is a combination of fire-cracked rock from several different levels, reflecting depths of between 10 to $25 \mathrm{cmbd}$. A pit, defined by the circular ring and the absence of rock, is clearly visible. Within this pit, and scattered at a lower density throughout the 20-30 cm level of Unit 1, was a variety of faunal material that was identified as bison, or consistent with bison-sized animals. The remains included a large section of a bison tibia. Interestingly, while these remains had extensive chemical weathering, none of the material was burned (see Appendix B).

Twenty-nine pieces of debitage, one utilized/retouched flake, and two projectile points were recovered from these two units. While mussel shell was noted in both units, quantities were minimal. Artifact density within this central area of the midden was about 27 items per cubic meter. We removed 3,972 fire-cracked rocks greater than one inch in size from Units 1 and 2. An additional $51.8 \mathrm{~kg}$ of rock less than one inch in size were recorded. While limestone was noted in these central units, sandstone accounted for 98 percent of the fire-cracked rock counted.

Unit 3 was also excavated in Feature 1, though it was placed on the ring of the feature. Figure 6-53 presents a profile of the south wall of this excavation unit. Comparison of this profile with that shown in Figure 6-51 suggests a higher rock density in Unit 3 . This suggestion is confirmed by noting that 4,556 fire-cracked rocks greater than one inch in size were removed from this unit. An additional $49.7 \mathrm{~kg}$ of rocks less than one inch in size were recovered. Fifteen artifacts, including 13 pieces of debitage, one projectile point, and one utilized/retouched flake, were also collected from the $.64 \mathrm{~m}^{3}$ of sediment screened in Unit 3 .

\section{Off-Midden Units}

Two 1-x-1-m units, identified as Units 4 and 5, were excavated outside of Feature 1 (see Figure 6-50). Both of these units were shallow containing an estimated $.68 \mathrm{~m}^{3}$ of deposits. These units reflected the same shallow depth to the underlying brownish-red clay as seen in the shovel tests, with both units encountering clay within $40 \mathrm{~cm}$ of the surface.

Artifacts were much more common in these external units with Unit 4 containing 55 pieces of chipped stone debitage and a utilized/retouched flake (ca. 175 items per cubic meter) while Unit 5 contained 45 pieces of chipped stone debitage and two biface fragments (ca. 130.6 items per cubic meter). Fire-cracked rock was noted in both units, with a feature, identified as Feature 3, recorded in Unit 5. As shown in Figure $6-54$, the feature is roughly $40 \mathrm{~cm}$ in width, and defined between 8 and $20 \mathrm{cmbd}$. It consisted of a concentration of fire-cracked sandstone. While no charcoal was observed in the fill, the sediment associated with the feature was a slightly darker color relative to the surrounding matrix.

\section{Artifact Summary}

Two hundred and fifty-three chipped stone artifacts were collected from 41BR420. This includes 244 flakes, three bifaces (Appendix F), three utilized or retouched items, and three projectile points. All of the chipped stone was chert. Roughly 77 percent of the flakes lacked cortex, with only two flakes having 100 percent dorsal cortex cover.

Three diagnostic projectile points were recovered from the site, all within the midden (Appendix E). A Late Archaic Frio point was recovered from Unit 3, Level 6. In addition, two point fragments, both probably Late Prehistoric arrow points, were recovered from Unit 1, Level 6, and Unit 2, Level 3.

\section{Other Samples}

As noted previously, a series of large mammal remains, some of which were Bison bison, were recovered from Unit 1, Level 3, in Feature 2. These included a tibia, a radial carpal, and a molar, along with several other unidentified pieces. While this material was chemically weathered, none of these items were burned. The only other item of vertebrate fauna recovered from the site was an unburned fragment of bird, also from Unit 1 (see Appendix B). 


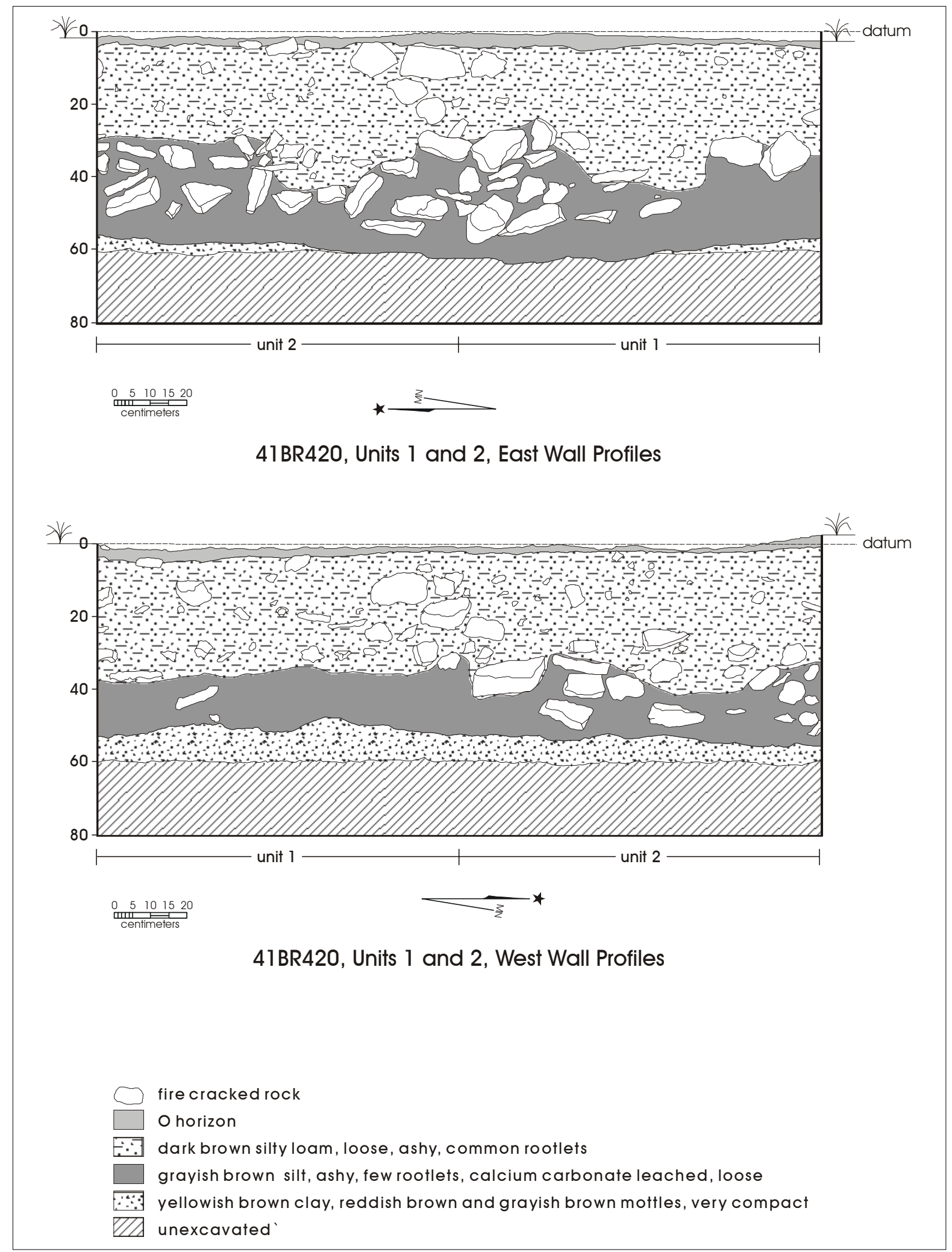

Figure 6-51. East (top) and west (bottom) profiles of Units 1 and 2 in Feature 1, site 41 BR420. 


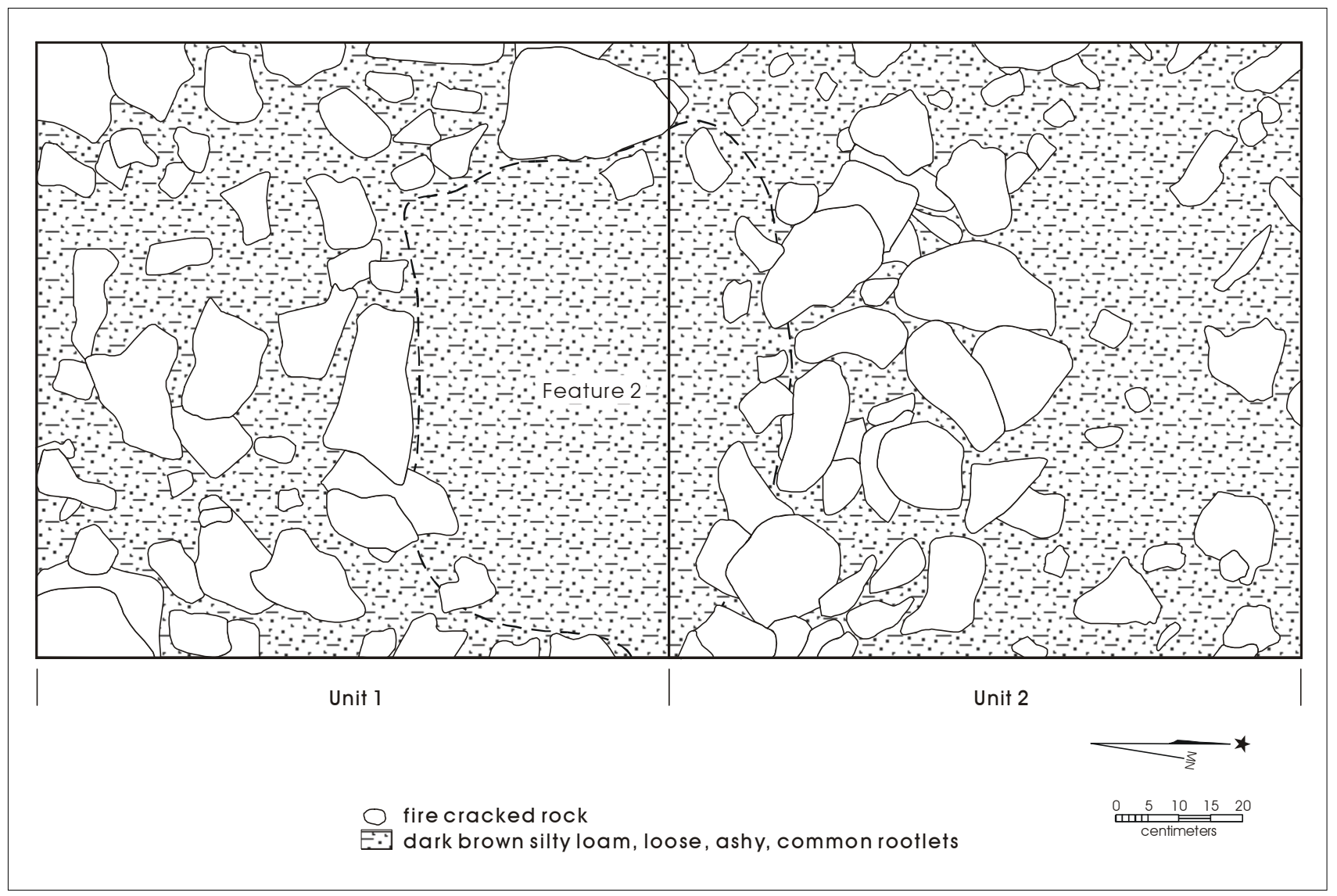

Figure 6-52. Plan view of Feature 2 at 10-25 cmbd, Units 1 and 2, site 41BR420.

As summarized by Dering (Appendix C), five samples from the midden were submitted for macrobotanical identification. Eight bulbs or bulb fragments and a burned clay ball were identified. One of the bulbs closely resembled dog's-tooth violet (Erythronium sp.). The other bulbs were not identified. Two flotation samples submitted from the midden contained small fragments of wood charcoal, including fragments of oak.

While mussel shell was recovered from excavation Units 1, 2 , and 3 within the midden, as well as external Unit 4, the amount of shell was minimal. Only 68 grams were recorded at the site. Only one sample from this site was in the shell identified by Goodfriend (Appendix D). This was a Potamilus purpuratus specimen.

\section{Radiocarbon Dates}

Two radiocarbon samples, both taken from midden Unit 3, were submitted from 41BR420. They represent Level 2 (10$20 \mathrm{cmbd})$ and Level 7 (60-70 cmbd). The corrected date for the Level 2 sample was $930 \pm 70$ years BP, while the corrected date for the Level 7 material was $1500 \pm 40 \mathrm{BP}$. Appendix A lists details of these dates. If these dates are in context, it appears that the beginning of midden use, associated with Level 7, was between A.D. 535 and 640, while use dates for Level 2 were between A.D. 1020 and 1180. Using the interval estimate in the OxCal radiocarbon calibration program (Ramsey 2000), there is a 95 percent probability that the interval between the bottom date and the upper date represents at least 390 years and no more 


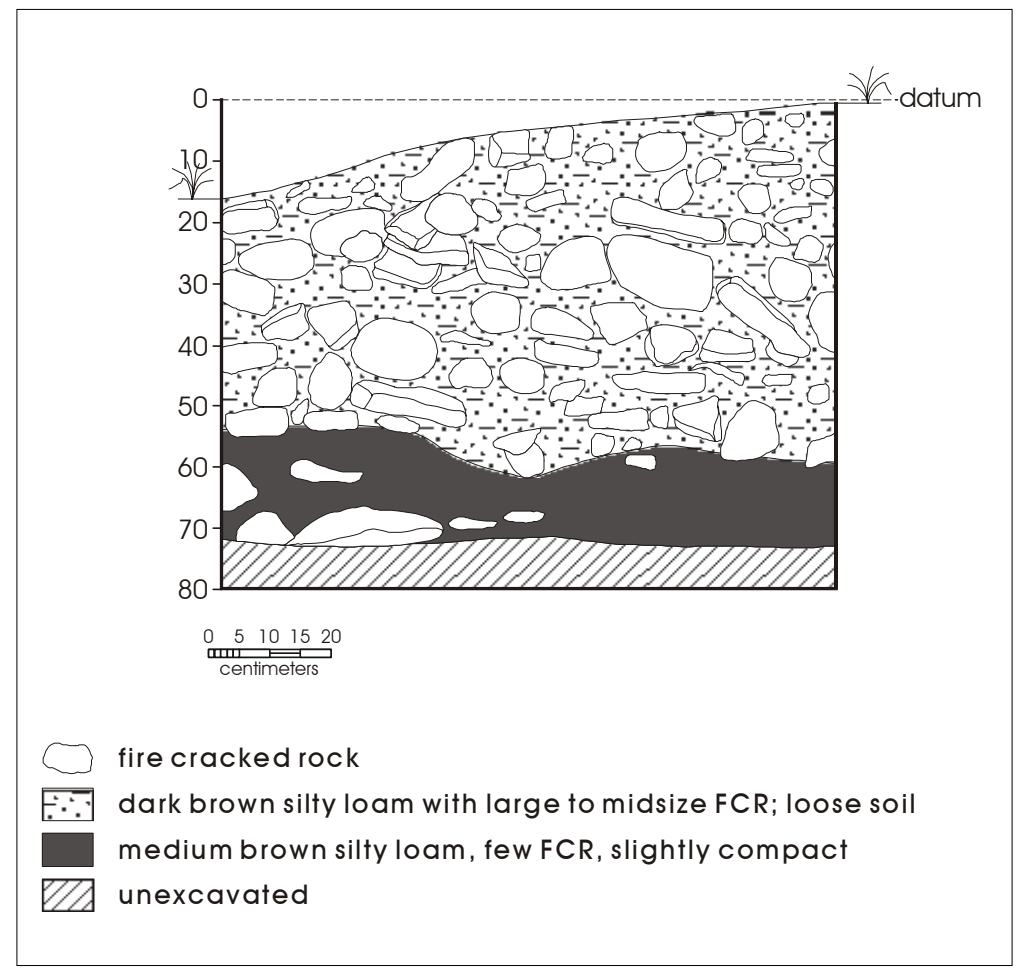

Figure 6-53. Profile of south wall of Unit 3, 41BR420.

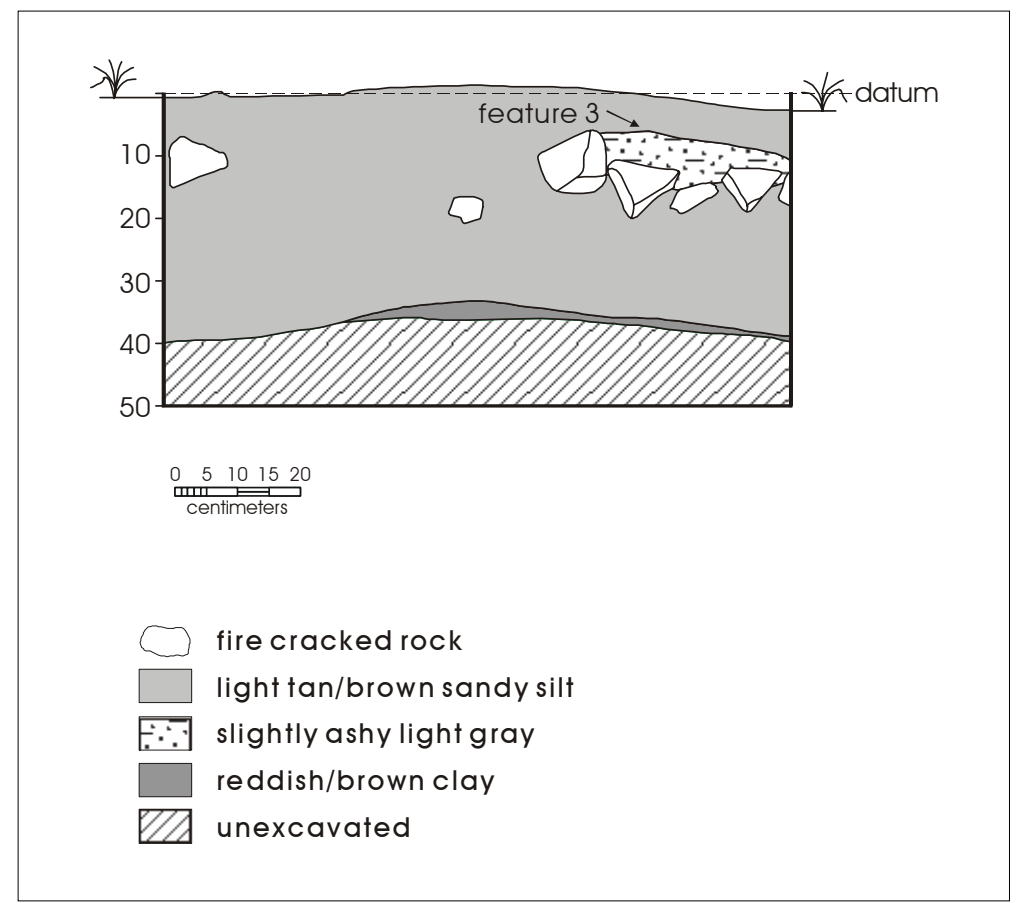

Figure 6-54. Profile of west wall of Unit 5 showing Feature 3, 41BR420. than 740 years. Using the midpoint of the distribution as an estimate, the midden may have formed in around 565 years, beginning at the close of the Late Archaic and lasting into the Late Prehistoric.

\section{Summary}

CAR's work at site 41BR420 suggests that the burned rock midden was used during the close of the Late Archaic period and into the Late Prehistoric period. Three diagnostic projectile points recovered from the midden also reflect Late Archaic and Late Prehistoric use.

Shovel testing and surface collection results from outside the midden revealed moderate surface and subsurface artifact densities, as well as shallowly buried deposits. The percentage of positive shovel tests was relatively low. Roughly 95 percent of the material recovered was within $30 \mathrm{~cm}$ of the surface.

In excavation units outside of the midden, an average artifact density of roughly 150 artifacts per cubic meter of sediment was present. As with the shovel test data, all of these units reflected shallow deposits. Within the burned rock midden, artifact density was lower, with an average of 25.8 items recovered per cubic meter. Both vertebrate faunal material and small quantities of mussel shell were present in the midden excavation units. Faunal material included the recovery of bison, though none of the specimens were burned. Macrobotanical samples submitted for identification consisted primarily of bulbs and bulb fragments, with dog's-tooth violet being identified. Flotation samples produced only wood charcoal, some of which represented oak.

Conditions for preservation of ethnobotanical material within the midden are good. In addition, we have no data to suggest that the context of the material recovered from the midden has been extensively disturbed. While worm and insect casts are common in the midden deposits, rodent burrowing was minimal (Appendix G). Outside of the midden, one feature was identified. 


\section{$41 \mathrm{BR} 433$}

\section{Site Description}

Wormser and Sullo-Prewitt (2001:103-105) describe site 41BR433 as a burned rock midden site and moderate to dense lithic scatter. TXARNG cultural resources staff recorded the site in 1995. They identified a single burned rock midden, roughly $10 \mathrm{~m}$ in diameter, 30 to $60 \mathrm{~cm}$ in height, and dominated by limestone. Wormser and SulloPrewitt (2001:104) noted a concentration of over 100 flakes, cores, and shatter, and suggest that this concentration may represent a lithic manufacturing area. As defined in 1995, the site covered an area of over $240 \mathrm{~m}$ by $100 \mathrm{~m}$, with the burned rock midden located on the northwest end of the site, and the lithic concentration on the southeastern edge.

A variety of artifacts were observed at this site, including a Late Archaic Castroville point, two biface fragments, two cores, and over 100 flakes (Wormser and Sullo-Prewitt 2001:104). Five shovel tests were excavated at the site to a maximum depth of $26 \mathrm{cmbs}$. No artifacts were recovered in any of these five tests (Wormser and Sullo-Prewitt 2001:105).

CAR archaeologists visited the site in the fall of 1999, and work was conducted during the spring of 2000. The midden was small and circular, with a clear central depression. The lithic concentration noted by Wormser and Sullo-Prewitt (2001:104) could not be relocated, and only a few artifacts were observed on the surface near the midden. While shovel tests were placed in the approximate area of the concentration, none were positive. CAR archaeologists also noted a single mortar hole, located to the northeast of the midden. The mortar is circular and roughly $20 \mathrm{~cm}$ in diameter. Additional mortar holes may be present in this area, but visibility is limited.

Given the shovel test results, CAR reduced the site boundary to primarily encompass the burned rock midden. Our revised site boundaries, shown in Figure 6-55, cover an area of about $7,090 \mathrm{~m}^{2} .41 \mathrm{BR} 433$ is at an elevation of roughly 1,470 feet (448 m) AMSL. When CAR visited the site in 1999, vegetation observed included grasses and oak, with prickly pear and yucca present at low densities. Ground visibility around the midden was generally high. While tree duff obscured the surface to the north and east of the midden, areas to the south and west were clear. The midden sits on a limestone outcrop, with bedrock frequently visible at the surface to the south of the feature.

\section{Shovel Test Results}

Fifty-six shovel tests were excavated in the area of site 41BR433 (see Figure 6-55). The majority of the shovel tests were focused around the single burned rock midden (Figure 6-56). Additional shovel tests were placed to the east of the midden to explore areas where TXARNG archaeologists had identified the lithic concentration. No shovel tests were intentionally excavated in the midden, though Shovel Test 24 clipped the northeastern edge of these deposits. Shovel tests were terminated when the underlying bedrock was encountered, when a compact, gravel and carbonate lens was hit, or when consecutive negative levels were encountered below $20 \mathrm{~cm}$. To the south and west of the midden, limestone bedrock was often encountered within $30 \mathrm{~cm}$. To the north and east of the midden, deposits were generally deeper. The shovel tests encompassed 165 levels, with all shovel tests being dug into Level $1(0-10 \mathrm{cmbs})$ and no shovel test excavated below $50 \mathrm{cmbs}$. Average shovel test depth was $29.5 \mathrm{cmbs}$.

No ground stone was encountered in any of the shovel tests and mussel shell was only recovered in Shovel Test 10. However, 80 flakes were recovered, as well as two bifaces, four utilized/retouched flakes, and a single core. In addition, roughly 398 pieces of burned and fire-cracked rock were recorded in the shovel tests, though about 80 percent of this total was from Shovel Test 24, the test that clipped the edge of the midden. Chipped stone was present in 42 percent of the shovel tests and burned or fire-cracked rock was recorded in 25 percent. Approximately 60 percent of the 52 shovel tests were positive.

The vertical distribution of this material suggests that the occupation was confined primarily to the upper $20 \mathrm{~cm}$ of deposits at 41BR433. Just over 96 percent of all chipped stone and 97 percent of all fire-cracked rock was recovered from the upper $20 \mathrm{~cm}$. Examination of Figure 6-56 shows that most of the positive shovel tests were concentrated on the north side of the midden, with tests to the southeast being negative.

\section{Surface Collections}

As noted previously, the lithic scatter described by Wormser and Sullo-Prewitt (2001:104) was not relocated. As no dense scatters were observed on the surface, no collection areas were placed at this site. In addition, no unique items were collected from the surface. 


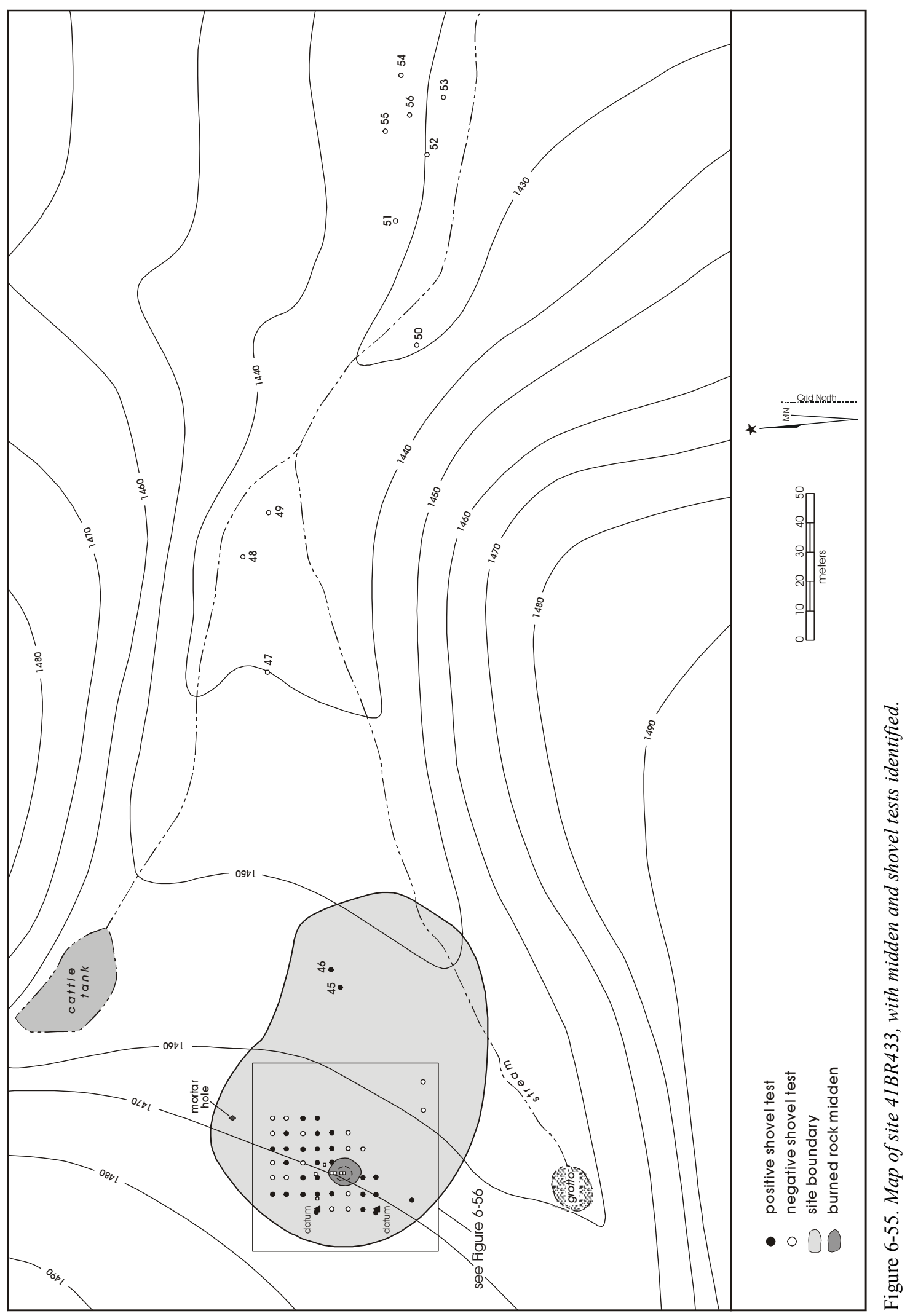




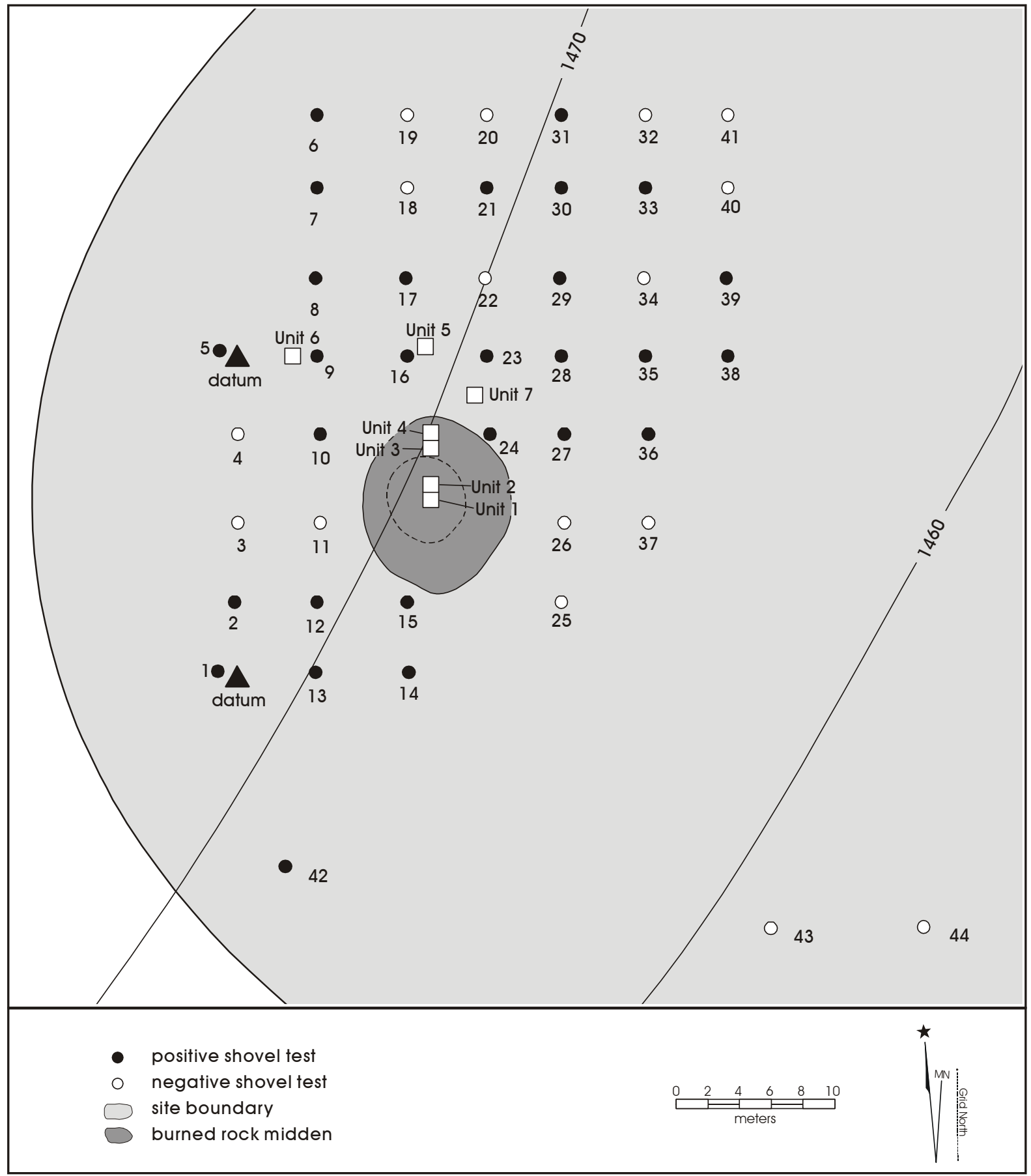

Figure 6-56. Midden area of $41 B R 433$ with positive shovel tests and excavation units identified. 


\section{Excavation Results}

Seven 1-x-1-m units were placed on this site (Figure 6-56). Two contiguous units were excavated in the center of the midden, and two more were placed on the midden ring. In addition, three units were excavated to the north of the midden in the area with high frequencies of positive shovel tests. A total volume of $3.3 \mathrm{~m}^{3}$ was excavated at this site.

\section{Midden Units}

The midden was designated Feature 1, and tested with four units. Two of these units, designated 1 and 2, were placed to straddle the visible, well-defined depression in the center of the feature (see Figure 6-56). The pit was originally suspected to be a modern intrusion, and, in fact, several pieces of metal were found in both Unit 1 and Unit 2, with one piece found as deep as $30-40 \mathrm{~cm}$. However, examination of Figure 6-57, a profile of the west wall of these two units, shows a large central pit. The pit is defined, in part, by a dramatic absence of larger tabular rocks in Unit 1, as well as distinctive sediment. Figure 6-58 presents a plan view of Unit 2 at 35 to $40 \mathrm{cmbd}$ that clearly shows this internal pit as well. Given that any clear disturbance was limited primarily to Unit 1, it is probable that this internal pit is directly related to the prehistoric use of the midden.

Reference to Figure 6-57 suggests that the vast majority of these two units, which had a volume of $1.25 \mathrm{~m}^{3}$, were entirely within midden fill (see Appendix G). We recovered 77 pieces of chipped stone debitage, two utilized/retouched flakes, two bifaces, a core, one projectile point fragment, and two ground stone fragments. Mussel shell was noted in both units, though quantities were minimal. In addition, four pieces of ochre were collected. Chipped and ground stone artifact density within this central area of the midden was 68 items per cubic meter.

CAR removed 6,085 fire-cracked rocks greater than one inch in size from Units 1 and 2. An additional $123 \mathrm{~kg}$ of rock less than one inch in size were recorded. This was the only burned rock midden on the project dominated by limestone. While sandstone was present, limestone accounted for the vast majority of the fire-cracked rock removed from this central area.

A second 1-x-2-m set of units, designated Units 3 and 4, were also excavated in Feature 1. Unit 4 fell on the far northern edge of the feature, and Unit 3 was on the apex of the midden ring. Figure 6-59 presents a profile of these units, with the sloping midden deposits visible. Figure 6-60 presents a plan view of Unit 4, at a depth of $20 \mathrm{~cm}$ into the midden deposits, which clearly shows the circular nature of this feature.

A volume of $1.11 \mathrm{~m}^{3}$ of sediment was removed and screened from these two units. Figure 6-59 shows that, with the exception of the bottom level, all of Unit 3 contains midden deposits. Only a portion of Unit 4 was within the midden deposits (see Appendix G). Unfortunately, the matrix from within the feature was not consistently separated, rendering any clear comparison of artifact differences between midden and non-midden deposits in several of the levels impossible. Nevertheless, in Unit 3, we collected 26 pieces of debitage, one biface, one projectile point fragment, two ground stone fragments, and one mano fragment from $.63 \mathrm{~m}^{3}$ of sediment. In addition, 5,750 fire-cracked rocks greater than one inch in size were removed from this unit, along with 52.35 $\mathrm{kg}$ of rocks less than one inch in size. From Unit 4, we collected thirty-six pieces of chipped stone, a biface, a utilized/retouched flake, three ground stone fragments, and one mano fragment from the $.48 \mathrm{~m}^{3}$ of sediment. A total of 2,587 fire-cracked rocks greater than one inch in size was removed from this unit, along with $85.57 \mathrm{~kg}$ of rocks less than one inch in size. As with the rocks in Units 1 and 2 , limestone accounted for the vast majority of the firecracked rock in both Units 3 and 4, though sandstone was also present.

\section{Off-Midden Units}

Three 1-x-1-m units, identified as Units 5, 6, and 7, were excavated outside of Feature 1 (see Figure 6-56). All three of these units were placed to the north of the feature, where shovel tests suggested deeper deposits. Nevertheless, all units proved to be shallow. All units encountered either sterile red-brown clay loam or the underlying bedrock within $40 \mathrm{~cm}$ of the surface. Figure 6-61 presents a profile for Unit 6 that is typical of these external units. In all, an estimated $.94 \mathrm{~m}^{3}$ of deposits were removed and screened from these three units.

Artifacts were more common in these non-midden units with Unit 5 containing 43 pieces of chipped stone debitage and three bifaces (ca. 139 items per cubic meter). Unit 6 contained only 12 pieces of chipped stone debitage and a single projectile point fragment ( 52 items per cubic meter). Unit 7 contained 22 pieces of chipped stone debitage (61 items per cubic meter). No fire-cracked rock was noted in any of these external units. 


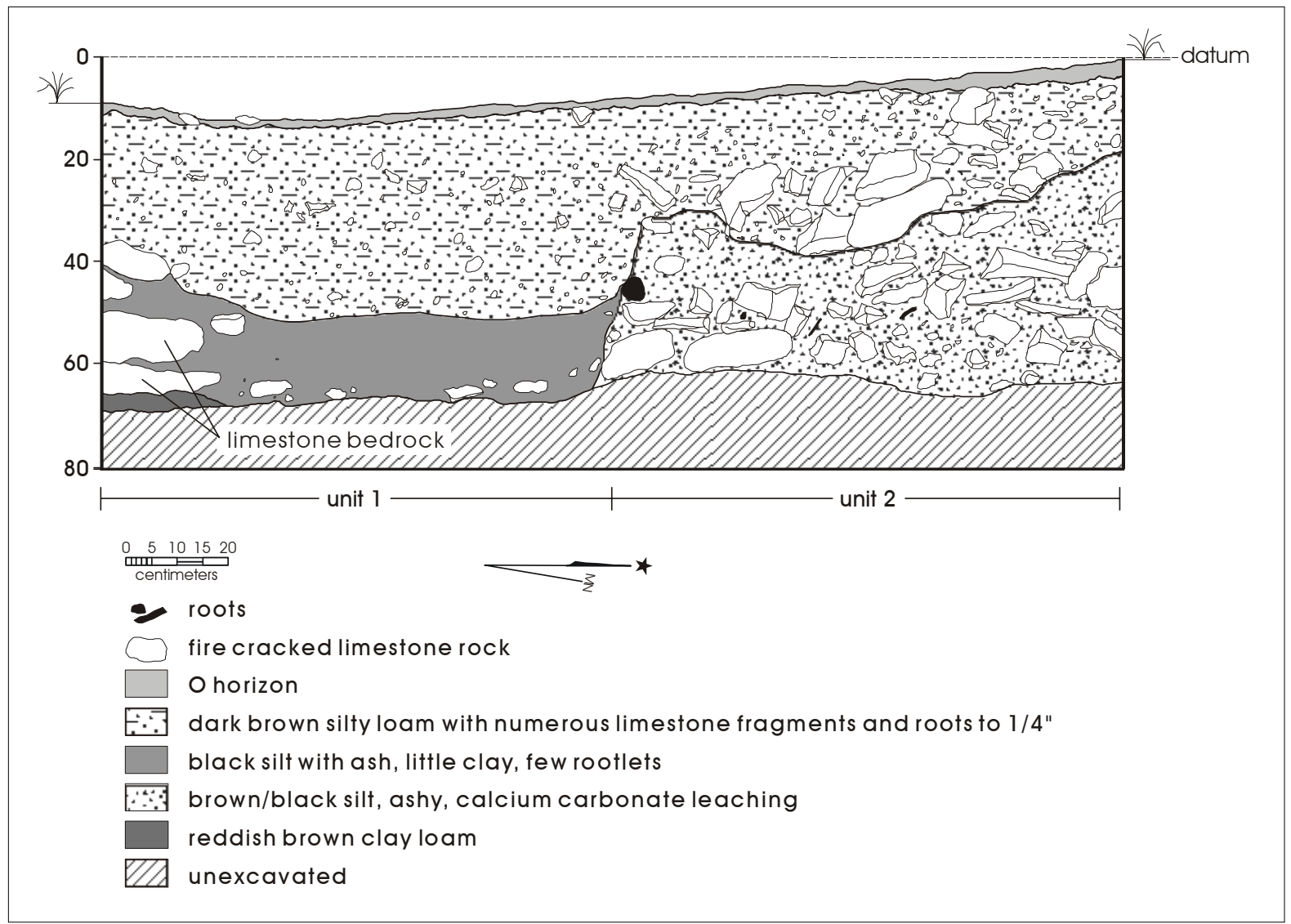

Figure 6-57. West wall profile of Units 1 and 2, $41 B R 433$.

\section{Artifact Summary}

Two hundred and forty-seven chipped and ground stone artifacts were collected from 41BR433. This included 216 flakes, nine bifaces, two cores, seven utilized or retouched items, and four projectile points. In addition, two mano fragments, and seven other ground stone fragments were recovered. Scans of selected bifaces and utilized/retouched flakes for this site are presented in Appendix F. Chert accounted for over 99 percent of all the chipped stone. Roughly 82 percent of the flakes lacked cortex, with only two flakes having 100 percent dorsal cortex cover.

Four projectile points, all untypable, were recovered from the site (Appendix E). Two of the items are arrow points, and the remaining two are dart points. The projectile points minimally suggest some Late Prehistoric use, with an earlier Archaic use also present.

\section{Other Samples}

No vertebrate faunal material was recovered from 41BR433. This may be related to preservation conditions, as recovery of carbonized material was also limited.

No macrobotanical samples were collected from this site. As summarized by Dering (Appendix C), only one of the two flotation samples submitted from the midden contained carbonized material. This material was identified as oak.

While mussel shell was recovered from Units 1, 2, 3 and 4, as well as Shovel Test 10, the amount of shell was limited. Less than 57 grams were recovered from this site. Eight samples were included in the material sent to Goodfriend for identification (Appendix D). Five of these samples were Quadrula houstonensis, one was Quadrula apiculata, and one was Amblema plicata. One sample could not be identified. 


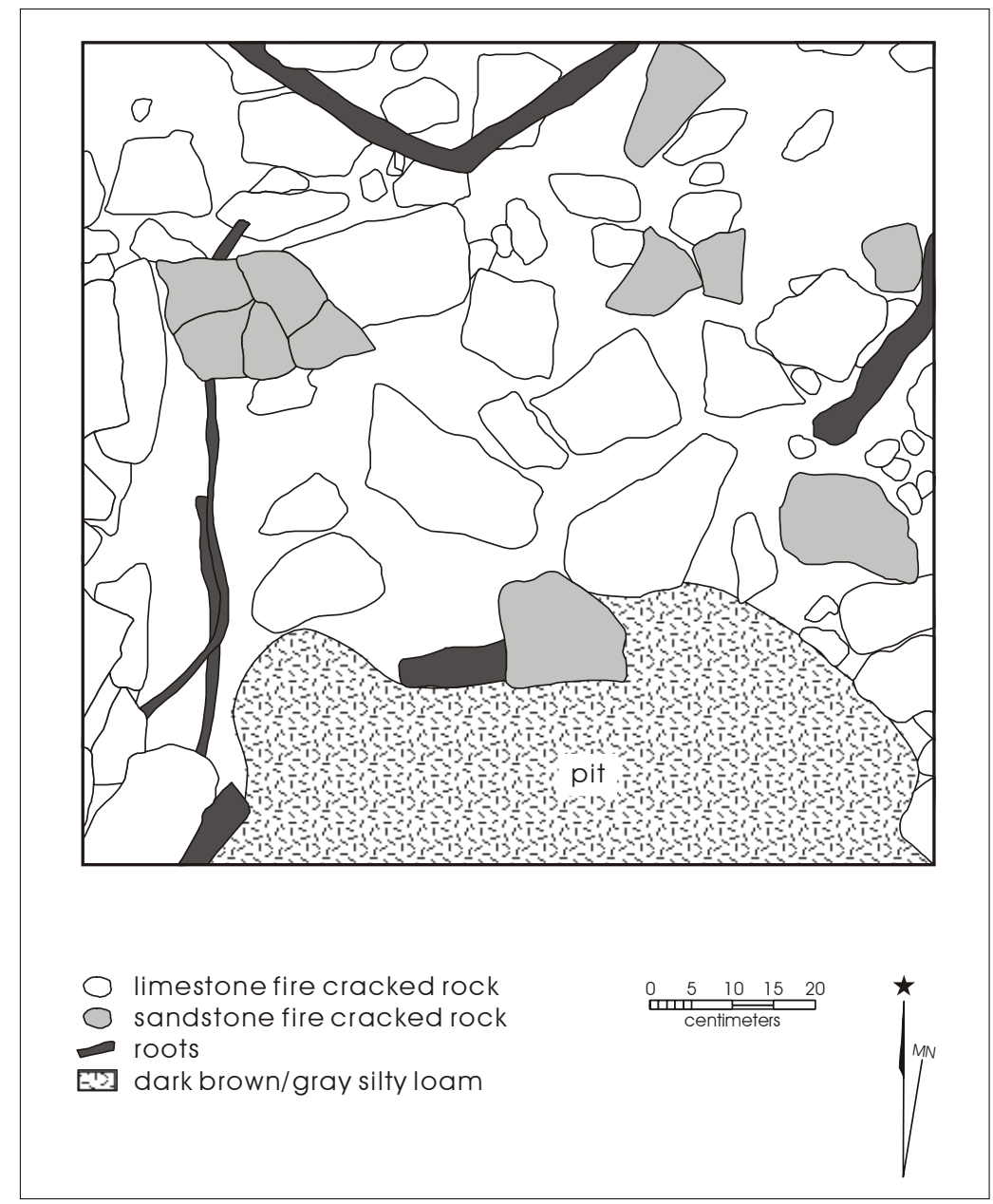

Figure 6-58. Plan view of Unit 2 at 35-40 cmbd, with pit area identified.

\section{Radiocarbon Dates}

As recovery of appropriately sized carbonized material was limited, only a single radiocarbon sample was submitted from 41BR433. The sample, from Unit 1, Level 6 (50-60 $\mathrm{cmbd}$ ), produced a corrected date of $900 \pm 50$ years BP (see Appendix A). If the date is in context, it appears that the midden was in use sometime between A.D. 1030 and 1210.

\section{Summary}

CAR's work at site 41BR433 suggests that the burned rock midden at this site dates to the Late Prehistoric period. The diagnostic projectile points recovered from the site are consistent with that Late Prehistoric period assignment, although an Archaic use is also suggested by the recovery of the dart point fragments.
Surface artifact density was minimal, and shovel testing demonstrated low subsurface densities. Limestone bedrock was frequently within $30 \mathrm{~cm}$ of the surface, and over 96 percent of the chipped stone and fire-cracked rock recovered in shovel tests was from the upper $20 \mathrm{~cm}$ of the deposits.

In excavation units outside of the midden, an average artifact density of roughly 86 artifacts per cubic meter was present. As with the shovel test results, these units were shallow, with most material being recovered within $30 \mathrm{~cm}$ of the surface. Excavation units within the center of the midden produced an artifact density slightly lower, with 68 artifacts per cubic meter of sediment. Unit 3, on the ring, had a density of 49 items per cubic meter of sediment. No vertebrate faunal material was recovered from the site, though mussel shell was present. No macrobotanical samples were collected. One of the two flotation samples produced oak wood charcoal. No economic plants were identified. 


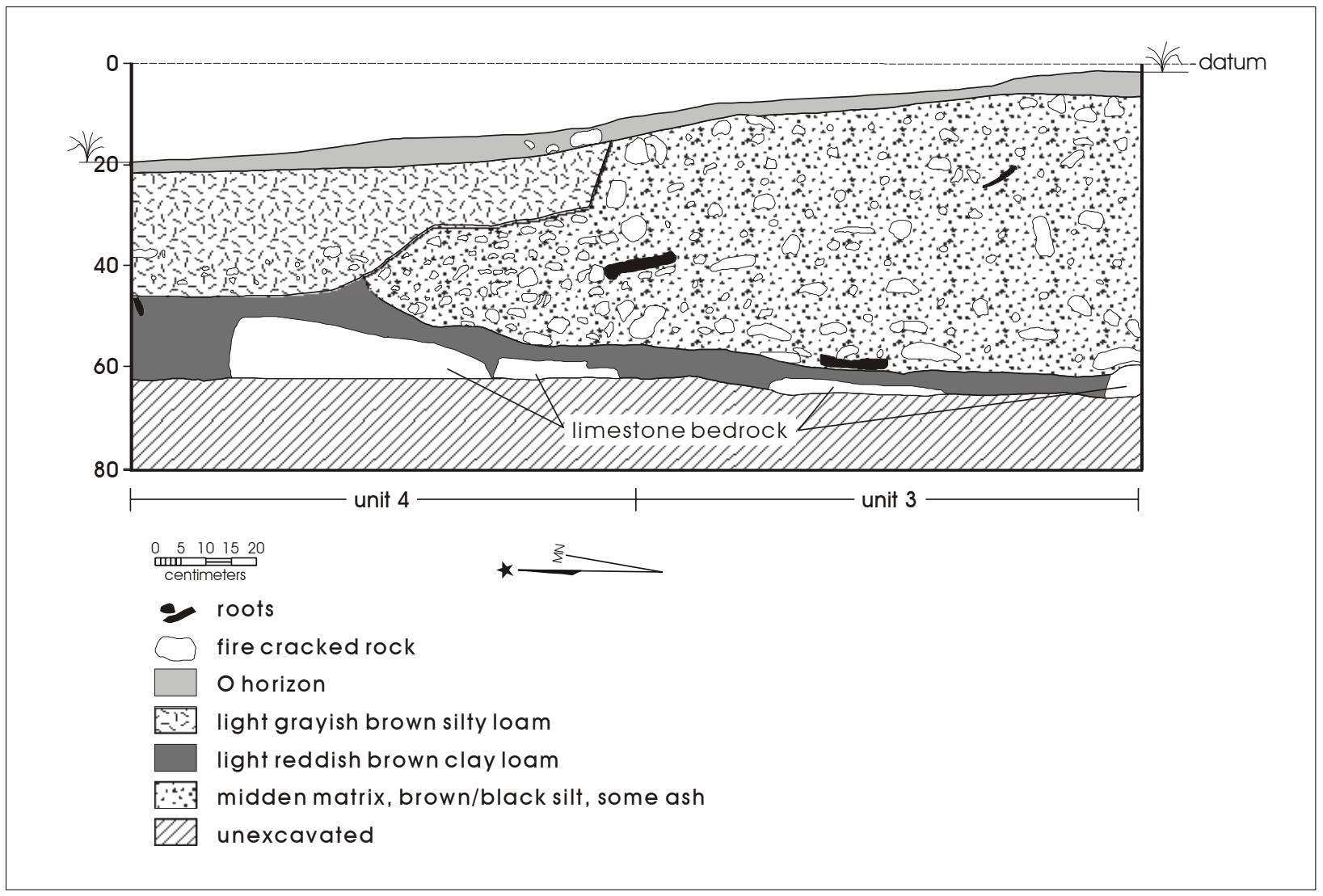

Figure 6-59. Profile of east wall of Units 3 and 4 in Feature 1 at 41 BR433.

Conditions for preservation of ethnobotanical material within the midden appear to be poor. As summarized by Bousman and Hodges (Appendix G), the midden deposits at 41BR433 appear to be both more fine-grained and more turbated than with most other middens excavated on this project. Outside of the midden, no features were identified and, while subsurface artifact densities are moderate, the deposits are shallow.

\section{$41 B R 441$}

\section{Site Description}

Wormser and Sullo-Prewitt (2001:109-110) describe site 41BR441 as a burned rock midden site. TXARNG cultural resources staff recorded the site in 1995. They identified a single burned rock midden that had been badly disturbed. The midden consisted of "two somewhat linear mounds and looks like heavy machinery had been used to scrape through the center..." (Wormser and Sullo-Prewitt 2001:109). Dark soil and numerous burned and fire-cracked sandstone rocks were noted in the midden area. The site itself was defined as covering an area roughly $200 \mathrm{~m}$ by $40 \mathrm{~m}$, with the burned rock midden located on the southeastern end of the site.

A variety of artifacts were observed at this site, including a Late Prehistoric Scallorn point base, several bifaces, cores, and over 150 flakes (Wormser and Sullo-Prewitt 2001:110). No shovel tests were excavated at the site.

CAR archaeologists visited the site in the fall of 1999, and work was conducted during the spring of 2000. The midden was manifested as three small, low mounds of fire-cracked sandstone covering an area of roughly $30 \mathrm{~m}$ by $15 \mathrm{~m}$. While no artifacts were observed in the midden area, scattered chipped stone was present to the west of the feature, and a low density of chipped stone was observed throughout the remaining portion of the site. The site covers an area of $9,540 \mathrm{~m}^{2}$, and is at an elevation of roughly 1,410 feet 


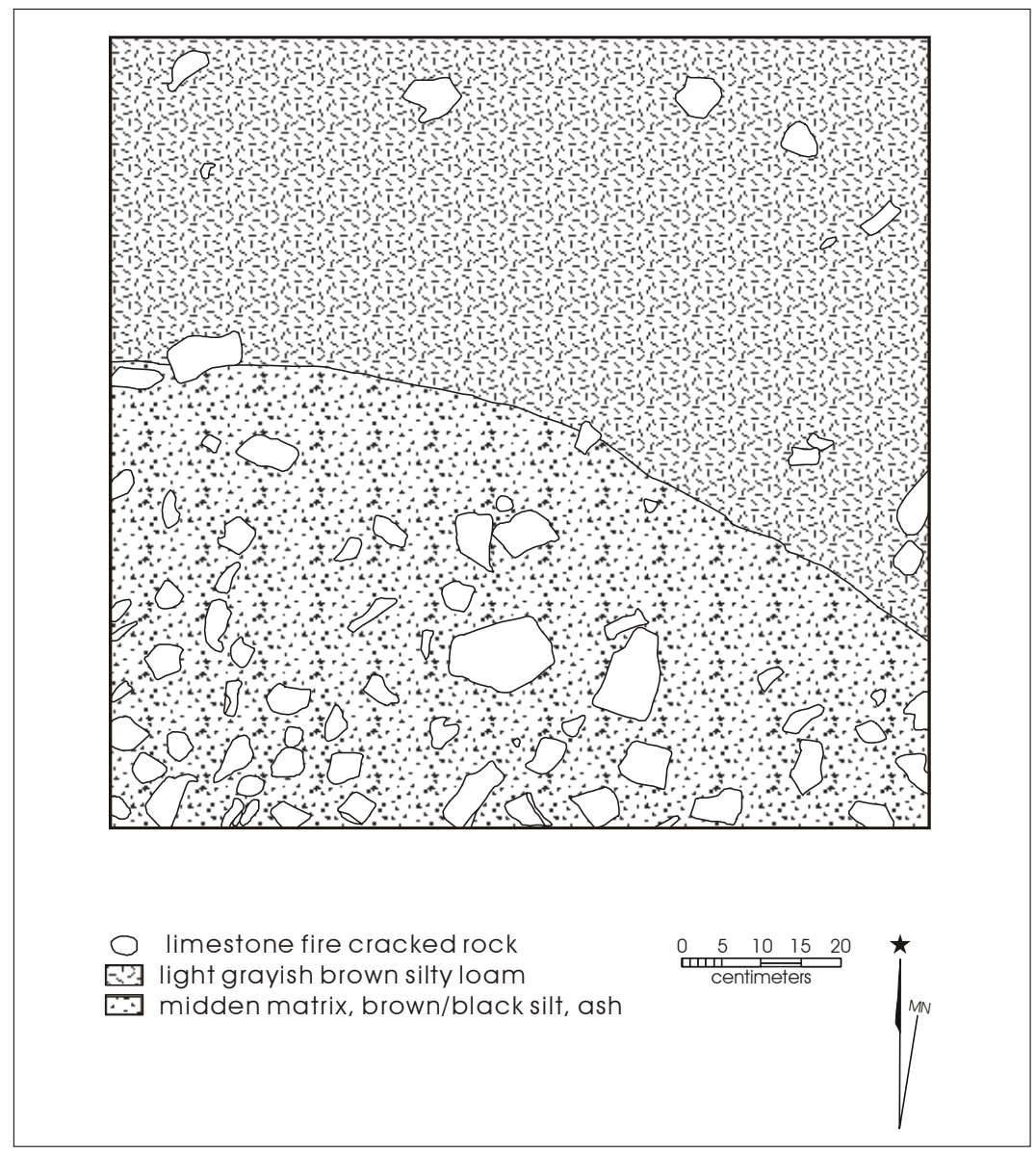

Figure 6-60. Plan view of Unit 4 at $20 \mathrm{cmbd}$, with Feature 1 boundary identified.

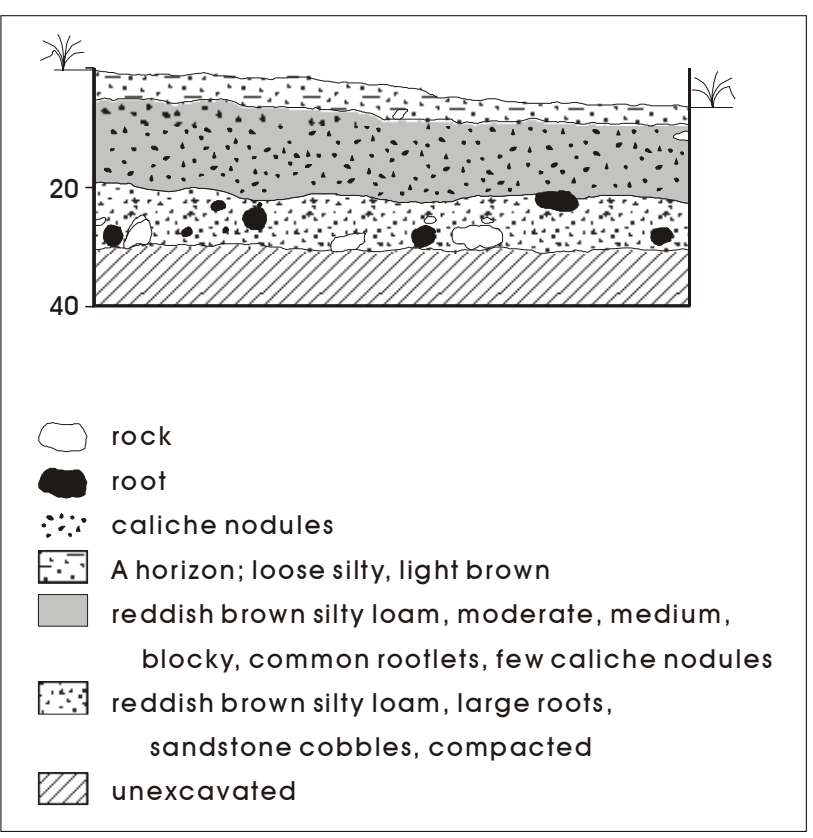

Figure 6-61. Profile of the north wall of Unit 6 at $41 B R 433$. (ca. $430 \mathrm{~m}$ ) AMSL (Figure 6-62). When CAR visited the site in 1999, vegetation observed included grasses, oak, juniper, prickly pear, cholla, and snakeweed. Ground visibility around the midden was generally low, with the ground surface obscured by leaf litter. The remaining areas of the site had good surface visibility.

\section{Shovel Test Results}

Thirty-seven shovel tests representing 129 separate levels were excavated at the site. Twenty-five shovel tests were excavated around the midden. An additional 12 shovel tests were excavated to the west and northwest of the midden (Figure 6-62). The shovel tests averaged roughly $35 \mathrm{cmbs}$. Tests were terminated either when three consecutive negative levels were recorded or when a hard, calcium carbonate dominated strata was encountered. Away from the midden area, the upper levels in shovel tests were primarily sandy, with lower levels frequently dominated by compact, yellowbrown clay. Around the midden area, sandy sediment was 


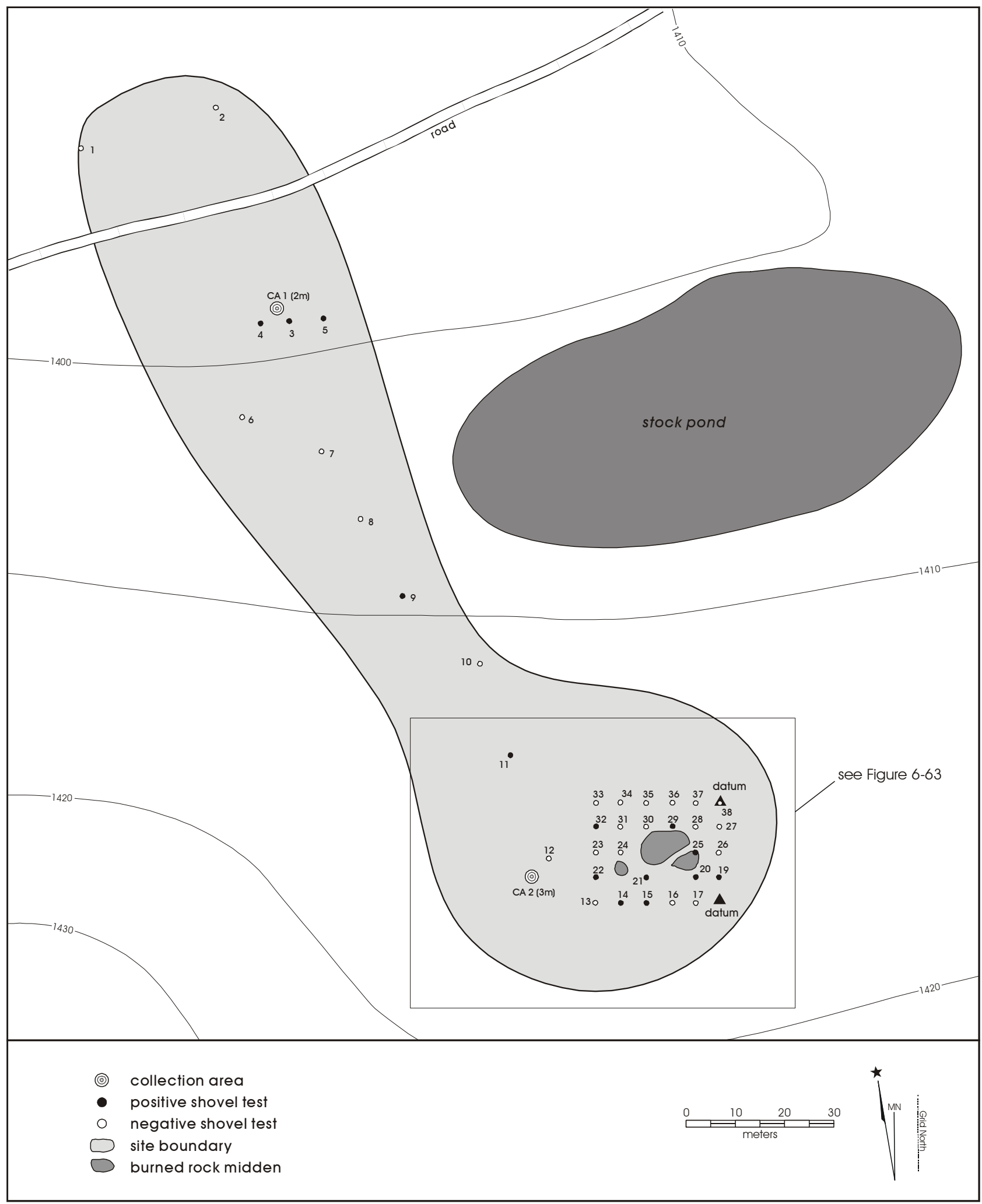

Figure 6-62. Map of site 41BR441 with midden, shovel tests, and collection areas identified. 
less common, with upper levels being dominated by silts and clays.

The number of positive shovel tests at 41BR441 was low. Only 37.8 percent of the 37 shovel tests had fire-cracked rock or chipped stone artifacts present. Only six of the 37 tests had chipped stone, and fire-cracked rock was recovered from only 10 of the tests (Figure 6-62).

In those shovel tests that were positive, a low number of items were recovered. The six shovel tests with chipped stone produced only seven flakes. While 700 pieces of firecracked rock were recorded, most of these were recovered from a small number of tests in the midden area. Both the chipped stone material and the fire-cracked rock were confined to the upper three levels $(0-30 \mathrm{cmbs})$ of the shovel tests, with most material being recovered in Level 1 (0-10 cmbs).

\section{Surface Collections}

Two surface collection areas were selected at this site (see Figure 6-62). The first of these was placed on the northern end of the site while the second area was placed to the west of the disturbed burned rock midden.

Collection Area 1, a circle with a radius of $2 \mathrm{~m}$, produced 73 pieces of debitage, four bifaces, one core, and one projectile point fragment. Artifact density was 6.3 items per square meter. About 81 percent of the debitage from this area lacked cortex, and there were no items with 100 percent dorsal cortex cover. Chert was the only material type recorded in this area. Note that a small amount of mussel shell was collected from this area.

Collection Area 2, consisting of a circle with a radius of 3 $\mathrm{m}$, produced 23 pieces of debitage and two cores. Artifact density was less than one item per square meter. Tertiary flakes dominated the debitage, with 19 of the 23 flakes lacking cortex. No flakes with 100 percent dorsal cortex cover were recovered. As with Collection Area 1, chert accounted for all of the material collected.

\section{Excavation Results}

Given the disturbed nature of the burned rock midden, and the low recovery rates in shovel tests, systematic testing was limited. Only two 1-x-1-m units were excavated at the site. In addition, a north-south running backhoe trench was cut through the midden area (Figure 6-63) in order to facilitate both defining the midden and providing a geoarchaeological description (see Appendix G). Unit 1 was designed to more clearly define the midden, as well as determine preservation potential, artifact content, and depth of deposits. An additional 1-x-1-m unit (Unit 2) was excavated to investigate the potential for deposits outside of the disturbed area (Figure 6-63). A volume of roughly $.82 \mathrm{~m}^{3}$ of sediment was removed and screened from these two excavation units.

\section{Midden Unit}

Given the disturbed nature of the burned rock midden, we decided to place a unit near the center of the two larger mounds in order to determine the potential for recovery of intact material. Unit 1 was excavated to a depth of $63 \mathrm{cmbd}$, with a total volume of roughly $.55 \mathrm{~m}^{3}$ removed and screened. Figure 6-64 provides a profile of the east wall of this excavation unit. Midden deposits were encountered at roughly 5 to $15 \mathrm{~cm}$ below the surface, and appeared to be roughly $35 \mathrm{~cm}$ in thickness. The midden deposits were underlain by pale, reddish-brown silty loam sediment.

Two features were assigned within Unit 1 . Feature 2 was identified as an increased concentration of tabular sandstone at $49 \mathrm{cmbd}$. Feature 3 was defined as a dark stain taking up the southeastern quad of Unit 1 at $60 \mathrm{cmbd}$. The stain was removed, revealing a basin-shaped area with a depth of 67 $\mathrm{cmbd}$. This feature may be the result of rodent activity.

Only four artifacts, all chipped stone debitage, were recovered from this excavation unit. Mussel shell was also present in the unit, with roughly 142 grams being recovered. From Unit 1, CAR removed 1,120 pieces of fire-cracked rock greater than one inch in size. The vast majority of this was sandstone. In addition, $30.5 \mathrm{~kg}$ of rock less than one inch in size was recorded from this unit.

Reference to Figure 6-63 shows the location of the backhoe trench relative to the three small mounds that comprised the remains of Feature 1. The trench was excavated both to provide geomorphic data, as well as in an attempt to more clearly define the feature (see Appendix G). As can be seen in Figure 6-65, a profile of a section of the west wall at the northern end of the trench, a central feature is clearly present. The pit is basin-shaped and roughly $1.60 \mathrm{~m}$ in width. The base of the pit is about $65 \mathrm{cmbd}$. The sediments within the midden are a black to dark gray sandy loam with common fire-cracked sandstone. Below the base of the pit the sediments are yellowish-brown sandy loam. 


\section{Off-Midden Unit}

Only a single non-midden $1-\mathrm{x}-1-\mathrm{m}$ unit (Unit 2) was excavated at this site. The unit was placed to explore the potential of off-midden deposits, and located to the south of the feature (Figure 6-63). Excavated to a depth of 30 $\mathrm{cmbd}$, this unit was essentially sterile. The deposits were primarily tan sandy loam, and only a single chipped stone flake was recovered.

\section{Artifact Summary}

One hundred and eight pieces of debitage, four bifaces, three cores, and a projectile point fragment were collected from 41BR441. Appendix F presents scans of the bifaces. All artifacts were made of chert. Approximately 80.5 percent of the flakes lacked cortex, with only a single flake having 100 percent dorsal cortex cover. The vast majority of this

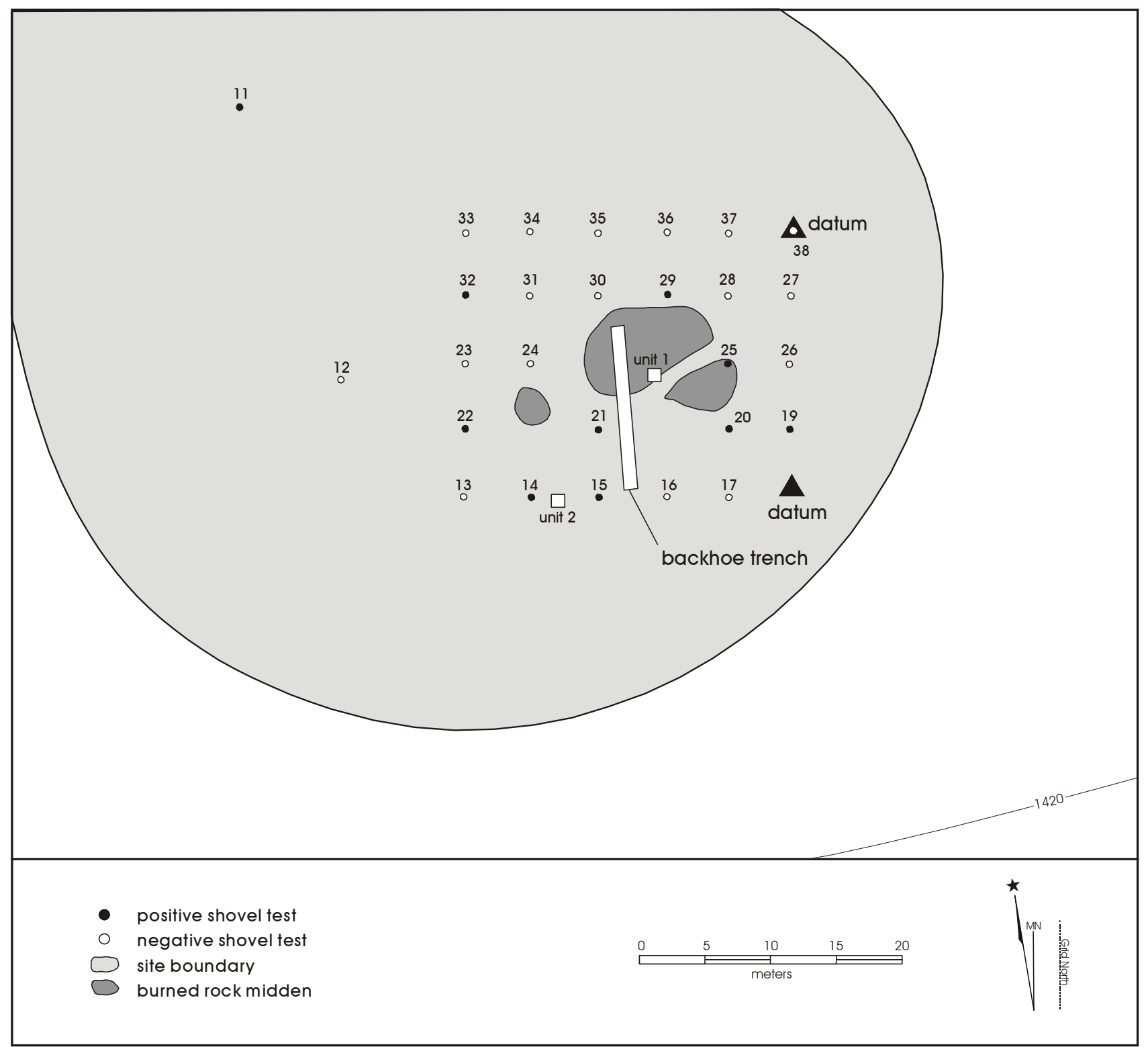

Figure 6-63. Blow-up of burned rock midden area on site $41 B R 441$ with excavation units and backhoe trench. 


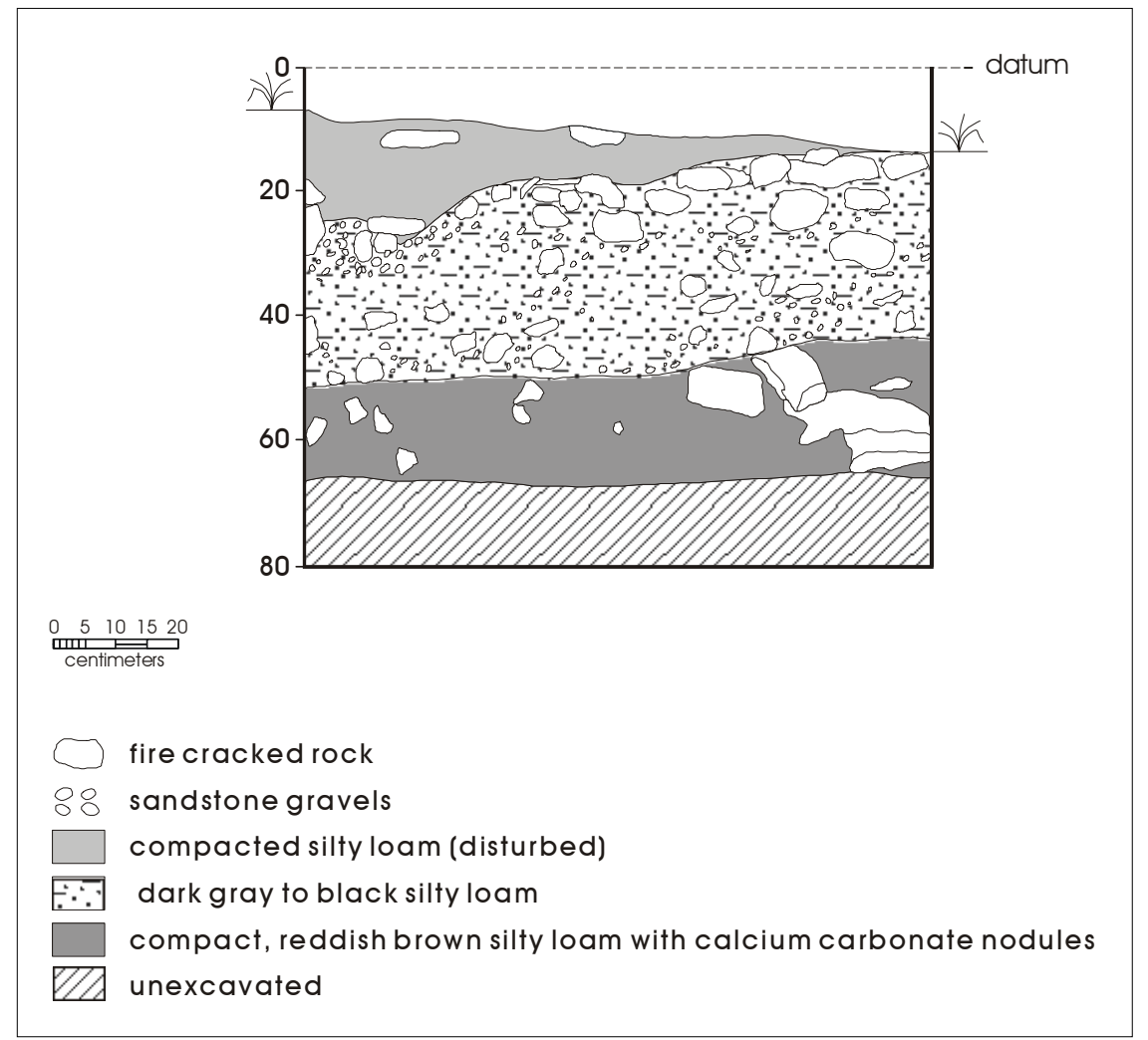

Figure 6-64. Profile of east wall of Unit 1, site 41BR441.

material was recovered from the two surface collection areas. Subsurface excavations produced only five artifacts.

A single projectile point fragment was collected from Collection Area 1. The point, shown in Appendix E, is probably a Late Prehistoric Fresno type.

\section{Other Samples}

A single piece of vertebrate fauna, the remains of an unidentified mammal, was recovered from the excavation at the site. The item was collected from Unit 1, and was not burned (Appendix B). While the low frequency of fauna may be a function of preservation, note that the level of excavation at this site was minimal.

No macrobotanical samples were collected from this site. As summarized by Dering (Appendix C), two flotation samples were submitted from the midden. One of the samples recovered an unidentified bulb. Both of the samples produced wood charcoal, with mesquite being identified.
Mussel shell was identified both on the surface of this site as well as in Unit 1. We recovered 197 grams of mussel shell. No specimens were submitted for identification.

\section{Radiocarbon Dates}

No radiocarbon samples were submitted from this site. Small amounts of charcoal were present both in Unit 1 and in the backhoe trench. However, given the generally small size of the samples, and the disturbed nature of the midden, no samples were selected.

\section{Summary}

CAR's work at site $41 \mathrm{BR} 441$ provided no direct dates on the midden. However, an additional diagnostic arrow point, consistent with the Late Prehistoric point collected by previous work at this site, was collected.

Shovel testing and surface collection results from outside the midden revealed low surface artifact density and minimal subsurface density. The percentage of positive shovel tests at both the site level, as well as around the midden, were low. While fire-cracked rock was plentiful in shovel tests near and in the disturbed midden, the 37 shovel tests produced only seven flakes.

In the single excavation unit placed outside of the midden, only a single artifact was recovered. The unit excavated in the midden area produced only four chipped stone items. Faunal material was limited to a single item, an unburned fragment from a mammal. Small amounts of mussel shell were present in the midden excavation unit. No radiocarbon samples were submitted from this site. No macrobotanical samples were submitted for identification; however, one of the flotation samples recovered an unidentified bulb, and both contained wood charcoal, with mesquite being identified.

Conditions for preservation of ethnobotanical material within the midden appear to be moderate. However, previous bulldozing had essentially destroyed the structure of the 


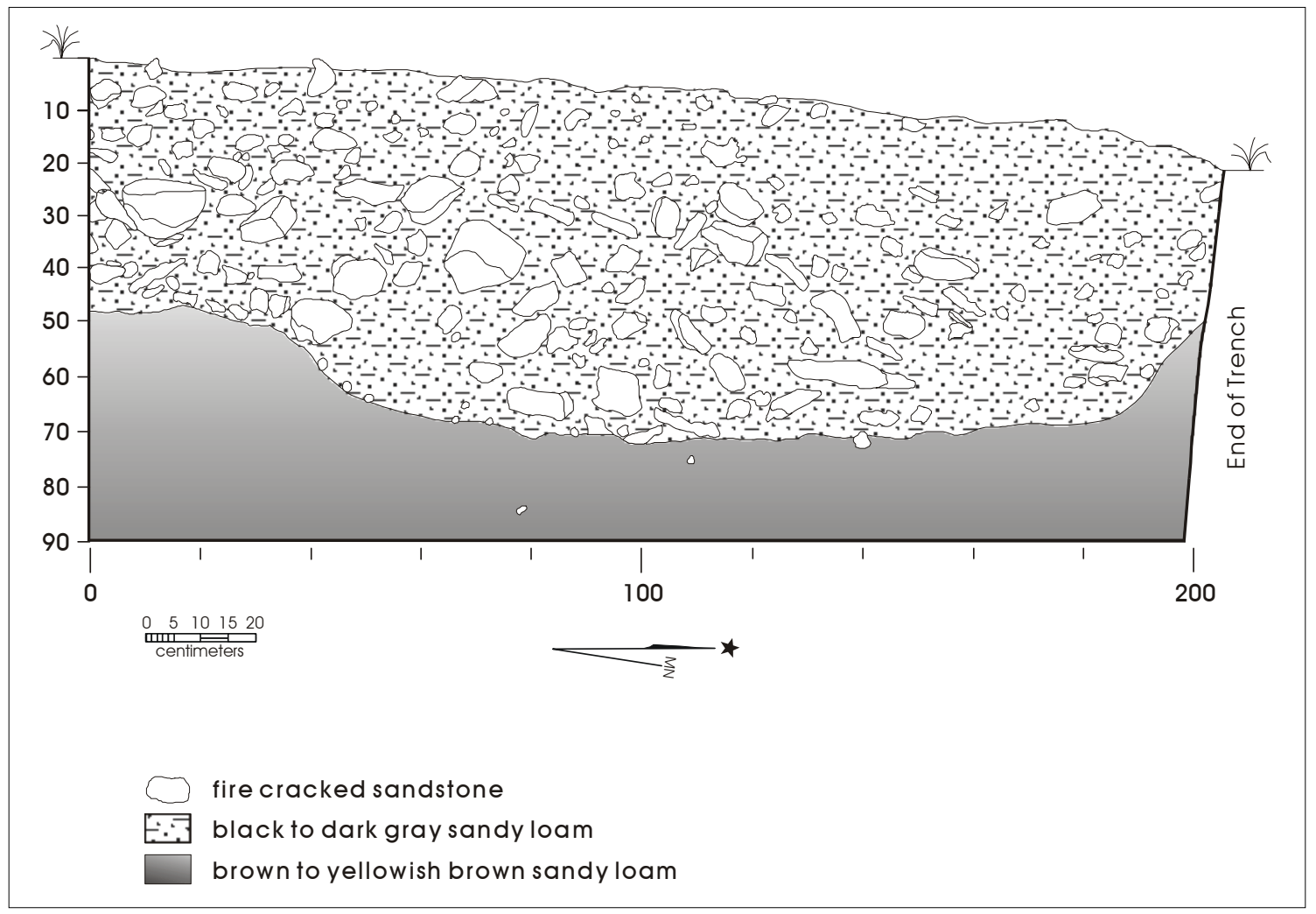

Figure 6-65. Profile of west wall of Backhoe Trench 1, 41BR441.

midden. While the backhoe trench described by Bousman and Hodges (Appendix G) clearly documents a basal feature within the midden, no features were identified outside of it.

\section{$41 \mathrm{BR} 473$}

\section{Site Description}

Site 41BR473 is described by Wormser and Sullo-Prewitt (2001:121-123) as a burned rock midden site with associated lithic debris on a sloping, upland terrace. TXARNG cultural resources staff originally recorded the site in 1995. The midden was described as a ring-shaped concentration of sandstone, roughly $15 \mathrm{~m}$ in diameter and approximately 1 to $1.5 \mathrm{~m}$ in height. A chipped stone concentration covering an area of 5 by $5 \mathrm{~m}$ was observed on the southern end of the site. At a site level, Wormser and Sullo-Prewitt (2001:123) noted only 10 artifacts. Two shovel tests were excavated at the site, producing a single piece of debitage. Both shovel tests were terminated within $30 \mathrm{~cm}$ of the surface.
CAR archaeologists visited the site in early 2001, and work was conducted during the spring of that same year. The elevation of 41BR473 is roughly 1,375 feet (ca. $419 \mathrm{~m}$ ) AMSL, and the site covers an area of about $9,075 \mathrm{~m}^{2}$. When CAR visited the site in 2001, vegetation consisted of short grasses, prickly pear, oak, mesquite, and juniper. The site is located about $800 \mathrm{~m}$ to the north of Devils River, and about $180 \mathrm{~m}$ south of an intermittent tributary.

The midden is roughly $15 \mathrm{~m}$ north-south by $13 \mathrm{~m}$ eastwest. A shallow, central depression is observable in the feature. The feature is on a small slope, rising roughly $1 \mathrm{~m}$ above the surface on the northern side, and about $50 \mathrm{~cm}$ above the surface on the southern side. It is dominated by sandstone. The southern portion of the site sits on the edge of a small ridge. At the time of CAR's visit to the site, no artifacts were observed around the midden, but the small lithic scatter described by Wormser and SulloPrewitt (2001:121) was relocated at the extreme southern end of the site. 


\section{Shovel Test Results}

Fifty-five shovel tests representing 302 separate levels were excavated at the site. Following the usual pattern of testing, the midden was surrounded by shovel tests on a 5-m grid. In addition, we excavated a ring of shovel tests around the central grid (Figure 6-66). Two shovel tests, numbers 27 and 29, were excavated on the midden periphery. The 55 shovel tests had an average depth of about $55 \mathrm{cmbs}$. The outlying shovel tests (see Figure 6-66) were frequently terminated when sandy, reddish-brown clay was encountered, usually at depths of between 40 and $50 \mathrm{cmbs}$. Those shovel tests often had high densities of gravel. Shovel tests closer to the midden frequently had high densities of sandstone and limestone gravels at depths of between 30 and $50 \mathrm{cmbs}$. These shovel tests were terminated when multiple sterile levels were encountered at depths below 30 $\mathrm{cm}$, or at a maximum depth of $70 \mathrm{cmbs}$. In a single shovel test, a hand auger was used to excavate to the maximum depth of 90 cmbs. Roughly 84 percent of the shovel tests were excavated to a depth of $50 \mathrm{cmbs}$.

A relatively high percentage of the shovel tests were positive at this site (Figure 6-66). Twenty-three of the 55 shovel tests produced chipped stone debitage, and fire-cracked rock was present in 33 shovel tests. Sixty-seven percent of the shovel tests excavated at this site were positive. As can be seen in Figure 6-66, those shovel tests close to the midden were frequently positive. Conversely, with the exception of a small quantity of fire-cracked rock in Shovel Test 46, none of the outlying shovel tests were positive.

Material recovered from the shovel tests included 66 flakes and one core. Over 98 percent of the chipped stone debitage was recovered between 0 and $40 \mathrm{cmbs}$, with 42 percent coming from Level $3(20-30 \mathrm{cmbs})$. Shovel Test 32 , located on the southern side of the midden, contained 25 flakes, almost 38 percent of the recovered debitage from all shovel tests.

While fire-cracked rock was noted as present in 84 different levels, counts were not made. Nevertheless, 91 percent of the levels with fire-cracked rock were within 0 to $40 \mathrm{cmbs}$, suggesting a similar distribution as the chipped stone material. While no other artifacts were recovered from the shovel testing, charcoal was noted in seven different shovel tests from as shallow as $20 \mathrm{~cm}$ to as deep as $80 \mathrm{~cm}$. In addition, mussel shell was noted in five different shovel tests.

\section{Surface Collections}

Given the low frequency of surface material present at this site, systematic surface collections were not attempted. In addition, no isolated collections were made at 41BR473.

\section{Excavation Results}

Four 1-x-1-m units were excavated at this site. Two units, designated 2 and 3 , were excavated in the center of the burned rock midden feature (Figure 6-67). In addition, a third unit was placed along the feature ring (Unit 4). Unit 1 was excavated to the south of the midden in the area where Shovel Test 32 had demonstrated high recovery rates for debitage. A volume of roughly $3.33 \mathrm{~m}^{3}$ of sediment was removed in these four units.

\section{Midden Units}

Three units were excavated within the burned rock midden (Figure 6-67). Units 2 and 3 were placed in the center of the midden. Unit 4 was excavated to the north of this 1-x-2-m excavation, and was positioned to cut through the midden ring.

From the central two units, we removed $1.77 \mathrm{~m}^{3}$ of sediment. Although both of the units were excavated to below the feature, examination of Figure 6-68, a profile of the east wall of these two units, shows that the vast majority of the sediments (ca. $1.57 \mathrm{~m}^{3}$ ) were within the midden. The upper $20 \mathrm{~cm}$ of deposits within these two units probably represents fill accumulated after feature use. The basin-shaped deposit below this upper zone, defined primarily by a high frequency of gravel and smaller fire-cracked rock, may also represent the infilling of the central feature after abandonment. While not visible in the profile, excavation notes from both units suggest that several different layers of larger rock were present in these units, possibly representing different use episodes.

Only nine artifacts, all chipped stone, were recovered from the $1.77 \mathrm{~m}^{3}$ of sediment screened from these two units, an artifact density of only 5.3 artifacts per cubic meter. Mussel shell was also present in the central midden, with just over 166 grams being collected.

Nine thousand, six hundred and eighteen pieces of firecracked rocks greater than one inch in size were removed from these two central units. An additional $189.9 \mathrm{~kg}$ of rock 


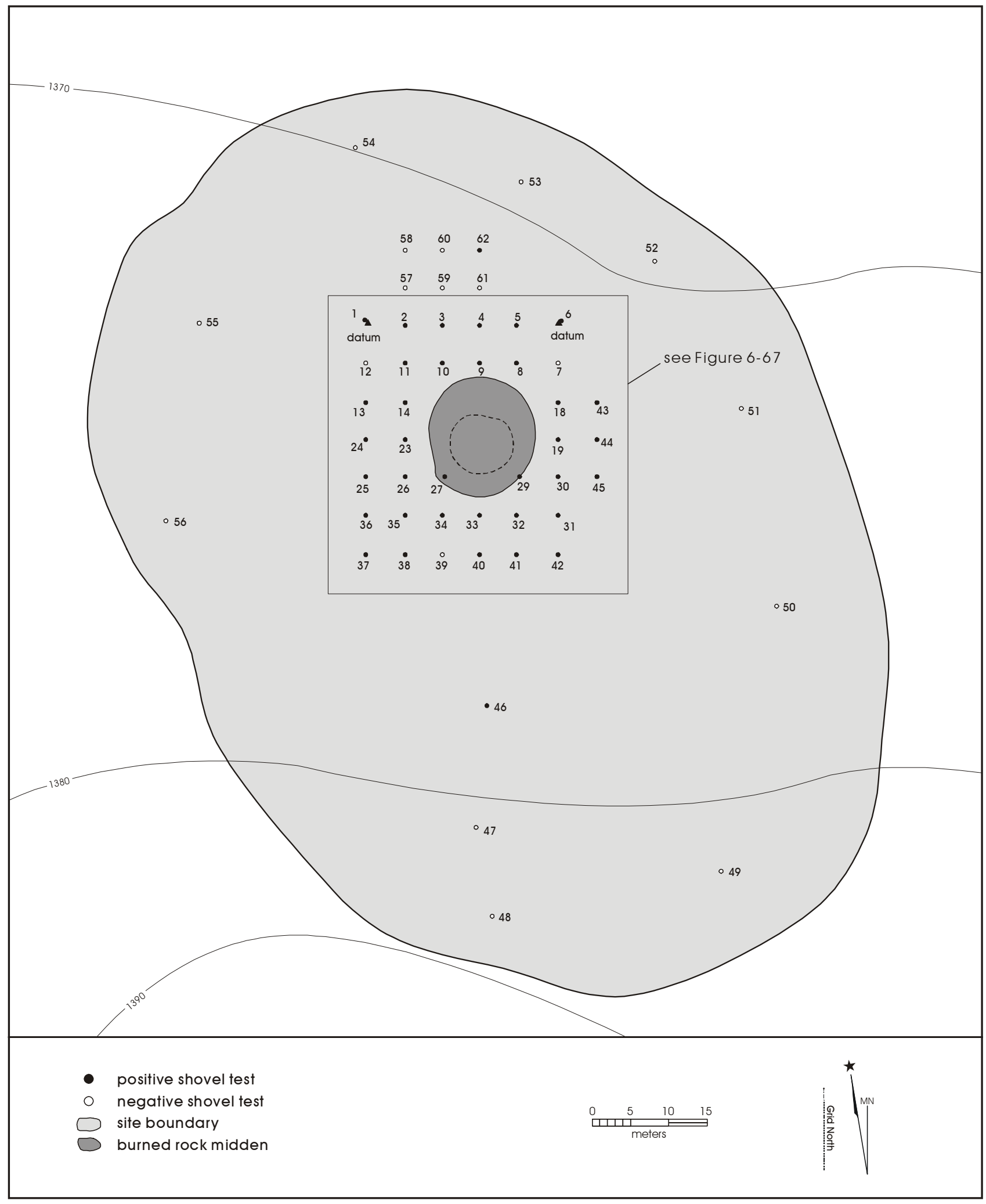

Figure 6-66. Site 41BR473 with burned rock midden and shovel tests identified. 


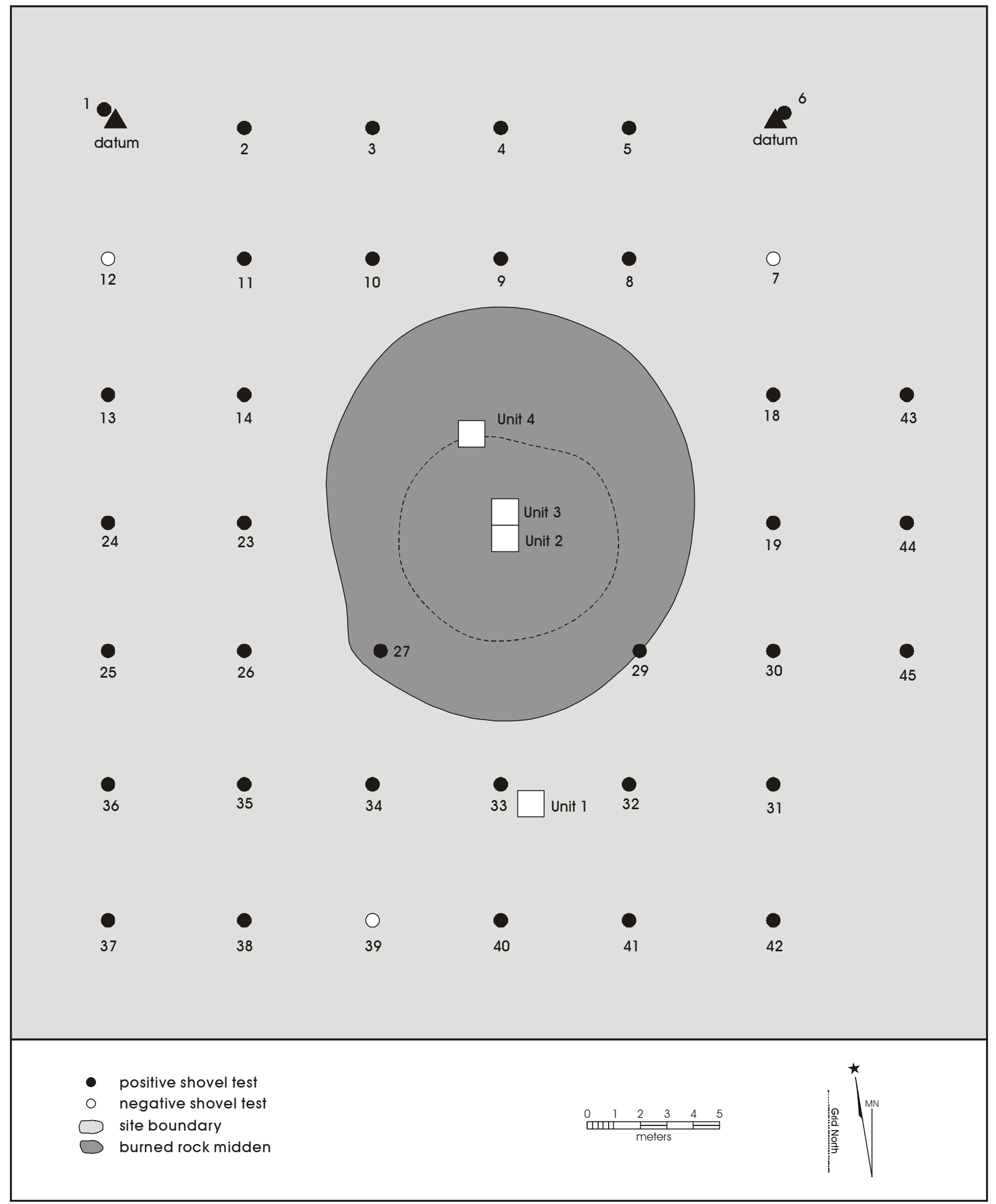

Figure 6-67. Site 41BR473 with burned rock midden and excavation units identified. 
less than one inch in size was also recorded. While raw material was not systematically monitored, a sample of 500 rocks demonstrated that sandstone accounted for 98 percent of the raw material, with limestone and chert also present.

Unit 4, located on the ring of the feature, was excavated to a depth of $1.18 \mathrm{~m}$ below surface. While no profile of this unit was drawn, Figure 6-69 provides a contour map and cross-section of Feature 1, the burned rock midden, with excavation units identified. A review of excavation notes suggests that below the initial $2-3 \mathrm{~cm}$ of organic material, sediments in Unit 4 were consistently a dark gray to black ashy silt. At approximately $1.14 \mathrm{~m}$ below surface, the base of the midden was encountered. The base was reddish-yellow silty clay. Rodent disturbance was noted at the base of the midden.

Only a single artifact, a flake from the initial level of excavation, was recovered from the removal of $1.14 \mathrm{~m}^{3}$ of sediment within Unit 4. Mussel shell was present in this ring unit, with just over 86 grams being collected.

A total of 8,546 pieces of fire-cracked rock greater than one inch in size was removed from this unit. An additional 81.7 $\mathrm{kg}$ of rock less than one inch in size was also recorded. Raw material was not systematically monitored from this unit, but it is certain that sandstone accounted for the vast majority of the observed stone.

\section{Off-Midden Unit}

The single external 1-x-1-m unit (Unit 1) was placed in the vicinity of Shovel Test 33 (see Figures 6-67 and 6-69). The unit was only excavated to a depth of $38 \mathrm{cmbd}$. While no profile is available for this unit, the excavation notes suggest that below the initial level, sediments were dominated by red sandy clay, with compact clay being encountered at about $35 \mathrm{cmbd}$.

In spite of the shallow nature of the deposits, a large number of artifacts were recovered. Three hundred and seventyseven pieces of chipped stone debitage were recovered from this excavation. In addition, two projectile points, four cores, six bifaces, and two utilized/retouched flakes were recovered. Most of the recovered material was from 20 to $40 \mathrm{~cm}$ below the surface. Several pieces of fire-cracked sandstone were noted in the excavations, along with a small amount of scattered charcoal. Mussel shell was also present, as were two pieces of mammalian fauna, one of which was burned. Artifact density in this unit was in excess of 1,028 items per cubic meter.

\section{Artifact Summary}

Four hundred and fifty-three pieces of debitage, six bifaces, five cores, and two utilized/retouched items were collected from 41BR473. Appendix F presents scans of selected tools from this site. Chert was the only tool stone represented. Just over 68 percent of the flakes lacked cortex, with only 10 flakes $(2.2 \%)$ having 100 percent dorsal cortex cover. The vast majority of the material recovered from this site came from Unit 1, with midden excavations producing minimal recovery of artifacts.

The two projectile points recovered from 41BR473 (see Appendix E) were an Ensor, suggesting a Late Archaic use, and a Perdiz, suggesting a Late Prehistoric use. Both points came from Unit 1, with the Ensor recovered from 20-30 cmbd, and the Perdiz recovered from $30-40 \mathrm{cmbd}$.

\section{Other Samples}

No vertebrate faunal material was recovered from the midden excavations at this site. As noted previously, Unit 2 produced two pieces of mammalian fauna, one of which was burned (Appendix B). The lack of faunal material from the midden may be related, in part, to preservation; however, carbonized material was recovered from the midden, suggesting that preservation conditions were adequate.

No macrobotanical identification samples were collected from this site. As summarized by Dering (Appendix C), both of the flotation samples submitted from the midden contained carbonized material. This carbonized wood was identified as oak.

As noted above, mussel shell was identified in all excavation units, as well as in several shovel tests. In all, over 273 grams of mussel shell was recovered from 41BR473. Goodfriend identified four samples from this site (Appendix D). These included Quadrula houstonensis $(\mathrm{n}=1)$, Amblema plicata $(\mathrm{n}=1)$, and Tritogonia verrucosa $(\mathrm{n}=2)$.

\section{Radiocarbon Dates}

Two radiocarbon samples, both from Unit 4 within the midden, were submitted for analysis. They were collected from 34-46 cmbd and 94-104 cmbd. The corrected date for the upper sample is $1000 \pm 40$ years BP, with the lower sample dating to $1170 \pm 40$. Appendix A presents details of these dates. If these dates are in context, it appears that the 


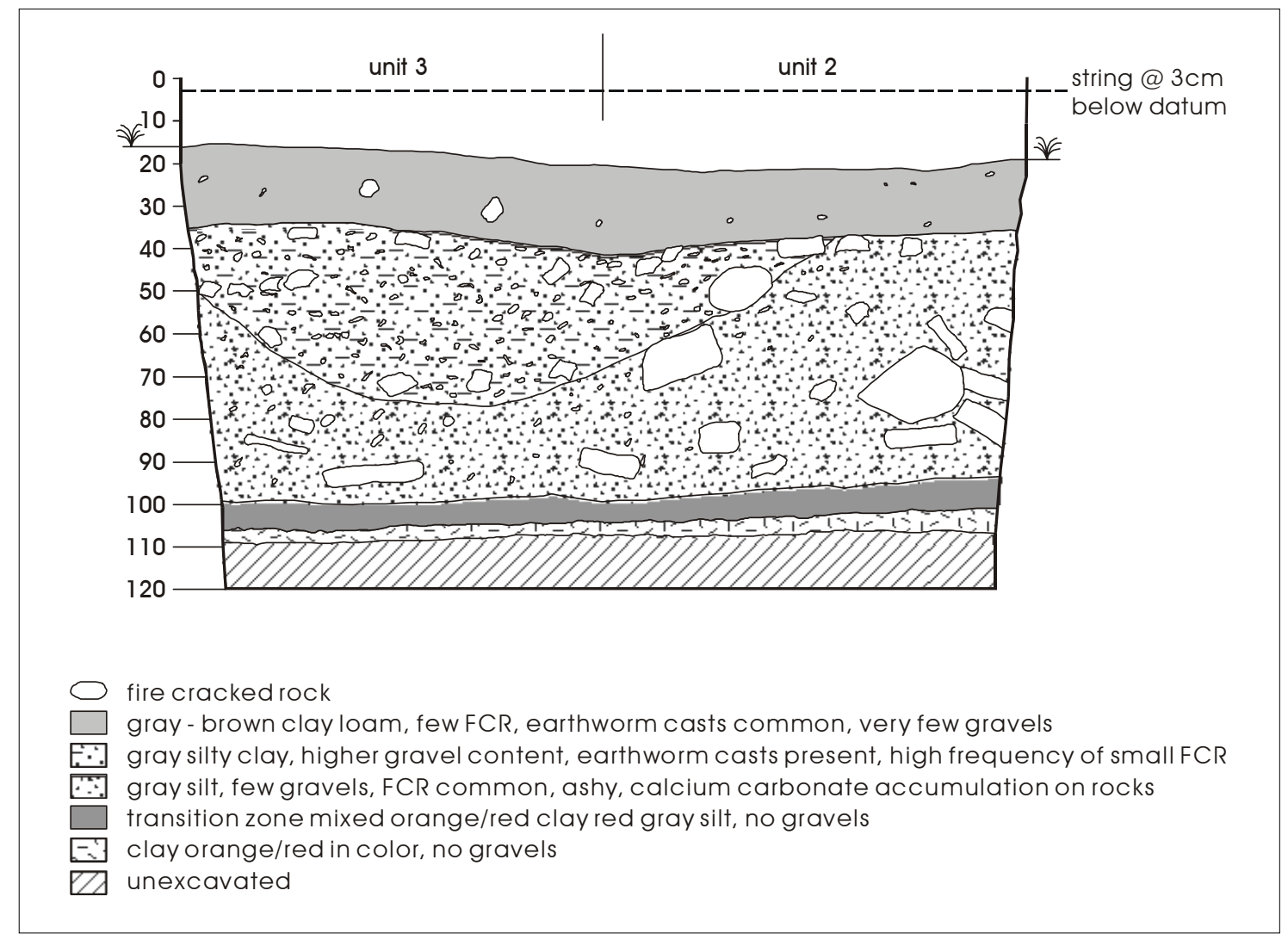

Figure 6-68. Profile of east walls of Units 2 and 3 on site $41 B R 473$.

midden began to form sometime before A.D. 780 and 940, with a date range on the upper sample of between A.D. 990 and 1160. Using the interval estimate in the OxCal radiocarbon calibration program (Ramsey 2000), there is a 95 percent probability that the interval between the bottom date and the upper date represents at least 30 years and no more than 350 years. Using the midpoint of the distribution as an estimate, the roughly $60 \mathrm{~cm}$ of deposits between the two dates may have been generated in about 190 years at the beginning of the Late Prehistoric period.

\section{Summary}

Our work at site $41 \mathrm{BR} 473$ suggests that the burned rock midden dates to the Late Prehistoric period. Two diagnostic projectile points recovered from the site suggest use in the Late Archaic and the Late Prehistoric periods.

Shovel testing from outside the midden revealed moderate to low subsurface density. The percentage of positive shovel tests was high, with 67 percent containing chipped stone or fire-cracked rock. Most of the material was recovered between 0 and $40 \mathrm{cmbs}$, with 42 percent of the debitage coming from 20 to $30 \mathrm{cmbs}$. Charcoal was present in several of the levels, as was mussel shell.

In the single excavation unit outside of the midden, an artifact density of over 1,000 items per cubic meter of sediment was present. Most of the material was from 20 to $40 \mathrm{cmbd}$. Burned bone, small amounts of charcoal, mussel shell, and fire-cracked rock were also present in this unit. Units excavated in the burned rock midden had artifact densities of only 3.4 items per cubic meter. No vertebrate faunal material was recovered from the midden excavation, though mussel shell was present. No macrobotanical samples were submitted for identification from these excavations. Flotation samples produced only oak wood charcoal.

Conditions for preservation of ethnobotanical material within the midden are moderate. In addition, we have no data to suggest that the context of the material recovered from the midden on the site has been extensively disturbed. 


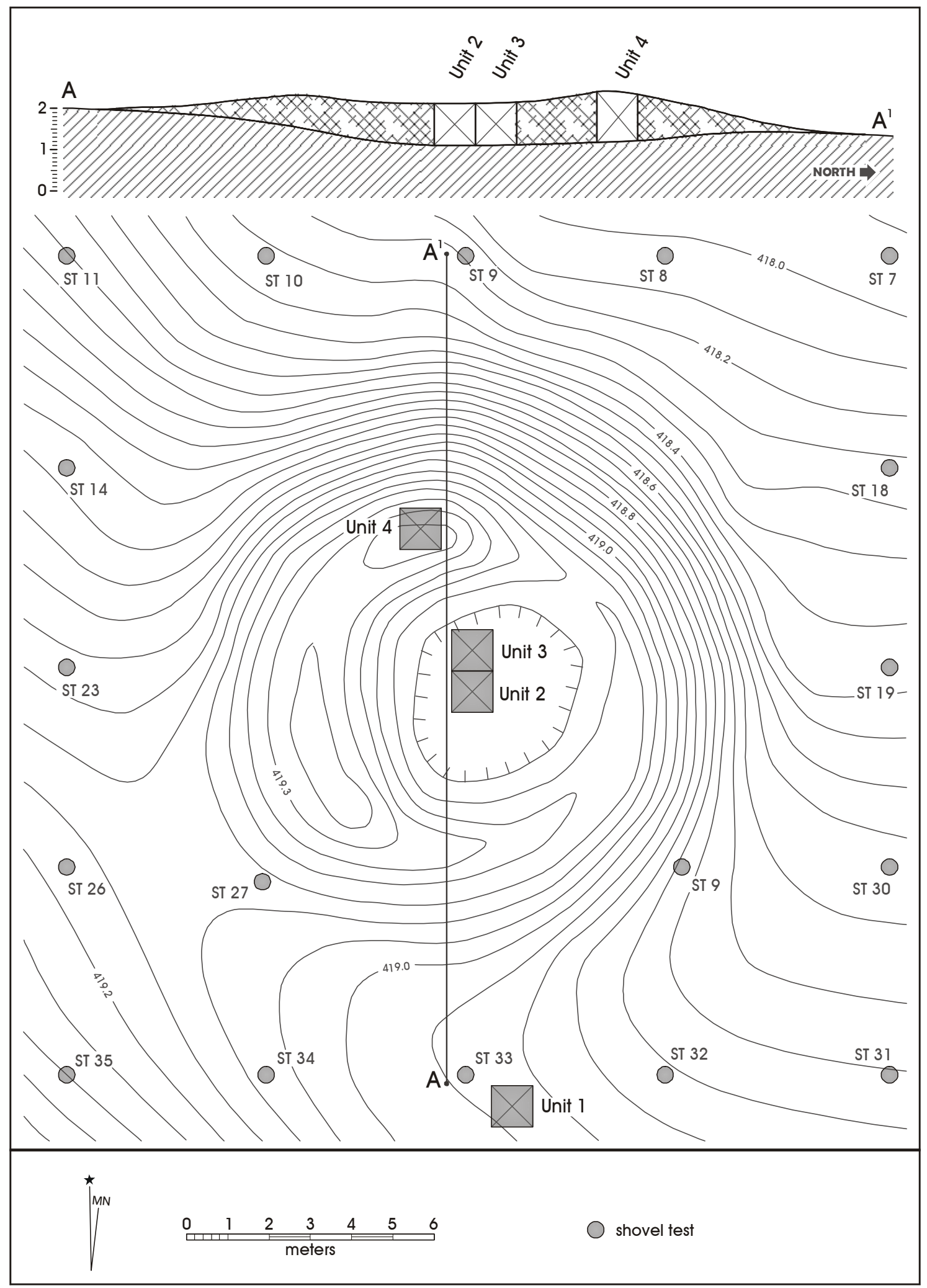

Figure 6-69. Contour map and cross-section of Feature 1, 41 BR473. 
While the field crew observed worm casts in the sediments, and while excavation notes suggest some disturbance of the lower levels of the midden by rodents, the level of disturbance is not extensive. Although excavation outside the midden was minimal, we documented high artifact densities associated with small amounts of charcoal, burned bone, mussel shell, and burned rock.

\section{$41 \mathrm{BR} 474$}

\section{Site Description}

Site 41BR474 is described by Wormser and Sullo-Prewitt (2001:123-125) as a burned rock midden site with an associated dense lithic scatter. TXARNG cultural resources staff originally recorded the site in 1995. Located along Lewis Creek, 41BR474 was described as having at least four burned rock middens, with two middens located at the northern end of the site, and two others located at the southern end. Examination of the Lewis Creek profile suggested that sediments could be over a meter deep, though no cultural material was observed in the profile.

Wormser and Sullo-Prewitt (2001:123) described the two southern middens as "crescent" shaped, with one being 17 $\mathrm{m}$ in length and $4 \mathrm{~m}$ in width, and the second being $17 \mathrm{~m}$ in length and $7.5 \mathrm{~m}$ in width. Both middens were described as being roughly $50 \mathrm{~cm}$ high, with a $2 \mathrm{~m}$ gap between these features. The northern middens were described as more elongated, and Wormser and Sullo-Prewitt suggested that these two middens could represent a single feature. A scatter of burned rock to the west of the two, roughly parallel features, was also recorded. Wormser and Sullo-Prewitt noted a high density of surface artifacts on this site, with the distribution occurring primarily between the four features. Two shovel tests were excavated at this site. Both shovel tests were positive, with debitage present in the upper 20 $\mathrm{cm}$ of Shovel Test 1 and in the upper $10 \mathrm{~cm}$ of Shovel Test 2. Both shovel tests were terminated within $30 \mathrm{~cm}$ of the surface when dense, red clay was encountered.

CAR archaeologists visited the site in the fall of 1999, and work was conducted during the spring of 2000. The elevation of 41BR 474 is roughly 1,385 feet (ca. $422 \mathrm{~m}$ ) AMSL, and the site covers an extensive area estimated to be $25,300 \mathrm{~m}^{2}$. When CAR visited the site in 2000 , vegetation consisted of short grasses and dense mesquite, with oak and juniper present along the drainage. Both during our initial visit, as well as during our work at this site, the grass was dense, obscuring much of the ground surface.
The four middens described by Wormser and Sullo-Prewitt were relocated, though they appeared to be the remains of two bulldozed features. The northern midden, designated Feature 1, and the southern midden, designated Feature 2, had roughly similar appearances, consisting of low, linear accumulations of fire-cracked sandstone. The mounds within each midden area were roughly parallel, with a distinctive low area between them. The smaller burned rock accumulation noted by Wormser and Sullo-Prewitt to the west of the northern features appeared to represent a pile of rock pushed out of the center of what was previously a single burned rock midden (Figure 6-70). At the time of CAR's visit to the site, a small number of artifacts were observed around the southern features, with a light scatter of material exposed in a few areas along the central portion of the site.

\section{Shovel Test Results}

Seventy-five shovel tests representing 239 separate levels were excavated at the site (Figure 6-70). Thirty-nine shovel tests were placed around the northern midden. Eight shovel tests were placed between the two middens. Finally, 28 shovel tests were excavated around the southern midden.

Figure 6-71 is a blow up of the Feature 1 area. The 39 shovel tests dug in this area were excavated to an average depth of $34.6 \mathrm{cmbs}$, with all shovel tests excavated to at least 20 $\mathrm{cmbs}$, and two shovel tests excavated to $60 \mathrm{cmbs}$. While clay dominated all sediments, the upper levels in this area tended to have higher silt and sand content, with clay increasing with depth. Shovel tests closer to Lewis Creek were frequently terminated when bedrock was encountered, usually within $30 \mathrm{~cm}$ of the surface. Shovel tests farther away from the creek were generally deeper, and termination was due to a lack of artifacts, or when hard, reddish-brown clay was encountered.

Twenty-nine of the 39 shovel tests had chipped stone present, and 30 of the tests had fire-cracked rock. Thirty-four of the 39 shovel tests $(87 \%)$ excavated around this feature were positive (Figure 6-71). One hundred and ninety-one pieces of chipped stone were recovered in this area. Most of the debitage was concentrated to the southeast and northeast of the midden, with lower recovery rates to the north and west, as well as in the central area of Figure 6-71. Ninety-seven percent of the debitage was within $30 \mathrm{~cm}$ of the surface. In addition, six bifaces, two utilized/retouched flakes, and one untypable dart point fragment were recovered. Nine hundred and sixty pieces of fire-cracked rock were counted from the shovel tests. Seventy-six percent of these rocks, however, 


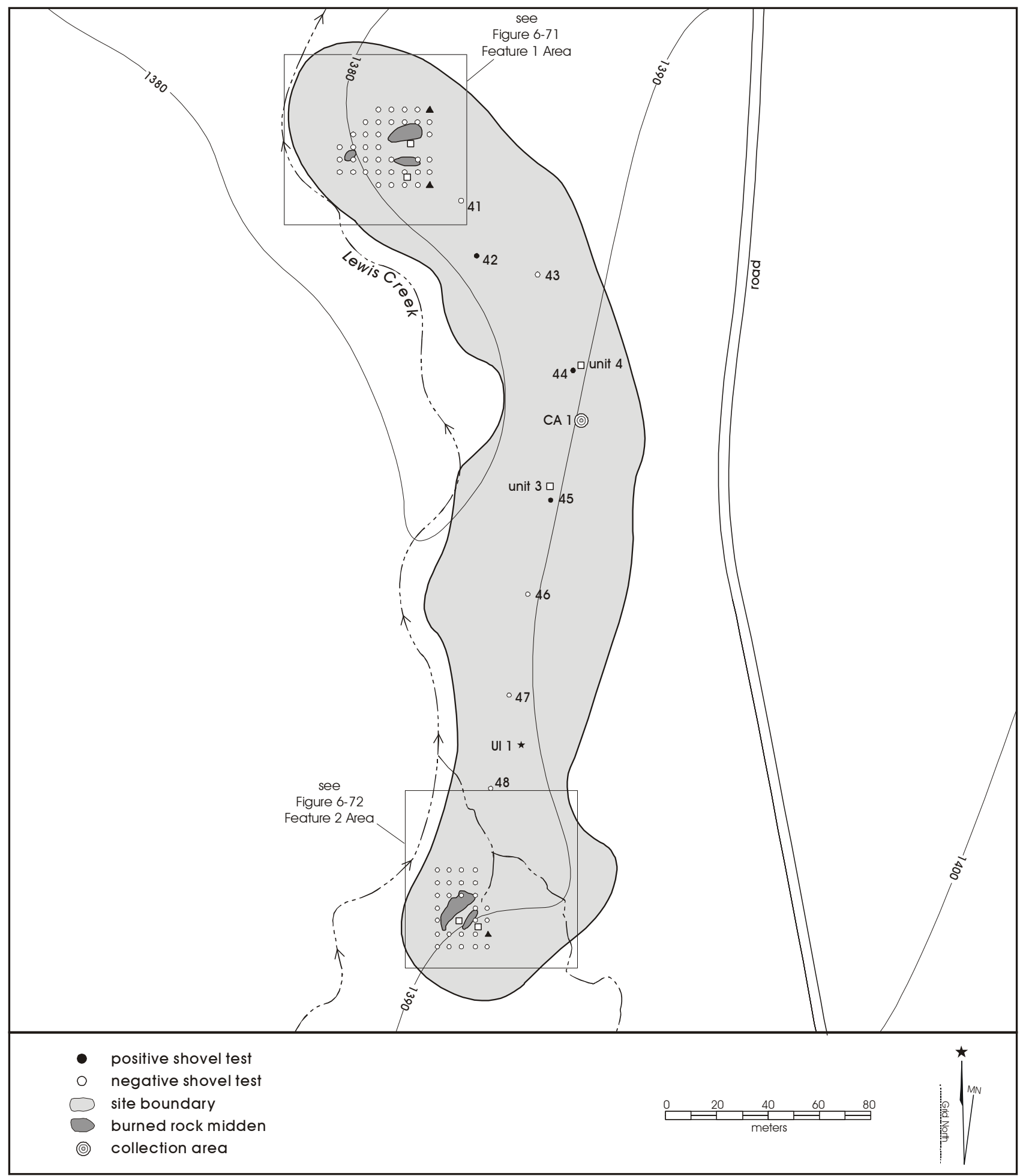

Figure 6-70. Site 41BR474 with burned rock middens and shovel tests locations identified. 


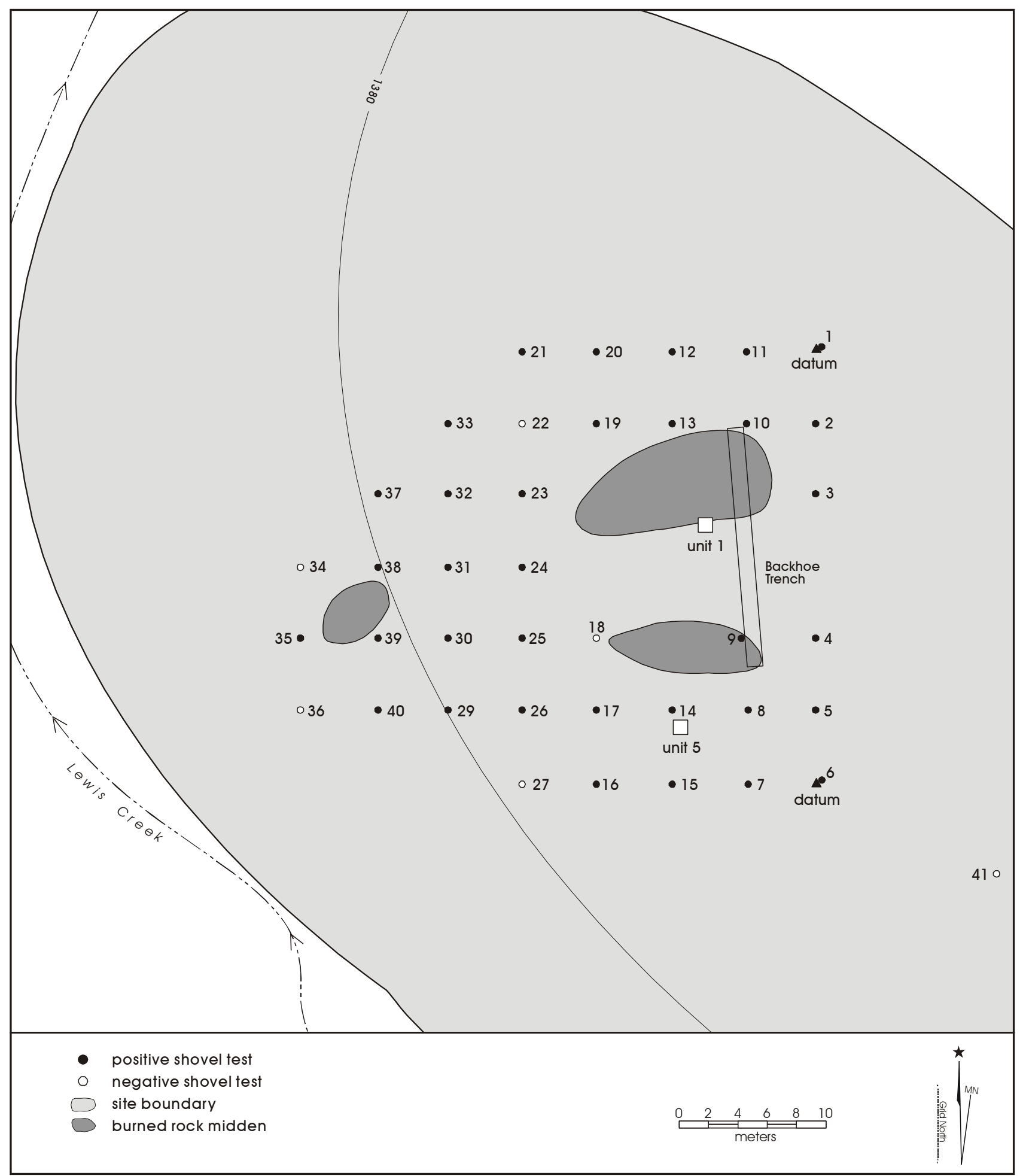

Figure 6-71. Feature 1 area on site $41 B R 474$. 
were recovered in Shovel Tests 3, 9, 24, and 25, all surrounding the midden area. The vertical distribution of fire-cracked rock was similar to the chipped stone distribution, with 99 percent of the material confined to the upper $30 \mathrm{~cm}$.

The eight shovel tests excavated between the two midden areas (Figure 6-70) were dug to an average depth of 31.3 $\mathrm{cmbs}$. These shovel tests were generally terminated when a reddish-brown clay was encountered. Three of the eight shovel tests were positive (Figure 6-70). Two of these had small quantities of fire-cracked rock and all three had lithic debitage. Eight pieces of debitage were recovered, with all material coming from within $20 \mathrm{~cm}$ of the surface.

Figure 6-72 shows the 28 shovel tests excavated in the southern midden area. These tests averaged just over $28 \mathrm{~cm}$ in depth. Shovel tests in this area were frequently terminated when blocky, reddish-brown clay was encountered, generally at depths between 20 and 30 cmbs.

Twenty-four of the 28 tests placed in this area were positive, with 23 having debitage and 19 having fire-cracked rock. One hundred and thirty-seven pieces of debitage, three bifaces, one utilized/retouched flake, one sandstone mano, and 301 pieces of fire-cracked rock were recovered from this area. Seventy-three percent of the fire-cracked rock came from two shovel tests, numbers 56 and 61, both of which were within the burned rock accumulations (see Figure 6-72). The lithic material was more evenly distributed across the area, with somewhat higher counts on the eastern side of the midden area. No material was recovered from below $30 \mathrm{~cm}$. Eightyseven percent of the debitage and 98 percent of the firecracked rock was recovered from the upper $20 \mathrm{~cm}$. Mussel shell was noted in two shovel tests, both near Feature 1.

The shovel tests results suggest shallow deposits at this site, with most material concentrated in the upper $30 \mathrm{~cm}$ of the deposits. Spatially, material is concentrated around the two midden areas, with few items recovered in the central portion of the site.

\section{Surface Collections}

While Wormser and Sullo-Prewitt (2001:123) noted a high surface artifact density, much of the ground surface was obscured by vegetation during our work at the site. Only a single systematic surface collection area was placed at this site. In addition, a single unique item, a probable Late Archaic Bulverde point, was collected (see Figure 6-70).
The collection area consisted of a circle, with a radius of 3 $\mathrm{m}$, located on the north-central portion of the site (see Figure 6-70). One biface and eighty-two pieces of chipped stone debitage were collected from this area. Artifact density was roughly 2.9 artifacts per square meter in this collection area. Approximately 73 percent of the debitage from this area lacked cortex, and none of the debitage had 100 percent cortex cover on the dorsal surface. Chert was the dominant material type, accounting for 99 percent of all the debitage.

\section{Excavation Results}

Six 1-x-1-m units were excavated at this site (see Figures 670, 6-71, and 6-72). Units 1 and 2 were placed in the central area of Features 1 and 2, respectively. Both of these units were placed in or on the border of the central, bulldozed area in an effort to identify any remaining deposits in these two features (see Figures 6-71 and 6-72). In addition, Unit 5 was placed outside of Feature 1 (Figure 6-71) and Unit 6 was placed outside of Feature 2 (Figure 6-72) to explore off-midden deposits. Finally, two units, numbers 3 and 4 , were placed in the intervening area, near positive shovel tests, to explore deposits within this large area (see Figure 6-70). A total volume of roughly $1.62 \mathrm{~m}^{3}$ of sediment was removed in these six units. All units were shallow, with a maximum depth of $40 \mathrm{cmbd}$.

In addition to these hand-excavated units, Bousman and Hodges cut three backhoe trenches on or near this site in conjunction with their geoarchaeological work (Appendix G). Trench 1 was excavated through Feature 1 (Figure 671). A second trench, designated Trench 3 , was excavated through Feature 2 (Figure 6-72). A final trench, designated Trench 2, was excavated off the site on a low terrace of Lewis Creek. Four profiles were described for these three trenches (see Appendix G).

\section{Midden Units}

Unit 1 was excavated in the central area of Feature 1 (Figure 6-71). The unit was excavated to a depth of $23 \mathrm{cmbd}$, with sterile, underlying clay present at about $18 \mathrm{cmbd}$. The upper sediments within this unit were a dark, ashy, silty clay that contained artifacts, fire-cracked rock, and charcoal.

This excavation yielded 26 pieces of debitage and one utilized/retouched flake. Artifact density in this unit was 117 items per cubic meter of sediment. Mussel shell was present in this midden unit, with 249.5 grams being collected from the shallow excavation. Sixty-four pieces of fire-cracked rock were present on the surface of this unit, and 2,261 


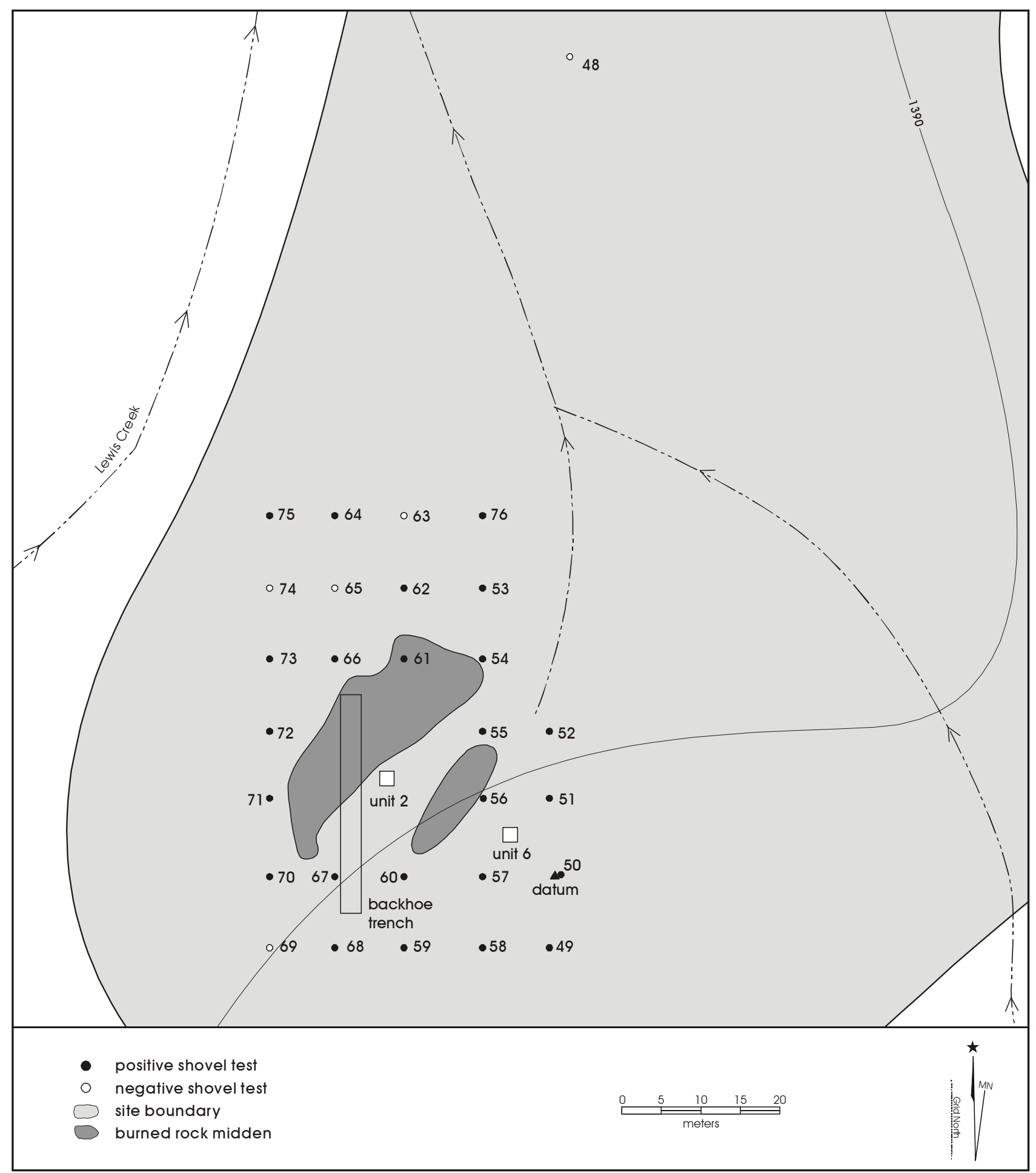

Figure 6-72. Feature 2 area on site 41BR474. 
fire-cracked rocks greater than one inch in size were removed during excavation. An additional $258.12 \mathrm{~kg}$ of rock less than one inch in size was also recorded. Sandstone accounted for 99 percent of the recorded raw material in the midden.

Unit 2 was placed in the center of Feature 2 (see Figure 672). The unit was only excavated to $17 \mathrm{cmbd}$, with the underlying clay being encountered at $14 \mathrm{cmbd}$. The upper 14 $\mathrm{cm}$ of this excavation were within dark clay silt, and as with Unit 1, charcoal, artifacts, and burned rock were present.

Unit 2 produced 26 pieces of debitage, a density of 200 artifacts per cubic meter of sediment. In addition, 267 pieces of fire-cracked rock greater than one inch in size were counted. No figures could be found for those items less than one inch in size and it is possible that this size fraction was either not weighed, or the data were lost. As with the first midden, sandstone accounted for the vast majority of the material. A small amount of mussel shell was also collected from this unit.

\section{Off-Midden Units}

Four external 1-x-1-m units were placed on this site. Each of these is discussed below.

Unit 3 was near positive Shovel Test 45 (Figure 6-70). The unit was only excavated to a depth of $23 \mathrm{cmbd}$. The upper 3 $\mathrm{cm}$ of this unit was primarily a brown sandy loam with high organics. Modern artifacts such as bullets and small pieces of metal were noted in this level. This upper level was underlain by fine, sandy sediment with some red and gray clay mottling present. Solid clay or clay loam was encountered at $18 \mathrm{~cm}$. In addition, several gravel deposits were noted throughout this shallow unit. Forty-one pieces of chipped stone debitage were recovered from this excavation, with 38 of these coming from the upper $13 \mathrm{~cm}$ of the deposits. Fire-cracked rock was noted in small quantities, but no counts were made.

Unit 4 was placed near positive Shovel Test 44 (Figure 670). The unit was excavated to a depth of $33 \mathrm{cmbd}$. The upper $13 \mathrm{~cm}$ of this unit contained sandy silt, yellowishbrown in color. The next $10 \mathrm{~cm}$ was darker brown sandy silt grading into reddish-brown silty clay. The last level was dominated by compact, reddish-brown clay. Twenty-two pieces of debitage were collected from this unit, with about 64 percent of this total coming from 3 to $13 \mathrm{cmbd}$. No artifacts were recovered from the reddish-brown clay sediment that dominated the deposits below $23 \mathrm{~cm}$. A small quantity of fire-cracked rock was present in the upper 23 $\mathrm{cm}$ of the unit, though no counts were made. In addition, charcoal flecks were noted from 3 to $13 \mathrm{cmbd}$.

Unit 5 was placed outside of Feature 1 (Figure 6-71). The unit was only excavated to a depth of $30 \mathrm{cmbd}$, with reddishbrown clay encountered between 20 and $30 \mathrm{cmbd}$. Artifact counts for this unit were relatively high, with 98 pieces of chipped stone recovered. Approximately 64 percent of this total came from Level 2, 10-20 cmbd. Only a single flake was recovered from below $20 \mathrm{~cm}$. Though not counted, a small amount of fire-cracked rock was noted between 0 and $20 \mathrm{cmbd}$.

Unit 6 was placed outside of Feature 2 (Figure 6-72). The unit was excavated to a depth of $40 \mathrm{cmbd}$, with dark brown clay encountered at $30 \mathrm{cmbd}$. The upper $30 \mathrm{~cm}$ were a mixture of brown silty clay and darker sandy silt with charcoal flecks present. Figure 6-73, a plan view of the unit at $10 \mathrm{cmbd}$, shows a darker area with several small pieces of fire-cracked sandstone. This area produced higher densities of fire-cracked rock down to $20 \mathrm{cmbd}$, with staining present down to $30 \mathrm{cmbd}$. This area may represent a portion of the Feature 2 edge that had not been obliterated by the bulldozing of the feature. From this unit, CAR recovered 107 chipped stone flakes and two bifaces, with 86 percent of the material coming from between 0 and $20 \mathrm{cmbd}$. Only two flakes were recovered from below $30 \mathrm{~cm}$. Fire-cracked rock was present in the upper $20 \mathrm{~cm}$, with 169 pieces of fire-cracked rock greater than one inch in size recovered. In addition, we collected 574 grams of rock less than one inch in size.

\section{Artifact Summary}

CAR collected 770 pieces of debitage, 11 bifaces, five retouched/utilized items, three projectile points, and one mano from 41BR474. Appendix F presents scans of selected tools from this site. Chert dominated the raw materials, accounting for over 99 percent of all chipped stone. Roughly 77 percent of the flakes lacked cortex, with only 11 flakes $(1.4 \%)$ having 100 percent dorsal cortex cover.

One of the three projectile points from the site was an untypable dart point. A probable Late Archaic Bulverde point was collected from the surface and a Late Archaic Castroville point was collected from the spoil of the backhoe trench in Feature 1. Appendix E provides scans of these projectile points. 


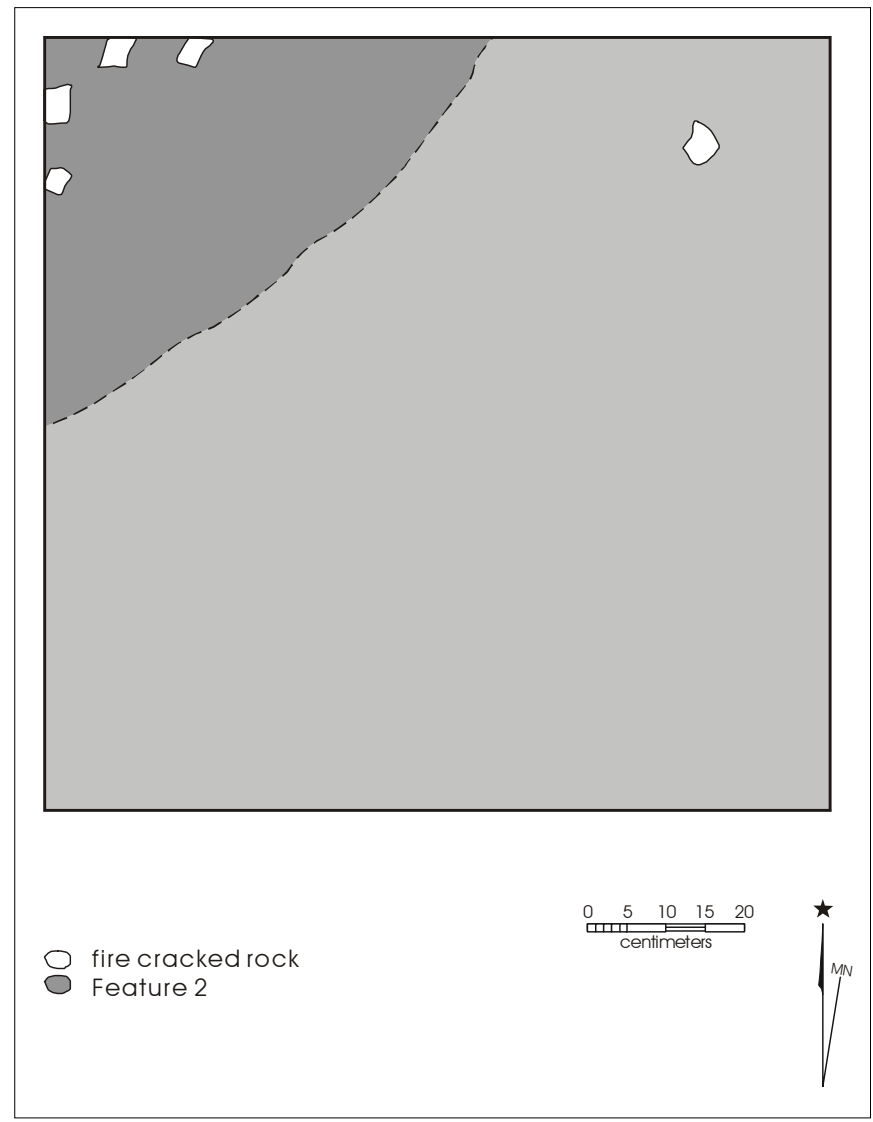

Figure 6-73. Plan view of Unit 6 at $10 \mathrm{cmbd}$ with possible edge of Feature 2 identified, $41 B R 474$.

\section{Other Samples}

No vertebrate faunal material was recovered in the excavations at this site. This lack of material is probably a function of the limited excavation, as well as the shallow nature of the deposits.

No macrobotanical identification samples were collected from this site. As summarized by Dering (Appendix C), both of the 1.5 liter flotation samples, one from each of the two middens, contained carbonized wood. That material was identified as oak.

As noted above, mussel shell was present in two of the shovel tests, as well as in Units 1 and 2. We recovered 327.4 grams of mussel shell from 41BR474. None of these samples, which were highly fragmentary, were submitted for identification.

\section{Radiocarbon Dates}

Two radiocarbon samples, one from each midden area, were submitted from this site. The first sample, from Feature 1, came from 25-27 cmbd in Unit 1. The corrected date for this sample was $960 \pm 40$ years BP. The second sample, from Feature 2, Unit 2, at 10-20 cmbd, produced a corrected date of $920 \pm 40 \mathrm{BP}$. Appendix A provides details of these dates. If these dates come from the bottom of the middens, they may minimally suggest beginning dates for midden use. If these dates are in context, it appears that Feature 1 may have been initially used sometime between A.D. 1020 and 1160, with Feature 2 use initiated between A.D. 1030 and 1170. Both features are Late Prehistoric in age.

\section{Summary}

CAR's work at site 41BR474 suggests that there are two burned rock middens present at this site. Both middens have been damaged by what appears to have been a series of bulldozer cuts through their centers. The damage is similar to that observed in the midden at 41BR441, located a few hundred meters to the south.

We were able to obtain radiocarbon dates from the bottoms of both of the burned rock middens. These dates suggest a Late Prehistoric period of use. The two diagnostic projectile points recovered from the site are earlier than these Late Prehistoric dates, suggesting a Late Archaic use of the area as well.

Shovel testing and surface collection results from outside the middens revealed moderate surface density and shallowly buried deposits. The percentage of positive shovel tests at a site level was high, with 87 percent of the shovel tests around Feature 1 and 86 percent of the shovel tests around Feature 2 being positive. In both areas, recovery rates were high. An average of 5.1 chipped stone items were recovered for every excavated shovel test in these two midden areas. Conversely, those shovel tests excavated between the middens produced a lower positive percentage of tests $(37.5 \%)$ and, on average, only one chipped stone item was recovered per excavated shovel test. At a site level, the vast majority of material was recovered from the upper $30 \mathrm{~cm}$ of the deposit. A single surface collection area produced moderate densities. 
In excavation units outside of the middens, recovery was high. However, in all cases, the deposits were shallow, with material primarily confined to the upper $20 \mathrm{~cm}$. The excavations in the two features were minimal, consisting of a single 1-x-1-m unit placed in each feature. Both units had moderate recovery of artifacts, though the context of these deposits is difficult to evaluate given the disturbed nature of the middens. While mussel shell was recovered, no vertebrate faunal material was recovered from the excavations at this site. No macrobotanical samples were collected for identification. Flotation samples produced oak wood charcoal from the two features.

Conditions for preservation of ethnobotanical material within the middens are low. In addition, the context of the material recovered from the middens on the site may have been extensively disturbed. Machinery has destroyed the structure of the two middens. Immediately outside of the middens, artifact densities are high. Between the two middens, densities are much lower.

\section{$41 \mathrm{BR} 478$}

\section{Site Description}

Wormser and Sullo-Prewitt (2001:127-129) describe site 41BR478 as a burned rock midden site with associated lithic debris. TXARNG cultural resources staff originally recorded the site in 1997. While no shovel tests were excavated, TXARNG archaeologists made observations on surface artifacts, and collected an Andice point, a possible Wells point, two additional unidentified point bases, two biface fragments, and two modified flakes. These artifacts suggest an Early Archaic occupation of the site.

CAR archaeologists visited the site in the fall of 1999, and work was conducted during the early spring and summer of 2001. Site 41BR478 contained a single burned rock midden. The site is located adjacent to Lewis Creek and the midden is located near the creek on the eastern end of the site. A series of lithic scatters are present, including a light scatter on the top of a low spur (Figure 6-74). The elevation of 41BR478 is roughly 1,400 feet (ca. $427 \mathrm{~m}$ ) AMSL, and the site covers an area of $8,550 \mathrm{~m}^{2}$. When CAR visited the site in 1999, vegetation consisted of short grasses, prickly pear, oak and mesquite.
The midden is roughly $10 \mathrm{~m}$ east-west by $15 \mathrm{~m}$ north-south A central depression was not observed, though several oak trees growing on the mound would have obscured any pit. The feature rises approximately $50 \mathrm{~cm}$ above the surrounding ground surface. The feature is dominated by sandstone. At the time of CAR's visit to the site, a light scatter of artifacts was observed to the north and west of the midden.

\section{Shovel Test Results}

Thirty shovel tests, representing 140 separate levels, were excavated at the site. Because the midden was located about $10 \mathrm{~m}$ from the edge of Lewis Creek, shovel testing was concentrated to the north of the midden, away from the drainage. Twenty-seven tests were excavated around the midden, and an additional three shovel tests were excavated to the north and east of the feature. No shovel tests were excavated in the midden. The 30 shovel tests averaged 47 $\mathrm{cmbs}$. Four of the 30 shovel tests were dug to below $60 \mathrm{~cm}$, and 29 of the 30 tests were excavated to at least $30 \mathrm{cmbs}$. Sediment was primarily a loose to compact brown to reddishbrown silt, with sandy silt recorded in some levels. In most cases, tests were terminated when consecutive negative levels were encountered at depths below $30 \mathrm{~cm}$, or when either yellow clay or a high frequency of gravel was encountered. The underlying clay and gravel were primarily present along the western edge of the midden. In several cases, the tests were terminated because depths were greater than $60 \mathrm{cmbs}$.

Figure 6-75 shows that 19 of the 30 shovel tests $(63 \%)$ were positive. Sixty percent of the tests had chipped stone present, and 33 percent had fire-cracked rock. Those shovel tests to the north and east of the midden were primarily positive, while tests in the western and southwestern sections were consistently negative.

Material recovered from the shovel tests included 104 flakes, one point, one biface, and two utilized/retouched flakes. Fire-cracked rock was not counted from the shovel tests at this site. However, fire-cracked rock was present in 29 different levels from 10 shovel tests. In addition, mussel shell was noted in five shovel tests. While 75 percent of the chipped stone debitage was recovered from the upper 30 $\mathrm{cm}$ of the shovel tests, material was present in all levels, with 12.5 percent of the material recovered from below 50 $\mathrm{cm}$ in depth. 


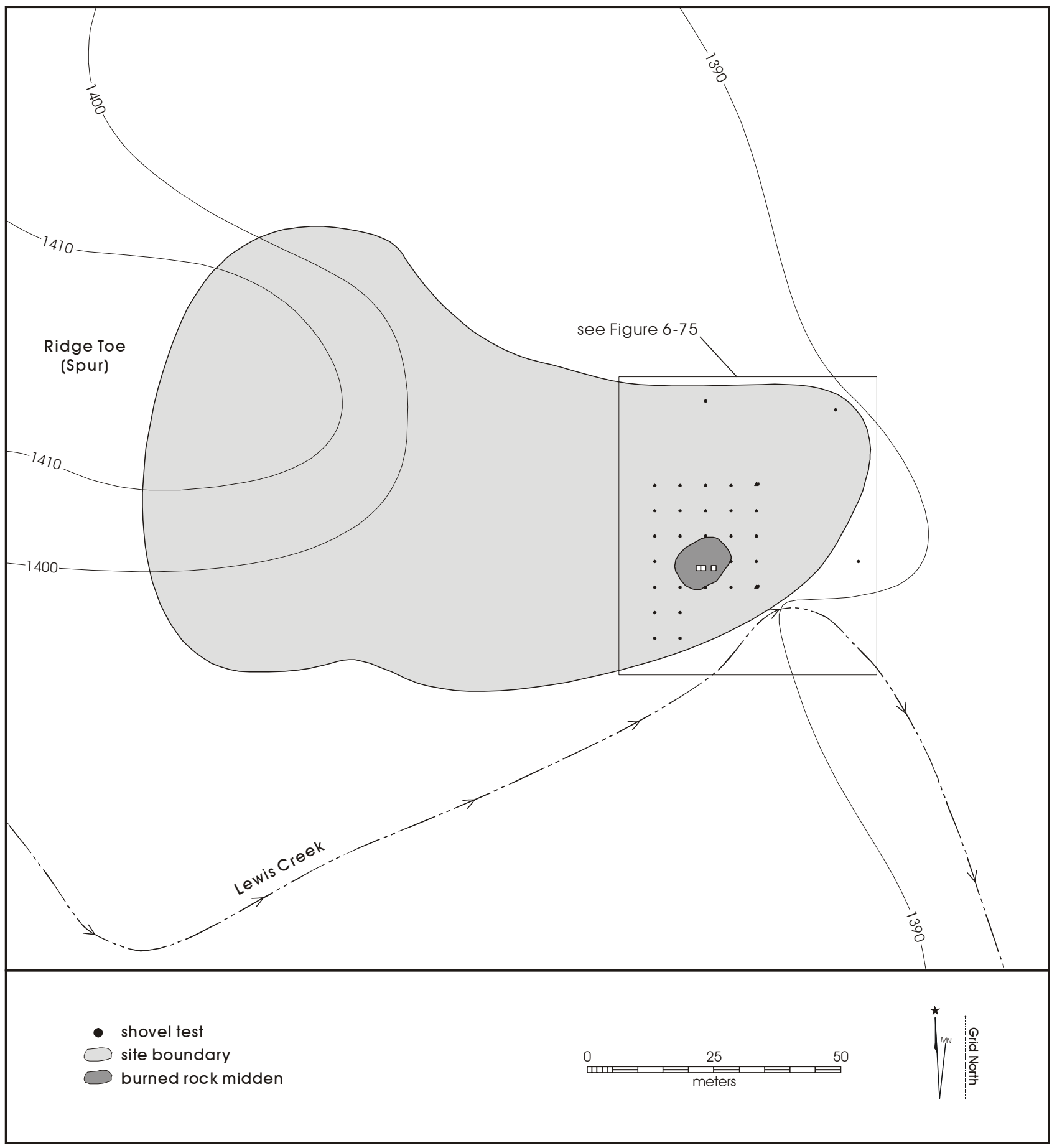

Figure 6-74. Site 41BR478 with burned rock midden and shovel tests identified. 


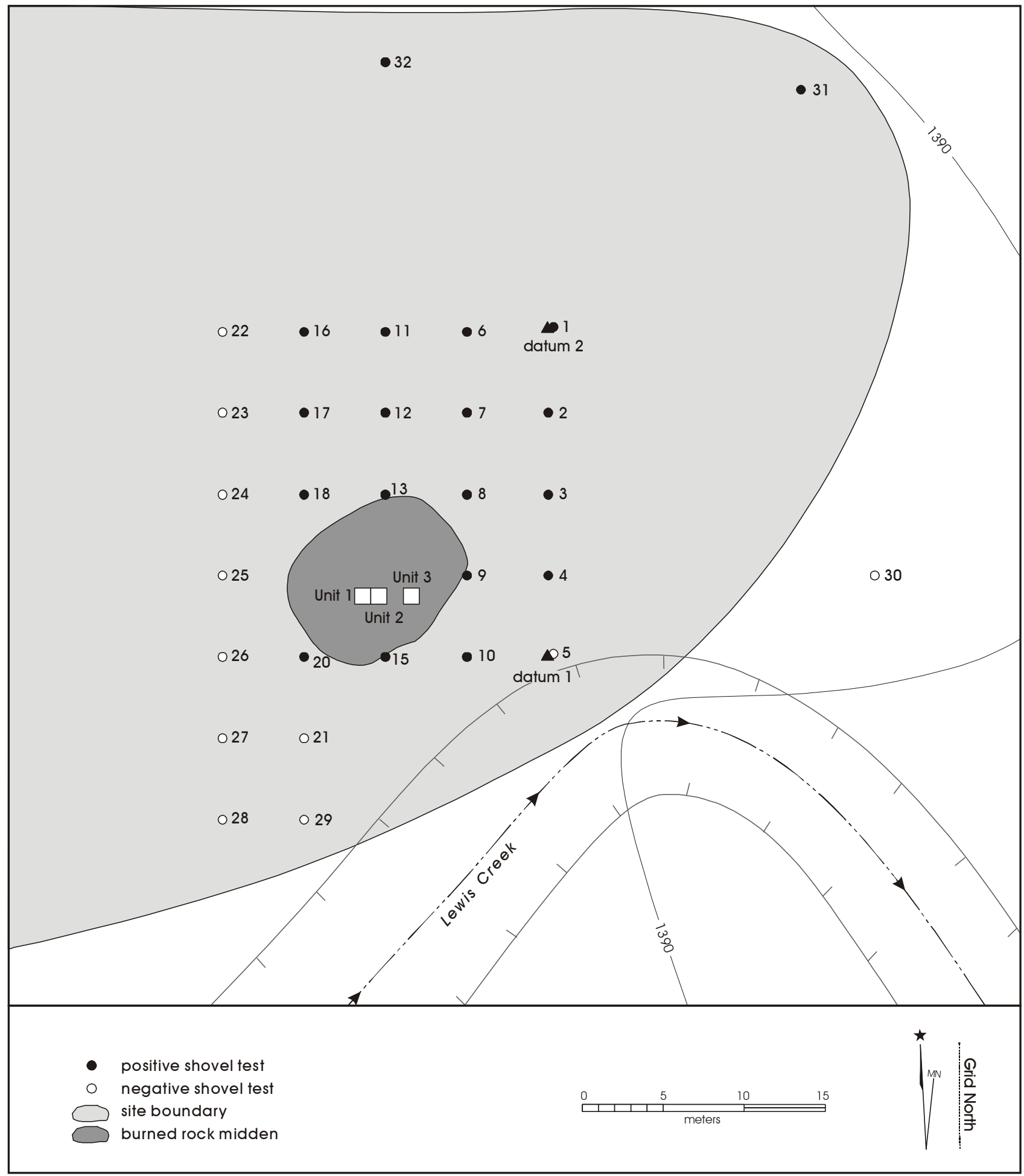

Figure 6-75. Midden area on $41 B R 478$ with shovel tests identified. 


\section{Surface Collections}

No systematic surface collections were made from this site. The density of material around the midden was minimal, and while material was present away from the midden, no concentrations were observed. No isolated collections were made.

\section{Excavation Results}

Three 1-x-1-m units were excavated at site 41BR478 (see Figure 6-75). All three units were placed in the midden. The decision to focus all testing on the midden was, in part, related to the high frequency of positive shovel tests at a site level, as well as the extreme depth of many of the recovered items in shovel tests. That is, shovel testing failed to identify any clear cluster of material that could serve as the focus of investigation.

\section{Midden Units}

Two contiguous units, designated Units 1 and 2, were excavated in the center of the midden, with the third unit placed $1 \mathrm{~m}$ to the east, along the midden edge. Figure 6-76 presents a profile of these three units.

Examination of the profile for Units 1 and 2 shows that the midden deposits consisted of roughly 60 to $65 \mathrm{~cm}$ of fill, divided into two distinct zones. These zones were underlain by yellowish silty clay. The upper zone in the midden was primarily gray clay loam, with increasing silt and calcium carbonate present in the second zone. A volume of $1.45 \mathrm{~m}^{3}$ of sediment was removed from these two midden units, with roughly $1.35 \mathrm{~m}^{3}$ being in midden deposits. No central features were identified in these units.

Artifact density within these two central units was high, with a recovery of 328 pieces of chipped stone debitage, six bifaces, three utilized/retouched items, three cores, and a projectile point. An artifact density of just over 235 artifacts per cubic meter of sediment was present in these central units. Mussel shell was also present, with just over 116 grams being collected.

From these two units we removed 7,303 pieces of firecracked rock greater than one inch in size. As additional $94.49 \mathrm{~kg}$ of rock less than one inch in size was also recorded. While raw material was not systematically recorded for this midden, sandstone, limestone, and conglomerate were observed, with sandstone accounting for well over 95 percent of the stone.
Unit 3, located closer to the midden edge, had a similar depositional sequence, though the distinction between the bottom of the midden and the yellowish silty clay base was not as clear as in the two central units (see Figure 6-76). Midden deposits accounted for roughly $.54 \mathrm{~m}^{3}$ of sediment, with an additional $.10 \mathrm{~m}^{3}$ excavated below the midden.

Artifact density within Unit 3 was high. Eighty pieces of chipped stone debitage, one projectile point, one biface, and two utilized/retouched items were recovered. A density of about 131 artifacts per cubic meter of sediment was present. This unit produced 101.75 grams of mussel shell.

Unit 3 contained 6,165 pieces of fire-cracked rock greater than one inch in size. An additional $54.09 \mathrm{~kg}$ of rock less than one inch in size was also recorded. The raw material pattern in this unit was similar to that observed in the two central units, with sandstone dominating the fire-cracked rock.

\section{Artifact Summary}

Five hundred and twelve pieces of debitage, eight bifaces, three cores, seven retouched/utilized items, and three projectile points were collected from 41BR478. Appendix F presents scans of selected tools from this site. Chert was the only tool stone represented. Roughly 80 percent of the flakes lacked cortex, with only five flakes $(1.0 \%)$ having 100 percent dorsal cortex cover.

The three projectile points (see Appendix E) include a Middle Archaic Nolan from Shovel Test 13, and two Late Archaic forms from the midden, a Pedernales and a Bulverde. These points, in combination with those collected by Wormser and Sullo-Prewitt (2001:127-129), suggest occupation throughout the Archaic period at this site.

\section{Other Samples}

Only three pieces of vertebrate fauna were recovered from CAR's work at 41BR478 (see Appendix B). As with several other sites, the low incidence of faunal recovery does not appear to be solely a function of preservation, as the recovery of carbonized material within the midden was adequate. Two metatarsals from a white-tailed deer (Odocoileus virginianus) were recovered from Shovel Test 4 . While neither specimen was burned, they were badly weathered. In addition, a fragment of turtle (Testudines sp.) was recovered from Unit 2 within the midden. This specimen was burned. 


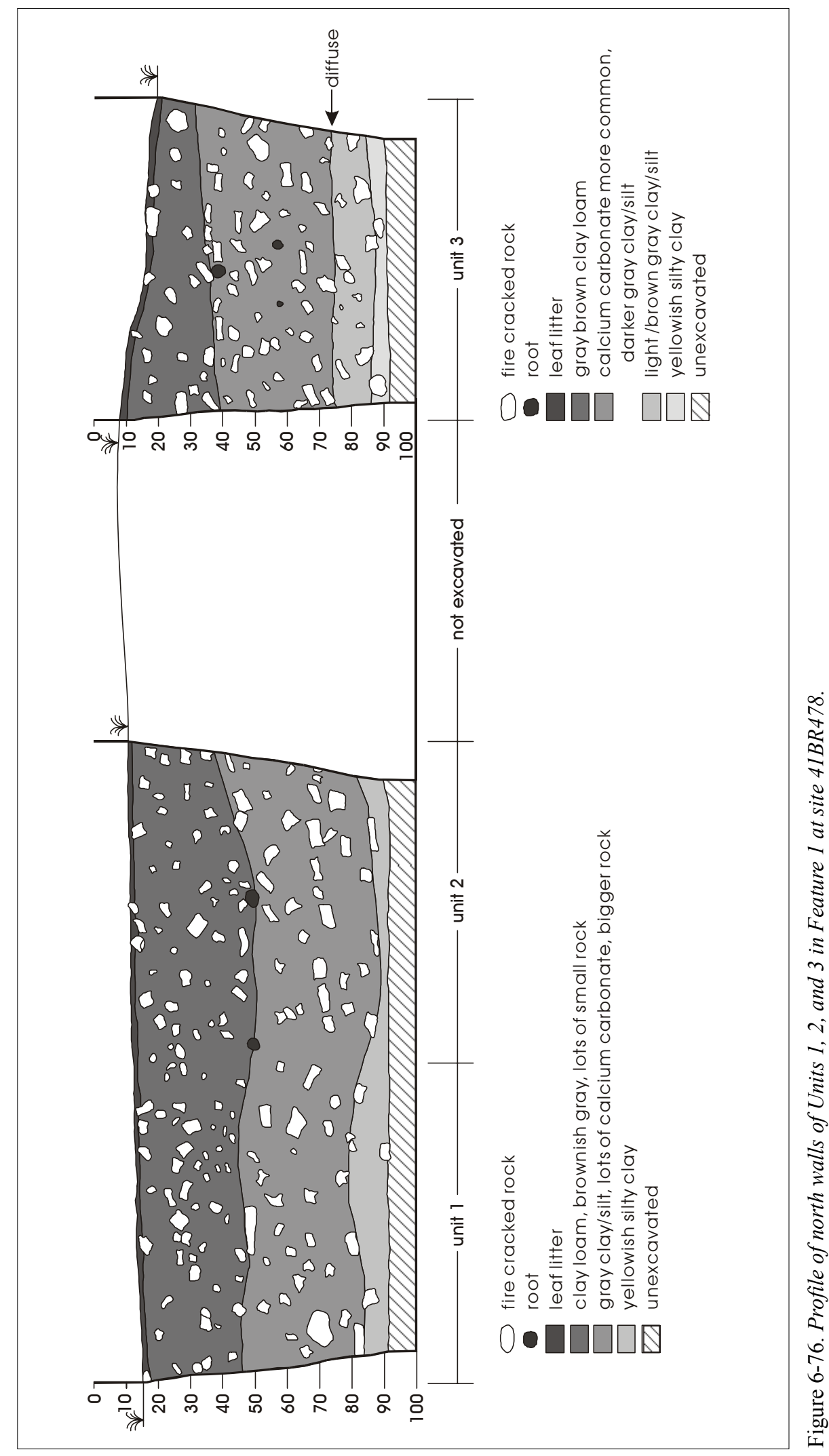


No macrobotanical identification samples were collected from this site. As summarized by Dering (Appendix C), both of the flotation samples from the midden contained carbonized wood, with mesquite and oak being identified. In addition, one sample contained a carbonized mesquite seed.

As noted above, mussel shell was identified in both the shovel tests and in the midden excavations. In all, over 265 grams of mussel shell were recovered from our work at the site. Goodfriend examined seven samples (Appendix D) and identified specimens of Quadrula apiculata $(\mathrm{n}=1)$, Quadrula houstonensis $(\mathrm{n}=3)$, Amblema plicata $(\mathrm{n}=1)$, and Cyrtonaias tampicoensis $(\mathrm{n}=1)$. One specimen was too fragmentary to identify.

\section{Radiocarbon Dates}

Two radiocarbon samples were submitted from the site. Both samples came from Unit 2, within the center of the midden. They represent Level $5(40-50 \mathrm{cmbd})$, within the midden, and a sample from Level $9(80-90 \mathrm{cmbd})$, below the base of the midden. The corrected date for the Level 5 sample is $1160 \pm 40$ years BP, while the Level 9 date is $2830 \pm 40 \mathrm{BP}$. Appendix A provides details of these dates. If these dates are in context, it appears that the midden was in use sometime around A.D. 780 and 960. The earlier date, with a range of 1040 to 910 B.C., does not date the onset of midden use, but probably represents an earlier occupation of the site.

\section{Summary}

CAR's work at site 41BR478 suggests that the burned rock midden dates to the Late Prehistoric period. An earlier radiocarbon date, taken from sediments below the midden, suggests that the site was also in use during the Late Archaic. Three diagnostic points collected from the site are consistent with that earlier use. In combination with diagnostics collected by Wormser and Sullo-Prewitt (2001:127-129), it appears that the site was occupied at some level throughout the Archaic and into the Late Prehistoric.

Shovel testing results from outside the midden revealed moderate subsurface density and buried deposits. The percentage of positive shovel tests at a site level was relatively high (63\%), and an average of 3.6 chipped stone items were present in the 30 excavated shovel tests. While 75 percent of the chipped stone was recovered within the upper $30 \mathrm{~cm}$ of the site, 12.5 percent was below $50 \mathrm{~cm}$ in depth.
No excavation units were placed outside of the midden. The three midden units produced high artifact densities. Within the central portion of the midden, density was over 235 artifacts per cubic meter of sediment. On the midden ring, density was roughly 131 artifacts per cubic meter of sediment. Both vertebrate faunal material and mussel shell were recovered from the site. While no macrobotanical samples were submitted for identification from this site, flotation samples produced wood charcoal identified as oak and mesquite. In addition, a single carbonized mesquite seed was present.

Conditions for preservation of ethnobotanical material within the midden are good. In addition, we have no data to suggest that the context of the material recovered from the midden on the site has been extensively disturbed. While worm casts were noted in the matrix of the midden, no extensive rodent disturbance was observed. Although no external excavation units were placed on this site, the shovel test data suggest moderate to high densities and, in some cases, the presence of deep deposits.

\section{$41 B R 480$}

\section{Site Description}

Wormser and Sullo-Prewitt (2001:129-130) describe this site as a burned rock midden site with a dense lithic scatter. TXARNG cultural resources staff originally recorded the site in 1997. The burned rock midden was described as a partially buried concentration of burned limestone located on the eastern edge of the site. In addition, what was recorded as a sheet midden, with a high surface density of associated lithic debris, was observed on the western edge of the site. Three shovel tests were excavated, and TXARNG archaeologists collected a single modified flake. The shovel tests all produced flakes or fire-cracked rock, though the average depth of the tests was only $8.3 \mathrm{cmbs}$, and no shovel test was excavated below $10 \mathrm{~cm}$.

CAR archaeologists visited the site in the fall of 1999, and work was conducted during the spring and summer of 2000. Site 41BR480 contained a single burned rock midden. The midden, composed primarily of sandstone rather than limestone, was only partially visible on the surface. It appeared as a very low rise, roughly $11 \mathrm{~m}$ by $8 \mathrm{~m}$, with only a minimal amount of fire-cracked rock on the surface. The feature described as a fire-cracked rock sheet midden was 
relocated, as was the dense lithic concentration. The site is located on the lower slope associated with a moderate ridge, and lies primarily on a terrace overlooking Devils River. The elevation of $41 \mathrm{BR} 480$ is roughly 1,375 feet (ca. 419 m) AMSL, and the site covers an area of about $10,400 \mathrm{~m}^{2}$ (Figure 6-77). When CAR visited the site in 1999, vegetation consisted of short grasses, oak and juniper.

\section{Shovel Test Results}

Sixty-three shovel tests were excavated at this site (Figure 6-77). Thirty-one shovel tests were excavated in the area adjacent to the sheet midden where a high density of surface lithic material was present (see Figures 6-77 and 6-78). Twenty-five shovel tests were excavated in and around the burned rock midden on the eastern edge of the site (Figure 6-79). An additional seven shovel tests were excavated to the north of the sheet midden area, as well as between the sheet midden and the burned rock midden (see Figure 6-77).

CAR's shovel tests averaged $34.4 \mathrm{cmbs}$. In the area near the sheet midden (Figure 6-78), shovel tests were shallow, with an average depth of $18 \mathrm{cmbs}$. Only a single shovel test was excavated below $20 \mathrm{cmbs}$. The shovel tests were terminated when dense, red clay was encountered. This was frequently at 10 to $20 \mathrm{cmbs}$. The 25 shovel tests excavated around the burned rock midden (Figures 6-79) were deeper. These tests averaged just over $30 \mathrm{~cm}$ in depth. The maximum shovel test depth was $70 \mathrm{cmbs}$, with most being terminated at $30 \mathrm{cmbs}$. As with the shovel tests in the sheet midden area, tests were terminated when the underlying red clay was encountered, usually at depths between 20 and $30 \mathrm{cmbs}$. The deeper shovel tests were generally in the midden, with surrounding shovel tests seldom excavated below $30 \mathrm{~cm}$. Finally, seven shovel tests were excavated to the northwest of the sheet midden, as well as in the area between the sheet midden and the burned rock midden (see Figure 6-77). These shovel tests averaged $41 \mathrm{cmbs}$, with most tests excavated below $20 \mathrm{~cm}$. Shovel tests were terminated either when the red clay was encountered, or when a dense lens of gravel was discovered, usually at depths below $40 \mathrm{~cm}$.

No ground stone was encountered in any of the shovel tests, and mussel shell was only noted in one shovel test. However, 299 pieces of lithic debitage, seven bifaces, two utilized/ retouched flakes, and 2,752 pieces of fire-cracked rock were recovered from the shovel tests. Fifty-eight of the 63 shovel tests $(92 \%)$ excavated at 41BR480 contained cultural material. Debitage recovered from the shovel tests was dominated by non-cortical pieces, with just over 80 percent of the 299 items lacking any cortex. Only four items had 100 percent dorsal cortex cover noted.

In the area near the sheet midden, 26 of the 31 shovel tests (84\%) were positive (Figure 6-78), with 25 containing chipped stone and 21 containing fire-cracked rock. One hundred and sixty pieces of debitage, four bifaces, and one utilized/retouched item (see Appendix F) were recovered from these shovel tests. Roughly 94 percent of this chipped stone was in Level $1(0-10 \mathrm{cmbs})$. Two hundred and forty pieces of fire-cracked rock were counted, with 82 percent recovered from Level 1.

All 25 of the tests excavated around the burned rock midden were positive (Figure 6-79). Forty-four pieces of debitage, one biface, and one utilized/retouched flake (see Appendix F) were recovered from 20 shovel tests, while 2,435 firecracked rocks were recovered from 22 tests. Ninety-three percent of the chipped stone came from the upper $20 \mathrm{~cm}$ of the shovel tests. The fire-cracked rock had a distribution concentrated around the surface manifestation of the burned rock midden. Based on shovel testing, Figure 6-79 shows the probable outline of the feature. The eight shovel tests excavated within this outline produced 2,268 fire-cracked rocks, an average recovery of 283.5 items per test, and frequently had rock at depths below $20 \mathrm{~cm}$. The 17 tests outside of the proposed midden area produced only 167 fire-cracked rocks, an average of roughly 10 items per test. In addition, 92 percent of the fire-cracked rocks recovered from outside of the probable midden area were recovered within $20 \mathrm{~cm}$ of the surface.

Finally, all seven of the shovel tests excavated to the northwest of the sheet-midden and between the sheet midden and the burned rock midden (see Figure 6-77) were positive. Ninety-five pieces of chipped stone debitage, two bifaces, and 77 pieces of fire-cracked rock were recovered from these seven shovel tests. However, 73 of the 97 chipped stone items, and 44 of the 77 fire-cracked rocks were from Shovel Test 33. This shovel test was also the only one with mussel shell. For these seven shovel tests, roughly 93 percent of the chipped stone and 74 percent of the fire-cracked rock came from within $20 \mathrm{~cm}$ of the surface.

A high percentage of the 63 shovel tests excavated at this site were positive. Outside of the burned rock midden, shovel 


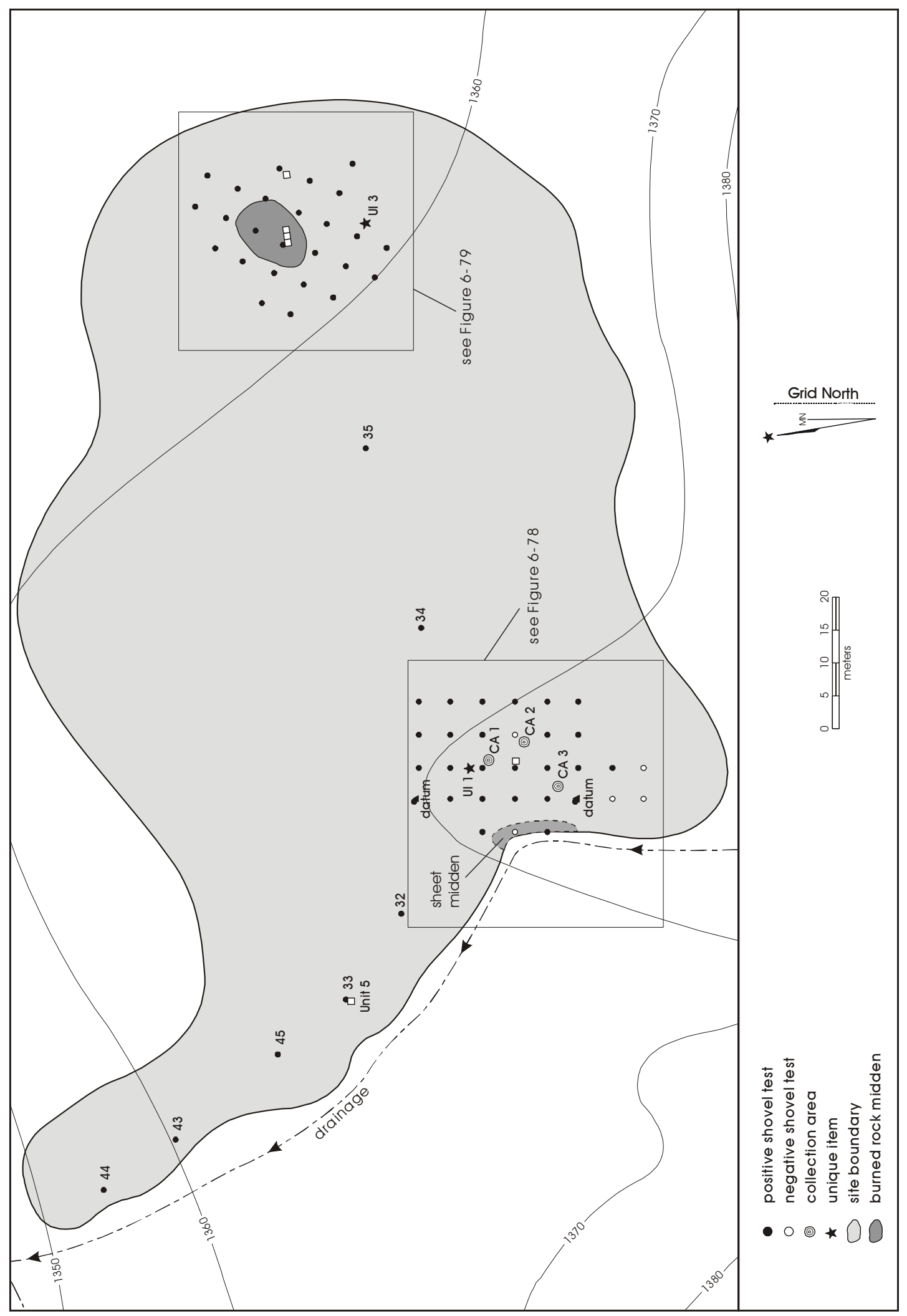

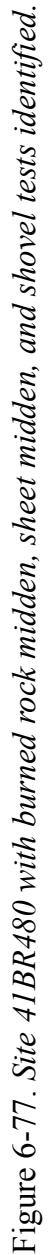




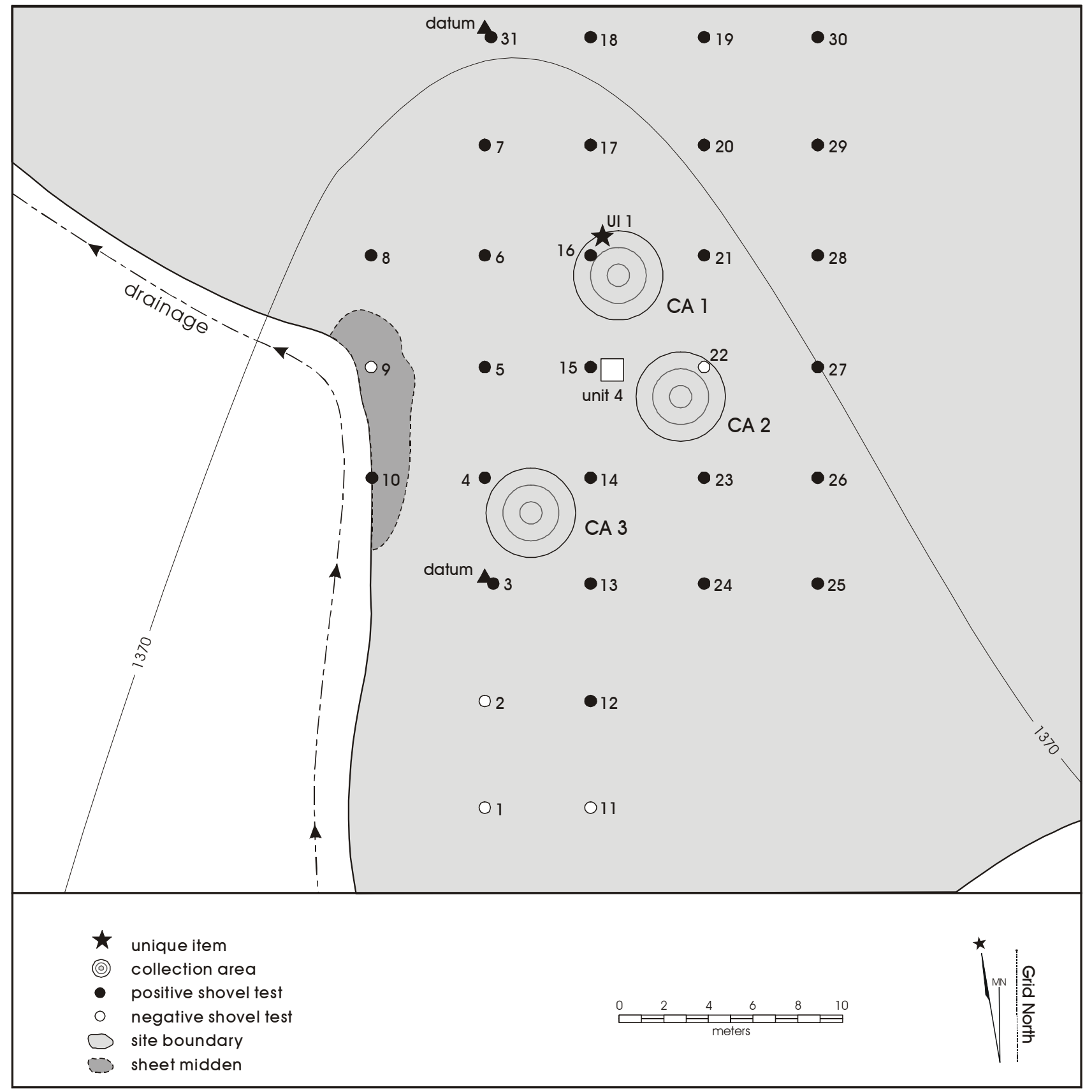

Figure 6-78. Blow-up of sheet midden area on $41 B R 480$. 
test results suggest a limited vertical distribution of material, with the vast majority of the recovered chipped stone and fire-cracked rock coming from the upper $20 \mathrm{~cm}$ of deposits. In fact, just over 96 percent of all chipped stone debitage was recovered from Levels 1 and 2, with roughly 70 percent coming from the first $10 \mathrm{~cm}$. Outside of the midden, 93 percent of all fire-cracked rock was from the upper $20 \mathrm{~cm}$, with 71 percent coming from Level 1 . The deposits at the site appear to be extremely shallow.

Further evidence for the relatively shallow nature of the deposits, especially in the area of the site with the sheet midden, can be seen in Figure 6-80. This figure is a profile of a portion of the sheet midden exposed in a north-south trending drainage on the western edge of the site (see Figure 6-78). The midden essentially starts at the surface, and extends to a maximum depth of roughly $40 \mathrm{~cm}$ below surface. The shallow nature of the feature is consistent with the shovel test data.

\section{Surface Collections}

As noted previously, surface density of material near the sheet midden was reasonably high. As a consequence, three collection areas were placed in this section of the site (Figure 6-78). The collection areas consisted of circles with a radius of $2 \mathrm{~m}$ and areas of roughly $12.57 \mathrm{~m}^{2}$.

Collection Area 1 produced 25 pieces of chipped stone debitage, three bifaces, and one utilized/retouched flake. Collection Area 2 yielded 16 pieces of debitage, one biface, one utilized/retouched flake, and one core. Collection Area 3 produced only five flakes but three cores were recovered. The highest artifact density was in Collection Area 1, with just over 2.3 items per square meter. The 46 pieces of chipped stone debitage recovered from the three collection areas were dominated by non-cortical items, with 72 percent lacking any cortex. There were no cases of flakes with 100 percent dorsal cortex cover.

\section{Excavation Results}

Six 1-x-1-m units containing an estimated $1.79 \mathrm{~m}^{3}$ of material were excavated at this site (see Figures 6-77, 6-78, and 6-79). Three contiguous 1-x-1-m units, designated Units 1, 2, and 3 , were excavated in Feature 1, the burned rock midden. In addition, a 1-x-1-m unit, designated Unit 6, was excavated to the east of the midden. A 1-x-1-m unit, designated Unit 4, was excavated to the east of the sheet midden. Finally,
Unit 5 was excavated near Shovel Test 33 to explore the high chipped stone and fire-cracked rock densities discovered in that test.

\section{Midden Units}

Figure 6-79 shows the general location of Units 1, 2, and 3 excavated within Feature 1. Figure 6-81 presents the northern profile of these three units. Examination of the profile reveals that the base of the midden was roughly 40 to $50 \mathrm{~cm}$ below surface, and all three units cut through the midden deposit. Bousman and Hodges (Appendix G) provide a detailed description of the sediments within Unit 1. As with all of the middens on this project that they examined, they note that worm casts are common in the sediments.

An estimated $1.26 \mathrm{~m}^{3}$ of sediment and rock were removed from the feature, with an additional $.53 \mathrm{~m}^{3}$ excavated below the feature. Sixty-seven artifacts were recovered from the midden deposits, including 56 pieces of debitage, five pieces of ochre, three metate fragments, one mano fragment, one biface, and one core. Only six artifacts were recovered from below the midden. Artifact density within the midden was 53.2 items per cubic meter. Below the midden, density dropped to roughly 11.3 items per cubic meter.

These three units contained 9,985 fire-cracked rocks greater than one inch in size. An additional $222 \mathrm{~kg}$ of rock less than one inch in size were recorded. While chert, conglomerate, and limestone were noted in the midden, sandstone accounted for over 99 percent of the fire-cracked rock counted.

An additional feature, designated Feature 4, was noted within Feature 1. The feature was defined at between 30 and 40 cmbd as an area lacking any rock and filled with black, dense clay. Figure 6-82 presents a plan view of the feature at 35 $\mathrm{cmbd}$. The feature may represent a later intrusion into Feature 1 , or reflect a small central pit related to the larger midden.

\section{Off-Midden Units}

Three 1-x-1-m units, containing an estimated $0.80 \mathrm{~m}^{3}$ of deposit, were excavated outside of the midden (see Figures 6-77, 6-78, and 6-79). Unit 4 was placed in the area of the sheet midden (Figure 6-78), and $.11 \mathrm{~m}^{3}$ of sediment were removed. Unit 5 was placed next to Shovel Test 33 to the northwest of the sheet midden area (Figure 6-77), and .52 $\mathrm{m}^{3}$ of sediment were removed. Finally, Unit 6 was positioned outside the burned-rock midden (Figure 6-79), and .17 $\mathrm{m}^{3}$ of sediment were removed from that excavation. 


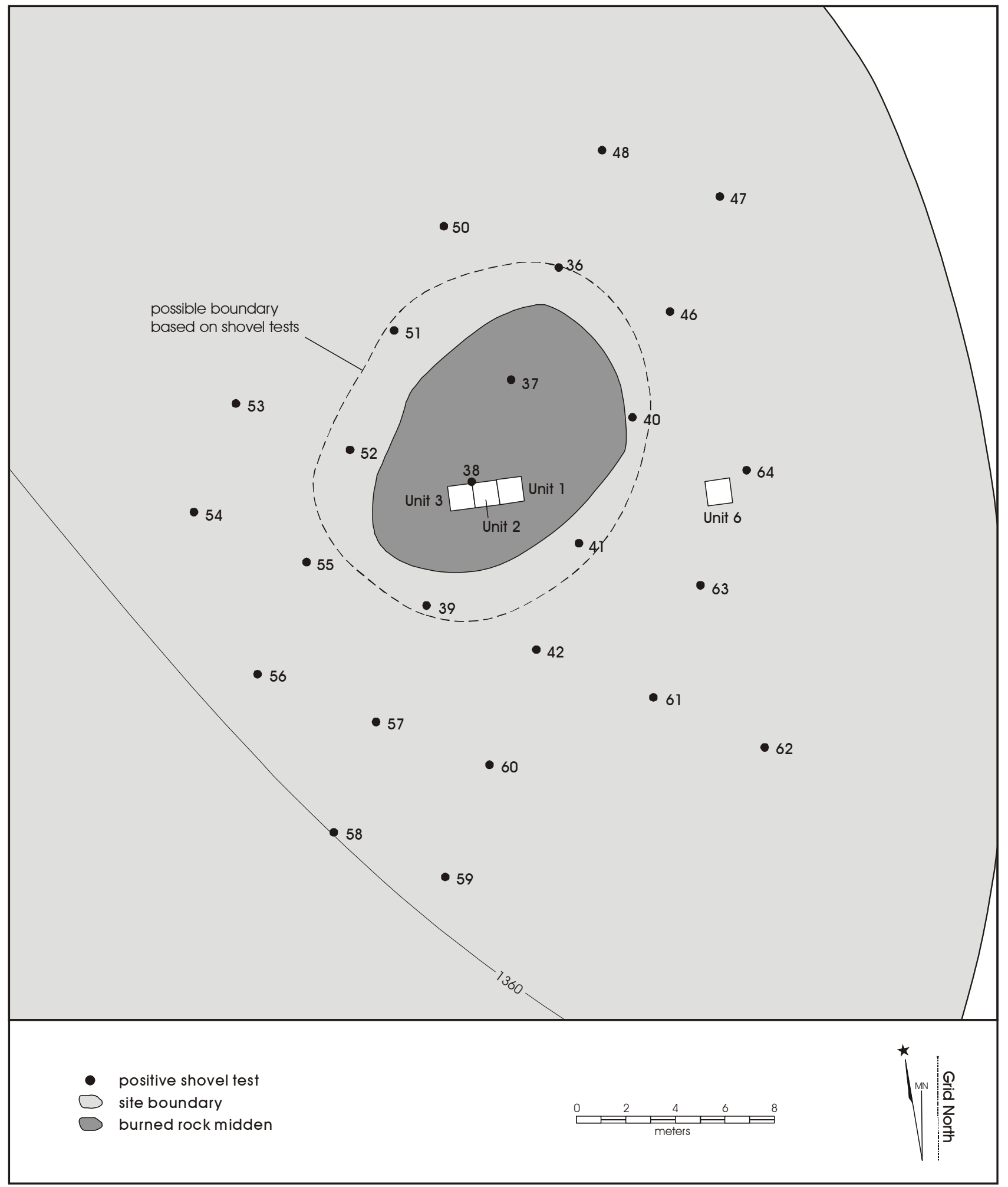

Figure 6-79. Blow-up of burned rock midden (Feature 1) area on $41 B R 480$. 


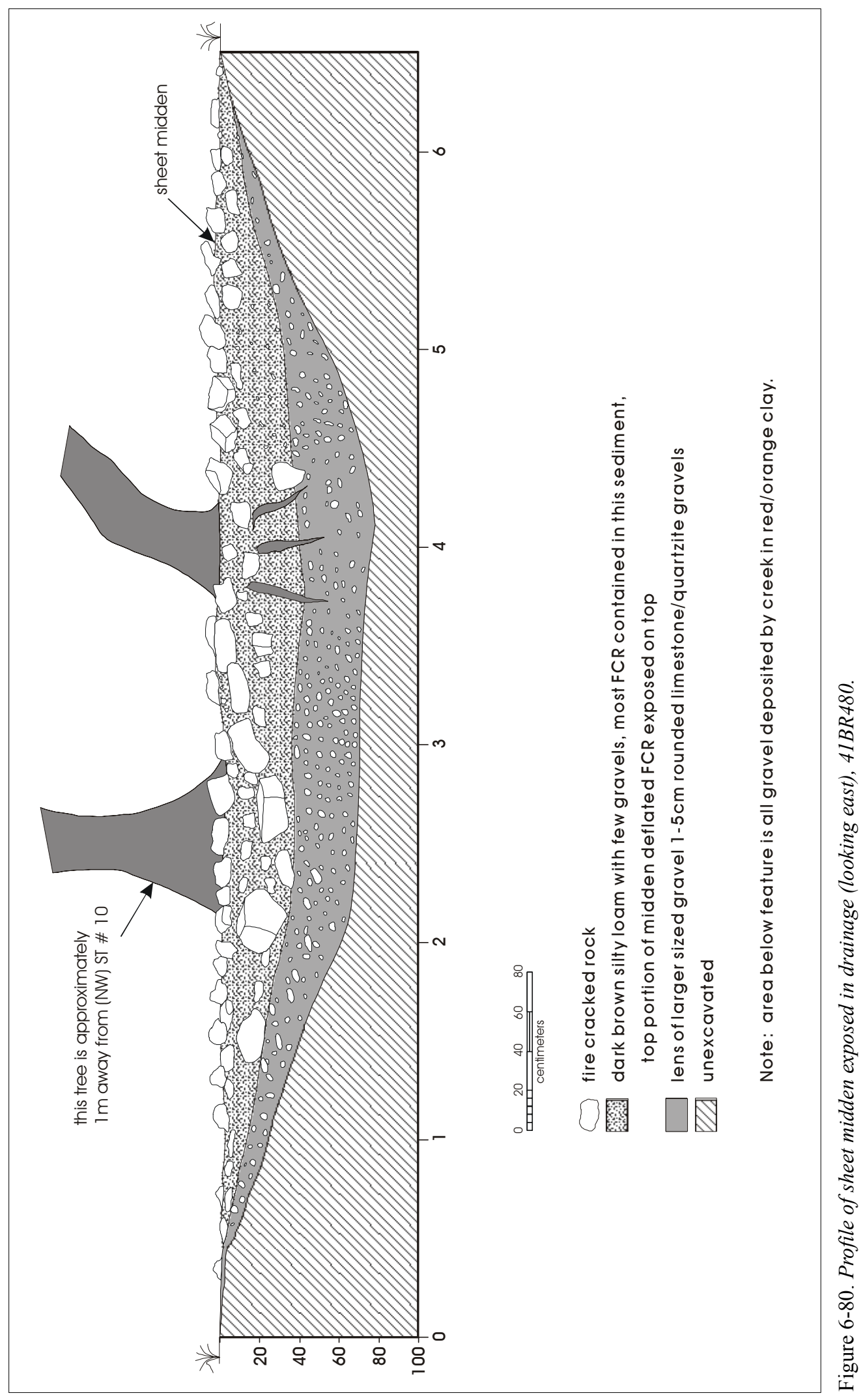


Density of material recovered within the units varied greatly, though in all cases the densities exceeded those within the midden. The lowest density was in Unit 6, where excavation produced 33 artifacts, a density of just over 188 items per cubic meter. The highest recovery rate was in Unit 5, where 445 artifacts were recovered for a density in excess of 855 items per cubic meter. Over 430 of the items recovered were found within the upper $20 \mathrm{~cm}$, with a rapid decrease below that elevation. The concentration of artifacts in the upper 20 $\mathrm{cm}$ characteristic of Units 5 and 6 was also present in Unit 4. Overall, 532 of the 544 artifacts recovered from external units (ca. 98\%) were found within $20 \mathrm{~cm}$ of the surface.

Fire-cracked rock was noted in all external excavation units, with 713 pieces greater than one inch in maximum size recovered. The majority of this total came from Unit 5, with 486 specimens. As with the chipped stone artifacts, the majority of the fire-cracked rock (ca. 95\%) came from the initial $20 \mathrm{~cm}$ of the excavations.

Two features, designated Features 2 and 3, were identified in these outside units. Feature 2, defined in Unit 5 near the surface, was identified as a dark gray silty loam, with a high concentration of unburned limestone cobbles and gravels, as well as fire-cracked limestone and sandstone. As can be seen in Figure 6-83, the feature was basin-shaped, with a maximum depth of $40 \mathrm{~cm}$. No charcoal was observed, though a high density of chipped stone was present, along with mussel shell. The function of the feature is not known, though the presence of burned rock suggests a large thermal feature. The feature has been disturbed, probably as a result of runoff and/or flooding associated with the nearby drainage.

Feature 3 was defined in Unit 4 . The feature was identified at approximately $5 \mathrm{cmbd}$ as three small $(\mathrm{ca} .20 \times 30 \mathrm{~cm}$ ), ashy deposits confined to the northwestern quadrant of the unit (see Figure 6-84). The deposit was extremely shallow, being no more than $4 \mathrm{~cm}$ in thickness. While no charcoal was observed in the feature, both fire-cracked rock and artifacts were present in this area of the excavation. The feature had no clearly defined boundaries. Excavation was terminated at approximately $11 \mathrm{cmbd}$ when the underlying red clay deposit was encountered.

\section{Artifact Summary}

Nine hundred and eighty-one chipped and ground stone artifacts were collected from 41BR480. This total includes 937 flakes, 14 bifaces, eight cores, 12 utilized or retouched items, four fragments of ground stone, and six pieces of ochre. Appendix F presents scans of selected tools from this site. Within the flakes, chert dominates the raw materials, accounting for over 99 percent of the material. Roughly 77 percent of the flakes lacked cortex, with only 13 flakes $(1.4 \%)$ having 100 percent dorsal cortex cover.

Only a single projectile point, recovered from Collection Area 1 (UI 1; Figure 6-78), was recovered from this site (Appendix E). The fragment probably represents a dart point, though it is untypable.

\section{Other Samples}

Seven pieces of vertebrate faunal material were recovered from this site (Appendix B). Six bone fragments, consistent with a deer-sized animal, were recovered from Unit 5. These were burned and showed extreme chemical weathering. In addition, a single bone fragment from a mammal of undetermined size was collected from Unit 6. This specimen was not burned.

No macrobotanical identification samples were collected from this site. As summarized by Dering (Appendix C), the single 1.5 liter flotation sample from the midden contained carbonized wood, however, the type of wood was not identified.

Shell was recovered from Shovel Test 33, excavation Unit 2 from within the midden, and excavation Units 4 and 5. However, in all cases the amount of shell was minimal, and only 42.8 grams of shell were recovered from the site. Three samples were included in the specimens identified by Goodfriend (Appendix D). All three were Quadrula houstonensis.

\section{Radiocarbon Dates}

No radiocarbon samples were submitted from this site. While small amounts of charcoal were recovered from Units 2 and 3 within the midden, the sizes of the individual pieces were extremely small.

\section{Summary}

CAR's work at site 41BR480 failed to provide any chronometric dates on the burned rock midden. At a site level, only a single, untypable dart point fragment was recovered. 


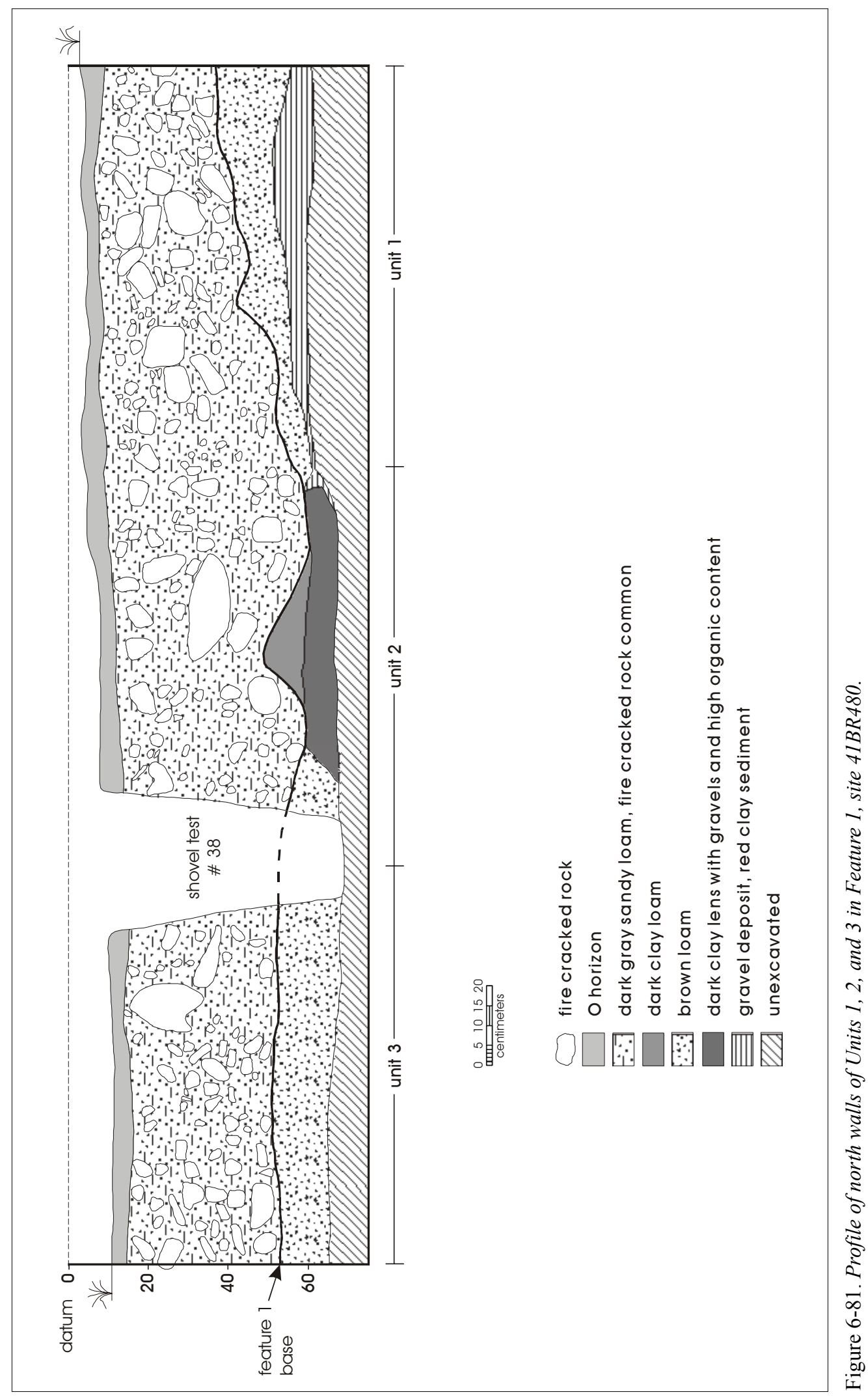


Surface collection suggests that some of the site appears to have been eroded, as evidenced by the high surface artifact counts. While 92 percent of the shovel tests excavated at this site were positive, deposits are shallowly buried. Over 96 percent of all chipped stone debitage was recovered from Levels 1 and 2, with roughly 70 percent coming from the first $10 \mathrm{~cm}$. Outside of the midden, 93 percent of all firecracked rock was from the upper $20 \mathrm{~cm}$, with 71 percent coming from Level 1

In excavation units outside of the midden, artifact density was high, with recovery in excess of 188 items per cubic meter of sediment. However, in conformance with the shovel test data, the deposits are extremely shallow. Overall, 532 of the 544 artifacts recovered from external excavation units (ca. 98\%) were found within $20 \mathrm{~cm}$ of the surface. Within the midden, artifact density was roughly 53 items per cubic meter of sediment. While several pieces of faunal material were recovered from the site, none of these were recovered from the midden. Mussel shell was present both in midden and non-midden excavation units. No macrobotanical samples were collected from this site. The single flotation sample, taken from the midden, produced carbonized wood.

Conditions for preservation of ethnobotanical material within the midden are poor. Nevertheless, we have no data to suggest that the context of the material recovered from the midden has been extensively disturbed. While worm casts are common in the midden deposits suggesting some turbation (see Appendix G), and while rodent burrowing was noted in both middens, the level of disturbance is not extensive. Outside of the midden, several features are present.

\section{$41 \mathrm{BR} 492$}

\section{Site Description}

Wormser and Sullo-Prewitt (2001:131-132) describe this site as a burned rock midden site. TXARNG cultural resources staff originally recorded the site in 1997. The burned rock midden was described as a 15 -m diameter, 50$60 \mathrm{~cm}$-high, round to oval concentration of rock. No surface artifacts were noted. A single shovel test, excavated to a depth of $15 \mathrm{cmbs}$, produced several pieces of sandstone that may have been burned, though no chipped stone was recovered. No collections were made from 41BR492.

CAR archaeologists visited the site in the fall of 1999, and work was conducted during the spring and summer of 2000.

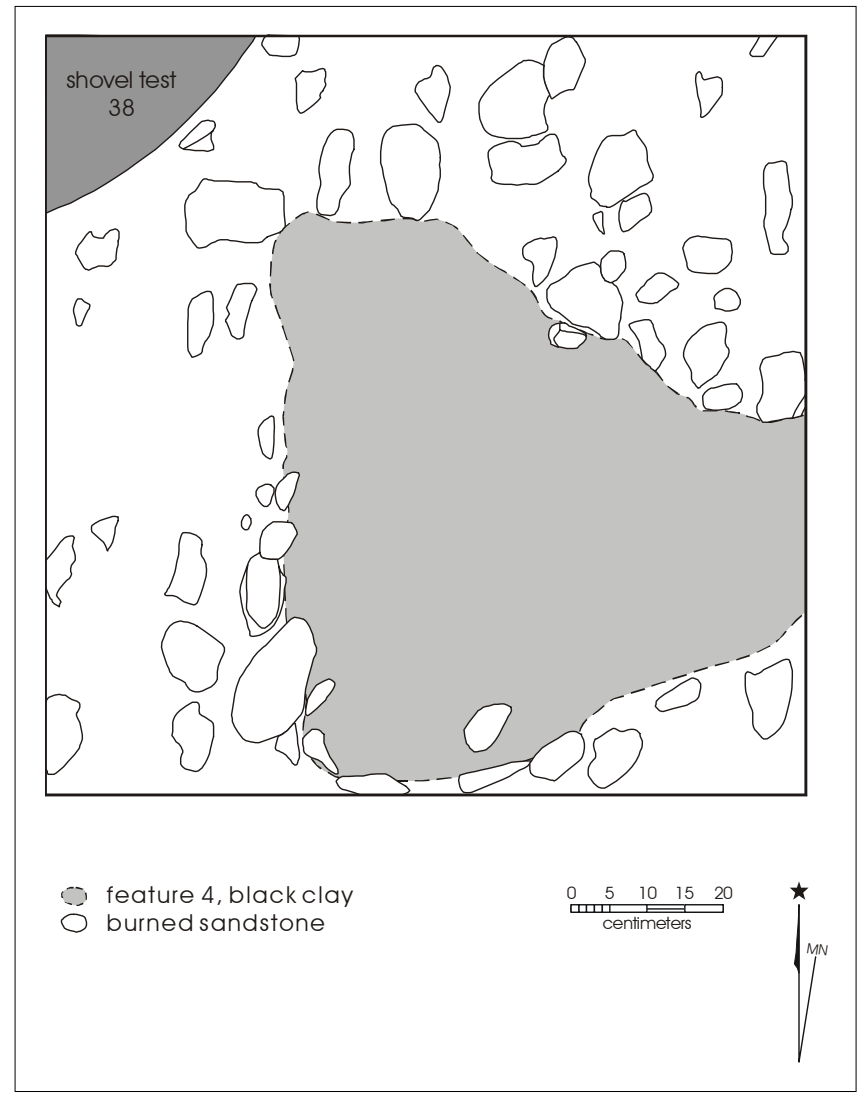

Figure 6-82. Plan view of Unit 2 showing Feature 4 at $35 \mathrm{cmbd}$, $41 B R 480$.

This site contained a single burned rock midden, roughly $13 \mathrm{~m}$ in diameter. The round midden, composed primarily of sandstone, was located roughly $30 \mathrm{~m}$ to the northeast of a steep ridge. Upon clearing the vegetation, the top of the feature had a clear central depression, surrounded by a low ring. The site is roughly $310 \mathrm{~m}$ from Lewis Creek at an elevation of about 1,390 feet (ca. $423.7 \mathrm{~m}$ ) AMSL. As defined by CAR, the site covers an area of about $4,200 \mathrm{~m}^{2}$ (Figure 6-85). In 1999, site vegetation consisted of short grasses, oak, mesquite, and prickly pear. Ground visibility was low.

\section{Shovel Test Results}

Thirty-nine shovel tests, centered on the burned rock midden, were excavated at this site (Figure 6-85). Shovel tests were terminated when brownish-red clay loam was encountered, or when consecutive sterile levels were encountered below $20 \mathrm{~cm}$. The clay loam was generally present at depths below $30 \mathrm{~cm}$. The sediments at the site were dominated by silt, and were compact to hard with small amounts of gravel 


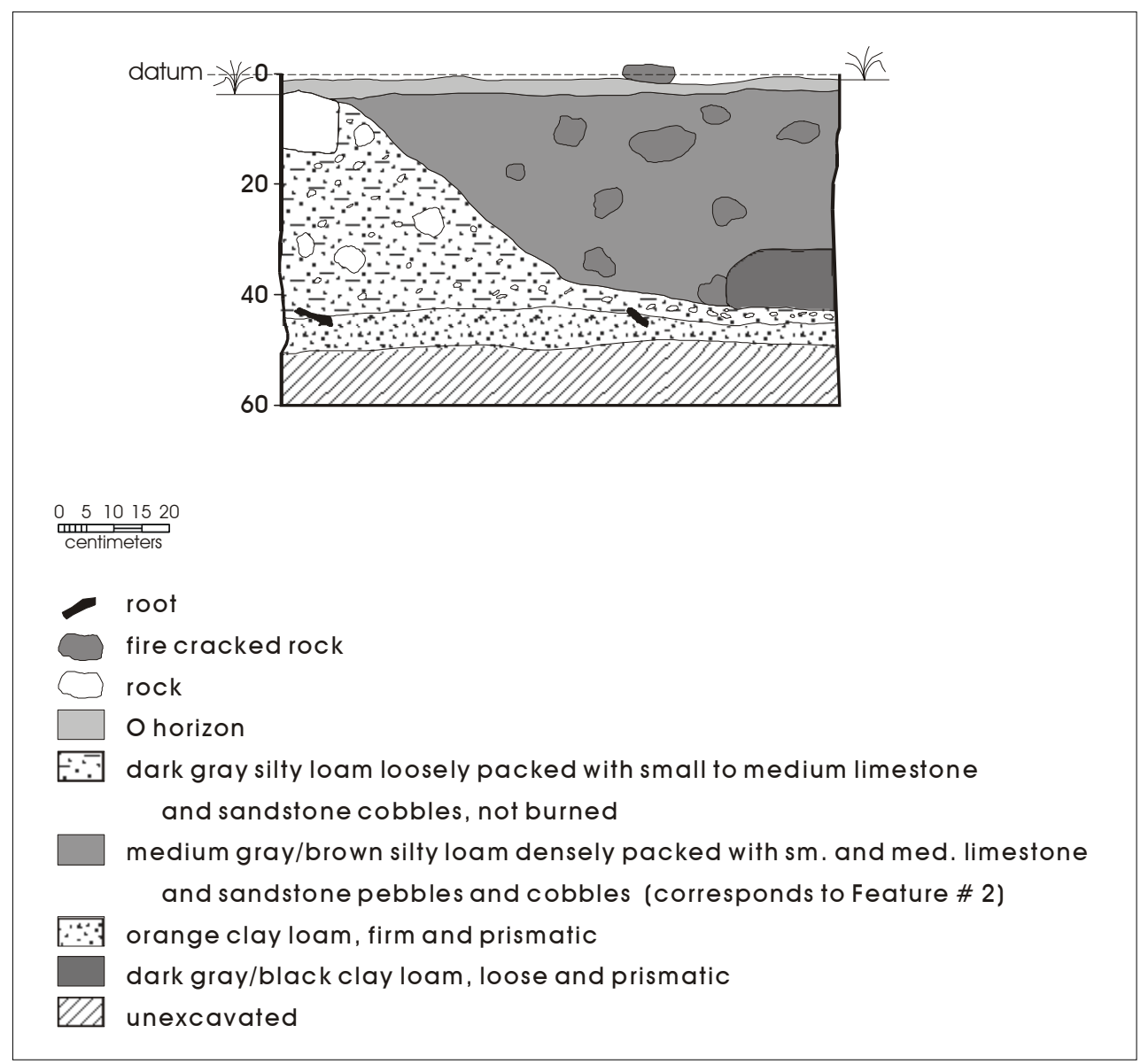

Figure 6-83. Profile of Feature 2, located in north wall of Unit 5, 41BR480.

frequently noted as inclusions. The 39 shovel tests encompassed 195 levels, with all shovel tests being dug into Level 3 (20-30 cmbs), and no shovel test excavated below $60 \mathrm{cmbs}$.

No ground stone artifacts or mussel shells were recorded in any of the shovel tests. However, 137 flakes were recovered, along with three bifaces, three cores, and two utilized/ retouched flakes. In addition, roughly 259 fire-cracked rocks were recorded in the shovel tests. Chipped stone was present in 72 percent of the shovel tests and burned rock was recorded in 59 percent. Ninety percent of the 39 shovel tests were positive at this site.

Seventy-nine percent of all chipped stone and 93 percent of all fire-cracked rock recovered in shovel tests at 41BR492 were within $30 \mathrm{~cm}$ of the surface. The density of chipped stone debitage within the first three levels $(0-30 \mathrm{~cm})$ was
.92 items per excavated level, with a density of only .37 items per level present below $30 \mathrm{~cm}$. Fire-cracked rock was even more concentrated near the surface, with a density of 2.06 items per level for the upper $30 \mathrm{~cm}$, and only .23 items per level below $30 \mathrm{~cm}$.

Many of the fire-cracked rock were clustered in shovel tests near the midden, with Shovel Tests 15 and 18 (see Figure 685 ) accounting for just over 62 percent of the 259 pieces recovered. Chipped stone was more consistently distributed across the site, with only Shovel Tests 8 and 30 having more than nine items present.

The shovel test results suggest that both chipped stone and fire-cracked rock are concentrated vertically within the upper $30 \mathrm{~cm}$ of sediment. Horizontally, fire-cracked rock is more commonly recovered near the midden, with chipped stone having a wider distribution. 


\section{Surface Collections}

As noted previously, ground visibility on the site at the time of our work was low, with much of the surface being covered by short grass. While no chipped stone artifacts were observed near the midden, the southern portion of the site had a low density of material scattered near a small drainage, as well as near Shovel Test 38. Two collection areas, each $3 \mathrm{~m}$ in diameter, were positioned in these two areas (Figure 6-85). Two unique items were also collected from this same area.

Both collection areas had extremely low densities. Collection Area 1 produced only seven pieces of debitage, along with a core and two utilized/retouched items. Collection Area 2 yielded seven pieces of debitage, a core, and a fragment of mussel shell. Unique Item 1 was an untypable projectile point fragment (see Appendix E), while Unique Item 2 was a biface fragment (Appendix F).

\section{Excavation Results}

Five 1-x-1-m units were excavated at this site (see Figure 6-85). Two contiguous 1-x-1-m units, designated Units 1 and 2, were excavated in the center of the midden. Unit 3 was excavated on the midden ring. Unit 4 was positioned to the northeast of the midden, while Unit 5 was positioned to the west. An estimated $5.65 \mathrm{~m}^{3}$ of material were removed from these five units.

\section{Midden Units}

The midden was designated Feature 1. Figure 6-86 presents a plan view and a cross-section of the midden area, with Units 1 and 2, excavated in the center of the midden, and Unit 3, excavated on the midden ring, identified.

Figure 6-87 presents a profile of the east wall of the two central units. No central feature was encountered within this 1-x-2-m excavation, though examination of the profile suggests that, below the organic material on the surface, four distinct layers are present. The upper three layers are associated with the midden. Bousman and Hodges (Appendix G) provide a detailed description of Unit 2. A volume of roughly $2.66 \mathrm{~m}^{3}$ of sediment and rock were removed from the feature in Units 1 and 2, with an additional $.11 \mathrm{~m}^{3}$ excavated below the feature. The central portion of the midden contained 99 artifacts, with only one artifact found below the midden. Artifact density within the midden

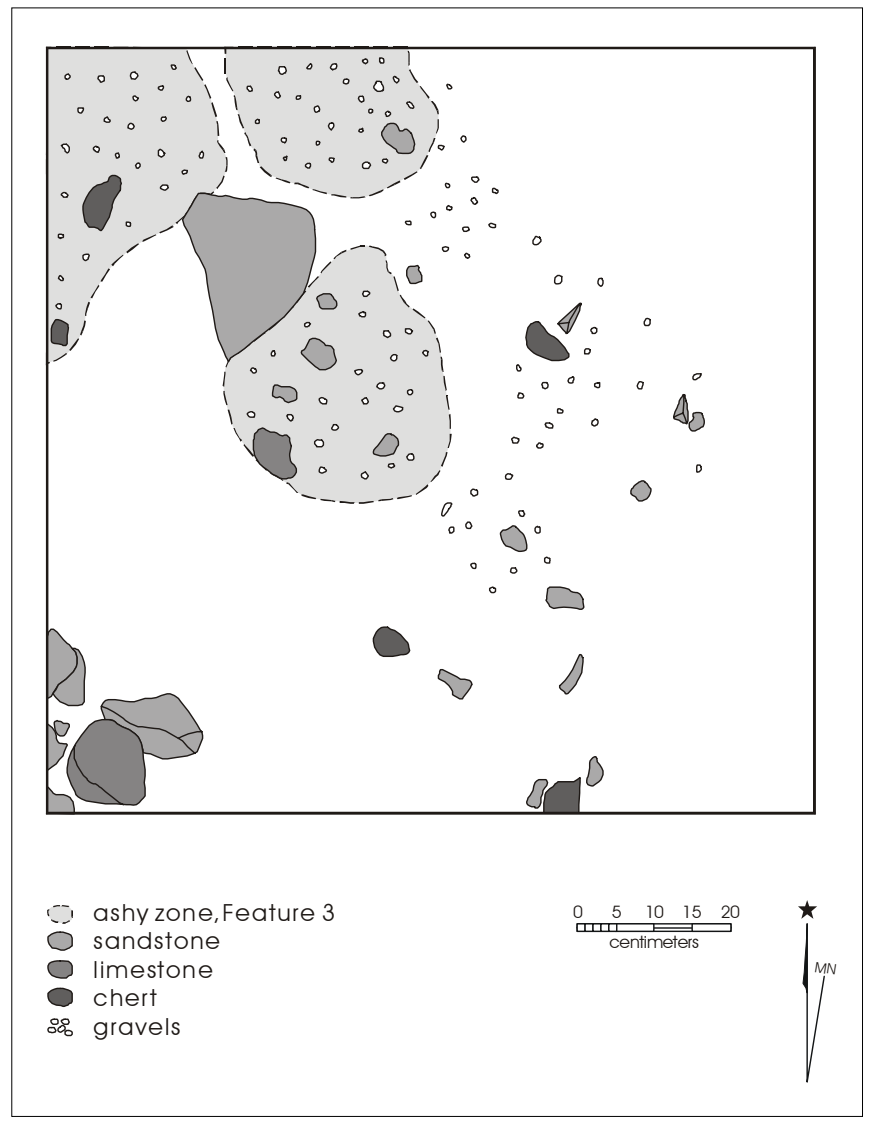

Figure 6-84. Plan view of Feature 3, Unit 4, at $10 \mathrm{cmbd}$, $41 \mathrm{BR} 480$.

was just over 37 items per cubic meter. Below the midden, density dropped to roughly nine items per cubic meter.

We recovered 17,081 fire-cracked rocks greater than one inch in size from these two central units. An additional $274.8 \mathrm{~kg}$ of rock less than one inch in size were recorded. While chert and limestone were noted in the rock, sandstone accounted for over 99 percent of the fire-cracked rock counted.

Figure 6-88 presents a profile of the west wall of Unit 3. Five major sediment zones are present below the organic horizon, with four of these being within the midden deposit. A volume of roughly $1.22 \mathrm{~m}^{3}$ of sediment was removed from the unit, with $1.18 \mathrm{~m}^{3}$ being within the midden and $.04 \mathrm{~m}^{3}$ being below the midden. Twenty-six artifacts were recovered from the excavation, all of which were within the midden fill. Artifact density within the midden portion of the unit was just over 22 items per cubic meter. 


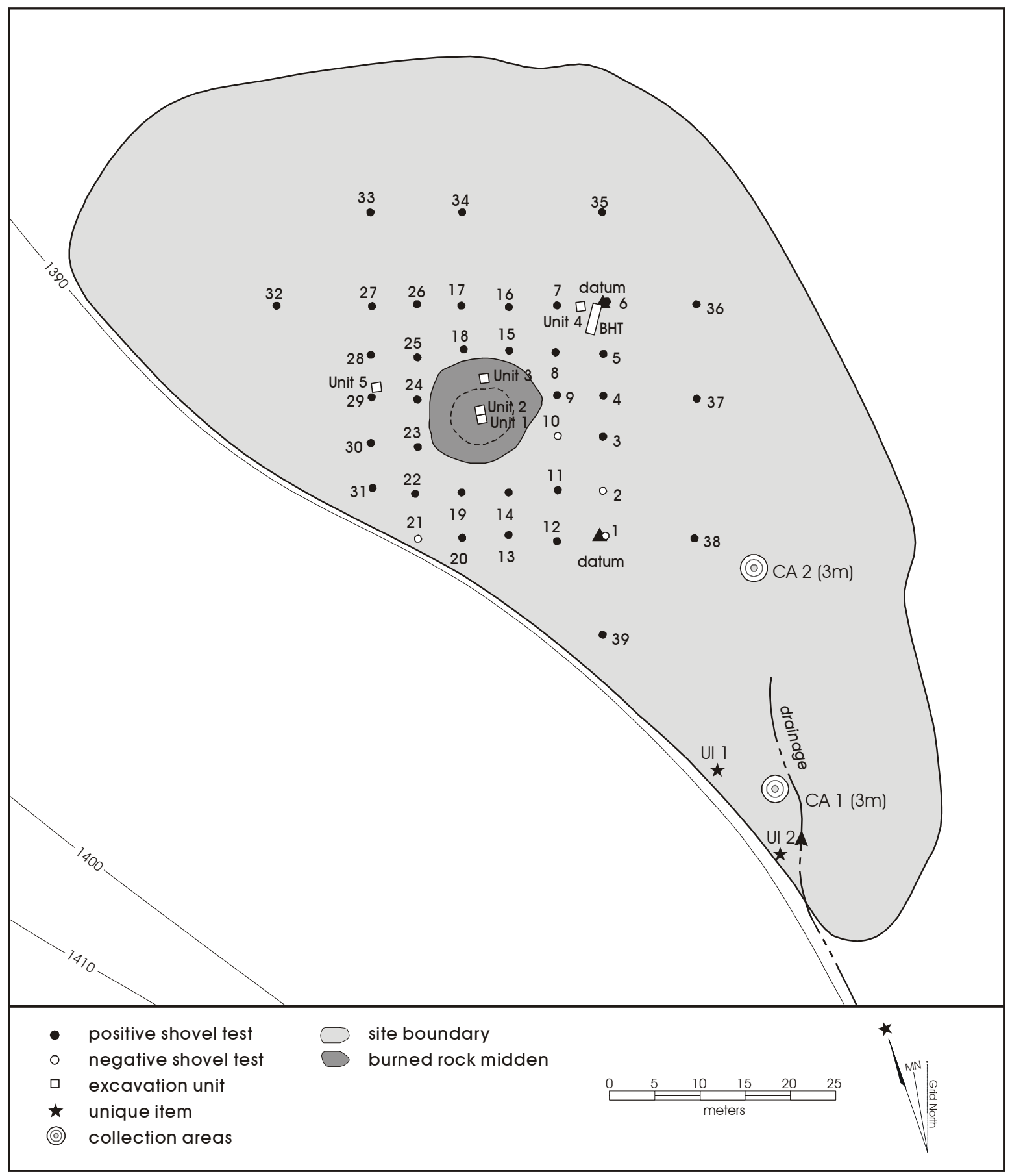

Figure 6-85. Site 41BR492 with burned rock midden, shovel tests, and excavation units identified. 

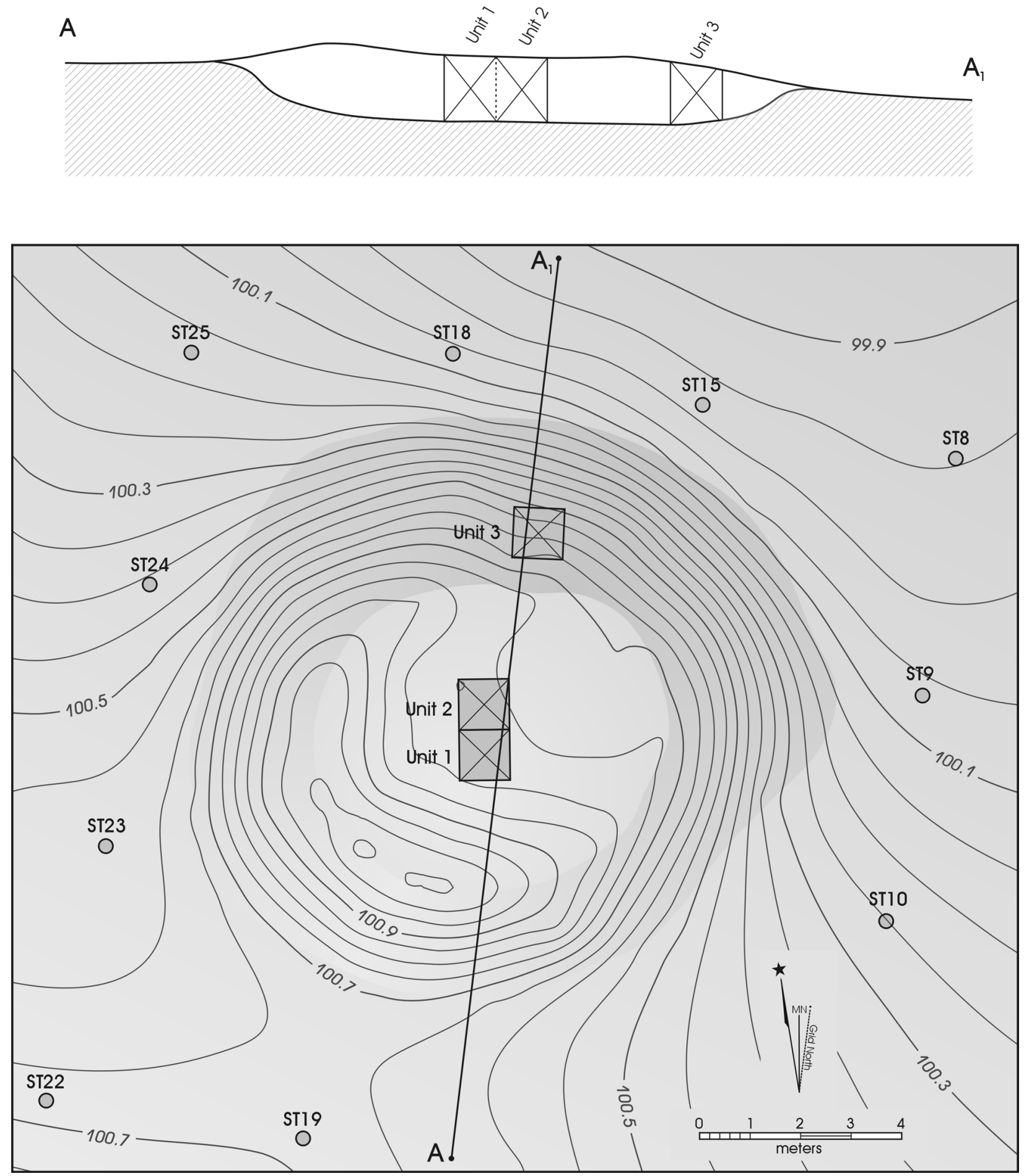

Figure 6-86. Plan view and cross-section of Feature 1 area, site 41 BR492. 
Comparison of Figure 6-88 with Figure 6-87, the profile of the two central units, will demonstrate that rock density is much higher and rock size is much smaller in Unit 3. A total of 12,188 fire-cracked rocks greater than one inch in size was recovered from this excavation, with sandstone accounting for over 99 percent of the material. In addition, $110.65 \mathrm{~kg}$ of rock less than one inch is size were recorded.

\section{Off-Midden Units}

Two 1-x-1-m units, designated Units 4 and 5, were excavated outside of the midden (see Figure 6-85). Figure 6-89 presents profiles of these units, the excavation of which removed an estimated .63 (Unit 4) and .33 (Unit 5) $\mathrm{m}^{3}$ of sediment.

Unit 4 was excavated to an average depth of $60 \mathrm{cmbd}$. Examination of the profile (Figure 6-89) shows three distinct sediment zones. Eighty-five pieces of debitage, seven lithic tools, and a piece of ochre were recovered from these zones for an artifact density of just over 147 items per cubic meter of sediment. No substantial peaks in the vertical distribution of artifacts were present. Roughly 95 percent of all artifacts recovered were spread between 10 and $50 \mathrm{cmbd}$, with Level $4(30-40 \mathrm{cmbd})$ having the highest recovery with 37 items. Only four artifacts were recovered from below $50 \mathrm{~cm}$, and no artifacts were recovered in Level 1. Fire-cracked rock was not counted from this unit, but a review of the field notes suggests that it was present in low quantities in several of the upper levels.

Unit 5, excavated to an average depth of $33 \mathrm{cmbd}$, contained three primary sediment zones below the organic horizon (see Figure 6-89). This included what appeared to be a buried A horizon. Artifact recovery in this unit was high, with 273 items present, a density of just over 827 items per cubic meter. Ninety-nine percent of the recovered material was from Levels 2 and 3, with 81 percent recovered from Level 2 (10-20 cmbd). This depth corresponds with the buried A horizon (Figure 6-89), and this level appears to represent a relatively intact deposit. Bousman and Hodges (Appendix G) provide a detailed description of this unit. As with Unit 4 , fire-cracked rocks were not counted from this unit.

No external features were identified during excavation, however, a feature was identified during the geomorphic work at the site (see Appendix G). A single backhoe trench was excavated approximately $1.5 \mathrm{~m}$ to the east of Unit 4 (see Figure 6-85); a basin-shaped, burned rock feature was encountered in the southern wall of that trench. The feature consisted of roughly 10 to 15 pieces of burned sandstone in a matrix of gray silt. No charcoal was observed in the profile wall. The top of the feature was approximately $10 \mathrm{~cm}$ below the surface, and the feature extended down to a maximum depth of $40 \mathrm{cmbd}$. The feature was roughly 70 $\mathrm{cm}$ in length in the trench wall, and it was not visible in the northern wall of the trench. Examination of the sediment removed by the backhoe revealed an additional 5 to 10 pieces of burned sandstone.

\section{Artifact Summary}

We collected 661 artifacts from 41BR492. This included 622 flakes, 10 bifaces, six cores, 15 utilized or retouched items, three projectile points, and five pieces of ochre. Appendix F presents scans of selected tools from this site. Within the flake assemblage, chert dominated the raw materials, accounting for over 99 percent of the tool stone. Roughly 78 percent of the flakes lacked cortex, with only 12 flakes (ca. 2\%) having 100 percent dorsal cortex cover.

Three projectile points were recovered from the site (Appendix E). A Late Archaic Castroville point was collected from Unit 1, Level 2. An untypable arrow point fragment was collected from Unit 4, Level 2. In addition, an untypable fragment was collected from the surface and designated UI 1. Minimally, the points suggest a Late Archaic and possibly Late Prehistoric use of the site.

\section{Other Samples}

Twelve pieces of vertebrate fauna were recovered from CAR's work at 41BR492 (see Appendix B). Much of this bone ( $\mathrm{n}=8$ pieces) came from Unit 4 , two specimens came from Unit 1, a single specimen was from Unit 3, and a single item was collected from Shovel Test 34. Two specimens, a fragment of a molar and a fragment of a phalange, were identified as Bovinae. While none of the bones were burned, the phalange had considerable chemical weathering. These items probably represent bison, as do three unidentified specimens classified as very large mammal. Six specimens could only be identified as mammal remains of undetermined size. One of these items had evidence of burning. Finally, a single bone from a bird of undetermined size was present.

No macrobotanical identification samples were collected from this site. As summarized by Dering (Appendix C), both of the flotation samples from the midden contained carbonized wood. One of the samples was identified as oak. The other sample was not identified. 


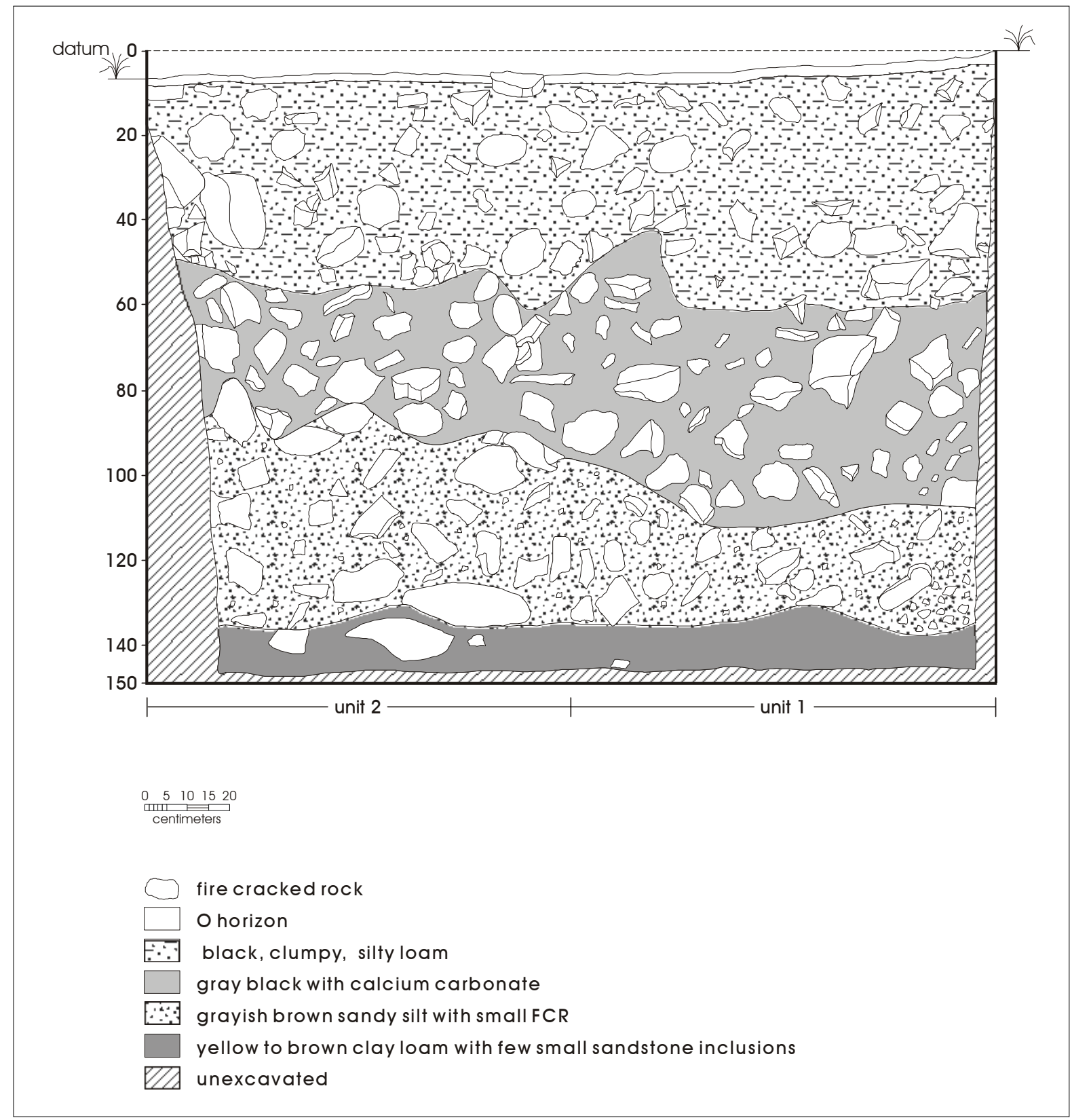

Figure 6-87. Profile of east walls of Units 1 and 2, Feature 1, site 41BR492. 
Mussel shell was recovered from four excavation units as well as from the surface of Collection Area 2. Most of the shell came from the two central midden units, with these two excavations producing over 203 grams. Shell was also present in Unit 3 and Unit 5. In all, just over 238 grams of shell were collected from this site. Four of the samples were submitted to Goodfriend for identification (Appendix D). Three of these were too fragmentary to identify. The fourth sample was identified as Potamilus purpuratus.

\section{Radiocarbon Dates}

Four radiocarbon samples were submitted from this site. All four were taken from Unit 3, excavated on the ring area of Feature 1. They represent Levels $2(10-20 \mathrm{cmbd}), 5$ (40$50 \mathrm{cmbd}), 8(70-80 \mathrm{cmbd})$, and $11(100-110 \mathrm{cmbd})$. The corrected date for the Level 2 sample is $880 \pm 40$ years BP. The Level 5 sample returned a corrected date of $790 \pm 50 \mathrm{BP}$. The corrected date for the Level 8 sample is $1240 \pm 40 \mathrm{BP}$,

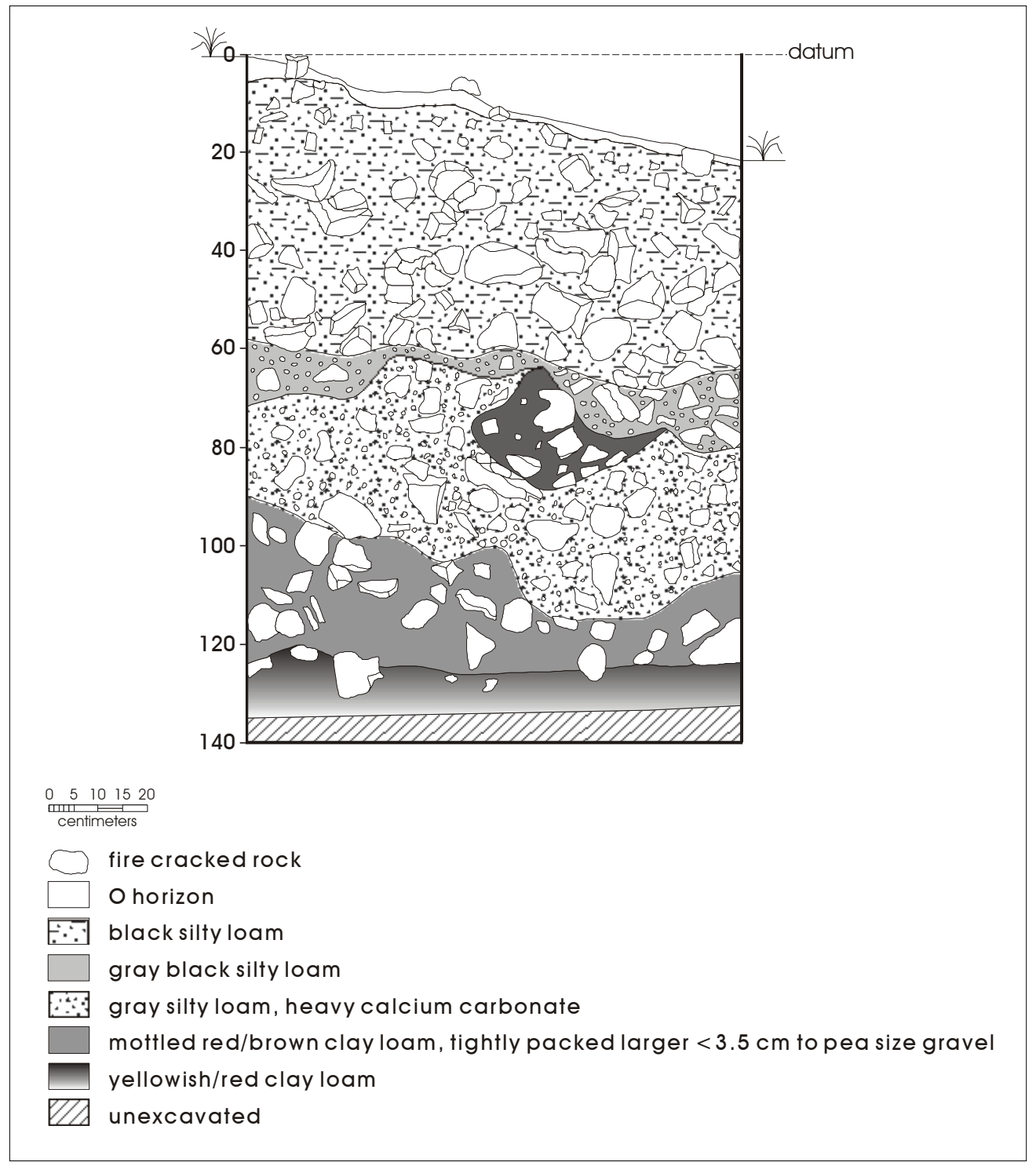

Figure 6-88. Profile of west wall of Unit 3, Feature 1, site 41 BR492. 


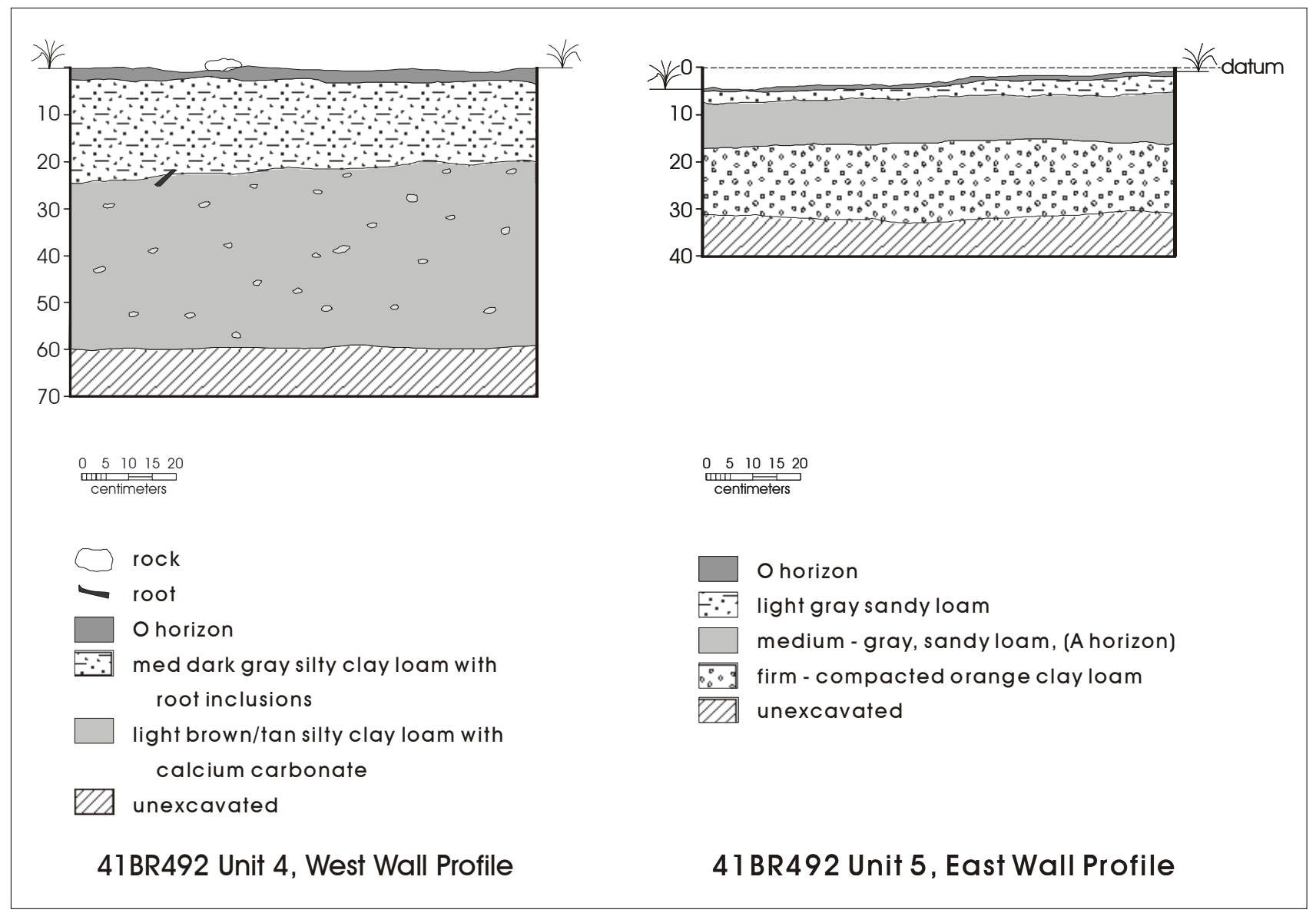

Figure 6-89. Profiles of Units 4 and 5 on site $41 B R 492$.

while the bottom date, from Level 11, is $2520 \pm 60 \mathrm{BP}$. Appendix A provides details of these dates. If these dates are in context, it appears that the beginning of midden use occurred sometime before 800-520 B.C., with the termination of use sometime around A.D. 1040 to 1220 . Using the interval estimate in the OxCal radiocarbon calibration program (Ramsey 2000), there is a 95 percent probability that the interval between the bottom date and the upper date represents at least 1,530 years and no more than 2,010 years. Using the midpoint of the distribution as an estimate, the midden may have formed in around 1,770 years. Initial use may have been during the Late Archaic, with most of the midden forming during the Late Prehistoric period.

\section{Summary}

CAR's work at site 41BR492 suggests that the burned rock midden dates to the Late Archaic, with substantial use during the Late Prehistoric. All of the diagnostic projectile points recovered from the site are consistent with the Late Archaic and Late Prehistoric period assignment.

Shovel testing and surface collection results from outside the middens revealed low surface density and shallowly buried deposits. The percentage of positive shovel tests was high, with 90 percent of the shovel tests excavated being positive. Both the chipped stone and fire-cracked rock 
densities were higher near the surface, with most material recovered within $30 \mathrm{~cm}$ of the surface. The two surface collection areas produced low densities of artifacts.

In excavation units outside of the midden, an average artifact density of roughly 381 artifacts per cubic meter was present. Unit 5 contained the highest density, with over 827 items per cubic meter of sediment. Within the midden, artifact density was much lower. The two central units produced a density of roughly 37 items per cubic meter, while the single ring unit (Unit 3 ) had a density of only 27 items per cubic meter of sediment. Both vertebrate faunal material and mussel shell was present in midden as well as non-midden excavation units. Several of these specimens were identified as bison. No macrobotanical samples were submitted for identification from this site. Flotation samples produced only wood charcoal. Some of the charcoal was identified as oak.

Conditions for preservation of ethnobotanical material within the midden are good. In addition, we have no data to suggest that the context of the material recovered from the midden has been extensively disturbed. While worm casts are common in the midden deposits suggesting some disturbance (see Appendix G), and while rodent burrowing was noted in the midden, the level of disturbance is not extensive. Outside of the midden, a feature was identified in a backhoe trench.

\section{$41 \mathrm{BR} 493$}

\section{Site Description}

Wormser and Sullo-Prewitt (2001:132-133) describe site 41BR493 as consisting of a burned rock midden. TXARNG cultural resources staff originally recorded and described the site in 1997. No shovel tests were excavated, and no surface artifacts were observed at the location.

CAR archaeologists visited the site in the spring of 2000, and work was conducted during the spring and summer of 2001. Site 41BR493 sits at the edge of a large, north-south trending ridge. A single crescent-shaped burned rock midden, measuring roughly $14 \mathrm{~m}$ in diameter, is the primary feature on the site. While a small amount of rusted metal, glass, and historic ceramics were observed on the surface, no prehistoric material was noted. The elevation of 41BR493 is roughly 1,300 feet (ca. $396.25 \mathrm{~m}$ ) AMSL. The site covers an area of about $3,850 \mathrm{~m}^{2}$ (Figure 6-90). When CAR visited the site in 2000 , the midden was covered by dense shrubby vegetation and short grasses. Within the immediate area of the midden, prickly pear and agarita were present, along with several elm and hackberry trees. The site is located roughly $175 \mathrm{~m}$ from an intermittent drainage, with Pecan Bayou roughly $900 \mathrm{~m}$ to the east.

The midden is roughly $13 \mathrm{~m}$ east-west by $16 \mathrm{~m}$ north-south. The feature is dominated by a large mound of burned rock to the north, with a possible central depression, surrounded by a very low ring of rock on the south. The feature is dominated by sandstone.

\section{Shovel Test Results}

As shown in Figure 6-90, most of the 39 shovel tests excavated at this site were concentrated to the north, east, and south of the midden. The area to the west was not tested as this was on the slope and little deposition was present over the exposed sandstone bedrock. Two shovel tests, numbers 32 and 17, were excavated in the midden. In addition, a handful of shovel tests were placed at greater distances from the midden to more clearly define site boundaries.

Shovel Test 5 was excavated to $70 \mathrm{cmbs}$, with an additional $80 \mathrm{~cm}$ excavated with a hand auger. This was done to more clearly define the sediments at this site. Excluding the single auger excavation, 205 separate levels were excavated in the site, with an average depth of $52.6 \mathrm{cmbs}$ for shovel tests. All shovel tests were excavated to at least $20 \mathrm{cmbs}$, with 38 of the 39 excavated to at least $40 \mathrm{cmbs}$.

The shovel/auger testing revealed that, with the exception of the two midden shovel tests, the upper 50 to $60 \mathrm{~cm}$ of sediment at the site was consistently a loose to compact brownish-yellow sand with varying amounts of clay. Gravels were often noted as present, especially in the upper levels. Below $60 \mathrm{~cm}$, clay increased, and the single auger test revealed compact, brown clay present to a minimum depth of $1.5 \mathrm{~m}$ below the current surface. When no artifacts were recovered, shovel tests were frequently terminated at a depth of $40 \mathrm{cmbs}$. In a small number of cases, shovel tests were terminated when solid rock was encountered.

Figure 6-90 shows that 25 of the 39 shovel tests (64\%) at the site were positive, with 17 (43.6\%) having chipped stone present and 17 having fire-cracked rock present. Shovel testing recovered 53 pieces of debitage and a single utilized/ retouched flake. While chipped stone was recovered to a depth of $90 \mathrm{cmbs}, 85$ percent of the 54 pieces of chipped 


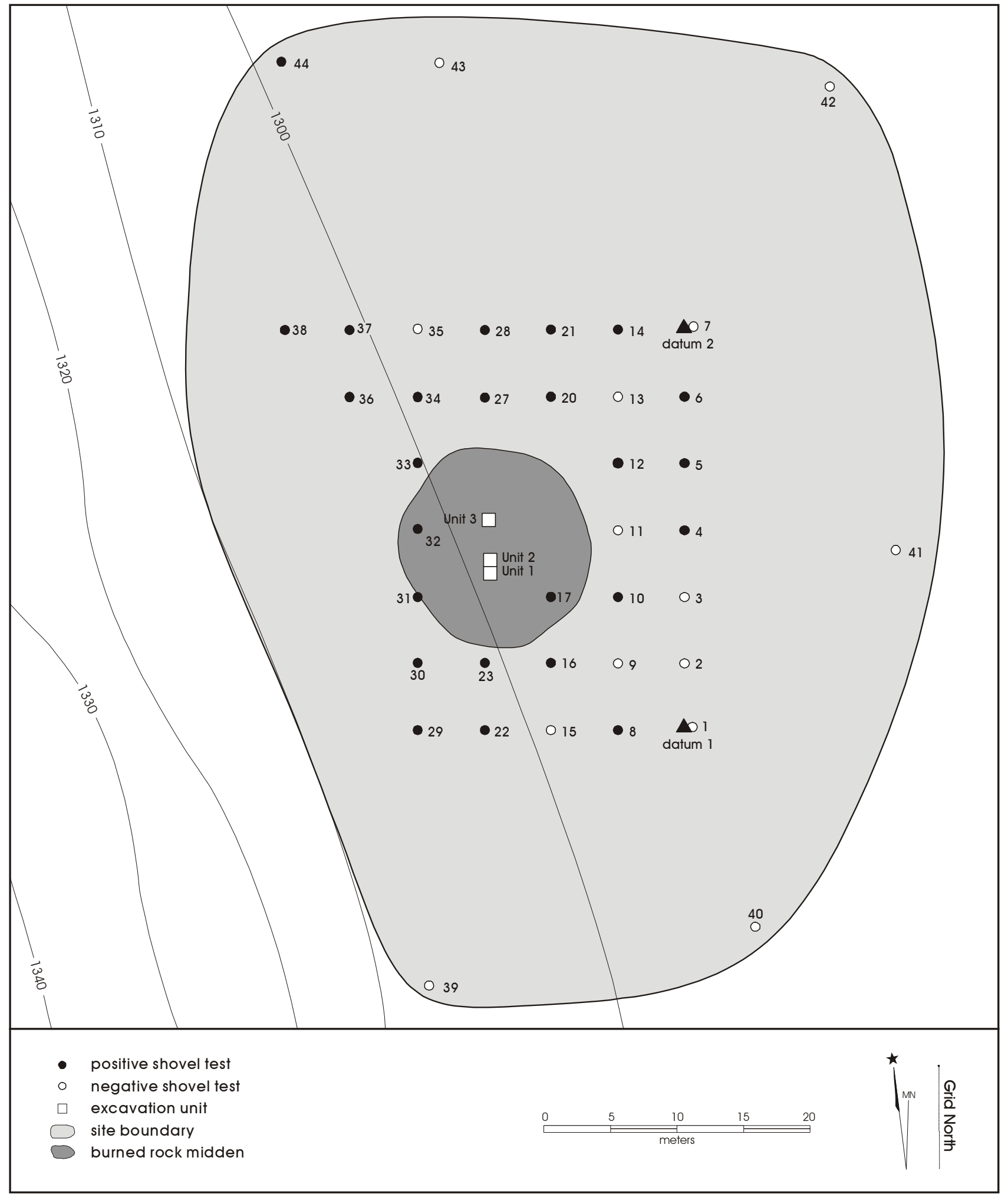

Figure 6-90. Site 41BR493 with burned rock midden, shovel tests, and excavation units identified. 
stone was recovered within $50 \mathrm{~cm}$ of the surface. Figure 6-91 presents the density of chipped stone recovery for these upper five levels at the site. The distribution is essentially bimodal, with a peak in Levels 1 and $2(0-20 \mathrm{cmbs})$, and a second peak in Level $4(30-40 \mathrm{cmbs})$. These two peaks may indicate two distinct occupation periods at this location.

Fire-cracked rock was not counted from shovel tests at the site, however, it was noted from 36 separate levels. Eliminating those shovel tests excavated in the midden, firecracked rock was present from Levels 1 through $6(0-60$ cmbs). Mussel shell was recovered from eight shovel tests, with Shovel Test 17, located in the midden, accounting for 46 percent of the recovered 26.6 grams of shell. In addition, rusted metal fragments, probably reflecting recent army activities, were noted in 27 levels, with 92.6 percent occurring within the upper $20 \mathrm{~cm}$ of the surface. Only Shovel Test 23 had any vertebrate faunal recovery, with the remains of a cottontail rabbit recovered from Level 4 . Three shovel tests $(37,38,44)$ had charcoal present-all at depths between 30 and $50 \mathrm{cmbs}$. Small amounts of historic ceramics and glass were also recovered from shovel testing at the site.

\section{Surface Collections}

Given the lack of prehistoric material observed on the surface, no collection areas were placed at this site. In addition, no unique items were collected.

\section{Excavation Results}

Three 1-x-1-m units were excavated at site 41BR493 (see Figure 6-90). All three were placed in the midden. A total volume of roughly $3.7 \mathrm{~m}^{3}$ of sediment was removed in these three units.

\section{Midden Units}

Two contiguous units, designated 1 and 2, were excavated in what was thought to be the central portion of the midden. Unit 3 was excavated to the north of these two units. It was placed on the high point of the sandstone rock pile, on what was though to be the ring of the midden.

Volumes of $.96 \mathrm{~m}^{3}$ and $1.08 \mathrm{~m}^{3}$ of sediment were removed from Units 1 and 2, respectively. While no profiles of Units 1 and 2 are available, a review of the notes and artifacts suggests that the upper $29 \mathrm{~cm}$ of both units had been disturbed. Eighty-nine pieces of rusted metal, glass, and whiteware ceramics were recovered from the excavation of these two units. All 89 pieces were within the upper $29 \mathrm{~cm}$ of the deposits, with most $(n=47)$ occurring between 8 and $18 \mathrm{~cm}$ below the modern surface. Both units were terminated at the base of the feature. No internal features were identified, though excavation notes do suggest that several different layers of rock, possibly representing different features or use episodes, were present in these central units.

Figure 6-92 presents a profile of the east wall of Unit 3. Note that the upper four levels of this profile have a high density of small rock. Examination of the excavation notes and artifact counts suggest that both metal and glass were present in this upper deposit. Twenty-four pieces of metal, some of which represent military shell fragments, as well as three pieces of glass, were recorded in this unit. All of this recent material occurred within the upper $37 \mathrm{~cm}$ of the unit, with most of the material $(n=14)$ occurring between 8 and $18 \mathrm{cmbd}$. It is likely that these upper four levels reflect recent disturbance of the midden deposits, possibly associated with military activity. The intact portion of the midden appears to be associated with the dark gray/brown silt shown in Figure 6-92. The base of the midden was at $170 \mathrm{cmbd}$, with the bottom $20 \mathrm{~cm}$ (150 to $170 \mathrm{cmbd}$ in Figure 6-92) being increasingly dominated by small gravels. Near the bottom of this ring excavation unit, it appears that the edge of a cluster of larger rocks was encountered that may have been the edge of a feature, though no feature designation was given to this cluster.

Few prehistoric artifacts were recovered from these midden excavations. Thirty-six pieces of chipped stone debitage, two bifaces, and one utilized/retouched flake were recovered from the $2.06 \mathrm{~m}^{3}$ of deposits removed from the central two units; a density of 19 items per cubic meter. Only 11 pieces of debitage and a single biface was recovered from Unit 3; an artifact density of only 7.2 artifacts per cubic meter of sediment.

Mussel shell was present in the midden. Just over 326 grams of mussel shell were recovered from the central excavation units, and 406 grams were recovered from Unit 3.

These three units contained 32,449 fire-cracked rocks greater than one inch in size. An additional $317.85 \mathrm{~kg}$ of rock less than one inch in size was also recorded. While specific counts on material were not made for this midden, sandstone accounted for the vast majority of the stone, though limestone and chert were noted in very small quantities. 


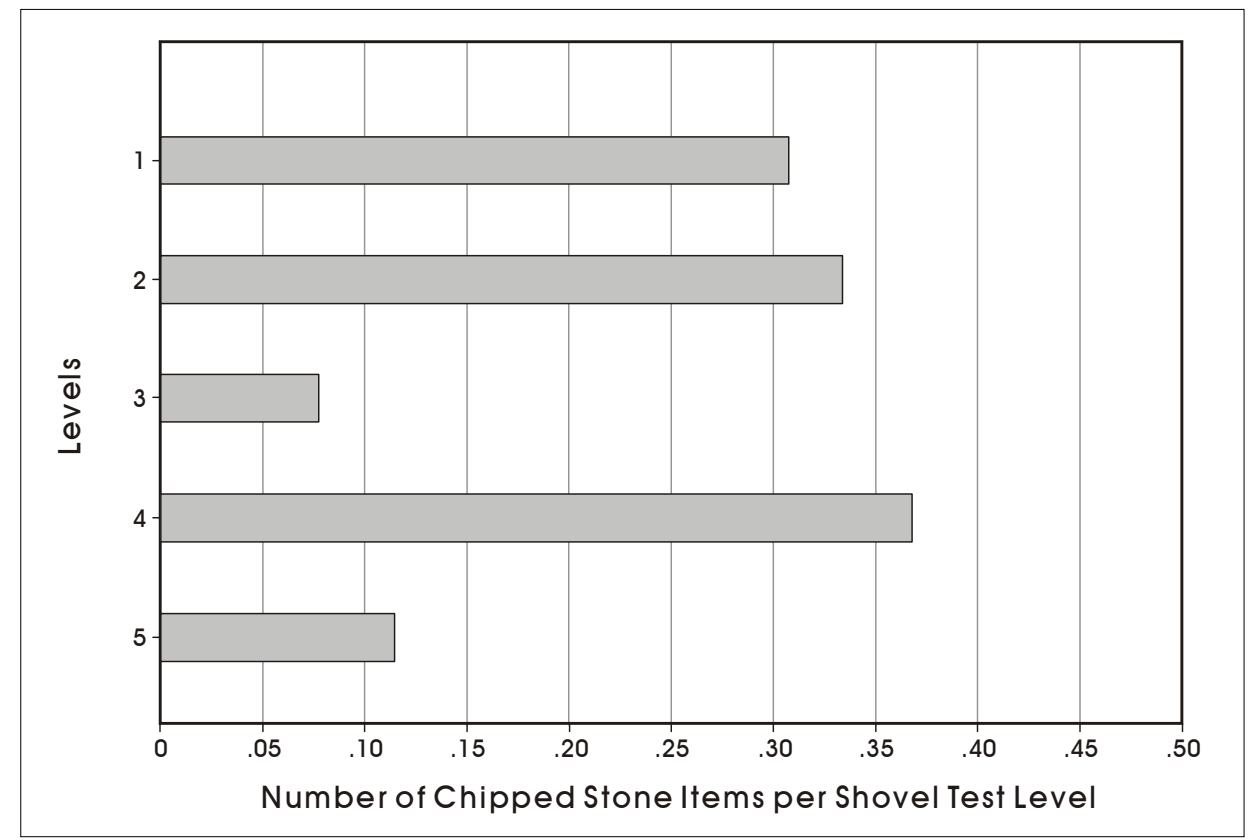

Figure 6-91. Density of chipped stone per level in shovel tests, Levels 1 through 5, at site $41 B R 493$.

\section{Artifact Summary}

One hundred and thirteen pieces of debitage, three bifaces, and two retouched/utilized items were collected from 41BR493. Appendix F presents scans of selected tools from this site. Chert accounted for 100 percent of all chipped stone. Roughly 73.5 percent of the flakes lacked cortex, with only a single flake $(0.9 \%)$ having 100 percent dorsal cortex cover. No projectile points were recovered from CAR's work at this site.

\section{Other Samples}

Five pieces of vertebrate faunal material were recovered from this site (Appendix B). A metapodial from a cottontail rabbit was recovered from Shovel Test 23. A fragment of a radius from a jackrabbit was recovered from Unit 3, Level 18. From Unit 2, Level 13, two burned fragments representing a mammal of undetermined size were recovered, as was a single fragment of a deer-sized mammal.

Eleven macrobotanical samples were submitted for identification from this site. As summarized by Dering (Appendix C), most contained bulbs or bulb fragments.
Eastern camas was identified in these samples. One of the flotation samples from the midden contained bulb fragments. In addition, both of the flotation samples contained carbonized wood identified as oak.

As noted before, mussel shell was identified in the shovel testing at this site. Shell was also common in the excavations. In all, over 758.8 grams of mussel shell were recovered during our work at the site. Goodfriend examined 15 samples (Appendix D) and identified specimens of Quadrula apiculata $(\mathrm{n}=2)$, Quadrula houstonensis $(\mathrm{n}=3)$, Amblema plicata $(\mathrm{n}=7)$, Potamilus purpuratus $(\mathrm{n}=1)$, and Tritogonia verrucosa $(\mathrm{n}=1)$. A fifteenth specimen was too fragmentary to identify.

\section{Radiocarbon Dates}

Three radiocarbon samples were submitted from the site, all from Unit 3. The samples came from Levels 5 (27-37 cmbd), 11 (86-96 cmbd), and 18 (156-166 cmbd). The corrected date for the Level 5 sample was $210 \pm 40 \mathrm{BP}$. The corrected date on the Level 11 sample was $880 \pm 40 \mathrm{BP}$. The Level 18 sample produced a corrected date of $970 \pm 40$ BP. Appendix A provides details of these dates. 


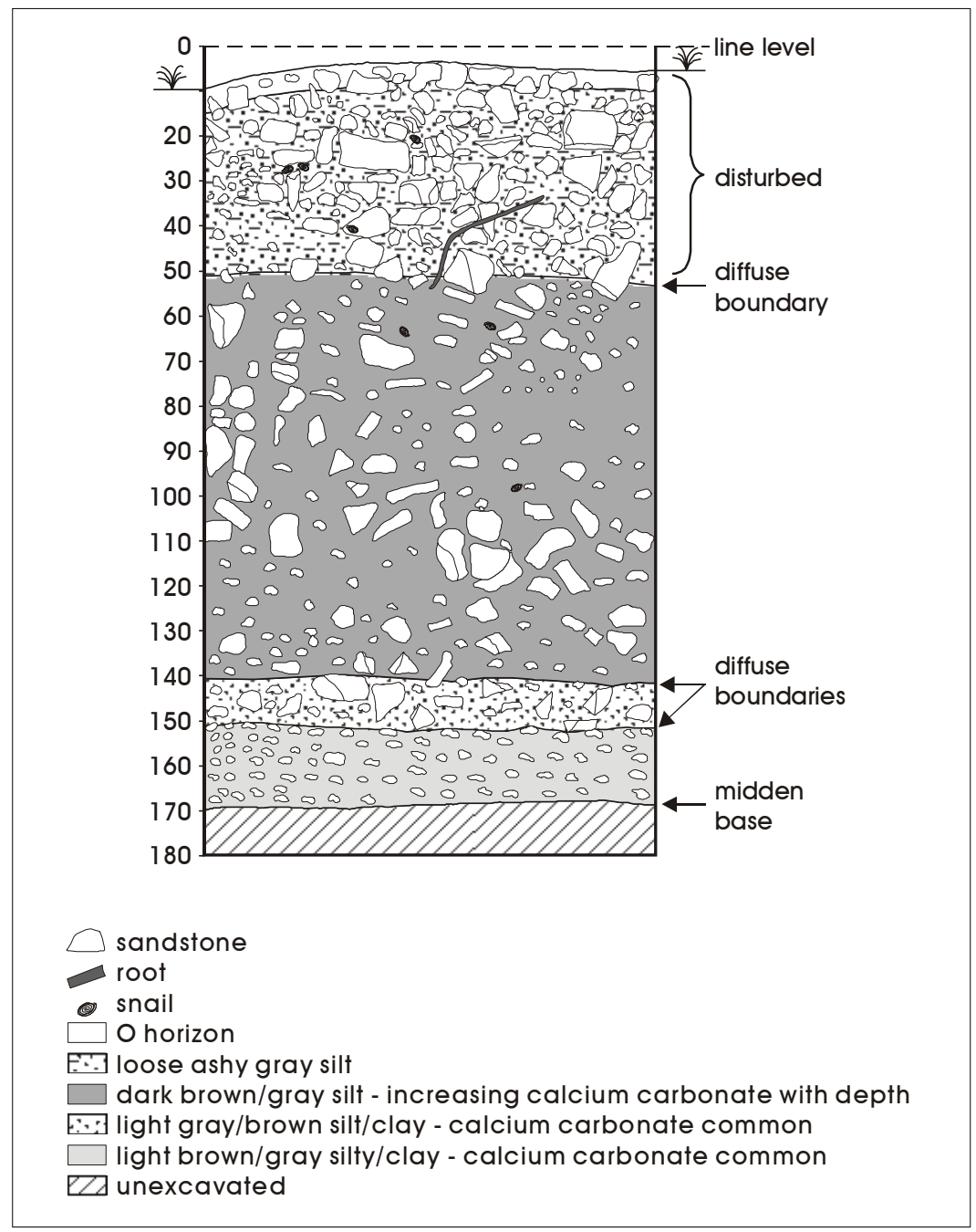

Figure 6-92. Profile of east wall of Unit 3 on site 41BR493.

The upper date, from Level 5, probably does not reflect the termination of midden use. Recall that Level 5 in this unit represented the bottom of the metal and glass contamination. When submitted, the sample was thought to be below that disturbance. However, the corrected, calibrated date produced by the OxCal radiocarbon calibration program (Ramsey 2000) of A.D. 1630 to 1960 suggests that the date probably reflects the disturbed portion of Unit 3 . If the remaining dates are in context and if they are related to midden use, the beginning of midden use, associated with Level 18, was sometime after A.D. 1010 to 1160 , with use dates for Level 11 being between A.D. 1040 and 1220.
Termination of the use of the midden occurred sometime after that date range.

Using the interval estimate in the OxCal radiocarbon calibration program (Ramsey 2000), there is a 95 percent probability that the interval between the bottom date and the Level 11 date represents no more than 200 years. The minimal time interval between the two dates is 0 years. Using the midpoint of the interval as an estimate, the material between Level 18 and Level 11, which represents approximately $70 \mathrm{~cm}$ of deposition, could have formed in roughly 100 years during the Late Prehistoric period. 


\section{Summary}

CAR's work at site 41BR493 suggests that the burned rock midden dates to the Late Prehistoric period. No diagnostic projectile points were recovered from the site. The site has historic and modern material on the surface.

Shovel testing results from outside the midden revealed buried deposits. Roughly two-thirds of the shovel tests were positive, with a small number of items recovered below 50 $\mathrm{cm}$. Examination of the distribution of artifacts within the upper $50 \mathrm{~cm}$ demonstrates a bimodal distribution of material. Charcoal was noted between 30 and $50 \mathrm{cmbs}$ in several shovel tests.

No excavation units were placed outside the midden. Excavation within the midden demonstrates that the upper $30 \mathrm{~cm}$ of the deposit has been disturbed. Artifact density within the two central units was only 19 items per cubic meter of sediment, while density on the ring of the midden was about seven items per cubic meter. Both vertebrate faunal material and mussel shell was present in the excavation units. Macrobotanical samples submitted for identification primarily contained bulbs or bulb fragments, with Eastern camas being identified. Both of the two flotation samples from the midden contained oak charcoal, and bulb fragments were present in one of the samples.

Conditions for preservation of ethnobotanical material within the midden are good. While the upper section of the midden has been disturbed by both historic and modern activities, intact deposits are present below $30 \mathrm{~cm}$. Outside of the midden, shovel testing revealed buried deposits, with charcoal present in several areas below $30 \mathrm{~cm}$.

\section{Chapter Summary}

This chapter has summarized the testing results for each of the 18 sites investigated on the current project. Sixteen of the 18 sites contained burned rock middens. Wormser and Sullo-Prewitt (2001) recommended these 16 sites for testing because of the presence of these features. The two sites without middens were recommended because they were thought to contain single-component occupations with moderate densities of material.

Our testing efforts have demonstrated that the two nonmidden sites, 41BR261 and 41BR276, lacked the attributes originally suspected by Wormser and Sullo-Prewitt. In contrast, many of the middens investigated on the project had excellent preservation and provided a variety of data. While the middens were consistently turbated by earthworms, as Bousman and Hodges note, it was only their excellent preservation that allowed the recording of that micro-disturbance (Appendix G). Good preservation conditions within many of the middens allowed for the recovery of ethnobotanical data, including the recovery of a variety of bulbs, as well as a mesquite seed. Wood charcoal was also identified, including oak, mesquite, juniper, and willow. The excellent preservation allowed the collection and processing of numerous radiocarbon dates from a variety of contexts. With few exceptions, these dates suggest a Late Prehistoric period of use for these burned rock middens. Faunal material was present at several sites, though in small numbers. Nevertheless, a variety of animals were identified, including bison. 



\title{
Chapter 7: Chronological Placement of Camp Bowie Burned Rock Middens
}

\author{
Raymond P. Mauldin and David L. Nickels
}

This chapter is the first of five that consider specific research issues regarding burned rock middens. While the previous chapter has summarized both the distribution of diagnostic artifacts as well as patterns in radiocarbon dates at a site level, the focus of the current chapter is specifically on establishing the chronology of the burned rock middens at Camp Bowie. It is, of course, difficult to separate chronological concerns from issues of midden construction, development, and use. These issues, discussed in the next chapter, are intimately linked, and understanding how middens developed has significant implications for assessing midden chronology. In spite of that linkage, this chapter focuses only on patterns in radiocarbon dates as well as patterns in diagnostic artifacts found within middens. A review of the extant radiocarbon dates from the Camp Bowie middens clearly shows that the principal period of use covered roughly 650 years between A.D. 750 and A.D. 1400 . While only 16 diagnostic artifacts were recovered from within middens, fifty percent of these diagnostics date to the Late Prehistoric period, with Late Archaic diagnostics being the second most common type (44\%). Aspects of these two data sets are compared to larger data sets outside of Camp Bowie. Those comparisons suggest that the Late Prehistoric assignment of the Camp Bowie material is not in conflict with a regional radiocarbon data set or regional patterns in diagnostic artifacts on burned rock midden sites in north-central Texas.

\section{Burned Rock Midden Chronology}

The review of chronological issues presented in Chapter 4 suggests that while earlier researchers, relying on diagnostic artifacts, frequently recognized a "bow and arrow" component in middens (e.g., Huskey 1935:109; Pearce 1932:49), Weir's review of extant data in the mid 1970s placed these features primarily between $5000 \mathrm{BP}$ and 1800 BP (Weir 1976; see also Prewitt 1981, 1985). The notion that middens were primarily Middle to Late Archaic in age was not seriously questioned until well after radiocarbon dating became a component of most research projects. While there were certainly reports of middens with radiocarbon dates from the Late Prehistoric (e.g., Goode 1991, 1994; Lukowski 1987), these dates were frequently considered either anomalous, or the Late Prehistoric occupation was not seen as contributing significantly to the formation of the midden itself, but simply forming a "veneer" over the earlier material (e.g., Collins 1994b:161-167; Ricklis and Collins 1994).

Black and Creel (1997) undertook the first large-scale consideration of radiocarbon dates on middens. Their compilation of radiocarbon assays from 35 middens demonstrated that the primary period of midden use as reflected by radiocarbon dates was at the end of the Late Archaic and into the Late Prehistoric periods. While it is also possible that earlier uses of the middens are not reflected by charcoal dates as a result of differential preservation (Black and Creel 1997:273-280), Black and Creel clearly demonstrate that a significant number of middens date to the end of the Late Archaic and into the Late Prehistoric.

\section{Radiocarbon Dates on Middens at Camp Bowie}

As summarized on a site-by-site basis in the previous chapter, we obtained 34 radiocarbon dates from the 18 tested sites. One radiocarbon date came from an external feature on 41BR87. In addition, we obtained one date from 41BR478 that was from below the midden deposit, and one date from 41BR493 that was from a disturbed level above the midden. The remaining 31 radiocarbon dates came from 17 different middens tested on 14 different sites.

The sampling strategy used to select radiocarbon samples from within middens focused on getting multiple dates from different levels within the same 1-x-1-m excavation unit. Whenever possible, these samples were obtained from the units positioned on the midden ring rather than within the center of the midden. In the following chapter, we will argue that the middens form from repeated cleaning of a central feature, with the removed material being deposited in the ring. If middens formed in this manner, then deposits located on the ring would have a lower probability of being disturbed relative to those in the central portion of the midden. When suitable multiple samples could not be obtained from a ring unit, or when no ring unit was excavated, samples were selected from the central units. Finally, a number of middens 
lacked multiple samples. In these cases, we attempted to obtain samples from the lowest possible level within the midden. All radiocarbon samples were on charcoal. In most cases, samples consisted of individual pieces of charred material that were frequently one to two centimeters in size. Larger pieces were selected to minimize the potential for movement of charcoal within the midden matrix. In some cases, the samples were point-provenienced from within a level, though most of the samples can only be assigned to a $10 \mathrm{~cm}$ range. All samples were AMS dated by Beta Analytic (see Appendix A for details).

Figure 7-1 presents an example of the sampling strategy. The figure represents the west wall profile of Unit 3 on 41BR492 with dates and sampling locations provided. The dates, presented to the left of the profile, represent a 2-sigma range. Note that while the upper two dates appear to be reversed, the dates are statistically indistinguishable from each other. That is, the dates could conceivably represent the same time, and do not, therefore, indicate a temporal reversal within the deposit. As will be demonstrated in the following discussion, the pattern of dates in Figure 7-1 is similar to the patterns revealed by the larger data set. That is, in those situations where we have multiple dates from the same unit there are no cases of clear temporal reversals in the Bowie midden deposits. This suggests that the deposits have not been extensively altered either by turbation or by movement of individual pieces of charcoal.

Figure 7-2 presents the probability distribution for each of these 31 midden dates from Camp Bowie. The individual dates have been calibrated and plotted using the OxCAL calibration program (Ramsey 2000). The dates are grouped by site, and within the site, by increasing depth. Dates from the same unit within a site are identified by different color groupings. The samples from sites with only a single date, or dates from different units within the same midden, are shaded in black. There are 10 sites from which we were able to obtain multiple dates from the same unit, including the case presented in Figure 7-1. These 10 color groupings in the figure are represented by 23 different dates. Reference to Figure 7-2 will show that in all cases with multiple dates from different levels the radiocarbon dates pattern as expected, with older dates occurring at increasing depth. That is, in no case is there a statistically significant reversal of the dates. While movement of the individual pieces within

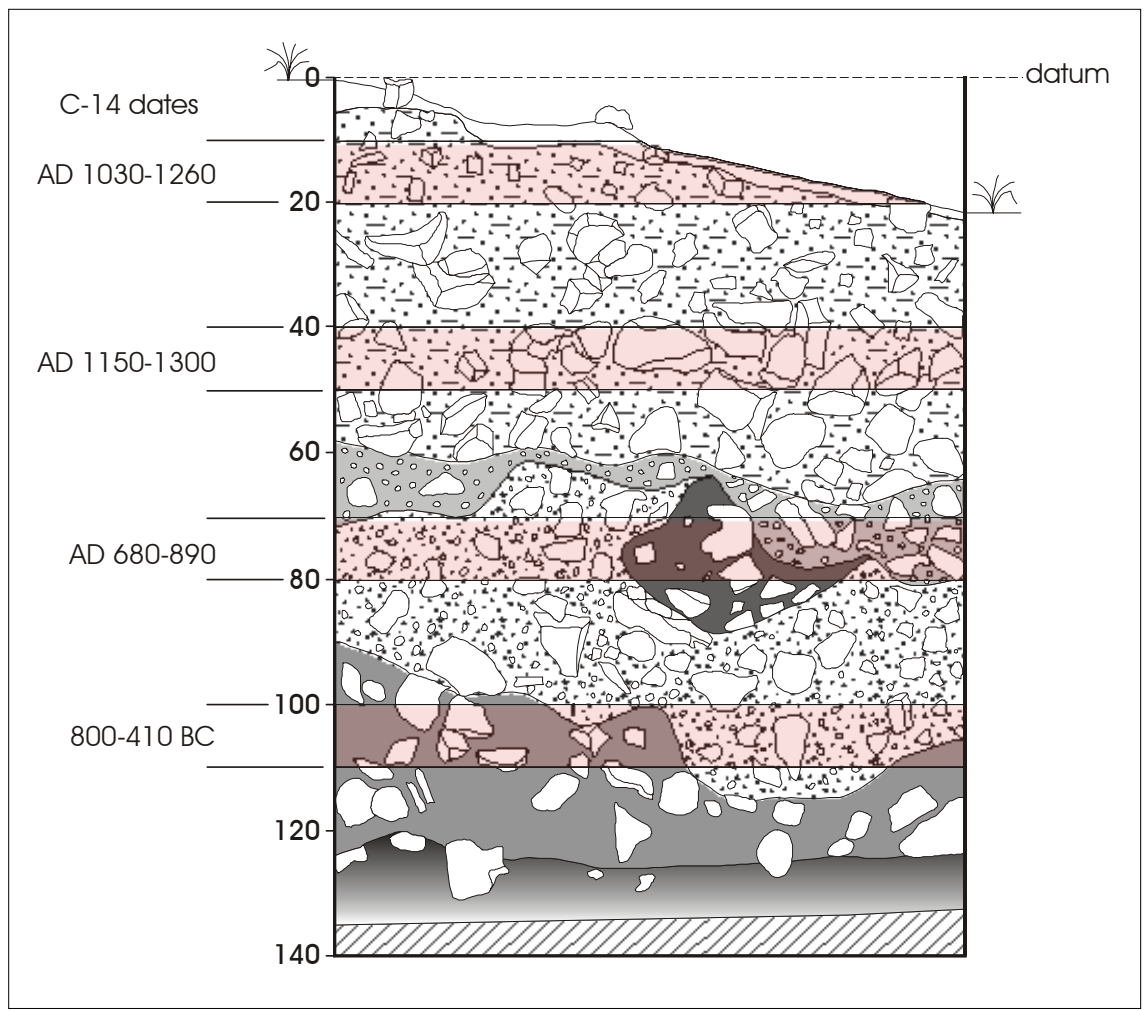

Figure 7-1. West wall of ring Unit 3 at 41BR492, with radiocarbon dates. 


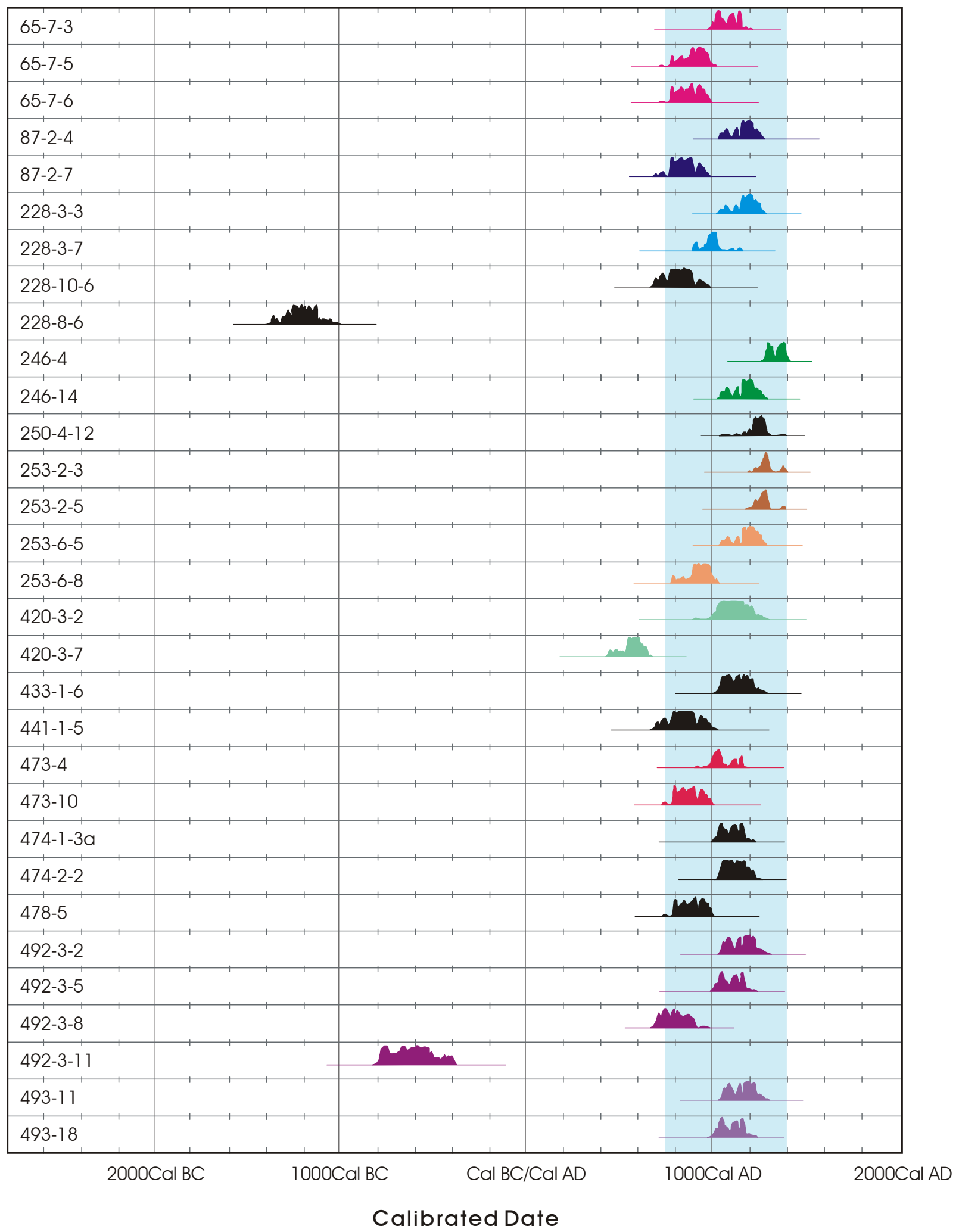

Figure 7-2. Probability distribution for 31 midden dates, with primary time period of use identified in blue. 
the matrix cannot be ruled out for any single case, the overall pattern of the 23 dates from the 10 different units with multiple dates is surprisingly consistent. The Bowie radiocarbon samples appear to be in good stratigraphic context.

Focusing on the overall pattern in Figure 7-2, note that 28 of the 31 dates (ca. 90\%) fall within a fairly narrow temporal window between A.D. 750 and A.D. 1400. One date is centered at roughly A.D. 600, and there are two earlier dates at roughly 600 B.C. and at 1200 B.C. To the degree that these 31 dates reflect the period of midden use, the Camp Bowie middens were primarily used during the Late Prehistoric period, with minimal Late Archaic use.

\section{Camp Bowie Radiocarbon Dates in Broader Context}

As noted previously, Black and Creel (1997) have recently compiled radiocarbon assays from 35 middens in Central Texas. Figure 7-3 compares the patterning of the Camp Bowie dates (dark gray) with that earlier data set (light gray). In order to generate the figure, we reviewed all dates presented by Black and Creel (1997). We eliminated all dated samples that were not on charcoal. We eliminated all dates with standard deviations greater than \pm 150 years. In many cases multiple dates are present for a given feature. In those cases where it was statistically appropriate to do so,

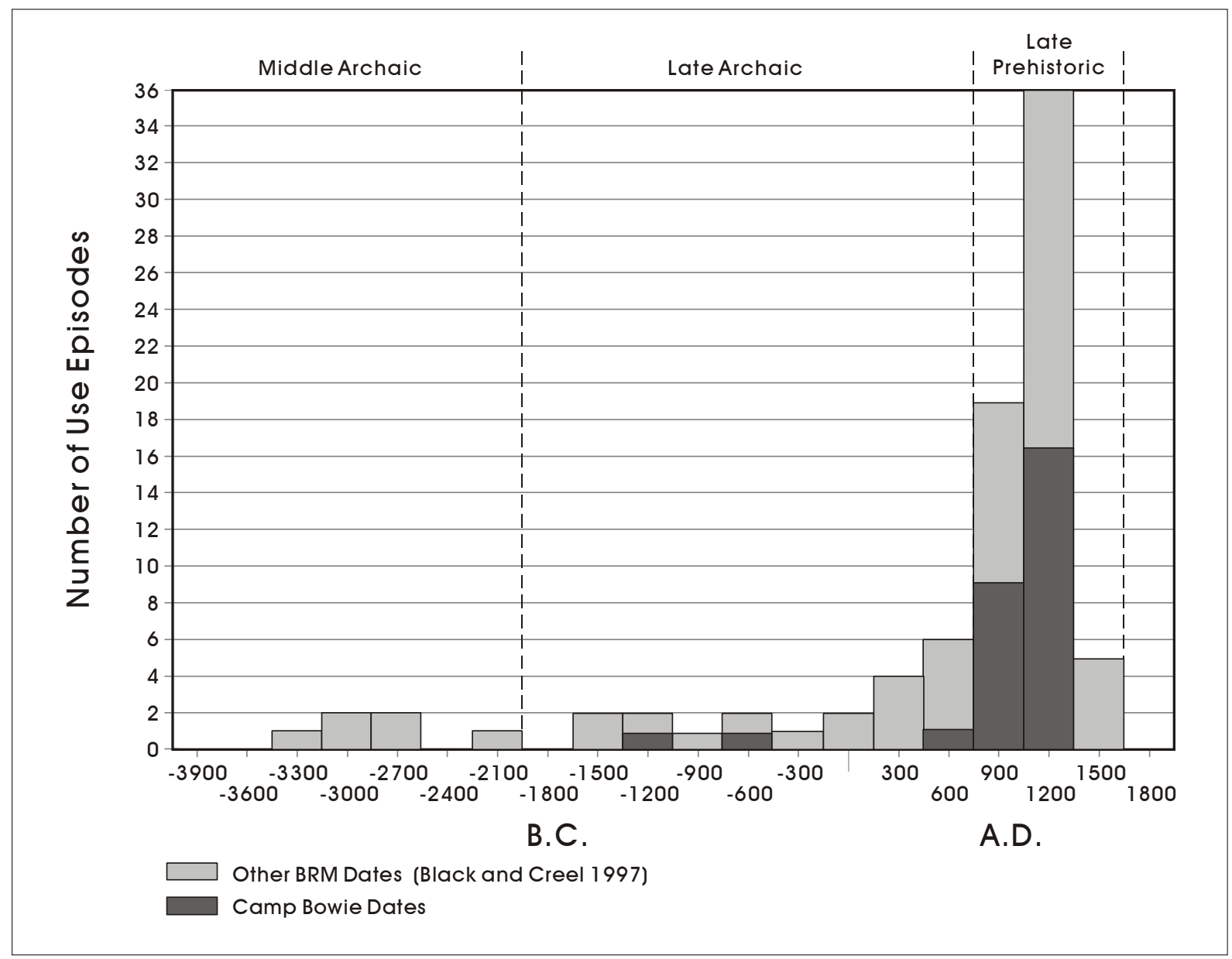

Figure 7-3. Radiocarbon dates on 87 midden use episodes from 40 sites in Central Texas with Camp Bowie dates identified in dark gray. 
individual dates were averaged using procedures in CALIB version 4.1.2 (Stuvier and Reimer 1993) to produce what we have termed "use episodes." A total of 87 use episodes, based on 150 individual radiocarbon dates from middens on 40 different sites located throughout central and north Texas are reflected in the resulting figure. The dates are plotted at the midpoint of the calibrated 2-sigma range.

Examination of Figure 7-3 clearly shows that the pattern of Late Prehistoric use revealed by the Camp Bowie data set is consistent with the larger data set compiled by Black and Creel (1997). When considered as a group, 62 of the 87 use events (71.3\%) date to the Late Prehistoric period. The Late Archaic is represented by 20 date events (ca. 23\%), the Middle Archaic is represented by six date events, and a single date event, not shown in the figure, is in the Early Archaic period. Clearly, these dates suggest a pattern of midden use concentrated in the Late Prehistoric, with some increased use occurring at the end of the Late Archaic. This pattern is considerably different than those suggested by earlier researchers (e.g., Weir 1976).

Several scenarios could account for the apparently late radiocarbon dates in both the Camp Bowie material as well as in the larger radiocarbon data set. These include both the presence of a Late Prehistoric "veneer" over an earlier Late or Middle Archaic midden core, as well as the possibility that the sample is significantly biased by differential preservation. However, examination of cases like that shown in Figure 7-1 does not support the "veneer" scenario as a possible explanation for the patterns. While this particular midden began to form in the Late Archaic, the majority of the deposits clearly date to the Late Prehistoric. Rather than representing a veneer, the Late Prehistoric material accounts for a minimum of $80 \mathrm{~cm}$ of the material within the $125 \mathrm{~cm}$ of deposits in this unit.

Numerous other cases like that shown in Figure 7-1 can be presented from the current project. Figure 7-4 presents two such examples from sites 41BR250 (left) and 41BR493 (right). For site 41BR250, a date of A.D. 1160-1290 is present on charcoal at $110-120 \mathrm{~cm}$ below the surface. For 41BR493, a bottom date of A.D. $990-1170$ is present at $156-166 \mathrm{~cm}$ below the surface. If the charcoal sampled had significantly moved through the deposits, then the pattern of associations can certainly be questioned. However, as noted previously, in no case do we have a statistically significant reversal in the radiocarbon dates. In 10 instances we have multiple dates from the same 1-x-1-m unit. None of the 23 dates from these 10 units are out of stratigraphic sequence. If charcoal samples, dating to the Late Prehistoric, are moving through these profiles, it seems unlikely that these stratigraphic relationships, with older dates consistently being deeper than younger dates, would be maintained for all 23 samples. The notion of a Late Prehistoric veneer obscuring the "true" age of the midden cannot be supported within the Camp Bowie radiocarbon dates.

The argument that charcoal from early middens, or from lower levels within middens, is frequently not preserved, and therefore these occupations would not be reflected in the radiocarbon data sets, is much more difficult to assess. Clearly, we would expect some preservation bias. Our sampling strategy, which relied on selecting larger pieces of charcoal to minimize the potential for movement of samples through the matrix, would exacerbate any preservation problems inherent in this data set. Nevertheless, on the current project we made a systematic attempt to date lower levels within middens, with some success. These lower levels frequently date to the Late Prehistoric (e.g., Figure 7-4). In fact, with two exceptions, lower levels in middens always date to the Late Prehistoric. It appears, then, that at least in the Camp Bowie data set, we have little data to suggest that lower levels do not date to the Late Prehistoric. While we cannot rule out the impacts of differential preservation on the overall dating patterns, the Camp Bowie radiocarbon samples provide no support for that suggestion.

\section{Diagnostic Artifacts within Middens at Camp Bowie}

The pattern in radiocarbon dates, both within Camp Bowie as well as within the larger data set, is different than that suggested by earlier researchers who argued, based mainly on the recovery of diagnostic projectile points from middens, that these features were primarily used during the Middle and Late Archaic periods. The potential discrepancy between late radiocarbon dates from middens that contain earlier diagnostics has been noted by several researchers (e.g., Black and Creel 1997:280; Leach and Bousman 2001[1998]). In this section, we examine diagnostic artifacts from within the Camp Bowie middens, and compare these to the patterns in radiocarbon dates. Interestingly, that comparison fails to reveal any significant contradiction between the two Camp Bowie data sets. We then consider diagnostic artifacts from burned rock midden sites throughout north-central Texas. The diagnostic patterns in this larger data set are consistent with our suggestion that burned rock middens were primarily used during the Late Prehistoric period. 


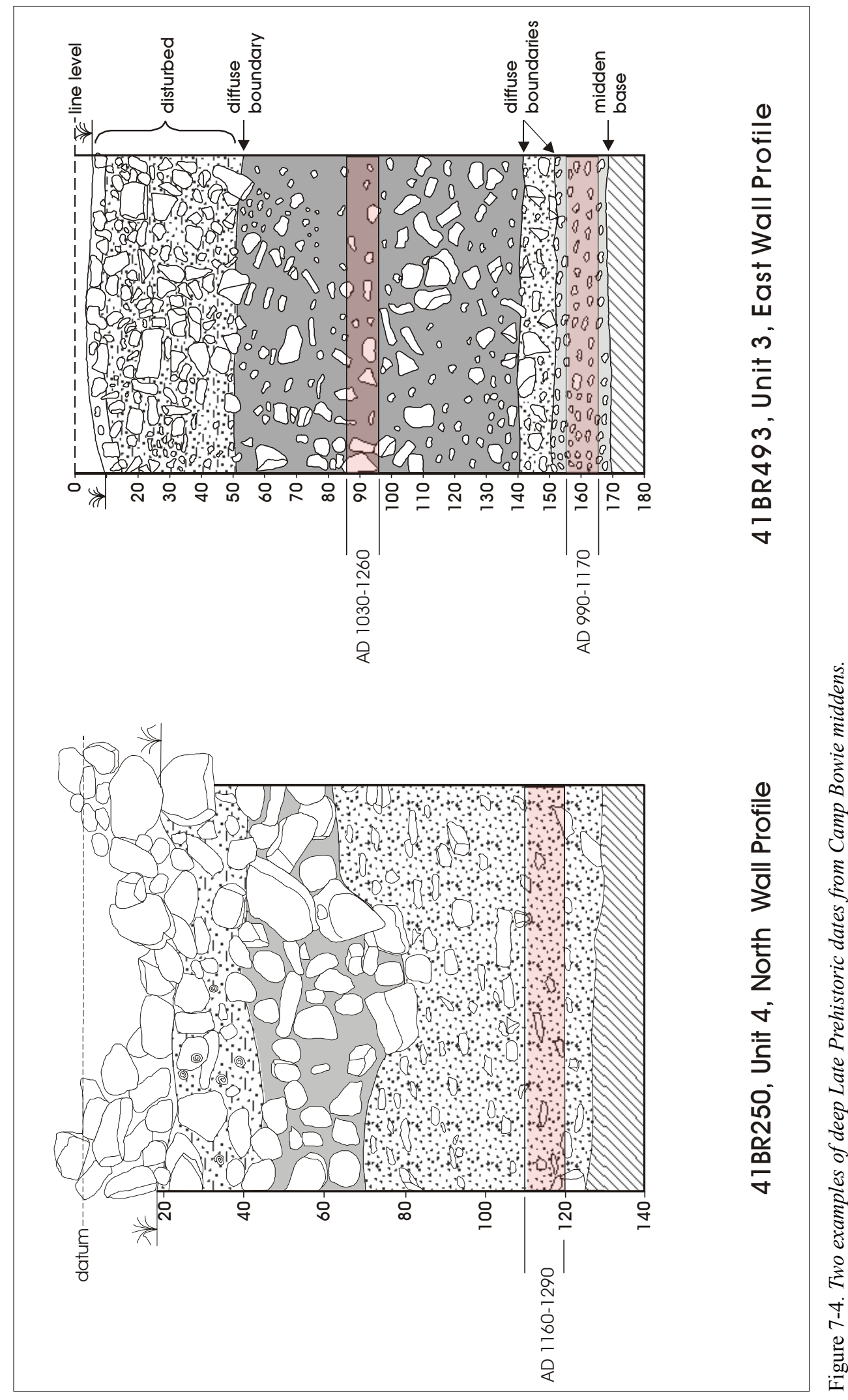


Table 7-1. Diagnostic Artifacts and Radiocarbon Dates by Periods for Camp Bowie Middens

\begin{tabular}{|c|c|c|c|c|c|c|c|c|c|c|}
\hline & \multicolumn{5}{|c|}{ Diagnostic Artifacts in Middens } & \multicolumn{5}{|c|}{ Radiocarbon Dates in Middens } \\
\hline 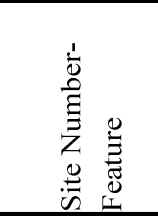 & 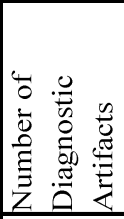 & 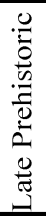 & 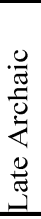 & 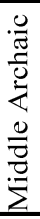 & 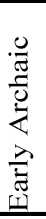 & 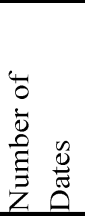 & 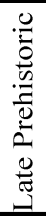 & 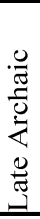 & 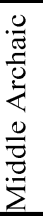 & 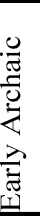 \\
\hline 41BR65-1 & 0 & 0 & 0 & 0 & 0 & 3 & 3 & 0 & 0 & 0 \\
\hline 41BR87-1 & 1 & 1 & 0 & 0 & 0 & 2 & 2 & 0 & 0 & 0 \\
\hline 41BR228-1 & 2 & 0 & 2 & 0 & 0 & 2 & 1 & 1 & 0 & 0 \\
\hline 41BR228-2 & 3 & 1 & 1 & 1 & 0 & 2 & 2 & 0 & 0 & 0 \\
\hline 41BR246-1 & 0 & 0 & 0 & 0 & 0 & 2 & 2 & 0 & 0 & 0 \\
\hline 41BR250-1 & 2 & 2 & 0 & 0 & 0 & 1 & 1 & 0 & 0 & 0 \\
\hline 41BR253-1 & 0 & 0 & 0 & $\underline{0}$ & 0 & 2 & 2 & 0 & 0 & 0 \\
\hline 41BR253-2 & 0 & 0 & 0 & 0 & 0 & 2 & 2 & 0 & 0 & 0 \\
\hline 41BR415-1 & 0 & 0 & 0 & 0 & 0 & 0 & 0 & 0 & 0 & 0 \\
\hline 41BR420-1 & 3 & 2 & 1 & 0 & 0 & 2 & 1 & 1 & 0 & 0 \\
\hline 41BR433-1 & 2 & 2 & 0 & $\underline{0}$ & 0 & 1 & 1 & 0 & 0 & 0 \\
\hline 41BR441-1 & 0 & 0 & 0 & 0 & 0 & 1 & 1 & 0 & 0 & 0 \\
\hline 41BR473-1 & 0 & 0 & 0 & 0 & 0 & 2 & 2 & 0 & 0 & 0 \\
\hline 41BR474-1 & 0 & 0 & 0 & 0 & 0 & 1 & 1 & 0 & 0 & 0 \\
\hline 41BR474-2 & 0 & 0 & 0 & 0 & 0 & 1 & 1 & 0 & 0 & 0 \\
\hline 41BR478-1 & 2 & 0 & 2 & 0 & 0 & 1 & 1 & 0 & 0 & 0 \\
\hline 41BR480-1 & 0 & 0 & 0 & 0 & 0 & 0 & 0 & 0 & 0 & 0 \\
\hline 41BR492-1 & 1 & 0 & 1 & $\underline{0}$ & 0 & 4 & 3 & 1 & 0 & 0 \\
\hline 41BR493-1 & 0 & 0 & 0 & 0 & 0 & 2 & 2 & 0 & 0 & 0 \\
\hline Totals & 16 & 8 & 7 & 1 & 0 & 31 & 28 & 3 & 0 & 0 \\
\hline
\end{tabular}

As noted in the individual site descriptions presented in the previous chapter, the number of artifacts recovered within middens at Camp Bowie, while variable, was generally low. This was especially the case for artifacts considered to be temporally diagnostic. Only 16 diagnostic artifacts were recovered from excavations conducted within 19 middens. Only eight different middens have diagnostics. Table 7-1 summarizes the distribution of diagnostic artifacts by midden and temporal period. Also provided are the associated radiocarbon dates, summarized by temporal period, from the middens. While the sample size is extremely small, reference to Table 7-1 shows that 50 percent of the diagnostics fall within the Late Prehistoric period and roughly 94 percent of the diagnostics fall either in the Late Prehistoric or Late Archaic, the periods reflected by the radiocarbon dates. Only a single diagnostic is outside of this temporal range. At a project level, these data do not seem to suggest a significant conflict between the diagnostics from within middens and the temporal range provided by the radiocarbon dates. Earlier diagnostics are clearly present in some cases, and the Late Archaic is over-represented by the total number of items relative to the radiocarbon pattern, but the same general time range is present in both data sets.

Consideration of this problem by individual middens also fails to reveal any significant conflict between the two data sets. There are five cases that have both Late Prehistoric diagnostic artifacts and radiocarbon dates. In all five cases, at least one of the radiocarbon dates falls within the Late Prehistoric. There are five cases with Late Archaic diagnostic artifacts and radiocarbon dates. In three of the five cases, at least one of the radiocarbon dates fall within the Late Archaic period. Finally, there is only a single case with Middle Archaic diagnostics. This case does not have an associated 
Middle Archaic radiocarbon date. Overall, in eight of the 11 cases where we recovered artifacts reflective of a given temporal period from middens, radiocarbon dates are present that overlap with the artifact time frame. The single Middle Archaic artifact, as well as two of the Late Archaic artifacts, were recovered in contexts not supported by radiocarbon dates (Table 7-1). This may be related to differential preservation of charcoal.

The pattern of diagnostic artifacts from the Camp Bowie burned rock middens do not seem to show a significant discrepancy relative to the radiocarbon dates. Both data sets show the major period of use to be in the Late Prehistoric, with secondary use in the Late Archaic. However, the small sample size of diagnostics in the current data set clearly hinders general interpretations. In order to consider this pattern at a broader scale, we conducted an extensive review of burned rock midden sites using data in the Texas Archeological Sites Atlas. Site forms for 447 burned rock midden sites, from 18 north-central Texas counties, were reviewed with specific concern for documenting the presence of burned rock middens and gathering information on diagnostic artifacts. The counties reviewed, identified in Figure 7-5 by gray shadings, were centered primarily on Brown County. Unfortunately, most of the sites lacked sufficiently detailed information in the Texas Sites Atlas for temporal assignment, or had other significant problems that made the data suspect. Such sites were eliminated from consideration.

The 13 counties with darker gray tones in Figure 7-5 contained 104 burned rock midden sites, with 145 different temporal components. Each of the counties had at least one burned rock midden site that had sufficiently detailed temporal information to allow assignment of the site to one or more temporal periods. Temporal assignment was done using the projectile point typology and phase assignments outlined by Collins (1995:376). In addition,

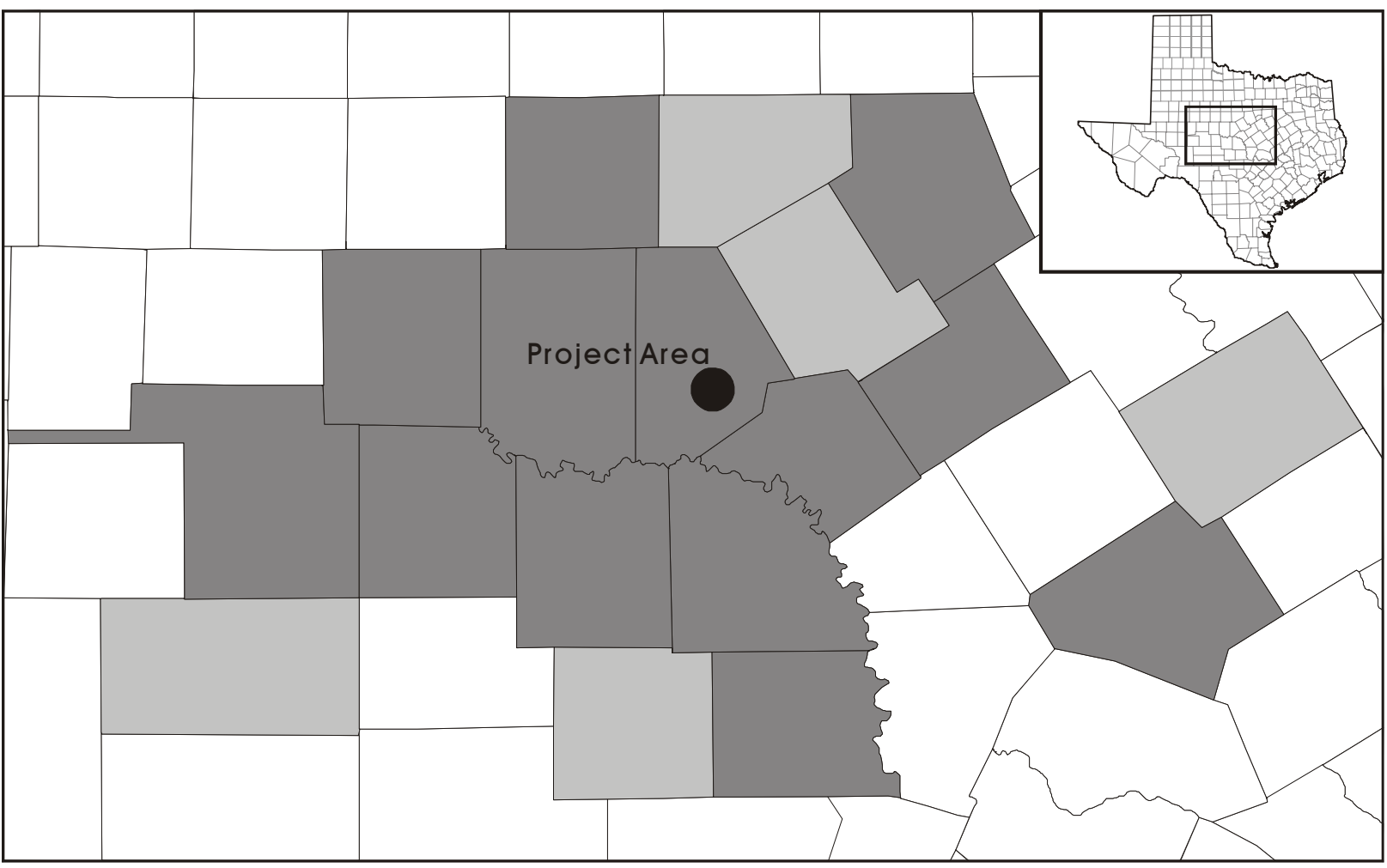

Counties in Final Data Set.

Counties reviewed but lacking appropriate sites.

Figure 7-5. Counties reviewed for midden sites with diagnostic artifacts. 
all sites with ceramics as well as all sites with "arrow points" noted in the description were deemed to have a Late Prehistoric component.

Appendix J presents these 104 sites, along with the specific point types used in the temporal assignment. The 145 temporal components identified included 52 from the Late Prehistoric, 56 dating to the Late Archaic, 25 from the Middle Archaic, 10 Early Archaic components, and two Paleoindian components.

Figure 7-6 (top) presents the number of temporal components per 100 years for the 145 components. The period length was estimated using Collins (1995:376). For example, the 52 Late Prehistoric components were divided by the length of the period (ca. 900 years). We then multiplied the resulting value of .05778 (the number of components per year) by 100 to arrive at the plotted value of 5.778. That is, there are 5.778 Late Prehistoric components for every 100 years within this data set. Examination of the top figure clearly shows that when adjusted for the length of the temporal period, sites with burned rock middens in this sample clearly are dominated by Late Prehistoric components. The pattern is, in fact, similar to that produced by the radiocarbon dates in Figure $7-3$, though recall that the component database is gathered at a site level rather than from individual middens.

Our decision to include "arrow points" as indicative of the Late Prehistoric certainly differentially increases the number of these components in our data set relative to earlier time periods. That is, the term "dart point," potentially indicative of any given Archaic period, was not included in our initial consideration as no specific Archaic period could be assigned to these "dart point" cases. The bottom graph in Figure 7-6, therefore, uses a restricted data set. In order to be assigned to the Late Prehistoric in this data set, a site was required to have either a specific Late Prehistoric projectile point form or ceramics. That is, we have eliminated the generic "arrow point" as a defining criterion for Late Prehistoric assignment (see Appendix J). This results in the elimination of 24 Late Prehistoric components from the data set. Nevertheless, examination of the bottom graph still clearly shows that when standardized for the length of a temporal period, burned rock middens within this data set are more common on sites that have Late Prehistoric material recorded.

\section{Summary}

The pattern in both radiocarbon dates and in diagnostic artifacts from middens on Camp Bowie document a Late Prehistoric chronological placement, with some representation in the Late Archaic. Comparisons of the Camp Bowie radiocarbon data set with that compiled by Black and Creel (1997) demonstrate that the Bowie dates are consistent with that larger sample. Similarly, a consideration of components identified by diagnostic artifacts from sites across 13 different north-central and west Texas counties, including Brown County, shows that burned rock middens are more likely to be located on sites with Late Prehistoric material. Both radiocarbon dates and patterns in diagnostics indicate that the Late Prehistoric period was the primary period of burned rock midden use, at least in this region.

Our review of these various data sets failed to find any significant discrepancy between patterns in radiocarbon dates and patterns in diagnostic artifacts for burned rock midden sites. Clearly, the Camp Bowie middens are predominately Late Prehistoric in age. This temporal pattern is different than that suggested by several earlier researchers who argued that burned rock middens were principally used during the Middle and Late Archaic (e.g., Weir 1976). A number of earlier middens have certainly been documented in the literature from Central Texas (e.g., Collins 1998; Hester 1971; Sorrow et al. 1967; Treece 1993), both through radiocarbon dating and through the recovery of diagnostic artifacts. Clearly, there are cases where early materials have been incorporated into later middens (e.g., Nickels et al. 2001[1998]), a process that may explain, in part, why in some cases diagnostics recovered are in conflict with the radiocarbon dates (Black and Creel 1997:280; Leach and Bousman 2001[1998]). However, our review of a variety of different data sets, both within Camp Bowie as well as in the larger north-central Texas area, suggests that the notion that this feature type primarily dates to the Middle and Late Archaic periods is open to question. 


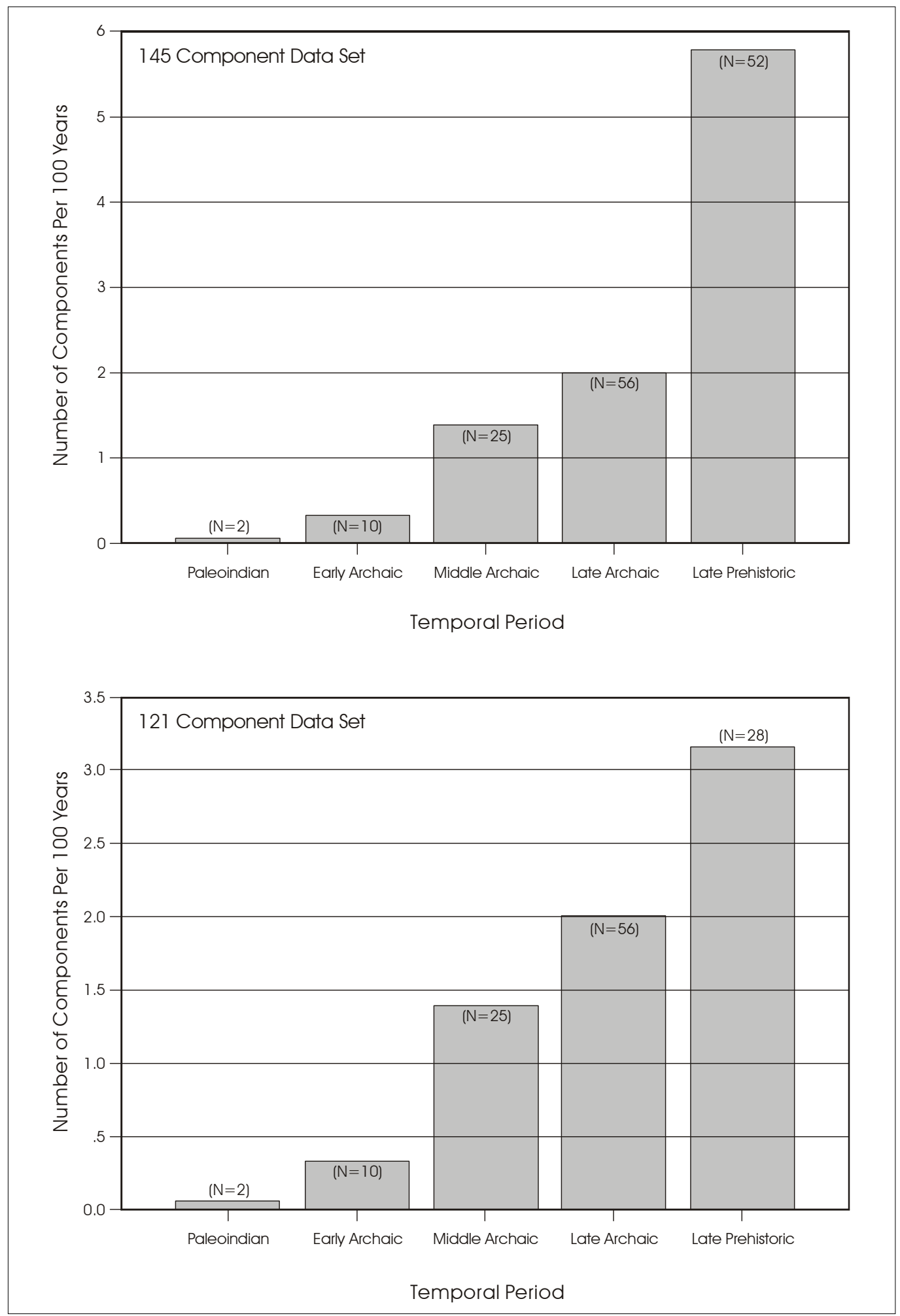

Figure 7-6. Components per 100 years by temporal period for burned rock middens in counties identified in Figure 7-5. Top graph includes "arrow points" as indicative of Late Prehistoric. Bottom graph includes only specific types of Late Prehistoric diagnostics. 


\title{
Chapter 8: Development of Burned Rock Middens at Camp Bowie
}

\author{
Raymond P. Mauldin
}

In the previous chapter, we argued that burned rock middens at Camp Bowie dated primarily to the Late Prehistoric period. That argument was based on radiocarbon dates, with an emphasis on obtaining dates from samples in the ring or torus of the midden. The emphasis on this location for sampling was based, in part, on our notion regarding how burned rock middens developed. We noted that the ring area of a midden probably developed as a result of the repeated cleaning out of a central feature, and, as such, would be less likely to be turbated. While other general models are briefly considered, this chapter explores that central feature model of midden development. Patterning in chipped stone and mussel shell, as well as patterning in the size and number of burned rock, is considered. These data are generally consistent with middens being formed as the result of the repeated use and maintenance of burned rock ovens. The final section of this chapter presents a detailed consideration of the midden on site 41BR492 in light of the general arguments developed in this chapter.

\section{Models of Midden Development}

As noted in Chapter 4, while a variety of specific scenarios have been suggested to explain how middens develop, they can be grouped into three general models. The first of these is what we term the "central feature model." Pearce (1919:230,1938) originally suggested components of this model. Under this general scenario, middens formed around a central thermal feature. Smaller, thermally fractured stone, which was replaced by larger stone, is discarded to form a ring or mound of rock around the central feature. More recently, researchers have seen this central feature as specifically reflecting earth ovens (see Black 1997; L. Ellis 1997; Leach and Bousman 2001[1998]). The second general model of midden formation is the intersecting hearth model. Originally suggested by Kelley and Campbell (1942), the development of middens in this scenario are the result of use and reuse of a limited area for stone-lined hearth features. The repeated use would result in a complex arrangement of hearths with obscure stratigraphic relationships (Kelley and Campbell 1942:320). Finally, Sorrow (1969; see also Hester 1970, 1971) proposed that middens represented "communal dumps" for discarded fragments of stone and other cultural debris. The communal dump model suggests that hearth construction was elsewhere, with the rock and other cultural debris being discarded in the midden.
Each of these three general models should have slightly different expectations for recovery of artifacts, patterns in burned rock, and the presence of internal features. For example, if the central feature model is a useful interpretation of these features, then internal features should be common and ring areas should never have features present, unless they post-date the midden. Conversely, in the intersecting hearth model, internal features may be present, but there should be no easily identifiable structure within the midden. Features, if they can be identified, should be equally likely to be present in the ring as in the central area of the midden. Finally, if the communal dump model is useful, we might expect variable but probably high recovery of chipped stone, little internal patterning of rock, and no internal features unless they post-date the majority of the midden.

While detailed discussions of patterning in chipped stone and burned rock are presented in this chapter, even a cursory review of the individual site descriptions presented in Chapter 6 suggests that both the communal dump model as well as the intersecting feature model for midden construction is not supported in the Camp Bowie data. While only a small portion on any single midden has been tested, and while several suggestive rock clusters were noted in a few instances, there were no cases of individual features being clearly identified within the ring components of the middens. While individual features were not identified in the majority of middens tested, when identified, clearly defined features were always located within the central areas. The very structure of most middens, with a low central area surrounded by a slight mound of rock, clearly is consistent only with the central feature model.

Burned rock midden features at Camp Bowie probably resulted from feature activities such as those depicted in Figure 8-1 (see L. Ellis 1997). That is, these middens probably represent the remains of repeatedly used central features, most likely the result of pit baking activities. Similar oven features are certainly identified in the ethnographic literature from throughout North America (e.g., Bell and Castetter 1941; Buskirk 1949; Castetter et al. 1938; Opler 1941; Pennington 1963; Spier 1933; Wandsnider 1997). These earthen-capped, rock-lined oven features are frequently reused and maintained. As Castetter et al. (1938:45) noted for the southern Diegueno of California, "[t]he pits were used over and over again each season. 


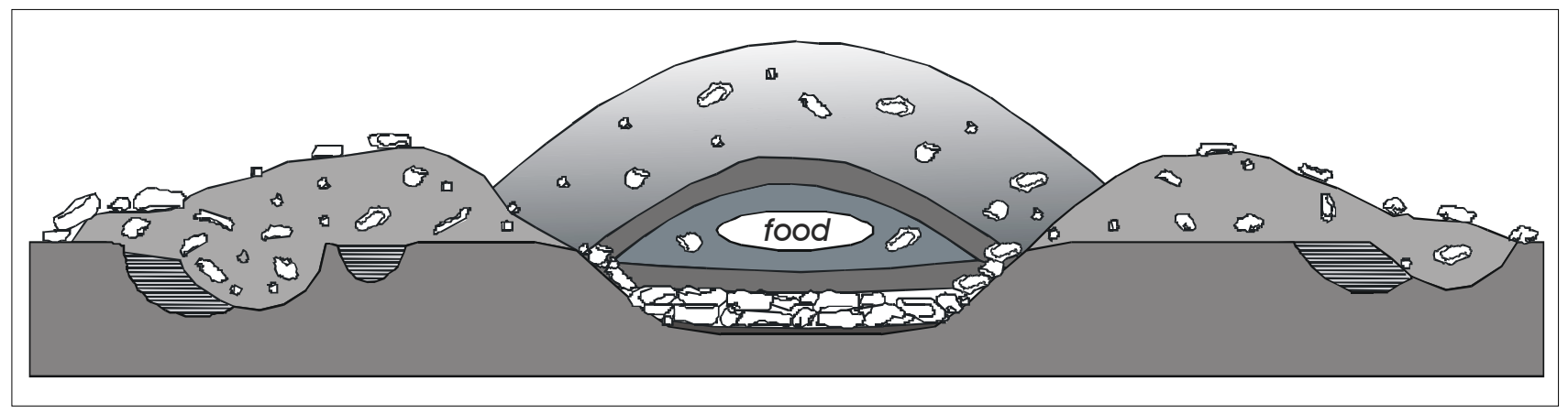

Figure 8-1. Schematic cross-section of a repeatedly used central-based roasting feature.

Due to the clearing out of the pits and replacement of firecracked boulders with new ones, some pits have a marginal refuse dump of considerable size." If the Camp Bowie middens were used in this manner, and if the middens accumulated over some length of time as suggested by the radiocarbon results in the previous chapter, then we can expect specific patterning both in artifact densities and in fire-cracked rock size and location. The remaining portion of this chapter considers these data sets in the context of this central feature model.

\section{Exploring Patterns in Artifacts and Mussel Shell in Midden and Non-midden Contexts}

As outlined in Chapter 6, and as should be clear from the discussion in Chapter 7 of diagnostics within the middens, the recovery of material from within middens was highly variable but generally low. If the features were used as suggested above, then the artifacts recovered from the feature are likely to be incidental to the feature use. Leach and Bousman (2001[1998]; see also Black and Creel 1997:280) provide the clearest discussion of this possibility. Briefly, they suggest that earlier material will be incorporated into the midden as a result of building the earthen cap over the central pit. The degree to which middens are constructed on top of extant camps should be a factor in midden content, as artifacts unrelated to the midden either temporally or behaviorally may be incorporated into the midden fill.

In order to explore this possibility, artifact density in midden and non-midden contexts is contrasted. Figure 8-2 presents a scatter plot of chipped stone artifact density as reflected in midden excavations (Y-axis) and in shovel tests outside of middens (X-axis) for 14 of the 16 sites with middens tested on Camp Bowie. Raw data are presented in Table 8-1. Sites 41BR474 and 41BR441 are not included as the middens on these sites had been disturbed. Shovel test artifact density was calculated by assuming that all shovel tests were circular with a diameter of $30 \mathrm{~cm}$. This assumption yields a volume of $.007069 \mathrm{~m}^{3}$ of sediment for a $10-\mathrm{cm}$ level. The number of levels excavated at a site outside of the midden(s) was then used to calculate the total volume of sediment removed in a shovel test. This figure, along with the number of artifacts recovered from these external tests, was then used to calculate external artifact densities per cubic meter. Ideally, the external 1-x-1-m excavation units on a site, rather than the shovel test data, would be used in this comparison, however, external units were routinely placed in areas of the site that had high lithic density. That is, units were placed, based on shovel tests, to investigate either high lithic densities or possible features. With regard to comparing lithic densities, then, the external $1-x-1-m$ units are clearly biased towards areas of high lithic density. While shovel test data may not provide the ideal comparison, the data are not biased towards high lithic density and they more accurately reflect site level observations.

Consideration of the patterns in Figure 8-2 shows that there is a strong, statistically significant positive relationship between site level shovel test artifact density and midden artifact density $(\mathrm{R}=.664 ; \mathrm{p}=.010)$. Middens with high internal artifact density are located on sites with high external artifact density. This pattern is consistent with the notion that one of the factors responsible for artifacts being present in midden sediments is that artifacts are incorporated into middens as a result of bringing in sediment that contains artifacts from previous occupations in order to form a cap for these oven features. That is, the pattern is consistent with the "incorporation" scenario discussed previously. 


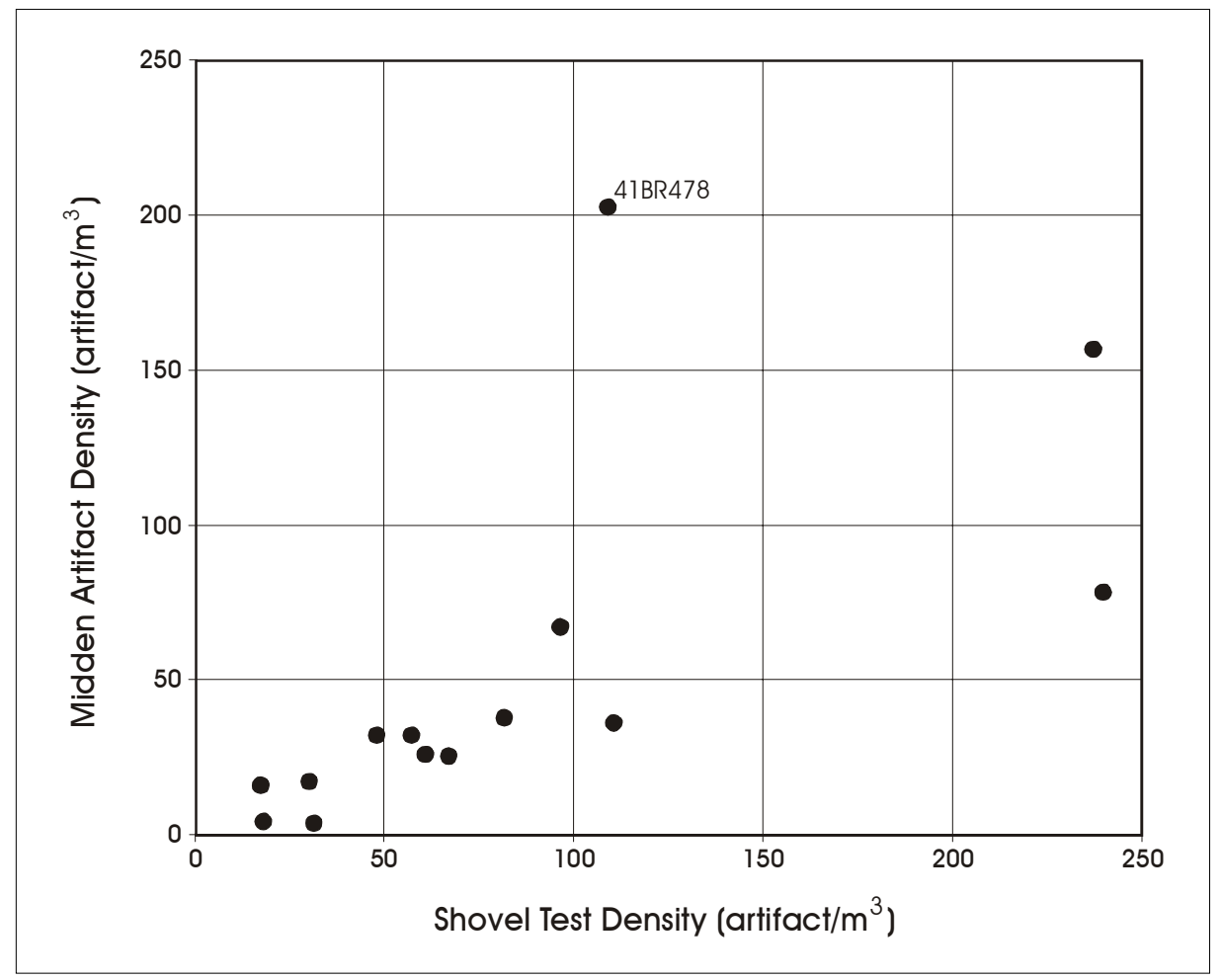

Figure 8-2. Plot of internal and external chipped stone densities from shovel tests.

However, in 13 of the 14 cases in Figure 8-2, midden densities are lower than site level artifact densities. At first glance, we would expect that if these features were repeatedly used over long periods of time-a pattern suggested by the radiocarbon results discussed in the previous chapter - lithic material would be concentrated at higher densities in middens as more and more sediment, with accompanying artifacts, is brought in to form the caps of the oven. This should result in a higher concentration of artifacts in the middens relative to the remaining portions of a site.

Figure 8-3, box plots comparing lithic densities for site and midden contexts, highlights these differences. Box plots, also known as box and whisker plots, provide a relatively simple method of summarizing and comparing distributions. Briefly, the upper and lower quartiles of a distribution form the upper and lower limits of the box. That is, 50 percent of the cases within a given distribution are within the box in the figure. The solid line in the box portrays the median value, so 50 percent of the cases in a distribution are to the right of the line, and 50 percent of the cases are to the left of the line. The lengths of the lines extending from the box, the "whiskers" in the box and whisker plot, are determined, in part, by the interquartile range (i.e., Q.75 - Q.25, the length of the "box"). For the line extending to the right of the box, the line terminates at the largest observation that is less than or equal to the upper quartile plus 1.5 times the interquartile range. For the line to the left of the box, the line terminates at the smallest value that is greater than or equal to the lower quartile minus 1.5 times the interquartile range. Values beyond the whiskers are termed outliers, and are identified by individual symbols. For the Figure 8-3 data, two outliers, identified by circles, are present within each distribution to the right of the boxes.

Comparisons of the two data sets in Figure 8-3 clearly shows that, while there is some overlap between the two distributions, as a group middens have lower chipped stone densities than are present on sites. This pattern appears to be opposite of what we would expect if artifacts were repeatedly introduced into middens along with sediment to form a cap. However, note that with each occupation of the site, additional lithic material is also added to the external site data set. External site density, then, is likely to be the result of 1) pre-midden levels of occupation, 2) depositional 
Table 8-1. Chipped Stone Data from Midden and Non-Midden Contexts

\begin{tabular}{|c|c|c|c|c|c|c|}
\hline Case & $\begin{array}{r}\text { Site } \\
41 \mathrm{BR} \\
\end{array}$ & Unit & Location & $\begin{array}{c}\text { Number of } \\
\text { Items }\end{array}$ & $\begin{array}{l}\text { Volume of } \\
\text { Sediment }\end{array}$ & $\begin{array}{c}\text { Chipped Stone } \\
\text { Density }\end{array}$ \\
\hline 1 & 65 & 1 & Ring & 44 & 0.74 & 59.5 \\
\hline 2 & 65 & 2 & Non-midden & 93 & 0.45 & 206.7 \\
\hline 3 & 65 & 3 & Non-midden & 52 & 0.4 & 130.0 \\
\hline 4 & 65 & 4 & Non-midden & 49 & 0.4 & 122.5 \\
\hline 5 & 65 & 5 & Non-midden & 13 & 0.28 & 46.4 \\
\hline 6 & 65 & 6 & Ring & 27 & 0.9 & 30.0 \\
\hline 7 & 65 & 7 & Ring & 19 & 0.82 & 23.2 \\
\hline 8 & 87 & 1 & Center & 27 & 0.7 & 38.6 \\
\hline 9 & 87 & 2 & Ring & 94 & 0.72 & 130.6 \\
\hline 10 & 87 & 3 & Ring & 46 & 0.7 & 65.7 \\
\hline 11 & 87 & 4 & Non-midden & 98 & 0.3 & 326.7 \\
\hline 12 & 87 & 5 & Non-midden & 20 & 0.24 & 83.3 \\
\hline 13 & 87 & 6 & Non-midden & 95 & 0.35 & 271.4 \\
\hline 14 & 87 & 7 & Non-midden & 58 & 0.35 & 165.7 \\
\hline 15 & 87 & 8 & Non-midden & 168 & 0.3 & 560.0 \\
\hline 16 & 228 & 1 & Center & 181 & 0.43 & 420.9 \\
\hline 17 & 228 & 2 & Ring & 133 & 0.66 & 201.5 \\
\hline 18 & 228 & 3 & Ring & 98 & 0.74 & 132.4 \\
\hline 19 & 228 & 4 & Non-midden & 230 & 0.29 & 793.1 \\
\hline 20 & 228 & 5 & Non-midden & 266 & 0.14 & 1900.0 \\
\hline 21 & 228 & 6 & Non-midden & 60 & 0.15 & 400.0 \\
\hline 22 & 228 & 7 & Non-midden & 715 & 0.34 & 2102.9 \\
\hline 23 & 228 & 8 & Unknown & 55 & 0.71 & 77.5 \\
\hline 24 & 228 & 9 & Unknown & 72 & 0.82 & 87.8 \\
\hline 25 & 228 & 10 & Unknown & 81 & 0.58 & 139.7 \\
\hline 26 & 246 & 1 & Center & 20 & 1.02 & 19.6 \\
\hline 27 & 246 & 2 & Ring & 26 & 1.5 & 17.3 \\
\hline 28 & 246 & 3 & Ring & 22 & 1.56 & 14.1 \\
\hline 29 & 246 & 4 & Ring & 12 & 0.955 & 12.6 \\
\hline 30 & 246 & 5 & Non-midden & 187 & 0.55 & 340.0 \\
\hline 31 & 250 & 1 & Ring & 5 & 0.94 & 5.3 \\
\hline 32 & 250 & 2 & Center & 3 & 0.93 & 3.2 \\
\hline 33 & 250 & 3 & Center & 5 & 1.07 & 4.7 \\
\hline 34 & 250 & 4 & Center & 5 & 1.23 & 4.1 \\
\hline 35 & 250 & 5 & Non-midden & 12 & 0.2 & 60.0 \\
\hline 36 & 253 & 1 & Center & 18 & 0.48 & 37.5 \\
\hline 37 & 253 & 2 & Center & 40 & 0.45 & 88.9 \\
\hline 38 & 253 & 3 & Ring & 13 & 0.39 & 33.3 \\
\hline 39 & 253 & 4 & Center & 4 & 0.53 & 7.5 \\
\hline 40 & 253 & 5 & Center & 10 & 0.72 & 13.9 \\
\hline 41 & 253 & 6 & Center & 2 & 0.77 & 2.6 \\
\hline 42 & 253 & 7 & Non-midden & 54 & 0.2 & 270.0 \\
\hline 43 & 253 & 8 & Non-midden & 185 & 0.16 & 1156.3 \\
\hline 44 & 253 & 9 & Non-midden & 5 & 0.47 & 10.6 \\
\hline 45 & 253 & 10 & Non-midden & 4 & 0.61 & 6.6 \\
\hline 46 & 415 & 1 & Center & 41 & 0.84 & 48.8 \\
\hline 47 & 415 & 2 & Center & 17 & 0.56 & 30.4 \\
\hline 48 & 415 & 3 & Ring & 3 & 0.48 & 6.3 \\
\hline 49 & 415 & 4 & Non-midden & 55 & 0.52 & 105.8 \\
\hline
\end{tabular}


Table 8-1. continued...

\begin{tabular}{|c|c|c|c|c|c|c|}
\hline Case & $\begin{array}{r}\text { Site } \\
41 \mathrm{BR} \\
\end{array}$ & Unit & Location & $\begin{array}{c}\text { Number of } \\
\text { Items }\end{array}$ & $\begin{array}{c}\text { Volume of } \\
\text { Sediment }\end{array}$ & $\begin{array}{c}\text { Chipped Stone } \\
\text { Density }\end{array}$ \\
\hline 50 & 415 & 5 & Non-midden & 13 & 0.27 & 48.1 \\
\hline 51 & 415 & 6 & Non-midden & 25 & 0.26 & 96.2 \\
\hline 52 & 415 & 7 & Non-midden & 21 & 0.26 & 80.8 \\
\hline 53 & 415 & 8 & Non-midden & 69 & 0.48 & 143.8 \\
\hline 54 & 420 & 1 & Center & 16 & 0.57 & 28.1 \\
\hline 55 & 420 & 2 & Center & 16 & 0.63 & 25.4 \\
\hline 56 & 420 & 3 & Ring & 15 & 0.64 & 23.4 \\
\hline 57 & 420 & 4 & Non-midden & 56 & 0.32 & 175.0 \\
\hline 58 & 420 & 5 & Non-midden & 47 & 0.37 & 127.0 \\
\hline 59 & 433 & 1 & Center & 56 & 0.6 & 93.3 \\
\hline 60 & 433 & 2 & Center & 27 & 0.59 & 45.8 \\
\hline 61 & 433 & 3 & Ring & 30 & 0.63 & 47.6 \\
\hline 62 & 433 & 4 & Ring & 42 & 0.48 & 87.5 \\
\hline 63 & 433 & 5 & Non-midden & 46 & 0.33 & 139.4 \\
\hline 64 & 433 & 6 & Non-midden & 12 & 0.25 & 48.0 \\
\hline 65 & 433 & 7 & Non-midden & 22 & 0.26 & 84.6 \\
\hline 66 & 473 & 1 & Non-midden & 389 & 0.38 & 1023.7 \\
\hline 67 & 473 & 2 & Center & 4 & 0.85 & 4.7 \\
\hline 68 & 473 & 3 & Center & 5 & 0.92 & 5.4 \\
\hline 69 & 473 & 4 & Ring & 1 & 0.88 & 1.1 \\
\hline 70 & 478 & 1 & Center & 191 & 0.7 & 272.9 \\
\hline 71 & 478 & 2 & Center & 149 & 0.75 & 198.7 \\
\hline 72 & 478 & 3 & Ring & 84 & 0.64 & 131.3 \\
\hline 73 & 480 & 1 & Unknown & 15 & 0.6 & 25.0 \\
\hline 74 & 480 & 2 & Unknown & 32 & 0.59 & 54.2 \\
\hline 75 & 480 & 3 & Unknown & 21 & 0.6 & 35.0 \\
\hline 76 & 480 & 4 & Non-midden & 67 & 0.11 & 609.1 \\
\hline 77 & 480 & 5 & Non-midden & 443 & 0.52 & 851.9 \\
\hline 78 & 480 & 6 & Non-midden & 33 & 0.17 & 194.1 \\
\hline 79 & 492 & 1 & Center & 46 & 1.4 & 32.9 \\
\hline 80 & 492 & 2 & Center & 53 & 1.37 & 38.7 \\
\hline 81 & 492 & 3 & Ring & 27 & 1.22 & 22.1 \\
\hline 82 & 492 & 4 & Non-midden & 91 & 0.63 & 144.4 \\
\hline 83 & 492 & 5 & Non-midden & 272 & 0.33 & 824.2 \\
\hline 84 & 493 & 1 & Center & 21 & 0.96 & 21.9 \\
\hline 85 & 493 & 2 & Center & 18 & 1.08 & 16.7 \\
\hline 86 & 493 & 3 & Ring & 25 & 1.66 & 15.1 \\
\hline
\end{tabular}

patterns present during the period of midden use, and 3) depositional patterns that post-date the use of the middens at a site. This complicates any straightforward interpretation of density differences in middens and non-middens.

In order to clarify the relationships between midden and off-midden densities, we consider a second data set, differences in mussel shell weights. As noted in Chapter 6, mussel shell was frequently present in low quantities in our excavations. Unlike the patterns in chipped stone densities, where our sampling strategies for the placement of external 1-x-1-m units potentially were biased with regard to lithic densities, the density of mussel shell was not a factor in considering placement of units. This data set, then, provides a comparison that involves $1-\mathrm{x}-1-\mathrm{m}$ units in both midden and non-midden contexts, rather than inferred volumes of sediment derived from shovel tests. A critical component for the comparison between midden and non-midden shell 


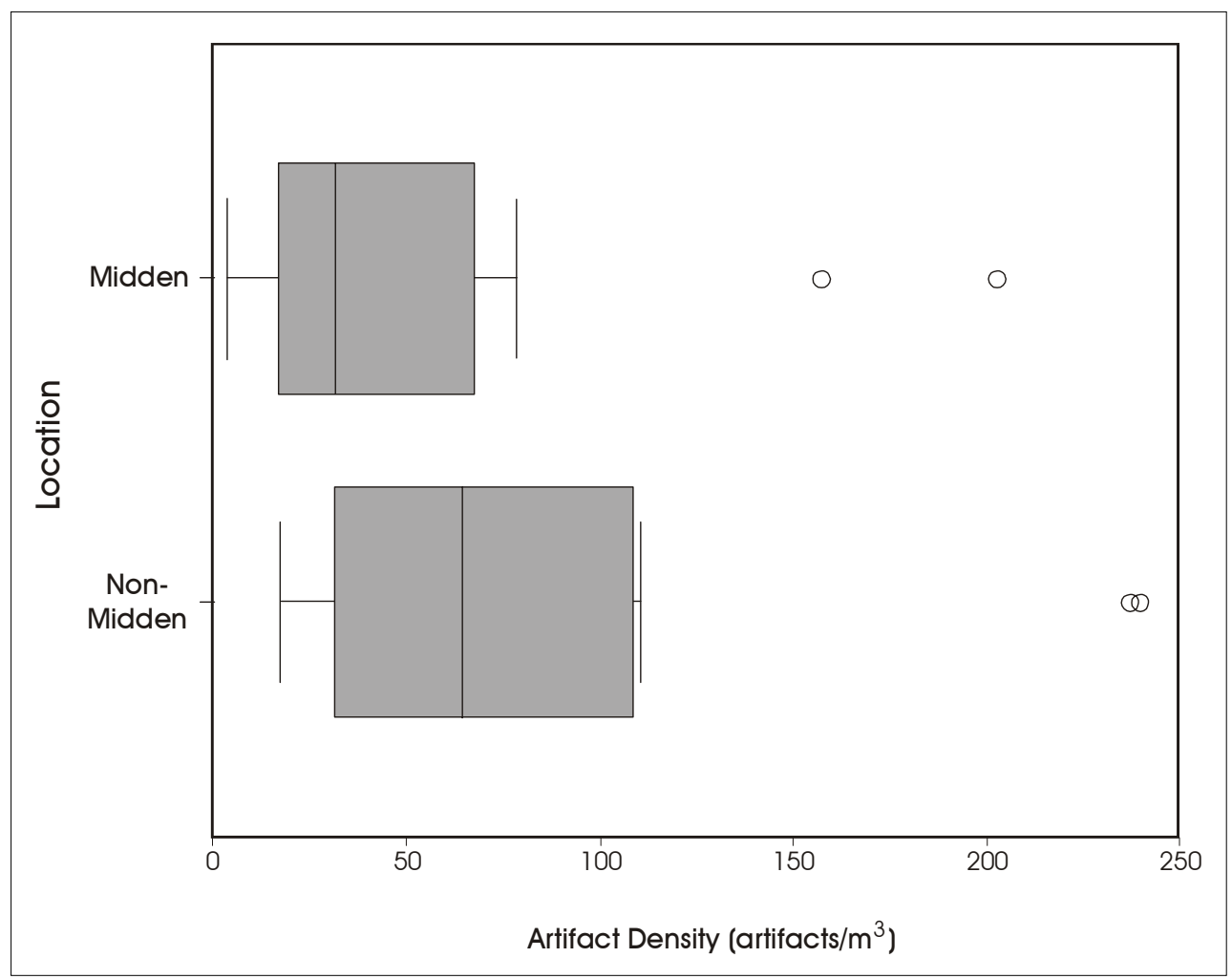

Figure 8-3. Box plots of midden and non-midden chipped stone densities.

are two assumptions regarding the nature of mussel shell at these sites. First, we suggest that some portion of the mussel shell recovered from the current project is non-cultural. Second, we suggest that much of the mussel shell may be significantly older than the time frame of midden use. If these two assumptions are correct, then unlike the chipped stone density differences discussed above, the consideration of mussel shell differences between midden and non-midden contexts are less likely to be impacted by significant additions of mussel shell during and after midden construction and use.

The assumption that some portion of the mussel shell recovered during our work at Camp Bowie is non-cultural is based on an analysis of amino acids for 39 archaeological samples and two modern samples of the genus Quadrula. Two different species of mussel, Quadrula houstonensis and Quadrula apiculata, are represented in this sample. The 39 samples come from 11 different sites and represent both midden and non-midden excavation contexts. The two modern samples were obtained from collections at the Smithsonian and provide expected ratios in the absence of any diagenetic changes in the samples. Dr. Glenn Goodfriend conducted the racemization analysis and the data are presented in Appendix D. Briefly, two different ratios of amino acids were analyzed from these samples. The first ratio involved aspartic acid (Asp) and glutamic acid (Glu). The amino acid Glu is more stable than Asp. The Asp/Glu ratio will decrease with increasing age. The second set involved amino acids D-alloisoleucine and L-isoleucine. The $\mathrm{A} / \mathrm{I}$ ratio will also change as a function of the age of a sample (see G. Ellis 1997; Ellis et al. 1996).

Over the time scale we are dealing with, the amount of diagenetic change due to the aging process is small. However, diagenetic changes in both these ratios can be dramatically accelerated if shells are exposed to heat. Heating of the samples causes a strong differential decomposition of Asp relative to Glu and will noticeably reduce the Asp/Glu ratio. This heating will also induce high $\mathrm{A} / \mathrm{I}$ racemization rates in a sample. Heated samples, then, should have low Asp/Glu ratios and high A/I values. Figure 8-4 plots the Asp/Glu ratios relative to the ratios for A/I values for the 39 archaeological and two modern samples (green in Figure 8-4) of Quadrula. Note that five samples, identified in red, are clearly separated from the remaining archaeological samples. This separation is consistent with patterns that would result from exposure to high heat. The 


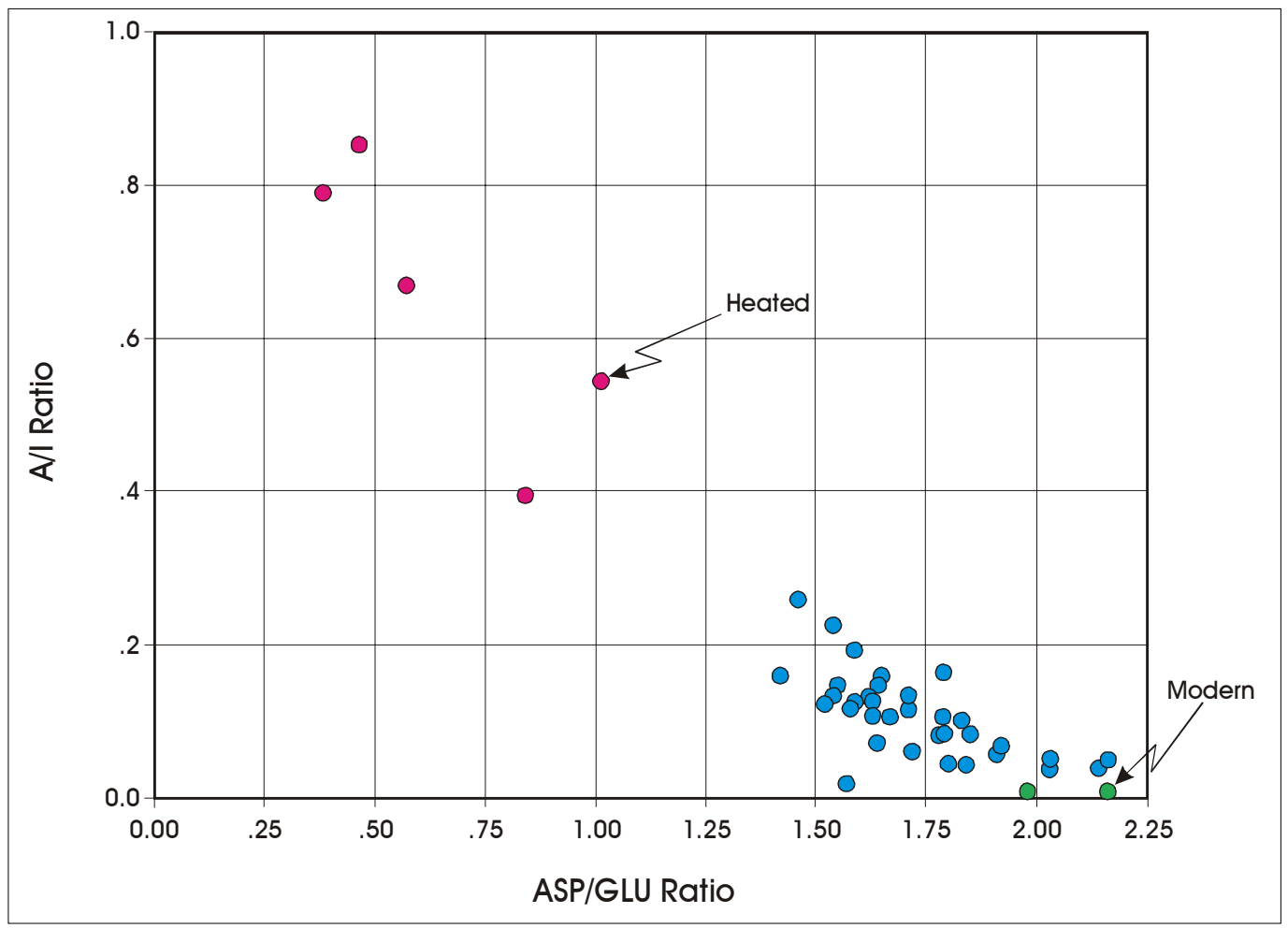

Figure 8-4. Asp/Glu ratios and A/I values for a sample of mussel shell (Quadrula) with heated, non-heated, and modern shell identified.

pattern suggests that in 34 of the 39 cases, shell has not been exposed to any significant heating. While heating, as such, does not mean that shell was cultural in origin, heating would seem to be a component of most cultural uses of mussel shell, at least for subsistence. The fact that only 12.8 percent of the shell tested was heated suggests that a component of the mussel shell may be non-cultural in origin.

The second assumption regarding shell involves age. For this element, we rely on the racemization of amino acids Lisoleucine to D-alloisoleucine (A/I). A/I values are clearly not an established absolute dating technique, and our use of them here is simply to assess the relative fit between the radiocarbon dates and the mussel shell $\mathrm{A} / \mathrm{I}$ values. While the racemization rates are complicated by the temperature history of a sample, and while different genera of mollusks probably have different rates of racemization (see Goodfriend and Mitterer 1988), shells of similar age from the same genus have similar A/I values (see Ellis et al. 1996). Racemization rates on mussels in general have not been established. However, work has been conducted on land snails, such as rabdotus, which suggests that for samples over the last 5,000 years, a rate of roughly 0.00267 per 100 years may be appropriate (G. Ellis 1997; see also Ellis et al.
1996). Unfortunately, no work has been conducted on the genus Quadrula to establish racemization rates. However, G. Ellis (1997) has conducted some preliminary work on another mussel species, Amblema plicata. Using associated radiocarbon dates he estimates an overall racemization rate of 0.0057 per 100 years for this mussel. This rate is over twice as fast as that established for rabdotus.

Figure 8-5 presents estimated age rates for the 34 non-heated samples using the racemization rate of 0.0057 per 100 years. Of the 34 samples, these estimated rates suggest that only 11 samples (light gray shading in Figure 8-5) date after A.D. 750. That is, 67.6 percent of the shell appears to predate the primary period of midden use on Camp Bowie. As noted above, the assumed racemization rate of 0.0057 is high relative to that established for rabdotus. However, if we assume a lower rate, then even a higher percentage of shell predates the period of midden use.

If the $\mathrm{A} / \mathrm{I}$ ratios and the $\mathrm{Asp} / \mathrm{Glu}$ ratios are both interpreted correctly, and if the sample of mussel shell is similar to the overall population of shell on the project, then the use of mussel shell as a subsistence item during the period of midden use would require the frequent consumption of raw, 


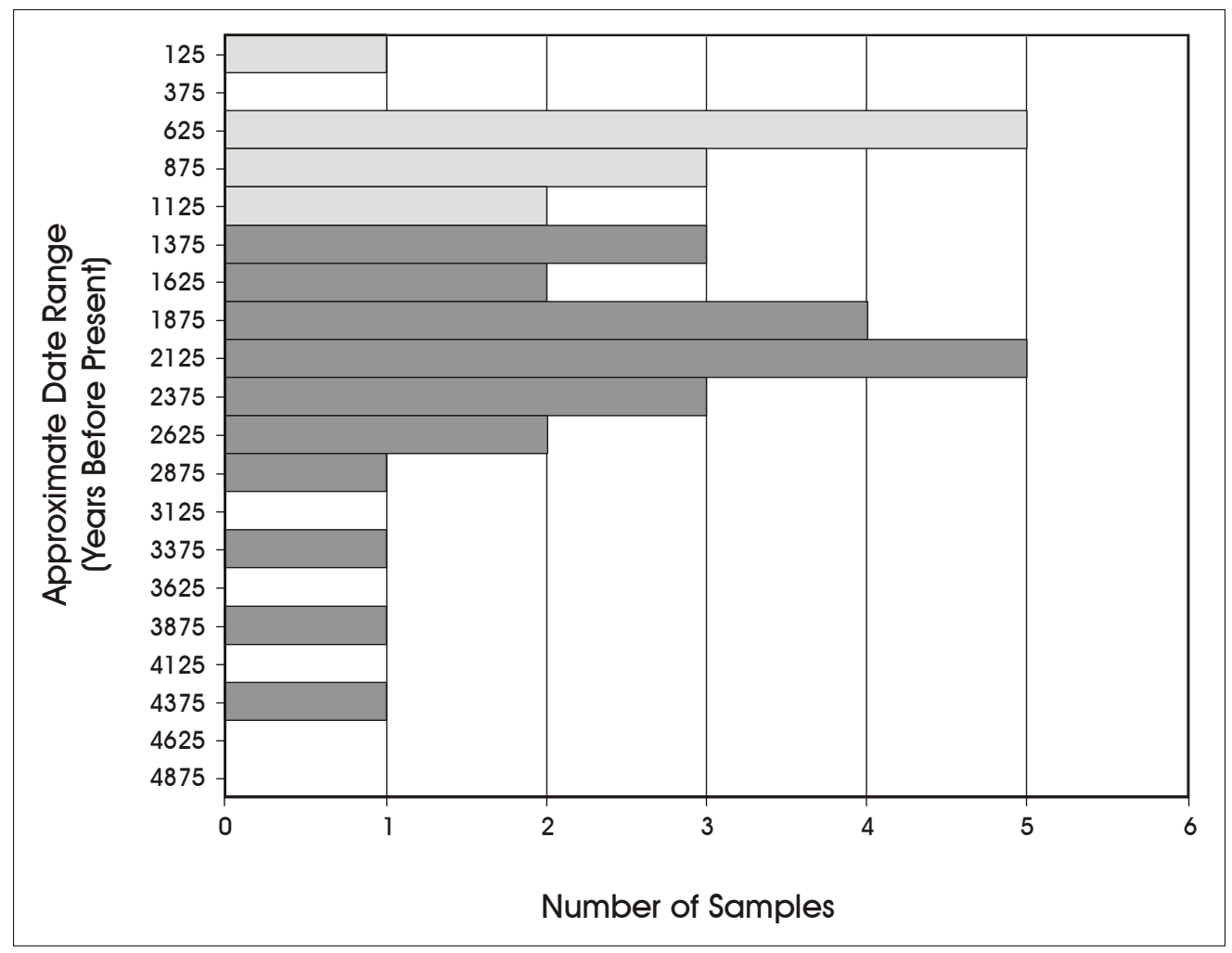

Figure 8-5. Estimated age of non-heated mussel shell using A/I ratios. Dark gray shading indicates samples predating primary period of midden use.

old shellfish. As this is an unwise strategy in almost any context; we will assume that a significant portion of the mussel shell recovered is either non-cultural, reflecting a general background scatter across the landscape, or that much of it is cultural but predates the midden occupation at these sites. Differences in mussel shell, then, should be less impacted by problems of accumulation that potentially plagued the lithic comparisons conducted previously.

Figure 8-6 presents a box plot of 47 1-x-1-m units in middens and $311-x-1-m$ units outside of middens considering shell weights per cubic meter of sediment. Here, midden units clearly have significantly higher densities relative to nonmidden units. That is, mussel shell is concentrated in middens. Mean shell density within middens is 95.29 grams per cubic meter. Outside of middens, average density is 41.18 grams per cubic meter. Such a pattern of concentration of shell in middens is generally consistent with the incorporation of shell as a result of adding sediment to cap the central features.

Interestingly, while the distribution of bone is not considered in detail, primarily because bone had a much more spotty distribution, bone weights also are concentrated in middens. The average bone weight outside of middens is 5.1 grams per cubic meter of sediment. Within middens, the average bone weight is 11.23 grams per cubic meter.

Patterns in chipped stone and mussel shell in middens and outside of middens on sites at Camp Bowie are, then, somewhat ambiguous with regard to the model of sediment being added as a cap to central features. The strong correlation between external and internal chipped stone density at a site, patterns in bone weights, and the concentration of mussel shell within middens relative to nonmidden areas clearly support the model. However, differences in chipped stone densities in middens and nonmidden contexts do not pattern as anticipated. The probability that significant accumulations of chipped stone were added to the off-site sample during or after midden use may account for this difference. Note also that in the case of mussel shell, as well as bone, we have assumed that some portion of these potential food remains will be deposited in the midden during the cooking event. That is, we assumed that, for example, some cooked mussels would be missed during extraction of the food. Similarly, we have 


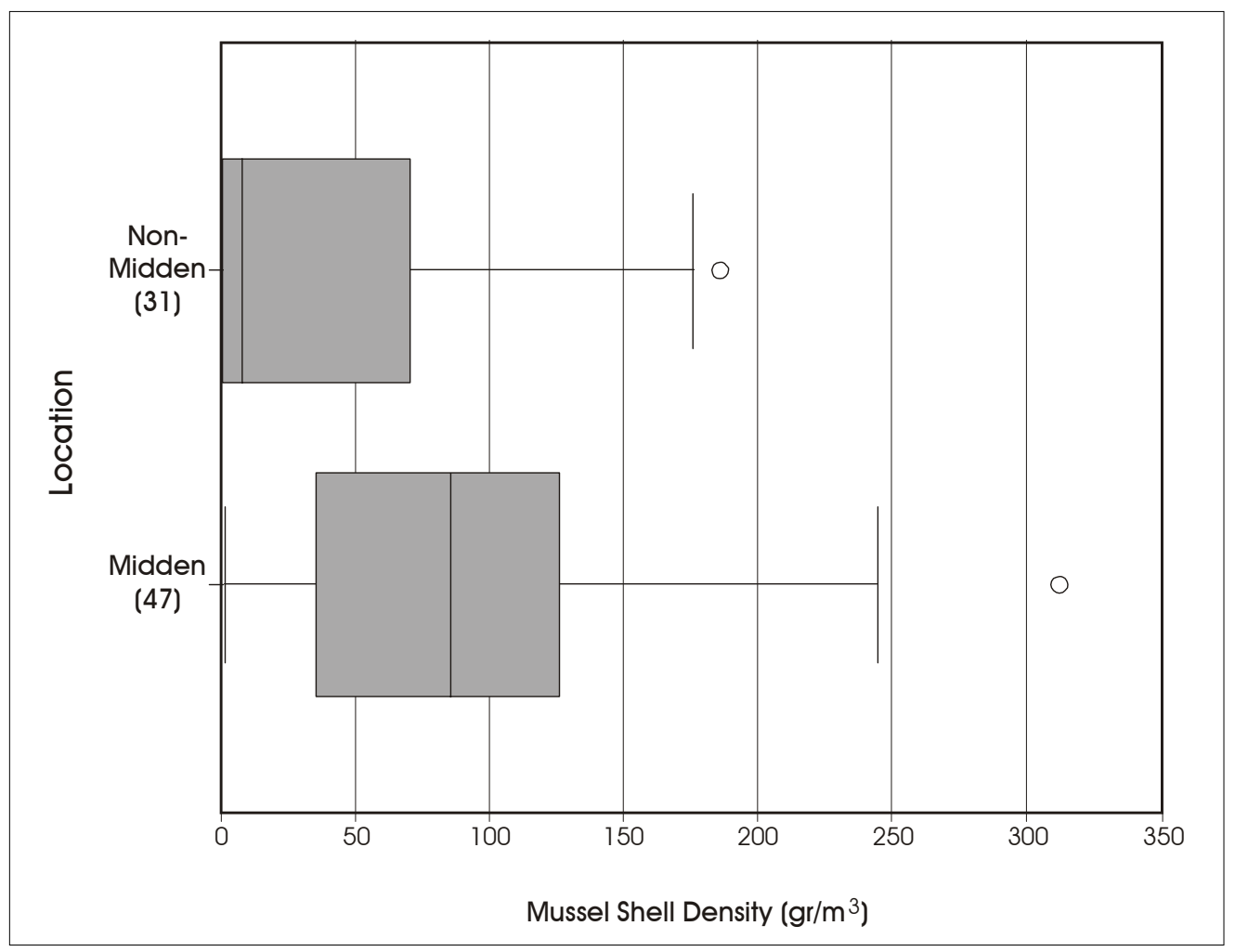

Figure 8-6. Box plots of midden and non-midden shell weights per cubic meter of sediment.

assumed that some portion of animal bone would be left within the midden. If, however, we make the assumption that all of the material is extracted, an assumption that seems especially reasonable with the vertebrate faunal material, then any remains found in the midden would likely represent secondary deposition, probably the result of incorporation as part of a "sediment cap" for the next cooking event.

\section{Patterns in Burned Rock}

Consideration of chipped stone and mussel shell density patterns, then, tend to support aspects of the overall model of incorporation. The current section considers patterns in burned rock within midden deposits in the context of evaluating midden accumulation. Specifically, we are concerned with evaluating aspects of the formation of middens by focusing on rock size and number. Figure 8-7 outlines a hypothetical model of how middens may accumulate over time. The model suggests that after a given use event, thermally shattered rocks are replaced by large rocks. We assume that this replacement is necessary, as shattered rocks would, given greater surface area relative to overall size, dissipate heat more quickly than the original larger rocks (see Jackson 1998:7). The broken rocks from the central pit are removed and discarded forming the ring. We anticipate that this process should result in distinct patterns of rock sizes and numbers in different portions of the feature. The ring portion of the midden should have relatively high frequencies of medium-sized rock, lower frequencies of large rock, and lower frequencies of small rock. That is, medium-sized rock should be over represented in the ring as a function of cleaning. It is likely that the cleaning would result in smaller rock fragments being concentrated in the interior of the feature, as these rocks would not be a priority for removal. Larger, unbroken rock, which would still maintain heat, would not be replaced. Therefore, the interior portion of the midden should also be dominated by larger rocks relative to the ring.

As noted in Chapter 5, to monitor rock size we counted and size graded all burned rock greater than one inch in size. Size grading was done by dropping the rocks though a series of wooden boxes with holes cut at sizes of one, two, and three inches. On some sites, rocks greater than three inches in size were measured, while on others, an additional size grade was established at six inches. We counted rock within 


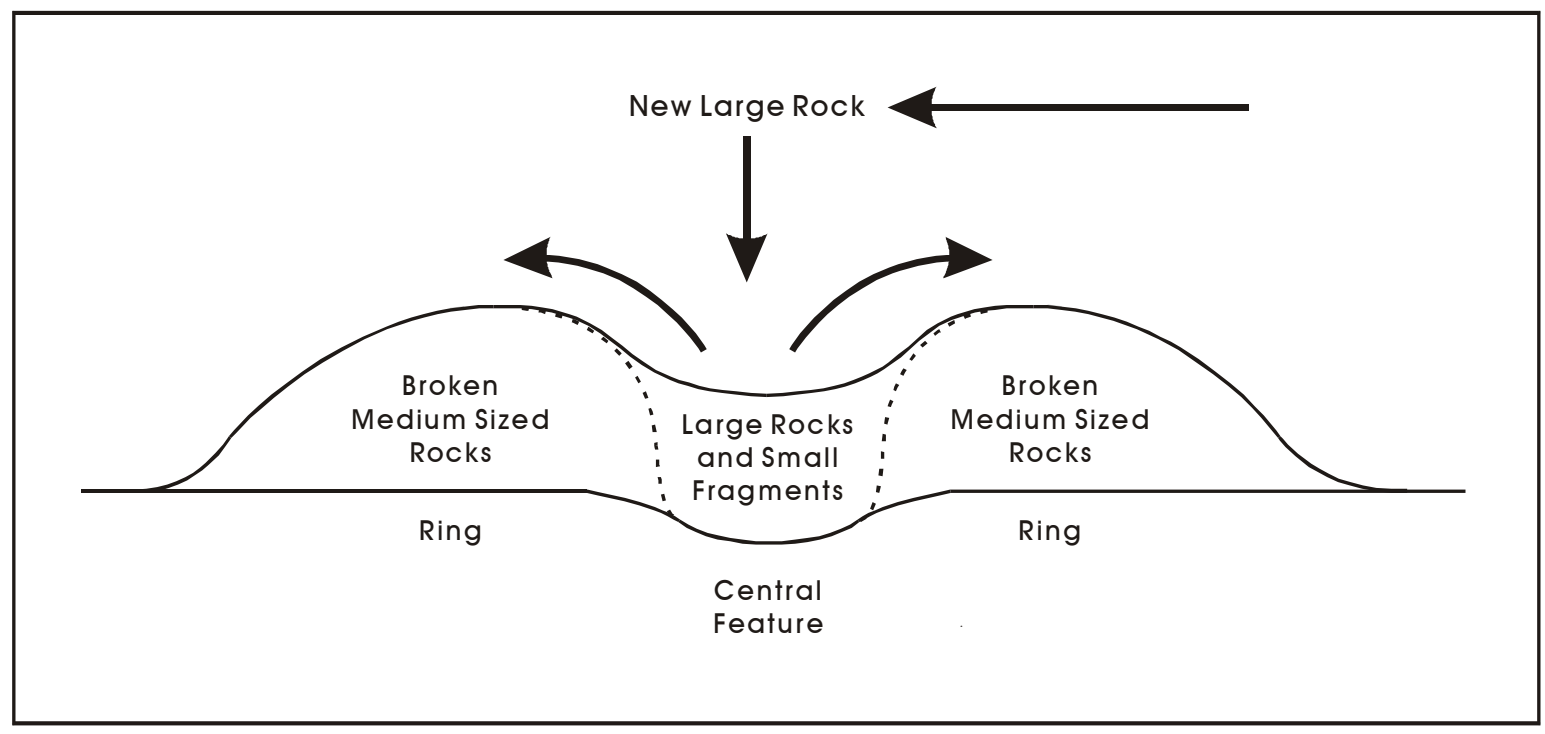

Figure 8-7. A model of midden accumulation as a function of rock breakage and replacement.

each size grade. At a project level, over 300,000 rocks were sized and counted using this method. Rock weights were obtained on all material less than one inch in size, with a total weight of over $3,200 \mathrm{~kg}$ of rock recorded.

The principal data set used here is presented in Table 8-2. It contains listings of rocks by size for 232,237 rocks from 44 burned rock midden units excavated on 13 different sites. In all cases except site 41BR433, sandstone made up more than 95 percent of the raw material. The 41BR433 samples are dominated by limestone. Sites 41BR441, 41BR474, and 41BR480 are not included in this table. While several units were placed in sites 41BR441 and 41BR474, the upper portions of these middens had been bulldozed, rendering any detailed rock data of little comparative value. On site 41BR480, the burned sandstone was extremely soft. Consequently, many of the excavators cut through the rock in the profiles rather than leaving the rock in place or removing it whole. In addition, it is unclear exactly where in this midden the three units fall. As outlined in Chapter 6, much of this midden was buried, and while we have a reasonable idea of the size of the midden based on shovel tests, whether the three units are located in the ring or in the central area is not clear. Consequently, these three units are not used in the comparisons. Units 8,9 , and 10 on site 41BR228 are also not included in the table. While these three units are clearly in a midden, it is unclear exactly where in the midden these units fall. Finally, note that Unit 4 on site 41BR433 is not included in the table. As outlined in the site description in Chapter 6, a significant percentage of this unit cuts through both midden and non-midden deposits.
That is, midden deposits were not separated from nonmidden deposits in some levels. While we could simply assign all rock in this case to the midden, Unit 3 at this site represents a similar location, being in the ring, and is completely within the feature.

An examination of the data in Table 8-2 will suggest that within a given excavation unit, the number of rocks varies substantially from a high of just over 13,000 to a low of just less than 1,000 . In part, this variability is related to the depth of the feature and the location of the unit, though other factors, such as distance to rock sources and the size and composition of the group constructing the feature, could potentially influence the number and size of rock originally introduced into the feature. In addition, excavation procedures, screening procedures, counting errors, recording errors, and potentially the geological source of the rock itself could certainly influence the overall patterns. Given the level of variability between units, and given that our interest is in comparing the relative differences in the sizes of burned rocks between units, we converted the counts for a given unit into percentages by size class. For example, Unit 1 on site 41BR65 contained 3,521 burned rocks greater than one inch in size, with 2,365 of these being between one and two inches, and 20 being greater than six inches (Table 8-2). For analytical comparisons, then, we converted the rock numbers to percentages. In this case, 67.2 percent of the rocks within this unit are within the one- to two-inch size class, while 0.57 percent of the rocks are greater than six inches in maximum size. There are 25 central units and 19 ring units available for comparison (see Table 8-2). 
Table 8-2. Rock Counts by Size Class for Burned Rock Midden Units

\begin{tabular}{|c|c|c|c|c|c|c|c|c|}
\hline \multirow[b]{2}{*}{\begin{tabular}{l}
\multicolumn{1}{c}{ Site } \\
Number \\
41BR
\end{tabular}} & \multirow[b]{2}{*}{ Unit } & \multirow[b]{2}{*}{$\begin{array}{c}\text { Location } \\
\text { Within } \\
\text { Midden }\end{array}$} & \multirow{2}{*}{$\begin{array}{c}\text { Rock Wgt. } \\
\text { (in grams) }\end{array}$} & \multicolumn{4}{|c|}{ Rock Counts } & \multirow[b]{2}{*}{$\begin{array}{c}\text { Total } \\
\text { Number } \\
\text { of Rock }\end{array}$} \\
\hline & & & & 1-2 inches & 2-3 inches & 3-6 inches & $>6$ inches & \\
\hline 65 & 1 & Ring & 28252 & 2365 & 880 & 256 & 20 & 3521 \\
\hline 65 & 6 & Ring & 25941 & 2374 & 1371 & 361 & 33 & 4139 \\
\hline 65 & 7 & Ring & 62828 & 4571 & 1558 & 408 & 24 & 6561 \\
\hline 87 & 1 & Center & 70217 & 2843 & 529 & 117 & 10 & 3499 \\
\hline 87 & 2 & Ring & 47450 & 2786 & 777 & 165 & 10 & 3738 \\
\hline 87 & 3 & Ring & 57918 & 2402 & 820 & 281 & 26 & 3529 \\
\hline 228 & 1 & Center & 54746 & 2552 & 351 & 99 & 39 & 3041 \\
\hline 228 & 2 & Ring & 82909 & 4117 & 795 & 181 & 29 & 5122 \\
\hline 228 & 3 & Ring & 61348 & 3598 & 1123 & 413 & 88 & 5222 \\
\hline 246 & 1 & Center & 108625 & 4796 & 543 & 140 & 39 & 5518 \\
\hline 246 & 2 & Ring & 125280 & 7238 & 1596 & 720 & 219 & 9773 \\
\hline 246 & 3 & Ring & 107355 & 6483 & 1489 & 715 & 188 & 8875 \\
\hline 246 & 4 & Ring & 65284 & 3236 & 986 & 431 & 46 & 4699 \\
\hline 250 & 1 & Ring & 44192 & 3208 & 1595 & 643 & 78 & 5524 \\
\hline 250 & 2 & Center & 71693 & 3547 & 709 & 335 & 112 & 4703 \\
\hline 250 & 3 & Center & 122154 & 7062 & 1061 & 316 & 132 & 8571 \\
\hline 250 & 4 & Center & 102300 & 6940 & 1807 & 681 & 143 & 9571 \\
\hline 253 & 1 & Center & 28282 & 763 & 133 & 49 & 11 & 956 \\
\hline 253 & 2 & Center & 34084 & 1495 & 275 & 48 & 12 & 1830 \\
\hline 253 & 3 & Ring & 11536 & 1151 & 303 & 101 & 37 & 1592 \\
\hline 253 & 4 & Center & 68662 & 3137 & 417 & 127 & 106 & 3787 \\
\hline 253 & 5 & Center & 67196 & 2271 & 306 & 120 & 83 & 2780 \\
\hline 253 & 6 & Center & 78604 & 2806 & 345 & 123 & 55 & 3329 \\
\hline 415 & 1 & Center & 85156 & 2823 & 529 & 405 & 104 & 3861 \\
\hline 415 & 2 & Center & 36159 & 1793 & 358 & 130 & 41 & 2322 \\
\hline 415 & 3 & Ring & 62216 & 2593 & 670 & 534 & 57 & 3854 \\
\hline 420 & 1 & Center & 18668 & 896 & 238 & 121 & 68 & 1323 \\
\hline 420 & 2 & Center & 26727 & 1625 & 260 & 169 & 89 & 2143 \\
\hline 420 & 3 & Ring & 40737 & 2611 & 894 & 271 & 31 & 3807 \\
\hline 433 & 1 & Center & 74862 & 2847 & 486 & 253 & 76 & 3662 \\
\hline 433 & 2 & Center & 47572 & 1934 & 327 & 143 & 19 & 2423 \\
\hline 433 & 3 & Ring & 52550 & 4478 & 1090 & 172 & 20 & 5760 \\
\hline 433 & 4 & Ring & 85568 & 2130 & 411 & 45 & 1 & 2587 \\
\hline 473 & 2 & Center & 98328 & 4301 & 593 & 209 & 94 & 5197 \\
\hline 473 & 3 & Center & 91616 & 3564 & 546 & 211 & 100 & 4421 \\
\hline 473 & 4 & Ring & 81764 & 5873 & 1799 & 837 & 37 & 8546 \\
\hline 478 & 1 & Center & 42325 & 2863 & 830 & 239 & 21 & 3953 \\
\hline 478 & 2 & Center & 52168 & 2508 & 581 & 228 & 33 & 3350 \\
\hline 478 & 3 & Ring & 54092 & 4263 & 1674 & 221 & 7 & 6165 \\
\hline 492 & 1 & Center & 137875 & 6088 & 1465 & 533 & 174 & 8260 \\
\hline 492 & 2 & Center & 136956 & 6297 & 1588 & 528 & 160 & 8573 \\
\hline 492 & 3 & Ring & 104338 & 8123 & 3242 & 757 & 63 & 12185 \\
\hline 493 & 1 & Center & 88830 & 7372 & 1730 & 391 & 71 & 9564 \\
\hline 493 & 2 & Center & 98034 & 7393 & 1803 & 445 & 76 & 9717 \\
\hline 493 & 3 & Ring & 130983 & 9652 & 2556 & 854 & 106 & 13168 \\
\hline TOTALS & & & 3174380 & 173768 & 43439 & 14526 & 2988 & 234721 \\
\hline
\end{tabular}


Figure 8-8 presents box plots comparing the percentages of rocks greater than six inches in size for units excavated in the rings with units excavated in the centers of middens. Examination of Figure 8-8 will suggest that while there is certainly some overlap between the two data sets, central units tend to have higher percentages of larger rocks relative to ring units. The median values are 0.79 percent for the ring units (mean $=0.98$ ) and 1.65 percent for the central units (mean=1.78). While formal statistical analysis of these percentage data are probably not appropriate, as the median value for the ring distribution lies outside of the box for the central unit distributions, we can probably conclude that central units have a significantly greater percentage of large rocks relative to ring units. Figure 8-9 presents box plots similar to those in Figure 8-8, but for the percentages of rocks greater than two inches and less than six inches. As a group, ring units have a significantly higher percentage of rocks in this medium size range than central units. The median percentage is 30.16 percent for ring units and 20.02 percent for central units. Finally, Figure 8-10 presents box plots comparing the percentages of rocks in the one- to twoinch size range for ring and central excavation units. Here, central units clearly have higher percentages relative to ring units. These overall patterns, then, are consistent with expectations derived from the use model presented in Figure 8-7. That is, medium-sized rocks are over represented in the ring, while central units have an over representation of both larger and smaller rocks.

Figure 8-11 presents a bivariate plot of the percentage of rocks greater than six inches against the percentage of rocks in the two- to six-inch range for each of the individual cases identified by central and ring units. While individual distributions overlap, it is clear that, in most cases, ring units have both higher percentages of medium-sized rock and lower percentages of larger rock relative to central units. These patterns in the larger rocks are consistent with the expectations derived from Figure 8-7.

Figure 8-12 considers weight differences in the less than one-inch fraction of rock for sites using data presented in Table 8-2. Note that site 41BR65 lacked any central excavation units, and therefore is not included in the comparison. All data have been standardized such that the value reflects the weight of items less than one inch in size recovered for a cubic meter of excavation. Given

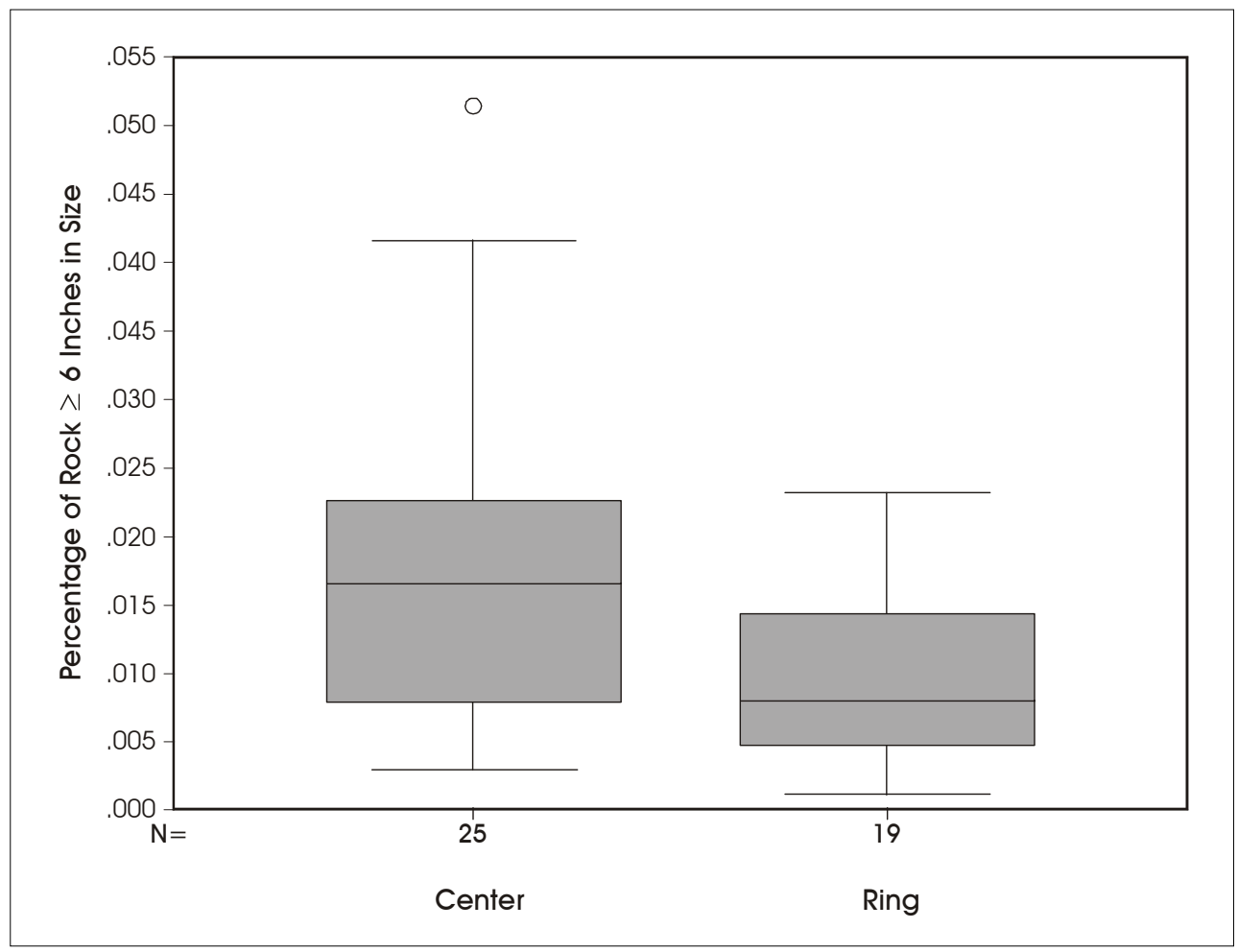

Figure 8-8. Box plots of percentages of rock in the 6-inch or greater size range for ring and central excavation units in middens. 


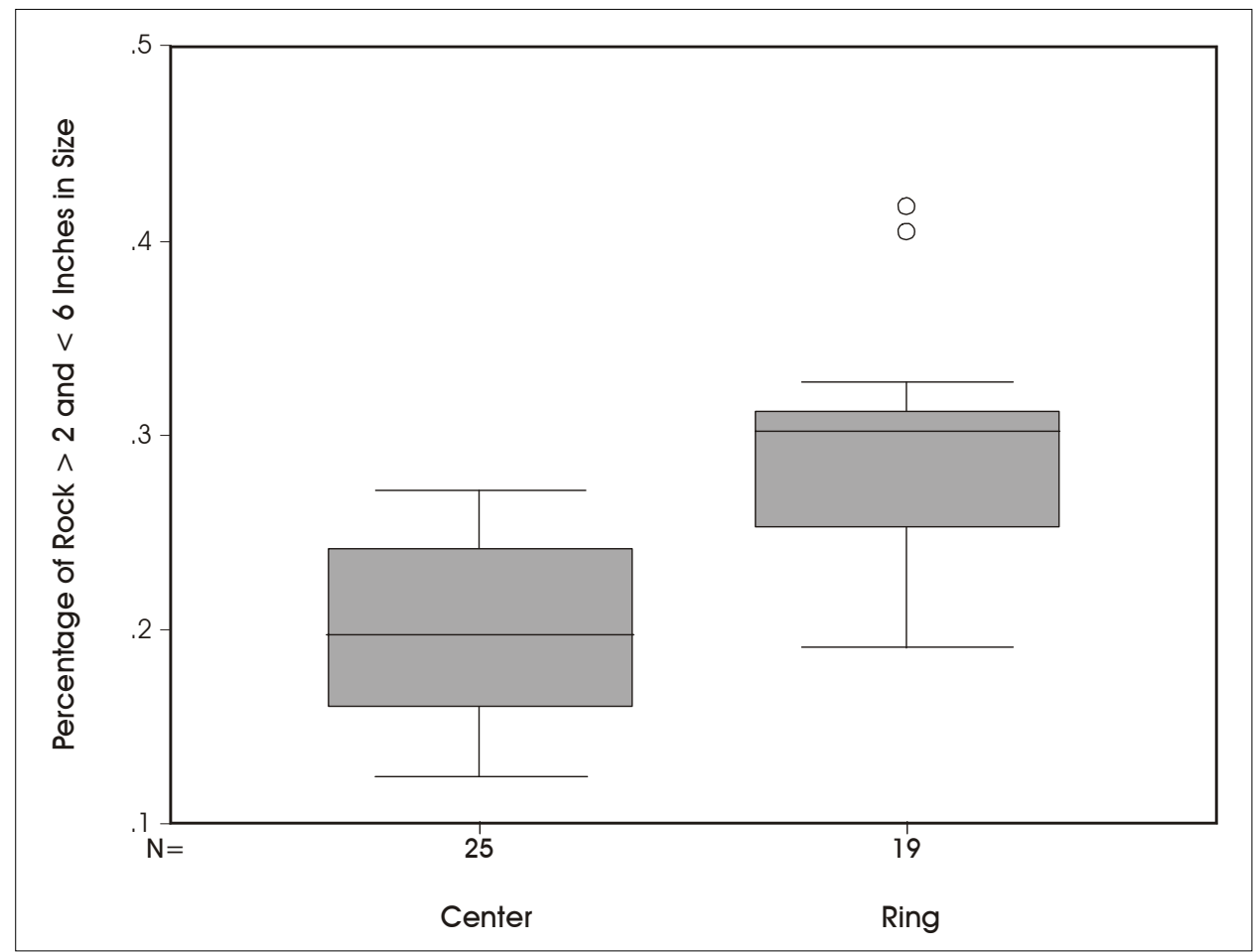

Figure 8-9. Box plots of percentages of rock in the 2-6-inch size range for ring and central excavation units in middens.

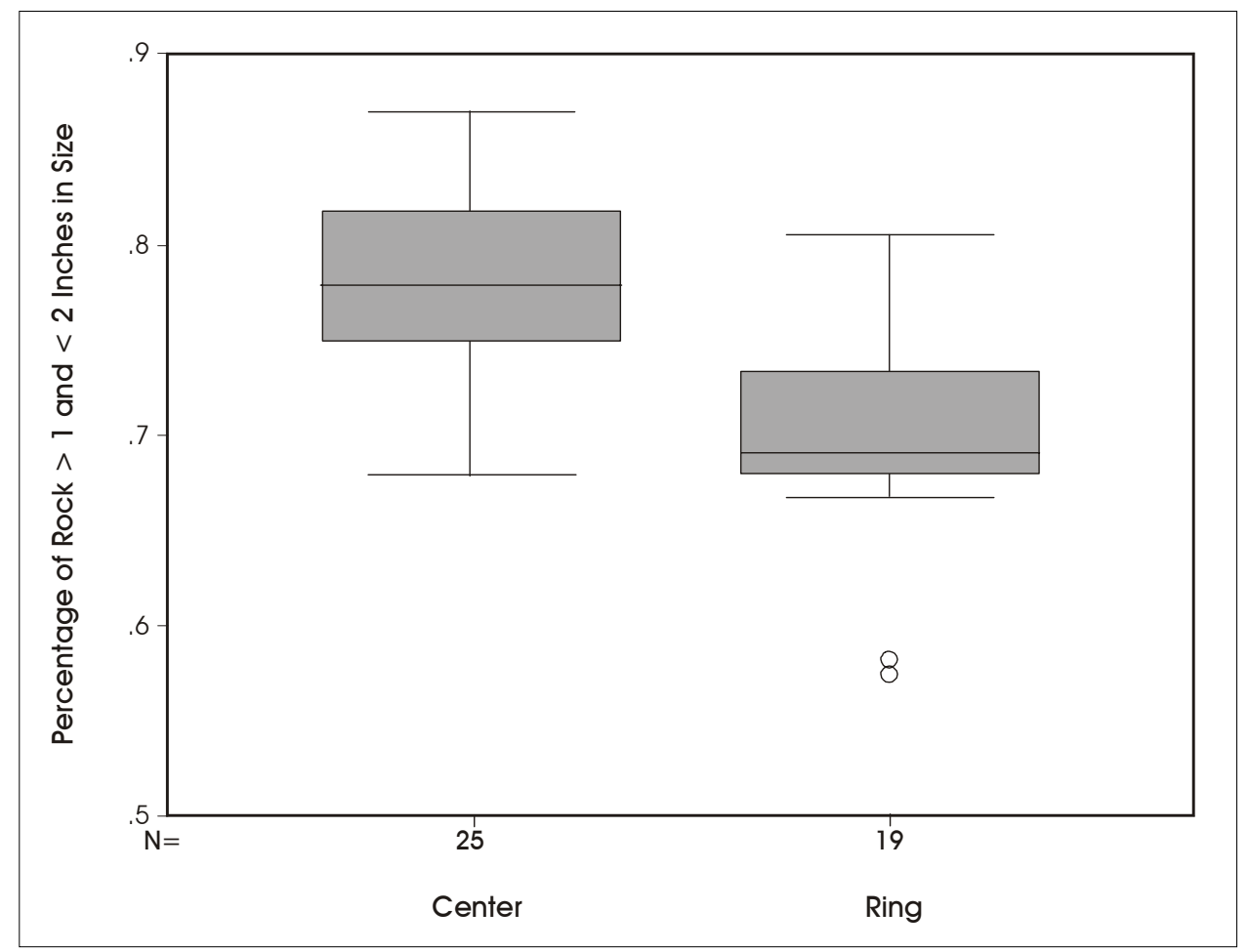

Figure 8-10. Box plots of percentages of rock in the 1-2-inch size range for ring and central excavation units in middens. 


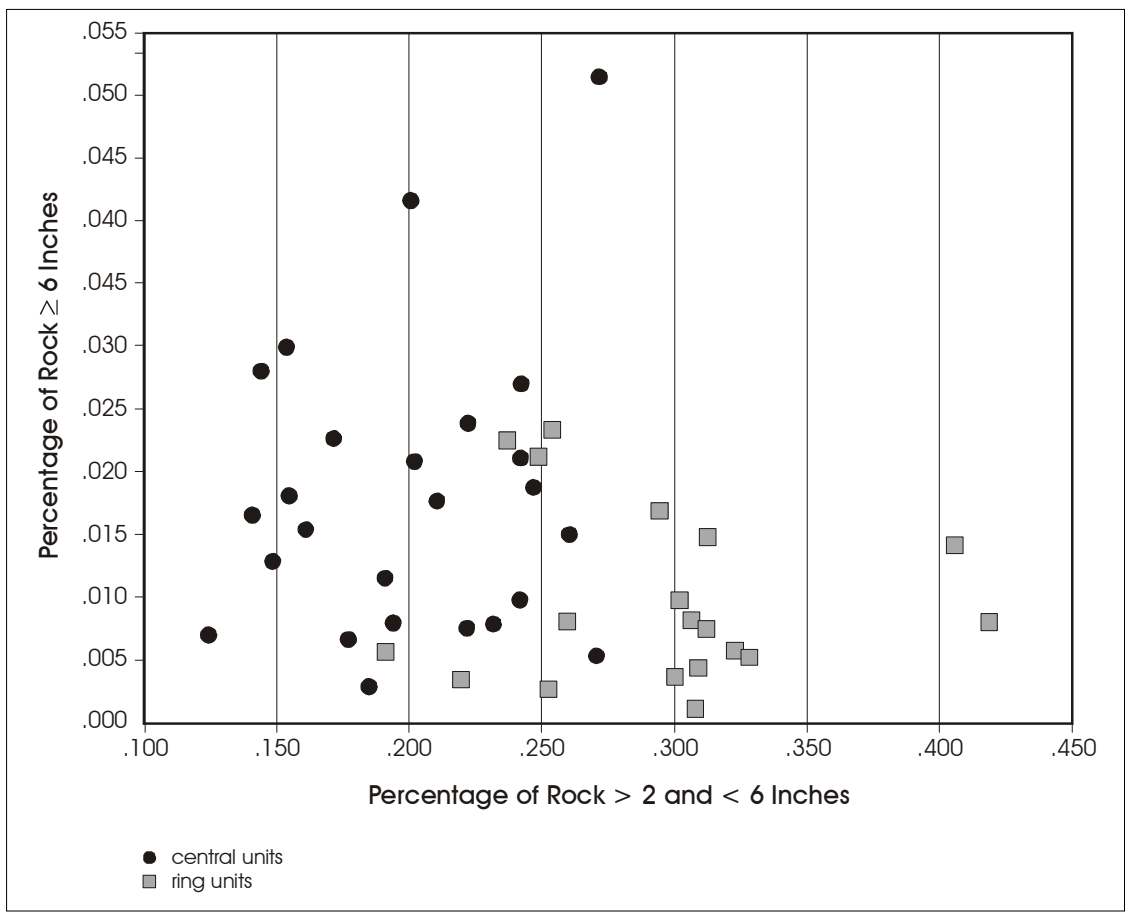

Figure 8-11. Plot of the percentages of rock in the >6-inch group against the 2-6-inch group for individual central and ring units.

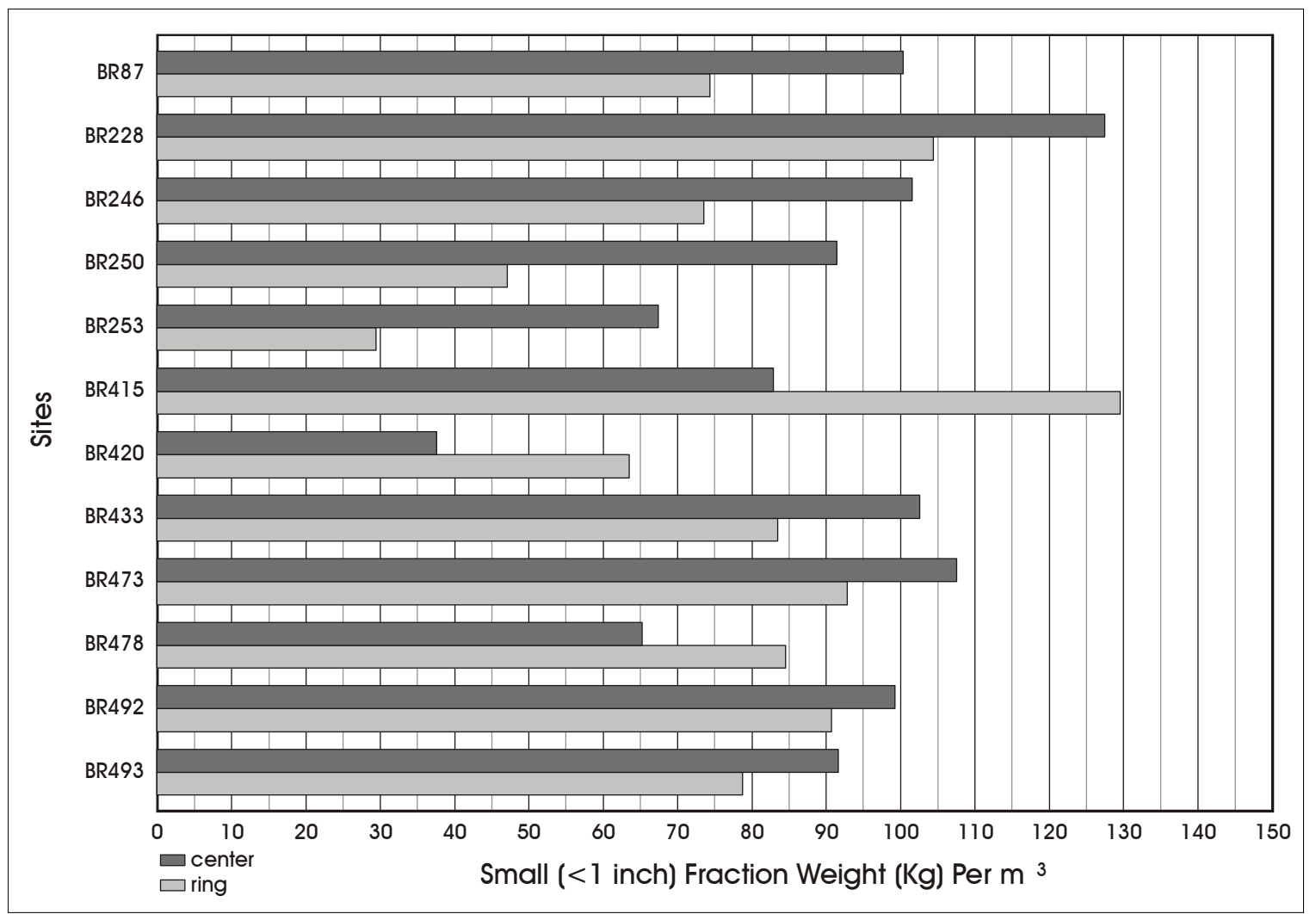

Figure 8-12. Standardized weights for the less than 1-inch size fraction by site for central and ring units. 
expectations outlined previously, we would expect that central units would have higher weights in the small fraction relative to the ring units. That expectation is supported, with nine of the 12 individual cases (75\%) having the proposed pattern. It is unclear what factors may account for the three cases (41BR415, 41BR420, and 41BR478) that are not consistent with the expectations.

Overall, then, patterns in rock sizes are consistent with the expectations derived from a model of midden formation similar to that outlined in Figure 8-7. While variability certainly exists between specific units that are not consistent with the model, there is general agreement with most of the expectations. These patterns are clearly not consistent with suggestions for either the multiple intersecting hearth model or expectations derived from the communal dump model. Given the previously demonstrated patterns in chipped stone and shell density, we conclude that burned rock middens, at least in the case of the Camp Bowie sites, appear to represent earth ovens that were repeatedly used and maintained.

\section{Exploring the Patterns: An Example from Site 41BR492}

The previous sections of this chapter have considered general patterns in a variety of different data sets. In this section, we explore aspects of these patterns in greater detail for the midden on site 41BR492. Specifically, we consider variation in fire-cracked rock size and number for specific levels within the midden. While this consideration provides clear support for the central pit feature model, it also identifies variation that may reflect differing intensities of use through time. The results of magnetic soil susceptibility samples also suggest differing use intensities. Overall, the results of our investigation of the midden on site $41 \mathrm{BR} 492$ clearly are consistent with our model of midden accumulation.

Feature 1 on site $41 \mathrm{BR} 492$ was selected for more detailed consideration because it is the only case with four radiocarbon dates. As outlined in Chapter 6, two units, designated 1 and 2, were excavated in the center of the feature, and an additional unit (Unit 3) was excavated in the midden ring. Figure 8-13 provides a cross-section of these three units, with their specific locations on the midden identified. All four radiocarbon dates come from the ring unit (see Figures 7-1 and 7-2). The dates span a period of roughly 1,900 years, from around 650 B.C. to A.D. 1250 .
Reference to Table 8-2 will demonstrate that 29,157 pieces of fire-cracked rock greater than one inch in size were counted and sized, and almost 385.5 kilograms of rock less than one inch in size were weighed, from these three midden units. Table 8-3 presents individual unit and level weights, counts, and sizes for the midden at 41BR492. Using that rock size data, Figure 8-14 (top) presents rock counts for the two internal and the single ring unit excavated at the site. Consistent with the overall patterns when considering middens as a group, both of the internal units at 41BR492 exceed the single ring unit in the number of rocks in the sixinch or greater size group (see Figure 8-8), and the ring unit exceeds the central units in the frequency of rocks within the two- to six-inch size range (see Figure 8-9). However, unlike the general patterns, where rocks in the one- to twoinch group were more common in the central units (see Figure 8-10), at site 41BR492 this size group is more common in the ring (see Figure 8-14, top). While reasons why individual middens have different patterns of rock breakage are not known, such difference may be related to characteristics within the sandstone used at individual sites, distance from the source of the sandstone, post-depositional processes, or excavation procedure. Differences in the largest two categories (three inches and larger) are highlighted in the bottom graph in Figure 8-14. Here the percentage of rocks by unit for the larger than three-inch size range is further broken down by one-inch size classes. While the ring unit has higher percentages below the fiveto six-inch size class, above six inches the internal units have higher percentages. That is, rocks in the larger size groups are clearly under represented in the ring relative to the central units within the midden.

Rock size is not simply randomly distributed within the midden. The non-random nature of the rock data is clearly apparent when we consider differences in rock size/weight data within and between units for this midden. For example, Figure 8-15 presents the standardized number of large rocks in Unit 2 against the standardized number of one to two inch rocks in Unit 3 by level. The standardization procedure, which produces a distribution with a mean of approximately zero and a standard deviation of one for each rock size class, allows us to easily plot and overlay a variety of different data sets, with different scales, on the same graph. Examination of Figure 8-15 will show considerable fluctuation in both data sets. Yet, the overall pattern is similar. That is, two different rock size groups from two different units pattern in predictable ways. The fact that high and low counts in large rock in the central unit have a rough 


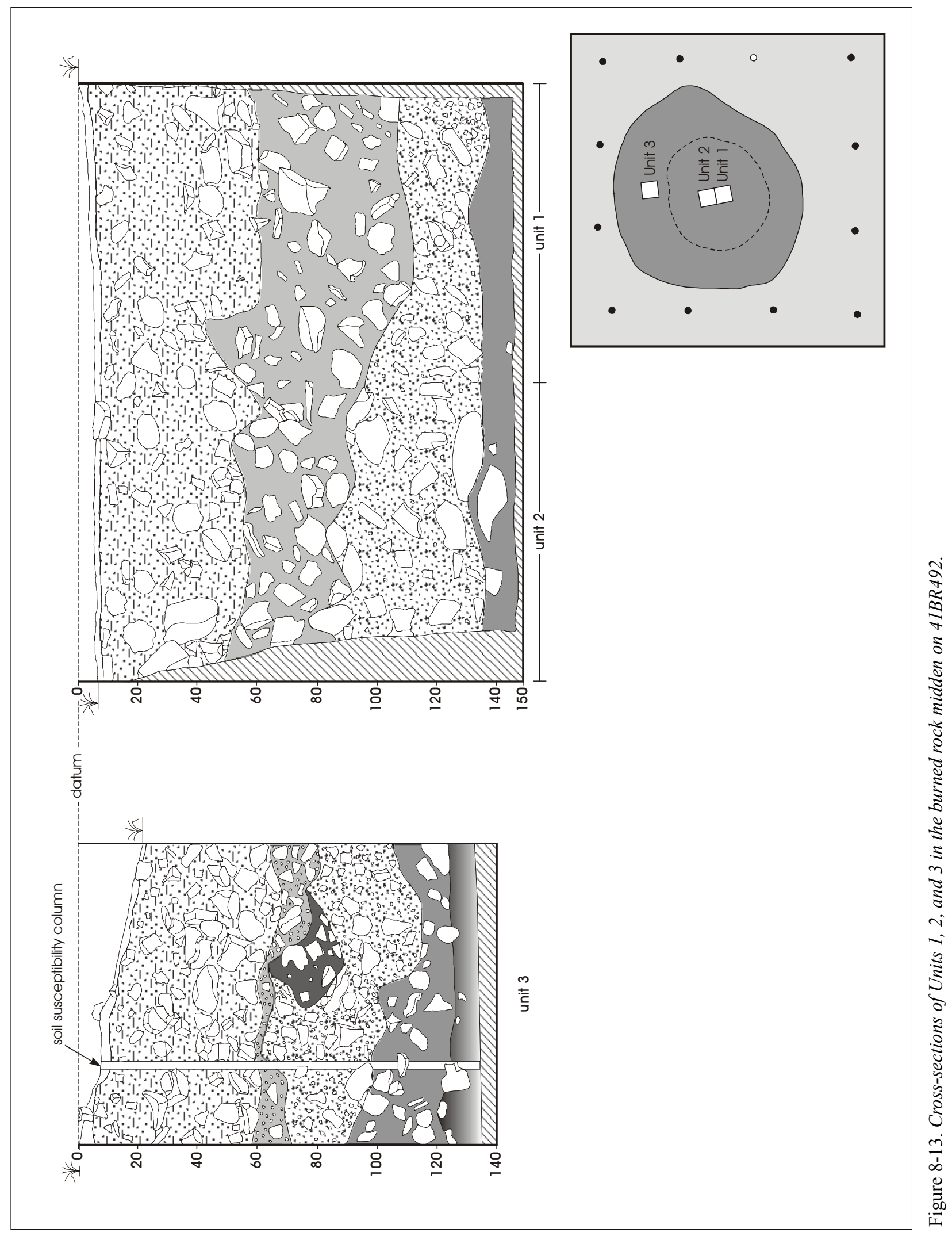


Table 8-3. Rock Weights (small fraction) and Number of Rocks by Size Class, Site 41BR492

\begin{tabular}{|c|c|c|c|c|c|c|c|}
\hline Unit & Level & $\begin{array}{c}\text { Small Fraction } \\
\text { Weight (gr.) }\end{array}$ & $\begin{array}{c}\text { Rock in } \\
1-2 \text { inch } \\
\text { range }\end{array}$ & $\begin{array}{c}\text { Rock in } \\
2-3 \text { inch } \\
\text { range } \\
\end{array}$ & $\begin{array}{c}\text { Rock in } \\
\text { 3-6 inch } \\
\text { range }\end{array}$ & $\begin{array}{c}\text { Rock in } \\
6+\text { inch } \\
\text { range }\end{array}$ & $\begin{array}{c}\begin{array}{c}\text { Total } \\
\text { Number } \\
\text { of Rock }\end{array} \\
\end{array}$ \\
\hline 1 & 1 & 538 & 69 & 32 & 17 & 3 & 121 \\
\hline 1 & 2 & 24366 & 834 & 166 & 44 & 2 & 1046 \\
\hline 1 & 3 & 16115 & 718 & 125 & 89 & 18 & 950 \\
\hline 1 & 4 & 10080 & 603 & 67 & 18 & 7 & 695 \\
\hline 1 & 5 & 7514 & 419 & 81 & 30 & 21 & 551 \\
\hline 1 & 6 & 3890 & 189 & 235 & 51 & 24 & 499 \\
\hline 1 & 7 & 7882 & 417 & 63 & 41 & 19 & 540 \\
\hline 1 & 8 & 9690 & 449 & 167 & 45 & 18 & 679 \\
\hline 1 & 9 & 11103 & 607 & 142 & 58 & 4 & 811 \\
\hline 1 & 10 & 16730 & 688 & 100 & 52 & 25 & 865 \\
\hline 1 & 11 & 9066 & 383 & 118 & 40 & 11 & 552 \\
\hline 1 & 12 & 8570 & 264 & 70 & 20 & 4 & 358 \\
\hline 1 & 13 & 7998 & 318 & 59 & 19 & 11 & 407 \\
\hline 1 & 14 & 4333 & 248 & 40 & 8 & 7 & 303 \\
\hline 2 & 1 & 162 & 14 & 18 & 40 & 2 & 74 \\
\hline 2 & 2 & 21004 & 1019 & 145 & 29 & 0 & 1193 \\
\hline 2 & 3 & 16500 & 1115 & 147 & 41 & 22 & 1325 \\
\hline 2 & 4 & 10116 & 378 & 265 & 61 & 21 & 725 \\
\hline 2 & 5 & 4364 & 248 & 63 & 26 & 12 & 349 \\
\hline 2 & 6 & 9956 & 291 & 129 & 14 & 1 & 435 \\
\hline 2 & 7 & 4631 & 369 & 154 & 64 & 15 & 602 \\
\hline 2 & 8 & 10356 & 412 & 109 & 43 & 16 & 580 \\
\hline 2 & 9 & 6731 & 409 & 77 & 45 & 13 & 544 \\
\hline 2 & 10 & 8736 & 567 & 188 & 66 & 27 & 848 \\
\hline 2 & 11 & 8533 & 416 & 108 & 47 & 20 & 591 \\
\hline 2 & 12 & 10870 & 458 & 85 & 24 & 1 & 568 \\
\hline 2 & 13 & 9821 & 439 & 64 & 17 & 3 & 523 \\
\hline 2 & 14 & 10506 & 97 & 20 & 5 & 1 & 123 \\
\hline 2 & 15 & 4670 & 90 & 16 & 6 & 6 & 118 \\
\hline 3 & 1 & 7808 & 517 & 149 & 50 & 3 & 719 \\
\hline 3 & 2 & 8469 & 643 & 161 & 46 & 0 & 850 \\
\hline 3 & 3 & 5930 & 458 & 87 & 37 & 5 & 587 \\
\hline 3 & 4 & 8832 & 895 & 339 & 83 & 13 & 1330 \\
\hline 3 & 5 & 6478 & 616 & 229 & 122 & 13 & 980 \\
\hline 3 & 6 & 3642 & 309 & 203 & 130 & 13 & 655 \\
\hline 3 & 7 & 6172 & 340 & 174 & 59 & 5 & 578 \\
\hline 3 & 8 & 7812 & 1211 & 536 & 52 & 2 & 1801 \\
\hline 3 & 9 & 10176 & 710 & 234 & 23 & 0 & 967 \\
\hline 3 & 10 & 9681 & 1045 & 273 & 9 & 0 & 1327 \\
\hline 3 & 11 & 12790 & 465 & 476 & 51 & 2 & 994 \\
\hline 3 & 12 & 20178 & 567 & 247 & 72 & 4 & 890 \\
\hline 3 & 13 & 2606 & 334 & 134 & 23 & 3 & 494 \\
\hline 3 & 14 & 76 & 13 & 0 & 0 & 0 & 13 \\
\hline
\end{tabular}


correspondence to high and low rock counts for small rocks in the ring unit clearly is consistent with the model of midden accumulation suggested here.

Figure 8-16 presents an additional comparison. Here, we contrast standardized values for our smallest category, rock weights less than one inch in size, with values of our largest category, rocks greater than or equal to six inches in size, for Unit 1. We would expect that these two data sets should also be correlated in this central unit, as we anticipate that material in the less than one-inch size fraction and the greater than or equal to six-inch size group should both be monitoring feature construction and maintenance. Consideration of the patterns will suggest that while in some cases, such as below Level 9, the two curves pattern nicely, there is considerable divergence in the curves in the upper levels. While the lack of patterning in some levels may be accounted for by turbation, probably as a result of reuse of the central feature area, it clearly suggests that there are aspects of the formation of this particular midden that do not fit our overall expectations.

Finally, Figure 8-17 presents a final example, the standardized number of rock within the one- to three-inch size range for ring Unit 3. Given the patterns in Figure 8-14 (top), this combined rock size range probably reflects most accurately the pattern of discard from the central feature area. Examination of Figure 8-17 will show considerable fluctuation within this ring unit in this particular size fraction. That is, there appear to be levels with extremely high discard rates, and periods when discard rates are less intensive.

Figure 8-18 compares the Figure 8-17 pattern with magnetic susceptibility (MS) readings for this unit. As outlined in Appendix $\mathrm{H}$, the magnetic susceptibility of a sediment sample can be thought of as a measure of how easily that sample can be magnetized (Dearing 1999; Gose and Nickels 2001[1998]). At low magnetic field strengths, this measure is primarily related to the concentration and grain size of ferro and ferromagnetic minerals in the sample (Gose and Nickels 2001[1998]). A number of processes can result in an increase in MS values in a sediment sample. Of these processes, those that are of concern here are related to an increase in the organic constitutes of sediments (see Collins et al. 1994; McClean and Kean 1993; Singer and Fine 1989). Sediments with higher organic content tend to have higher magnetic susceptibility values (Reynolds and King 1995). Cultural processes, such as the concentration of ash and charcoal on a surface, would also produce higher MS readings. If the fluctuating rock density graph in Figure 8-17 reflects periods of more intensive use, then we would expect at least some relationship between these peaks and peaks in soil susceptibility measures. That is, periods of high maintenance of the midden should generate both increased medium-sized rock as well as increased amounts of ash and charcoal as a function of more closely spaced use events or more intensive use of the central feature. Examination of the plot in Figure 8-18 clearly shows that these two data sets are closely related. While the patterns diverge in the upper $20 \mathrm{~cm}$ of the deposit, both the location and intensity of high and low values in the rock data are closely reflected in the susceptibility values. The overlap in these two data sets, then, clearly suggests that the rock patterns are reflecting different intensities of midden use.

To the right of the plot in Figure 8-18 we also list the radiocarbon date ranges for this midden presented previously in Chapter 6. While precise comparisons of the three more intensive use peaks in the rock data and the specific time interval are not possible, it appears that two of the three more intensive periods of use occurred after about A.D. 680 to 890 , with the earlier peak occurring sometime after the 800 to 410 B.C. range. That is, not only did most of the midden accumulate after A.D. 680 , but also two of the more intensive periods of use also probably occurred in the Late Prehistoric period. This pattern of high intensity use is consistent with the chronometric discussion presented in the previous chapter.

\section{Summary}

Using patterns in chipped stone, mussel shell, and firecracked rock, this chapter has investigated how burned rock middens may develop. For the sites and features discussed here, the data are consistent with a model of midden development that involves repeated use and maintenance of a central feature, probably capped with earth, to form an oven. The strongest support for the Camp Bowie middens representing this type of feature comes from the analysis of patterning in fire-cracked rock. At a project level, rock size differences are clearly patterned, with both larger and smaller rock having a higher frequency in the central excavation units within middens, and medium-sized rock having a higher frequency in ring units. An investigation of rock sizes within one midden at site 41BR492 shows impressive correspondence between variations in different rock sizes from different units, as well as patterns of rock discard and soil susceptibility readings. While the patterns are not always 


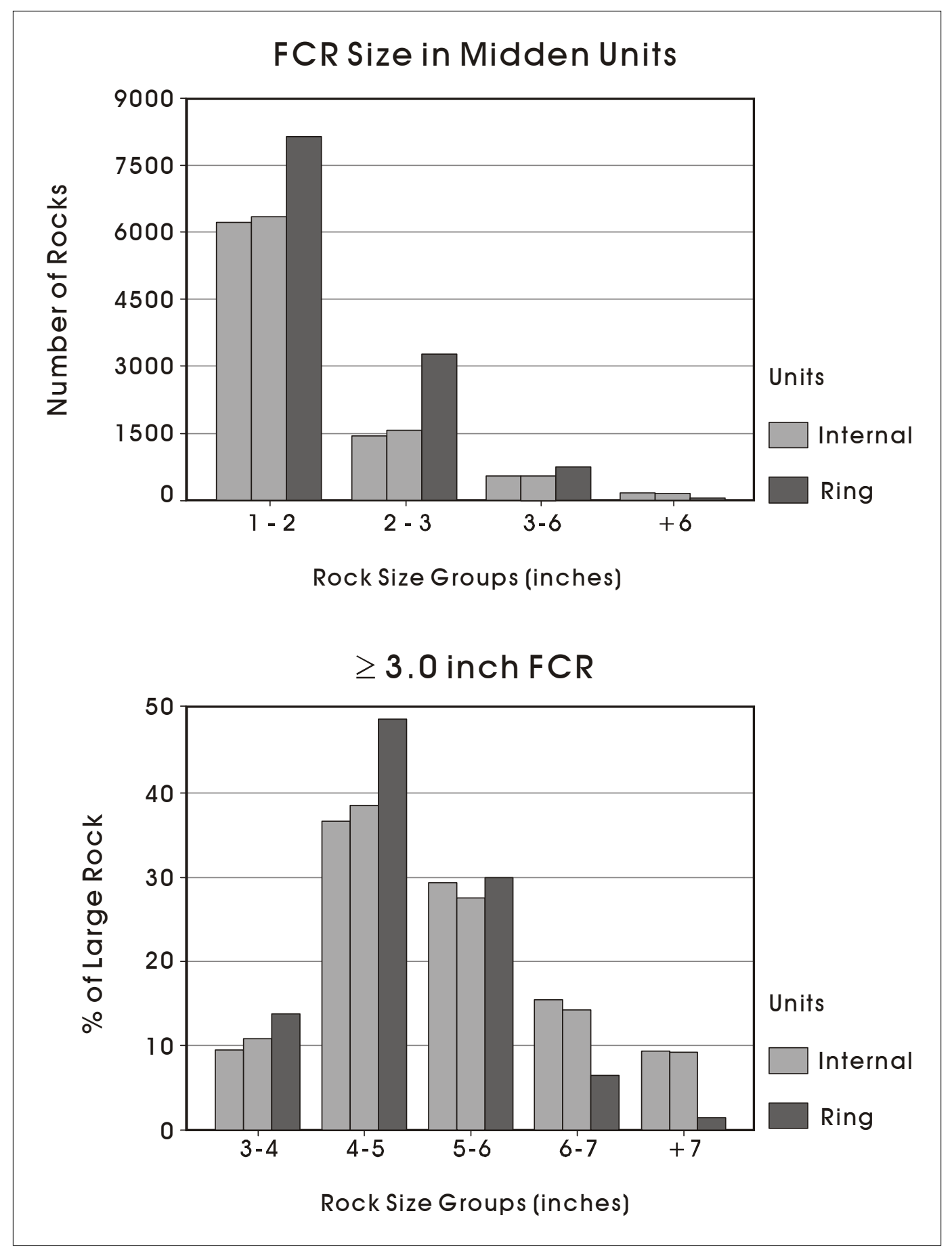

Figure 8-14. Rock size data for the 41 BR492 midden. Top: rock counts by major size groups. Bottom: percentage of 3-inch and larger size rocks by one-inch size classes. 


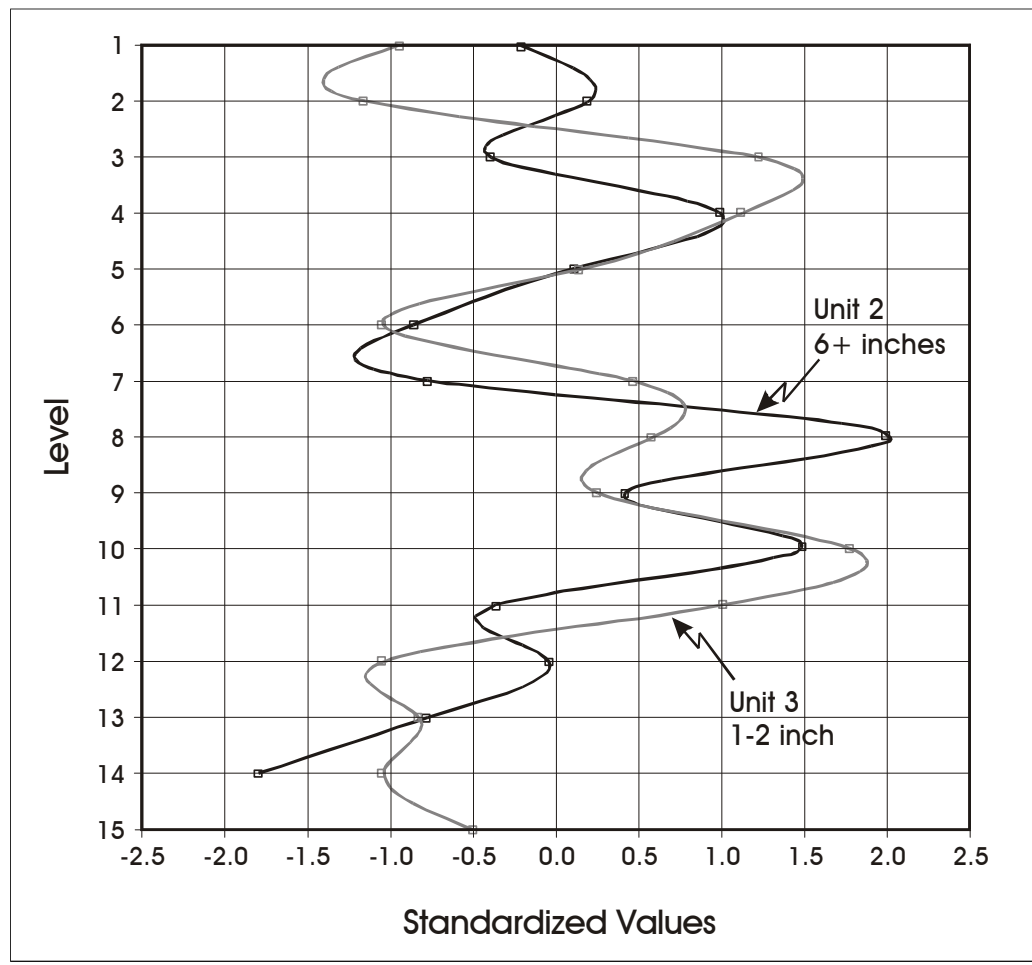

Figure 8-15. Large rocks in Unit 2 and 1-2 inch sized rocks in Unit 3 by level, 41BR492. Data are standardized.

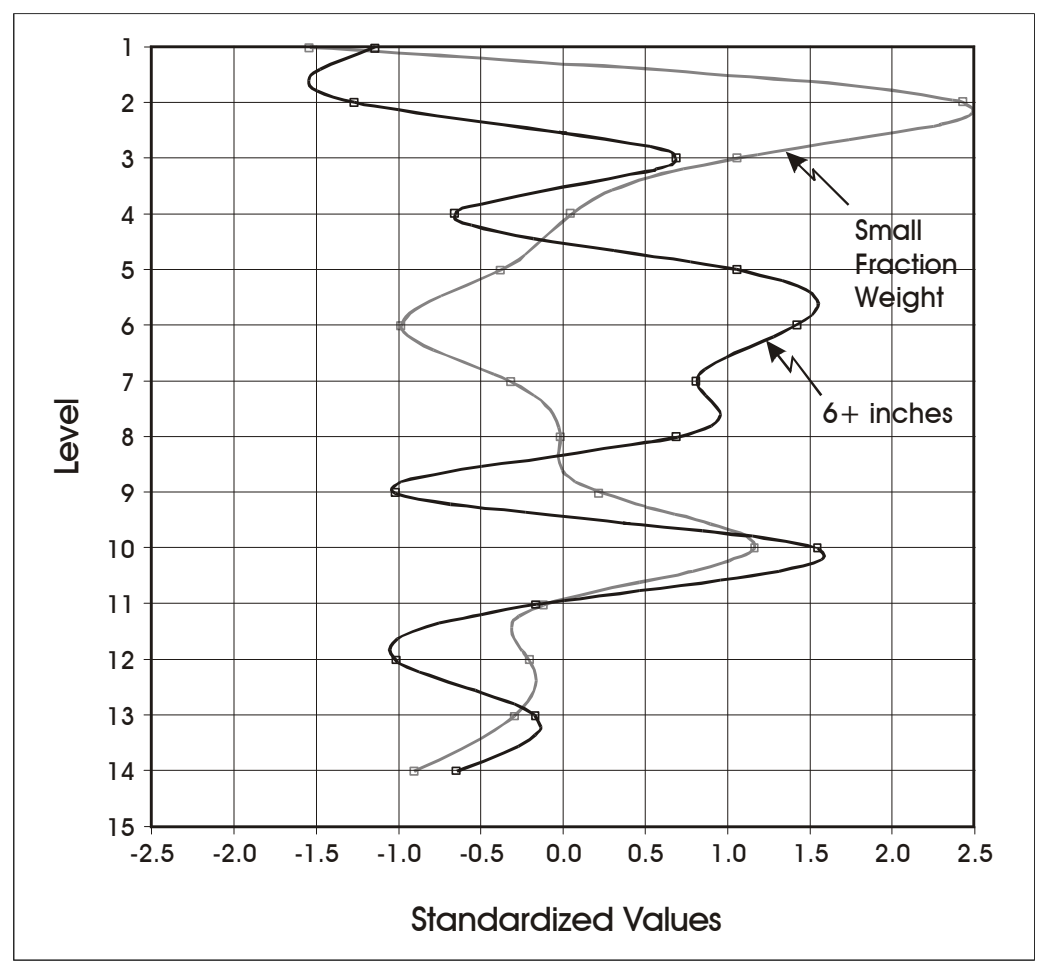

Figure 8-16. Comparison of standardized values of rock weights less than one inch in size with values of rocks greater than or equal to six inches in size, Unit 1, 41BR492. 


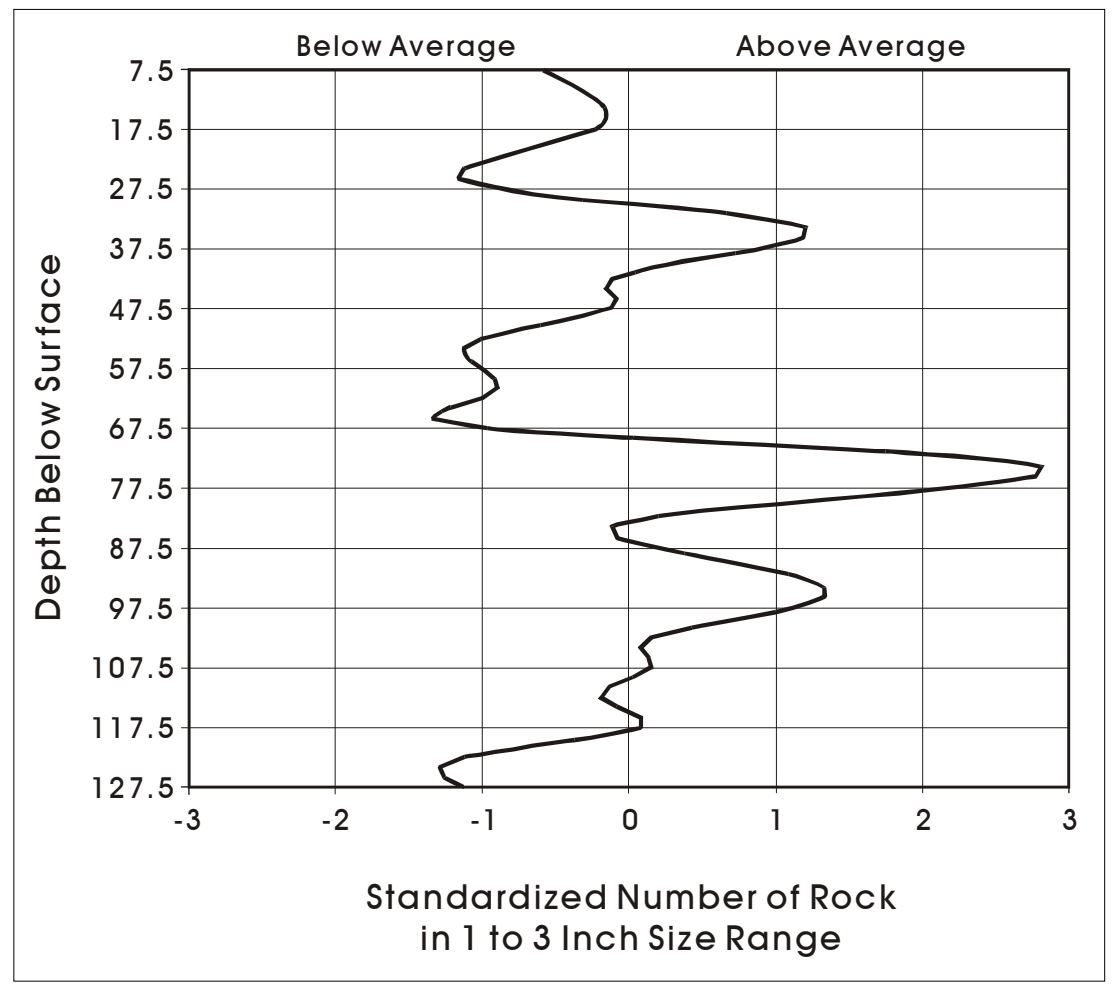

Figure 8-17. The standardized number of rocks within the 1-3-inch size range for ring Unit 3, 41BR492.

clear-cut within this midden, or within specific data sets at a project level, it would be extremely difficult to account for the correspondences demonstrated without reference to some pattern of differential discard and replacement of stone around a central pit feature.

We conclude that the burned rock middens at Camp Bowie reflect the remains of repeatedly used and maintained central features, probably capped by the addition of sediment. While both mussel shell and bone concentrations within the middens are consistent with the addition of sediment over these central features to form classic earth ovens, the density patterns in chipped stone are ambiguous. While the size of debitage in the various components of the middens may also be expected to pattern in these units (e.g., Leach and Bousman 2001[1998]:139-145), the overall debitage sample size available from the Camp Bowie material precludes any detailed consideration of size differences along these lines. Nevertheless, the overall patterns discussed for the Camp Bowie middens clearly are consistent with the central-based feature model, and are inconsistent with models of midden development that rely on intersecting hearths or on site level maintenance forming communal dumps. Data presented in the subsequent chapter, which discusses subsistence, adds additional support to the notion that at least some of these features were earth ovens used specifically to process geophytes (i.e., bulbs and tubers). 


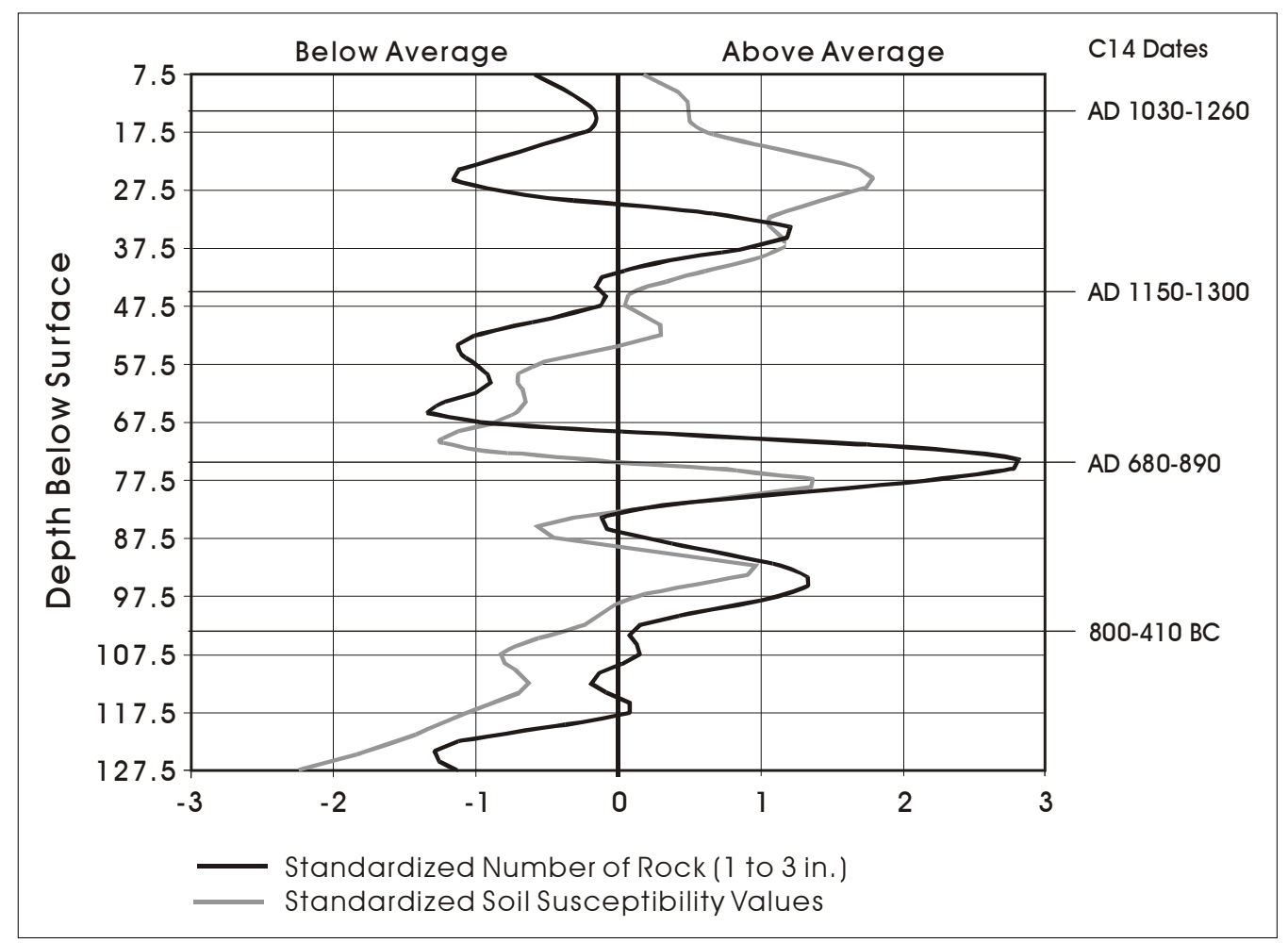

Figure 8-18. Comparison of rock in the 1-3-inch size range and magnetic susceptibility (MS) readings for Unit 3, 41BR492. Data are standardized. 


\title{
Chapter 9: Subsistence Issues in Camp Bowie Middens
}

\author{
Raymond P. Mauldin
}

In the previous two chapters we argued that the middens investigated at Camp Bowie probably reflect the remains of repeatedly used features and that the most intensive use occurred primarily between A.D. 750 and A.D. 1400. Furthermore, we suggested that these central features are probably capped by sediment and represent earth ovens. This chapter explores questions that focus on what was being processed in these large earth oven features. After a short recap of previous research in this arena, four different subsistence related data sets are brought to bear on this question. These data sets are mussel shell, vertebrate faunal remains, macrobotanical identifications, and the results of flotation analyses. As hinted in the previous chapter during the discussion on mussel shell, the primary problem faced is deciding what materials found in a midden are related to midden function, including possible fuel wood, resources processed, and packing material, and what items represent secondary deposits unrelated to midden use. While all four data sets are summarized, the most probable data sets reflecting direct evidence of midden use are produced by macrobotanical identifications. While neither shell nor bone can be eliminated as possible candidates for some level of processing, the macrobotanical identifications, supported by the flotation results, strongly suggest that, at least at Camp Bowie, the middens were used primarily to process a specific set of resources consisting primarily of plant bulbs. Building on this suggestion, ecological and nutritional characteristics of bulbs, focusing primarily on camas (Camassia sp.) is then considered. Using that overview, the final portion of this chapter speculates on some aspects of the role of bulbs in the subsistence base at Camp Bowie.

\section{Midden Function}

As summarized in Chapter 4, researchers have made a variety of suggestions regarding the plants and animals possibly processed in middens. A wide diversity of plants, including sotol, yucca, prickly pear pads and seeds, gourds, geophytes, acorns, and a variety of small seeds (see overviews in Dering 1997; Howard 1994) have been recovered from midden contexts. Summaries by Decker (1997; see also Neck 1997), as well as Meissner's summary in Appendix B, provide a variety of animal identifications as well. Minimally, animals identified in middens include large herbivores (e.g., bison, deer), carnivores, small mammals (e.g., cottontail, jackrabbit), and aquatic resources (e.g., turtle, mussel). Citing that diversity, Black and Creel (1997) suggest that it is highly probable that a variety of different foods were processed in these features. They suggest that a search for a single group of plants or animals that are consistently processed with burned rock middens may not be productive. Yet, at various points, other researchers have argued that middens were used to process a single food type. These more specific resource suggestions have focused on two likely food candidates, sotol (Goode 1994:85-91; Wilson 1930:59-61) and acorns, with acorns being the more popular choice (e.g., Black and McGraw 1985; Creel 1978, 1986, 1994, 1997; Gunn and Mahula 1977:279; Turner 1989:186).

Those researchers who argue for a limited set of resources processed in middens, as well as those who argue for a variety of resources processed in middens, frequently assume that midden content reflects what was processed. While there are exceptions to this form of argument (see especially Creel 1986, 1994, 1997), most researchers assume that what was found in a midden was what was cooked in it. This is a completely reasonable argument in most circumstances. However, given the suggestions that middens represent ovens that were capped by sediment, and the observation that in some cases that sediment may contain artifacts and ecofacts, some component of what was recovered from a midden may not reflect what was processed in that midden. Deciding what does, and what does not, reflect midden use is a difficult problem.

Here, we will proceed using two assumptions. First, we will assume that the probability of recovering items in middens that are not related to midden use is inversely related to their preservation potential. In order to be available for incorporation into a midden as part of the cap, the material would have to be of greater age than the midden. Consequently, if we recover charred material from within a midden, there is a lower probability that the charred material represents a secondary incorporation, as non-midden charcoal would have a lower probability of preservation given greater age. At the other extreme, if we recover chipped stone from a midden, there is a greater probability that some of that chipped stone reflects activities not directly associated with midden use. Shell, then, may have a fairly 
high probability for incorporation while bone may have a slightly lower probability, especially when it is not calcined. In addition, we might expect bone probability to pattern with bone density. Note, however, that in all cases the true probability is unknown, and that different chemical and mechanical conditions differentially impact different classes of material. Finally, additional material, including bone, shell, and charcoal, could all be incorporated into middens after use, especially in the center of these features. This postmidden possibility further complicates any clear interpretation of patterning.

The second assumption employed is that material found primarily in midden contexts has a higher probability of reflecting midden use relative to material found both in and outside of middens. For example, if carbonized seeds were present only in midden contexts, then we would assume that those seeds would have a higher probability of being processed in middens. Conversely, if seeds were present both in and outside of middens, the probability of incorporation would be increased. That is, it would be unlikely that items are incorporated into middens if those items do not have some presence outside of midden contexts. Only in situations where all of the material processed in a midden was completely removed, consumed, and any remains deposited at a discrete location away from the midden, would the associations suggested not pattern as anticipated. While this certainly could happen for an individual event, the long use history of any single midden reduces that probability.

While the validity of these two assumptions can certainly be questioned in specific situations, and while a variety of "what if" scenarios can be thought of that would result in patterns of preservation and incorporation of materials that are not consistent with the assumptions, they do have utility in considering broad patterns of materials within a variety of middens. In the following section, these two assumptions are used to consider the patterns of recovery within middens at Camp Bowie.

\section{The Camp Bowie Midden Subsistence Data}

As summarized in Chapter 6, at an individual site level a variety of data sets with possible subsistence implications were obtained from CAR's work at burned rock middens at Camp Bowie. The raw data are discussed both in that chapter, as well as in specific appendices in volume 2 of this report.

\section{Mussel Shell}

A review of Chapter 6 will show that mussel shell was ubiquitous at these sites. Mussel shell occurred in a variety of contexts, being present in test excavations and shovel tests, and shell was recovered in several surface collections on this project. While shell was frequently encountered, the overall quantity was low. In all cases where mussel shell was observed, it was recorded on field forms. However, in some cases, such as on site 41BR65, we only have presence/ absence data as the shell was not weighed. Nevertheless, over $5.78 \mathrm{~kg}$ of mussel shell was collected during this project. As weights on whole shell in the sample ranged from between 6 and 30 grams, this weight represents less than 200 individual bivalves for the entire project.

Dr. Goodfriend identified six different species (Appendix D) in a sample of specimens from this project. The most common was Quadrula houstonensis, accounting for 33 percent of the identified mussels. This was followed by Amblema plicata (30\%) and Quadrula apiculata (17\%). Potamilus purpuratus, Tritogonia verrucosa, and Cyrtonaias tampicoensis were also present in small quantities. A review of Howells et al. (1996) failed to identify any specific environmental constraints for these species.

As Claassen (1998:53-70) notes, when removed from an aquatic environment, shell, composed primarily of various carbonates, has excellent preservation potential. While both chemical and mechanical processes can result in shell fragmentation and eventually destruction, the time frame required, especially in terrestrial settings, appears to be significantly greater than that considered here. That is, shell deposited within the time frame represented on our archaeological sites should have a good probability of being recovered.

As noted above, shell was common on the project, though not in great quantity. Mussel shell occurred on all 16 sites with middens tested on the current project. On these sites, shell was present in all middens. It also occurred off midden on all 16 sites. That is, mussel shell was present both within middens as well as outside of middens. Given the assumptions above, we suggest that shell, with its good preservation potential, has a high probability of being incorporated into middens. In addition, note that the A/I racemization results presented in the previous chapter are consistent with this incorporation. Even employing a high 
racemization rate, many of the samples that were tested probably dated well before the age of the middens. While we cannot rule out the possibility that mussels were cooked in the Camp Bowie middens, we can suggest that there is a high probability that much of the shell found in the middens is unrelated to midden function.

\section{Vertebrate Faunal Remains}

Unlike shell, the recovery of vertebrate faunal material from the excavation was much more spotty. Meissner (Appendix B) notes that 290 fragments of faunal material, weighing 524.32 grams, were collected on the project. Only a small number of taxa were identified to genus level, and Meissner noted that the bone was in poor condition. In spite of the low recovery and poor condition of the material, reference to Appendix B will show that material characterized as bison, Bovinae, and bison-sized mammals accounted for the majority of the faunal material by weight (427.2 grams), with deer, Artiodactyla, and deer-sized mammals contributing 57.07 grams. Most of the identified bone probably reflects bison- and deer-sized animals.

Bone preservation is probably less than that of shell on the current project. While preservation potential of bone seems to correlate with bone density (see Lyman 1996:223-293), it is clear that a variety of taphonomic processes, including mechanical and chemical processes, can degrade and eventually destroy bone. Meissner (Appendix B) clearly documents the impact of chemical processes on the current sample. Specifically, she notes that "virtually all" of the faunal material recovered showed at least some degree of chemical weathering, probably as a result of bacteria and/ or fungi destroying the bone. Meissner states that, especially in basic soils, micro-organisms digest the collagen fraction of the bone, secreting acids that dissolve the hydroxyapatite fraction (Appendix B). The results of this process are clearly apparent in Figure 9-1. Black spots of fungus are clearly visible on this deer metatarsal fragment from site 41BR478. Note also the "pitted" surface of the item.

Bone preservation, then, was less than ideal, and this certainly is reflected in the low frequency of identification noted above. Nevertheless, bone was recovered from 11 of the 16 midden sites. In four of these cases (36.4\%), bone was only recovered in the middens. In two cases $(18.2 \%)$, bone was recovered off-midden, but was not present in the middens. Given the assumptions above, we suggest that bone, with relatively lower preservation potential than shell, has a high to moderate probability of being incorporated into middens. It is commonly present off-midden, being in that context on 82 percent of the sites with bone.

\section{Macrobotanical Identifications}

Certainly in terms of the subsistence data discussed in this chapter, the most interesting recovery was in the macrobotanical identifications of charred material. The identification of primary interest consisted of 367 charred specimens identified in the field as "seeds." First seen on site 41BR65, the first site excavated on this project, these burned, often broken materials were frequently collected during excavation. Subsequently, a systematic search of all charcoal samples collected from the project was made in the lab, and a handful of additional specimens were identified. In all, 77 different proveniences containing these charred "seeds" were submitted to Dr. Philip Dering for identification.

As summarized in Appendix C, many of these items were identified as geophytes. Specifically, Dering recorded 367 bulbs, bulb fragments, and tubers. These represented a minimum of three, and possibly four, different plants, including Eastern camus (Camassia scilloides), wild onion (Allium sp.), and dog's-tooth violet (Erythronium mesochoreum). In addition, tubers were detected that were similar to reference material identified as prairie turnip (Pediomelum sp.), though the identification could not be verified. Figure 9-2 presents examples of some of the recovered geophytes.

Preservation potential of these items relative to both shell and bone is low. Reference to Figure 9-2, which presents a collection of bulb and bulb fragments from Camp Bowie middens, clearly shows that many of the collected items are fragmentary. Their relatively low preservation potential suggests that they would have a low probability of being incorporated into middens as secondary deposits.

Discounting those items recovered from flotation, geophytes were identified at eight of the 16 midden sites. Within these eight sites, they were always present in middens. Conversely, only in one case were they present off-midden (12.5\%). In fact, of the 367 bulbs and bulb fragments recovered, 99.5 percent were recovered from middens. In combination with their low overall preservation potential, these data suggest that geophytes have the highest probability of being directly related to midden use. 


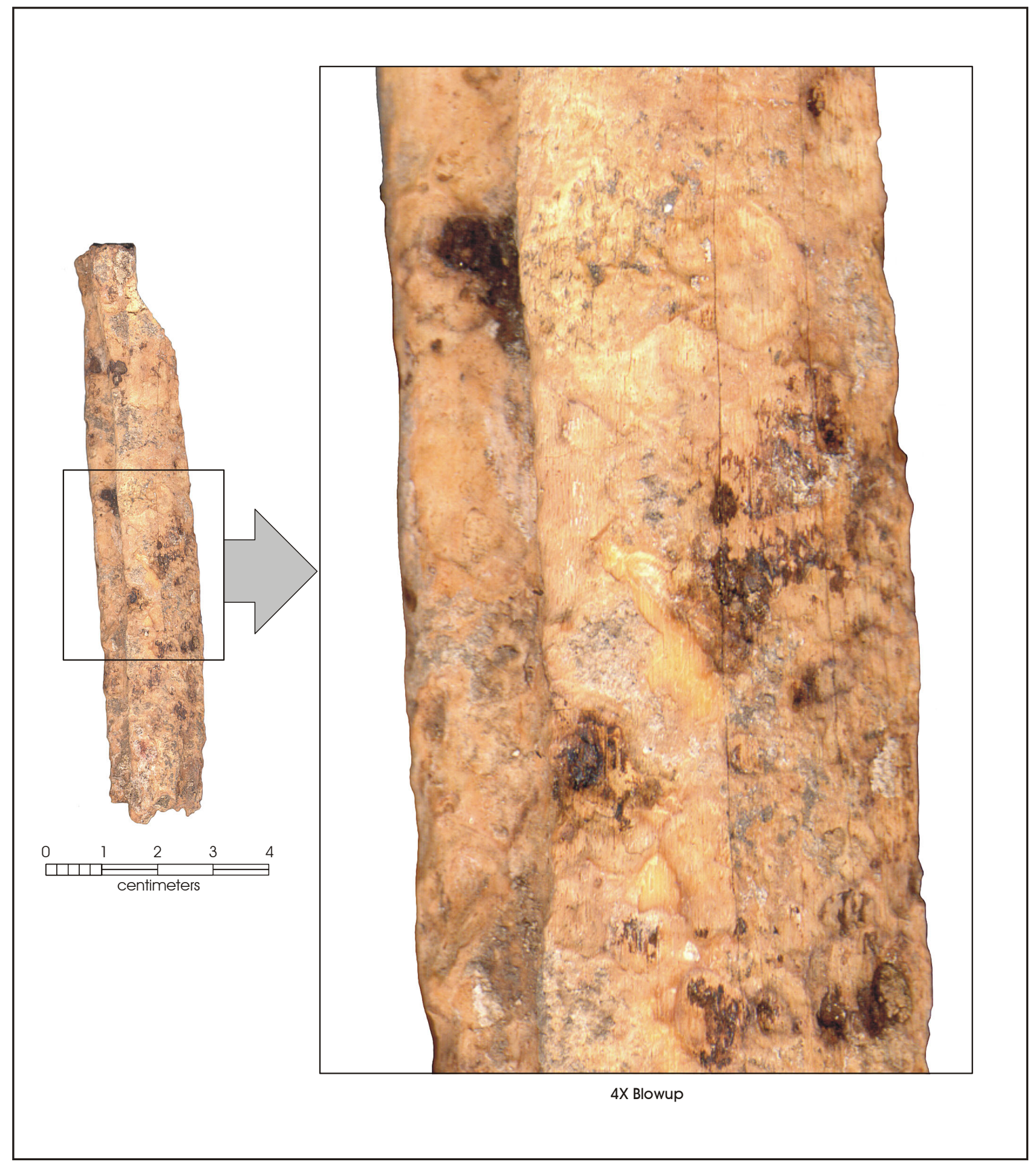

Figure 9-1. Fragment of white-tailed deer metatarsal exhibiting chemical weathering and fungus (from site 41BR478). 


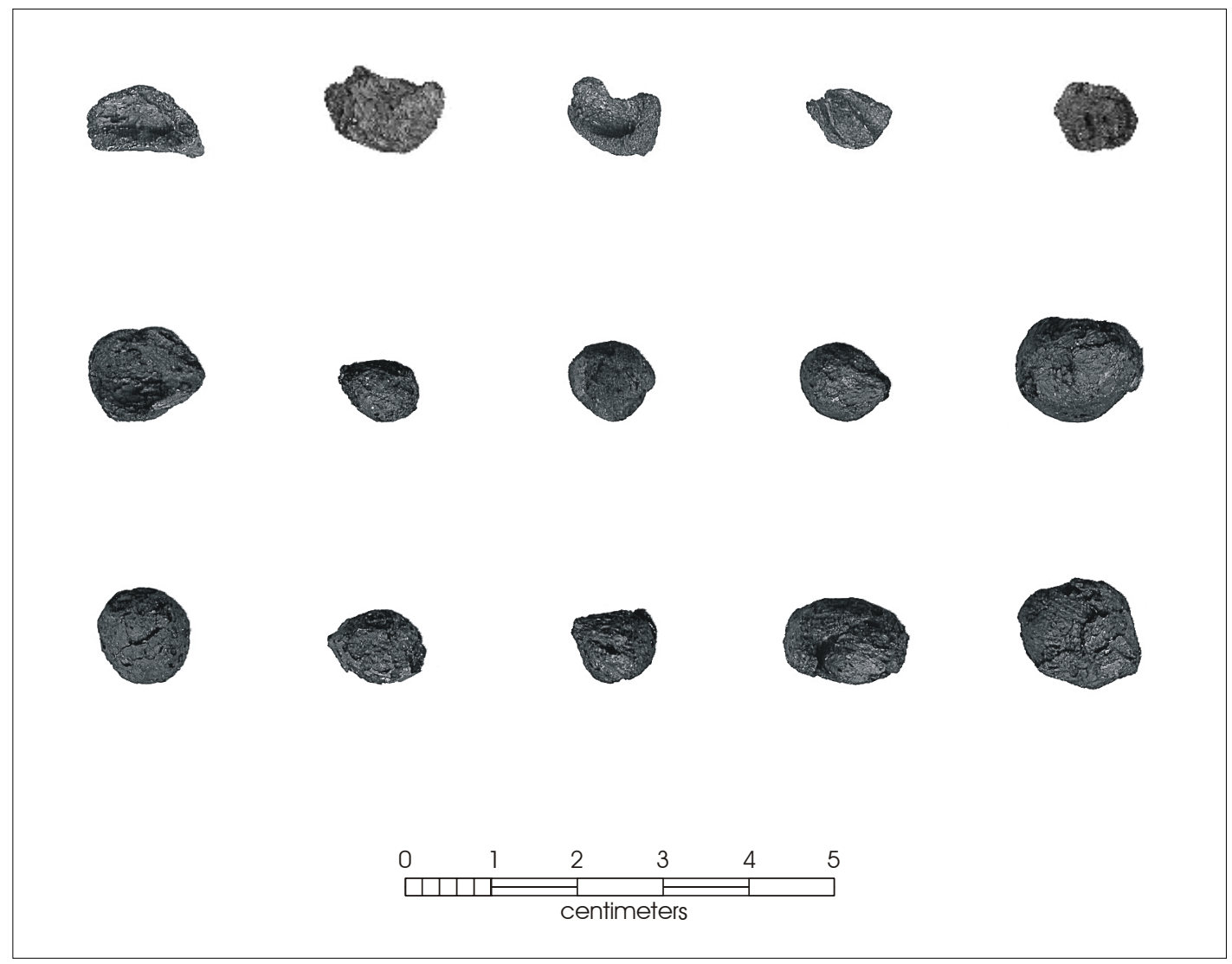

Figure 9-2. Collected bulbs and bulb fragments from sites at Camp Bowie.

In addition to the identification of geophytes, reference to Appendix C suggests that a secondary identification, referred to as "slag," was present in many of the samples. Specifically, Dering notes this material from sites 41BR65, 41BR228, 41BR246, 41BR250, 41BR253, 41BR420, and 41BR493. In addition, CAR collected samples from 41BR87 and 41BR492, though they were not submitted to Dering for analysis. In addition, field notes suggest that this material was also present, though not collected, on site 41BR478, and it may have been present on several other midden sites. Dering suggests that this "slag" is carbonized sap coming from plant material. He notes that he has seen such material oozing out of bulbs, agave/sotol, nuts, and many types of seeds, including mesquite and cheno-ams (Philip Dering, personal communication 2002). While this material was not consistently collected, it is our impression that it only occurred in midden deposits.

Figure 9-3 presents several examples of this "slag" material. The top two rows consist of specimens taken from Camp Bowie middens. The bottom two rows in the figure present examples of material created at CAR by dropping water, saturated with sugar and cornstarch, onto sediment heated to 300 degrees centigrade. The appearance of the modern samples is remarkably similar to those of the prehistoric cases. The author has been unable to create anything resembling this structure with animal fats. Only liquids with high carbohydrates seem to produce the caramelized, bubbly appearance of the "slag" surface. These data, coupled with the observations of Dering noted previously, suggest that the presence of this "slag" probably reflects the presence of plants with high starch and/or sugar content during heating of these ovens

In an effort to determine more about the structure of the slag deposits, Dr. Dave Olmos, Coordinator of Electron Microscopy Labs at UTSA, analyzed the chemical composition of a prehistoric slag sample using a JEOL 840 microscope with an Oxford INCA X-ray analysis unit. That analysis suggests the slag is dominated by carbon, with the atomic weight of this element in the sample being 51.82 percent. Oxygen comprises 47.54 percent. Four trace 


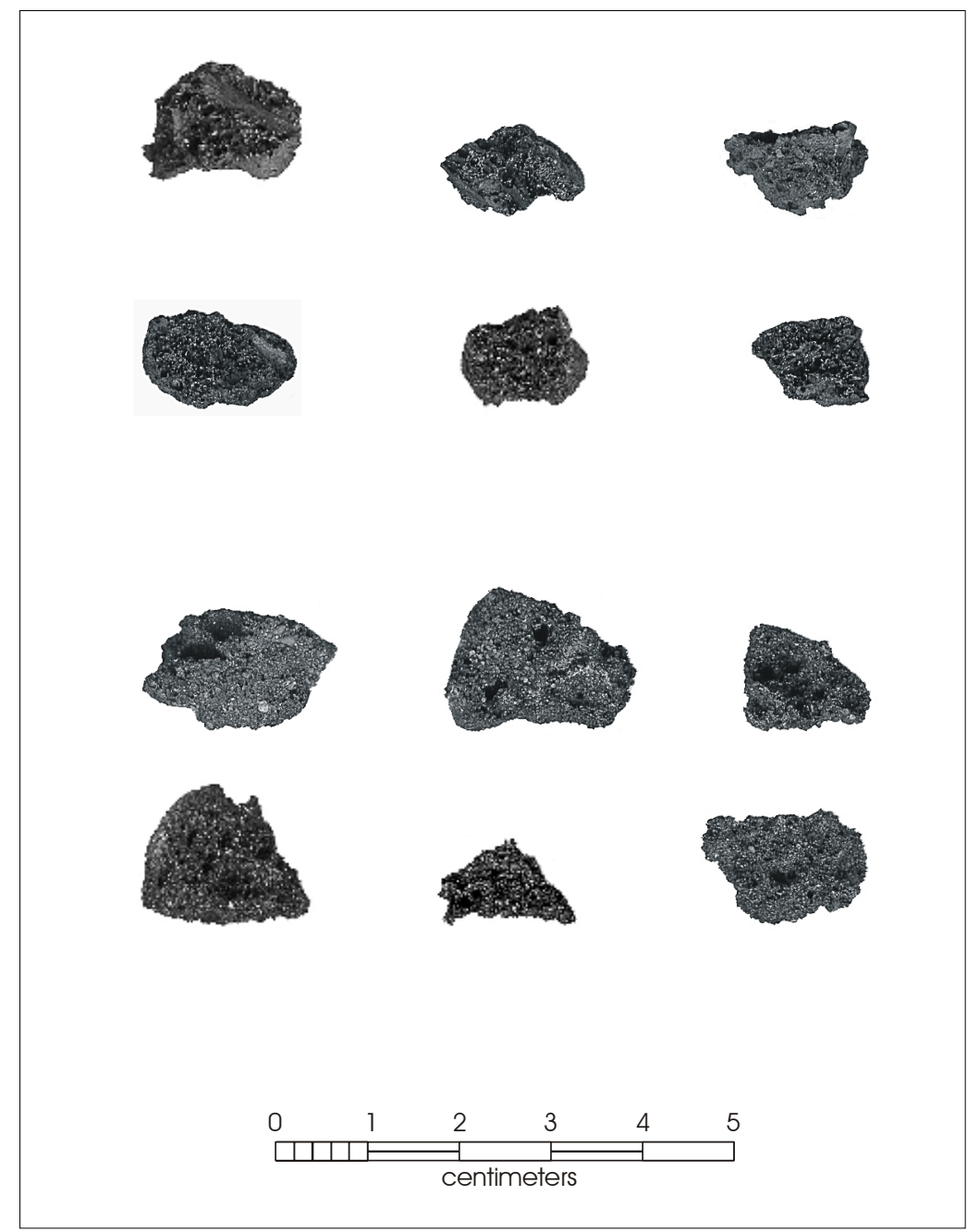

Figure 9-3. Examples of "slag" collected from middens (top six specimens), and "slag" created at CAR (bottom six specimens).

elements, aluminum, silica, copper, and zinc were also present at percentages below .5. Comparison of these trace elements to data on camas suggests that zinc is the only one present in camas (Thoms 1989:163-164). Though the scales of analysis are not comparable, and thus small amounts of silica, copper, and aluminum may be present in camas but not revealed by the gross nutritional analysis, some portion of our elemental signature may also reflect the sediment bound up in the slag. We are pursuing additional work on this issue. However, presently we can suggest that the slag probably reflects some component related to plantspossibly related to either packing material or material actually processed in the midden.

\section{Flotation Results}

Thirty-six flotation samples were submitted from the 16 sites with middens on the current project. A sediment volume of just over 51 liters was floated and the resulting light fraction sent to Dering for analysis (see Appendix C). Unfortunately, no samples were submitted from outside of middens. Flotation results, then, only can serve to support the patterns seen above. Comparisons between midden and non-midden contexts are not possible.

Nevertheless, a review of Appendix $C$ will show that 35 of the 36 samples $(97.2 \%)$ had charred material recovered, with 
both wood and economic plant parts present. As with the macrobotanical identifications discussed previously, the flotation samples produced evidence of geophytes. Specifically, 28 bulb fragments were recovered from six different samples on five different sites. The flotation results further resulted in the identification of geophytes on site 41BR441, a site where no macrobotanical identification existed. In addition to the geophytes, a single seed of mesquite was recovered from site 41BR478. As, on average, only two samples were submitted from any given midden, and as the maximum size of any individual sample did not exceed 1.5 liters of sediment, the level of recovery clearly suggests that these plants were common at these sites, and that significant economic data remain in these midden features.

Note that 318 pieces of wood charcoal were also recovered from the 35 flotation samples with recovery. Of the 273 pieces (9.4 grams) of wood charcoal identified to species, 248 pieces (8.1 grams) were identified as oak. Oak, then, represents over 86 percent by weight and over 90 percent by number of the total identified wood. Mesquite $(\mathrm{n}=18$; .09 grams), juniper ( $n=5 ; .03$ grams), and willow ( $n=2 ; .01$ grams) were also identified. Within the flotation samples, mesquite was present from only three contexts. Interestingly, the single mesquite seed recovered was from one of these three contexts that also contained mesquite wood. While Dering (Appendix C) concludes that the presence of the mesquite seed suggests that this resource may have made a significant contribution to subsistence, it is also possible that the seed was simply introduced to this provenience along with the mesquite fuel wood. As such, the presence of a mesquite seed may not reflect any significant subsistence contribution from that resource.

\section{Summary}

Focusing on preservation, we assumed that the probability of recovering items in middens that are not related to midden use is directly related to their preservation potential. In order to be available for incorporation into a midden as part of the cap, the material would have to be of greater age than the midden. Our review suggests that in the current setting, shell probably has the highest preservation potential. While chemical processes are clearly altering the bone at these sites, the preservation potential of bone is still probably greater than that of carbonized plant remains. We suggest, then, that plant remains found in middens would have the lowest potential for incorporation as they would have the lowest potential for preservation.
The second assumption employed was that material found primarily in midden contexts has a higher probability of reflecting midden use relative to material found both in and outside of middens. As summarized above, shell was present on all 16 sites. Shell was recovered both outside of middens and within middens on each site. That is, there were no cases in which shell was only found within middens. Bone was recovered from 11 sites. In four of those cases (36.4\%), bone was only recovered from the middens. In two cases (18.2\%), bone was recovered off-midden, but was not present in the middens. Using only the macro-identifications, geophytes were recovered from eight sites. In just over 62 percent of these cases, geophytes were recovered only from within middens. In addition, there were no cases where geophytes were recovered off-midden but not present in the midden. Finally, note that over 99 percent of the 367 bulbs and bulb fragments recovered from the project were from middens. The distribution and implications of "slag" is more difficult to interpret. However, it appears that this material minimally results from plants, and represents secretions from either packing material or from the material being processed in the middens. We conclude that while an occasional mussel or other animal may have been cooked in burned rock middens identified on this project, it appears likely that these features were primarily used in processing plants. Specifically, these features were used to process a variety of geophytes.

\section{Camp Bowie Middens and Geophyte Processing}

Based on the summary of what was found in the middens, as well as a consideration of the probability of incorporation of various subsistence classes, it seems probable that many of the middens tested on the current project are associated with processing a variety of geophytes. Geophytes are herbaceous plants with underground storage organs. The underground storage organs, commonly classified as bulbs, tubers, corms, and tuberous roots, contain quantities of carbohydrates and other nutrients that the plant uses to survive periods of adverse climate. As summarized by Dering (Appendix C), the recovery of these types of resources, especially from burned rock middens, has become increasingly common over the last couple of decades. Dering notes that at least five different bulb taxa have been identified from a variety of sites in central Texas.

Dering, in Appendix C, provides several examples of geophytes, including photos of tubers from Pediomelum 
(tuber), and a variety of bulbs including both onion (Allium) and camas (Camassia). Figure 9-4 supplements those examples. Note that while no modern examples of Eastern camas could be located, Figure 9-4 presents some modern examples of common camas (C. quamash), as well as two examples of cooked camas bulbs. Descriptions of Eastern camas suggest that bulbs of this plant are most similar to those of common camas. For common camas, bulbs range in size from about three to five centimeters in diameter, with mature camas bulbs weighing about five grams (Thoms 1989).

There is a growing body of evidence that suggests that root foods similar to those depicted in Figure 9-4 made a contribution to the central Texas diet throughout much of the prehistoric sequence. The earliest evidence for use of these types of resources comes from the Wilson-Leonard site, where a small number of charred bulbs, identified as Eastern camas, have been dated to around $8000 \mathrm{BP}$ (Stafford 1998:1054). When coupled with the recovery of over 400 bulbs and bulb fragments from 10 different middens on nine different sites discussed previously, it appears that geophytes have been used, at some level, at least from the Early Archaic through the Late Prehistoric. Subsequently, this food type is considered in more detail. Focusing primarily on camas, as it is by far the most frequently represented species in the current data set, a variety of issues that are relevant to assessing geophytes in the Camp Bowie samples are considered. These include the nutritional composition, processing requirements, modern distribution, growing conditions, and density in geophytes.

\section{Nutritional Composition and Processing Requirements of Geophytes}

Nutritional analyses of the types of geophytes under consideration here are limited. Yanovsky and Kingsbury (1938) provide the principal analysis considered here. Their data on raw geophytes suggest that, in general, carbohydrates are abundant in these storage organs, with small amounts of protein, fiber, and ash present. Data on six different analyses of C. quamash suggest that about 71 percent of the weight of these bulbs was composed of carbohydrates. The carbohydrate composition of wild onions (Allium nuttali)
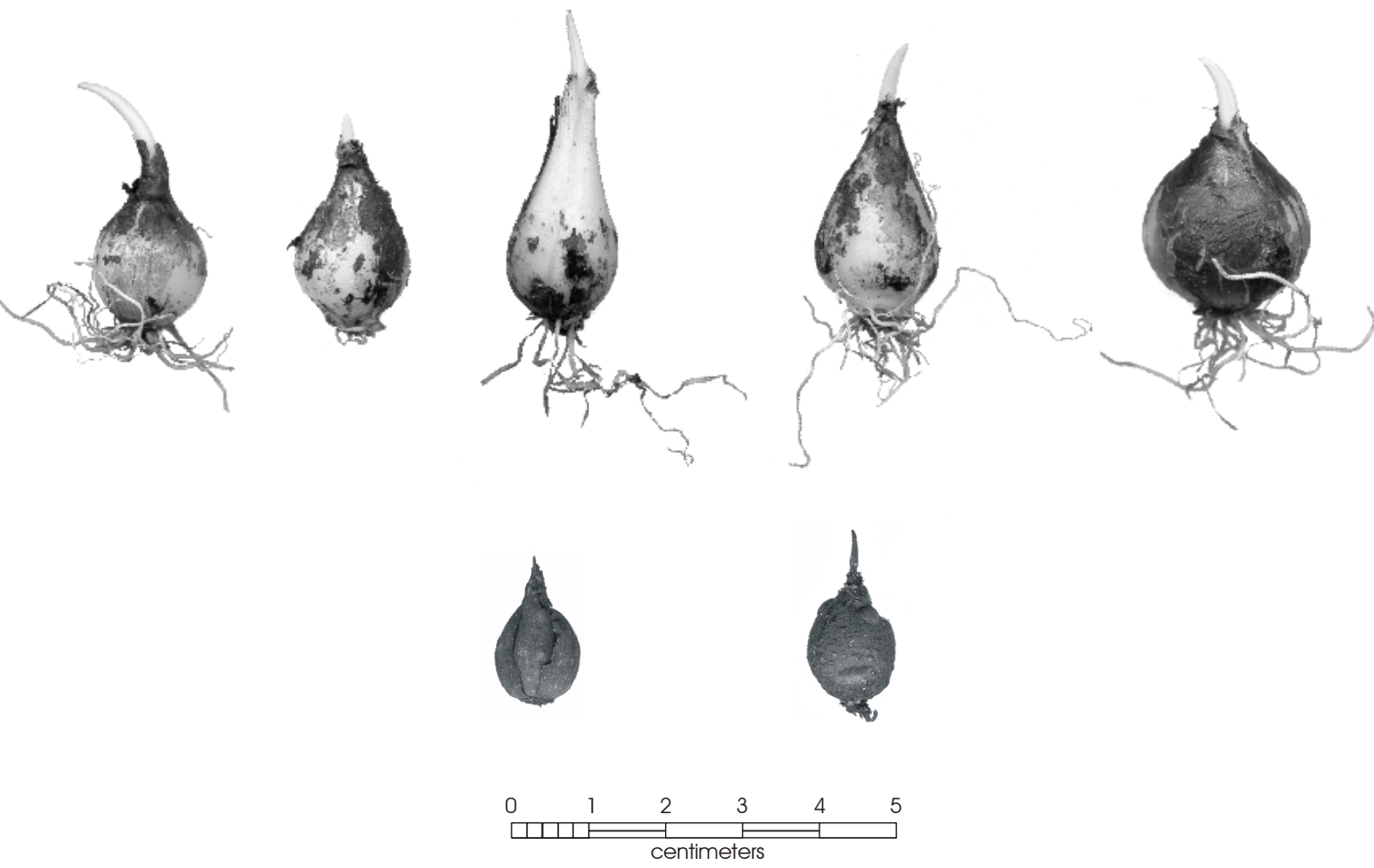

Figure 9-4. Examples of raw (top row) and baked (bottom row) bulbs of common camas (C. quamash). 
was roughly 69 percent, with dog's-tooth violet (Erythronium grandiflorun) having a carbohydrate weight of 76 percent. The composition of the carbohydrates within these three species varied, with both camas and wild onions having high percentages of sugars and no starch, and dog'stooth violet having high percentages of starch and low percentages of sugars. Protein, fiber, and ash were variable, but appear to consistently account for around 10 percent by weight (Yanovsky and Kingsbury 1938). Estimates of caloric returns are available for common camas (C. quamash), though figures for Eastern camas (C. scilloides), the species present in our archaeological cases, could not be located. While values vary, Thoms (1989:162-165) notes that caloric return for 100 grams of fresh camas is roughly $149 \mathrm{kcal}$.

As geophytes represent belowground storage organs for plant growth, the nutritional quality of the bulbs should certainly vary throughout the year. While data on seasonal changes in camas could not be located, Wandsnider (1997:23) notes that the time period when the "maximum amount of energy could be harvested from the plant is just before that energy is directed into reproduction." This suggestion seems to be supported by ethnographic data on camas harvesting. While the bulbs can be collected at any time of the year, Wandsnider (1997:23) notes that camas was frequently processed just after flowering. In the current study area, camas probably flowers during the months of April and May. Thoms (1989:155), however, suggests that the bulk of camas processing in the Northwest (United States) occurred between June and early September, after the "flowers begin to fade."

As summarized by several researchers (e.g., Thoms 1989; Wandsnider 1997), without cooking, a significant component of most carbohydrates cannot be easily digested. Most starch must be gelatinized by exposure to heat and moisture before humans can gain significant nutritional benefit. Similarly, complex non-starch polysaccharides, including inulin, a polymer of fructose common in camas (Konlande and Robson 1972), must be hydrolysized in order to be digestible. Exposure to heat over time will break down the complex polysaccharides into simple sugars that humans can readily digest (Konlande and Robson 1972; Wandsnider 1997:7-8, 21-25).

Wandsnider's (1997) overview of ethnographic cooking techniques notes that long-term pit baking, often with the addition of both rock and water, is the principal method used when high amounts of inulin are present. Several excellent accounts of common camas processing are available, with some of the more detailed summarized by Thoms (1989). The typical processing method involves the excavation of a pit, about $3 \mathrm{~m}$ across and roughly $50 \mathrm{~cm}$ deep. The pit is then commonly lined with stones, and a large fire built on the stones. Bedding material is then placed over the coals, and the geophytes are placed in the oven. The feature is then covered with more packing material, and then with a layer of earth. Cooking time is always a minimum of 24 hours, with times as long as 72 hours reported. The pits are then opened, and the material extracted. Note that these cooking methods would effectively render the carbohydrates in geophytes such as camas, onion, and dog's-tooth violet, digestible for humans.

\section{Growing Conditions, Distribution, and Density of Camas}

The nutritional and associated processing requirements of camas, as well as other geophytes, clearly are consistent with features such as those described at Camp Bowie. We now turn to consideration of the distribution, growing conditions, and density of camas.

Data provided by the USDA Natural Resource Conservation Service (USDA, NRCS 2001) and the USGS Northern Prairie Wildlife Research Center (USGS, NPWRC 2001) suggests that Eastern camas is adapted to fine- and mediumtextured soils, with $\mathrm{pH}$ ranges of between 4.2 and 6.5. The plant thrives in precipitation ranges of between 30 and 55 inches a year, with high early spring moisture being the most critical. Eastern camas has a low drought tolerance, a medium fire tolerance, and appears to be shade tolerant. The active growing period is in the spring and summer, with blooms occurring in mid-spring. Eastern camas requires a minimum of 100 frost-free days, and may require exposure to freezing temperatures during the winter. The plant blooms in mid-spring, producing a pale blue flower. Bulbs take roughly four to five years to mature to maximum size (Thoms 1989:65; USDA, NRCS 2001; USGS, NPWRC 2001). In addition, there appears to be a relationship between the size of the aboveground part of the plant and the size of the bulb that allows collectors to recognize and selectively harvest mature bulbs (Thoms 1989:67).

Tull (1999:111) provides a short summary of this plant in Texas. She notes that currently, the plant is not common in the state. Furthermore, she notes that the plant is easily confused with Zigadenus nutalli, the death camas. As the name implies, death camas is highly toxic to a variety of 
animals, including humans. After flowering, however, which probably occurs during the months of April and May in the central Texas area, the pale blue flowers of Eastern camas are easily distinguished from those of the death camas.

Figure 9-5 presents the probable historic distribution of Eastern camas. These data are based on Gould's (1942) account, as well as more recent data abstracted from both the USDA Natural Resource Conservation Service (2001) and the USGS Northern Prairie Wildlife Research Center (2001). Consistent with the growing characteristics of the bulb discussed above, the plant seems to be primarily in moderately wet settings. While the expected distribution of camas is widespread, it is likely that growing season length limits the distribution to the north, and a lack of cooler winter temperatures and/or a lack of adequate rainfall limits the distribution to the south. The southwestern end of the distribution terminates in central Texas, to the south of the current Camp Bowie area. As summarized in Chapter 2, current yearly rainfall at Brownwood is about 26 inches (66 $\mathrm{cm}$ ), with peaks in May and September, and the highest annual rainfall was just over 42 inches. It is likely, then, that higher rainfall totals, probably over 30 inches, are indicated during the period of midden use at Camp Bowie, where this plant was apparently common. In addition, note that as much of central Texas is at one end of the historic distribution of camas, relatively small climatic changes, then, could potentially have a significant impact on both the range and density of this plant in the study area.

Density estimates on Eastern camas in Texas could not be located. However, Thoms (1989:77-79) provides density estimates for common camas in the northwestern United States, as well as data on the density of domestic onions and other bulbs. His data suggest densities range from a "fairly low" density of 75 mature camas bulbs per square meter to a high of 410 bulbs per square meter under average conditions (Thoms 1989:79, 167-170). Thoms (1989:169) uses an estimate of 150 mature bulbs per square meter in modeling camas exploitation. Turner and Kuhnlein (1983:212) report densities of up to 200 flowering camas per square meter in the Pacific Northwest, with many immature plants not counted in that number. In contrast Smith et al. (2001:172) report a density for sego lilies (Calochortus nuttalli), which produce a bulb similar in size to camas that was also used ethnographically, of only four to six plants per square meter in Wyoming. Using data from Thoms (1989), a single collector in a moderately dense patch of camas can collect roughly 41 kilograms of camas per day. Assuming that each bulb is five grams, 41 kilograms would represent 8,200 individual plants. In one week, a group of 10 people could collect roughly 574,000 bulbs.

\section{Geophytes and Subsistence at Camp Bowie}

The above summary clearly suggests that burned rock middens at Camp Bowie were probably used for processing plants, specifically geophytes such as Eastern camas and wild onion. The chemical structure of these plants requires processing consistent with their presence in burned rock middens. This final section of this chapter speculates on the probable role of geophytes in subsistence at Camp Bowie.

A review of several studies suggests that processing of geophytes is a "low return" subsistence option. Based on both experimental (e.g., Dering 1999; Kornfeld 1994; Simms 1984; Smith et al. 2001) and ethnographic (e.g., Couture et al. 1986; Greaves 1997; Thoms 1989) research, it is clear that collecting of roots involves a great deal of work. While estimates on processing time, density, and collecting time vary widely, high collecting and processing costs are clearly associated with these foods. This would especially be the case for those food types, such as camas, that would require long-term baking to render the plant digestible. While geophytes appear to be reliable, using most rankings, and employing traditional optimal foraging theory, these resources would be one of the last food groups to be added to a diet. They would only be employed under circumstances when other food resources, most of which clearly appear to be higher ranked, were not available. In spite of this low ranking, however, it is clear that these resources were being used at Camp Bowie, primarily throughout much of the Late Prehistoric period. Data summarized earlier suggests that these plants have been used at least since the Early Archaic in other parts of the state. Does the presence of these plants in Camp Bowie middens suggest that Late Prehistoric subsistence in this part of the state reflected a wide diet breadth? In part, the answer to this question hinges on having a minimal understanding of, among other things, 1) the probable season during which geophytes were collected and 2) the alternatives available during that season. While we lack specific information on both of these areas, the previous summaries of nutritional quality and plant characteristics allows some level of speculation concerning the season of geophyte exploitation. 


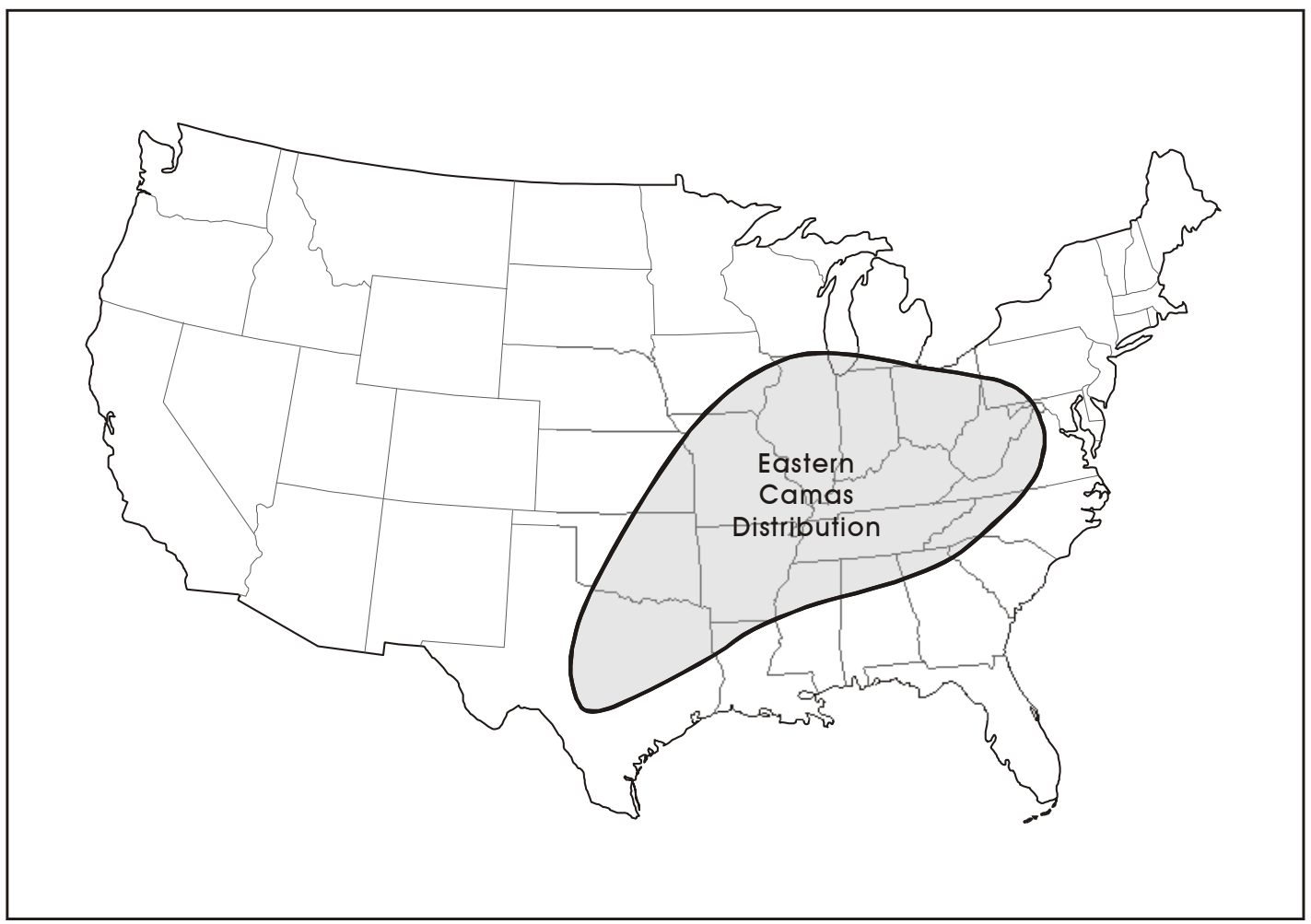

Figure 9-5. Historic distribution of Eastern camas.

While these types of plants could be collected at any time during the year, the most probable time for collection in the current study area is just after flowering, probably in April or May. It is at this time when nutritional quality of the bulbs should be high. In addition, the presence of the flowers provides clear identification of the plant, eliminating any unfortunate confusion with death camas. Flower sizes also would provide an indication of the maturity of the bulb. While all bulbs could be collected, selective processing of the slower growing bulb would assure higher returns as well as provide for longer sustainability of the patch. Such selective harvesting has been documented ethnographically (Thoms 1989).

If these low return resources were collected and processed during the early spring, a period that seems likely given the characteristics of the plant, then the exploitation of geophytes must be considered in the context of other available resources at that time of year. What other resources might be available during this period? Surprisingly, little detailed work on seasonal availability of floral and faunal resources could be located for this area of Texas. However, some qualitative plant data exist for Hill County, roughly $170 \mathrm{~km}$ to the east of the current project area. Brown (1989), using data developed by Skinner et al. (1978), presents probable periods of plant food availability by month in three different environmental settings. His data suggest that the late fall is likely to be the period of greatest plant availability for human consumption. For example, during the month of April, these data suggest that five different plant species potentially used by prehistoric populations for food were available. In contrast, the month of September has 25 different plant species listed (Brown 1989:204-207). Data on faunal resources could not be located, but it is probable that the nutritional quality of many animals, including deer and bison, would be lowest during the early spring (see Speth 1990; Speth and Scott 1989). Given these conditions, the incorporation of geophytes, a low return resource, into the early spring diet may reflect the lack of alternatives during this period. Note also that consumption of high carbohydrate resources, such as geophytes, at this time of year may also have additional nutritional benefits beyond simply caloric return (see Speth 1990; Spielman 1989). 


\section{Summary}

This chapter explored questions that focus on what was being processed in the large earth oven features tested on this project. A consideration of mussel shell, vertebrate fauna, macrobotanical identifications, and the results of flotation analyses suggested that the most probable data sets reflecting direct evidence of midden use were revealed by flotation and macrobotanical identifications. While neither shell nor bone can be eliminated as possible candidates for some level of processing, the flotation data and the macrobotanical identifications strongly suggest that, at least at Camp Bowie, the middens were used primarily to process plants, with a specific focus on geophytes. A short review of available data on the nutritional characteristics of these plants, their necessary processing requirements, and their historic distribution all are consistent with that suggestion. Using ethnographic and experimental data, primarily centered on camas exploitation, the final section of this chapter speculated on the role of geophytes in the subsistence base. While a variety of data exists to suggest that these plants are low-return resources, primarily as a result of extensive collecting and processing time, their incorporation in the diet during early spring may suggest that alternative, higher ranked resources were not available during that period. 


\title{
Chapter 10: Investigating Midden Sites at Camp Bowie
}

\author{
Raymond P. Mauldin
}

\section{Introduction}

The previous three chapters have considered when the Camp Bowie middens were used, how these middens may have functioned, and what items may have been processed in the middens. In this chapter, we shift our focus away from the middens as such, and consider patterning at a site level. As outlined in Chapter 4, a component of the research issues considered at Camp Bowie involved aspects that can be grouped under the general topic of site structure. These issues included investigating the manner in which various components of a site (e.g., burned rock middens, off-midden features, artifact clusters) may be related. In part, this was designed to answer questions regarding the role of these sites within the regional land use system. That is, do these sites represent special purpose occupations with activities centered on the midden? Do they represent residential occupations with the midden being only one component of a variety of general activities conducted at a given location? What components of the artifacts and other features on a given site are unrelated to midden use, being either earlier or later in time?

Unfortunately, answering these questions in anything approaching a definitive way is, in most cases, simply not possible. As outlined in Chapter 7, middens were commonly used for several hundred years. A review of diagnostics on sites, presented in Chapter 6, has shown that sites frequently had diagnostics that spanned an even greater period of time. Even if we could clearly separate the chipped and ground stone artifacts and the fire-cracked rock that were deposited on the site during the period of midden use from the materials that were deposited earlier or later in time, the notion that locations were used in a consistent manner for several hundred years is probably not tenable. Even short-term ethnographic descriptions of hunter-gatherer mobility and settlement suggest that yearly changes in the use of a location can be expected, in part, as a result of changing resource structure (e.g., Kelly 1995; McGee 1898; Silberbauer 1981:245; Steward 1938; Tanaka 1980:80; Yellen 1977, 1978). Sometimes areas were used in a residential manner, and sometimes these same locations were used as special purpose sites (e.g., Steward 1938:152-159). Sometimes the same areas were used for different purposes at different times during the year (e.g., Kelly 1995:111-120). What would the material culture generated by such a system, even over a few years, look like? Currently we lack any detailed information that would allow us to answer this question. Furthermore, the archaeological record is generated, in part, by a number of such systems operating over several thousand years. While we have no idea what sort of variability in artifacts and features such a series of systems may produce, it is unlikely that dividing the world up into two discrete site classes (i.e., "special purpose" and "residential") is going to be a very useful approach to investigating and understanding that variability.

Nevertheless, making a number of assumptions, and building on patterns identified in the previous chapters, we can begin to make some probable suggestions regarding characteristics of burned rock midden sites in the Camp Bowie area. The initial section of this chapter, then, attempts to develop expectations for two different roles that burned rock midden sites may have had. Specifically, we contrast expectations for burned rock midden sites functioning as special purpose locations with expectations for burned rock midden sites being residential in nature. We then consider two broad measures that seem to be related to the intensity and nature of these occupations. Looking at site density in combination with two chipped stone attributes suggests that some burned rock midden sites seem to be more specialized in nature.

We then consider data on the location of middens within a handful of sites. Finally, we consider the distribution of burned rock midden sites relative to other prehistoric sites in terms of distance to water. While the quantity of data available and the lack of well-developed methodology for addressing these types of questions limit any firm conclusion, sites with middens on Camp Bowie tend to match our notions regarding "special purpose" locations more closely than our notions of residential sites.

\section{Expectations for the Role of Midden Sites}

We assume, given the patterns documented in the previous two chapters, that middens were specialized features. If the sites were specialized, that is if the sites were not residential in nature, what would the sites look like? We suggested in Chapter 4 that if burned rock midden sites were specialized, they should contain a narrow range of artifact and feature 
types, as well as a low density of artifacts and features. We suggested that the distribution of material should be centered on the midden. Conversely, it may be the case that burned rock middens are only one component of a more general, residential occupation. Under that position, we suggested that midden sites should have a rich and abundant artifact and feature assemblage. We also suggested that if burned rock midden sites were residential in nature, then it should be the case that middens, which represent intrusive activities that require large quantities of fuel and rock and generate a great deal of debris, should be on the margins of sites. Finally, we suggested a third possibility in which midden sites are a product of site reuse under changing site functions (e.g., specialized burned rock midden activity site reoccupied as residential camps). Under that scenario, artifacts and features found away from the midden have no systemic behavioral relationship to the midden itself, but high assemblage richness may be anticipated at the site level.

In order to explore which of these possibilities are most likely, we would need large samples of artifacts and features collected and observed in a consistent manner from all sites. Furthermore, we would need extensive testing outside of the middens, again in a consistent manner, in order to insure that we had adequately sampled the site level data. On the current testing project, we simply lack these data. While, as outlined in Chapter 6, we excavated 40 1-x-1-m units off midden on these 16 sites, the total site area represented by these 16 sites was in excess of $185 \mathrm{~m}^{2}$. In addition, two of the sites had no external units excavated, and on four of the sites only a single $1-x-1-m$ unit was excavated. The single best sampled site is 41BR87, with five 1-x-1-m units on a site that minimally covers $5,675 \mathrm{~m}^{2}$, a sample covering less than one tenth of one percent of the site area. Given these figures, it is extremely unlikely that we have anything representing an adequate sample from non-midden contexts. Comparison of feature and artifact variety is not possible with these limited data sets.

We had originally hoped that surface collections and observations would supplement that minimal excavation sample; however, given different depositional and erosional conditions, not all sites had surface artifacts, and consequently not all sites had surface collections. Finally, while we do have large samples of artifacts from most sites if we use all lithics, it is likely the different collecting methods (i.e., surface collection, shovel testing, test excavations) used to generate that larger data set biased these samples. In most contexts, surface collections produce assemblages that have larger items. For example, the maximum length of chipped stone from surface collections of site 41BR253 yielded a mean of $21.6 \mathrm{~mm}(\mathrm{n}=301)$. Off-midden excavation at the same site produced a mean chipped stone size of $19.0 \mathrm{~mm}$ $(\mathrm{n}=237)$. Similarly, at site 41BR480, surface chipped stone had a mean length of $24.1 \mathrm{~mm}(\mathrm{n}=46)$, while excavated chipped stone had a mean of $18.7 \mathrm{~mm}(\mathrm{n}=891)$. These size differences are probably a result of differential exposure on the surface. However, regardless of the causes of these differences, any factor that sorts on artifact size will condition artifact types (see Mauldin and Nickels 2001). As such, surface collected samples will tend to have different frequencies of different types of artifacts on the same site, in part simply due to size sorting. Further complicating the use of these data is the differential contribution of surface collected material on a given site.

Given these problems we rely on the shovel test data. These data are available for all sites. In addition, we have good spatial distribution of shovel tests within a site, though they are often at a higher frequency near middens. Unfortunately, the overall number of items recovered in shovel tests is low. The average number of items recovered in shovel tests for all 16 midden sites is only 134 items per site. Eight of the 16 sites have less than 100 items, and on four of these smaller assemblage sites the number of items is less than 50 . These low sample sizes make it difficult to consider artifact variety in any useful way.

\section{Artifact Density and Chipped Stone Characteristics}

The combination of minimal testing outside of middens, the lack of compatibility between data sets collected in different ways, and the relatively low sample sizes at some sites in the shovel test data precludes any detailed consideration of either feature variety or artifact variety. We can, however, explore other aspects that may begin to suggest the degree to which these sites reflect either special purpose or residential locations. These include three different measures, artifact density, non-cortical percentages in lithic debitage, and size variability in lithic debitage. Each of these measures is discussed.

As envisioned here, residential sites should have higher artifact density relative to special purpose locations as a function of the number of person days spent at a location as well as the frequency and variety of activities conducted. This expectation is certainly complicated by the probability that special purpose locations were reoccupied. In addition, 
some special purpose locations could, depending on the nature of the activities, generate a high density of debris. Nevertheless, in most cases residential sites should have higher artifact densities relative to special purpose locations.

Tomka (personal communication 2002) suggests that two measures on chipped stone data may be useful for identifying certain classes of special purpose locations relative to residential sites. Specifically, he suggests that residential sites, as a result of both their relatively longer use and wider range of activities, are likely to have a wide range of reduction strategies represented. Conversely, special purpose locations may have a more restricted range of reduction strategies. At least some special purpose locations should have assemblages with higher frequencies of non-cortical debitage as a function of greater frequencies of refurbishing/ resharpening tools. While this activity should certainly be conducted at residential sites as well, residential assemblages should also include a more complete range of reduction strategies. These same activities should also result in lower variability in flake size at some special purpose locations. While these measures are certainly complicated by the possibility of reoccupation, and while it is possible that some special purpose locations, perhaps as a function of access to raw materials, would have a variety of reduction strategies represented, these two measures provide some general expectations that can be considered with our available shovel test data.

All three measures rely on relative, qualitative differences between groups of assemblages. For example, we have suggested that special purpose locations should have "lower" artifact density, "higher" non-cortical percentages, and "lower" variability in flake size relative to residential sites. "Lower" and "higher" are not quantified. In addition, all three measures have a fair degree of ambiguity associated with their interpretation.

Focusing just on the 16 midden sites, then, we can ask if any of these three measures provide consistent results that might allow at least some preliminary suggestions regarding the nature of these occupations. In order to consider these various measures, we scaled the range of values for each data set such that a score of 0 was assigned to the lowest value for a given variable in the table, and a score of 100 was assigned to the highest value. This allowed for bivariate plots of scores using the same scales, but it does not change the relative relationship between values. Table 10-1 presents the 16 sites along with the raw and the scaled data. The variability measure on flake length is the coefficient of variability (standard deviation/mean). This coefficient allows for assessing variability in situations with different means.

Figure 10-1 presents the initial bivariate plot that compares site artifact density with non-cortical debitage. Each variable has been arbitrarily divided at 50, producing four sections in the plot. Those sites that fall in the upper left quadrant have higher non-cortical values and low artifact density values. These are consistent with our expectations for special purpose locations. Those that fall in the lower right quadrant have higher artifact densities and lower non-cortical debitage percentages. These are consistent with expectations for residential locations. The remaining two quadrants are ambiguous. That is, we have no interpretations tied to these quadrants. Examination of Figure 10-1 clearly shows that most sites fall in the special purpose area of the graph, with a single site falling in the residential area. In addition, four sites are in the other two quadrants.

Figures 10-2 and 10-3 present bivariate plots for the remaining variables. In Figure 10-2, variability in flake length is along the $\mathrm{X}$-axis, with non-cortical debitage along the Y. In Figure 10-3, site artifact density and variability in flake length are compared. As with Figure 10-1, most sites cluster in the special purpose area of the graph, with either no residential cases (Figure 10-2) or a single residential case (Figure 10-3) being identified.

Table 10-2 summarizes the assignments by site derived from these three plots. In 10 of the 16 cases, the sites are consistent with special purpose expectations in all three plots. There is no case where the sites are consistent in all three plots with residential expectations. Overall, only two sites, 41BR87 and 41BR228, have data consistent with any expectations for a residential occupation, while 14 sites have at least some consistency with special purpose expectations.

Based on these results, can we conclude that burned rock midden sites are primarily special purpose? Probably not, for even if we ignore the potential ambiguities in the initial measures, the use of the value of 50 as a division point between the residential and special purpose portions of the table is arbitrary. It is based on aesthetics and symmetry rather than research. We can, conclude, however, that within this group of 16 midden sites, most tend to have characteristics that are more consistent with our poorly developed expectations regarding special purpose locations. More interestingly, perhaps, is the observation that no site 
Table 10-1. Midden Sites with Raw and Scaled Data on Lithic Assemblages

\begin{tabular}{|c|c|c|c|c|c|c|}
\hline & & & & & \\
\hline & & & & & \\
\hline
\end{tabular}

has consistent "residential" characteristics, and only two sites, 41BR87 and 41BR228, have any characteristics that are consistent with our residential expectations.

In the case of site 41BR228, we have substantial evidence that the site was occupied prior to the construction of the middens. Reference to the site description in Chapter 6 will show that this site has diagnostic artifacts indicating occupation from the Early Archaic through the Late Prehistoric. The two middens at this location produced radiocarbon dates in the Late Prehistoric and the Late Archaic. Site 41BR228, then, is an example of middens being placed on previously occupied locations. This probably accounts, in part, for the high density in this case. Site 41BR87 also has some evidence for earlier use. Late Archaic diagnostic artifacts were recovered on this site while the midden has a series of dates placing the period of use in the Late Prehistoric.

\section{Midden Location on Sites}

In Chapter 4, we suggested that if burned rock midden sites were residential in nature, then it should be the case that middens, which represent intrusive activities that require large quantities of fuel and rock, and generate a great deal of debris, should be on the margins of sites. At first glance, investigating this problem looks pretty clear. All that should be required is to look at a site map and see if the midden is in the center. There are, however, two potential problems with that approach. First, it is necessary to assume that we have adequately established the site boundaries in all cases. Our testing efforts primarily centered on the middens as it was the presence of these features that Wormser and SulloPrewitt (2001) used to argue that these sites required additional investigation. While in most cases our shovel testing and surface observations were at a scale that effectively established site boundaries, in several cases, such as on sites 41BR65, 41BR87, and 41BR492, negative shovel tests were not consistently obtained on the site margins. These site boundaries include a buffer that may, or may not, accurately reflect the distribution of material.

Secondly, it is necessary to assume that the distribution of artifacts that comprise the site dates more or less to the same time as the midden, for if the material is earlier or later in time, then the midden placement relative to that overall distribution is unlikely to be relevant. That is, the site's boundaries are determined by the distribution of all material, 
not just the distribution of material generated during the period of midden use. The location of a midden, then, would have to be compared to the distribution generated during that same time period, not to the overall distribution.

Table 10-3 summarizes the temporal affiliation of middens and sites by major time periods. Periods of midden use, established by radiocarbon dates, are compared to overall site dates, using diagnostics. There are 14 sites with radiocarbon dates on middens. In eight of these 14 cases, there is evidence for some level of occupation prior to the time period of midden use. The distribution of material at these eight sites, then, probably does not reflect material exclusively generated during midden use. The six cases in which we lack evidence for earlier use are 41BR65, 41BR253, 41BR420, 41BR441, 41BR492, and 41BR493.

Examination of site maps presented previously in Chapter 6 will suggest that both of the middens on site 41BR253 are on the margin of the site. Similarly, the midden on site 41BR441 is located on the southern edge of the distribution. At site 41BR420, the placement of the midden is to the south of the site. Assuming that the materials that make up these sites date to the same time frame as midden use, these three cases are consistent with our expectations for residential occupations. Note, however, that in all three cases, artifact density patterns as well as chipped stone patterns are consistently "special purpose" in appearance. In fact, site 41BR441 had the lowest overall artifact density on the project, clearly not consistent with our expectations for a residential use site. Conversely, two sites, 41BR65 and 41BR493, have central midden locations. These locations are clearly not consistent with the assumed "residential" pattern.

\section{Distance to Water}

The final variable considered in this chapter involves the location of sites with regard to water. If burned rock midden sites are residential in nature, we might expect that one of the factors involved in determining their location would be distance to water. Long-term, residential occupations should, on average, be located closer to water primarily as a result of demands associated with larger populations. Conversely, the location of more specialized occupations may be determined by other factors, such as the distribution of raw

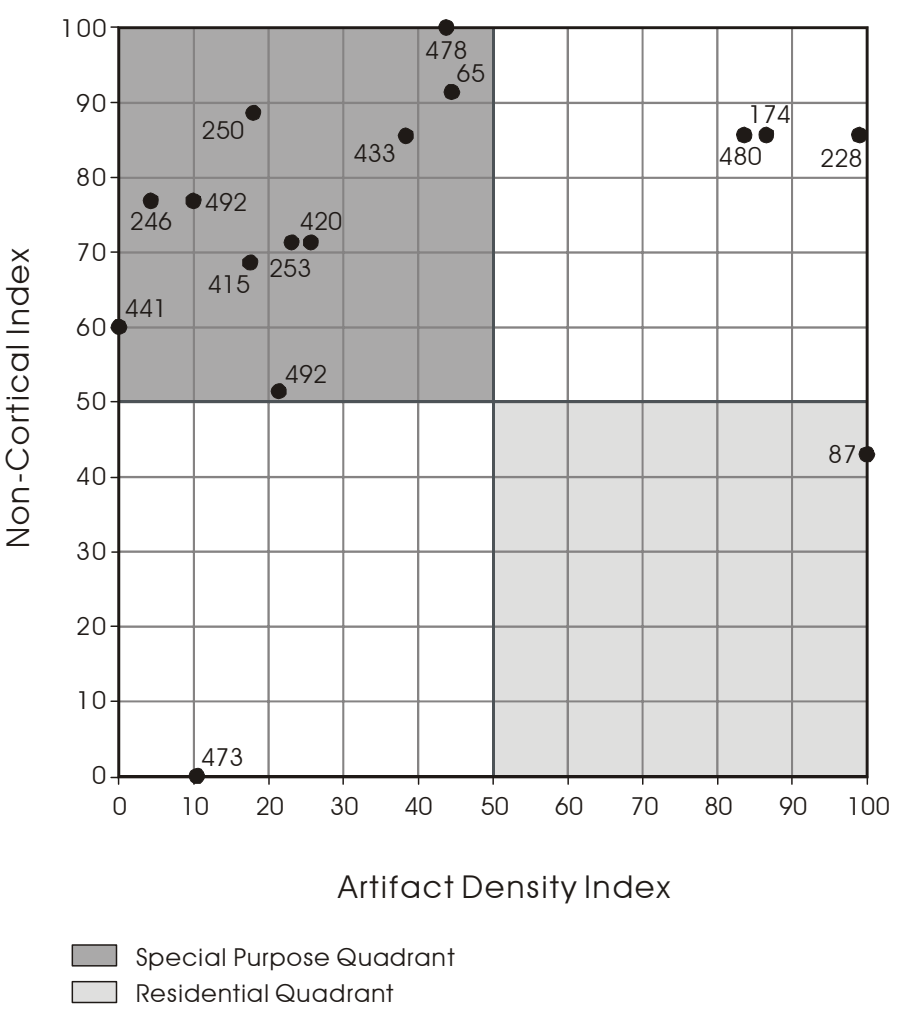

Figure 10-1. Plot of indexed site artifact density and indexed non-cortical debitage for burned rock midden sites with residential and special purpose quadrants identified.

material resources or specific food types. While access to water may be one of those considerations, the short-term nature of more specialized occupations, coupled with other requirements, should result in a more widespread distribution of specialized sites across the landscape.

As outlined in Chapter 2, the distribution and availability of water within Camp Bowie has certainly changed over the last century. Examination of the current water resources within and surrounding Camp Bowie suggests that while there is, at present, only one major flowing river-Pecan Bayou - several streams certainly flow seasonally. In addition, there are a number of second-order drainages that probably, in the recent past, had water present on a more consistent basis. In considering distance to water, then, we consider all drainages identified on the USGS quadrangle sheets for Camp Bowie and the surrounding area.

Using only prehistoric sites from the Camp Bowie survey conducted by Wormser and Sullo-Prewitt (2001), there are 


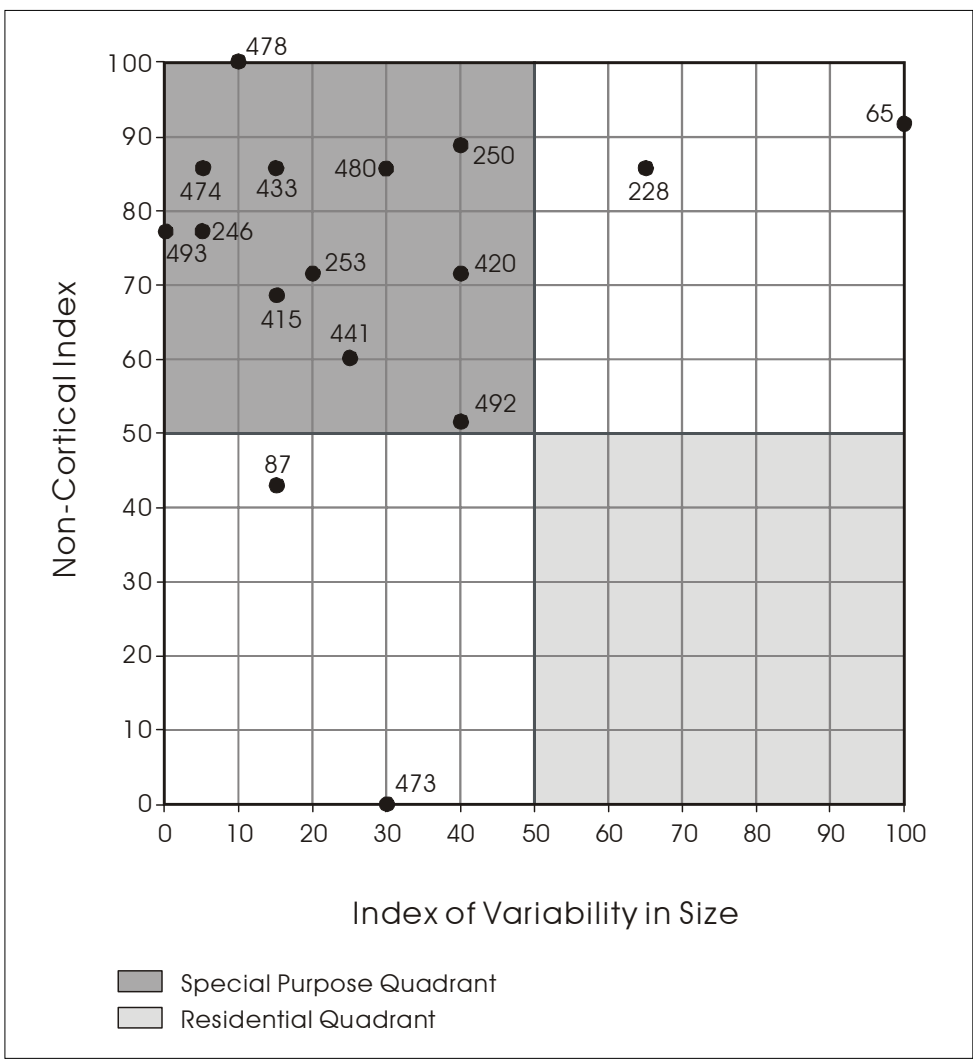

Figure 10-2. Plot of indexed coefficient of variability for flake length and indexed non-cortical debitage for burned rock midden sites with residential and special purpose quadrants identified.

Figure 10-3. Plot of indexed site artifact density and indexed coefficient of variability for flake length with residential and special purpose quadrants identified.

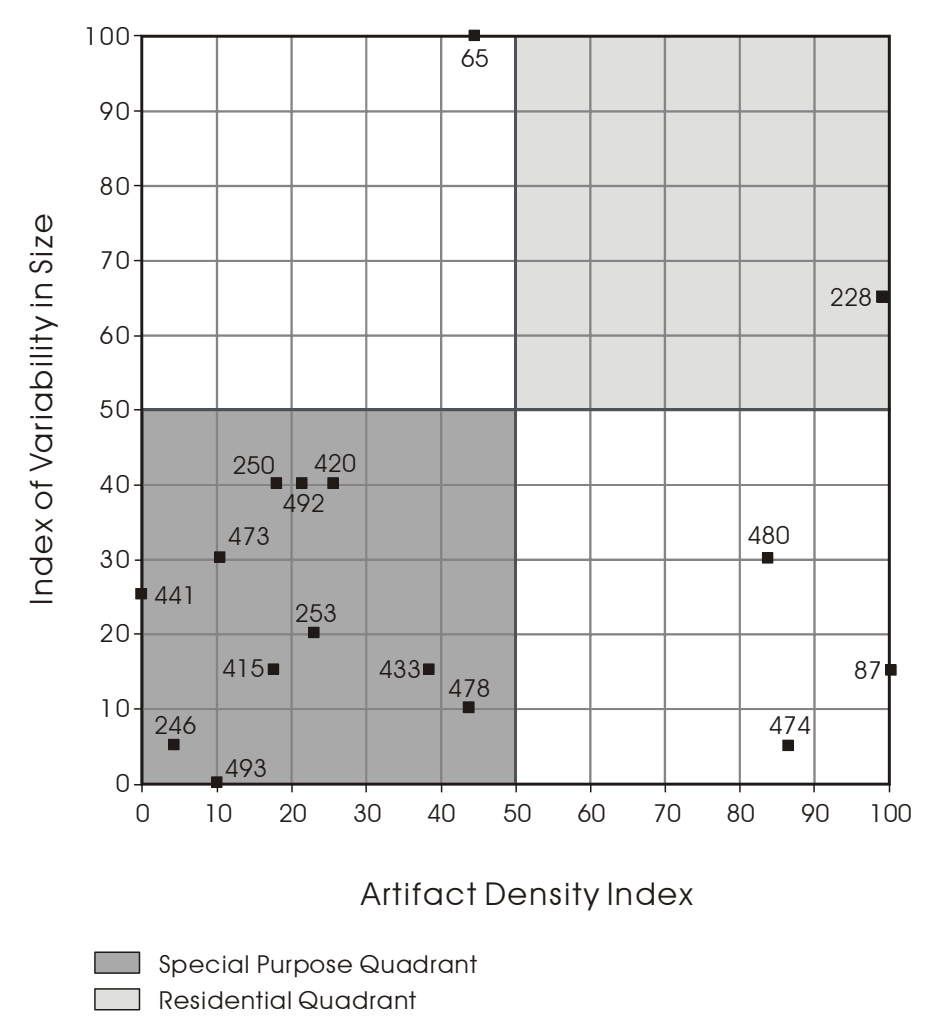


Table 10-2. Summary Characteristics of Individual Sites in Figures 10-1 through 10-3

\begin{tabular}{|c|c|c|c|}
\hline Site \# 41BR & Figure 10-1 & Figure 10-2 & Figure 10-3 \\
\hline 65 & Special Purpose & ---------------- & ----------------- \\
\hline 87 & Residential & ----------------- & ----------------- \\
\hline 228 & ----------------- & ------------------- & Residential \\
\hline 246 & Special Purpose & Special Purpose & Special Purpose \\
\hline 250 & Special Purpose & Special Purpose & Special Purpose \\
\hline 253 & Special Purpose & Special Purpose & Special Purpose \\
\hline 415 & Special Purpose & Special Purpose & Special Purpose \\
\hline 420 & Special Purpose & Special Purpose & Special Purpose \\
\hline 433 & Special Purpose & Special Purpose & Special Purpose \\
\hline 441 & Special Purpose & Special Purpose & Special Purpose \\
\hline 473 & ------------------ & Special Purpose & Special Purpose \\
\hline 474 & 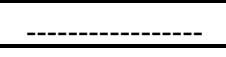 & Special Purpose & - - - - - \\
\hline 478 & Special Purpose & Special Purpose & Special Purpose \\
\hline 480 & - ------------------ & Special Purpose & - \\
\hline 492 & Special Purpose & Special Purpose & Special Purpose \\
\hline 493 & Special Purpose & Special Purpose & Special Purpose \\
\hline
\end{tabular}

156 prehistoric sites available for consideration. Seventeen of these sites have burned rock middens. That number includes the 16 sites tested on the current project, as well as site 41BR380. That site is recorded as having a burned rock midden, but subsequent attempts to relocate $41 \mathrm{BR} 380$ have been unsuccessful. Nevertheless, we will include this site in our consideration. Note that the remaining 139 sites represent a mixture of sites classified as "limited activity" and "residential." That classification is, of course, based primarily on surface data, and appears to be related primarily to site size and density of material (see Wormser and SulloPrewitt 2001). The classification, then, probably does not accurately reflect the nature of the occupation, but rather, like other measures used here, is simply an approximation.

Figure 10-4 presents a box plot of the distance to all drainages from burned rock midden sites as well as all other prehistoric sites. If burned rock midden sites are consistently residential in nature, then as a group, they should be located closer to water resources when contrasted to other prehistoric sites if these other sites include a mixture of limited activity and residential occupations. The pattern in Figure 10-4 clearly suggests that there are no significant differences between these two groups. The medians are essentially identical, as are the overall distributions. Burned rock midden sites are located an average distance of 209 m away from drainages, while all other prehistoric sites have an average distance of $216 \mathrm{~m}$. The fact that burned rock midden sites, as a group, do not show any significant tendency to be located closer to water when contrasted to other sites, sites that probably contain both residential and special purpose locations, is not consistent with our expectations for a residential focus.

\section{Summary}

While any detailed analysis of artifact variety on the 16 midden sites was limited by the lack of available data and concerns with the comparability of data, considering both the patterns in artifact density and chipped stone variability, as well as limited data on the placement of middens on sites shows that in most cases, sites with middens match our notions regarding "special purpose" locations. No locations consistently matched our expectations for "residential" sites. Similarly, burned rock midden sites are not, as a group, located significantly closer to drainages, another expectation for residential occupation. While our methodological tools for considering these types of questions are clearly limited, we can suggest that sites with middens on Camp Bowie tend to match our notions regarding special purpose locations more closely than they match our notions of residential sites. 
Table 10-3. Comparison of Midden Radiocarbon Dates and Site Level Diagnostic Dates

\begin{tabular}{|c|c|c|c|c|c|c|c|c|}
\hline & \multicolumn{4}{|c|}{ Midden Radiocarbon Date Ranges } & \multicolumn{4}{|c|}{ Periods of Diagnostic Artifacts on Sites } \\
\hline 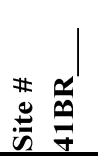 & 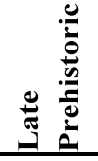 & 蒙 & 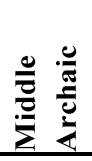 & 肴 & 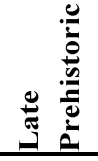 & 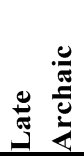 & 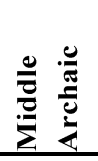 & 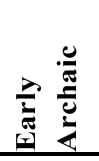 \\
\hline 65 & Yes & Yes & & & & Yes & & \\
\hline 87 & Yes & & & & Yes & Yes & & \\
\hline 228 & Yes & Yes & & & Yes & Yes & Yes & Yes \\
\hline 246 & Yes & & & & Yes & & Yes & \\
\hline 250 & Yes & & & & Yes & Yes & & \\
\hline 253 & Yes & & & & Yes & & & \\
\hline 420 & Yes & Yes & & & Yes & Yes & & \\
\hline 433 & Yes & & & & Yes & Yes & & \\
\hline 441 & Yes & & & & Yes & & & \\
\hline 473 & Yes & & & & Yes & Yes & & \\
\hline 474 & Yes & & & & & Yes & & \\
\hline 478 & Yes & & & & & Yes & Yes & Yes \\
\hline 492 & Yes & Yes & & & Yes & Yes & & \\
\hline 493 & Yes & & & & & & & \\
\hline Totals & 14 & 4 & 0 & 0 & 10 & 10 & 3 & 2 \\
\hline
\end{tabular}

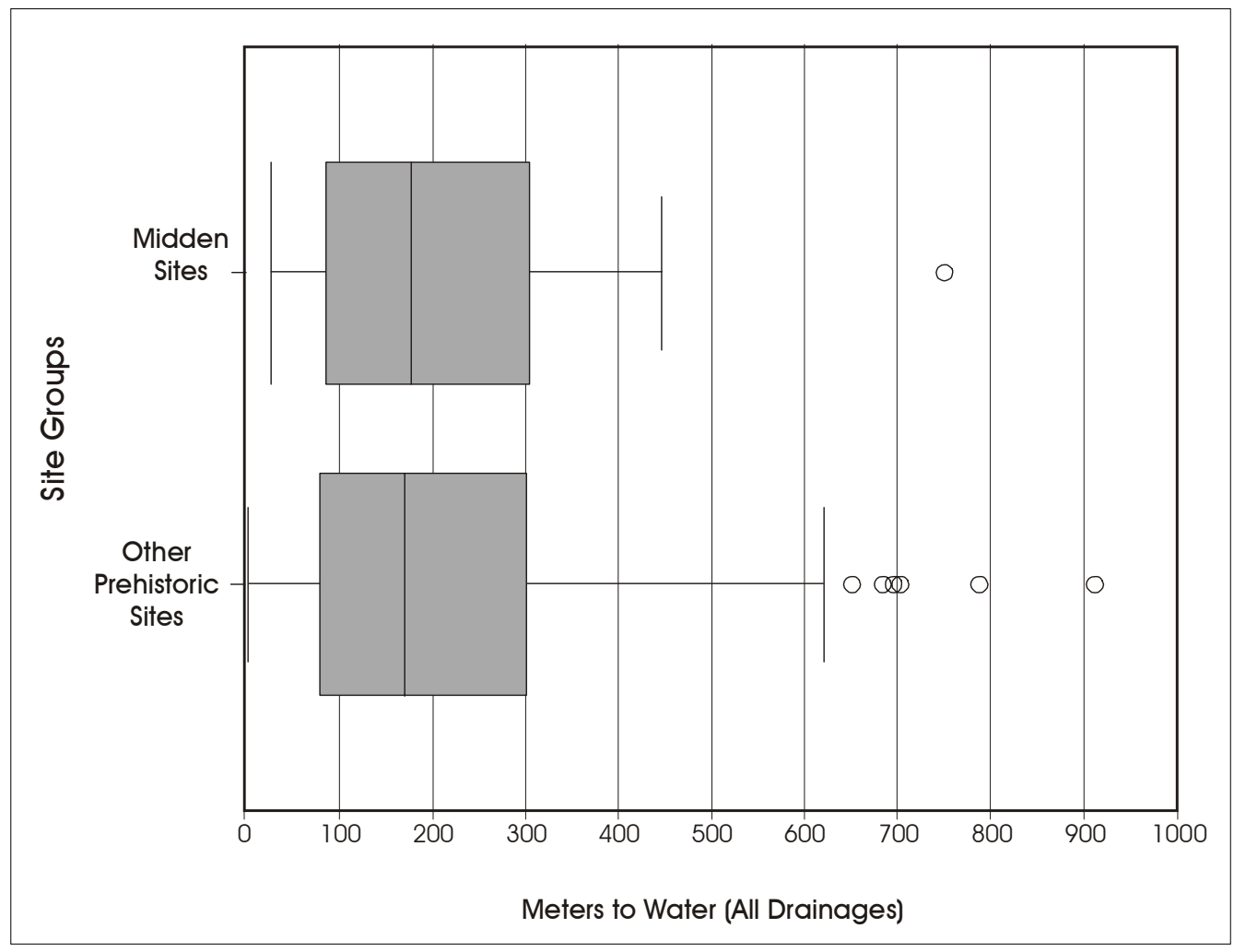

Figure 10-4. Box plots of distance to drainages for burned rock midden sites and other prehistoric sites at Camp Bowie. 


\title{
Chapter 1 1: Burned Rock Middens in Texas
}

\author{
Raymond P. Mauldin and David L. Nickels
}

In the previous four chapters, we have focused on various aspects of burned rock middens at Camp Bowie. We have argued that the middens tested within the camp date primarily to the Late Prehistoric period, that they represent earth ovens, that they were primarily used to process geophytes, and that they are located on sites that probably represent special purpose locations. In the current chapter, we use the understanding of middens developed from the Camp Bowie data to consider several broader patterns in midden use at larger scales. This chapter consists of four sections. The initial section develops a general model of burned rock midden use. Employing experimental data, we consider three components, rock, wood, and food, which are involved in midden use. We argue that wood availability is a critical element in understanding several aspects of burned rock midden use. The second section of this chapter explores the implications of wood availability. Specifically, we suggest that different patterns of midden reuse, as measured by midden size, may be conditioned by wood availability. The third section of this chapter considers the spatial distribution of burned rock middens in Texas using data from the Texas Archeological Sites Atlas. While these data are less than ideal, we suggest that there are probably two broad patterns of burned rock midden use. These two patterns are probably related to different sets of resources (sotol/agave and geophytes) processed in middens. The final section of this chapter provides a short review of the burned rock midden research.

\section{Modeling Burned Rock Oven Use Parameters}

Given the patterns documented in the previous chapters, it should be clear that burned rock middens at Camp Bowie are the result of frequent processing of large quantities of plant foods with massive quantities of rock and fuel. Here, we attempt to quantify, at least to a limited degree, qualitative terms such as "frequent," "large," and "massive." While speculative, some degree of quantification seems to be necessary if we are going to begin to understand the dynamics of burned rock oven use.

Several experimental studies allow us to begin to investigate amounts of rock and wood necessary in these types of features. For example, Dering (1999:664-666) provides data on a series of five experimentally constructed earth ovens that are of interest. The ovens, modeled on Archaic period features in Texas, were $1.5 \mathrm{~m}$ in diameter and $50 \mathrm{~cm}$ in depth. An average of $250 \mathrm{~kg}$ of limestone rock, and $224 \mathrm{~kg}$ of wood, were used to heat the ovens, which were used to process both lechuguilla and sotol. Leach et al. (2001[1998]:275283) report data for an experimental earth oven that was $1.3 \mathrm{~m}$ in diameter and $30 \mathrm{~cm}$ deep. For this smaller oven, roughly $63 \mathrm{~kg}$ of wood and $91 \mathrm{~kg}$ of limestone were used. Finally, Thoms (1989:255-256) describes the construction and firing of an earth oven for camas processing. The oven, roughly $2 \mathrm{~m}$ in diameter, required about $294 \mathrm{~kg}$ of rock and "a few hundred" kilograms of wood. Thoms (1989) also reports several ethnographic descriptions that clearly demonstrate that substantial, and probably roughly equal weights of wood and rock, were required for processing root foods in earth ovens.

In the two studies with quantitative measures of wood and rock, weights of rock exceeded the weights of wood, though not by a significant amount. Wood weights are roughly 10 to 30 percent less than the rock weights. When we consider multiple firings, however, combined wood weights should significantly exceed rock weights, as some portion of rock from a single firing event will be available for reuse. How many times could rock be reused? Clearly, a variety of factors, minimally including rock type and firing temperatures, should be involved in determining the number of potential uses. Black (1997:266), citing descriptions of rock reuse in modern sotol processing, suggests that four firings may be a reasonable estimate. However, Leach et al. (2001[1998]) demonstrate that after two firings of their experimental earth oven, significant breakage was present in the feature rock. While using limestone, a dense material relative to the sandstone present in most of the Camp Bowie middens, their data suggest that the total replacement of rock would be necessary before a third firing could occur. Jackson (1998), however, suggests that sandstone, because it is more coarse-grained and porous, is more elastic and therefore more likely to withstand a variety of temperature ranges without significant fracturing. In the absence of experimental data on the sandstone at Camp Bowie, we will simply assume that the use life of sandstone on the order of two firings, though this is probably an underestimate. Assuming, then, that the use life for rock is roughly two firings, almost 
$450 \mathrm{~kg}$ of wood and $250 \mathrm{~kg}$ of rock would be required for a feature such as that described by Dering (1999).

Dering (1999:665) notes that each firing event produced roughly $0.13 \mathrm{~m}^{3}$ of refuse and that 15 firing events of a 1.5 $\mathrm{m}$ diameter, $0.5 \mathrm{~m}$ deep pit would generate roughly $1 \mathrm{~m}^{3}$ of debris if rocks could be used twice. While clearly speculative, these data can be used to provide a guess as to both the number of use events and the amount of wood and rock required for a given midden. For example, based on our limited testing, the large midden ( $12 \mathrm{~m} \mathrm{x} 10 \mathrm{~m} \times 1.45$ m) on site 41BR492 has an estimated volume of $74.6 \mathrm{~m}^{3}$ of debris within the discard (ring) area of the feature. Using Dering's estimate of debris generation, this volume may represent as many as 1,120 separate firings.

This number of firings seems somewhat excessive, especially in light of other estimates of use events for burned rock middens. For example, using estimates based on rock weight for a given feature use event, and assuming that rocks could be used four times, Black (1997:265-266) notes that as many as 320 separate firings may be present at the Honey Creek (41MS32) burned rock midden. Assuming a use life of two firing events per rock, as we have done above for our 41BR492 example, then 160 firing events are represented at the Honey Creek midden. Note, however, that the Honey Creek midden was relatively small, with a total volume estimated at $38.5 \mathrm{~m}^{3}$. At middens on Camp Bowie, our data suggests that the ring (discard) area usually represented about 80 percent of the total feature volume. Assuming a similar ratio at Honey Creek, then roughly $31 \mathrm{~m}^{3}$ of discard material is in the ring area. Using Dering's debris generation figure, it would have taken about 465 events to produce this midden, roughly 2.9 times as many firings as Black estimates.

We suspect that the features represented on Camp Bowie were bigger than the $1.5-\mathrm{m}$ features constructed by Dering, and thus would generate more debris per firing than his estimates. Given this observation, as well as the differences in the Honey Creek estimates noted above, we conservatively assume that our use of Dering's estimates consistently produce a higher number of firings by a factor of 2.9, a figure seen at Honey Creek. Even using this lower estimate, roughly 386 firings would be required to produce the $74.6 \mathrm{~m}^{3}$ of debris in the ring at the midden on 41BR492. This number of firings would require roughly $86,500 \mathrm{~kg}$ of wood over the life of the feature (386 events x $224 \mathrm{~kg}$ ). Using estimates on dry oak, for which a cubic foot of wood weighs roughly $20 \mathrm{~kg}$ (Camm 1958:64), this is roughly 33.8 cords of oak. This amount of wood can be represented as a 10-x-10-foot solid block of oak, rising 43.25 feet in the air. That is a lot of wood. No small amount of rock would be involved, either. Three hundred and eighty-six firing events would require the acquisition of roughly $48,250 \mathrm{~kg}(106,150$ lbs.) of rock ([386 events x $250 \mathrm{~kg}$ rock]/ 2 uses per rock).

In addition to wood and rock, packing material, as well as the food plants, would be required. While the quantity and type of packing material was probably related to what was being cooked, and while we could find no estimates for how much insulating material would commonly be used, 386 events would certainly require a significant amount of vegetation, as well as a significant amount of food. Thoms (1989) suggests, referencing ethnographic accounts, that several hundred kilograms of camas were processed at one time in large earth oven features. Dering (1999) was able to process 25 to 30 sotol and agave hearts in his experimental ovens. Based on the size of camas bulbs, we would guess that about 5,000 bulbs (ca. $25 \mathrm{~kg}$ ) might be a reasonable estimate for geophytes in a similar sized feature. If this guess is even in the ballpark, and if bulbs were the principal food resource processed in the midden at 41BR492, almost two million bulbs would have been processed. Even when we recall that this particular midden was occupied at varying levels of intensity for over 1,000 years, these figures are impressive.

The above speculation clearly suggests that the distribution of wood and rock, along with insulating material and the food resource itself, should be critical components in determining earth oven placement and patterns of use. These suggestions are supported by ethnographic sources. Citing a variety of studies, Thoms (1989:254) notes that processing camas "at or near the procurement site... was practical only to the extent that... fuel, rocks, and packing materials... could be locally found." He further cites examples of dense camas fields not being collected because of a lack of available wood for processing (Thoms 1989:254).

The cases described by Thoms (1989) involve the processing of large quantities of camas. Under those conditions, where processing of up to $700 \mathrm{~kg}$ of camas, probably well in excess of 100,000 bulbs, may occur in a single firing event, movement of raw bulbs to areas with high densities of wood and rock may not be a viable strategy, especially if locations existed where bulbs, wood, and rock co-occurred. We suspect that with smaller quantities of processing, and in environments with more patchy distributions of wood, bulbs would likely be transported to locations with supplies of wood and rock. While the distribution and density of wood 
within the current study area is not well documented, and while that distribution and density has certainly been completely altered by recent land management practices, it is unlikely that wood was ubiquitous across the environment. We may expect that higher densities of wood are associated with drainages, as well as the base of slopes and similar locations with deeper soils and higher runoffs. Rock exposure is also likely to be high in these same two settings. Assuming that foods are moved to these locations, we should expect middens to be located in these settings. However, as demonstrated in the previous chapter, sites with middens show no significant association with drainages when compared to prehistoric sites without middens. Both groups are, on average, a little over $200 \mathrm{~m}$ away from drainages.

We lack data on the distribution of rock that would allow a similar assessment; however, we can compare the distribution of burned rock midden sites with all other prehistoric sites relative to the geological units presented in Chapter 2 (see Barnes 1976). Table 11-1 presents the results of a chi-square test considering these associations. Note that site 41BR380, a burned rock midden site that was not part of this testing effort and could not be relocated, was not included in this table. As documented in that table, there is a strong, significant association between these geological units and the distribution of burned rock midden sites. Fourteen of 16 midden sites $(87.5 \%)$ are located in the Strawn Group, a Pennsylvanian age deposit dominated by sandstone, shale, conglomerate, and limestone. The Strawn Group also has several sandstone outcrops noted as present. Conversely, only 30 percent of the 139 non-midden prehistoric sites are in this unit. The adjusted residual value of 4.5 for the burned rock midden site and Strawn Group cell suggests that this particular association is significant (see Everitt 1977; Haberman 1973 for discussion of adjusted residuals). While this association, as such, does not necessarily mean that rock was a major factor in the location of these features, it does suggest that some component of that unit is probably relevant to the placement of these sites. Interestingly, one of the two sites not in the Strawn Group setting, 41BR474, is located next to Lewis Creek. The remaining site, 41BR228, is also in a setting with exposed sandstone. In fact, our field observations suggest that all of the burned rock midden sites tested have access to rock, with most being located along the base of ridges with exposed sandstone.

Table 11-1. Chi-Square Cross-tab with Adjusted Residual Values for Sites by Geological Formation

\begin{tabular}{|c|c|c|c|c|}
\hline \multirow[b]{2}{*}{ Geological Unit } & & \multicolumn{2}{|c|}{ Site Type } & \multirow[b]{2}{*}{ Totals } \\
\hline & & BRM Sites & Other Sites & \\
\hline Strawn & Observed & 14 & 42 & 56 \\
\hline Group & Adjusted Residual & 4.5 & -4.5 & \\
\hline Holocene & Observed & 1 & 4 & 5 \\
\hline Alluvium & Adjusted Residual & 0.7 & -0.7 & \\
\hline Undivided & Observed & 1 & 71 & 72 \\
\hline Surficial Deposits & Adjusted Residual & -3.4 & 3.4 & \\
\hline Twin Peak & Observed & 0 & 22 & 22 \\
\hline Formation & Adjusted Residual & -1.7 & 1.7 & \\
\hline & Totals & 16 & 139 & 155 \\
\hline
\end{tabular}

Chi-Square $=22.278$

$\mathrm{df}=3$

$\mathrm{P}$ value $<0.001$ 


\section{Exploring the Implications of Wood Use Demands}

Middens, then, at least within Camp Bowie, seem to be positioned primarily with respect to rock availability rather than wood availability, even though wood accounts for a higher weight when multiple feature events are considered. This may be related to the observation that costs associated with rock and wood procurement should behave very differently over time. With increasing frequencies of midden use, costs associated with wood procurement should increase dramatically as wood in the immediate area is exhausted. Conversely, while costs associated with securing appropriately sized rocks may increase slightly over time as larger rocks become less common, rock is unlikely to see the significant increase in cost that can be anticipated in wood procurement. The rate of increase over time is likely to be significantly greater for wood.

The potential increase in costs associated with wood procurement can be seen in Figure 11-1. These data provide an example of the impact of even small-scale wood collection events on the overall cost of collection. The figure is derived from a series of experiments related to wood collection conducted in the northern Chihuahuan Desert (see Mauldin 1995). A single individual collected identical volumes, representing roughly $12.5 \mathrm{~kg}$, of dead wood. All collection events were initiated from the same point on the landscape. Note that while the time required for a given collection initially decreased, after the third collection event, collection time begins to rapidly increase. The last collection event (\#6) required over 22 minutes of searching. After that event, the individual involved was not predisposed to continue the experiment, despite repeated requests.

The Chihuahuan Desert, unlike much of Central Texas, is certainly an environment where wood is not plentiful. However, note that the amount of wood collected per event (ca. $12.5 \mathrm{~kg}$ ) was minimal when compared to that probably required for the firing of a burned rock midden (ca. 245 $\mathrm{kg}$ ). If this same sort of exponential growth in costs associated with wood collection in the Chihuahuan case is applicable to wood collection for burned rock middens, over time, collecting wood in almost any Central Texas environment, regardless of the initial wood densities and rate of wood rejuvenation, should result in significant increases in collection costs. Given the amount of wood involved in burned rock midden use, wood collection costs are probably always going to increase exponentially regardless of the initial location. The decision to locate burned rock middens with respect to rock resources, rather than wood resources, in spite of the fact the weight of wood used will be greater, may be understandable from this longer-term perspective. The temporary or long-term abandonment of midden locations may, in turn, be conditioned by the inevitable excessive costs associated with fuel wood procurement.

Based on this speculation, Figure 11-2 presents a possible scenario for costs associated with collecting rock and wood over time under conditions of three different wood densities. We expect, then, that wood density should have an impact on the frequency of reuse. Reuse of a particular midden would be a function, in part, of the initial wood density and the rate at which fuel resources are regenerated. We expect that environments with higher rainfall and deeper soils will have both higher fuel wood densities, as well as quicker regeneration rates, relative to environments with lower rainfall and shallower soils. We expect that, other things being equal, reuse of burned rock middens in areas of low wood density and low rates of rejuvenation of wood should occur at a low frequency as a function of rapidly increasing costs of wood acquisition. Conversely, in areas of high wood density, areas that should have higher rates of wood rejuvenation, reuse of burned rock middens should be more frequent. Of course, other things are not equal. Factors that should impact reuse rates beyond simple wood density minimally include differences and changes in regional population densities, different demands for resources, different patterns of mobility, changes in the structure of competing resources, and differential densities of available food resources processed in middens. All of these factors are impossible to monitor with any degree of confidence. For the sake of this exploration, then, we will proceed as if wood density was the only variable of interest, but we realize that is it only one of several critical variables. Given this simplifying assumption, middens in low fuel wood areas should be smaller in overall volume. Middens in areas of denser fuel wood should, on average, be larger in size as a result of greater numbers of uses.

Figure 11-3 is a vegetation map that attempts to monitor the distribution of wood across a portion of the state. We generated the figure by combining various vegetation categories on the Vegetation Types of Texas map (TPW 1984). Areas in orange represent locations dominated by grasslands. Yellow areas are dominated by creosote bush, with tarbush, mesquite shrubs, ocotillo, yucca, lechuguilla, and saltbush. Dark green areas are primarily mesquitedominated settings, with plants such as salt cedar brush, 


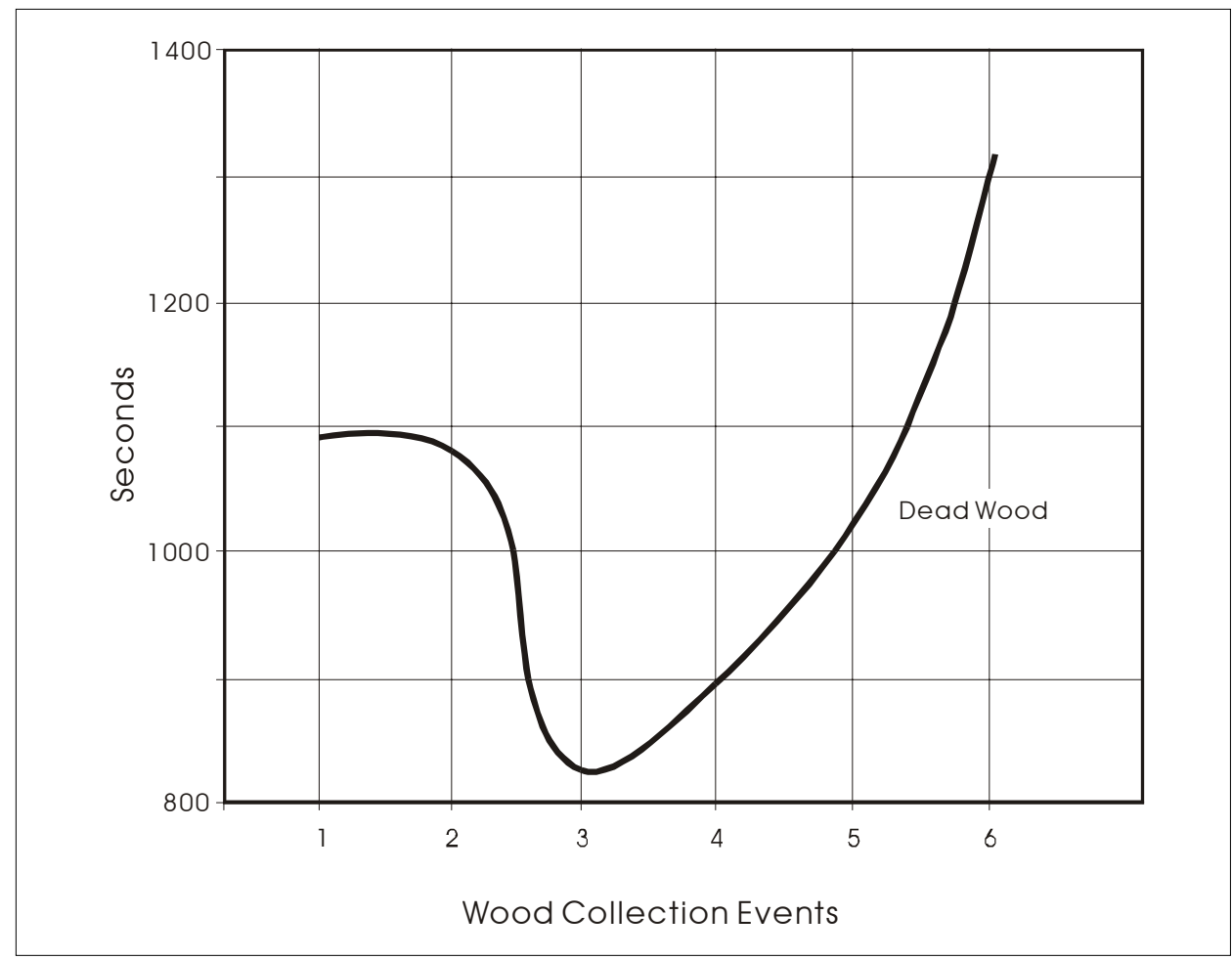

Figure 11-1. Wood collection rates for multiple events in the Chihuahuan Desert.

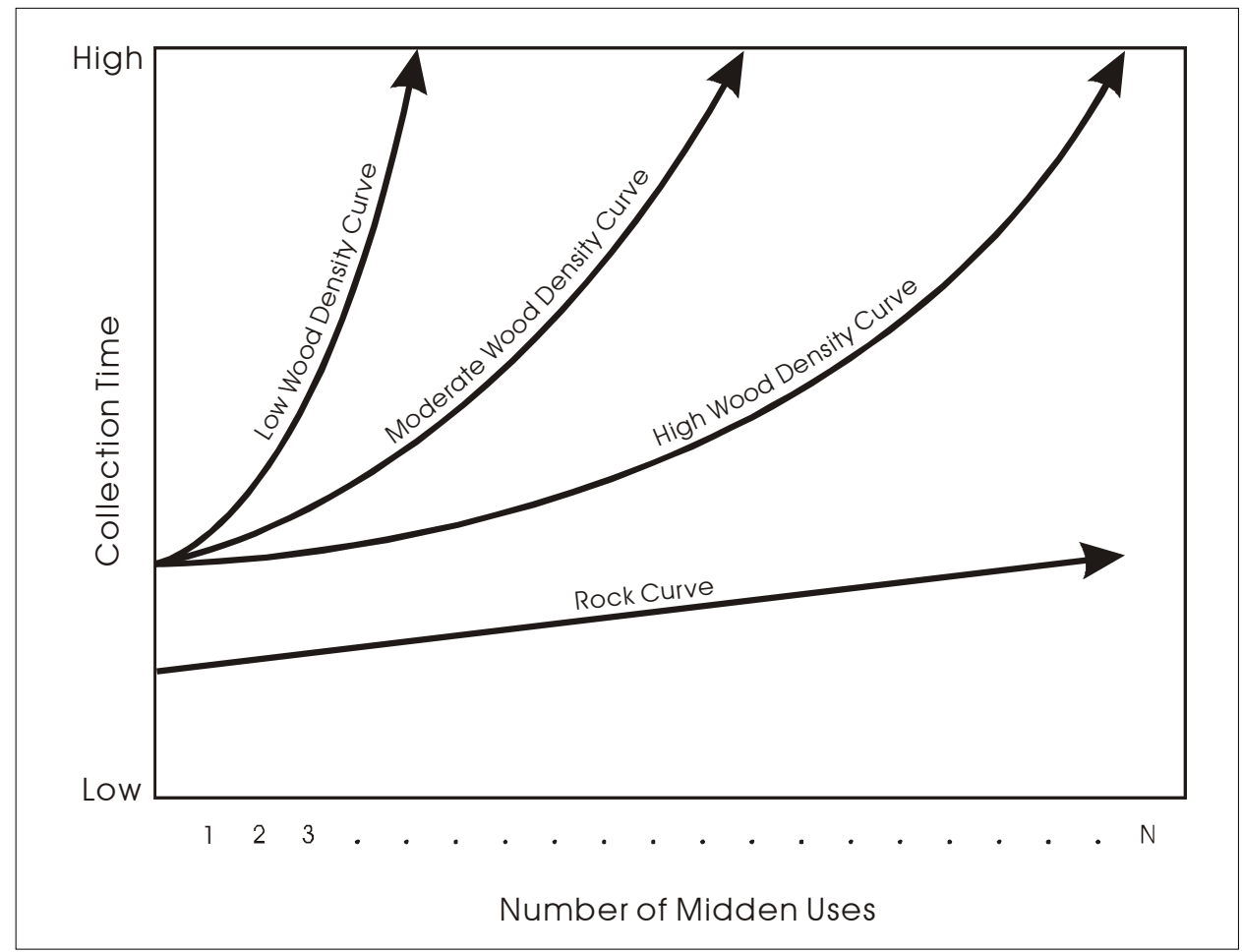

Figure 11-2. Possible collection cost curves for rock and wood in three different wood densities. 


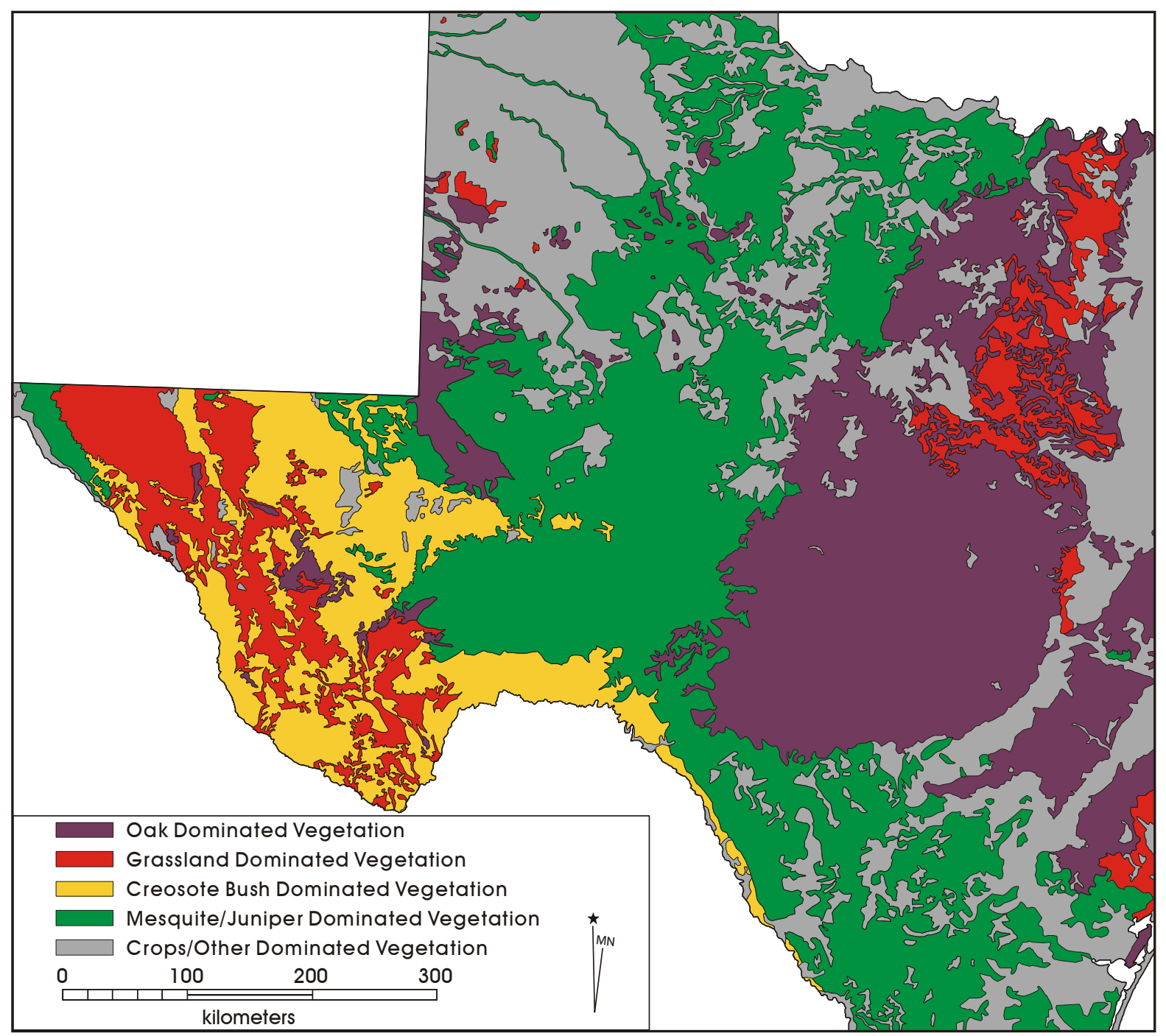

Figure 11-3. Vegetation map monitoring wood availability for central and west Texas.

hackberry brush, juniper, and sand sage present. Finally, settings dominated by oak are depicted in purple. The map is, of course, a simplification of the modern distribution of vegetation types. That distribution is not an accurate reflection of prehistoric patterns, having been dramatically altered by both climate change and, more importantly, radical changes in land use practices. Nevertheless, the map provides some indication of large-scale environmental differences in wood. While quantitative data on wood density and regeneration rates are not available for these various areas, we suggest that each of these areas should have different wood densities as well as regeneration rates. In turn, this should result in different patterns of midden reuse.

\section{Midden Size Characteristics}

We lack data on midden volumes that would allow a direct comparison between wood density and midden size. As an initial consideration of the suggestion that midden reuse should be higher in areas that have high densities of wood, and that reoccupation should result in larger middens, we compare the height of middens above ground surface and the maximum dimension of middens for two counties, Brown County and Culberson County. Reference to Figure 11-3 will show that Brown County is located within the higher wood density areas (purple) of the figure. Grassland and creosote bush vegetation types dominate Culberson County, 
located in far west Texas. We expect, then, that relative to Brown, Culberson has little wood and low rates of wood regeneration. Middens, then, should be larger in Brown County relative to Culberson County as a function of higher frequencies of reoccupation.

Data were gathered from the Texas Archeological Sites Atlas. All cases with data on middens within these two counties were reviewed to record both midden height and diameter. Figure 11-4 presents box plots comparing midden heights for 27 middens in Brown County with 38 cases in Culberson County. While the differences are not extreme, and while a significant portion of the boxes overlap, Brown County middens, as a group, are slightly taller than middens in Culberson County. The Brown County middens are, on average, $92.9 \mathrm{~cm}$ above the ground, while Culberson County middens are $82.2 \mathrm{~cm}$. By itself, this difference is probably not statistically significant.
Figure 11-5 compares our other proxy measure, midden diameter, for these two counties. The patterns in these box plots clearly are significantly different. Middens in Brown County $(n=37)$ are substantially larger in diameter relative to those in Culberson County $(\mathrm{n}=40)$. Mean diameter for Culberson County burned rock middens is $7.14 \mathrm{~m}$. In contrast, the mean diameter for Brown County middens is $11.92 \mathrm{~m}$. More telling is the fact that of those middens with recorded diameters, 75 percent of those from Brown County are greater than or equal to $10 \mathrm{~m}$ in diameter, and over 75 percent of the middens in Culberson County are less than $10 \mathrm{~m}$ in diameter. When combined with the relatively minimal differences in midden height noted above (Figure 11-4), these data clearly suggest that Brown County middens are larger in overall volume. While more comparisons are certainly warranted, including consideration of other factors such as the distribution of water, packing material, rock, and food resources, these initial comparisons are consistent with our model of the impact of fuel wood resources and regeneration rates as a factor in midden reuse.

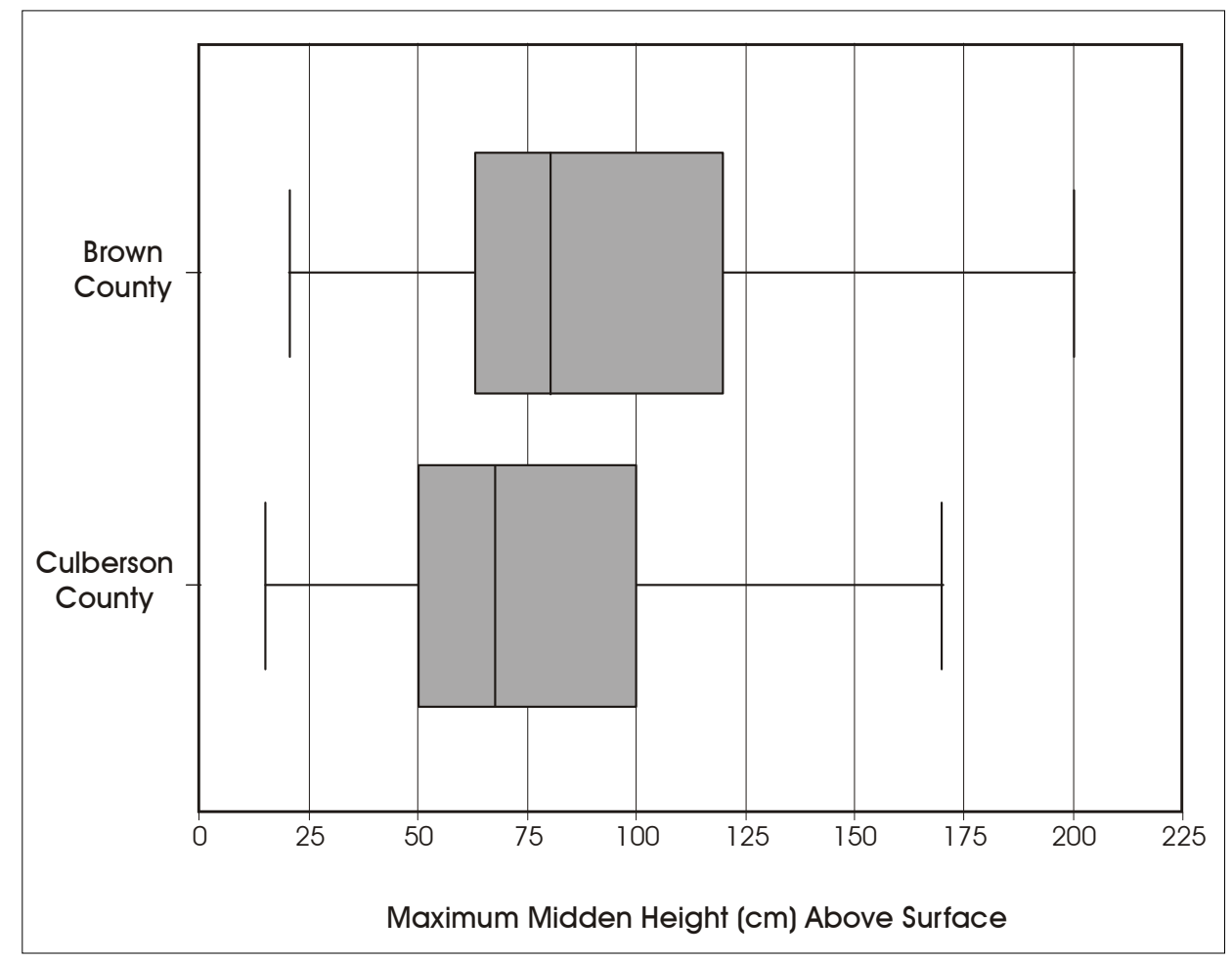

Figure 11-4. Box plots comparing midden heights for 27 middens in Brown County and 38 middens in Culberson County. 


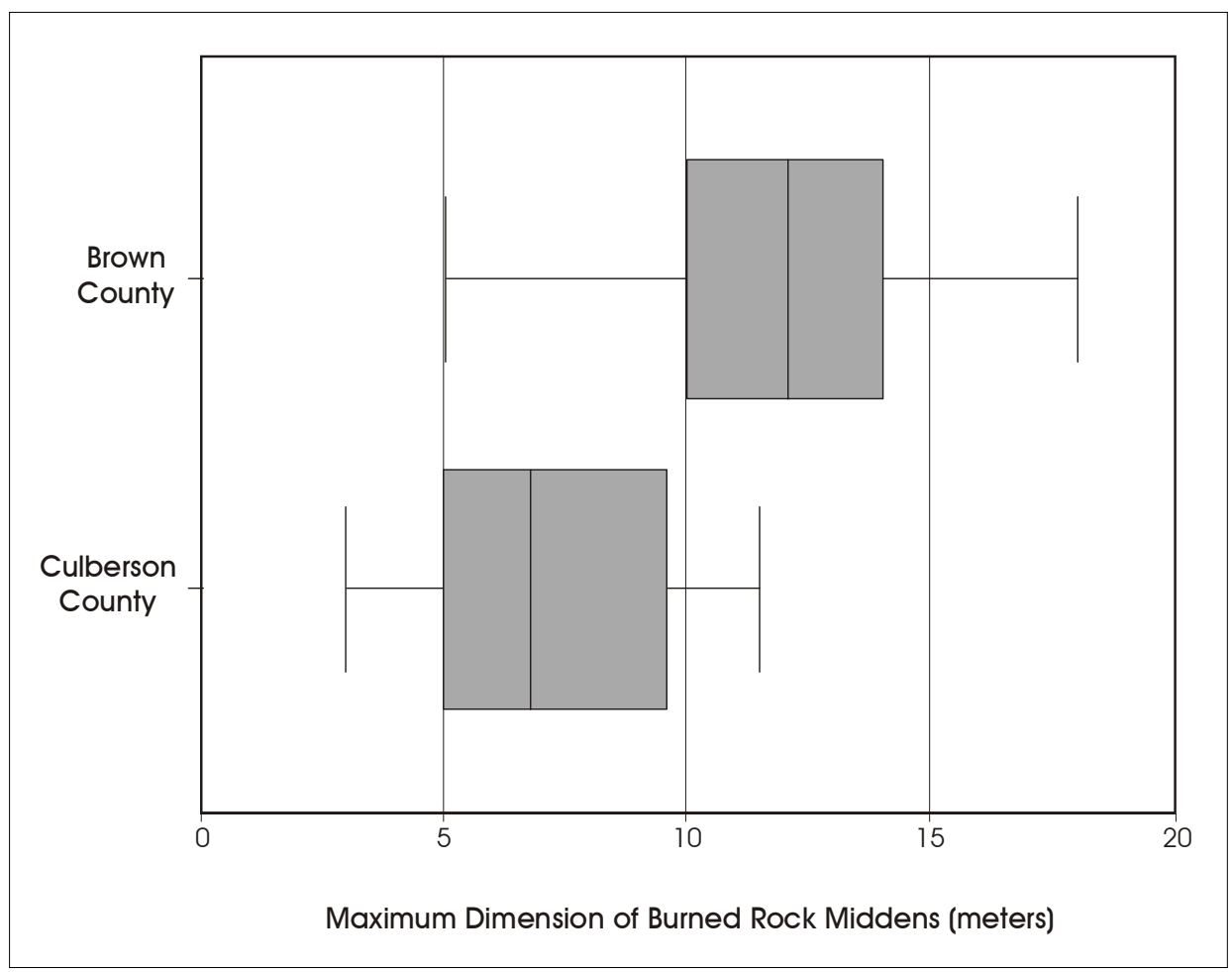

Figure 11-5. Box plots comparing midden diameter for 37 middens in Brown County with 40 middens in Culberson County.

\section{Burned Rock Midden Distributions in Texas}

Establishing the importance of wood in burned rock middens, especially in light of the distributional patterns of different wood environments shown in Figure 11-3, has additional implications for understanding aspects of these features. Following suggestions of earlier researchers (e.g., Black and McGraw 1985; Gunn and Mahula 1977:279; see also Turner 1989), Creel (1986) has argued that acorns were a principal food resource processed in burned rock middens. As support for this proposition, Creel $(1986,1994)$ demonstrates a significant relationship between the modern distributions of oak savanna/woodlands and burned rock middens. In his most recent consideration of this argument, Creel (1997) compares the distribution of middens in an 18 county area for central Texas with the distribution of oak and sotol. Using the percentage of burned rock midden sites within a county, Creel marshals a convincing argument that 1) oak is closely associated with the distribution of burned rock midden sites in his study area, 2) the distribution of sotol lacks the strong correlation with burned rock midden sites seen for oak, and 3) counties where both oak and sotol occurred seem to have higher occurrences of burned rock midden sites. Using these associations, as well as a variety of secondary considerations, Creel concludes that acorns are likely to be a primary food resource processed in burned rock middens, with some level of sotol processing also probably occurring in those counties with high midden densities (Creel 1997:93-97).

Our discussion presented in the previous sections suggests the possibility that the strong correlation between burned rock middens and oak is related to the need for abundant fuel wood rather than the need for acorns, a possibility acknowledged by Creel (1997:94). Inspired by Creel's innovative distributional study, we undertook a similar, though slightly more ambitious, version of his approach. Table 11-2 presents data on the percentage of burned rock midden sites for 70 counties across Texas. For 58 of these 70 counties, the data were gathered from the Texas Archeological Sites Atlas between 2000 and 2002. The remaining 12 counties were taken from the distributional study reported by Creel (1997). For the current distributional study, we initially selected a series of counties located throughout the state. We added counties, working out from 
Table 11-2. County Level Burned Rock Midden Data

\begin{tabular}{|c|c|c|c|c|c|c|c|}
\hline County & Sites & Incomplete & Good & BRM & Percent & Source & Notes \\
\hline Bandera & & & 147 & 56 & 0.38 & Creel 1997 & \\
\hline Bexar & & & & & 0.07 & Creel 1997 & \\
\hline Bosque & 93 & 10 & 83 & 1 & 0.01 & This Study & $33 \%$ Random Sample \\
\hline Brewster & 1367 & 176 & 1191 & 74 & 0.06 & This Study & \\
\hline Brooks & 45 & 28 & 17 & 0 & 0.00 & This Study & Small Sample of Sites \\
\hline Brown & 494 & 91 & 403 & 85 & 0.21 & This Study & \\
\hline Burnet & 105 & 18 & 87 & 12 & 0.14 & This Study & $31 \%$ Random Sample \\
\hline Caldwell & 80 & 14 & 66 & 1 & 0.02 & This Study & \\
\hline Callahan & 43 & 27 & 16 & 4 & 0.25 & This Study & Small Sample of Sites \\
\hline Coke & & & & & 0.05 & Creel 1997 & \\
\hline Coleman & 271 & 30 & 241 & 47 & 0.20 & This Study & \\
\hline Comanche & 80 & 2 & 78 & 3 & 0.04 & This Study & \\
\hline Concho & 296 & 24 & 272 & 39 & 0.14 & This Study & \\
\hline Crane & 27 & 5 & 22 & 0 & 0.00 & This Study & Small Sample of Sites \\
\hline Crockett & 300 & 85 & 215 & 93 & 0.43 & This Study & $33 \%$ Random Sample \\
\hline Culberson & 591 & 18 & 573 & 132 & 0.23 & This Study & \\
\hline Dallas & 379 & 102 & 277 & 0 & 0.00 & This Study & \\
\hline Edwards & . & & 122 & 62 & 0.51 & Creel 1997 & \\
\hline Erath & 35 & 8 & 27 & 2 & 0.07 & This Study & Small Sample of Sites \\
\hline Fort Bend & 262 & 51 & 211 & 0 & 0.00 & This Study & \\
\hline Gaines & 57 & 4 & 53 & 0 & 0.00 & This Study & \\
\hline Gillespie & & & 274 & 31 & 0.11 & Creel 1997 & \\
\hline Hamilton & 43 & 10 & 33 & 6 & 0.18 & This Study & Small Sample of Sites \\
\hline Harrison & 806 & 197 & 609 & 0 & 0.00 & This Study & \\
\hline Hays & & & & . & 0.23 & Creel 1997 & \\
\hline Jackson & 186 & 14 & 172 & 0 & 0.00 & This Study & \\
\hline Jeff Davis & 173 & 9 & 164 & 23 & 0.14 & This Study & \\
\hline Johnson & 48 & 27 & 21 & 1 & 0.05 & This Study & \\
\hline Jones & 101 & 51 & 50 & 3 & 0.06 & This Study & \\
\hline Karnes & 113 & 18 & 95 & 0 & 0.00 & This Study & \\
\hline Kendall & & & & & 0.23 & Creel 1997 & \\
\hline Kent & 163 & 13 & 150 & 0 & 0.00 & This Study & \\
\hline Kerr & & & 470 & 193 & 0.41 & Creel 1997 & \\
\hline Kimble & & & 118 & 21 & 0.18 & Creel 1997 & \\
\hline Kinney & 135 & 90 & 45 & 15 & 0.33 & This Study & Small Sample of Sites \\
\hline Lampasas & 40 & 11 & 29 & 6 & 0.21 & This Study & Small Sample of Sites \\
\hline Leon & 397 & 82 & 315 & 0 & 0.00 & This Study & \\
\hline Live Oak & 298 & 59 & 239 & 0 & 0.00 & This Study & \\
\hline Llano & 417 & 54 & 363 & 7 & 0.02 & This Study & \\
\hline Mason & 65 & 40 & 25 & 7 & 0.28 & This Study & Small Sample of Sites \\
\hline McCulloch & 41 & 10 & 31 & 12 & 0.39 & This Study & Small Sample of Sites \\
\hline McLennan & 251 & 57 & 194 & 2 & 0.01 & This Study & \\
\hline Medina & & & 69 & 4 & 0.06 & Creel 1997 & \\
\hline Menard & 26 & 18 & 8 & 1 & 0.13 & This Study & Small Sample of Sites \\
\hline
\end{tabular}


Table 11-2. continued...

\begin{tabular}{|l|c|c|c|c|c|l|l|}
\hline \multicolumn{1}{|c|}{ County } & Sites & Incomplete & Good & BRM & Percent & Source & \multicolumn{1}{|c|}{ Notes } \\
\hline Midland & 38 & 6 & 32 & 1 & 0.03 & This Study & Small Sample of Sites \\
\hline Milam & 113 & 39 & 74 & 0 & 0.00 & This Study & 30\% Random Sample \\
\hline Mills & 96 & 36 & 60 & 16 & 0.27 & This Study & \\
\hline Mitchell & 80 & 7 & 73 & 2 & 0.03 & This Study & \\
\hline Moore & 189 & 30 & 159 & 0 & 0.00 & This Study & \\
\hline Pecos & 168 & 26 & 142 & 55 & 0.39 & This Study & 31\% Random Sample \\
\hline Real & 74 & 10 & 64 & 36 & 0.56 & This Study & \\
\hline Reagan & 70 & 10 & 60 & 2 & 0.03 & This Study & \\
\hline Reeves & 42 & 8 & 34 & 2 & 0.06 & This Study & Small Sample of Sites \\
\hline Runnels & 202 & 11 & 191 & 23 & 0.12 & This Study & \\
\hline San Saba & 159 & 43 & 116 & 27 & 0.23 & This Study & \\
\hline Shackelford & 73 & 3 & 70 & 1 & 0.01 & This Study & \\
\hline Schleicher & & & &. & 0.35 & Creel 1997 & \\
\hline Sutton & 67 & 25 & 42 & 21 & 0.50 & This Study & Small Sample of Sites \\
\hline Throckmorton & 28 & 3 & 25 & 0 & 0.00 & This Study & Small Sample of Sites \\
\hline Tom Green & 540 & 87 & 453 & 39 & 0.09 & This Study & \\
\hline Tyler & 63 & 11 & 52 & 0 & 0.00 & This Study & \\
\hline Upton & 21 & 3 & 18 & 1 & 0.06 & This Study & Small Sample of Sites \\
\hline Uvalde &. & & 320 & 146 & 0.46 & Creel 1997 & \\
\hline Ward & 75 & 13 & 62 & 1 & 0.02 & This Study & \\
\hline Washington & 68 & 14 & 54 & 0 & 0.00 & This Study & \\
\hline Webb & 487 & 277 & 210 & 0 & 0.00 & This Study & \\
\hline Williams & 863 & 315 & 548 & 121 & 0.22 & This Study & \\
\hline Wilson & 110 & 10 & 100 & 2 & 0.02 & This Study & \\
\hline Wise & 47 & 15 & 32 & 0 & 0.00 & This Study & Small Sample of Sites \\
\hline Zavala & 409 & 104 & 305 & 0 & 0.00 & This Study & \\
\hline
\end{tabular}

Brown County, in order to document the overall, state level distribution. Figure 11-6 highlights those counties considered in the distributional study. We only used counties with a minimum of 20 sites recorded. As can be seen in the table, most counties had well over 50 sites recorded, with an average of just over 205 sites per county.

Anyone who has attempted to use the Texas Sites Atlas database is painfully aware that the data are frequently inadequate. We reviewed 11,910 sites in the Atlas. Of these, 2,559 sites (21.5\%) were eliminated from consideration. These sites either lacked forms, had "corrupt field" warnings posted, or were simply not detailed enough to allow us to determine if a burned rock midden was present. Finally, note that for five counties identified in Table 11-2, we employed a random number generator to select a sample of ca. 30 percent of the available sites in the database, using the number of recorded sites as the population. This was undertaken as the number of sites recorded were simply too numerous to count given temporal and budgetary considerations. In all five cases, the number of recorded sites exceeded 270 sites, and a minimum of 90 site forms were reviewed.

The percentage figures listed in Table 11-2 are not equivalent to the number of burned rock middens within a county, let alone the density of middens. The same density of middens within two different counties could, using the percentage measures, produce radically different percentage values simply as a function of differing numbers of recorded sites. Only in a situation where complete survey coverage of all counties existed would the number of sites with burned rock middens be reflected directly in the percentage data, and even in those cases the number of middens and midden 
density would still be unknown. Nevertheless, the percentage data is the best available approximation of the relative intensity of midden use.

Using the center of a given county as a plotting point, Figure 11-7 presents a density map of the percentage of burned rock middens across the state. Note that of the 96 counties covered by the distribution, we lack data for 40 cases. That is, these county percentages are interpolated based on surrounding counties. The boundaries of the distribution in the figure are well-defined based on a series of counties with no reported burned rock middens as well as a series of counties with percentages below 10 (see Figure 11-6; Table 11-2). The overall distribution depicted in Figure 11-7, then, probably is an accurate reflection of where middens are, and are not, present across the state.

Examination of Figure 11-7 suggests that the distribution of burned rock middens within the state is tightly confined. Middens were not reported for counties examined in much of south Texas. Middens are lacking in east and north Texas. Nor are they present in the Panhandle area. Middens appear

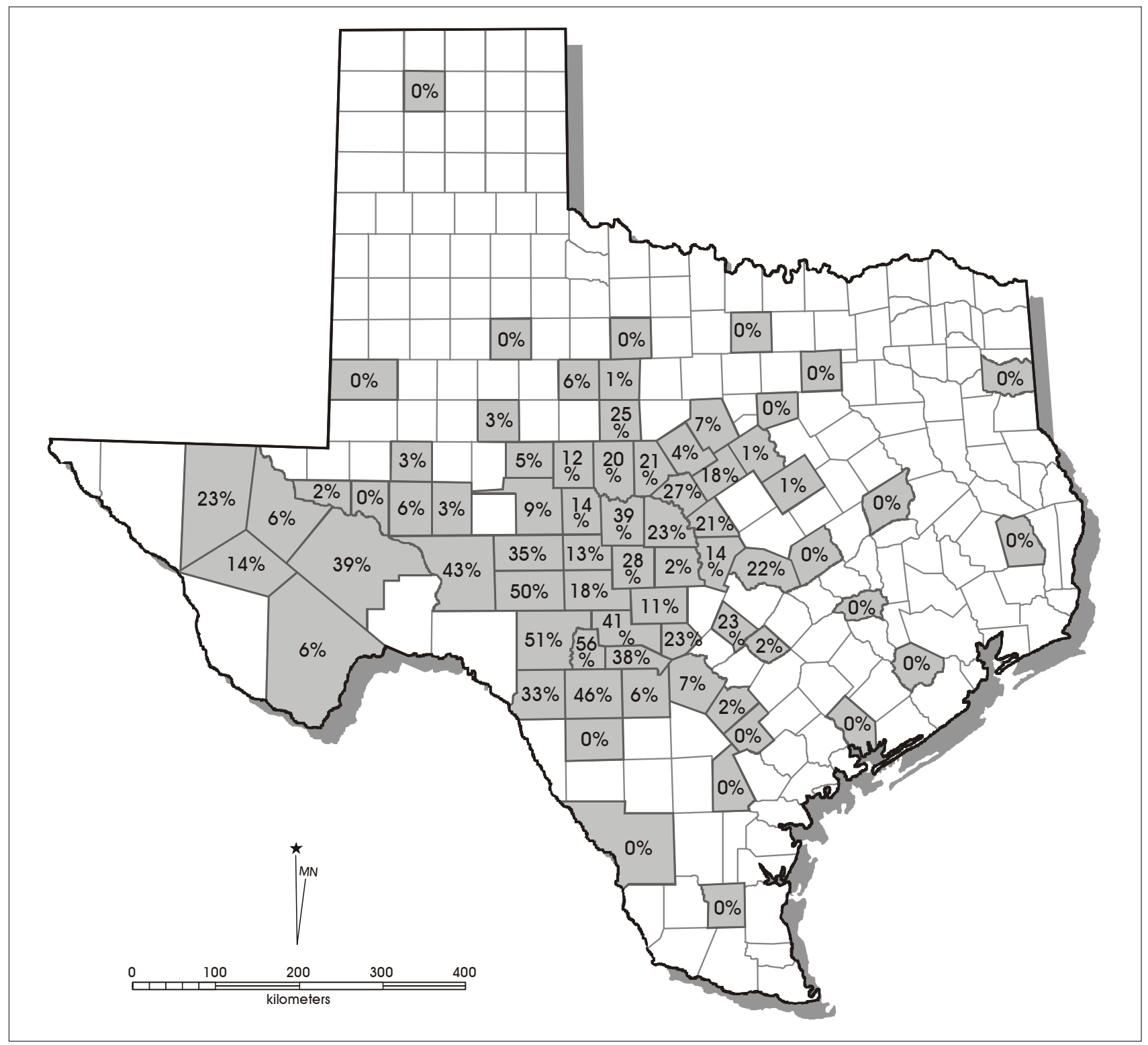

Figure 11-6. Counties used in distributional study, with percentages of burned rock middens identified. 


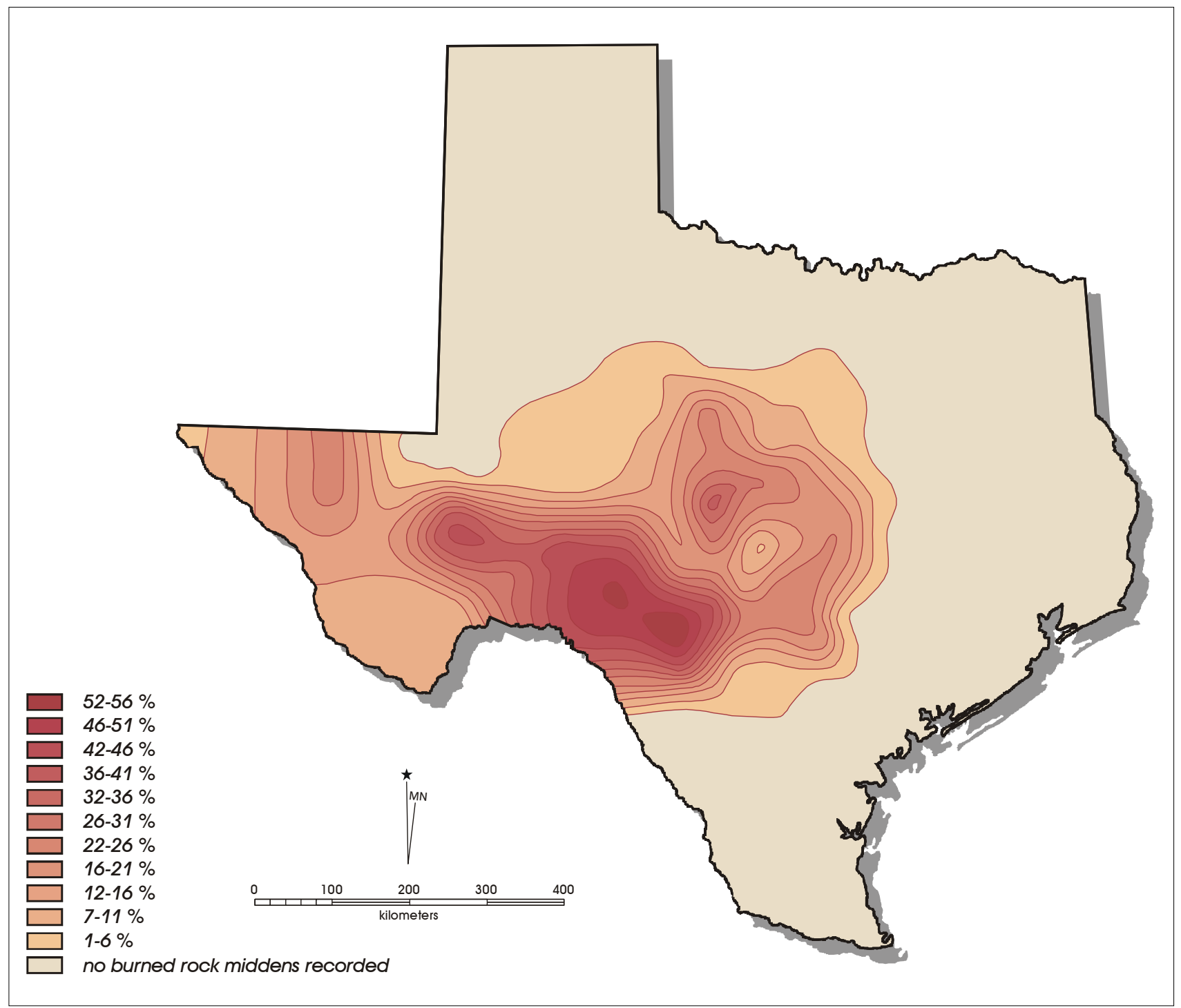

Figure 11-7. Density map of the percentage of burned rock middens across Texas.

to be concentrated primarily on the Edwards Plateau and in west Texas. Comparisons of Figure 11-7 with the wood distribution map (Figure 11-3) supports aspects of Creel's $(1986,1994,1997)$ original association between burned rock middens and oak distributions. This is especially the case on the Edwards Plateau. In addition, it could be argued that a slightly expanded prehistoric distribution of oak-dominated settings, to the southwest and to the west, could accommodate as much as half of the overall distribution of burned rock middens. Nevertheless, even if we equate oak presence with acorn processing, it is unlikely that oak ever dominated the entire distribution of burned rock middens shown in Figure 11-7. The distribution to the west and southwest of the Edwards Plateau is clearly not associated with oak, and by extension clearly not associated with acorn processing. Following the suggestion by Goode (1994; see also Creel 1997; Dering 1999), sotol and lechuguilla are the most likely candidates for processing in burned rock middens in the southern section of the Plateau, as well as to the west. Sotol and lechuguilla are present in these settings. A variety of ethnographic accounts (e.g., Basehart 1973; Buskirk 1949; Castetter et al. 1938; Castetter and Opler 1936; Pennington 1963; Spier 1933) document the use of these plants, processed in earth ovens, throughout New 
Mexico, Northern Mexico, Arizona, and into California. In addition, several archaeological reports from far west Texas (e.g., Hinds et al. 1994) document the recovery of burned agaves from earth ovens.

Figure 11-7 also identifies several isolated "hot spots." The percentage data show high values in the southwestern portion of the distribution, centered on Real, Edwards, Val Verde, and Crockett counties. This appears to be the same pattern previously identified by Creel (1997). As we lack data from Terrell County, this same distribution may continue to the west, into Pecos County. That distribution does appear to be distinct, however, from one in Culberson County, as we have data from Jeff Davis, as well as Brewster, Reeves, Ward, and Loving counties that suggest a distinct break. Finally, a third hot spot is centered in the northern portion of the distribution. Included in that distribution are the counties of McCulloch, San Saba, Mills, Brown, Coleman, and Callahan. That distribution appears to be distinct from the southwestern distribution, being separated by a series of counties with lower values, including Coke, Tom Green, Menard, Mason, and Llano. This northern distribution is equivalent to one identified previously by Creel (1997).

While the northern distribution may reflect acorn processing as Creel (1997) suggests, that distribution is also consistent with the southern end of the distribution of geophytes presented previously in Figure 9-5. Unlike acorns and oak, geophytes have no possibility of being used as a fuel resource. These resources clearly were being used in the Camp Bowie middens in Brown County, and as summarized by Dering (Appendix C), are increasingly common in other middens within central Texas. We cannot rule out acorns as a significant food resource processed in burned rock middens; however, the documentation that a substantial amount of wood is necessary for processing food in middens, combined with the fact that oak is the major wood identified in central Texas burned rock middens (see Appendix C; Dering 1997), suggests that the recovery of burned acorns from some middens may simply represent incidental burning associated with the use of oak as a fuel wood.

If geophytes, rather than acorns, were the focus of most middens in north-central Texas, why are there no middens to the north? Figure 9-5, presented previously, showed that camas distribution, for example, continues to the north. Other geophytes are certainly also in this northern section of the state. Figure 11-3 shows that oak continues to the north as well. We have food and fuel, why don't we have middens? At present, we have no real answer to that question. We can suggest, however, that if we are correct about geophytes, then the answer probably lies in considering alternative resources. Recall that geophytes are low return resources, potentially used only for a limited time during the early spring. We suspect that resource structure to the north is different, and that higher ranked resource alternatives may have been available that reduced the importance of geophytes. At present, however, we have no suggestions as to what these alternative resources might have been.

As noted earlier, the southwestern distribution in Figure 117 probably reflects the use of Agave lechuguilla and sotol. As we argued with oak, it is unlikely that high densities of geophytes ever were present over the entire range of middens reflected in Figure 11-7. Finally, as noted by Creel (1997), those counties with the highest percentages of burned rock middens seem to be on the border between the areas to the west, probably associated with sotol and agave processing, and the areas to the north. While Creel suggested that these higher percentages might reflect both processing of sotol and acorns, we would suggest that sotol, lechuguilla, and geophytes are a more likely mix.

\section{Summary of Burned Rock Midden Research}

This chapter, along with the previous four chapters, has been primarily concerned with understanding aspects of burned rock middens. This feature type was present on 16 of the 18 sites investigated during this project, and it was on the basis of this feature type that Wormser and Sullo-Prewitt (2001) recommended that these 16 sites be tested. While the subsequent chapter provides recommendations on all 18 tested sites, this section provides a short review of the burned rock midden research.

Chapter 7 presented an argument that burned rock middens within Camp Bowie date primarily between A.D. 700 and A.D. 1450. A consideration of a series of radiocarbon dates from the Camp Bowie middens, combined with a more regional investigation of diagnostic artifacts from burned rock midden sites, supports a Late Prehistoric focus. The Late Prehistoric focus for burned rock middens at Camp Bowie produced by the radiocarbon dates is consistent with a larger sample of dates compiled by Black and Creel (1997) for much of central Texas. These various data sets document that burned rock middens are primarily a Late Prehistoric, rather than a Middle or Late Archaic, phenomena. This is not to argue that earlier middens are not present. Clearly, 
they are. Nor is it to argue that problems such as differential preservation of charcoal from earlier middens may not be biasing the overall pattern. However, our results, especially when combined with the earlier patterns of Black and Creel (1997; see also Treece 1993), suggest that the "veneer hypothesis" is probably not a useful way to "explain" late dates in most middens. In multiple cases on the current project, we were unable to find a significant number of earlier dates even though we consistently attempted to date deep levels within these features. If the Late Prehistoric material is a "veneer" over the "true" Middle or Late Archaic midden deposits, the veneer often accounts for 80 to 90 percent of a midden on Camp Bowie. That is a rather thick veneer. In our initial review of the literature on dates in burned rock middens prior to this project, we came away with the impression that middens were primarily Middle and Late Archaic features. While earlier researchers had certainly identified Late Prehistoric burned rock midden features, the Late Prehistoric was not the principal time period of use. Perhaps it is now time to reverse that impression. While a variety of questions remain regarding where earlier middens occur, as well as what the trajectory of midden use is in differing parts of Texas, these features appear to be primarily Late Prehistoric in age, at least judging from the radiocarbon dates.

In Chapter 8, we used a variety of different data sets to investigate how the Camp Bowie middens were formed. The patterns in count, size, and weight of burned rock in the rings relative to the central areas are probably the most relevant in this regard. These data are consistent with a model of a central thermal feature surrounded by discarded, broken rock. While the results of the investigation of various data sets potentially relevant to documenting the incorporation of sediment as a cap over these features were not as clearcut, the weight of this evidence seems to suggest that these were capped thermal features. At least in the case of the Camp Bowie middens, then, our limited testing suggests that these features represent earth ovens. We found no support for either a model of multiple, intersecting features producing the overall mound, or for the mound representing communal dumps. While it is certainly possible that these activities produced middens in other contexts, this does not appear to be the case at Camp Bowie. Again, this conclusion is essentially the same as that arrived at by Black and Creel (1997), though they arrived there from a different set of arguments. It will be interesting if future research on middens can marshal data that is consistent with either the communal dump or intersecting hearth model of midden formation.
An additional component of Chapter 8 is worth noting in this summary. Using radiocarbon dates, rock size differences, and fluctuating patterns in soil susceptibility values from our best-dated feature, a midden on 41BR492, we demonstrated that while this midden formed in well over 1,000 years, the vast majority of the debris was generated during a relatively short period of time, perhaps within a few hundred years. More critically, these patterns suggest several periods of intensive use, separated by periods of lower use frequency. These patterns may be related to fluctuations in the availability of what was being processed in the middens, fluctuations in availability of wood resources, more general changes in settlement and subsistence, or a combination of these and other factors. This analysis, however, clearly suggests that while middens may be formed over hundreds of years, there are periods of intensive use that are worthy of documentation and investigation in other contexts.

Chapter 9 investigated what food resources were processed in the Camp Bowie middens. The consideration of what was processed within a midden is complicated, especially if some component of what is in a feature is likely to be incorporated as a result of the capping of that feature with sediment. This possibility required that we develop evaluation procedures that identify, to the degree possible, the probability that certain classes of material are, and are not, associated with midden use. We had three broad classes of data that could reflect subsistence in middens - mussel shell, animal bone, and a series of charred geophytes, primarily consisting of bulbs. Comparing midden with non-midden deposits, as well as considering the preservation potential of these various classes of artifacts, we argued that the most likely candidate for reflecting midden use were the carbonized geophytes. Nearly 400 individual bulbs and bulb fragments were recovered from our work at Camp Bowie. With regard to the presence of these geophytes, we were fortunate to have excellent preservation conditions in many of the middens tested. We were also fortunate to have Dr. Philip Dering perform the analysis on these remains. As outlined in Appendix C, Dering was able to identify several of the bulbs as reflecting wild onion, dog's-tooth violet, and Eastern camas. Camas bulbs were the most frequently recognized. A review of geophytes, centered on camas, clearly suggests that geophytes in general, and camas in particular, would have been a viable, though low return, resource. More interestingly, it is probable that this particular bulb was harvested during a fairly short period of time, probably in the spring. 
The degree to which these subsistence patterns seen at Camp Bowie can be generalized to other areas of the state was, to some degree, addressed in the current chapter. Clearly, any notion that, at least within Texas, burned rock middens were only used to process a single resource, be it geophytes, sotol, agave, or acorns, should be dismissed. Nevertheless, we think we can suggest that these features were primarily used to process plants, and more specifically plants with high starch content. While other plants, and even an occasional animal, may have been processed in these features, they were designed for the processing of high starch plants. Interestingly acorns, a long-time favorite answer to the question "what was processed in burned rock middens?" does not fit this high starch profile.

Patterns identified in Chapter 9, especially the possibility that these features were focused on geophytes and that camas, the principal resource, was harvested and processed during a short seasonal window of time, suggest that in the case of Camp Bowie, these features might be classified as "special purpose." Chapter 10 considered aspects of the sites on which these specialized features were present. Specifically, we attempted to investigate whether the sites were "residential" or "special purpose" in nature. While the methodological tools available for considering these types of questions are limited, the site level data within Camp Bowie were more consistent with a specialized use.

Finally, the current chapter used a variety of experimental and ethnographic data on the quantities of rock, wood, and food potentially involved in midden use, along with data on wood collection rates and distributional information on vegetation to begin to refine our understanding of burned rock middens in Texas. We argued that patterns in fuel wood resources are a critical component in understanding patterns of midden reuse. Primarily as a result of excessive costs associated with wood collection over time, we suggest that middens may have been abandoned until the area had a sufficient number of years to rejuvenate. That rejuvenation rate will be different in different environments. In addition, the differential distribution of these fuel wood resources may help to account for the strong association of burned rock middens with oak, an association that has previously been seen as related to the use of acorns. Considering the spatial distribution of the percentage of sites with burned rock middens across the state, we suggested that two different sets of plant food resources (sotol and geophytes), each with different spatial distributions, might be the major food resources processed in middens within the state. 



\title{
Chapter 12:
}

\section{Recommendations}

\author{
Raymond P. Mauldin
}

The previous 11 chapters have presented the results of testing associated with determining eligibility status for 18 prehistoric archaeological sites tested on Camp Bowie in Brown County, Texas. The work was conducted by the Center for Archaeological Research at The University of Texas at San Antonio under contract from the Texas Army National Guard. The field portion of the project was conducted during several different sessions between late 1999 and the summer of 2001. This chapter considers site eligibility for the 18 sites tested on this project. We provide a short review of the salient points of each site, along with recommendations for eligibility to the National Register of Historic Places (NRHP) and designations as State Archeological Landmarks (SAL).

\section{Site Eligibility Recommendations}

As discussed in Chapter 4, site and/or feature integrity is our primary criteria for site eligibility. The main goal of the testing efforts, then, was focused on determining the degree of integrity of the archaeological deposits and features present at each site. A secondary goal of the testing was to investigate the degree to which the archaeological deposits could yield information relevant to understanding the nature of burned rock midden sites and/or various aspects of regional prehistory (i.e., subsistence practices, technological organization, chronological frameworks).

In this chapter we provide a brief summary of each site with specific reference to issues of integrity both at a site and feature level. This consists of summarizing the degree of disturbance on a site, as well as in features at a site, caused by either natural (e.g., erosion/slopewash, rodent disturbance) or cultural (e.g., historic or modern intrusions, road maintenance) processes. We then consider the temporal span reflected in chronometric information (radiocarbon dates, diagnostics), as well as the nature of subsurface deposits. Finally, we consider the recovery, or potential for recovery, of additional chronometric information as well as economic data (i.e., floral and faunal resources). Details on each site can be found in Chapter 6.

\section{BR65}

The integrity of data contained within site 41BR65 appears to be good. While historical material is present, and while some damage to the site has occurred as a result of military activity, the majority of the site appears intact. No areas of extensive erosion were noted. While rodent activity was noted in the midden during excavation, and while worms have impacted the midden sediment, the disturbance appears to be minimal. Our work at this site revealed buried deposits, with moderate density and variety of chipped stone. Outside of the midden, buried features are present, several with charcoal. We have no data to suggest that the context of the material on the site, or contained within the midden feature, has been extensively disturbed.

Radiocarbon dates place the midden in the Late Prehistoric period. We have little data on the chronometric placement of the remaining prehistoric portion of the site. A single fragment of a projectile point, collected from the surface, may represent a Late Archaic manufacturing period.

Preservation of ethnobotanical material within the midden is excellent. Vertebrate faunal remains and mussel shell were recovered from this site, with macrobotanical samples, as well as flotation samples from the midden, producing high frequencies of bulbs. Wood charcoal was also identified in the sample.

The midden, then, has excellent preservation potential, with only moderate levels of disturbance on the site. We therefore suggest that the data contained within 41BR65 are potentially applicable to a variety of current and future research questions within the region and at a state level. Our limited testing has certainly not exhausted that potential. CAR recommends that this site be considered eligible for inclusion to the NRHP under criterion D of 36CFR 60.4. The site possesses integrity and has yielded, and is likely to yield, information important in prehistory. In addition, by providing new information, 41BR65 has the potential to contribute to a better understanding of Texas prehistory. As 
such, CAR recommends that the site be designated as a SAL under the Antiquities Code of Texas (Rules of Practice and Procedure for the Antiquities Code of Texas, Section 26.8).

\section{BR87}

The integrity of data contained within site 41BR87 appears to be excellent. No recent damage was observed and no areas of erosion were noted. A fence line cuts through a portion of the site with minimal impact. Rodent activity was noted in the midden during excavation, and while worms have impacted these sediments, the disturbance appears to be minimal. Our work at this site revealed buried deposits, with high density and variety of chipped stone. Outside of the midden, buried, datable features are present. We have no data to suggest that the context of the material on the site, or contained within the midden feature, has been extensively disturbed.

Radiocarbon dates from the midden place these deposits in the Late Prehistoric period. We have an external date early in the Late Prehistoric period. Projectile points suggest an occupation span from the end of the Late Archaic into the Late Prehistoric.

Preservation of ethnobotanical material within the midden is excellent. While no animal bone was recovered, mussel shell was present. Macrobotanical samples, as well as flotation samples from the midden, produced bulbs, and wood charcoal was identified.

The site has an essentially intact midden with good preservation. In addition, the site has external features, and appears to represent a limited time range. Based on these data, we suggest that site 41BR87 contains data sets that are potentially applicable to a variety of current and future research questions within the region and at a state level. Our limited testing has certainly not exhausted that potential. CAR recommends that this site be considered eligible for inclusion to the NRHP under criterion D of 36CFR 60.4. The site possesses integrity and has yielded, and is likely to yield, information important in prehistory. In addition, by providing new information, 41BR87 has the potential to contribute to a better understanding of Texas prehistory. As such, CAR recommends that the site be designated as a SAL under the Antiquities Code of Texas (Rules of Practice and Procedure for the Antiquities Code of Texas, Section 26.8).

\section{BR228}

The integrity of data contained within site 41BR228 appears to be somewhat mixed. Some damage to the site has occurred as a result of military training activities. In addition, several areas of the site have been eroded. Rodent and worm activity was noted in both of the middens during excavation. The level of disturbance appears to be minimal in the eastern midden (Feature 1). Rodent disturbance was clearly present in the western midden (Feature 4), especially in the lower levels. Our work at this site revealed buried deposits in some areas, with moderate density and variety of chipped stone. Outside of the middens, a buried feature was recorded. Distributional data in shovel tests suggest multiple, buried occupations may be present in some areas, though at shallow depths.

Radiocarbon dates place Feature 1 in the Late Prehistoric period. Feature 4 has two dates that suggest both Late Prehistoric and Late Archaic use. Chronometric data from the remaining portions of the site suggest a long history of occupation, spanning much of the period between the Early Archaic and Late Prehistoric periods.

Preservation of ethnobotanical material within the two middens is good. While no animal bone was recovered from this site, mussel shell was present. Macrobotanical samples, as well as flotation samples from the midden, produced bulbs and wood charcoal.

We suggest that portions of site $41 \mathrm{BR} 228$ contain data that are potentially applicable to a variety of current and future research questions within the region and at a state level. Specifically, we suggest that while much of the site may represent mixed, shallow deposits, the two midden areas contain significant data. Our limited testing has certainly not exhausted that data potential. CAR recommends that these portions of site 41BR228 makes this site eligible for inclusion to the NRHP under criterion D of 36CFR 60.4. The middens at this site possess adequate integrity. They have yielded, and are likely to yield, information important in prehistory. In addition, by providing new information, middens on this site have the potential to contribute to a better understanding of Texas prehistory. As such, CAR recommends that the site be designated as a SAL under the Antiquities Code of Texas (Rules of Practice and Procedure for the Antiquities Code of Texas, Section 26.8). 


\section{BR246}

The integrity of data contained within site 41BR246 appears to be good. Some damage to the site may have occurred as a result of the construction of a cattle tank nearby, and some erosion and displacement of artifacts on the northern end of the site has occurred. However, the area around the midden and the midden itself has not been extensively disturbed. While rodent activity was noted in the midden during excavation, and while worms have impacted the midden sediment, the disturbance appears to be minimal. Our work at this site revealed buried deposits outside the midden, though no external features were noted.

Radiocarbon dates place the midden in the Late Prehistoric period. Projectile points from outside the midden suggest occupation in both the Middle Archaic and the Late Prehistoric. The Middle Archaic material is probably associated with the material off the slope near the northern end of the site.

Preservation of ethnobotanical material within the midden is excellent. Vertebrate faunal material and mussel shell were recovered from the midden, with macrobotanical samples, as well as flotation samples from the midden, producing high frequencies of bulbs. Wood charcoal was identified.

We suggest that the data contained within 41BR246 are potentially applicable to a variety of current and future research questions within the region and at a state level. The midden has good preservation, represents a limited time range, and disturbances within these deposits are minimal. CAR recommends that this site be considered eligible for inclusion to the NRHP under criterion D of 36CFR 60.4. The site possesses good integrity, especially around and within the midden. It has yielded, and is likely to yield, information important in prehistory. In addition, 41BR246 has the potential to contribute to a better understanding of Texas prehistory. As such, CAR recommends that the site be designated as a SAL under the Antiquities Code of Texas (Rules of Practice and Procedure for the Antiquities Code of Texas, Section 26.8).

\section{BR250}

The integrity of data contained within site 41BR250 appears to be mixed. The area of the site to the west of the midden along the exposed ridge has clearly been eroded. This is indicated both by the high density of surface material, including gravels, along the ridgeline as well as the shallow depth of sediment. The midden appears to be essentially intact, in spite of minor rodent and worm activity. Our work at this site revealed shallowly buried deposits. No features other than the midden were noted.

Radiocarbon dates place the midden in the Late Prehistoric period. A single ceramic sherd, recovered from the midden, is consistent with that temporal placement. Away from the midden along the ridge, surface collected projectile points suggest an Early or Middle Archaic and a Late Archaic occupation.

Preservation of ethnobotanical material within the midden is excellent. Vertebrate faunal material and mussel shell were recovered from the midden, with macrobotanical samples producing high frequencies of bulbs. Wood charcoal was identified in the flotation samples.

We suggest that the data contained within 41BR250 are potentially applicable to a variety of current and future research questions within the region and at a state level. The midden has excellent preservation and appears to represent a limited time frame. Our limited testing has certainly not exhausted that potential. CAR recommends that this site be considered eligible for inclusion to the NRHP under criterion D of 36CFR 60.4. While portions of the site along the ridge, probably dating to the Middle and Late Archaic periods, are eroded, the Late Prehistoric midden is clearly intact. The midden deposit has yielded, and is likely to yield, information important in prehistory. In addition, 41BR250 has the potential to contribute to a better understanding of Texas prehistory. As such, CAR recommends that the site be designated as a SAL under the Antiquities Code of Texas (Rules of Practice and Procedure for the Antiquities Code of Texas, Section 26.8).

\section{BR253}

The integrity of data contained within site 41BR253 appears to be good. While some areas of erosion have occurred, the overall impact is minimal. While rodent and worm activity was noted in both of the middens during excavation, the disturbance is not extensive. Our work at this site revealed shallowly buried deposits, with moderate density and variety of chipped stone. Outside of the middens, features are present. We have no data to suggest that the context of the material on the site, or contained within the two middens, has been extensively disturbed. 
Radiocarbon dates place both of the middens in the Late Prehistoric. A variety of diagnostics recovered from 41BR253 are consistent with that Late Prehistoric assignment.

Preservation of ethnobotanical material within both of the middens is excellent. Vertebrate faunal material and mussel shell were recovered from this site, with macrobotanical samples, as well as flotation samples from the middens producing bulbs. Wood charcoal was identified in the flotation samples. In addition, human remains, possibly representing two different individuals, were present in one of the middens.

The site appears to represent occupation during only the Late Prehistoric period. The presence of essentially intact middens, external deposits, as well as human remains, make these deposits applicable to a variety of research questions within the region and at a state level. CAR recommends that this site be considered eligible for inclusion to the NRHP under criterion D of 36CFR 60.4. The site possesses integrity and has yielded, and is likely to yield, information important in prehistory. In addition, by providing new information, 41BR253 has the potential to contribute to a better understanding of Texas prehistory. As such, CAR recommends that the site be designated as a SAL under the Antiquities Code of Texas (Rules of Practice and Procedure for the Antiquities Code of Texas, Section 26.8).

\section{BR261}

Site 41BR261 was one of two sites tested on the current project that lacked burned rock middens. Wormser and Sullo-Prewitt (2001:67) recommended the site for testing as the site contained evidence of a single component, possibly an Early Archaic campsite based on the recovery of three Pandale projectile points. In addition, limited shovel testing by Wormser and Sullo-Prewitt produced buried material in one shovel test.

Shovel testing, surface collection, and excavation results from CAR's work at the site revealed low densities of both surface and subsurface material. The site is located on a series of sloping colluvial fans. Surface material has certainly been displaced. While a surface feature was tested, excavation results documented that the feature was eroded and no ethnobotanical remains or datable material was recovered. While previous work at the site had recovered three Pandale points, our work produced a single point, probably Late Archaic in age.
No vertebrate faunal material or mussel shell was present in either the shovel tests or the excavation units. Conditions for preservation at the site are poor. Surface densities are low, and subsurface deposits appear to be minimal.

We suggest that the site has little significant data and has questionable integrity. In addition, the site has low preservation potential. Finally, note that 41BR261 does not appear to represent a single component occupation. Consequently, CAR recommends that this site be considered not eligible for inclusion to the NRHP under any criteria. Site 41BR261 is not recommended for designated as a SAL. No data of significance are present at this site and no further work is recommended.

\section{$41 \mathrm{BR} 276$}

Site 41BR276 was the second site tested on the current project that lacked a burned rock midden. Wormser and Sullo-Prewitt (2001:74-75) described the site as a Late Archaic open campsite. Limited shovel testing suggested a buried component was present. On this basis, Wormser and Sullo-Prewitt (2001:75) recommended further evaluation of the site.

When the site was initially recorded in 1995 by TXARNG cultural resources staff, a "jeep trail" was noted as being present (Wormser and Sullo-Prewitt (2001:75). When CAR visited the site in 1999, it was clear that 41BR276 has been impacted by maintenance activity associated with that "trail." The road had been widened and deepened by grading.

Shovel testing, surface collection, and excavation results from CAR's work at the site revealed a low density of both surface and subsurface material. While a disturbed surface feature was tested in the roadway, excavation results documented that the feature had no depth. No additional diagnostics were recovered. No vertebrate faunal material was present in either the shovel tests or the excavation units. Conditions for preservation at the site are poor.

We suggest that the site has little integrity remaining, it has been heavily impacted by the road construction. The site has low preservation potential. Consequently, CAR recommends that site 41BR276 be considered not eligible for inclusion to the NRHP under any criteria. This site is not recommended for designation as a SAL. No data of significance are present at 41BR276 and no further work is recommended. 


\section{BR415}

The integrity of data contained within site 41BR415 is open to question. A road runs through the center of the site. In addition, a portion of the site appears to have been disturbed by grading. The site sits on a small slope, and some artifact movement has certainly occurred as a result of natural processes. Within the midden, rodent activity appears to have been more extensive than in most other middens. Our work at this site revealed shallowly buried deposits, with moderate density of artifacts. Outside of the midden, features were present, but they also had poor preservation.

Mussel shell was recovered from the site, though vertebrate faunal material was absent. Carbonized material within the midden was not common. No macrobotanical samples were collected during the excavations. The two flotation samples from the burned rock midden produced very low recovery, with only a fragment of wood charcoal identified.

We have minimal data on the chronometric placement of either the midden or the remaining portion of the site. Diagnostic points recovered by Wormser and Sullo-Prewitt (2001:93-96) suggest use of the site over a long time period, with diagnostics reflecting Middle Archaic, Late Archaic, and Late Prehistoric time frames. No additional diagnostics were recovered during CAR's work at the site.

We suggest that the data contained within 41BR415 have questionable integrity. While some classes of potentially significant data are present, our limited testing suggests that the cultural and physical integrity of deposits at the site may be compromised. CAR recommends that this site be considered not eligible for inclusion to the NRHP under any criteria. The site possesses questionable integrity, and as such, it is unlikely to yield information important in prehistory. The site also fails to clearly meet criteria for designation as a SAL. No further work is recommended at 41BR415.

\section{BR420}

The integrity of data contained within site 41BR420 appears to be good. While historical disturbance is present, the impacts to the prehistoric material are minimal. Erosion is present, but is primarily confined to the northern portion of the site, well away from the burned rock midden. Rodent activity was noted in the midden during excavation, along with worm casts. However, these disturbances are minimal. Our work at this site revealed buried deposits, with moderate density of chipped stone. Outside of the midden, an external feature was present, though no charcoal was observed in the fill.

CAR's work at site 41BR420 suggests that the burned rock midden was used during the close of the Late Archaic period and into the Late Prehistoric period. Three diagnostic projectile points recovered from the midden also reflect Late Archaic and Late Prehistoric use. No non-midden chronometric data were recovered.

Preservation of ethnobotanical material within the midden is excellent. Both vertebrate faunal material and small quantities of mussel shell were present in the midden excavation units. Faunal material included the recovery of bison, though none of the specimens were burned. Macrobotanical samples submitted for identification consisted primarily of bulbs and bulb fragments, with dog'stooth violet being identified. Flotation samples produced only wood charcoal, some of which was oak.

We suggest that the data contained within 41BR420 are potentially applicable to a variety of current and future research questions within the region and at a state level. Our limited testing has certainly not exhausted that potential. CAR recommends that this site be considered eligible for inclusion to the NRHP under criterion D of 36CFR 60.4. The site possesses integrity and has yielded, and is likely to yield, information important in prehistory. In addition, by providing new information, $41 \mathrm{BR} 420$ has the potential to contribute to a better understanding of Texas prehistory. As such, CAR recommends that the site be designated as a SAL under the Antiquities Code of Texas (Rules of Practice and Procedure for the Antiquities Code of Texas, Section 26.8).

\section{$41 \mathrm{BR} 433$}

The integrity of data contained within site 41BR433 appears to be moderate. While some damage to the small limestone burned rock midden at the site has occurred as a result of military activity, the majority of both the site and the midden appear to be intact. No areas of extensive erosion were noted. Rodent activity was clearly noted in the midden during excavation, and worms have impacted the midden sediment. Our work at this site revealed shallowly buried deposits, with moderate density and variety of chipped stone. Surface artifact density was minimal and almost all of the chipped stone and fire-cracked rock recovered in shovel tests was from the upper $20 \mathrm{~cm}$ of the deposits. Outside of the midden, 
buried features were not observed. We have no data to suggest that the context of the material on the site has been extensively disturbed.

Radiocarbon dates place the burned rock midden in the Late Prehistoric period. The diagnostic projectile points recovered from the site are consistent with that Late Prehistoric period assignment, although an Archaic use is also suggested by the recovery of dart point fragments.

Conditions for preservation of ethnobotanical material within the midden appear to be poor. The midden deposits at 41BR433 appear to be both more fine-grained and more turbated than most other middens excavated on this project. No vertebrate faunal material was recovered from the site, though mussel shell was present. No macrobotanical samples were collected. Flotation samples produced small amounts of wood charcoal.

In spite of the poor preservation within the midden, a radiocarbon sample was recovered and flotation samples produced carbonized material. The presence of a small midden that seems to reflect a relatively brief temporal span, as well as the presence of off-midden deposits, suggests that the data contained within $41 \mathrm{BR} 433$ are potentially applicable to a variety of current and future research questions. Our limited testing has certainly not exhausted that potential. CAR recommends that this site be considered eligible for inclusion to the NRHP under criterion D of 36CFR 60.4. The site possesses integrity and has yielded, and is likely to yield, information important in prehistory. In addition, by providing new information, 41BR433 has the potential to contribute to a better understanding of Texas prehistory. As such, CAR recommends that the site be designated as a SAL under the Antiquities Code of Texas (Rules of Practice and Procedure for the Antiquities Code of Texas, Section 26.8).

\section{BR441}

The integrity of data contained within site 41BR441 appears to be compromised. The single midden, located on the edge of the site, has been extensively damaged by heavy machinery. A series of cattle tanks in this general area, including one just to the east of the site, has resulted in a concentration of animals in this area. Probably as a result of that concentration, some damage to the site as a result of erosion was noted. Both rodents and worms have impacted those midden sediments that were not destroyed by bulldozing. Our work at this site revealed low artifact density. Outside of the midden, no features were discovered in the shovel testing. The single external excavation unit, placed near the midden, was essentially sterile.

CAR's work at site 41BR441 provided no direct dates on the midden. However, a diagnostic arrow point, consistent with the Late Prehistoric point collected by Wormser and Sullo-Prewitt (2001), was collected.

Vertebrate faunal material was limited to a single unburned item from a mammal. Small amounts of mussel shell were present in the midden excavation unit. While no macrobotanical samples were submitted for identification, conditions for preservation of ethnobotanical material within the midden appear to be moderate. One of the flotation samples recovered an unidentified bulb, and both of the midden samples contained wood charcoal, with mesquite being identified. The backhoe trench described by Bousman and Hodges (see Appendix G) documents a basal midden feature.

We suggest that as the midden has been bulldozed, and as deposits away from the midden are eroded, site 41BR441 has little potential. Our limited testing has documented the feature. As such, CAR recommends that this site should not be considered eligible for inclusion to the NRHP under any criteria. The site lacks integrity. It is unlikely to yield information important to prehistory. The site does not qualify for designation as a SAL, and no further work is recommended at this site.

\section{$41 \mathrm{BR} 473$}

The integrity of data contained within site 41BR473 appears to be good. No damage to the area was noted and no areas of erosion were observed. While rodent activity was noted in the midden during excavation, and while worms have impacted the midden sediment, the disturbance appears to be minimal. Outside of the midden, our work revealed buried deposits, with variable densities of chipped stone. Most of the material was recovered between 20 to $30 \mathrm{cmbs}$. Charcoal was present in several of the shovel test levels, as was mussel shell. In the single non-midden excavation unit, an artifact density of over 1,000 items per cubic meter of sediment was present and this unit contained burned bone, small amounts of charcoal, mussel shell, and fire-cracked rocks. 
Radiocarbon dates suggest that the burned rock midden dates to the Late Prehistoric period. Two diagnostic projectile points recovered from the site suggest use in the Late Archaic and the Late Prehistoric periods.

Preservation of ethnobotanical material within the midden is moderate. While no vertebrate faunal material was recovered from those excavations, mussel shell was present. No macrobotanical samples were submitted for identification, but flotation recovered wood charcoal.

We lack data to suggest that the context of the material recovered from the midden on the site has been extensively disturbed. Although excavation outside the midden was minimal, we documented high artifact densities associated with small amounts of charcoal, burned bone, mussel shell, and burned rock. We suggest that the data contained within 41BR473 are potentially applicable to a variety of current and future research questions within the region and at a state level. CAR recommends that this site be considered eligible for inclusion to the NRHP under criterion D of 36CFR 60.4. The site possesses integrity and has yielded, and is likely to yield, information important in prehistory. In addition, by providing new information, 41BR473 has the potential to contribute to a better understanding of Texas prehistory. As such, CAR recommends that the site be designated as a SAL under the Antiquities Code of Texas (Rules of Practice and Procedure for the Antiquities Code of Texas, Section 26.8).

\section{$41 \mathrm{BR} 474$}

The integrity of data contained within site 41BR474 appears to be compromised. Both of the two middens at this site have been impacted by heavy machinery, essentially destroying the midden structure. The damage, probably caused by a bulldozer, is similar to that observed in the midden at 41BR441, located a few hundred meters to the south. While no areas of extensive erosion were noted, several small areas within the site are eroded. Our work at this site revealed shallowly buried deposits, with moderate to high density of chipped stone near the middens, and low density of material away from the middens. However, historic and modern materials are mixed with the prehistoric artifacts.

We were able to obtain radiocarbon dates from the bottoms of both of the burned rock middens. These dates suggest a Late Prehistoric period of use. The two diagnostic projectile points recovered from the site are earlier than these
Late Prehistoric dates, suggesting a Late Archaic use of the area as well.

Conditions for preservation of ethnobotanical material within the middens are low given that almost no midden sediments remain. In addition, the context of the material recovered from the middens on the site may have been extensively disturbed. While mussel shell was recovered, no vertebrate faunal material was recovered from the excavations at this site. No macrobotanical samples were collected for identification. Flotation samples produced oak wood charcoal from the two features.

The bulldozing of the two middens at site 41BR474 has essentially destroyed the integrity of these deposits. When combined with the low density and mixed context of material between the features, we suggest that this site is not eligible for inclusion to the NRHP under any criteria. The site possesses little integrity. This site should not be designated as a SAL. No further work is recommended at this site.

\section{$41 \mathrm{BR} 478$}

The integrity of data contained within site $41 \mathrm{BR} 478$ appears to be good. Conditions for preservation of ethnobotanical material within the midden are good. In addition, we have no data to suggest that the context of the material recovered from the midden on the site has been extensively disturbed. While worm casts were noted in the matrix of the midden, no extensive rodent disturbance was observed. Some erosion is present away from the midden. Shovel testing results from outside the midden revealed moderate subsurface density and buried deposits. While 75 percent of the chipped stone was recovered within the upper $30 \mathrm{~cm}$ of the site, 12.5 percent was below $50 \mathrm{~cm}$ in depth, suggesting the possibility of multiple, buried occupations. We have no data to suggest that the context of the material on the site, or contained within the midden feature, has been extensively disturbed.

CAR's work at site 41BR478 suggests that the burned rock midden dates to the Late Prehistoric period. An earlier radiocarbon date, taken from sediments below the midden, suggests that the site was also in use during the Late Archaic. Three diagnostic points collected from the site are consistent with that earlier use. In combination with diagnostics collected by Wormser and Sullo-Prewitt (2001:127-129), it appears that the site was occupied at some level throughout the Archaic and into the Late Prehistoric. 
Preservation of ethnobotanical material within the midden is good. Both vertebrate faunal material and mussel shell were recovered. While no macrobotanical samples were submitted for identification, flotation samples produced wood charcoal identified as oak and mesquite. In addition, a single carbonized mesquite seed was present.

The data contained within $41 \mathrm{BR} 478$ are potentially applicable to a variety of current and future research questions within the region and at a state level. 41BR478 contains an intact midden dating to a narrow temporal range with moderate to good preservation potential. Our limited testing has certainly not exhausted that potential. CAR recommends that this site be considered eligible for inclusion to the NRHP under criterion D of 36CFR 60.4. The site possesses integrity and has yielded, and is likely to yield, information important in prehistory. In addition, by providing new information, 41BR478 has the potential to contribute to a better understanding of Texas prehistory. As such, CAR recommends that the site be designated as a SAL under the Antiquities Code of Texas (Rules of Practice and Procedure for the Antiquities Code of Texas, Section 26.8).

\section{BR480}

The integrity of data contained within site 41BR480 appears to be limited. While no military disturbance was noted, portions of the site have been eroded. Worm casts are common in the midden deposits suggesting some turbation, and while rodent burrowing was noted in both middens, the level of disturbance is not extensive. Outside of the middens, deposits are shallowly buried. High densities are present on portions of the surface, probably as a function of erosion. Almost all of the artifacts recovered from excavation outside of the midden areas were recovered from the upper $20 \mathrm{~cm}$, with roughly 70 percent coming from the first $10 \mathrm{~cm}$. External features were present, but these appeared to have little preservation.

We have little data on the chronometric placement of this site. CAR's work at 41BR480 failed to provide any chronometric dates on the burned rock midden. At a site level, only a single, untypable dart point fragment was recovered.

Conditions for preservation of ethnobotanical material within the burned rock midden are poor. While several pieces of animal bone were recovered from the site, none of these were recovered from the midden. Mussel shell was present both in midden and non-midden excavation units. No macrobotanical samples were collected from this site. The single flotation sample, taken from the midden, produced carbonized wood.

We suggest that the data contained within 41BR480 are of questionable integrity. These data have little potential for making a significant contribution to current or future research questions within the region and at a state level. CAR recommends that this site be considered not eligible for inclusion to the NRHP under any criteria. Site 41BR480 lacks attributes that would qualify it for designation as a SAL. No further work is recommended at this site.

\section{$41 \mathrm{BR} 492$}

The integrity of data contained within site 41BR492 appears to be good. No military or ranching damage to the deposits were observed. No areas of extensive erosion were noted. Both rodent and worm activity was noted in the midden, but this disturbance appears to be minimal. Shovel testing and surface collection results from outside the midden revealed low surface density and shallowly buried deposits. Artifact densities were higher near the surface, with most material recovered within the first $30 \mathrm{~cm}$. Outside of the midden, a buried feature with charcoal was exposed in a backhoe trench. We have no data to suggest that the context of the material on the site, or contained within the midden feature, has been extensively disturbed.

Radiocarbon dates from the midden at site 41BR492 suggest that the burned rock midden dates to the Late Archaic, with substantial use during the Late Prehistoric. All of the diagnostic projectile points recovered from the site are consistent with the Late Archaic period and Late Prehistoric period assignment.

Conditions for preservation of ethnobotanical material within the midden are good. We recovered both vertebrate faunal material and mussel shell from midden as well as non-midden excavation units. Several of these specimens were identified as bison. No macrobotanical samples were submitted for identification from this site. Flotation samples produced wood charcoal.

The data contained within site $41 \mathrm{BR} 492$ are potentially applicable to a variety of current and future research questions within the region and at a state level. 41BR492 contains an intact midden with good to moderate preservation potential, as well as off-midden deposits, 
including features. Our limited testing at this site has certainly not exhausted the potential of 41BR492. CAR recommends that this site be considered eligible for inclusion to the NRHP under criterion D of 36CFR 60.4. The site possesses integrity and has yielded, and is likely to yield, information important in prehistory. In addition, by providing new information, 41BR492 has the potential to contribute to a better understanding of Texas prehistory. As such, CAR recommends that the site be designated as a SAL under the Antiquities Code of Texas (Rules of Practice and Procedure for the Antiquities Code of Texas, Section 26.8).

\section{BR493}

The integrity of data contained within site 41BR493 appears to be good. While some material representing military activity is present on the surface of the site, the majority of the site appears intact. Excavation within the midden demonstrates that the upper $30 \mathrm{~cm}$ of the deposit has been disturbed by recent military activity. Below the disturbance, however, midden deposits appear to be intact. Rodent activity was noted in the midden during excavation and worms have impacted the midden sediment. However, in both cases the disturbance appears to be minimal. No areas of extensive erosion were noted on a site level. Shovel testing results from outside the midden revealed buried deposits. Roughly two-thirds of the shovel tests were positive. Examination of the distribution of artifacts within the upper $50 \mathrm{~cm}$ demonstrates a bimodal distribution of material, possibly indicating multiple occupations. Charcoal was noted between 30 and $50 \mathrm{cmbs}$ in several shovel tests.

CAR's work at site 41BR493 suggests that the burned rock midden dates to the Late Prehistoric period. No diagnostic projectile points were recovered from the site.

Preservation of ethnobotanical material within the midden is excellent. Both vertebrate faunal material and mussel shell was recovered. Macrobotanical samples submitted for identification primarily contained bulbs or bulb fragments of Eastern camas and wild onion. Both of the two flotation samples from the midden contained bulb fragments, and wood charcoal was also present. Outside of the midden, shovel testing revealed charcoal in several locations below $30 \mathrm{~cm}$.

We suggest that the data contained within 41BR493 are potentially applicable to a variety of current and future research questions within the region and at a state level. CAR recommends that this site be considered eligible for inclusion to the NRHP under criterion D of 36CFR 60.4. The site possesses integrity and has yielded, and is likely to yield, information important in prehistory. In addition, by providing new information, 41BR493 has the potential to contribute to a better understanding of Texas prehistory. As such, CAR recommends that the site be designated as a SAL under the Antiquities Code of Texas (Rules of Practice and Procedure for the Antiquities Code of Texas, Section 26.8).

\section{Recommendation Summary}

Using the excavation and analytical work summarized in this report, we suggest that in twelve cases significant data are present on sites tested on this project. These sites are 41BR65, 41BR87, 41BR228, 41BR246, 41BR250, 41BR253, 41BR420, 41BR433, 41BR473, 41BR478, 41BR492, and 41BR493. CAR recommends that these 12 sites be considered eligible for inclusion to the National Register of Historic places, and warrant designations as State Archeological Landmarks. Avoidance of these locations by training activities or some form of mitigation at these sites, primarily centered on the middens themselves, will be necessary. In the case of the remaining sites, our testing suggests that they either lack clear evidence of any significant data (41BR261 and 41BR276) or have data of questionable integrity (41BR415, 41BR441, 41BR474, and 41BR480). CAR recommends that these sites are not eligible for inclusion to the National Register of Historic Places and they do not warrant designation as State Archeological Landmarks. No further work is recommended on these six sites.

\section{Report Summary}

This report has summarized the results of eligibility testing on 18 sites at Camp Bowie. The report can be broadly divided into two sections. The initial section, consisting of chapters 1 through 6 , provided background information on the region, details on the overall perspective of the project, outlined methods, and provided descriptions of the results of our testing efforts. Specifically, the initial chapter provided a short overview of the project. Chapters 2 and 3 provided background information on the area, including a review of the cultural history and background to the physical environment of the region. The fourth chapter outlined the overall research perspective that guided both the fieldwork and the production of the report. As burned rock middens were one of the principal features used to recommend most of the sites tested as potentially eligible to the National 
Register of Historical Places as well as for State Archeological Landmark status, included in that chapter was a historical overview of burned rock midden research. The fifth chapter outlined the methodology used in the field, laboratory, and analytical phases of the project. Chapter 6 provided a site by site discussion of the work performed, as well as the results of that work. Supporting documentation for that chapter can be found in volume 2 of this document.

Chapters 7 though 11, summarized at the close of the previous chapter, constituted the second section of this report. That section dealt specifically with various aspects of burned rock middens. These features have been the focus of research in central Texas since the beginning of the last century. During that time, three primary concerns have been paramount in understanding burned rock middens. These have essentially centered on questions of midden construction, midden use, and the temporal placement of these features. The testing at Camp Bowie allowed us to systematically consider several of these research issues, both within the camp as well as at larger spatial scales. The results of the current project, especially when combined with other recent studies (e.g., Black et al. 1997), suggest that we may now be close to answering these basic questions with regard to this feature type. 


\section{References Cited}

Abbott, J. T., and C. D. Frederick

1990 Proton Magnetometer Investigations of Burned Rock Middens in West-Central Texas: Clues to Formation Processes. Journal of Archaeological Science 17:535-545.

Adjutant General's Department of Texas

1992 Environmental Assessment, Camp Bowie: Land Acquisition. Prepared by Adjutant General's Department of Texas, Facilities and Engineering, Austin in conjunctions with ENECO Tech, Inc., Environmental Consultants, Austin. Manuscript on file Center for Archaeological Research, The University of Texas at San Antonio.

Aten, L. E.

1979 Indians of the Upper Texas Coast: Ethnohistoric and Archaeological Frameworks. Unpublished Ph.D. thesis. Department of Anthropology, The University of Texas at Austin.

Barnes, V. E.

1976 Geologic Atlas of Texas, Brownwood Sheet. Scale 1:250,000. Bureau of Economic Geology, The University of Texas, Austin.

Basehart, H. W.

1973 Mescalero Apache Subsistence Patterns. In Technical Manual: 1973 Survey of the Tularosa Basin, Tularosa, New Mexico. Human Systems Research, Tularosa.

Bell, W. H., and E. F. Castetter

1941 Ethnobiological Studies in the American Southwest, VII. The Utilization of Yucca, Sotol and Beargrass by the Aborigines in the American Southwest. Bulletin 372. University of New Mexico, Albuquerque.

Black, S. L.

1986 The Clemente and Herminia Hinojosa Site, 41JW8: A Toyah Horizon Campsite in Southern Texas. Special Report No. 18. Center for Archaeological Research, The University of Texas at San Antonio.

1989a Central Texas Plateau Prairie. From the Gulf Coast to the Rio Grande: Human Adaptation in Central, South and Lower Pecos Texas, by T. R. Hester, S. L. Black, D. G. Steele, B. W. Olive, A. A. Fox, K. J. Reinhard, and L. C. Bement, pp. 17-38. Research Series No. 33. Arkansas Archeological Survey, Fayetteville.

1989b Environmental Setting. From the Gulf Coast to the Rio Grande: Human Adaptation in the Central, South, and Lower Pecos Texas, by T. R. Hester, S. L. Black, D. G. Steele, B. W. Olive, A. A. Fox, K. J. Reinhard, and L. C. Bement, pp. 5-17. Research Series No. 33. Arkansas Archeological Survey, Fayetteville.

1997 Scenarios of Midden Accumulation. In Hot Rock Cooking on the Greater Edwards Plateau: Four Burned Rock Midden Sites in West Central Texas, edited by S. L. Black, L. W. Ellis, D. G. Creel, and G. T. Goode, pp. 140-150. Studies in Archeology 22. Texas Archeological Research Laboratory, The University of Texas at Austin.

Black, S. L., and D. G. Creel

1997 The Central Texas Burned Rock Midden Reconsidered. In Hot Rock cooking on the Greater Edwards Plateau: Four Burned Rock Midden Sites in West Central Texas, edited by S. L. Black, L. W. Ellis, D. G. Creel, and G. T. Goode, pp. 446-515. Studies in Archeology 22. Texas Archeological Research Laboratory, The University of Texas at Austin. 
Black, S. L., L. W. Ellis, D. G. Creel, and G. T. Goode

1997 Hot Rock Cooking on the Greater Edwards Plateau: Four Burned Rock Midden Sites in West Central Texas (two volumes). Studies in Archeology 22. Texas Archeological Research Laboratory, The University of Texas at Austin; Texas Department of Transportation Environmental Affairs Department, Archeology Studies Program, Report 2.

Black, S. L., and A. J. McGraw

1985 The Panther Springs Creek Site: Cultural Change and Continuity in the Upper Salado Creek Drainage, SouthCentral Texas. Archaeological Survey Report, No. 100. Center for Archaeological Research, The University of Texas at San Antonio.

Bomar, G. W.

1995 Texas Weather. Second edition, revised. University of Texas Press, Austin.

Bousman, C. B.

1992 Preliminary Oxygen-Isotope Evidence for Late Pleistocene-Early Holocene Climatic Change. Current Research in the Pleistocene 9:78-80.

1994 The Central Texas Pollen Record: A Reinterpretation. Current Research in the Pleistocene 11:79-81.

1998 Paleoenvironmental Change in Central Texas: The Palynological Evidence. Plains Anthropologist 164(43):201219.

Briggs, A. K.

1992 An Archaeological Survey of Sample Areas within the Proposed Camp Bowie Acquisition Area, near Brownwood, Brown County, Texas. Manuscript on file at the Texas Historical Commission.

Brown, D.

1989 Prehistoric Subsistence Strategies in Northeastern Central Texas. Bulletin of the Texas Archeological Society 59:201-244.

1998 Late Holocene Climates of North-Central Texas. Plains Anthropologist 164(43):157-172.

Bryant, V. M., Jr., and R. G. Holloway

1985 Late-Quaternary Paleoenvironmental Record of Texas: An Overview of the Pollen Evidence. In Pollen Records of Late-Quaternary North American Sediments, edited by V. T. Bryant, Jr., and R. G. Holloway, pp. 39-70. American Association of Stratigraphic Palynologists Foundation, Dallas.

Bryant, V. M., Jr., and H. J. Shafer

1977 The Late Quaternary Paleoenvironment of Texas: A Model for the Archeologist. Bulletin of the Texas Archeological Society 48:1-25.

Buskirk, W.

1949 Western Apache Subsistence Economy. Unpublished Ph.D. dissertation. University of New Mexico, Albuquerque.

Butler, R. F.

1992 Paleomagnetism: Magnetic Domains to Geologic Terranes. Blackwell Scientific Publications, Boston.

Camm, F. J.

1958 Mathematical Tables and Formulae. Philosophical Library. New York. 
Campbell, T. N.

1952 Early Archaeological Investigations in the Vicinity of Brownwood, Texas. The Record 10(3):10-14.

Campbell, T. N., and T. J. Campbell

1981 Historic Indians of the Choke Canyon Reservoir Surrounding Area, Southern Texas. Choke Canyon Series, No. 1. Center for Archaeological Research, The University of Texas at San Antonio.

Camper, H. A.

1991 Pollen Analysis of Patschke Bog. Unpublished M.S. thesis, Department of Botany, Texas A\&M University, Bryant. Data archived at the World Data Center for paleoclimatology data. NOAA/NGDC Paleoclimatology Program, Boulder.

Caran, S. C.

1998 Quaternary Paleoenvironmental and Paleoclimatic Reconstruction: A Discussion and Critique, with Examples from the Southern High Plains. Plains Anthropologist 164(43):111-124.

Castetter, E. F., W. H. Bell, and A. R. Grove

1938 The Early Utilization and the Distribution of Agave in the American Southwest. University of New Mexico Bulletin, Biological Series Vol. 5, No. 4. University of New Mexico Press, Albuquerque.

Castetter, E. F., and M. E. Opler

1936 The Ethnobiology of the Chiricahua and Mescalero Apache. University of New Mexico Bulletin no. 297. Ethnobiological Studies in the American Southwest 3. University of New Mexico Press, Albuquerque.

Claassen, C.

1998 Shells. Cambridge Manuals in Archaeology. Cambridge University Press, Cambridge.

Clower, D. F.

1980 Soil Survey of Brown and Mills County, Texas. United States Department of Agriculture, Soil Conservation Service and the Texas Agricultural Experimental Station.

Collins, M. B.

1994a Thoughts on future investigations of burned rock middens. In The Burned Rock Middens of Texas: An Archeological Symposium, edited by T. R. Hester, pp. 1-24. Studies in Archeology 13, Texas Archeological Research Laboratory, The University of Texas, Austin.

1994b Chapter 6: Late Archaic Evidence in the Project Area. In Archaic and Late Prehistoric human ecology in the Middle Onion Creek Valley, Hays County, Texas. Volume 1: Archaeological Components, edited by R. A. Ricklis and M. B. Collins, pp. 101-189. Studies in Archaeology 19, Texas Archaeological Research Laboratory, The University of Texas, Austin.

1995 Forty Years of Archeology in Central Texas. Bulletin of the Texas Archeological Society 66:361-400.

1998 Wilson-Leonard: An 11,000-year Record of Hunter-Gatherers in Central Texas. Studies in Archeology 31, Texas Archeological Research Laboratory, The University of Texas at Austin and Archeology Studies Program Report 10, Environmental Affairs Division, Texas Department of Transportation, Austin.

Collins, M. B., W. A. Gose, and S. Shaw

1994 Preliminary Geomorphological Findings at Dust and Nearby Caves. Journal of Alabama Archaeology 40:35-56. 
Couture, M. D., M. F. Ricks, and L. Housley

1986 Foraging Behavior of a Contemporary Northern Great Basin Population. Journal of California and Great Basin Anthropology 8:150-160.

Creel, D. G.

1978 An Archeological Survey in the South Concho River Area, West Central Texas. Bulletin of the Texas Archeological Society 49:241-307.

1986 Study of Prehistoric Burned Rock Middens in West Central Texas. Unpublished Ph.D. dissertation. Department of Anthropology, The University of Arizona, Tucson.

1994 Assessing the Relationship Between Burned Rock Midden Distribution and Archaic Subsistence in West Central Texas. In The Burned Rock Middens of Texas: An Archeological Symposium, edited by T. R. Hester, pp. 33-43. Studies in Archeology 13, Texas Archeological Research Laboratory, The University of Texas, Austin.

1997 Analysis of the Distribution of Burned Rock Midden Sites in the Study Area. In Hot Rock Cooking on the Greater Edwards Plateau: Four Burned Rock Midden Sites in West Central Texas, edited by S. L. Black, L. W. Ellis, D. G. Creel, and G. T. Goode, pp. 89-98. Studies in Archeology 22, Texas Archeological Research Laboratory, The University of Texas at Austin.

Creel, D., R. F. Scott IV, and M. B. Collins

1990 A Faunal Record From West Central Texas and its Bearing on Late Holocene Bison Population Changes in the Southern Plains. Plains Anthropologist 35:55-69.

Dearing, J.

1999 Environmental Magnetic Susceptibility. Chi publishing, Kenilworth, England.

Decker, S.

1997 Appendix A: Provenience Tables. In Hot Rock Cooking on the Greater Edwards Plateau: Four Burned Rock Midden Sites in West Central Texas, Volume 2, by S. L. Black, L. W. Ellis, D. G. Creel, and G. T. Goode, pp. 341392. Studies in Archeology 22, Texas Archeological Research Laboratory, The University of Texas at Austin and Archeology Studies Program, Report 2, Environmental Affairs Department, Texas Department of Transportation, Austin.

Dering, J. P.

1997 Formation Processes and the Plant Economy at Burned Rock Middens: The View from a Rockshelter. Manuscript on file, Center for Environmental Archaeology, Texas A\&M University, College Station.

1999 Earth Oven Processing in Archaic Period Economics: An Example from a Semi-Arid Savannah in South-Central North America. American Antiquity 64(4):659-674.

Dillehay, T.

1974 Late Quaternary Bison Population Changes on the Southern Plains. Plains Anthropologist 19(64):180-196.

Drake, N. F, and R. A. Thompson

1893 Report on the Colorado Coal Field of Texas. Fourth Annual Report, 1802, Part 7. Geological Survey of Texas, Bureau of Economic Geology, The University of Texas at Austin. 
Ellis, G. L.

1997 Appendix G: Amino Acid Racemization Dating of Amblema Plicata from the Corn Creek Middens. In Hot Rock Cooking on the Greater Edwards Plateau: Four Burned Rock Midden Sites in West Texas, Volume 2, by S. L. Black, L. W. Ellis, D. G. Creel, and G. T. Goode, pp. 641-657. Studies in Archeology 22, Texas Archeological Research Laboratory, The University of Texas at Austin and Archeology Studies Program Report 2, Texas Department of Transportation, Austin.

Ellis, L. W.

1997 Hot Rock Technology. In Hot Rock Cooking on the Greater Edwards Plateau: Four Burned Rock Midden Sites in West Texas, Volume 1, by S. L. Black, L. W. Ellis, D. G. Creel, and G. T. Goode, pp. 43-81. Studies in Archeology 22, Texas Archeological Research Laboratory, The University of Texas at Austin and Archeology Studies Program Report 2, Texas Department of Transportation, Austin.

Ellis, G. L., G. A. Goodfriend, J. T. Abbott, R. E. Hare, and D. W. Von Endt

1996 Assessment of Integrity and Geochronology of Archaeological Sites Using Amino Acid Racemization in Land Snails: Examples from Central Texas. Geoarchaeology 11:189-213.

Everitt, B. S.

1977 The Analysis of Contingency Tables. Chapman and Hall, London.

Fenneman, N.

1931 Physiography of the Western United States. McGraw Hill, New York.

Fox, A. A., and D. E. Fox

1967 The Classen Rockshelter, 41BX23. Manuscript on file, Center for Archaeological Research, The University of Texas at San Antonio.

Frederick, C. D.

1998 Late Quaternary Clay Dune Sedimentation on the Llano Estacado. Plains Anthropologist (43)164:137-156.

Fredlund, G.

1994 The Phytolith Record at the Wilson-Leonard Site. Program and Abstracts, 52nd Plains Conference, 65th Annual Meeting of the Texas Archeological Society. Lubbock.

Fredlund, G. G., C. B. Bousman, and D. K. Boyd

1998 The Holocene Phytolith Record from Morgan Playa in the Rolling Plains of Texas. Plains Anthropologist (43)164:187-200.

Gearhart, R. L.

1987 A Study of Central Texas Burned Rock Middens: Their Formation, Function and Rate of Accumulation. Unpublished M.A. thesis, Department of Anthropology, The University of Missouri, Columbia.

Gearhart, B., and M. W. Voellinger

1986 Archaeological Testing on Sites 41BR313 and 41BR314, Brown County, Texas. Manuscript on file, Texas Historical Commission, Austin, Texas. 
Givens, R. D.

1968 A Preliminary Report on Excavations at Hitzfelder Cave. Bulletin of the Texas Archeological Society 38:47-50.

Goode, G. T.

1991 Late Prehistoric Burned Rock Middens in Central Texas. In The Burned Rock Middens of Texas: An Archaeological Symposium, edited by T. R. Hester, pp. 71-93. Studies in Archeology 13. Texas Archeological Research Laboratory, The University of Texas at Austin.

Goodfriend, G. A., and R. M. Mitterer

1988 Late Quaternary Land Snails from the North Coast of Jamaica: Local Extinctions and Climate Change. Palaeogeography, Palaeoclimatology, Palaeoecology 63:293-311.

Gose, W. A., and D. L. Nickels

2001[1998] Archaeomagnetic and Magnetic Susceptibility Analyses. In Test Excavations at the Culebra Creek Site, 41BX126, Bexar County, Texas. D. L. Nickels, C. B. Bousman, J. D. Leach, and D. A. Cargill, pp. 204-214. Archaeological Survey Report No. 265, Center for Archaeological Research, The University of Texas at San Antonio. Archeology Studies Program, Report 3, Environmental Affairs Division, Texas Department of Transportation, Austin.

Gould, F. W.

1942 A Systematic Treatment of the Genus Camassia Lindl. American Midland Naturalist 28:712-742.

1975 Texas Plants-A Checklist and Ecological Summary. Bulletin MP-585:5-14. Texas Agricultural Experimentation Station, College Station.

Greaves, R. D.

1997 Ethnoarchaeological Investigation of Subsistence Mobility, Resource Targeting, and Technological Organization Among Pume Foragers of Venezuela. Unpublished Ph.D. dissertation, Department of Anthropology, University of New Mexico, Albuquerque.

Gunn, J., and R. Mahula

1977 Hop Hill: Culture and Climate Change in Central Texas. Special Report No 5. Center for Archaeological Research, The University of Texas at San Antonio.

Haberman, S. J.

1973 The Analysis of Residuals in Cross-classified Tables. Biometrics 29:205-220.

Hall, G. D.

1981 Allens Creek: A Study in the Cultural Prehistory of the Brazos River Valley, Texas. Research Report 61. Texas Archeological Survey, The University of Texas at Austin.

Hall, S. A., and S. Valastro, Jr.

1995 Grassland Vegetation in the Southern Great Plains during the Last Glacial Maximum. Quaternary Research 44:237-245. 
Hester, T. R.

1970 Burned Rock Middens on the Southwestern Edge of the Edwards Plateau, Texas. Plains Anthropologist 15:237250

1971 Archeological Investigations at the La Jita Site, Uvalde County, Texas. Bulletin of the Texas Archeological Society 42: 51-148.

1973 The Formation of a Burned Rock Midden: a California Example. The Record 30(1):4. Dallas Archeological Society, Dallas, Texas.

1991 The Burned Rock Middens of Texas: An Archeological Symposium. Studies in Archeology 13, Texas Archeological Research Laboratory, The University of Texas at Austin.

1995 The Prehistory of South Texas. Bulletin of the Texas Archeological Society 66:427-459.

Hester, T. R. (editor)

1994 The Burned Rock Middens of Texas: An Archeological Symposium. Studies in Archeology 13, Texas Archeological Research Laboratory, The University of Texas, Austin.

Highley, L., C. Graves, and G. Judson

1978 Archeological Investigations at Scorpion Cave (41ME7), Medina County, Texas. Bulletin of the Texas Archeological Society 49:139-194.

Hinds, M. H., S. A. Tomka, and K. W. Kibler

1994 Data Recovery Excavations at the Wind Canyon Site, 41HZ119, Hudspeth County, Texas. Reports of Investigations, Number 99. Prewitt and Associates, Inc., Austin, Texas.

Hoffrichter, N., and B. O. Davis (editors)

1981 TAS Field School, 1979, Eubank Ranch, Cross Cut, Texas. Field School Committee, Texas Archeological Society, Austin, Texas.

Hofman, J. L.

1989 Prehistoric Culture History-Hunters and Gatherers in the Southern Great Plains. In From Clovis to Comanchero: Archeological Overview of the Southern Great Plains, by J. L. Hofman, R. L. Brooks, J. S. Hays, D. W. Owsley, R. L. Jantz, M. K. Marks, and M. H. Manhein, pp. 25-60. Research Series No. 35. Arkansas Archeological Survey, Fayetteville.

Holliday, V. T.

1985 Holocene Soil-Geomorphological Relations in a Semi-Arid Environment: The Southern High Plains of Texas. In Soils and Quaternary Landscape Evolution, edited by J. Boardman, pp. 325-357. John Wiley \& Sons, Inc., New York.

Horizon Environmental Services, Inc.

1992 Appendix A: Detailed Ecological Resources Description. In Environmental Assessment, Camp Bowie: Land Acquisition. Prepared by Adjutant General's Department of Texas, Facilities and Engineering, Austin in conjunction with ENECO Tech, Inc., Environmental Consultants, Austin. Manuscript on file Center for Archaeological Research, The University of Texas at San Antonio. 
Houk, B. A., and J. C. Lohse

1993 Archaeological Investigations at the Mingo Site, Bandera County, Texas. Bulletin of the Texas Archeological Society 61:193-247.

Howard, M. A.

1983 A Quantitative Study of the Booker Site and Other Burned Rock Midden Sites of the Lake Travis Basin, Central Texas. Unpublished Masters thesis, Department of Anthropology, The University of Texas at Austin.

1991 Burned Rock Midden Excavations, Hearths and Botanical Remains. In The Burned Rock Middens of Texas: An Archaeological Symposium, edited by T. R. Hester, pp. 45-69. Studies in Archeology 13. Texas Archeological Research Laboratory, The University of Texas at Austin.

Howells, R. G., R. W. Neck, and H. D. Murray

1996 Freshwater Mussels of Texas. Texas Parks and Wildlife Department, Inland Fisheries Division, Austin.

Huebner, J. A.

1991 Late Prehistoric Bison Populations in Central and Southern Texas. Plains Anthropologist 36(137):343-358.

Humphrey, J. D., and C. R. Ferring

1994 Stable Isotope Evidence for Latest Pleistocene and Holocene Climate Change in North-central Texas. Quaternary Research 41:200-213.

Hurt, R. D.

1980 Archeological Investigations of Portions of the Middle Concho Valley. Unpublished Masters Thesis, Texas Tech University, Lubbock.

Huskey, V.

1935 An Archaeological Survey of the Nueces Canyon of Texas. In Bulletin of the Texas Archeological and Paleontological Society 7:104-114.

Jackson, M. A.

1998 Ethnoarcheological Experiments and New Insights on the Nature of Fire-Cracked Rock. Paper presented at the Fourth Headwaters Experimental Workshop, October $16^{\text {th }}-18^{\text {th }}$. Dripping Springs, Texas.

Johnson, L., Jr.

1995 Past Cultures and Climates at Jonas Terrace, 41ME29, Medina County, Texas. Office of the State Archeologist, Report 40. Texas Department of Transportation and Texas Historical Commission, Austin.

Johnson, L., Jr., and G. T. Goode

1994 A New Try at Dating and Characterizing Holocene Climates, as well as Archeological Periods, on the Edwards Plateau. Bulletin of the Texas Archeological Society 65:1-51.

Johnson, E., and V. T. Holliday

1986 The Archaic Record at Lubbock Lake. In Current Trends in Southern Plains Archeology, edited by T. G. Baugh. Plains Anthropologist Memoir 22:7-54.

Jones, C. J.

1980 A Further Experiment in Stone Boiling: A Calcining Process for Acorns. La Tierra 8(2):30-38. 
Kegley, G. P., and A. Black

1978 An Archaeological Survey of Cordell and Camp Bowie City Park Sites, Brownwood, Texas. Texas Antiquities Committee, Austin, Texas.

Kelley, J. C., and T. N. Campbell

1942 What are the burnt rock mounds of Texas? American Antiquity 7:319-322.

Kelly, R.

1995 The Foraging Spectrum: Diversity in Hunter-Gatherer Lifeways. The Smithsonian Institution. Washington D.C.

Kibler, K. W.

1998 Late Holocene Environmental Effects on Sandstone Rockshelter Formation and Sedimentation on the Southern Plains. Plains Anthropologist (43)64:173-186.

Kirby, F. E., and R. Moir

1976 Brownwood Dam Modifications and Archaeological Assessment. Archaeology Research Program, Southern Methodist University, Reports in Archaeology No. 95, Dallas, Texas.

Kornfeld, M.

1994 Pull of the Hills: Affluent Foragers of the Western Black Hills. Unpublished Ph.D. dissertation, Department of Anthropology, University of Massachusetts, Amherst.

Konlande, J. E., and J. R. K. Robson

1972 The Nutritive Value of Cooked Camas as Consumed by Flathead Indians. Ecology of Food and Nutrition 2:193195.

Leach, J. D., and C. B. Bousman

2001[1998] Cultural and Secondary Formation Process: On the Dynamic Accumulation of Burned Rock Middens. Chapter 7 in Test Excavations at the Culebra Creek Site, 41BX126, San Antonio, Texas, by D. L. Nickels, C. B. Bousman, J. D. Leach, and D. A. Cargill, pp. 119-145. Archaeological Survey Report, No. 265, Center for Archaeological Research The University of Texas at San Antonio and Archeological Studies, Report 3, Environmental Affairs Division, Texas Department of Transportation, Austin.

Leach, J. D., D. L. Nickels, B. K. Moses, and R. Jones.

2001[1998] Appendix D: Estimating Rates of Burned Rock Discard: Results from an Experimental Earth Oven. In Test Excavations at the Culebra Creek Site, 41BX126, San Antonio, Texas, by D. L. Nickels, C. B. Bousman, J. D. Leach, and D. A. Cargill, pp. 275-282. Archaeological Survey Report, No. 265, Center for Archaeological Research The University of Texas at San Antonio and Archeological Studies, Report 3, Environmental Affairs Division, Texas Department of Transportation, Austin.

Leffler, J. J.

2002 Ranchers, Farmers, Soldiers, and the CCC: The Background for Seven Historical Sites at Camp Bowie, Brown County, Texas. Archaeological Survey Report, No. 325. Center for Archaeological Research, The University of Texas at San Antonio. 
Lukowski, P. D.

1987 Archaeological Investigations along the Leona River Watershed, Uvalde County, Texas. Archaeological Survey Report, No. 132. Center for Archaeological Research, The University of Texas at San Antonio.

1988 Archaeological Investigations at 41BX1, Bexar County, Texas. Archaeological Survey Report, No. 135. Center for Archaeological Research, The University of Texas at San Antonio.

Lyman, R. L.

1996 Vertebrate Taphonomy. Cambridge Manuals in Archaeology. Cambridge University Press, Cambridge.

McClean, R. G., and W. F. Kean

1993 Contributions of Wood Ash Magnetism to Archeomagnetic Properties of Fire Pits and Hearths. Earth and Planetary Science Letters 119:387-394.

McGee, W. J.

1898 The Seri Indians. Annual Report of the U.S. Bureau of Ethnology. Seventeenth Annual Report, part 1. GPO, Washington, D.C.

Mauldin, R. P.

1995 Groping for the Past: Investigation Archaeological Patterns Across Space and Time in the Southern Southwestern United States. Unpublished Ph.D. dissertation, Department of Anthropology, The University of New Mexico, Albuquerque.

Mauldin, R. P, and D. L Nickels

2001 Chapter 2: An Overview of the Twin Buttes Archaeological Project. In An Archaeological Survey of Twin Buttes Reservoir, Tom Green County, Texas, by R. P. Mauldin and D. L. Nickels, pp. 5-24. Archaeological Survey Report, No. 300. Center for Archaeological Research, The University of Texas at San Antonio.

Meissner, B. A.

1993 Where the Buffalo Roam: Archaeological Evidence of Bison Populations in South and Central Texas. Manuscript on file, Center for Archaeological Research, The University of Texas at San Antonio.

Nance, H. S., and E. G. Wermund

1993 Geological and Climatic Survey: Camp Bowie Military Reservation, Brownwood, Texas. Bureau of Economic Geology, The University of Texas at Austin, Texas.

National Climate Data Center (NCDC)

2001 Online Climate Data for Brownwood, Texas. Available at $<\mathrm{http}: / / \mathrm{lwf}$.ncdc.noaa.gov/ oa/climate/climatedata.html $>$

Nature Conservancy of Texas

1996 Land Cover Analysis of Texas Army National Guard Training Sites. Report submitted to the Texas Adjutant General's Department.

Neck, R. W.

1997 Appendix F: Freshwater Mussel Remains and Snail Shell from Four Burned Rock Midden Sites in Central Texas. In Hot Rock Cooking on the Greater Edwards Plateau: Four Burned Rock Midden Sites in West Central Texas, Volume 2, by S. L. Black, L. W. Ellis, D. G. Creel, and G. T. Goode, pp. 629-640. Studies in Archeology 22, Texas Archeological Research Laboratory, The University of Texas at Austin and Archeology Studies Program, Report 2, Environmental Affairs Department, Texas Department of Transportation, Austin. 
Nickels, D. L., C. B. Bousman, J. D. Leach, and D. A. Cargill

2001[1998] Test Excavations at the Culebra Creek Site, 41BX126, San Antonio, Texas. Archaeological Survey Report, No. 265, Center for Archaeological Research The University of Texas at San Antonio and Archeological Studies, Report 3, Environmental Affairs Division, Texas Department of Transportation, Austin.

Nordt, L. C., T. W. Boutton, J. S. Jacob, and R. Mandel

1994 Late Quaternary Climates of Central Texas Based on the Stable Isotopic Composition of Organic Carbon. Program and Abstracts, 52nd Plains Conference, 65th Annual Meeting of the Texas Archeological Society, Lubbock.

Opler, E. M.

1941 An Apache Life-Way: The Economical, Social, and Religious Institutions of the Chiricuahua Indians. The University of Chicago Publications in Anthropology, Ethnological Series. University of Chicago Press, Chicago.

Patterson, L. W.

1988 Intergroup Conflict in Prehistoric Texas. Houston Archeological Society Journal 90:8-10.

Pearce, J. E.

1919 Indian Mounds and Other Relics of Indian Life in Texas. American Anthropologist 21:223-234

1932 The Present Status of Texas Archeology. Bulletin of the Texas Archeological and Paleontological Society 4:4454.

1938 The Burnt-Rock Midden-Mounds of Central and West Texas. Manuscript on file at Texas Archeological Research Laboratory, The University of Texas at Austin. Document first written in 1920 and revised in 1938.

Pennington, C. W.

1963 The Tarahumar of Mexico: Their Environment and Material Culture. University of Utah Press, Salt Lake City.

Potzger, J. E., and B. C. Tharp

1943 Pollen records of Canadian Spruce and Fir from a Texas Bog. Science 98:584.

1947 Pollen Profile from a Texas Bog. Ecology 28:274-280.

Prewitt, E. R.

1974 Archeological Investigations at the Loeve-Fox Site, Williams County, Texas. Research Report 49. Texas Archeological Survey, The University of Texas at Austin.

1981 Culture Chronology in Central Texas. Bulletin of the Texas Archeological Society 52:65-89.

1985 From Circleville to Toyah: Comments on Central Texas Chronology. Bulletin of the Texas Archeological Society 54:201-238.

1994 Burned Rock Middens: A Summary of Previous Investigations and Interpretations. In The Burned Rock Middens of Texas: An Archeological Symposium, edited by T. R. Hester, pp. 25-32. Studies in Archeology 13, Texas Archeological Research Laboratory, The University of Texas, Austin.

Prikryl, D. J.

1983 An Archaeological Survey of the City of Brownwood Proposed Sanitary Landfill Site, Brown County, Texas. Prewitt and Associates, Austin, Texas.

Quigg, J. M., and G. L. Ellis

1994 Burned Rock Mound Chronometric Investigations. In Archeological Investigations on 571 Prehistoric Sites at Fort Hood, Bell and Coryell Counties, Texas, edited by W. N. Trierweiler, pp. 203-274. United States Army Fort Hood Archeological Resource Management Series, Research Report No. 31. Mariah and Associates, Inc., Austin. 
Ramsey, C. B.

2000 OxCal Program Version 3.5. Radiocarbon Accelerator Unit, University of Oxford. Oxford, U.K.

Reynolds, R. L., and J. W. King

1995 Magnetic Records of Climate Change. U.S. National Report to I.U.G.G., 1991-1994. American Geophysical Union. $<$ http://www.agu.ong/revgeophys/reyno100/reyno100.html > Accessed April 2001.

Ricklis, R. A., and K. A. Cox

1998 Holocene Climatic and Environmental Change in the Texas Coastal Zone: Some Geoarchaeological and Ecofactual Indicators. Plains Anthropologist 164(43):125-136.

Ricklis, R. A., and M. B. Collins

1994 Archaic and Late Prehistoric Human Ecology in the Middle Onion Creek Valley, Hays County, Texas. Studies in Archeology 19. Texas Archeological Research Laboratory, The University of Texas at Austin.

Robinson, R. L.

1979 Biosilica and Climatic Change at 41GD21 and 41GD21A. In Archaeological Investigations of Two Prehistoric Sites on the Coleto Creek Drainage, Goliad County, Texas, edited by D. E. Fox, pp. 102-113. Archaeological Survey Report, No. 69. Center for Archaeological Research, The University of Texas at San Antonio.

1982 Biosilica Analysis of Three Prehistoric Archaeological Sites in the Choke Canyon Reservoir, Live Oak County, Texas: Preliminary Summary of Climatic Implications. In Archaeological Investigations at Choke Canyon Reservoir, South Texas: The Phase I Findings, edited by G. D. Hall, S. L. Black, and C. Graves, pp. 597-610. Choke Canyon Series, No. 5. Center for Archaeological Research, The University of Texas at San Antonio.

Shafer, H. J., E. P. Baxter, and P. Dering

1975a Upper Pecan Bayou Watershed, Brown County, Texas, An Archaeological Survey of Structure No. 30. Archaeological Research Laboratory, Texas A\&M University, College Station, Texas.

1975b Brownwood Laterals Watershed, Brown County Texas: Archaeological Surveys of Floodwater Retarding Structures 1, Z24, 5, 18, 24 and 2. Report No. 13, Archaeological Research Laboratory, Texas A\&M University, College Station, Texas.

Shafer, H. J., E. P. Baxter, and T. B. Stearns

1976 Archeological Assessment at Upper Pecan Bayou and Brownwood Lateral Watershed, Brown County, Texas. Report No. 29. Anthropology Laboratory, Texas A\&M University.

Silberbauer, G. B.

1981 Hunter \& Habitat in the Central Kalahari Desert. Cambridge University Press, New York.

Simms, S. R.

1984 Aboriginal Great Basin Foraging Strategies: An Evolutionary Analysis. Ph.D. dissertation, The University of Utah, Salt Lake City. University Microfilms, Ann Arbor

Singer, M. J., and P. Fine

1989 Pedogenic Factors Affecting Magnetic Susceptibility of Northern California Soils. Soil Science of America Journal 53:1119-1127.

Skelton, D. W.

1977 Archeological Investigations at the Fayette Power Project, Fayette County, Texas. Research Report 60. Texas Archeological Survey, The University of Texas at Austin. 
Skinner, S. A., C. Shaw, K. Huckabay, and M. L. Bartsch

1978 An Evaluation of Archaeological Resources at Aquilla Lake. Research Report, Archaeology Research Program, Southern Methodist University, Dallas.

Smith, G. S., W. Martin, and K. A. Johansen

2001 Sego Lilies and Prehistoric Foragers: Return Rates, Pit Ovens, and Carbohydrates. Journal of Archaeological Science 28:169-183.

Sorrow, W. M.

1969 Archaeological Investigations at the John Ischy Site: A Burnt Rock Midden in Williamson County, Texas. Papers of the Texas Archeological Salvage project No 18, Texas Archeological Salvage Project, The University of Texas at Austin.

Sorrow, W. M., H. J. Shafer, and R. E. Ross

1967 Excavations at Stillhouse Hollow Reservoir. Papers No. 11. Texas Archeological Survey, The University of Texas at Austin.

Speth, J.

1990 Seasonality, Resource Stress, and Food Sharing in So-Called "Egalitarian" Foraging Societies. Journal of Anthropological Archaeology 9:148-188.

Speth, J., and S. Scott

1989 Horticulture and Large Mammal Hunting: The Role of Resource Depletion and the Constraints of Time and Labor. In Farmers as Hunters: The Implications of Sedentism, edited by S. Kent, pp. 71-79. Cambridge University Press, Cambridge.

Spielman, K. (editor)

1989 A Review: Dietary Restrictions on Hunter-Gatherer Women and the Implications for Fertility and Infant Mortality. Human Ecology 17:321-345.

Spier, L.

1933 Yuman Tribes of the Gila River. University of Chicago Publications in Anthropology. University of Chicago Press, Chicago.

Stafford, T. W., Jr.

1998 Radiocarbon Chronostratigraphy. In Wilson-Leonard: An 11,000-year Archeological Record of Hunter-Gatherers in Central Texas, Volume IV: Archeological Features and Technical Analyses, edited by M. B. Collins., pp. 1039-1066. Studies in Archeology 31, Texas Archeological Research Laboratory, The University of Texas at Austin and Archeology Studies Program, Report 10, Texas Department of Transportation, Environmental Affairs Division, Austin.

Stahle, D. W., and W. K. Cleaveland

1995 Texas Paleolithic Climate Data from Daily to Millennial Time Scales. In Changing Climate of Texas: Predictability and Implications for the Future, edited by J. Norwine, J. R. Giardino, G. R. North. J. B. Valdes, pp. 46-96. Texas A\&M University, College Station. 
Steele, D. G., and C. Assad Hunter

1986 Analysis of Vertebrate Faunal Remains from 41MC222 and 41MC296, McMullen County, Texas. In The Prehistoric Sites at Choke Canyon Reservoir, Southern Texas: Results of Phase II Archaeological Investigations, edited by G. D. Hall, T. R. Hester, and S. L. Black. Choke Canyon Series, No. 10. Center for Archaeological Research, The University of Texas at San Antonio.

Steward, J. H.

1938 Basin-Plateau Aboriginal Sociopolitical Groups. Bureau of American Anthropology, Bulletin 120, GPO, Washington, D.C.

Story, D. A.

1985 Adaptive Strategies of Archaic Cultures of the West Gulf Coastal Plain. In Prehistoric Food Production in North America, edited by R. I. Ford, pp. 19-56. Anthropological Papers No. 75. Museum of Anthropology, University of Michigan, Ann Arbor.

Stuvier, M., and P. J. Reimer

1993 Extended ${ }^{14} \mathrm{C}$ Database and Revised CALIB Radiocarbon Calibration Program, Radiocarbon 35:215-230.

Swanson, E. R.

1995 Geo-Texas. A guide to the Earth Sciences. Texas A\&M University Press, College Station, Texas.

Takac, P. R., M. B. Collins, and W. A. Gose

1993 The archeomagnetic investigation of burned limestone rocks: an interpretive technique (abstract). Abstracts of the $58^{\text {th }}$ Annual Meeting, Society for American Archaeology, Washington.

Taylor, A. J., and C. L. Highley

1995 Archaeological Investigations at the Loma Sandia Site (41LK28): A Prehistoric Campsite in Live Oak County, Texas. 2 volumes. Studies in Archeology No. 20. Texas Archeological Research Laboratory, The University of Texas at Austin.

Texas Parks and Wildlife Department (TPW)

1984 The Vegetation Types of Texas. Map available at <http://www.tpwd.state.tx.us/gis/veg/>.

1994 Biological Inventory of Camp Bowie. Prepared for the Texas National Guard by the Texas Heritage Program Resource Protection Division of the Texas Parks and Wildlife Department, Austin, Texas.

Thoms, A. V.

1989 The Northern Roots of Hunter-Gatherer Intensification: Camas and the Pacific Northwest. Unpublished Ph.D. dissertation. Washington State Univeristy, Pullman.

Toomey, R. S., M. D. Blum, and S. Valastro, Jr.

1993 Late Quaternary Climates and Environments of the Edwards Plateau, Texas. Global and Planetary Change 7:299-320.

Toomey, R. S., and T. W. Stafford, Jr.

1994 Paleoenvironmental and Radiocarbon Study of the Deposits from Hall's Cave, Kerr County, Texas. Program and Abstracts, 52nd Plains Conference, 65th Annual Meeting of the Texas Archeological Society, Lubbock. 
Treece, A. C.

1993 Chapter 9: Summary and Conclusions. In Cultural Resource Investigations in the O. H. Ivie Reservoir, Concho, Colman, and Runnels Counties, Texas. Volume III: Data Recovery Results from Non-Ceramic Sites, by A. C. Treece, C. Lintz, W. N. Trierweiler, J. M. Quigg, and K. A. Miller, pp. 477-598. Technical Report No. 346-III. Mariah Associates, Austin, Texas.

Tull, D.

1999 Edible and Useful Plants of Texas and the Southwest. University of Texas Press, Austin.

Turner, S. E.

1989 Exploring the Possibilities of Acorn Utilization in the Burned Rock Middens of Texas. Bulletin of the Texas Archeological Society 59:177-191.

Turner, S. E., and T. R. Hester

1993 A Field Guide to Stone Artifacts of Texas Indians. Second Edition. Gulf Publishing, Houston.

Turner, N. J., and H. V. Kuhnlein

1983 Camas (Camassia spp.) and riceroot (Fritillaria spp.): Two liliaceous "root" foods of the Northwest Coast Indians. Ecology of Food and Nutrition 13:199-219.

USDA, NRCS

2001 Camassia scilloides (Raf.) Cory at The PLANTS Database, Version 3.5. $<$ http://plants.usda.gov> National Plant Data Center, Baton Rouge.

USGS, NPWRC

2001 Atlantic Camass (Camassia scilloides). Northern Prairie Wildlife Research Center. USGS Midwestern Wetland Flora. $<$ http://www.npwrc.usgs.gov/resource/othrdata/plntguid/species/camascil.htm>

Wandsnider, L.

1997 The Roasted and the Boiled: Food Composition and Heat Treatment with Special Emphasis on Pit-Hearth Cooking. Journal of Anthropological Archaeology 16:1-48.

Weir, F. A.

1976 The Central Texas Archaic. Unpublished Ph.D. dissertation. Anthropology Department, Washington State University.

Wilson, E. W.

1930 Burned Rock Mounds of Southwest Texas. Bulletin of the Texas Archeological and Paleontological Society 2:59-63.

Witkind, W. M.

1977 An Experiment in Stone Boiling. In Hop Hill: Culture and Climatic Change in Central Texas, edited by J. Gunn, and R. Mahula, pp. 205-208. Special Report No. 5. Center for Archaeological Research, University of Texas at San Antonio.

Wormser, A. J., G. P. Davis, and C. Leshley

1994 Archaeological Investigation of Proposed Camp Bowie Firebreak, Brown County, Texas. The Adjutant General's Department of Texas. Manuscript on file at the Texas Historical Commission, Austin, Texas. 
Wormser, A. J., and S. Sullo-Prewitt

2001 Cultural Resources Inventory of Camp Bowie, Brownwood, Texas. Archaeological Survey Report, No. 317. Center for Archaeological Research, The University of Texas at San Antonio.

Wormser, A. J., D. M. Sullo, and S. C. Stringer

1997 Archaeological Investigations of the Proposed Tank Training Area at Camp Bowie, Brown County, Texas. The Adjutant General's Department of Texas. Manuscript on file at the Texas Historical Commission, Austin, Texas.

Yanovsky, E., and R. M. Kingsbury

1938 Analysis of some Indian food plants. Association of Official Agricultural Chemists 21:648-665.

Yellen, J.

1977 Archaeological Approaches to the Present. Academic Press, New York.

1978 Long-term Hunter-Gatherer Adaptation to Desert Environments: A Biogeographical Perspective. World Archaeology 8:262-274. 